\title{
BRITISH MUSEUM \\ (NATURAL HISTORY)
}

\section{SOUTHERN AFRIGAN MAMMALS \\ I 758 to 195 I:}

A RECLASSIFICATION

\author{
by \\ J. R. ELLERMAN \\ T. G. S. MORRISON-SCOTT $x$ refs \\ and \\ R. W. HAYMAN
}




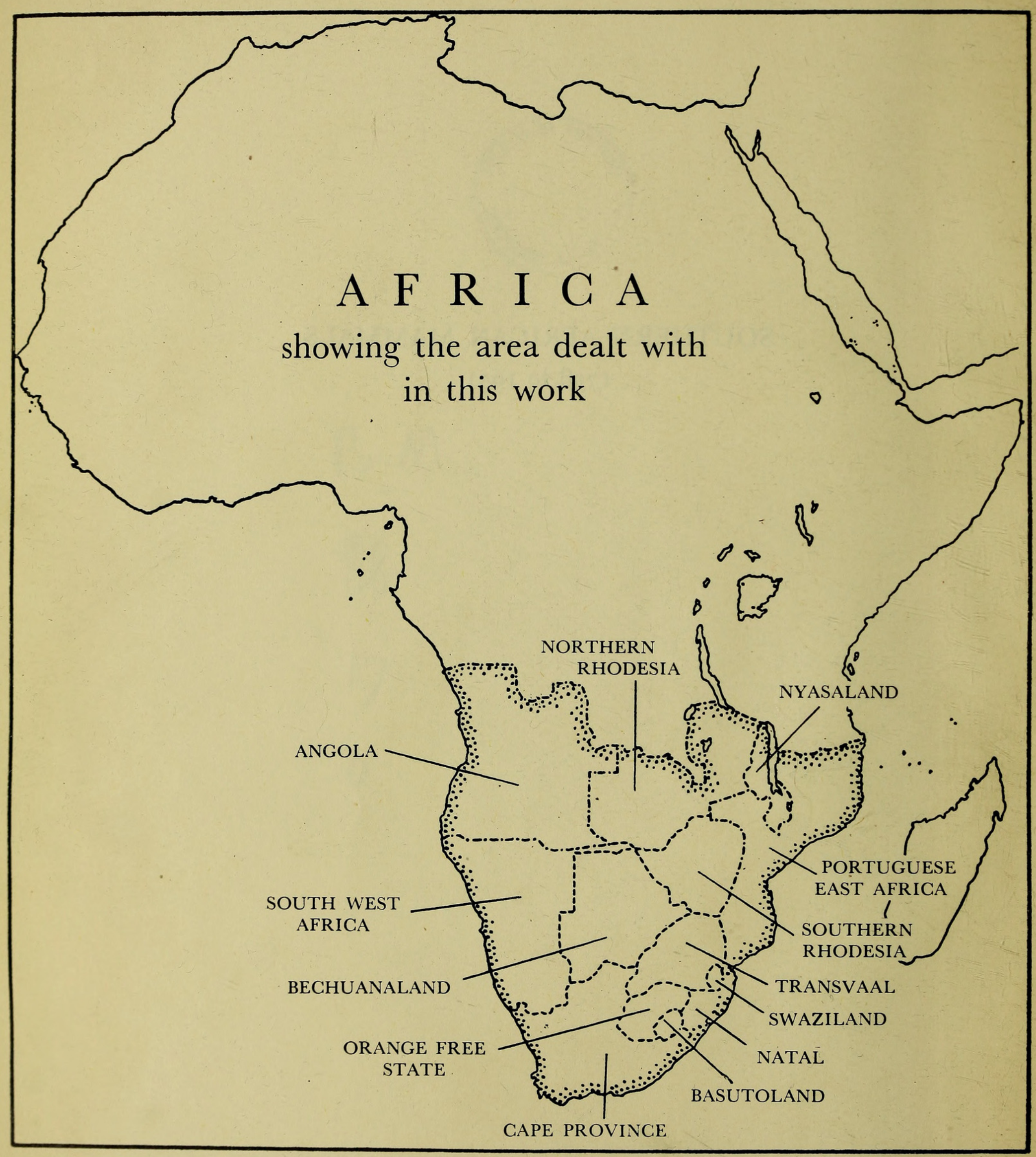




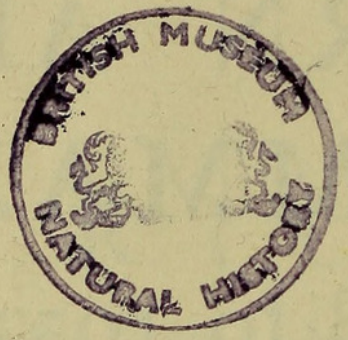

Sold at the British Museum (Natural History), Cromwell Road, S.W.7. and by

B. Quaritch Ltd.; and H.M. Stationery Office 


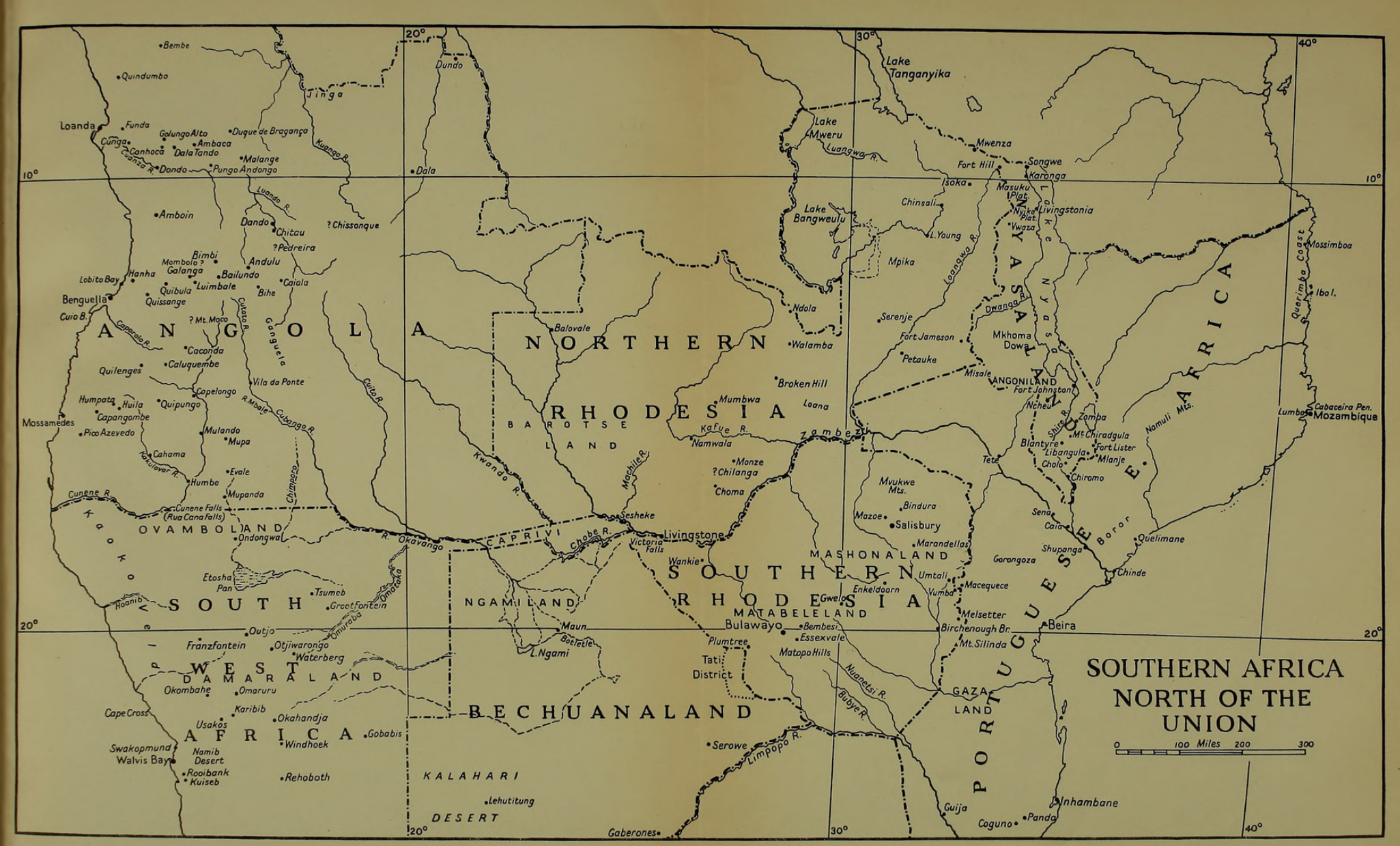




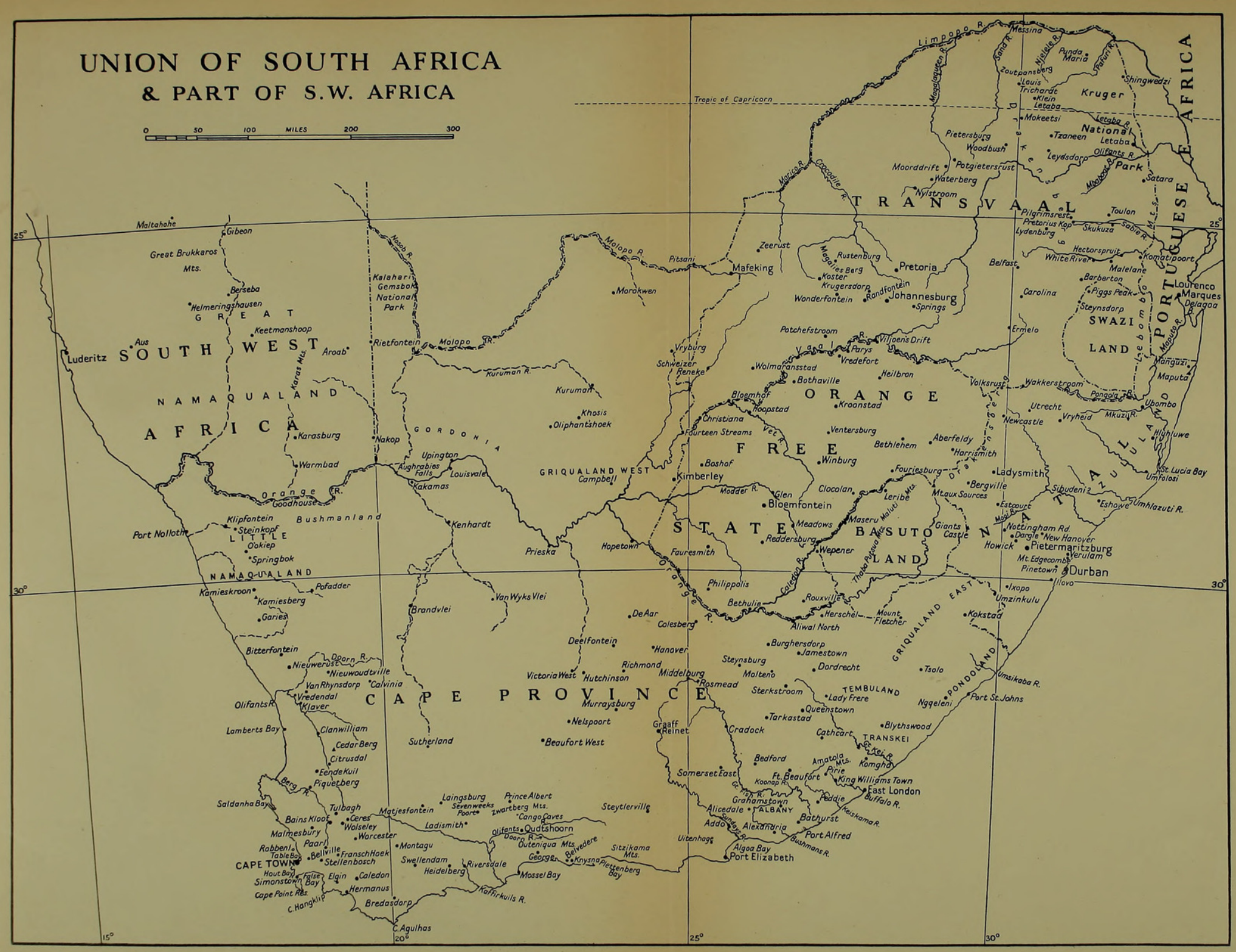




\section{INTRODUGTION}

\section{AREA GOVERED By THIS WORK}

He area covered by this work is the Union of South Africa, Bechuanaland, Southern Rhodesia, Northern Rhodesia, Nyasaland, South-West Africa, Portuguese East Africa (sometimes referred to as Mozambique, though we reserve this term for the province itself), and Angola (but not including the Portuguese territory of Kabinda, which lies north of the River Congo).

These limits are, we realize, artificial and, having dealt with southern Africa the ideal would have been to go on and deal with the whole of the Ethiopian region. But the Belgian Congo has been adequately dealt with by Schouteden, 1944-6, De zoogdieren van Belgisch-Congo en van Ruanda-Urundi, Ann. Mus. Congo Belge, Zoologie, 3: I-576, and Tanganyika Territory has been well listed by Swynnerton \& Hayman, I95 I, A checklist of the land mammals of the Tanganyika Territory and the Zanzibar Protectorate, F.E. Afr. Nat. Hist. Soc. 20: 274-392. And in general our reason for not extending our work to the north of these areas has been lack of opportunity.

\section{Previous Works on this Area}

The standard list of African mammals is Allen, I939, A Checklist of African Mammals, Bull. Mus. Comp. Zool. Harv. 83. This great work is, and will be for years, the source book on African mammals. Our reason for offering the work which follows is twofold. In the first place, fourteen years have elapsed since Allen's work, and consequently there are newly-described forms to be recorded, and fresh knowledge has been gained about forms previously known. Secondly, Allen's list is alphabetical and therefore uncritical. For instance, in the Oryginae Aegoryx and Oryx are separated by Hippotragus, which is an entirely artificial and unfortunate arrangement, and inconvenient to the reader. On this latter ground alone we have therefore thought that a new list was justified. Nevertheless, we desire to acknowledge our very great indebtedness to the late G. M. Allen, whose monumental work has been such a boon to all workers on African mammals since I939, and has, of course, been our springboard.

With regard to the imposing work of Roberts ${ }^{1}$ (195 I, The Mammals of South Africa) we find ourselves in some difficulty. The canon "de mortuis ... " is one to which men of goodwill universally subscribe: on the other hand we believe that in scientific work there is an overriding consideration. We therefore record, with regret, that the scientific thought of the last few decades appears to have had little influence on this author's taxonomic assessments, and that his systematics to the last were little advanced from those of Père Heude who, in the I880s, had five specimens of

${ }^{1}$ Dr. Austin Roberts died on 5th May, 1948. An obituary notice appeared in Ann. Transv. Mus. 1949, 21: 153 . 
Sika Deer from the island of Formosa, and described five species. It is permissible, and indeed often mandatory, to describe a new form on the basis of one specimen. But in the case of races we believe it to be unwise, certainly as a routine.

Further, the description of new forms for the sake of describing them, a sort of parlour game in which our predecessors vied with one another to see who could have the most names to his "credit", seems to have been a vanity which found its echo in Roberts. We have also noticed four instances in which he described a race as new on two separate occasions, in one case with a different type specimen and type locality; such mishaps are, however, only the least of the disadvantages of mass production.

\section{METHOD OF THIS WORK}

We have attempted a reclassification of the mammals of our area, based on the extensive material in the study collections of the British Museum and the Transvaal Museum, and type specimens in the South African Museum, Cape Town, and taking into account the conclusions of recent workers in the field.

The arrangement is intended to be a natural one, and in broad outline largely follows Simpson (1945). Within the species the races are arranged in order of chronological priority, for the convenience of subsequent revisers.

We recognize that our treatment of races has been uneven. This is simply a reflection of incomplete evidence, and the results should be interpreted in the light of the following general principles, and bearing in mind that whereas it is open to anyone validly (nomenclaturally) to describe a new race in a few hastily written lines, it is quite a different matter to collect together enough evidence conclusively to show that such a description should not have been made.

Inevitably, therefore, if the taxonomy of a group, or an area, is to be reduced to some reasonable order, one is forced to supplement direct evidence with indirect, such as the reliability of the judgment of the author concerned, as assessed from his described forms for which direct comparative evidence is available, combined with the degree of variability known to exist in the form concerned, its genetic stability, and the extent of the isolation of the population. In this latter connection it may be observed that large, free-ranging forms, such as lions and many of the antelopes, must clearly be less likely to form stable geographical races than some very small mammals, many of which never move more than a few hundred yards from the place where they were born.

The whole question of the appropriateness of the formal trinominal recognition of races, the ascription of a finite label to something which is not finite in nature, is in our view debatable. This opinion is not new ( $c f$. the "clines" of Huxley) and has recently been re-advocated (T.C.S.M-S., I952, A list of British mammals, 4), but we are aware that the idea of abandoning the formal nomenclatural recognition of races will as yet profoundly shock the orthodox. We nevertheless believe that it will come to be accepted. For the time being, however, we list races, sifted in accordance with the principles, and subject to the limitations, which we mention.

We have also made some reduction in the currently accepted species, and recog- 


\section{INTRODUCTION}

nize 350 in our area. We have examined, and provided keys for, all of these with the exception of fourteen species of Chiroptera, which are unrepresented in the British Museum, and thirty-two species of Cetacea and Sirenia.

The distributions of the species are given in some detail where we have the information, but are necessarily only roughly drawn in other areas. We draw attention to this lest the failure to mention any particular area be taken to imply the nonoccurrence there of the species.

We would draw attention to the fact that the keys to the genera and species have been devised with special attention to forms occurring in South Africa, and all of them may not hold good if extralimital material be taken into account.

The synonyms printed in parentheses are those of which we are doubtful.

\section{ACKNOWLEDGEMENTS}

We record, with gratitude, our indebtedness to Mr. G. H. E. Hopkins and Mr. L. R. Conisbee for kindly reading through the proof sheets and making helpful suggestions, and also to the following gentlemen for the help given to J. R. E. while working in South Africa: Colonel J. A. B. Sandenbergh, Warden of the Kruger National Park; Mr Stephen Roche, of Toulon; Dr. S. H. Skaife and Dr. K. Barnard, of the South African Museum, Cape Town; Dr. V. Fitzsimons and Dr. B. Lundholm, of the Transvaal Museum, Pretoria (Dr. Lundholm has now left Pretoria); Mr. D. H. S. Davis, of the Plague Research Laboratory, Johannesburg; Mr. Hollings, ranger at De Beers, Kimberley district; and Mr. B. Bezuidenhout.

We also acknowledge the assistance we have received in the Mammal Room from Miss J. M. Ingles, particularly with regard to the laborious business of checking the references of original descriptions.

British Museum (Natural History)

J. R. ElLERMAN

T. C. S. MORRISON-SGOTT

R. W. HAYMAN

9th April, I953 



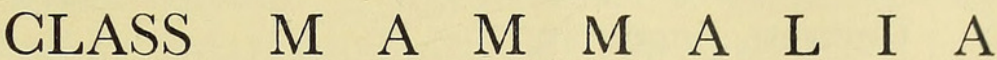

Simpson (1945) is the basic work for the classification of mammals. The mammals with which this work is concerned all belong to the Infraclass Eutheria, which Simpson divides into four cohorts:

UNGUICULATA

Orders: Insectivora, Chiroptera, Primates, Pholidota.

\section{GLIRES}

Orders: Lagomorpha, Rodentia.

\section{MUTICA}

Order: Cetacea.

FERUNGULATA

Superorder: FERAE

Order: Carnivora (with Pinnipedia).

Superorder: Protungulata

Order: Tubulidentata.

Superorder: PAENUNGULATA

Orders: Proboscidea, Hyracoidea, Sirenia.

Superorder: Mesaxonia

Order: Perissodactyla.

Superorder: PARAXonia

Order: Artiodactyla.

We follow the broad outline of this classification except that, as in our last work, we retain the Pinnipedia as an order.

ORDERS: I. Insectivora, page 6

2. Chiroptera, page $4^{2}$

3. Primates, page 89

4. Pholidota, page I03

5. Carnivora, page 105

6. Pinnipedia, page 152

7. Tubulidentata, page 154

8. Proboscidea, page 155

9. Hyracoidea, page 157

Io. Perissodactyla, page 162

I I. Artiodactyla, page I 68 
12. Lagomorpha, page 2 I 2

13. Rodentia, page 222

I4. Sirenia, page 324

I5. Cetacea, page 325

\section{ORDER INSEGTIVORA}

Small mammals with short limbs, the fingers and toes with claws; relatively primitive brain structure; no opposability of the first finger or toe, the nose usually rather long; the main upper cheekteeth $\mathrm{W}$-shaped or V-shaped; if the first upper and lower incisor are enlarged, then in the upper jaw these teeth are joined to the main cheekteeth by a series of small unicuspid teeth.

Simpson's classification of the South African families, 1945:

Order INSECTIVORA

Superfamily: Tenrecoidea.

Family: Potamogalidae.

Superfamily: Chrysochloroidea.

Family: Chrysochloridae.

Superfamily: Erinaceoidea.

Family: Erinaceidae.

Superfamily: Macroscelidoidea.

Family: Macroscelididae.

Superfamily: Soricoidea.

Family: Soricidae (Subfamily: Crocidurinae).

Roberts' classification, I95 I (in general agreement with the views of the late Dr. Broom) :

\section{Order: MENOTYPHLA}

Family: Macroscelididae.

Order: LIPOTYPHLA

Suborder: Erinaceoidea.

Family: Erinaceidae.

Suborder: Soricoidea.

Family: Crociduridae (= Soricidae as here understood).

\section{Order: GHRYSOCHLORIDEA}

Family: Chrysochloridae.

The family Potamogalidae is not dealt with by Roberts as it is extralimital to the region he dealt with. 
For remarks on the status of the Menotyphla see Ellerman \& Morrison-Scott, I95I, 8.

Simpson (1945) states "Broom ... has shown that the chrysochlorids are basically different from the other 'zalambdodonts'. He removed them from the Insectivora altogether and made a new order for them. This seems too radical."

Broom (P.Z.S. I9I5, 35I and I927, 235) separated the Chrysochloridae from the Insectivora as the order Chrysochloridea. He did this chiefly on the different structure of Jacobson's organ and on the lack of the mesethmoid bone in the Golden Moles. But we are not convinced that these characters are of sufficient significance to justify a separate order, especially as they appear to be present only in juvenile skulls, and apparently only three out of some ten species of the Chrysochloridae have so far been examined. Further, neither Broom nor Roux (1947, Acta Zoologica, 28: I65) who supports Broom, seems to have compared all the Insectivora with these characters in mind.

For the moment we retain the Chrysochloridae in the Insectivora.

For further details of the structure of the skull in this family, see Broom, Igi6, On the structure of the skull in Chrysochloris, P.Z.S. 449.

I. The main upper cheekteeth $\mathrm{W}$-shaped.

The main upper cheekteeth V-shaped.

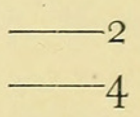

2. First lower incisor enlarged and thrown forwards; first upper incisor also large (and joined to the main cheekteeth by a series of small upper unicuspid teeth). Zygoma incomplete.

Family SORICIDAE, page I8.

First lower incisor not much enlarged nor thrown forwards; zygoma normally complete.

3. Brain cavity relatively smaller. In Africa, tail vestigial and back densely covered with spines. Pubic symphysis short or absent (Flower \& Lydekker, I89I).

Family ERINACEIDAE, page I 7 .

Brain cavity relatively larger. Tail long, and hindfoot relatively long. Back not spiny. Pubic symphysis long (Flower \& Lydekker, I89I).

Family MACROSCELIDIDAE, page 7 .

4. Animal modified for aquatic life, with long, laterally compressed tail. Zygoma incomplete. (Five digits to fore- and hindfeet.)

Family POTAMOGALIDAE, page 32 .

Animals highly modified for subterranean life, with no visible tail, eyes and ears absent or rudimentary; the digging done with 2 or at most 3 enlarged foreclaws, the other fingers much reduced. Five hindtoes. Zygoma present.

Family GHR YSOCHLORIDAE, page 32.

\section{FAMILY M A G R S GE L I D I D A E}

The classification adopted here is outlined in Ellerman \& Morrison-Scott, I95I, I4-I5. It may be noted that Winge (I923) recognized a special subfamily "Rhynchocynini" for Rhynchocyon, contrasted with all the other genera, and there 
is much to be said in favour of this classification as the dental characters of Rhynchocyon differ widely from those of the other Macroscelididae.

I. Upper incisors reduced to one, which is nearly vestigial, so that there is little functional dentition in front of the upper canine, which is enlarged and dominant. (Large species; no hallux; manus with three functional digits and a minute but clawed D.5).

Three upper incisors, canine not enlarged.

2. Large species, length of skull $48.5 \mathrm{~mm}$. and more, usually over $50 \mathrm{~mm}$. No hallux. The bullae not enlarged.

Genus RHYNCHOCYON, page I6

Smaller species, skull $40.5 \mathrm{~mm}$. and less, usually less than $40 \mathrm{~mm}$. With a small hallux.

3. Bullae much enlarged, showing conspicuously in the superior aspect of the skull.

Bullae relatively small, or much less enlarged.

Genus MACROSCELIDES, page I3

Genus ELEPHANTULUS, page 8

\section{Genus ELEPHANTULUS Thomas \& Schwann, igo6}

I906. Elephantulus Thomas \& Schwann, Abstr. P.Z.S. No. 33: ıо; P.Z.S. 577. Macroscelides rupestris A. Smith.

1906. Nasilio Thomas \& Schwann, Abstr. P.Z.S. No. 33: ıо; P.Z.S. 578.

Macroscelides brachyrhynchus A. Smith. Valid as a subgenus.

1937. Elephantomys Broom, S. Afr. J. Sci. 33: 758. E. langi Broom, from cave deposits at Schurveberg; Transvaal; valid as a subgenus to include also the living E. intufi.

I. Eleven lower teeth; a small but functional extra hind lower molar normally present.

Ten lower teeth; two lower molars.

Elephantulus (Nasilio) brachyrhynchus, ${ }^{1}$ page 9

2. The fifth tooth from the back in the upper toothrow is large, fourcusped and molariform. The bullae are not flattened, so that the external part of the bulla is on a much lower level as seen in ventral view than the median part.

Elephantulus (Elephantomys) intufi, page Io

The fifth tooth from the back in the upper toothrow is narrow, twocusped and sectorial. The bullae are somewhat flattened, so that as seen in ventral view the external part of the bulla is about on the same level as the median part.

Elephantulus rupestris, ${ }^{2}$ page 12

G. Allen (I939) listed Elephantulus rufescens Peters, I 878 (a probable subspecies of E. rozeti Duvernoy; 1833 ) from Mozambique, but we have reason to believe that this record is erroneous.

${ }^{1}$ We are inclined to treat Nasilio as a subgenus of Elephantulus.

${ }^{2}$ Elephantulus rupestris as based on a cotype in the British Museum and outlined in Ellerman and Morrison-Scott, I95I, I4-15; not E. rupestris of Roberts 195 I, which we think =intufi. 


\section{INSECTIVORA - MACROSCELIDIDAE}

\section{Subgenus NASILIO Thomas \& Schwann, Igo6}

Elephantulus brachyrhynchus A. Smith, 1836

Short-snouted Elephant-Shrew. Kortneusklaasneus ${ }^{1}$

Distribution $^{2}$ : in the Union, the Transvaal (Rustenburg district, Pretoria Pietersburg, Klein Letaba, Tzaneen, etc.). Portuguese East Africa, including Tete; Melsetter district, Mazoe, Bulawayo, etc., in Southern Rhodesia; Ngamiland, northern South-West Africa (Grootfontein district, western Caprivi, parts of Ovamboland (Shortridge)). Central and southern Angola northwards at least to Chitau. Northern Rhodesia, where widely distributed; Nyasaland. North of the limits of this work, the Belgian Congo, Kenya, Tanganyika and Uganda.

Elephantulus bRaghyrhynghus braghyrhynghus A. Smith, 1836

I836. Macroscelides brachyrynchus A. Smith, Report Exped. Explor. Cent. Africa, 42. Between Latakoo [near Kuruman] and the Tropic, (either southern Bechuanaland or northern Cape Province.)

I844. Macroscelides brevirostris Schinz, Synops. Mamm. I: 284. Substitute for brachyrhynchus.

(I852. Macroscelides fuscus Peters, Reise nach Mossamb. Zool. I: Säug. 87. Boror (12 miles from Quelimane, northern Portuguese East Africa).)

Range includes the western Transvaal and probably the dry western parts of Southern Rhodesia (Roberts). Nyasaland, part.

ElephantUlus BRAGHyRHyNGHUS BRAGHyURUS Bocage, I 882

I882. Macroscelides brachyura Bocage, J. Sci. Math. Phys. Nat., Lisboa, 9: 27. Caconda, south-east of Benguela, Angola.

ELEPHANTULUS BRAGHYRHYNGHUS SGHINZI Noack, I 889

I889. Macroscelides brachyrhynchus var. schinzi Noack, Zool. Jahrb. 4: ig8. Ondongastamm, Ovamboland, South-West Africa. Ranges to Humpata and Quillenges, south-western Angola.

Elephantulus BRAGHyrhynghus malosae Thomas, I 898

I 898. Macroscelides brachyrhynchus malosae Thomas, P.Z.S. I897: 928. Mount Malosa, (north of Zomba), $5500 \mathrm{ft}$., southern Nyasaland.

ElePhantulus BRAGHYRHyNGHUS TZANEENENSIS Roberts, I929

1929. Nasilio brachyrhyncha tzaneenensis Roberts, Ann. Transv. Mus. I3: 85. Tzaneen (west of the Kruger National Park, and near Woodbush), eastern Transvaal.

Elephantulus BRAGHyrhynchus LANGi Roberts, I929

1929. Nasilio brachyrhyncha langi Roberts, Ann. Transv. Mus. I3: 85. Mazambo, lower Limpopo River, southern Portuguese East Africa.

1 The Afrikaans name skeerbekmuis is used by Shortridge for some of the Soricidae as well as for members of the Macroscelididae.

${ }^{2}$ It should be noted that the small mammals of the Kruger National Park, Transvaal (Insectivora and smaller Rodentia) are not yet well known. 
ElePhaNTUlus BRAGHYRHYNGHUS SHORTRIDGEI Roberts, I929 1929. Nasilio brachyrhyncha shortridgei Roberts, Ann. Transv. Mus. I3: 86. Ndola (near the Congo border), western Northern Rhodesia.

Elephantulus BRAGHYRHYNGHUS MABABIENSIS Roberts, I932 1932. Nasilio brachyrhynchus mababiensis Roberts, Ann. Transv. Mus. 15: I8. Tsotsoroga Pan, Ngamiland, northern Bechuanaland.

Elephantulus BRAGHyRHynchus SElindensis Roberts, I937 1937. Nasilio brachyrhyncha selindensis Roberts, Ann. Transv. Mus. 19: 99. Mt. Selinda, Melsetter district, eastern Southern Rhodesia. Roberts also quoted specimens from the Bulawayo district.

\section{Subgenus ELEPHANTOMYS Broom, I937}

Elephantulus intufi A. Smith, $18{ }_{3} 6$

Bushveld Elephant-Shrew. Bosveldklaasneus

Distribution: in the Union, the British Museum possesses specimens from Klipfontein (north of Steinkopf) in Little Namaqualand, Louisvale (south bank of Orange River, near Upington), and Kenhardt, north-western Cape Province. Besides these places, Roberts quotes specimens from Cradock, Grahamstown, Upington, the Aughrabies Falls and Van Wyk's Vlei, Cape Province. Hewitt (I93 I) quoted one species of the genus from the eastern Cape (saying that vandami was the only one of three varieties "actually known to us") and localities quoted by that author included Rosmead (near Middleburg), Dordrecht (near Aliwal North), and Alicedale. The type locality was in the western Transvaal. South-West Africa; from about the Tropic of Capricorn to the Kaokoveld and Ovamboland (Shortridge); forms also named by Roberts from Great Namaqualand. Bechuanaland, and Matabeleland, Southern Rhodesia. Western Angola. Recorded from southern Tanganyika by Swynnerton \& Hayman, I95I.

(In this work a classification is offered which is different from that of Roberts, owing to a difference of opinion as to the status of E. rupestris, which we take as the species with the narrow upper P.3, on account of the holotype in the British Museum. All Roberts' types have been examined, and all types and other material in the British Museum. But owing to confusion between rupestris and intufi by earlier authors, it becomes difficult to ascertain their exact distributions.)

Elephantulus intufi intufi A. Smith, 1836

1836. Macroscelides intufi A. Smith, Report Exped. Explor. C. Africa, 42. Flats beyond Kurrichaine, Marico district, western Transvaal. Range: western and northern Transvaal and adjacent parts of Bechuanaland and Matabeleland (Roberts). 
Elephantulus intufi Alexanderi Ogilby, I 838

1838. Macroscelides alexandri Ogilby, P.Z.S. 5. Damaraland, South-West Africa (Windhoek nominated by Roberts, I 95 I ). (Named after Captain Alexander). Ranges southwards to Berseba, Great Namaqualand, according to Roberts, and recorded from several localities in western Angola, northwards to Hanha, by Hill \& Carter.

Elephantulus intufi vandami Roberts, i 924

1924. Elephantulus vandami Roberts, Ann. Transv. Mus. I0: 62. Cradock, eastern Cape Province. Range also includes Grahamstown and Van Wyk's Vlei, Cape Province.

Elephantulus intufi Kalaharigus Roberts, I $93^{2}$

1932. Elephantulus intufi kalaharicus Roberts, Ann. Transv. Mus. I5: i 7. Damara Pan, central Kalahari, Bechuanaland.

Elephantulus intufi mossamedensis Hill \& Carter, 1937

1937. Elephantulus intufi mossamedensis Hill \& Carter, Amer. Mus. Novit. No. 937: I. I I $\mathrm{km}$. east of Mossamedes, south-western Angola.

Elephantulus intufi baRlowi Roberts, 1938

1938. Elephantulus barlowi Roberts, Ann. Transv. Mus. I 9: 233. Aus (inland from Luderitz), Great Namaqualand, South-West Africa.

Elephantulus intufi namibensis Roberts, 1938

1938. Elephantulus namibensis Roberts, Ann. Transv. Mus. 19: 233. 45 miles north of Aus, Great Namaqualand, South-West Africa.

Elephantulus intufi campbelli Roberts, 1938

1938. Elephantulus intufi campbelli Roberts, Ann. Transv. Mus. 19: 234. Barby Farm, 25 miles west of Helmeringshausen (west of Berseba, Great Namaqualand), South-West Africa.

(1938. Elephantulus rupestris tarri Roberts, Ann. Transv. Mus. 19: 234. Barby Farm, 25 miles west of Helmeringshausen, Great Namaqualand, South-West Africa.)

Elephantulus intUfi OKOMBAhENSIS Roberts, I 946

I946. Elephantulus barlowi okombahensis Roberts, Ann. Transv. Mus. 20: 309. Okombahe, Omaruru, Damaraland, South-West Africa.

(1946. Elephantulus intufi mchughi Roberts, Ann. Transv. Mus. 20: 309. Okombahe, Omaruru, Damaraland, South-West Africa.)

Elephantulus intufi GORdoniensis Roberts, I 946

I946. Elephantulus barlowi gordoniensis Roberts, Ann. Transv. Mus. 20: 309. Upington, Gordonia district, north of the Orange River, northern Cape Province.

(195I. Elephantulus rupestris rupestris Roberts, Mamm. S. Africa, 28. Not of A. Smith, I 83 I.)

Specimens in B.M. similar to this form from Klipfontein (Little Namaqualand), Louisvale (near Upington) and Kenhardt, Cape Province. 
Subgenus ELEPHANTULUS Thomas \& Schwann, I9o6

Elephantulus rupestris A. Smith, 1831

Rock Elephant-Shrew. Klipklaasneus

Distribution: in the Union, the Transvaal (widely distributed, including Rustenburg, Krugersdorp, Zoutpansberg, Woodbush, Pretoria, Johannesburg), Utrecht in northern Natal, the Orange Free State (Vredefort, Fauresmith, Meadows, Bothaville, etc.), and in the Cape Province, Little Namaqualand (recorded from the Kamiesberg, O’okiep, Springbok), Klaver, Lamberts Bay, Tulbagh, Wolseley, western Cape; Deelfontein, Richmond, Hanover, Port Elizabeth, etc. (Skulls in British Museum examined from Deelfontein, Vredefort, Johannesburg and Woodbush). North of the Union, from Gaberones, south-eastern Bechuanaland, and Southern Rhodesia. Unless the form kobosensis from south of Rehoboth belongs to this species, it is probable that all forms from South-West Africa should be referred to E. intufi.

Elephantulus RUPESTRIS RUPESTRIS A. Smith, I 83 I

I83 I. Macroscelides rupestris A. Smith, P.Z.S. I830-3I: I I (January). Also I83 I, S. Afr. J. I, No. 5: io (October). Mountains near the mouth of the Orange River.

1830. Macroscelides typus Lesson, Cent. Zool. 5 I. Not of A. Smith, I829.

Elephantulus Rupestris EdWARdi A. Smith, i 839

I 839. Macroscelides edwardii A. Smith, Illustr. Zool. S. Africa, Mamm. pl. I4. Near Oliphants River; thought by Roberts and Shortridge to be the Olifants River in the Oudtshoorn district, south-western Cape Province.

1939. Macroscelides edwardsii G. Allen, Checklist African Mamm., 5 and of earlier authors.

ElePhANTUlus RUPESTRIS MYURUS Thomas \& Schwann, igo6

1906. Elephantulus rupestris myurus Thomas \& Schwann, P.Z.S. 586. Woodbush, north-eastern Transvaal. Range: Woodbush to Zoutpansberg, northern Transvaal; also recorded from Matabeleland, Southern Rhodesia.

Elephantulus RUPestris Jamesoni Chubb, igo9

I 909. Elephantulus rupestris jamesoni Chubb, Ann. Transv. Mus. I: I8 8 . Johannesburg, Transvaal. Range: the grassveld plateau of southern Transvaal (eastwards to Drakensberg and Utrecht, Natal) and Orange Free State (southwards to Meadows, westwards to Bothaville), and westwards into Gaberones district, Bechuanaland.

ElePHANTUlus RUPESTRIS MAPOGONENSIS Roberts, I9I 7

I9I 7. Elephantulus rupestris mapogonensis Roberts, Ann. Transv. Mus. 5: 277. Njelele River, north of the Zoutpansberg, northern Transvaal. 
Elephantulus RUPestris GAPEnsis Roberts, I 924

1924. Elephantulus capensis Roberts, Ann. Transv. Mus. Io: 62. Klaver, western Cape Province. Range: western Cape Province from Little Namaqualand to Wolseley and Tulbagh.

Elephantulus (?) RUPESTRIS KobOSEnsis Roberts, I 938

1938. Elephantulus kobosensis Roberts, Ann. Transv. Mus. 19: 233. Kobos, 30 miles south-west of Rehoboth, South-West Africa.

Elephantulus RUPESTRIS KAROensis Roberts, I938

1938. Elephantulus karoensis Roberts, Ann. Transv. Mus. I9: 234. Deelfontein, north of Richmond, central Cape Province. Range: Deelfontein, Hanover, Richmond and Hutchinson (on the Karroo), and Port Elizabeth (Roberts).

Elephantulus RUPestris centralis Roberts, i 946

1946. Elephantulus myurus centralis Roberts, Ann. Transv. Mus. 20: 3 I o. Fauresmith, western Orange Free State. Range includes Reddersburg, O.F.S. and Burghersdorp, north-eastern Cape Province.

\section{Genus MAGROSGELIDES A. Smith, I 829}

I829. Macroscelides A. Smith, Zool. J. 4: 435. Macroscelides typus A. Smith $=$ Sorex proboscideus Shaw.

I829. Eumerus I. Geoffroy, Ann. Sci. Nat. I8: I72, published as Eumère, for latinization of name see p. 470 . Name published and put into synonymy at same time.

I830. Macroscelis Fischer, Syn. Mamm. Addenda, 657.

I83I. Rhinomys Lichtenstein, Darst. Säugeth. pl. 38 and text. Rhinomys jaculus Lichtenstein $=$ Sorex proboscideus Shaw.

Macroscelides proboscideus Shaw, I80o.

Short-eared Elephant-Shrew. Kortoorklaasneus

Distribution: Cape Province; north of Upington; Little Namaqualand (Port Nolloth, Klipfontein (north of Steinkopf), the Kamiesberg), Van Rhynsdorp, Lamberts Bay region, the Oudtshoorn district, the greater part of the Karroo, including several places in Bushmanland, Matjesfontein, Deelfontein, Hanover, Cradock, east of Calvinia, Middelburg district, and to Grahamstown. South-West Africa; Great Namaqualand; possibly but not certainly Damaraland.

Magroscelides PROBoscideus PRoboscideus Shaw, I80o

I8oo. Sorex proboscideus Shaw, Gen. Zool. Mamm. I: 536. Cape of Good Hope. According to Roberts, from Roodewal, Oudtshoorn division, south-western Cape Province.

I 829. Macroscelides typus A. Smith, Zool. J. 4: 436. "Interior of South Africa." (Roodewal, Oudtshoorn division, Cape Province (Roberts).) 
MAGroscelides PROBOSCIDEus PROBOSCIDEus [contd.]

I831. Rhinomys jaculus Licthenstein, Darst. Säugeth. pl. $3^{8}$ and text. "East coast of South Africa."

I838. Macroscelides typicus A. Smith, Illustr. Zool. S. Africa, Mamm. pl. io. Renaming of typus.

Specimens quoted from Beaufort West and Matjesfontein, Cape Province by Roberts.

MaGrosaelides PRobosaideus melanotis Ogilby, i 838

I838. Macroscelides melanotis Ogilby, P.Z.S. 5. Said to be from Damaraland, SouthWest Africa (but not subsequently collected there; Shortridge thought it was from Great Namaqualand; Roberts disagrees).

MAGrosaelides PRoboscideus hewitti Roberts, I929

i929. Macroscelides proboscideus hewitti Roberts, Ann. Transv. Mus. I3: 86. Cradock, eastern Cape Province. Range includes Hanover, Deelfontein, etc.

MaGrosaelides PROBOsaideus GHIVERsi Roberts, I933

I933. Macroscelides proboscideus chiversi Roberts, Ann. Transv. Mus. I5: 265. 76 miles north of Upington (south of the Kuruman River), northern Cape Province.

MAGROSGElides PROBOsGideus LANGi Roberts, I933

I933. Macroscelides proboscideus langi Roberts, Ann. Transv. Mus. 15: 265. Vlermuisklip, Van Rhynsdorp district, western Cape Province.

Magrosaelides probosaideus isabellinus Shortridge \& Carter, I938

I938. Macroscelides typicus isabellinus Shortridge \& Carter, Ann. S. Afr. Mus. 32: 283. Port Nolloth, coast of Little Namaqualand, north-western Cape Province.

MaGrosaelides PROBOsaideus Ausensis Roberts, I938

I938. Macroscelides typicus ausensis Roberts, Ann. Transv. Mus. 19: 231. 20 miles north of Aus village, Great Namaqualand, South-West Africa.

MaGrosaelides PROBOSGIDeus HAREI Roberts, I $93^{8}$

I938. Macroscelides typicus harei Roberts, Ann. Transv. Mus. I9: 232. Brospan, midway between Brandvlei and Van Wyk's Vlei, Great Bushmanland, western Cape Province.

Magrosaelides PROBOsGideus BRANDVleiensis Roberts, I938

I938. Macroscelides typicus brandvleiensis Roberts, Ann. Transv. Mus. I9: 232. Brandvlei, Great Bushmanland, western Cape Province.

Macrosaelides probosaideus Galviniensis Roberts, i938

I938. Macroscelides typicus calviniensis Roberts, Ann. Transv. Mus. 19: 232. I5 miles east of Calvinia, western Cape Province. 


\section{Genus PETRODROMUS Peters, I 846}

I 846. Petrodromus Peters, Ber. Preuss. Akad. Wiss. 257. Petrodromus tetradactylus Peters. i 916. Cercoctenus Hollister, Smithson. Misc. Coll. 66, I : I. Petrodromus sultan Thomas. I918. Mesoctenus Thomas, Ann. Mag. N.H. I: 366. Petrodromus rovumae Thomas.

We follow Swynnerton \& Hayman (I95I) in recognizing no subgenera in this genus.

I. The underside of the tail is normal and not rough to the touch.

\section{Petrodromus tetradactylus, page i 5}

The underside of the tail is rough to the touch, the bristles usually terminating in knobs.

2. The underside of the tail has the bristles ciearly terminating in knobs, this specialization being at its greatest development. Petrodromus sultan, page i 6

The underside of the tail is rough but clearly less specialized when seen through a magnifying glass.

Petrodromus rovumae, page i 6

\section{Petrodromus tetradactylus Peters, I 846}

Four-toed Elephant-Shrew. Groot of bosklaasneus

Distribution: in the Union, known with certainty only from Zululand. (There is said to be a Petrodromus north of the Zoutpansberg, northern Transvaal, but no specimens have been taken.) Portuguese East Africa, including districts of Tete, Beira and Gorongoza. Southern Rhodesia, Melsetter district. The eastern Caprivi, South West Africa (Shortridge). Recorded from north-eastern Angola. Northern Rhodesia, and Nyasaland. Beyond the limits of this work, the Belgian Congo and Tanganyika.

Petrodromus tetradactylus tetradactylus Peters, i 846

i 846. Petrodromus tetradactylus Peters, Ber. Preuss. Akad. Wiss. 258. Tete, on the Zambezi, Portuguese East Africa. Ranges to southern Nyasaland, and has been recorded from the Petauke district, Northern Rhodesia.

Petrodromus tetradactylus venustus Thomas, igo 3

I 903. Petrodromus venustus Thomas, Ann. Mag. N.H. I 2: 339. Namwiwe, about Io ${ }^{\circ}$ S., $33^{\circ}$ E., near Namitawa, northern Nyasaland.

1913. Petrodromus occidentalis Roberts, Ann. Transv. Mus. 4: 69. North-western Rhodesia.

This race has been recorded from the Kafue region, Northern Rhodesia.

Petrodromus tetradactylus tordayi Thomas, igio

I910. Petrodromus tordayi Thomas, Ann. Mag. N.H. 5: 83. Misumba, Sankuru River, south-central Belgian Congo. Recorded from Dundo, north-eastern Angola by Hayman (I95I).

Petrodromus tetradagtylus beirae Roberts, igi 3

1913. Petrodromus beirae Roberts, Ann. Transv. Mus. 4: 69. Zimbiti, Beira, southern Portuguese East Africa. 
Petrodromus tetradagtylus Warreni Thomas, igi 8

1918. Petrodromus tetradactylus warreni Thomas, Ann. Mag. N.H.I: 364. Manguzi (about 6 miles from the coast and about the same distance from the Portuguese border), northern Zululand, Natal.

Petrodromus tetradactylus swynnertoni Thomas, igi 8

I918. Petrodromus tetradactylus swynnertoni Thomas, Ann. Mag. N.H. I: 368 . Mount Selinda, Chirinda Forest, Melsetter, eastern Southern Rhodesia.

Petrodromus rovumae Thomas, I897 Rovuma Four-toed Elephant-Shrew

Distribution: northern Portuguese East Africa and Tanganyika.

Petrodromus rovumae rovumae Thomas, i 897

I897. Petrodromus rovumae Thomas, P.Z.S. 434. Rovuma River, ioo miles inland, Newala district, south-eastern Tanganyika.

I918. Petrodromus (Mesoctenus) mossambicus Thomas, Ann. Mag. N.H. I: 369. Cabaceira (the peninsula forming the northern arm of Mozambique Bay, near Mozambique Island), northern Portuguese East Africa.

Specimens in B.M. from Lumbo, northern Portuguese East Africa.

Petrodromus sultan Thomas, 1897

Knob-bristled Forest Elephant-Shrew. Knopharige bosklaasneus

Distribution: Portuguese East Africa, Tanganyika, Kenya.

Petrodromus sultan sultan Thomas, i897. (Extralimital.) I897. Petrodromus sultani Thomas, P.Z.S. 435. Mombasa, Kenya. 1898. Petrodromus sultan Thomas, P.Z.S. I897: 928. "Misprinted sultani in original description. The name is a substantive in apposition" (Thomas). Ranges to Tanganyika.

Petrodromus sultan sahwanni Thomas \& Wroughton, i907 1907. Petrodromus schwanni Thomas \& Wroughton, P.Z.S. 289. Coguno, Inhambane district, southern Portuguese East Africa.

\section{Genus RHYNGHOGYON Peters, I 847}

1847. Rhynchocyon Peters, Ber. Preuss. Akad. Wiss. 36. Rhynchocyon cirnei Peters. 1918. Rhinonax Thomas, Ann. Mag. N.H. I: 370. Rhynchocyon chrysopygus Günther from Kenya. Valid as a subgenus.

\section{Subgenus RHYNCHOCYON Peters, I847}

The typical subgenus is characterized by the "chessboard" pattern on the back. This genus is very distinct from the others, and should probably be regarded as a special subfamily Rhynchocyoninae. 
Rhynchocyon cirnei Peters, I 847

Checkered Elephant-Shrew

Distribution: north of the Zambezi in Portuguese East Africa; Nyasaland; Tanganyika, with similar forms (? subspecies) in the Belgian Congo.

Rhynchocyon CIRnei CiRnei Peters, I847

1847. Rhynchocyon cirnei Peters, Ber. Preuss. Akad. Wiss. 37. Quelimane, Boror district, north of the Zambezi, coastal Portuguese East Africa. Has been recorded from Zomba, southern Nyasaland.

RHYNGHOGYON CIRNEI MAGRURUS Günther, I88I

I88I. Rhynchocyon macrurus Günther, P.Z.S. I63. "Eastern Africa, banks of Rovuma River, $8^{\circ}$ S." Quoted by Allen as "Rovuma River, $8^{\circ}$ S., Tanganyika Territory." The following comment by Moreau, Hopkins \& Hayman ( I 946) indicates this as on the border of Portuguese East Africa. "No part of the Rovuma River is nearer the Equator than $10^{\circ} 30^{\prime} \mathrm{S}$. There is no evidence that the reference to $8^{\circ} \mathrm{S}$. (which appears in the original) is any other than a pure error. The type specimen was definitely collected by Kirk on the second Rovuma trip with Livingstone. The map in Livingstone (I865) shows clearly the highest point reached on the river. The type locality can be restricted to 'Rovuma River, Tanganyika-Portuguese East African border, east of $38^{\circ} 20^{\prime}$ E'.'”

Rhynchocyon (?) CIRnei ReIGHaRdi Reichenow, i 886

1886. Rhynchocyon reichardi Reichenow, Zool. Anz. 9: 316. Marungu, southern Belgian Congo. Recorded from northern Nyasaland by Thomas.

Rhynchocyon CIRnEI HeNdersoni Thomas, I9O2

1902. Rhynchocyon hendersoni Thomas, Ann. Mag. N.H. I0: 403. Nyika Plateau (probably near Livingstonia), west of Lake Nyasa, northern Nyasaland.

\section{FAMILY E R I N A G E I D A E \\ Subfamily E $\mathrm{r}$ i $\mathrm{n}$ a $\mathrm{c}$ e $\mathrm{i} \mathrm{n}$ a $\mathrm{e}$}

Genus ERINACEUS Linnaeus, I $75^{8}$

I758. Erinaceus Linnaeus, Syst. Nat. Ioth ed. I: 52. Erinaceus europaeus Linnaeus, from Sweden.

1848. Atelerix Pomel, Arch. Sci. Phys. Nat. Genève, 9: 251. Erinaceus albiventris Wagner, from Senegambia. Valid as a subgenus.

1867. Peroëchinus Fitzinger, S.B. Akad. Wiss. Wien. 54, I: $565 ; 56$, г : 856. Erinaceus pruneri Wagner, from the Sudan, which is probably a race of $E$. albiventris Wagner.

1918. Aethechinus Thomas, Ann. Mag. N.H. I: 194. Erinaceus algirus Duvernoy \& Lereboullet, from Algeria. 
Subgenus ATELERIX Pomel, I848

There is only one species in South Africa. There are several species of the genus Erinaceus named from south of the Sahara, but whether any of them are valid or whether, when all are revised, they may stand as races of the prior name in the subgenus, E. frontalis from South Africa, we do not know. But south of the Sahara there seems little difference except the presence or absence of the hallux, which is not a constant character (see J. Allen, 1922, Bull. Amer. Mus. N.H. 47: 13, who reports both conditions in the same litter in E. langi from the Belgian Congo). See also Ellerman \& Morrison-Scott, I95 I, I6. Atelerix is separated subgenerically from Erinaceus as typified by $E$. europaeus on account of having the third upper incisor two-rooted, and a wide median parting among the spines of the crown (impossible or difficult to check in dried skins).

Erinaceus frontalis A. Smith, I83 I

Cape Hedgehog. Krimpvarkie

Distribution: in the Union, the grassveld districts of the Transvaal (including Krugersdorp, Johannesburg, Pretoria, east of Pietersburg, Woodbush), across the Drakensberg into Natal, the Orange Free State (Vredefort, etc.), and the eastern Karroo districts of Cape Province, from near Prieska and Deelfontein to Queenstown (Shortridge), Gradock, Hanover, Middelburg, Steynsburg, southwards to the Albany district; also near Kimberley and Upington (where rare). Has apparently been recorded from Southern Rhodesia. South-West Africa, "sparsely distributed throughout South-West Africa, and appears to be particularly scarce from Great Namaqualand southwards" (Shortridge, I934). South-western Angola.

ERINAGeus frontalis frontalis A. Smith, i83i

I83 I. Erinaceus frontalis A. Smith, S. Afr. J. I: No. 5, Io. Northern parts of the district of Graaff Reinet, Cape Province (here restricted).

I83 I. Erinaceus capensis A. Smith, Philos. Mag. 9: 61. Nom. nud.

I877. Erinaceus fractilis Peters, S.B. Ges. Naturf. Fr. Berl. 79 (lapsus).

Erinageus frontalis angolae Thomas, igi 8

1882. Erinaceus diadematus Dobson, Monogr. Insectivora, I: Io. Not of Fitzinger, I867. Angola.

I918. Aethechinus angolae Thomas, Ann. Mag. N.H. I: 230. Benguela, south-western Angola.

\section{FAMILY S O R I C I D A E}

We have already (I95I, 4I) explained our reasons for the rejection of the subfamily Crocidurinae of Simpson and others. The South African genera would be referable to that group, if recognized, being characterized by having the teeth all white.

We do not think that in the region now under discussion there are more than two valid genera, Crocidura and Suncus. Myosorex, which has long been recognized by virtually all authors, is supposed to differ from these by having seven lower 
teeth, which is said to be unique in the Soricidae. But examination of specimens of this supposed genus shows that the extra seventh tooth is so vestigial that when present it can barely be seen with the aid of a lens and does not seem of generic value even if constant. Our researches lead us to the conclusion, however, that it is very rarely present. Myosorex lacks the long caudal bristles of the tail characteristic of typical Suncus and Crocidura (as does the much later named Sylvisorex), but we do not think this is of more than subgeneric value. There is individual variation in this character in different species of Crocidura, some of which have the bristles barely traceable. We propose therefore to treat Myosorex as a subgenus of Suncus, and Sylvisorex as a synonym of Myosorex.

Pending a general review of the genus Crocidura south of the Sahara (G. Allen lists over one hundred supposed species), little can be offered by way of revision of the species now under discussion, but it does seem fairly clear that, until someone can undertake the herculean task, seven can be maintained as valid. Dollman's revision, I9I $5^{-1916}$, has been extensively used, but is now out of date in some ways; too much attention is paid therein to colour details, some of which seem not at all clear when the specimens are examined; and two characters have been used for specific purposes which do not seem, upon examination, to be very clearly borne out. These are the partial reduction of the elongated bristles on the tail in some species, and the fact that in some forms (olivieri, fumosa) the second upper unicuspid is supposed to be smaller than the third, whereas in related species this is supposed to be not so. But this character, too, has proved individually variable in at least one form (occidentalis).

Our tentative classification of Crocidura in South Africa is based on the following:

Crocidura suaveolens; pygmy species, skull not known to reach I $8 \mathrm{~mm}$. (In South Africa the tail may sometimes individually exceed 70 per cent of the head and body, but when all specimens are taken into account for each race it appears that this is not normal. See also our I95I work for definitions).

Crocidura russula; a few outlying forms may possibly represent this species, which we defined in $195 \mathrm{I}$ as with the skull over $18 \mathrm{~mm}$. but in the majority of specimens under $20 \mathrm{~mm}$.; tail normally less than 70 per cent of head and body.

Crocidura flavescens (January, I 827); giant species, skull not normally under $25 \mathrm{~mm}$., and may be over $30 \mathrm{~mm}$. We very tentatively unite all the larger forms of southern and eastern Africa, and as olivieri (retained by us in I95I) dates from May, I827, that would also be regarded as an outlying race of flavescens.

Then there are left a very large number of named forms which have the skull in the majority of specimens normally at least $20 \mathrm{~mm}$. but under $25 \mathrm{~mm}$. (exceptions in both directions rare). These correspond to the attenuata-like species of Asia, but some of the African names antedate that name.

They further seem to divide quite clearly into three colour groups, which seem to represent (I) a very pale species; (2) a very dark, almost blackish species; and (3) an intermediate species, neither very dark nor very pale.

The very pale species is rare, and seems more or less confined to desert regions. The prior name seems to be Crocidura smithi. It is further characterized by its rather short tail, about 47-57 per cent of the head and body. The other two species occur 
together in one or two places. We tentatively adopt pilosa as the prior name for the very dark species, in the absence of knowledge of extralimital forms, some of which may antedate. The tail is well over half the head and body, rarely over 70 per cent of it, most often though not always over 60 per cent. The prior name for the intermediate species is Crocidura cyanea; but this group appears to contain two species, which occur together in some places in the Union, and which differ in average tail length; typical cyanea and races have the tail rather long, normally (or in the majority of specimens) at least 60 per cent of the head and body; this percentage is not, or only very rarely reached individually, in the species which we define as Crocidura hirta. It may perhaps be mentioned that the well-known East African species fumosa is here regarded as belonging to C. pilosa; and that in typical pilosa and fumosa the skull can, rarely and individually, be under $20 \mathrm{~mm}$. in length, and so the same size as $C$. russula. The majority of specimens, however, so far as measurements are available to us, seem to have the skull over $20 \mathrm{~mm}$., and, at least on average, to be larger than $C$. russula. Most of the species here retained seem to range into East Africa. These results must be regarded as provisional.

With 30 (rarely 32 ) teeth. Genus SUNCUS, page 20

With 28 teeth.

Genus CROCIDURA, page 24

\section{Genus SUNGUS Ehrenberg, I 833}

1833. Suncus Ehrenberg in Hemprich \& Ehrenberg, Symb. Phys. Mamm. 2: k. Suncus sacer Ehrenberg, the Egyptian race of Sorex murinus Linnaeus, from Java.

I838. Myosorex Gray, P.Z.S. I837: I 23, I 24. Sorex varius Smuts. Valid as a subgenus. 1839. Pachyura de Sélys Longchamps, Études de Micromamm. 32. Sorex etruscus Savi.

1904. Sylvisorex Thomas, Abstr. P.Z.S. No. ıо: 12; P.Z.S. 1905, 1904, 2: 190. Crocidura morio Gray, from Southern Nigeria.

I. No caudal bristle-hairs present.

With elongated caudal bristle-hairs at least traceable.

2. Tail longer than head and body.

Tail shorter than head and body.

3. Feet pale.

Feet dark.
Suncus (Myosorex) megalura, ${ }^{1}$ page 24

Suncus (Myosorex) varius, ${ }^{2}$ page 22 Suncus (Myosorex) cafer, page 23

4. The head and body length averages less than $60 \mathrm{~mm}$. in all forms $(65 \mathrm{~mm}$. appears to be the maximum for an individual in South Africa).

Suncus etruscus, page $2 \mathrm{I}$

The head and body is $64 \mathrm{~mm}$. and more (in the majority of specimens examined it is not under $70 \mathrm{~mm}$.).

Suncus lixus, ${ }^{3}$ page 22

${ }^{1}$ It should be noted that the prior name for the group of very longtailed Shrews hitherto referred to "Sylvisorex" appears to be megalura Jentink, I888, from Liberia.

${ }^{2}$ The differences between varius and cafer are not very remarkable, but they seem to occur together.

${ }^{3}$ Suncus lixus; a non-pygmy species closely resembling the Indian species $S$. stoliczkanus, but it 


\section{Subgenus SUNCUS Ehrenberg, I 833}

See Ellerman \& Morrison-Scott, I95 I, 65 for an outline of the main species (or species groups) in Europe and Asia. Several shrews in the Union appear broadly speaking to agree with $S$. etruscus, as defined by us, in size. (Except for gracilis, some of these are closer in size to the Indian form nitidofulvus, which we regarded as a race of etruscus but noted as being a little larger than is normal in the Palaearctic etruscus). As etruscus is known from Algeria and northern Nigeria, and it appears there are very small forms in Eastern Africa, we see no reason why these southern forms should not be regarded as outlying races of $S$. etruscus.

Suncus etruscus Savi, I822 Dwarf Shrew. Kleinste Dwergskeerbekmuis

Distribution: as here understood, in the Union, forms are named from Port Elizabeth and East London, Tulbagh, and Doorn River (Cape Province), the Orange Free State (Bothaville), and Natal, and localities include Pretoria, Transvaal, Aberfeldy (near Harrismith), Orange Free State, Estcourt and Zululand, Natal, Pondoland, Griqualand East, Deelfontein, Klaver and Eendekuil (near Piquetberg), all Cape Province. Very small forms are named from Tanganyika and Kenya; the range includes northern Nigeria, Algeria, the Mediterranean region of Europe from Spain and France eastwards, and to the Caucasus, Russian Turkestan, Persia, Palestine, also Ceylon, India and Burma (for details see Ellerman \& Morrison-Scott, I95I), and perhaps the Malay States.

Suncus etruscus etruscus Savi, i822. (Extralimital)

1822. Sorex etruscus Savi, Nuovo Giorn. de Letterati, Pisa, I: 6o. Pisa, Italy.

Suncus etruscus GRAcilis Blainville, 1838

1838. Sorex gracilis Blainville, Ann. Sci. Nat. Zool. io: i 20. Cape of Good Hope (Port Elizabeth, southern Cape Province, fide Roberts).

192 I. Pachyura chriseos Kershaw, Ann. Durban Mus. 3: 31. Durban, Natal.

Range: Zululand to Port Elizabeth, also quoted by Roberts from Pondoland,

Pretoria, and Viljoensdrift, northern Orange Free State.

Suncus etruscus varilla Thomas, I895

1895. Crocidura (Pachyura) varilla Thomas, Ann. Mag. N.H. I6: 54. East London, eastern Cape Province.

Suncus etruscus orangiae Roberts, i 924

1924. Pachyura orangiae Roberts, Ann. Transv. Mus. Io: 6r. Angra Pequina, Bothaville, north-western Orange Free State. Range includes part of the southern Transvaal.

appears that normally the feet are paler in lixus. We regard gratulus as a southern race of lixus. We have measurements for the largest form of the etruscus group in South Africa (warreni, Transvaal Museum collection), and seven skins give an average of $56 \mathrm{~mm}$. These appear rather smaller than the figures given by Roberts (195I). The form is not represented in London. It is possible that it represents lixus, but its status is not certain. 
Suncus (?) etruscus WARReni Roberts, I929

1929. Suncus warreni Roberts, Ann. Transv. Mus. 13: 84. Doorn River (Van Rhynsdorp district), western Cape Province.

Suncus etruscus tulbaghensis Roberts, I946

1946. Suncus tulbaghensis Roberts, Ann. Transv. Mus. 20: 312. Tulbagh, southwestern Cape Province.

Suncus Etruscus natalensis Roberts, I 946

I946. Suncus orangiae natalensis Roberts, Ann. Transv. Mus. 20: 312. 25 miles southeast of Ixopo, south-western Natal. Range includes Griqualand East, eastern Cape Province, and northwards to Vryheid, Natal.

Suncus lixus Thomas, I 898

Greater Dwarf Shrew. Groter Grysdwergskeerbekmuis

Distribution: Nyika Plateau, Nyasaland; Ndola in Northern Rhodesia; Legogot, Transvaal (Roberts also quotes it from Barberton and Tzaneen, Transvaal, but one of these specimens is rather smaller than usual and may not be authentic). A specimen in London from Kabompo district, Northern Rhodesia (identified as gratulus) is in size as this species but rather too dark for gratulus. The species also occurs in Tanganyika and Kenya.

Suncus Lixus LIxus Thomas, I 898

1898. Crocidura (Pachyura) lixa Thomas, P.Z.S. I897: 930. Nyika Plateau (between ${ }^{\circ} 0^{\circ}$ and $\mathrm{II}^{\circ} \mathrm{S}$. and between $33^{\circ} 4 \mathrm{O}^{\prime}$ and $34^{\circ} \mathrm{Io}^{\prime} \mathrm{E}$., 6000-8700 ft.), northern Nyasaland.

Suncus lixus GRatulus Thomas \& Schwann, 1907

1907. Pachyura gratula Thomas \& Schwann, P.Z.S. 1906: 78ı. Legogot (near White River Village, near the southern border of the Kruger National Park), eastern Transvaal.

\section{Subgenus MYOSOREX Gray, I838}

Suncus varius Smuts, 1832

Forest Shrew. Bosskeerbekmuis

Distribution: Natal (including Estcourt, Illovo, Zululand, etc.); Transvaal (near Wakkerstroom, Legogot, Tzaneen district, Koster and Randfontein (west of Johannesburg) ); Basutoland; in the Cape Province, Little Namaqualand (Port Nolloth, the Kamiesberg), Citrusdal, Clanwilliam, Elgin, Cape Town, Simonstown, Knysna, George, Algoa Bay, Grahamstown, Port St. Johns (Pondoland). Myosorex was recorded from Dordrecht (near Aliwal North) by Shortridge. 
Suncus VARIUS VARIUS Smuts, I 832

1832. Sorex varius Smuts, Enum. Mamm. Cap. io8. Algoa Bay, eastern Cape Province.

I832. Sorex capensis Smuts, Enum. Mamm. Cap. 8. Not of E. Geoffroy, i8 i I.

i 838. Sorex herpestes Duvernoy, L'Institut, 6: i i I (April); Mém. Soc. Mus. H.N.

Strasbourg, 2, 3: LL, 2. Swellendam district, south-western Cape Province (here restricted).

Range: western and southern Cape Province to Zululand and eastern Transvaal.

Suncus Varius tRansvaAlensis Roberts, I 924

1924. Myosorex transvaalensis Roberts, Ann. Transv. Mus. IO: 6I. Koster (south-west of Rustenburg), western Transvaal. Also known from Randfontein (west of Johannesburg) and the Maluti Mountains, Basutoland.

Suncus VARIUS PONDOENSIS Roberts, I 946

1946. Myosorex varius pondoensis Roberts, Ann. Transv. Mus. 20: 3I I. Tegweni, Port St. Johns, Pondoland, eastern Cape Province. Also known from parts of Natal.

Suncus cafer Sundevall, I 846

Dark-footed Forest Shrew. Natalse Bosskeerbekmuis

Distribution: Natal, Zululand; eastern Transvaal (Wakkerstroom, Woodbush, Zoutpansberg); Port St. Johns and Ngqeleni, Pondoland, Pirie (near King William's Town), eastern Cape Province. Chirinda Forest, Umtali and Vumba, eastern Southern Rhodesia.

Suncus CAFER GAFer Sundevall, I 846

1846. Sorex cafer Sundevall, Öfvers. Vetensk. Akad. Förh. Stockholm, 3: I Ig. Port Natal (=Durban), Natal. Range: Natal midlands to Durban (?) (Roberts).

Suncus GAFER SClAteri Thomas \& Schwann, I905

1905. Myosorex sclateri Thomas \& Schwann, Abstr. P.Z.S. No. I5: I0; P.Z.S. I: I 3 I. Ngoye Forest, Eshowe district, Zululand, Natal.

Suncus CAFER Tenuis Thomas \& Schwann, I905

I905. Myosorex tenuis Thomas \& Schwann, P.Z.S. I: 132. Zuurbron, near Wakkerstroom, south-eastern Transvaal. Ranges northwards to Woodbush, Mariepskop and Zoutpansberg, Transvaal, and Southern Rhodesian localities as above.

Suncus CAFER TALPINUS Thomas \& Schwann, I905

1905. Myosorex sclateri talpinus Thomas \& Schwann, P.Z.S. I: 262. Umfolosi, Zululand, Natal. 
Suncus GAFER AfFinis Thomas \& Schwann, I905

1905. Myosorex sclateri affinis Thomas \& Schwann, P.Z.S. I: 262. Sibudeni, Zululand, Natal.

Suncus CAFER SWINNyi Chubb, igo8

1908. Myosorex swinnyi Chubb, Ann. Transv. Mus. I, 2, Suppl.: I. Port St. Johns district, Pondoland, eastern Cape Province.

Suncus megalura Jentink, I888 Climbing Shrew: Klimskeerbekmuis

Distribution: as here understood (better known in literature as Sylvisorex sorella and its races); Vumba (Gorongoza district, border between Southern Rhodesia and Portuguese East Africa), Nyasaland, Northern Rhodesia, Angola (Mombolo). North of the limits of this work, Uganda, Kenya, Abyssinia, the Belgian Congo, Cameroons, Gold Coast and Liberia.

Suncus megalura megalura Jentink, i 888. (Extralimital) I 888. Pachyura megalura Jentink, Notes Leyden Mus. I0: 48. Schlieffelinsville, Junk River, Liberia.

Suncus megalura sorella Thomas, 1898

I898. Myosorex (?) sorella Thomas, P.Z.S. I897: 930. Masuku Plateau, northern Nyasaland.

Suncus Megalura Sheppardi Kershaw, I92 I

1921. Sylvisorex gemmeus sheppardi Kershaw, Ann. Durban Mus. 3: 32. Vumba, Gorongoza Province, near the Southern Rhodesian-Portuguese East African border.

Sungus megalura angolensis Roberts, ig29

1929. Sylvisorex angolensis Roberts, Ann. Transv. Mus. 13: 84. Mombolo (=Namba), I I ${ }^{\circ} 35^{\prime}$ S., western central Angola.

\section{Genus GROGIDURA Wagler, I 832}

I832. Crocidura Wagler, Isis, 275. Sorex leucodon Hermann, from Strasbourg, eastern France.

I86o. Rhinomus Murray, Proc. Roy. Phys. Soc. Edinburgh, 2: I59. Rhinomus soricoides Murray, from southern Nigeria.

i9ı. Heliosorex Heller, Smithson. Misc. Coll. 56, i 5: 6. Heliosorex roosevelti Heller, from East Africa.

See particularly Dollman, On the African shrewes belonging to the genus Crocidura; Ann. Mag. N.H. I915, 15: 507, 562; I6: 66, I24, 357, 506 and 1916, I7: 188.

The listing of species in this genus is provisional.

I. Small species, the condylobasal length of the skull does not reach $18 \mathrm{~mm}$. Crocidura suaveolens, page 25

Larger species, the condylobasal length of the skull is not normally below I $8 \mathrm{~mm}$. 
2. Very large species, the condylobasal length of the skull is not normally under $25 \mathrm{~mm}$.

Crocidura flavescens, page 30

Smaller species, the condylobasal length of the skull is normally less than $25 \mathrm{~mm}$.

3. Small-medium in size; the majority of the specimens have the condylobasal length of the skull less than $20 \mathrm{~mm}$., or $20 \mathrm{~mm}$. at maximum.

Crocidura russula, page 26

Large-medium in size; the majority of the specimens have the condylobasal length of the skull more than $20 \mathrm{~mm}$. in length.

4. Very dark, blackish in colour or nearly so dorsally.

Less dark in colour.

5. Very pale in colour dorsally.

Less pale in colour.

$-4^{2}$

6. Tail averages relatively longer, normally at least 60 per cent of the head and body length.

Crocidura cyanea, page 27

Tail averages shorter, below 60 per cent of the head and body length.

Crocidura hirta, ${ }^{3}$ page 28

Crocidura suaveolens Pallas, i 8 i I

Tiny Musk-Shrew; Lesser Whitetoothed Shrew. Dwergskeerbekmuis

Distribution: widely distributed in the Palaearctic region, from Europe south of the Baltic to the Pacific coast of China, Persia, etc., Morocco and Algeria. Forms probably referable to this species occur in the Sudan, Kenya, Uganda, Tanganyika; and in South Africa, from Angola (Chitau, Capelongo, Caconda, Mossamedes district), Nyasaland, Northern Rhodesia, in South-West Africa from the Okavango region (Grootfontein district to western Caprivi), Ngamiland, etc., and in the Union, Tzaneen and Pretoria, Transvaal.

Crocidura suaveolens suaveolens Pallas, i8 i i. (Extralimital) I8I I. Sorex suaveolens Pallas, Zoogr. Ross. Asiat. I: I33. Khersones, Crimea, southern Russia.

Crocidura suaveolens bicolor Bocage, i 898

I898. Crocidura bicolor Bocage, J. Sci. Math. Phys. Nat., Lisboa, I: 29. Gambos, Mossamedes district, Angola.

Crocidura suaveolens woosnami Dollman, igi 5

I915. Crocidura bicolor woosnami Dollman, Ann. Mag. N.H. 15: 516. Lake Ngami, Bechuanaland. Range: Transvaal, Northern Rhodesia (Roberts), the Kalahari.

${ }^{1}$ Rare individual exceptions in the forms beirae and nyikae. In a genus as large as this, individual exceptions to some of the characters given seem inevitable.

${ }^{2}$ Rare individual exceptions in pilosa, shortridgei and (in East Africa) fumosa.

${ }^{3}$ As thus defined, these two species (cyanea and hirta) occur together in some places. 
Crocidura suaveolens hendersoni Dollman, igi 5

I9I 5. Crocidura bicolor hendersoni Dollman, Ann. Mag. N.H. 15: 517. "Livingstonia, $4000 \mathrm{ft}$., Nyasaland. This is about $10^{\circ} 35^{\prime} \mathrm{S}$. on the west side of Lake Nyasa" (Moreau, Hopkins \& Hayman, I 946).

Based on one specimen with badly broken skull.

Grocidura russula Hermann, I 780

Common European White-toothed Shrew. Mariko-skeerbekmuis

Distribution: widely distributed in the Palaearctic region of Europe south of the Baltic eastwards intermittently to Japan, South-western Asia; Morocco, Algeria. Evidently represented in East Africa, and similar forms occur in Angola, Northern Rhodesia, and parts of the Transvaal (Marico, near Barberton, Pretoria, etc.)

Crocidura russula russula Hermann, i 780 . (Extralimital) I780. Sorex russulus Hermann in Zimmermann, Geogr. Gesch. 2: 382. Near Strasbourg, Bas-Rhin, eastern France.

Crocidura Russula mariquensis A. Smith, i 844 I844. Sorex mariquensis A. Smith, Illustr. Zool. S. Africa, Mamm. pl. 44, fig. I. "Wooded ravine near the Tropic of Capricorn." Marico River, near its junction with the Limpopo, western Transvaal (Roberts).

(1836. Sorex concolor A. Smith, Rept. Exped. Explor. C. Africa, 43. "Country about Latakoo" = Kuruman, northern Cape Province. Status uncertain).

Crocidura Russula silacea Thomas, I895

I895. Crocidura silacea Thomas, Ann. Mag. N.H. I6: 53. Figtree Creek, de Kaap, Barberton district, eastern Transvaal. (Also recorded from Pretoria, Transvaal).

Crocidura (?) Russula pitmani Barclay, $193^{2}$

I932. Crocidura pitmani Barclay, Ann. Mag. N.H. Io: 440. Maluwe-Serenje district, $3800 \mathrm{ft}$., Northern Rhodesia. Based on one "barely adult" female. Status dubious.

Crocidura (?)Russula chitauensis Hill \& Carter, 1937

1937. Crocidura chitauensis Hill \& Carter, Amer. Mus. Novit. No. 937: 3. Chitau, 4930 ft., Central Angola.

Crocidura (?)Russula maQuassiensis Roberts, i946

1946. Crocidura maquassiensis Roberts, Ann. Transv. Mus. 20: 312. Maquassi, Wolmaransstad district, western Transvaal. Based on one specimen with all the measurements of the russula group except the tail which exceeds 70 per cent of the head and body. 
Crocidura cyanea Duvernoy, 1838

Reddish-grey Musk-Shrew. Rooigrysskeerbekmuis

Distribution: Cape Province; the Kamiesberg, Little Namaqualand, Citrusdal (Shortridge used the name martensi for most of the specimens presumably referable to cyanea, which is the sole form noted by Roberts for the western Cape Province); Oudtshoorn district, Cradock, Deelfontein, Port St. Johns, and Vryburg. Zululand; the Transvaal, districts of Legogot, Woodbush, Zoutpansberg, Pietersburg, Johannesburg, etc. Swaziland. Recorded from Salisbury, Southern Rhodesia. Damaraland, South-West Africa. Northern Rhodesia. Angola. Northwards to the Belgian Congo, and apparently as far north as the Sudan.

Crocidura cyanea cyanea Duvernoy, i8 38

i838. Sorex cyaneus Duvernoy, L'Institut, 6: i i (April); Mém. Soc. Mus. H.N. Strasbourg, 2, 3: LL, 2. "La Rivière des Éléphants, au sud de l'Afrique."

I841. Sorex infumatus Wagner in Schreber, Säugth. Suppl. 2: 76. Cape of Good Hope. 1860. Sorex argentatus Sundevall in Grill, K. Svenska Vetensk. Akad. Handl. 2:

No. Io, i6, footnote. Roodeval, Oudtshoorn division, south-western Cape Province.

Range: quoted by Roberts from western Cape Province northwards to Damaraland, and (argentata) Oudtshoorn division and Cradock, Cape Province. Deelfontein (British Museum).

Crocidura cyanea martensi Dobson, i8go

189o. Crocidura martensii Dobson, Ann. Mag. N.H. 6: 496. "Cape of Good Hope." 1931. Crocidura holobrunneus Roberts, Ann. Transv. Mus. I4: 225. Mariepskop, Pilgrims Rest district, eastern Transvaal. (This is not certainly separable from martensi in colour.)

Range: recorded from Zululand and Zoutpansberg, Transvaal.

Crocidura cyanea elegta Dollman, igio

I9 10. Crocidura electa Dollman, Ann. Mag. N.H. 5: i 75. "Kamtoby," south of Lake Tanganyika, Northern Rhodesia. "We have been unable to find this on any map, and residents near the south end of Lake Tanganyika know of no such place. Brédo has suggested to us that 'Kamtoby' is a mistake for 'Kambole' (pronounced as three syllables), 40 miles west of Abercorn, Northern Rhodesia, and an old-established mission station at $4000 \mathrm{ft}$. overlooking the south end of Lake Tanganyika. This locality Kambole, taken in conjunction with the date of the specimen, fits well with the dates and localities of other specimens obtained by the collector.' (Moreau, Hopkins \& Hayman, I946.)

Crocidura cyanea pondoeinsis Roberts, I9I3

1913. Crocidura pondoensis Roberts, Ann. Transv. Mus. 4: 7r. Ngqeleni district, west of Port St. Johns, Pondoland, eastern Cape Province. Roberts says it also occurs in Zululand, but it is very close to martensi, perhaps a synonym of that form. 
Crocidura cyanea erica Dollman, igi 5

I9I 5. Crocidura erica Dollman, Ann. Mag. N.H. 15: 514. Pungo Andongo, northern Angola. Also recorded from Hanha, Luimbale and Benguela, Angola. A long-tailed form according to the measurements given by Hill \& Carter.

Grocidura Gyanea vryburgensis Roberts, I 946

1946. Crocidura martensi vryburgensis Roberts, Ann. Transv. Mus. 20: 313. Vryburg, northern Cape Province.

Crocidura hirta Peters, $185^{2}$

Zambezi Lesser Red Musk-Shrew. Sambesiese Kleinrooiskeerbekmuis

This is much like the earlier-named C. cyanea, but occurs with it, and has an average shorter tail.

Distribution: Angola (Caconda, Mossamedes, Bihé), Southern Rhodesia (Salisbury, Mt. Chirinda, etc.), Northern Rhodesia, Nyasaland, South-West Africa (Kaokoveld, Waterberg, etc.), Portuguese East Africa (Tete, Beira, near Inhambane and Lumbo, north of the Zambezi), the eastern Transvaal (Pietersburg, Tzaneen, Barberton district), Zululand, Natal and Swaziland. Further to the north the Belgian Congo, Tanganyika and probably elsewhere in East Africa.

Grocidura hirta hirta Peters, 1852

I852. Crocidura hirta Peters, Reise nach Mossambique, Zool. I, Säugeth., 78. Tete, Zambezi, Portuguese East Africa.

1852. Crocidura canescens Peters, loc. cit. 83. Tete, Portuguese East Africa.

I852. Crocidura annellata Peters, loc. cit. 85. Tete, Portuguese East Africa.

Ranges to Northern Rhodesia (Balovale, Ndola, and other localities), Nyasaland, the Kaokoveld in South-West Africa, Angola, Maputa in northern Zululand, Tanganyika, etc.

Crocidura hirta sagralis Peters, 1852

1852. Crocidura sacralis Peters, Reise nach Mossambique, Zool. I, Säugeth. 82. Cabaceira Peninsula (north of the Zambezi), Portuguese East Africa.

Crocidura hirta flavidula Thomas \& Schwann, I905

I905. Crocidura flavescens flavidula Thomas \& Schwann, P.Z.S. I: 264. Umfolosi, Zululand, Natal. Range includes Swaziland, and Legogot and Tzaneen, eastern Transvaal.

Crocidura hirta beirae Dollman, igi5

I9I5. Crocidura beirae Dollman, Ann. Mag. N.H. 15: 51 I. Beira, south of the Zambezi, coastal Portuguese East Africa. A relatively large race.

Crocidura (?)hirta cuanzensis Hill \& Carter, 1937

1937. Crocidura cuanzensis Hill \& Carter, Amer. Mus. Novit. No. 937; 2. Chitau, 4930 ft., central Angola. 
Incertae sedis:

CRocidura NigRicans Bocage, i 889

I889. Crocidura nigricans Bocage, J. Sci. Math. Phys. Nat., Lisboa, I: 28. Quindumbo, Benguela district, Angola.

Possibly an earlier name for the next species; colour very dark, blackish, but condyloincisive length $20 \mathrm{~mm}$. or less, fide Hill \& Carter. We have not seen this species.

Crocidura pilosa Dobson, I 890

Black Musk-Shrew. Swartskeerbekmuis

Distribution: the Orange Free State, Pretoria and Woodbush, Transvaal, Mooi River, Natal; Coguno (near Inhambane), Portuguese East Africa, the western Caprivi in northern South-West Africa, Southern Rhodesia, Angola, Nyasaland (Chiromo, Nyika Plateau, etc.), Northern Rhodesia (where it occurs with hirta). As here understood, Kenya, Tanganyika, Abyssinia, southern Belgian Congo.

CRocidura pilosa pilosa Dobson, i 890

I 89o. Crocidura pilosa Dobson, Ann. Mag. N.H. 6: 496. Transvaal; Roberts nominates Pretoria as type locality. Range includes the Orange Free State.

Crocidura pilosa sylvia Thomas \& Schwann, igo6

1906. Crocidura sylvia Thomas \& Schwann, P.Z.S. 587. Woodbush, eastern Transvaal. Also recorded from Coguno, Inhambane district, Portuguese East Africa and Mooi River, Natal.

Grocidura Pilosa neavei Wroughton, ig07

1907. Crocidura neavei Wroughton, Manchester Mem. 5I, 5: 7. Kafue River, Northern Rhodesia. "After comparing dates and localities of other specimens in Neave's collection we are satisfied that the type locality can be restricted to 'Upper Kafue River, near Ndola, Northern Rhodesia'" (Moreau, Hopkins \& Hayman, I946). Hill \& Carter record a specimen from Humpata, Angola.

This and the last race are supposed to have the caudal bristle hairs few, restricted to the base of the tail; but at least in sylvia there is individual variation in this character.

Crocidura pilosa turba Dollman, igio ${ }^{1}$

I910. Crocidura turba Dollman, Ann. Mag. N.H. 5: i 76. Chilui Island, Lake Bangweulu, Northern Rhodesia.

(I9I5. Crocidura zena Dollman, Ann. Mag. N.H. I5: 5I . Chilui Island, Lake Bangweulu, Northern Rhodesia).

The British Museum has specimens from several localities in Northern Rhodesia, and from the southern Belgian Congo.

1 The form Crocidura luna Dollman, igro, Ann. Mag. N.H. 5: i 75, Bunkeya River, Katanga, southern Belgian Congo, has been recorded from the Melsetter district, Southern Rhodesia, but we have reason to think that these specimens are not authentic. The type of luna is more like cyanea in colour, whereas the Southern Rhodesian specimens seem to belong with pilosa. 
Crocidura pilosa johnstoni Dollman, i9i 5

I9I5. Crocidura fumosa johnstoni Dollman, Ann. Mag. N.H. 15: 510. Chiromo, I $6^{\circ} 30^{\prime}$ S., $35^{\circ}$ Io' E., southern Nyasaland.

Crocidura pilosa angolae Dollman, igi 5

I9I5. Crocidura turba angolae Dollman, Ann. Mag. N.H. 15: 510. Bailundu country, Angola.

I9I5. Crocidura ansorgei Dollman, Ann. Mag. N.H. 15: 5I I. Duque de Bragança, north-western Angola.

Crocidura pilosa nyikae Dollman, i9I5

19I5. Crocidura beirae nyikae Dollman, Ann. Mag. N.H. 15: 512. Nyika Plateau, $7000 \mathrm{ft}$., northern Nyasaland.

CRocidura PILOSA Shortridgei St. Leger, I932

1932. Crocidura shortridgei St. Leger, Ann. Mag. N.H. Io: 84. Popa Falls, western Caprivi, northern South-West Africa. Range: the Okavango and Caprivi district.

Crocidura smithi Thomas, I 895

Desert Musk-Shrew. Kalahari-skeerbekmuis

Distribution: in the Union known from the Orange Free State and the northern Cape Province (the Molopo River district, Kuruman). South-West Africa; Gobabis district, Damaraland, the Caprivi, and the Kalahari desert. Angola (Capelongo, in the south-western portion). If the form katharina belongs here, the northern part of Northern Rhodesia (Ndola).

Allied forms from the Sudan, Abyssinia and Kenya.

Crocidura SMithi smithi Thomas, i895 (Extralimital)

I895. Crocidura (Crocidura) smithii Thomas, Ann. Mag. N.H. I6: 5I. Upper Webi

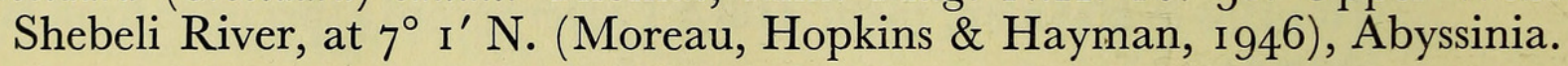

Crocidura smithi deserti Schwann, igo6

I906. Crocidura deserti Schwann, P.Z.S. I03. Molopo River, west of Morokwen, near the Bechuanaland border, extreme northern Cape Province. Range: South African localities quoted above, Ndola excepted.

Crocidura (?)Smithi Katharina Kershaw, I922

I922. Crocidura katharina Kershaw, Ann. Mag. N.H. Io: Io I. Ndola, near the Congo border, Northern Rhodesia. Rather a small form; skull length of type approximately $20 \mathrm{~mm}$.

Crocidura flavescens I. Geoffroy, 1827

Giant Musk-Shrew. Rooiskeerbekmuis

The broadest possible view is taken of this species, which differs from those above in its larger size. There are some distinct types here listed as races, but so far as we 
know, none of them occur together. There does not seem to be any striking difference between occidentalis and its supposed races and flavescens, and there is no clear difference in the size of their skulls when all specimens are taken into account. The tail tends to be relatively shorter in flavescens than in olivieri, occidentalis and allies, but the differences do not amount to very much.

Distribution: in the Union, the eastern Transvaal (near Wakkerstroom), Zululand, Natal (including Estcourt and Durban), and in the Cape Province, near Kokstad, Pondoland, Uitenhage, King William's Town, Knysna, Tokai (near Cape Town), Elgin and Franschhoek (near Paarl). South-West Africa; recorded from the Okavango region. Eastern Southern Rhodesia. Northern Rhodesia. Angola. Most of East Africa (probably excepting Somaliland), and much of West Africa, to Sierra Leone. Northwards to Egypt (olivieri, Lesson, May, 1827).

Crocidura flavescens flavescens I. Geoffroy (January), i 827

I827. Sorex flavescens I. Geoffroy, Dict. Class, II: 324 (January). Mém. Mus. H.N. Paris, I5: I 26 (December). "Le Cafrérie et le pays des Hottentots." Roberts nominates King William's Town, eastern Cape Province.

I829. Sorex cinnamomeus Lichtenstein, Verh. Ges. Naturf. Fr. Berlin, I: 385. Kaffraria.

I833. Sorex capensis A. Smith, S. Afr. J. 2: 62. Renaming of flavescens.

I 846. Sorex rutilus Sundevall, Ofvers. Vetensk. Akad. Förh. Stockholm, 3: I I 9, note. "Port Natal" = Durban, Natal.

Range: eastern Cape Province to Natal and eastern Transvaal.

Crocidura flavescens occidentalis Pucheran, i 855

1855. Pachyura occidentalis Pucheran, Rev. Zool. Paris, 7: I54. Gabon, West Africa. Has been recorded from Duque de Bragança, northern Angola.

Crocidura flavescens anchietae Bocage, i 889 I889. Crocidura anchietae Bocage, J. Sci. Math. Phys. Nat., Lisboa, I: 26. Caconda (Benguela district), Angola.

Grocidura flavescens zuleika Dollman, igi 5

I9I 5. Crocidura nyansae zuleika Dollman, Ann. Mag. N.H. 15: 509. Chirinda Forest. Melsetter district, eastern Southern Rhodesia.

Grocidura flavescens hera Dollman, igi 5

I9 15. Crocidura hera Dollman, Ann. Mag. N.H. 15: 509. Shire highlands, Blantyre district, southern Nyasaland.

Crocidura flavescens herero St. Leger, I932

1932. Crocidura nyanzae herero St. Leger, Ann. Mag. N.H. Io: 85. Mbambi, Grootfontein-Caprivi border, South-West Africa. The British Museum also has specimens from Northern Rhodesia. 
Crocidura flavescens knysnae Roberts, 1946

1946. Crocidura flavescens knysnae Roberts, Ann. Transv. Mus. 20: 3 I3. Knysna, southern Cape Province. Ranges westwards to the Cape Peninsula.

The following may belong to this group:

Crocidura luimbalensis Hill \& Carter, I937, Amer. Mus. Novit. No. 937: i. Luimbale, I $2^{\circ}$ I $5^{\prime}$ S., $15{ }^{\circ} 20^{\prime}$ E., Angola.

? Unidentifiable: Crocidura capensoides, described as Sorex capensoides A. Smith, I 838 , S. Afr. J. 2: 62. Near Cape Town. Type in British Museum, in a very bad condition.

\section{FAMILY PO T A M O G A L I D A E}

Genus POTAMOgale du Chaillu, i86o

186o. Cynogale du Chaillu, Proc. Boston Soc. N.H. 7: 36 r. Cynogale velox du Chaillu. Not of Gray, I837.

i86o. Potamogale du Chaillu, Proc. Boston Soc. N.H. 7: 363. Cynogale velox du Chaillu.

I862. Mythomys Gray, P.Z.S. I86I: 275. Cynogale velox du Chaillu.

ı865. Bayonia Bocage, Mem. Acad. Sci. Lisboa, 4, I: Mem. 2, p. 3. I865, P.Z.S. 402. Bayonia velox $=$ Potamogale velox du Chaillu.

Potamogale velox du Chaillu, I86o

Otter-Shrew

Distribution: Angola (recorded from Chitau, Duque de Bragança, Caconda, Ambaca, near Loanda, Rio Côle), and Northern Rhodesia, the Bangweulu swamps where it is not common. Also the Belgian Congo, Gabon and southern Nigeria.

Potamogale velox du Chaillu, i86o

ı86o. Cynogale velox du Chaillu, Proc. Boston Soc. N.H. 7: 36r. Equatorial Africa = Gabon, West Africa.

i 895. Potamogale allmani Jentink, Notes Leyden Mus. I6: 236 . Old Calabar, West Africa.

I9I 5. Potamogale velox argens Thomas, Ann. Mag. N.H. I6: 470. Medje, on a branch of the Ituri, about $27^{\circ} 4 \mathrm{o}^{\prime}$ E., $2^{\circ} 2 \mathrm{O}^{\prime}$ N., Belgian Congo.

\section{FAMILY C H R Y S O C H L O R I D A E}

On the genera see Roberts, I924, Ann. Transv. Mus. 10: 63; Forcart, 1942, Beiträge zur Kenntnis der Insectivoren-familie Chrysochloridae, Rev. Suisse Zool. 49: I. An attempted revision of the Genera.

We suggest that there are five valid genera, and perhaps ten or eleven species, in the region south of the Zambezi-Cunene rivers, with two other groups of species (perhaps a few more) north of that region. The dental formula is not necessarily a 
valid generic (or even specific) character in this order; see Ellerman \& MorrisonScott, I95 I, 29, 30. For instance in the original series of Amblysomus gunningi (the type of Roberts' supposed genus "Neamblysomus"), all collected at the same time and place, the type skull has ro/Io teeth each side; one specimen has Io/Io on one side and 9/10 on the other; the other half dozen or so specimens have 9/10 teeth each side. Again, a large series of restricted Chrysochloris has been collected in Namaqualand and the western Cape Province; in this, 40 teeth is the normal dentition, but it is not constant; the form "tenuis" was based upon a specimen which has 36 teeth, and the form namaquensis sometimes has 9 upper teeth instead of the normal io, and sometimes 9 on one side and Io the other (Broom, in litt).

The dental formula is incidentally known to be highly variable within the Eurasian genus Talpa; see Schwarz's classification, I948, P.Z.S. I I8: 36-48.

We therefore ignore dental formula as a generic character in the Chrysochloridae, and suggest that the characters of the functional clawed digging fingers and the bullae are important, and that there are five valid genera only, which may be keyed as follows:

I. Larger species, the length of the skull is $32.8 \mathrm{~mm}$. and more, its width $20.2 \mathrm{~mm}$. and more; the upper toothrow I $2.7 \mathrm{~mm}$. and more (Roberts). Zygomatic arch produced upwards posteriorly and meeting the lambdoid crest at the back.

Genus CHRYSOSPALAX, page $4^{\mathrm{I}}$

Smaller species, the length of the skull $30.5 \mathrm{~mm}$. and less, its width $20 \mathrm{~mm}$. and less; upper toothrow under I $2 \mathrm{~mm}$. (Roberts). Zygomatic arch not produced backwards as just described, and the posterior part of the skull much less specialized.

2. With temporal bullae, showing clearly in superior aspect of the skull. No temporal bullae.

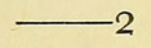

3. Manus with large inner digit pad and 3 well-developed claws, the third not much smaller than the other two. Frontal region of skull more expanded.

Genus CRYPTOCHLORIS, page 39

Manus with no large inner digit pad and 2 well-developed claws; frontal region of skull less expanded.

Genus CHRYSOCHLORIS, page $39^{1}$

4. Manus with 3 well-developed claws, the third not very much smaller than the others. Length of skull $20.6 \mathrm{~mm}$. and less, its width I6.I-I $8.2 \mathrm{~mm}$. (breadthlength index 85-90, Roberts). Genus EREMITALPA, page 38

Manus with 2 well-developed claws. Skull not under $21 \mathrm{~mm}$., its width proportionately less (index below $8_{3}$, Roberts).

Genus AMBLYSOMUS, page 34

"Chrysotricha" = "Calcochloris", "Neamblysomus" and "Chlorotalpa" are here regarded as being synonyms of Amblysomus.

1 The extralimital East African Chrysochloris stuhlmanni Matschie, I894, with its race fosteri St. Leger, I931, Uganda belong to Chrysochloris as here understood (not "Chlorotalpa") and differ from Chrysochloris asiatica in the considerably narrower skull, and the bullae show less in upper view of skull than they do in the South African species. 


\section{Genus AMBLYSOMUS Pomel, I 848}

I 848. Amblysomus Pomel, Arch. Sci. Phys. Nat. Genève, 9: 247. Chrysochloris hottentotus A. Smith.

1867. Calcochloris Mivart, J. Anat. Phys. 2 (= ser. 2, vol. I): I33. Chrysochloris obtusirostris Peters.

1907. Chrysotricha Broom, Trans. S. Afr. Phil. Soc. I8: 303. Chrysochloris obtusirostris Peters

1924. Neamblysomus Roberts, Ann. Transv. Mus. Io: 64. Chrysochloris gunningi Broom.

1924. Chlorotalpa Roberts, Ann. Transv. Mus. Io: 64. Chrysochloris duthieae Broom. I942. Huetia Forcart, Rev. Suisse Zool. 49: 2. Chrysochloris leucorhina Huet.

Authors who divide this group into some five genera should note that Calcochloris antedates Chrysotricha for the obtusirostris group.

I. Skull wide, its width $\mathrm{I} 5.7-\mathrm{I} 7 \mathrm{~mm}$., its length $2 \mathrm{I}-24.2 \mathrm{~mm}$. (Breadth-length index 69-73, Roberts; 76, four skulls in B.M.). Amblysomus obtusirostris, page 35 Skull narrower (breadth-length index $58-66$, Roberts). In species with the skull of similar size (i.e., below $25 \mathrm{~mm}$.) the width is $14^{-16} \mathrm{~mm}$., but only once over I 5.7 mm. in Roberts' figures and in B.M.

$-2$

2. Relatively small species, skull length $25 \mathrm{~mm}$. and less. Usually with distinct light markings on part of the face. Amblysomus sclateri, ${ }^{1}$ page 35 Relatively large species, skull in long series quoted by Roberts, and in B.M., only less than $25 \mathrm{~mm}$. in three individuals. In adult, usually little or no pale markings on the face.

3. Extra hindmost molars, if present, shaped differently from those in front of them. Posterior talonid of lower molars absent or if present, feebly developed. Amblysomus gunningi, ${ }^{2}$ page $3^{8}$

Extra hindmost molars absent. With well-developed posterior talonid to lower molars. Amblysomus hottentotus, ${ }^{3}$ page 36

${ }^{1}$ A. sclateri represents Chlorotalpa of Roberts. All named forms from the Union are regarded as conspecific. The species (?) $A$. marleyi Roberts seems closely allied, but it is described as having 36 teeth, and sclateri and allies have 40 teeth. But as already noted dental formula is not constant in several of the other species, and marleyi might be merely an outlying race of sclateri.

${ }^{2}$ Amblysomus gunningi, type of Neamblysomus Roberts. For variation in dental formula see above. Not a well-known species. The characters given are mainly from Roberts, who uses the shape of the hindmost molars to distinguish the species from the sclateri group.

${ }^{3}$ In addition, the species Amblysomus leucorhinus has, according to Hill \& Carter, been recorded from Angola, where rare. It is not represented in London, and no specimens were seen in the South African Museum (Cape Town) nor in the Transvaal museum. Its characters would seem to be, from the original description, total length of skull 2 I mm., bullae not showing in superior aspect of skull, apparently two functional claws in the manus, face white, teeth Io/Io. It is probably the prior name for the group referred by Roberts to Chlorotalpa. The form congicus Thomas, I 9 io from the Belgian Congo, which has been regarded as a race of leucorhinus, has more of the face white than is the case in sclateri and obtusirostris and seems to have the width of the skull (about 68 per cent) slightly wider than sclateri and intermediate between it and obtusirostris, its skull length being about as in leucorhinus. 
Amblysomus obtusirostris Peters, I85 I

Yellow Golden Mole. Geel Kruipmol

Type of Calcochloris Mivart, I868 (which antedates Chrysotricha Broom, I907).

Distribution: Zululand and Portuguese East Africa (districts of Inhambane, Lourenço Marques, etc.).

Amblysomus obtusirostris obtusirostris Peters, i 85 I I 85I. Chrysochloris obtusirostris Peters, Ber. Preuss. Akad. Wiss. 467. Inhambane, $24^{\circ}$ S., coastal Portuguese East Africa.

Amblysomus obtusirostris chrysillus Thomas \& Schwann, I905

I905. Amblysomus chrysillus Thomas \& Schwann, P.Z.S. I: 26 I. Delagoa Bay, coastal southern Portuguese East Africa. Ranges to the Umfolosi River, Zululand. The skull is smaller than in related forms.

Amblysomus obtusirostris Limpopoensis Roberts, I 946

I946. Chrysotricha obtusirostris limpopoensis Roberts, Ann. Transv. Mus. 20: 3 I I. Masiene, north of the mouth of the Limpopo River, southern Portuguese East Africa.

Amblysomus leucorhinus Huet, I 885 Congo Golden Mole

Distribution: has been recorded from Cuango, north-central Angola (Hill \& Carter). The Belgian Congo, the Cameroons.

Amblysomus leugorhinus leugorhinus Huet, I 885 I 885. Chrysochloris leucorhina Huet, Nouv. Arch. Mus. H.N. Paris, 8:8. The Congo, on the coast of the Gulf of Guinea. Has been recorded from Angola.

Amblysomus sclateri Broom, 1907. (Part of the genus Chlorotalpa of Roberts.) Sclater's Golden Mole. Sclaterse Kruipmol

Distribution: Possibly Zululand, if marleyi can be referred here; Wakkerstroom, Transvaal; the Orange Free State; Basutoland; in the Cape Province, Sutherland, Beaufort West, New Bethesda (north of Graaff Reinet, specimen in B.M.), Herschel (near Aliwal North), Knysna and Port Elizabeth.

Amblysomus sclateri sGlateri Broom, i907

1907. Chrysochloris sclateri Broom, Ann. Mag. N.H. 19: 263. (March, I907). Beaufort West, western central Cape Province. Range includes Herschel and Basutoland (part).

Amblysomus sclateri duthieae Broom, ig07

1907. Chrysochloris duthieae Broom, Trans. S. Afr. Phil. Soc. I 8: 292. (24 December, I907). Knysna, southern Cape Province. Also known from Port Elizabeth. 
Amblysomus salateri montanus Roberts, I924

1924. Chlorotalpa montana Roberts, Ann. Transv. Mus. I0: 64. Kastrol Nek, 6,500 ft., east of the town of Wakkerstroom, south-eastern Transvaal.

Amblysomus (?)SGLATERI MARLEYi Roberts, I93 I

I93 I. Amblysomus marleyi Roberts, Ann. Transv. Mus. I4: 225. Ubombo, Zululand, Natal. Possibly a valid species; see remarks above, page 34 , footnote I.

Amblysomus SGLATERi guillarmodi Roberts, 1936

1936. Chlorotalpa guillarmodi Roberts, Ann. Transv. Mus. 18: 253. Mamathes, north-western Basutoland. Ranges to Clocolan in the eastern Orange Free State.

Amblysomus sGlateri SHORTRIDgei Broom, i950

1950. Chlorotalpa shortridgei Broom, Ann. Transv. Mus. 21: 238. Sutherland (roughly Ioo miles west of Beaufort West), western-central Cape Province.

Apparently a similar form has been named from the Inyanga district of Southern Rhodesia.

\section{Amblysomus hottentotus A. Smith, 1829}

Hottentot Golden Mole. Hotnotkruipmol

There are two main colour types found in this group, a reddish and a blackish (or dark brown). Roberts refers them to two groups of species, and says that both occur together in Pondoland and Grahamstown. Whether two valid species or two colour phases are indicated here is not yet clear. Hewitt (I93I) recognized one form in Pondoland characterized by the dorsal area being glossy blackish, and said that a small proportion of the Pondoland specimens are coloured much like ordinary hottentotus (i.e., reddish), while at Grahamstown the colour of the specimens was said to vary considerably, some being quite dark above although the majority were reddish brown, and with albinos and semi-albinos occasionally found. Colour distinctions in subterranean mammals are not well understood. There appear to be no other differences between the two supposed groups that are of great importance, and we prefer to suggest that possibly two colour phases are indicated in this species rather than to recognize two distinct species based on colour alone.

Distribution: the Transvaal (Wakkerstroom, Carolina, Belfast, etc.), Swaziland, Zululand, Natal (including Pietermaritzburg, Durban, near Verulam, etc.), the Orange Free State (Heilbron, Fouriesburg, etc.) and in the Cape Province, Pondoland, King William's Town, Grahamstown, Bedford, Somerset East, Port Elizabeth, Fort Beaufort, near Kokstad, Knysna, George, Swellendam, Stellenbosch, Franschhoek (near Paarl).

It seems that too many races have been named in this species. 
Amblysomus hottentotus hottentotus A. Smith, I829

I829. Chrysochloris hottentotus A. Smith, Zool. J. 4: 436. "Interior parts of South Africa"; Grahamstown, eastern Cape Province according to Roberts.

I83 I. Chrysochloris holosericea Lichtenstein, Darst. Säugeth. pl. 4I and text. "Interior of Cape Colony on the borders of Kafferland."

I841. Chrysochloris affinis Wagner, in Schreber, Säugth. Suppl. 2: i23. No locality. I841. Chrysochloris albirostris Wagner, loc. cit., I 24. "Kafferland." Based on a young specimen according to Roberts.

I84I. Chrysochloris rutilans Wagner, loc. cit. I 25. "Kafferland."

(1946. Amblysomus hottentotus natalensis Roberts, Ann. Transv. Mus. 20: 3 I I. Durban, Natal.)

Range includes Port Elizabeth and the Transkei.

Amblysomus hotTentotus IRIS Thomas \& Schwann, I905

1905. Amblysomus iris Thomas \& Schwann, Abstr. P.Z.S. No. I8: 23; P.Z.S. I: 259. Umfolosi Station, Zululand, Natal.

If this species is divisible into two, based on colour, then the present is the prior name for the dark races. It is a relatively small form.

Amblysomus hottentotus corRiae Thomas \& Schwann, I905

1905. Amblysomus corriae Thomas \& Schwann, Abstr. P.Z.S. No. 20: 5; P.Z.S. 2: 57. Knysna, southern Cape Province. Range: Knysna and George forested areas. Much like iris, but averages larger.

Amblysomus hottentotus pondoliae Thomas \& Schwann, I905

I905. Amblysomus hottentotus pondoliae Thomas \& Schwann, P.Z.S. I: 26o. Notinsila, western Pondoland, eastern Cape Province.

Amblysomus hottentotus longigeps Broom, i 907

I907. Chrysochloris hottentota longiceps Broom, Trans. S. Afr. Phil. Soc. I8: 299. Near Pietermaritzburg, Natal.

I907. Chrysochloris hottentota albifrons Broom, Trans. S. Afr. Phil. Soc. I8: 302. Howick, Natal.

Range: Natal midlands; averages slightly larger than the typical race, as in pondoliae.

Roberts has also named the following nominal races, all of which are, like pondoliae and longiceps, very similar to the typical race but slightly larger on average:

I946. Amblysomus hottentotus devilliersi Roberts, Ann. Transv. Mus. 20: 3 Io. Lamotte, Franschhoek (near Paarl), western Cape Province; specimens from Stellenbosch also quoted.

I946. Amblysomus hottentotus swellendamensis Roberts, Ann. Transv. Mus. 20: 3 Io. Grootvadersbosch, Swellendam district, south-western Cape Province.

1946. Amblysomus hottentotus drakensbergensis Roberts, Ann. Transv. Mus. 20: 3 10. Wakkerstroom, south-eastern Transvaal. Ranges from Giants Castle, Natal to Belfast, eastern Transvaal. 
Amblysomus hottentotus SEPtentRionalis Roberts, I9I3

1913. Amblysomus corriae septentrionalis Roberts, Ann. Transv. Mus. 4: 73. Wakkerstroom, south-eastern Transvaal. Based on one specimen, allied to but larger than corriae. (Probably the later named reddish form drakensbergensis of the same ground is a colour phase of this form.)

Amblysomus hottentotus gaRneri Roberts, i9I 7

i9i 7. Amblysomus hottentotus garneri Roberts, Ann. Transv. Mus. 5: 278. Commissioner's residence, Piggs Peak, Swaziland.

Amblysomus hottentotus oRAngensis Roberts, I946

1946. Amblysomus hottentotus orangensis Roberts, Ann. Transv. Mus. 20: 310. Vaalbank, Heilbron district, northern Orange Free State. Range also includes Viljoensdrift and Parys, northern Orange Free State.

Amblysomus hottentotus littoralis Roberts, I 946

1946. Amblysomus corriae littoralis Roberts, Ann. Transv. Mus. 20: 3 I I. Umhloti River, near Verulam (north of Durban), Natal. To this form Roberts refers also specimens from Grahamstown and Port St. Johns which do not conform to the typical reddish colouring of the typical race. See remarks above, under the species.

Amblysomus gunningi Broom, I 908

Gunning's Golden Mole. Gunningse Kruipmol

This is the type of "Neamblysomus" of Roberts. It might equally well be regarded, taking a very broad view, as an aberrant outlying subspecies of $A$. hottentotus. For variation in its dental formula see above, page 33 .

Distribution: Woodbush, Transvaal.

Amblysomus gunningi Broom, igo8

I908. Chrysochloris gunningi Broom, Ann. Transv. Mus. I: I4. Woodbush, eastern Transvaal.

\section{Genus EREMITALPA Roberts, 1924}

1924. Eremitalpa Roberts, Ann. Transv. Mus. Io: 63. Chrysochloris granti Broom.

Eremitalpa granti Broom, I907

Grant's Desert Golden Mole. Woestynkruipmol

Distribution: Little Namaqualand (Port Nolloth and Garies), and near Lamberts Bay, western Cape Province. 
EREMITALPA GRANTI GRANTI Broom, I907

1907. Chrysochloris granti Broom, Ann. Mag. N.H. 19: 265. Garies (south of the Kamiesberg in southern Little Namaqualand), north-western Cape Province.

EREmitalPa granti Gana Broom, i950

1950. Eremitalpa granti cana Broom, Ann. Transv. Mus. 21: 240. Lamberts Bay (coast westwards from Clanwilliam), western Cape Province.

Genus CRYPTOGHLORIS Shortridge \& Carter, I938

1938. Cryptochloris Shortridge \& Carter, Ann. S. Afr. Mus. 32: 284. Cryptochloris zyli Shortridge \& Carter.

Gryptochloris wintoni Broom, $1907^{1}$

De Winton's Golden Mole. De Wintonse Kruipmol

Distribution: two forms are known, one from Port Nolloth, coastal Little Namaqualand, and the other from near Lamberts Bay, western Cape Province.

CRYPTOGhloris Wintoni Wintoni Broom, igo7

1907. Chrysochloris wintoni Broom, Ann. Mag. N.H. 19: 264. Port Nolloth, coast of Little Namaqualand, north-western Cape Province.

Gryptoghloris wintoni zyli Shortridge \& Carter, I938

1938. Cryptochloris zyli Shortridge \& Carter, Ann. S. Afr. Mus. 32: 284. Compagnies Drift, Io miles inland from Lamberts Bay (coast westwards from Clanwilliam), western Cape Province.

\section{Genus GHRYSOGHLORIS Lacépède, I 799}

1799. Chrysochloris Lacépède, Tabl. Mamm. 7. Chrysochloris capensis Lacépède = Talpa asiatica Linnaeus.

Tentatively all named forms from the western Cape Province, which is the range of typical Chrysochloris, are here regarded as races of the first named asiatica.

As here understood this genus contains two species or groups of species; the asiatica group, with the skull broader, from the western Cape Province, and the stuhlmanni group, with the skull narrower, from Uganda, Tanganyika and the Belgian Congo.

${ }^{1}$ Neither of the forms in this genus is well known. The second, $z y l i$, seems to have a slightly larger and narrower skull than wintoni. 
Chrysochloris asiatica Linnaeus, $175^{8}$

Cape Golden Mole. Kaapse Kruipmol

Distribution: the western Cape Province; Robben Island, Cape Town, Worcester, Citrusdal, Eendekuil, Lamberts Bay, Klaver, Nieuwoudtville, 54 miles east of Calvinia, Little Namaqualand (Garies, inland from Port Nolloth, the Kamiesberg). Recorded in 1838 from Damaraland, but apparently not subsequently collected north of the Union.

Chrysochloris asiatica asiatica Linnaeus, i $75^{8}$

I758. Talpa asiatica Linnaeus, Syst. Nat. Ioth ed. I: 53. "Siberia." Usually the locality is taken as the Cape of Good Hope.

I 777. Talpa inaurata Schreber, Säugth. pl. I57. Cape of Good Hope.

I 778. Talpa aurea Pallas in Schreber, Säugth. 3: 562. Alternative name for inaurata.

I 799. Chrysochloris capensis Lacépède, Tabl. Mamm. 7. Cape of Good Hope.

I 799. Chrysochloris rubra Lacépède in Didot's Buffon, H.N. Quad. I 4: I 58. Cape of Good Hope.

Range: region of Cape Town to Worcester, south-western Cape Province.

Chrysoghloris asiatica damarensis Ogilby, i 838

I838. Chrysochloris damarensis Ogilby, P.Z.S. 5. Damaraland, South-West Africa. (But no Golden Moles have since been collected in South-West Africa and Shortridge (1934) says that a specimen which he carried about on one of his expeditions there was not recognized by any of the local natives.)

Chrysochloris asiatica namaquensis Broom, igo7

1907. Chrysochloris namaquensis Broom, Ann. Mag. N.H. 19: 266. Garies (south of the Kamiesberg in southern Little Namaqualand), north-western Cape Province.

1907. Chrysochloris tenuis Broom, Ann. Mag. N.H. 19: 267. Garies, Little Namaqualand, north-western Cape Province. (Based on two skulls having 36 instead of 40 teeth.)

1946. Chrysochloris dixoni Broom, Ann. Transv. Mus. 20: 329. Roodeberg Kloof, Garies, Little Namaqualand, north-western Cape Province.

1946. Chrysochloris elegans Broom, Ann. Transv. Mus. 20: 33 I. Eselfontein, 4,500 ft., Kamiesberg, central Little Namaqualand, north-western Cape Province.

1946. Chrysochloris shortridgei Broom, Ann. Transv. Mus. 20: 333. I 5 miles inland from Port Nolloth, coastal Little Namaqualand, north-western Cape Province.

C. a. namaquensis is a relatively small race.

Chrysoghloris asiatica minor Roberts, igi9

I919. Chrysochloris minor Roberts, Ann. Transv. Mus. 6: i I3. Klaver (on the Olifants River, and south of Van Rhynsdorp), western Cape Province.

1950. Chrysochloris asiatica visserae Broom, Ann. Transv. Mus. 21: 237. Eendekuil (north of Piquetberg), western Cape Province. 
Chrysoghloris asiatica bayoni de Beaux, ig2 I

I92 I. Chrysochloris bayoni de Beaux, Atti Soc. Ital. Sci. Nat. 6o: 236. Robben Island, off Cape Town.

Roberts made this a synonym of the typical race. But a specimen in the British Museum with the skull length $25.2 \mathrm{~mm}$. is larger than our other specimens of this species, and larger than any quoted by Roberts (I95I).

Chrysoghloris asiatica congolor Shortridge \& Carter, I938

1938. Chrysochloris concolor Shortridge \& Carter, Ann. S. Afr. Mus. 32: 284. 3 miles west of Nieuwoudtville (midway between Calvinia and Van Rhynsdorp), western Cape Province.

CHRYSOGHLORIS ASIATICA TAYLORI Broom, I950

1950. Chrysochloris asiatica taylori Broom, Ann. Transv. Mus. 21: 236. Lamberts Bay (coast west of Clanwilliam), western Cape Province.

Chrysoghloris asiatica visagiei Broom, i950

1950. Chrysochloris visagiei Broom, Ann. Transv. Mus. 21: 238. Gouna, 54 miles east of Calvinia, western Cape Province.

\section{Genus CHRYSOSPALAX Gill, I 883}

I883. Chrysospalax Gill, Standard Nat. Hist. 5 (Mammalia): i37. Chrysochloris trevelyani Günther. Type fixed by Roberts, I924, Ann. Transv. Mus. Io: 64. 1892. Bematiscus Cope, Amer. Nat. 26: i 27, footnote. Chrysochloris villosa A. Smith (see Thomas, ig05, P.Z.S. $1: 259$ ).

Larger species; adult specimens with head and body length $198 \mathrm{~mm}$. and more; length of the adult skull $40.5 \mathrm{~mm}$. and more. Chrysospalax trevelyani, page 42 Smaller; length of the head and body I $75 \mathrm{~mm}$. and less; length of the skull $36.5 \mathrm{~mm}$. and less.

Chrysospalax villosus, page $4^{\mathrm{I}}$

Chrysospalax villosus A. Smith, I 833

Rough-haired Golden Mole. Grofhaarkruipmol

Distribution: Natal (Durban, Pietermaritzburg), the Transvaal (Springs (near Johannesburg), Pretoria, Wakkerstroom), and the eastern Cape Province (Griqualand East).

Ghrysospalax villosus villosus A. Smith, i 833

I833. Chrysochloris villosa A. Smith, S. Afr. J. 2: 81. "Towards Natal." (Near Durban, fide Roberts.)

Chrysospalax villosus transvaalensis Broom, igi3

igi3. Bematiscus transvaalensis Broom, Abstr. P.Z.S. No. I2I: 25 (May, I9I3). P.Z.S. 546. Endicot, Springs (east of Johannesburg), Transvaal.

I9I3. Chrysospalax pratensis Roberts, Ann. Transv. Mus. 4: 74. (October, I9I3). Pretoria, Transvaai. 
Chrysospalax villosus leschae Broom, igi 8

I918. Bematiscus leschae Broom, P.Z.S. i89. St. Cuthberts, "Isolo" (= Tsolo?), Griqualand East, eastern Cape Province.

Ghrysospalax villosus dobsoni Broom, igi 8

I918. Bematiscus dobsoni Broom, P.Z.S. igo. Pietermaritzburg, midlands of Natal.

Chrysospalax villosus RUfopallidus Roberts, I924

I924. Bematisius rufopallidus Roberts, Ann. Transv. Mus. Io: 65. Wakkerstroom, south-eastern Transvaal.

Chrysospalax trevelyani Günther, I 875

Giant Golden Mole. Reuse Kruipmol

Distribution: Port St. Johns (Pondoland), and Pirie forest, near King William's Town, eastern Cape Province.

Chrysospalax trevelyani Günther, 1875

I875. Chrysochloris trevelyani Günther, P.Z.S. 3 I I. Pirie forest, near King William's Town, eastern Cape Province.

\section{ORDER G H I R O P T E R A}

Distinguished from the other orders by having the forelimbs modified as wings which are used for true flight.

On this order see:

Dobson, 1878, Catalogue of Chiroptera in the British Museum.

Miller, I907, The Families and Genera of Bats, Bull. U.S. Nat. Mus. No. 57.

Andersen, K., I912. Catalogue of the Chiroptera in the British Museum, I. Megachiroptera (all published).

I. Second finger retaining evident degree of independence, its ungual phalange present; humerus with trochiter and trochin small, the former never articulating with the scapula; mandible with angular process broad and low, or practically absent; margin of ear forming a complete ring. Skull with postorbital processes.

Family PTEROPO DIDAE, page $43^{1}$

Second finger scarcely, if at all, independent from the third, its ungual phalange absent; humerus with trochiter and trochin large, the former usually articulating with scapula; mandible with angular process well developed, long and narrow: margin of ear not forming a complete ring.

2. Premaxillaries absent. Premaxillaries present.

Family MEGADERMATIDAE, page 54

${ }^{1}$ The characters given for the families of the Chiroptera are mainly from G. S. Miller (1907). The classification of the Pteropodidae follows K. Andersen (I912). 


\section{CHIROPTERA - PTEROPODIDAE}

3. Premaxillaries usually free, always incomplete, their boundaries never obliterated.

Premaxillaries always fused with surrounding parts, complete or incomplete, their boundaries very early obliterated. (Skull lacks postorbital processes).

4. Premaxillaries represented by nasal branch only, or with a very incomplete palatal branch. Skull with postorbital processes. Tail perforates upper surface of interfemoral membrane. Family EMBALLONURIDAE, page 50 Premaxillaries represented by palatal branch only.

5. Premaxillaries bony throughout, in contact with each other and with maxillaries; tragus present; fibula absent; skull with postorbital processes; muzzle simpler.

Family NYGTERIDAE, page 5I

Premaxillaries partly cartilaginous, free from each other and from maxillaries; tragus absent; fibula present; skull without postorbital processes; muzzle with conspicuous noseleaf.

Family RHINOLOPHIDAE, page 55

6. Fibula robust, contributing largely to strength of short, stout leg; tail always produced well beyond the interfemoral membrane.

Family MOLOSSIDAE, page 63

Fibula slender or rudimentary, not contributing essentially to strength of long slender leg; tail not or scarcely produced beyond the interfemoral membrane.

Family VESPERTILIONIDAE, page 70

\section{SUB-ORDER MEgAGHIROPTERA}

\section{FAMILY P T E R O P O D I D A E}

The classic work on this family is by Knud Andersen (I9I2). Simpson (I945) who takes the view that recent specialists recognize too many genera in this order lists only three valid genera in South Africa. (He does not even recognize Hypsignathus, a. very distinct genus, which Miller retained.) However, we think that all the genera recognized by $\mathrm{K}$. Andersen are valid as judged by modern standards.

In the keys to the Chiroptera we are able to include only species which have been examined and are represented in the British Museum.

I. Facial axis of skull conspicuously deflected against basicraniaı axis; alveolar line, if projected backwards, passing through middle or upper edge of occipital condyle or through some point of supraoccipital.

Facial axis of skull very little deflected against basicranial axis; alveolar line, if projected backwards, passing through lower edge of occipital condyle or even some distance below condyle. 
2. Bullae form short bony auditory meatus; premaxillae spaced in front; first lower molar equal to second and third combined. Genus EIDOLON, page 44 Bullae without bony auditory meatus; premaxillae in contact or fused in front; first lower molar shorter than second and third combined.

Genus ROUSETTUS, page 45

3. Braincase not flattened posteriorly; more than 3 upper cheekteeth.

Braincase flattened posteriorly; 3 upper cheekteeth.

Genus MYONYCTERIS, page $5^{\circ}$

4. Rostrum short, orbit to tip of nasals equal to or less than lachrymal breadth.

Genus MICROPTEROPUS, page 49

Rostrum long, orbit to tip of nasals much longer than lachrymal breadth.

5. Rostrum long and narrow, postdental palate deeply depressed posteriorly.

Genus EPOMOPHORUS, page 47

Rostrum long and broad, postdental palate flattened posteriorly.

6. Rostrum not deeper than usual; premaxillae in simple contact in front, males with shoulder pouches and erectile shoulder brushes; muzzle without cutaneous leaves; outer ridge of lower molars simple. Genus EPOMOPS, ${ }^{1}$ page 46

Rostrum considerably increased in depth; premaxillae ankylosed together anteriorly; no shoulder pouches or brushes; upper lip with cutaneous leaves; outer ridge of lower molars bilobed or trilobed.

Genus HYPSIGNATHUS, ${ }^{2}$ page 47

Sub-FAmily $\mathrm{P}$ t e r o p o d i n a e

Genus EIDOLON Rafinesque, i 8 I 5

I8I5. Eidolon Rafinesque, Analyse de la Nature, 54. Vespertilio vampyrus helvus Kerr. For note on validity of Eidolon Rafinesque and fixing of type species see K. Andersen, I908, Ann. Mag. N.H. I: 432.

1861. Pterocyon Peters, Mber. Preuss. Akad. Wiss. 423. Pterocyon palaeceus Peters = Vespertilio vampyrus helvus Kerr.

I88 I. Leiponyx Jentink, Notes Leyden Mus. 3: 6o. Leiponyx büttikoferi Jentink = Vespertilio vampyrus helvus Kerr.

Eidolon helvum Kerr, I 792

Straw-coloured Fruit-Bat. Geelvrugtevlermuis

Distribution: over nearly the whole continent as a migrant (Roberts). Has been recorded from Little Namaqualand, Bedford and Steynsburg (eastern Cape Province), Griqualand West; Harrismith (Orange Free State), Rustenburg and Pretoria,

${ }^{1}$ For further details separating Epomops from Epomophorus see K. Andersen, 1912, 5 I 4.

${ }^{2}$ Another genus of Pteropodidae, Plerotes, is unrepresented in London. It seems nearest Epomophorus and allies, but with 4 upper cheekteeth and simpler palate ridges. For further characters see K. Andersen, I912. 
Transvaal, etc. Mashonaland, Southern Rhodesia, Nyasaland, Ndola in Northern Rhodesia; Angola, whence recorded from Benguela, Caconda and other localities. Beyond the limits of this work, to Somaliland and the Sudan, thence to Senegambia. A closely allied form occurs in Arabia.

\section{Eidolon HeLvum Kerr, I 792}

I 792. Vespertilio vampyrus helvus Kerr, Linnaeus's Animal Kingd. xvii, 9I. Senegal, West Africa (fixed by K. Andersen, I907, Ann. Mag. N.H. I9: 504).

I803. Pteropus stramineus E. Geoffroy, Cat. Mamm. Mus. H.N. Paris, 48 (no locality); not available, this work having been shown to be unpublished (Sherborn, Index Animalium, i80 I-50, p. lviii). i 8 i o. Ann. Mus. H.N. Paris, 15: 95. (Timor, corrected to Sennaar by Temminck, I837, Mon. Mamm. 2: 84.)

\section{Genus ROUSETTUS Gray, I82 I}

I82 I. Rousettus Gray, London Med. Repos. I5: 299. Pteropus aegyptiacus E. Geoffroy. 1843. Xantharpyia Gray, List Mamm. B.M., xix, 37. Pteropus amplexicaudatus E. Geoffroy, from Timor.

I844. Eleutherura Gray, Voy. Sulphur, I: 29. Pteropus leachii A. Smith.

1852. Cynonycteris Peters, Reise nach Mossambique, Säugeth. 25. Pteropus collaris Illiger = Pteropus leachii A. Smith.

I912. Stenonycteris K. Andersen, Cat. Chiroptera B.M. I: 23. Rousettus lanosus Thomas, from Uganda. Valid as a subgenus.

1912. Lissonycteris K. Andersen, Cat. Chiroptera B.M. I: 23. Cynonycteris angolensis Bocage. Valid as a subgenus.

The South African form leachi is here considered as a subspecies of $R$. aegvptiacus. Braincase strongly deflected; premaxillaries in contact; first lower premolar much larger in bulk than a lower incisor; wings from first toe.

Rousettus aegyptiacus, page 45

Braincase only slightly deflected; premaxillaries fused; first lower premolar equal in bulk to a lower incisor or only a little larger; wings from second toe.

Rousettus (Lissonycteris) angolensis, page 46

\section{Subgenus ROUSETTUS Gray, I82 I}

Rousettus aegyptiacus E. Geoffroy, I810

Egyptian Fruit-Bat; Cape Fruit-Bat. Kaapse Vrugtevlermuis

Distribution; coastal belt of the southern Cape Province, Cape Town, Knysna, Grahamstown, Pondoland; Natal, Zululand; Portuguese East Africa (Inhambane, K. Andersen); Angola (recorded from Hanha, Pungo Andongo, Quindumbo); northwards to Tanganyika, Kenya, Uganda, the Belgian Congo, Gabon; Egypt, Cyprus, Syria, Palestine. 
Rousettus aegyptiagus aegyptiagus E. Geoffroy, i8io

i81 . Pteropus egyptiacus E. Geoffroy, Ann. Mus. H.N. Paris, 15: 96 (misprint), corrected to aegyptiacus in I8I8, Description de l'Egypte, H.N. 2: I34. Great Pyramid, Giza, Egypt. Range includes the Angolan localities above.

Rousettus Aegyptiagus Leaghi A. Smith, i 829

I829. Pteropus leachii A. Smith, Zool. J. 4: 433. "Gardens about Cape Town."

I 823. Pteropus collaris Lichtenstein, Verz. Doublett. Zool. Mus. Berlin, 3, 5. Not of Illiger, I8I5.

1832. Pteropus hottentottus Temminck in Smuts, Enum. Mamm. Cap. 3. Cape Town. Range: coastal belt of southern Cape Province, Natal, Portuguese East Africa, Tanganyika, Kenya, Uganda, the Congo.

Subgenus LISSONYCTERIS K. Andersen, I9I2

Rousettus angolensis Bocage, 1898

Bocage's Fruit-Bat

Distribution: Angola (Amboin, Hanha, Quibula). Tanganyika and Kenya to the Cameroons.

Rousettus ANGolensis Bocage, I 898

I898. Cynonycteris angolensis Bocage, J. Sci. Math. Phys. Nat., Lisboa, 5: I33. Pungo Andongo, $9^{\circ} 4 \mathrm{o}^{\prime}$ S., $15^{\circ} 4 \mathrm{o}^{\prime}$ E., I, 200 m., northern Angola.

Genus PLEROTES K. Andersen, igio

i9ı. Plerotes K. Andersen, Ann. Mag. N.H. 5: 97. Epomophorus anchietae Seabra.

Plerotes anchietai Seabra, Igoo

Anchieta's Fruit-Bat

Distribution: Angola (Chitau, Galanga). The lower Congo.

Plerotes anchietai Seabra, igoo

I900. Epomophorus anchietae Seabra, J. Sci. Math. Phys. Nat., Lisboa, 6: i 6. Galanga, north-east of Benguela, Angola.

Genus EPOMOPS Gray, 1870

I870. Epomops Gray, Cat. Monkeys, Lemurs and Fruiteating Bats B.M., I 26. Epomophorus franqueti Tomes.

Three interdental palate ridges; postdental palate with two pairs of strong triangular ridges at middle, and one or a few thin ridges at palation border.

Four interdental and about five to seven postdental palate ridges.

Epomops dobsoni, page 47

Epomops franqueti, page 47 
Epomops franqueti Tomes, I860

Franquet's Fruit-Bat

Distribution: Angola (recorded from Malange and Mossamedes). Northern Rhodesia (Abercorn). Tanganyika; westwards to southern Nigeria and the Gold Coast.

EPOMOPS FRANQUETI FRANQUETI Tomes, I86o 1860. Epomophorus franqueti Tomes, P.Z.S. 54. Gabon, West Africa. I862. Epomophorus comptus H. Allen, Proc. Acad. Nat. Sci. Philad. I86I: I 58. "West Africa" (= Gabon).

Epomops dobsoni Bocage, I 889 Dobson's Fruit-Bat

Distribution: Angola, whence recorded from several localities (apparently chiefly in the western and central districts). Katanga, southern Belgian Congo.

Epomops Dobsoni Bocage, i 889

I889. Epomophorus dobsonii Bocage, J. Sci. Math. Phys. Nat., Lisboa, I: I. Quindumbo, Benguela district, western Angola.

\section{Genus HYPSIGNATHUS $H$. Allen, I86 I}

I86 I. Hypsignathus H. Allen, Proc. Acad. Nat. Sci. Philad., I56. Hypsignathus monstrosus H. Allen.

Hypsignathus monstrosus $H$. Allen, I 86 I Hammer-headed Fruit-Bat

Distribution: recorded from Dundo, north-eastern Angola. Uganda westwards to Gambia, and including Fernando Po.

Hypsignathus monstrosus H. Allen, i 86 I

I86 I. Hypsignathus monstrosus H. Allen, Proc. Acad. Nat. Sci. Philad., I57. "West Africa" (= Gabon).

Genus EPOMOPHORUS, Bennett, $18{ }_{3} 6$

1836. Epomophorus Bennett, P.Z.S. I835: I49. Pteropus epomophorus Bennett = Pteropus gambianus Ogilby, from Gambia, West Africa.

I. Relatively small species, forearm about $66.5 \mathrm{~mm}$. and less; males not conspicuously larger than females

Epomophorus labiatus, page 48

Relatively larger species, forearm (in interlimital species) about $72 \mathrm{~mm}$. and more; males conspicuously larger than females.

2. One well-developed postdental palate ridge.

Two well-developed postdental palate ridges. 
3. Fourth palate ridge much nearer the third than the fifth.

Epomophorus angolensis, page 49

Fourth palate ridge about halfway between the third and the fifth.

Epomophorus crypturus, page 49

For further comparison of these species and their distinguishing characters compared with other extralimital species see K. Andersen, I9I2, 520.

Epomophorus labiatus Temminck, I 837 Little Epauletted Fruit-Bat

Distribution: Northern Rhodesia (B.M.) Tanganyika, Abyssinia, the Sudan.

Epomophorus labiatus labiatus Temminck, i 837 . (Extralimital)

I837. Pteropus labiatus Temminck, Mon. Mamm. 2: 83. Sennaar, Sudan. (K. Andersen); originally given as "Abyssinia."

EPOMOPHORUS LABIATUS MINOR Dobson, I880

I880. Epomophorus minor Dobson, P.Z.S. I879: 715. Zanzibar. Ranges to Fort Jameson, Northern Rhodesia.

Epomophorus wahlbergi Sundevall, 1846

Wahlberg's Epauletted Fruit-Bat. Wahlbergse Witkolvrugtevlermuis

Distribution: in the Union, known from Grahamstown, King William's Town and Port St. Johns, eastern Cape Province; ? the eastern Orange Free State (Shortridge); Zululand, Durban, Natal and the eastern Transvaal, (Tzaneen, Hectorspruit, Steynsdorp). Portuguese East Africa (Inhambane district and west of Beira), Southern Rhodesia (Mashonaland, Matabeleland), Nyasaland, Northern Rhodesia, Angola, whence recorded from many localities. Tanganyika, Kenya to the Cameroons.

Epomophorus WAHLbergi WAHLbergi Sundevall, i 846

I846. Pteropus wahlbergi Sundevall, Öfvers. Vetensk. Akad. Förh. Stockholm, 3: I I8. Near "Port Natal" = Durban, Natal.

I870. Epomophorus macrocephalus var. unicolor Gray, Cat. Monkeys, Lemurs and Fruit-eating Bats B.M., I 25. Shupanga, on the Zambezi, $18^{\circ}$ S., Portuguese East Africa.

1870. Epomophorus gambianus Gray, loc. cit. I26, and of earlier authors, but not of Ogilby, I 835 .

Range: Eastern Cape Province to Kenya.

Epomophorus WAHLBergi haldemani Halowell, i 846

1846. Pteropus haldemani Halowell, Proc. Acad. Nat. Sci. Philad. 3: 52. "West Africa" (?Liberia).

I899. Epomophorus zenkeri Matschie, Megachiroptera Berlin Mus., 46. Lower Guinea; lectotype from Chinchoxo, Cabinda, Angola.

Range: from Benguela, Angola to the Cameroons, Tanganyika, etc. 
Epomophorus crypturus Peters, 1852

Peters' Epauletted Fruit-Bat. Kleinvrugtevlermuis

Distribution: in the Union, Pirie (near King William's Town, B.M.), the Transvaal (Zoutpansberg, Tzaneen and Barberton districts). Portuguese East Africa (districts of Tete and Beira included, also Lumbo (north of the Zambezi) ); eastern Southern Rhodesia, Ngamiland, Nyasaland, Northern Rhodesia, northwards to Katanga (southern Belgian Congo).

Epomophorus Grypturus Peters, 1852

1852. Epomophorus crypturus Peters, Reise nach Mossambique, Säugeth. 26. Tete, on the Zambezi, western Portuguese East Africa.

Epomophorus angolensis Gray, 1870

Angolan Epauletted Fruit-Bat

Distribution: Angola (Hanha, Benguela, Chitau, Mupa, Cubango), and the north-western parts of South-West Africa.

Epomophorus ANGolensis Gray, I870

1870. Epomophorus macrocephalus var. angolensis Gray, Cat. Monkeys, Lemurs and Fruit-eating Bats B.M., I 25. Angola.

\section{Genus MICROPTEROPUS Matschie, I 899}

I899. Micropteropus Matschie, Megachiroptera Berlin Mus., 36, 57. Epomophorus pusillus Peters.

The recently described Micropteropus grandis, which is unrepresented in London, is considerably larger than M. pusillus: its forearm is $65.8 \mathrm{~mm}$. (about $50-53 \mathrm{~mm}$. in pusillus).

Micropteropus pusillus Peters, I 868

Dwarf Epauletted Fruit-Bat

Distribution: Angola (Canhoca, Malange). Tanganyika, the eastern side of Lake Victoria, the Bahr-el-Ghazal (southern Sudan) and Abyssinia to Gambia.

Micropteropus pusillus Peters, i 868

1868. Epomophorus pusillus Peters, Mber. Preuss. Akad. Wiss. 1867: 87o. Gambia, West Africa.

Micropteropus grandis Sanborn, I950

Distribution: Dundo, north-eastern Angola; Thysville, Lower Congo.

Migropteropus Grandis Sanborn, i950

1950. Micropteropus grandis Sanborn, Publ. Cult. Comp. Diamantes Angola, No. Io:

55. Dundo, Lunda, north-eastern Angola. 


\section{SOUTHERN AFRICAN MAMMALS I758-195I}

Genus MYONYGTERIS Matschie, I 899

I899. Myonycteris Matschie, Megachiroptera Berlin Mus. 6I, 63. Cynonycteris torquatus Dobson.

1912. Phygetis K. Andersen, Cat. Chiroptera B.M. I: 579. Cynonycteris brachycephala Bocage, from São Thomé Island, West Africa. Valid as a subgenus.

Subgenus MYONYCTERIS Matschie, I899

Myonycteris torquata Dobson, 1878

Little Collared Fruit-Bat

Distribution: Angola, the Belgian Congo, the Cameroons.

Myonygteris torQuata Dobson, 1878

I878. Cynonycteris torquata Dobson, Cat. Chiroptera B.M., 71, 76. Angola.

SUB-ORDER MIGROGHIROPTERA

FAMILY E M B A L L O N U R I D A E

Lightly-built species with forearm normally below $50 \mathrm{~mm}$., frontals not conspicuously concave, and coronoid process of mandible lower.

Genus COLEURA, page $5^{\circ}$

Heavily-built species with forearm normally over $50 \mathrm{~mm}$., frontals conspicuously concave, and coronoid process of mandible higher.

Genus TAPHOZOUS, page $5^{\mathrm{I}}$

Coleura is near the earlier-named genus Emballonura but has one upper incisor (in Emballonura there are two).

Genus COLEURA Peters, I867

I867. Coleura Peters, Mber. Preuss. Akad. Wiss. 479. Emballonura afra Peters.

Coleura afra Peters, $185^{2}$

Southern Sheath-tailed Bat

Distribution: Tete, Portuguese East Africa; Benguela, Angola (in the B.M.); Tanganyika, Kenya, with a closely allied form in Somaliland, the Sudan, the Congo, and southern Arabia.

Coleura afra Peters, 1852

1852. Emballonura afra Peters, Reise nach Mossambique, Säugeth. 51. Tete, on the Zambezi, Portuguese East Africa. 
Genus TAPHOZOUS E. Geoffroy, 1818

I8I8. Taphozous E. Geoffroy, Description de l'Egypte, 2: i I3. Taphozous perforatus E. Geoffroy, from Egypt.

1838. Saccolaimus Temminck, Tijdschr. Natuur. Gesch. 5: 6. (As a subgenus.)

Taphozous saccolaimus Temminck, from Java. Valid as a subgenus.

1922. Liponycteris Thomas, Ann. Mag. N.H. 9: 267. Taphozous nudiventris Cretzschmar, from Egypt. Valid as a subgenus.

Only one species of this genus occurs in South Africa; it was the second to be named in the genus, and differs from $T$. perforatus (according to Dobson) in having the throat naked below, and in having a rudimentary gular sac present in the female.

Subgenus TAPHOZOUS E. Geoffroy, I818

Taphozous mauritianus E. Geoffroy, I8 8

South African Tomb-Bat. Witlyfvlermuis

Distribution: in the Union, the Transvaal (Zoutpansberg, near Pretoria, Tzaneen), Natal (including Durban), Alicedale (near Grahamstown) eastern Cape Province (also a I9o I record from Heidelberg in the Swellendam division of the southwestern Cape Province). Angola (recorded from Mossamedes, Humbe, Benguela, Loanda, Duque de Bragança, etc.). Nyasaland. Further to the north, Kenya, Tanganyika, the Belgian Congo, Lado; Mauritius, Madagascar, etc.

Taphozous mauritianus E. Geoffroy, i 818

I8ı. Taphozous mauritianus E. Geoffroy, Description de l'Egypte, 2: 127. Island of Mauritius (east of Madagascar).

I838. Taphozous leucopterus Temminck, Tijdschr. Natuur. Gesch. 5: i2. "Interior of South Africa."

I90o. Taphozous maritianus (sic) var. cinerascens Seabra, J. Sci. Math. Phys. Nat., Lisboa, 6: 77. Benguela, south-western Angola.

\section{FAMILY N Y G T E R I D A E}

\section{Genus NYGTERIS G. Cuvier and E. Geoffroy, I 795}

I 795. Nycteris G. Guvier and E. Geoffroy, Mag. Encyclop. 2: I86, nom. nud. Vespertilio hispidus Schreber. Name validated by Opinion I I of International Commission on Zoological Nomenclature.

I838. Petalia Gray, Mag. Zool. Bot. 2: 494. Nycteris javanicus E. Geoffroy, from Java.

I. The lower P.4 relatively large. (Upper incisors bifid.)

The lower P.4 small.

2. Smaller, forearm about $34 \mathrm{~mm}$.

Larger, forearm about $39 \frac{1}{2}-45 \mathrm{~mm}$.

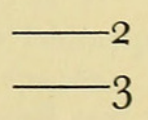

${ }^{1} \mathcal{N}$. arge is separable from the Oriental $\mathcal{N}$. javanica because that species has the upper incisors trifid (B.M. material). 
3. Upper incisors trifid. (Forearm about 38-4I mm., ear I 7-24 mm.)

Upper incisors bifid.

Nycteris hispida, page 52

4. Tragus pyriform (free portion narrowest at base, its outer and inner margins evenly convex (K. Andersen) ). (Forearm about $42 \frac{1}{2}-49 \mathrm{~mm}$., ear $28-37 \mathrm{~mm}$.)

Nycteris thebaica, ${ }^{1}$ page 53

Tragus semilunate (inner margin joins the upper one in a sharp angle ( $\mathrm{K}$. Andersen)).

5. Forearm about 40-42 mm. (Ear about 29-34 mm.) Nycteris woodi, page 54 Forearm about $47 \frac{1}{2} \mathrm{~mm}$. and more. (Ear $28-34 \mathrm{~mm}$.)

Nycteris macrotis, ${ }^{2}$ page 54

Nycteris nana $\mathrm{K}$. Andersen, I9I2

Little Slit-faced Bat

Distribution: Dundo, north-eastern Angola; Spanish Guinea, Belgian Congo, Western Kenya.

NyGTeris Nana K. Andersen, I9I 2

I912. Petalia nana K. Andersen, Ann. Mag. N.H. 10: 547. Benito River, Spanish Guinea.

Nycteris arge Thomas, 1903

Bates' Slit-faced Bat

Distribution: Dundo, north-eastern Angola; Western Kenya, Belgian Congo, Cameroons, Liberia.

Nygteris ARge Thomas, I903

I903. Nycteris arge Thomas, Ann. Mag. N.H. I2: 633. Efulen, Cameroons.

Nycteris hispida Schreber, I 774

Hairy Slit-faced Bat. Harige Langoorvlermuis

Distribution: recorded from Port St. Johns, Pondoland (Hewitt, I93 I). Inhambane, Portuguese East Africa. Angola (Mossamedes, Mt. Moco). Tanganyika, Kenya, southern Sudan, westwards to Senegal.

${ }^{1}$ It is customary to divide this species into two, $\mathcal{N}$. thebaica and $\mathcal{N}$. capensis because thebaica is supposed to have the small lower premolar more reduced and internal to the toothrow, whereas $\mathcal{N}$. capensis is supposed to have the small lower premolar in the toothrow. Examination of material in the British Museum shows that the character is largely an individual one, and is by no means constant in either species. No other characters have been found to separate these two species, and accordingly they are here merged.

${ }^{2} \mathcal{N}$. macrotis has the ear length $28-32 \mathrm{~mm}$., thereby differing from $\mathcal{N}$. aethiopica (which incidentally it antedates), which has them $22-26 \mathrm{~mm}$. in our material. But the Nyasaland form oriana has the ears 28-34 mm., and is therefore thought to represent macrotis. 
Nycteris HisPida hispida Schreber, I774. (Extralimital)

I774. Vespertilio hispidus Schreber, Säugth. I: I69, pl. 56. Senegal.

Nycteris hispida villosa Peters, I 852

1852. Nycteris villosa Peters, Reise nach Mossambique, Säugeth. 48. Inhambane (south of the Zambezi), coastal Portuguese East Africa.

Nycteris thebaica E. Geoffroy, I8I8.

Egyptian Slit-faced Bat; Cape Slit-faced Bat. Kaapse Langoorvlermuis

Distribution: in the Cape Province, Little Namaqualand (Goodhouse, Klipfontein, Port Nolloth, Garies), near Lamberts Bay, Swellendam, Knysna, widely distributed in the eastern Cape Province, Louisvale (opposite Upington), Kuruman. Zululand, Natal, Swaziland. The Transvaal; districts of Rustenburg, Pietersburg, Pretoria, Hectorspruit; the Kruger National Park (Skukuza) according to Stevenson-Hamilton. South-West Africa; "plentiful throughout from the Orange River to CuneneOkavango rivers" (Shortridge). Recorded from several localities in Angola. Southern Rhodesia, Northern Rhodesia, Nyasaland. Portuguese East Africa (Tete included). Further to the north, Tanganyika, Kenya, Somaliland, Abyssinia, Eritrea, the Belgian Congo, northwards to Egypt, Palestine, Arabia and Corfu.

Nygteris thebaica t'Hebaica E. Geoffroy, i8i8. (Extralimital) I8I8. Nycteris thebaicus E. Geoffroy, Description de l'Egypte, 2: i i 9. Egypt.

Nygteris thebaiga Gapensis A. Smith, I829

I 829. Nycteris capensis A. Smith, Zool. J. 4: 434. Interior of South Africa; Swellendam, south-western Cape Province nominated by Roberts (I95I).

I 829. Nycteris affinis A. Smith, loc. cit. No locality. Grahamstown, eastern Gape Province nominated as type locality by Roberts (I95I).

I840. Nycteris discolor Wagner in Schreber's Säugth. Suppl. I: 440. "Südspitze von Afrika." Knysna, according to Roberts.

I852. Nycteris fuliginosa Peter, Reise nach Mossambique, Säugeth. 46. Boror, I 2 miles north-west of Quelimane, north of the Zambezi, Portuguese East Africa.

Range: southern Cape Province to Zululand, Transvaal, Southern Rhodesia, Portuguese East Africa, Nyasaland, Northern Rhodesia, Ovamboland (part), Tanganyika.

Nycteris thebaica angolensis Peters, i87 I

I871. Nycteris angolensis Peters, Mber. Preuss. Akad. Wiss. 1870: 903. Caconda, east of Benguela, Angola (type locality restricted by Hill \& Carter, I94I).

Nycteris thebaica damarensis Peters, i87 I

I871. Nycteris damarensis Peters, Mber. Preuss. Akad. Wiss. I870: 905. Otjimbingue, Damaraland, South-West Africa. Range: from the Orange River and Little Namaqualand to the Kaokoveld, Damaraland, Ngamiland, southern Angola, Tanganyika (part). 
Nycteris macrotis Dobson, 1876

Large-eared Slit-faced Bat

Distribution: as here understood, Nyasaland, Angola (Mossamedes (B.M.), Dundo); Tanganyika, the Belgian Congo, Nigeria to Gambia.

NyGTeris MAGrotis magrotis Dobson, i 876

I876. Nycteris macrotis Dobson, Monogr. Asiatic Chiroptera, 8o., (N.V.) Sierra Leone, West Africa. Ranges to Angola.

NyGTERIS MAGRotis ORIANA Kershaw, I922

1922. Nycteris oriana Kershaw, Ann. Mag. N.H. Io: i 79. Chiromo, Shire Valley, ( $16^{\circ} 32^{\prime}$ S., $35^{\circ} 9^{\prime}$ E., $200 \mathrm{ft}$.), southern Nyasaland. Ranges to Tanganyika.

Nycteris woodi $\mathrm{K}$. Andersen, I9I4

Wood's Slit-faced Bat. Woodse Langoorvlermuis

Distribution: Southern Rhodesia, and Northern Rhodesia.

NyGTERIS WOODI WOODI K. Andersen, I9I4

I914. Nycteris woodi K. Andersen, Ann. Mag. N.H. I3: 563. Chilanga, 4, roo ft. Northern Rhodesia. "Chilanga is the site of an old administrative headquarters ten miles east of Lusaka, the present capital of Northern Rhodesia (Lancaster, in litt.)" (Moreau, Hopkins \& Hayman, I946).

NyGTERIS WOODI SABIENsis Roberts, I946

1946. Nycteris woodi sabiensis Roberts, Ann. Transv. Mus. 20: 304. Birchenough Bridge, Sabi River, Melsetter district of south-eastern Southern Rhodesia.

\section{FAMILY M E G A D E R M A T I D A E}

Genus LAVIA Gray, $18{ }_{3} 8$

I838. Lavia Gray, Mag. Zool. \& Bot. 2: 490. Megaderma frons E. Geoffroy. 1846. Livia Agassiz, Nomenclator Zool. Mamm. addenda, 6 (misspelling).

This genus differs from Megaderma in the more normal, less distorted W-pattern of its upper molars.

Lavia frons E. Geoffroy, I8Io

Yellow-winged Bat

Distribution: in South Africa doubtful, but has been recorded from Ndola, Northern Rhodesia (Pitman, 1934). Tanganyika, Kenya, Uganda, the Sudan, westwards to Senegal.

LAVIA FRons E. Geoffroy, i8io

I81 0 . Megaderma frons E. Geoffroy, Ann. Mus. H.N. Paris, 15: 192. Senegal. 


\title{
FAMILY R H I N O L O P H I D A E
}

I. Toes with 2 phalanges each; pelvis with postacetabular foramen (Miller). SUBFAMILy Hipposiderinae- -2

Toes (except hallux) with 3 phalanges each; pelvis without postacetabular foramen (Miller).

$$
\text { SUBFAMILy Rhinolophinae; Genus RHINOLOPHUS, page } 55
$$

2. Rostrum less than half as long as braincase; nasal inflation inconspicuous; ears low. Small, forearm $32-35.8 \mathrm{~mm}$.

Genus CLOEOTIS, page 62

Rostrum at least half as long as braincase; nasal inflation conspicuous; ears more prominent. In South Africa larger, forearm about $42 \mathrm{~mm}$. and more.

Genus HIPPOSIDEROS, page 6o

\author{
SubFAmily $\mathrm{R}$ h i $\mathrm{n}$ o $\mathrm{l}$ o $\mathrm{p} \mathrm{h}$ i $\mathrm{n}$ a $\mathrm{e}$
}

Genus RHINOLOPHUS Lacépède, I 799

I 799. Rhinolophus Lacépède, Tabl. Mamm. I5. Vespertilio ferrumequinum Schreber, from France.

I847. Aquias Gray, P.Z.S. I 5. Rhinolophus luctus Temminck, from Java (here restricted). I90 I. Euryalus Matschie, S.B. Ges. Naturf. Fr. Berlin, 225. Rhinolophus mehelyi Matschie, from Rumania.

The most recent reviews of this very large genus are Tate, i939, Amer. Mus. Nov. No. 1036, and 1943, Amer. Mus. Nov. No. I 2 I9. These papers deal with the Oriental members of the genus, and slightly modify the arrangements of K. Andersen, I905, Ann. Mag. N.H. I6: 243, 281, 289 and 648; 1905, P.Z.S. 2: 75, I 2 I; and I9I8, Ann. Mag. N.H. 2: 374 .

In the 1905 papers (P.Z.S. and Ann. Mag. N.H. ${ }_{16}$ : 648) the African members of the genus are dealt with and compared with their Asiatic allies.

According to the classification offered by Tate, it appears that only three groups occur in South Africa:

(I) the pusillus group, based on a species from Java.

(2) the luctus group, also based on a species from Java (Tate has merged Andersen's macrotis group. (based on a species from Nepal) with the luctus group; K. Andersen placed certain African species in his macrotis group).

(3) the ferrumequinum group, based on the type and earliest named species in the genus, from France.

We have to thank Dr. G. C. Sanborn of the Chicago Natural History Museum for much help in dealing with this difficult genus.

I. Width of horseshoe over $9 \mathrm{~mm}$. (Roberts). Skull length exceeds $23 \mathrm{~mm}$.

Width of horseshoe below $9 \mathrm{~mm}$. (Roberts). Skull length not exceeding $23 \mathrm{~mm}$. 
2. Larger, forearm $6 \mathrm{I}-67 \mathrm{~mm}$. Skull length $26.7-29.6 \mathrm{~mm}$.

Rhinolophus hildebrandti, page 60 Smaller, forearm $48 \frac{1}{2}-5^{8} \mathrm{~mm}$. Skull length in South Africa $24 \cdot 3^{-25 \cdot 4} \mathrm{~mm}$.

Rhinolophus fumigatus, ${ }^{1}$ page 60

3. P.3 external to toothrow, canine and P.4 in contact.

$\mathrm{P} .3$ in toothrow, canine and P.4 not in contact.

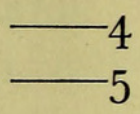

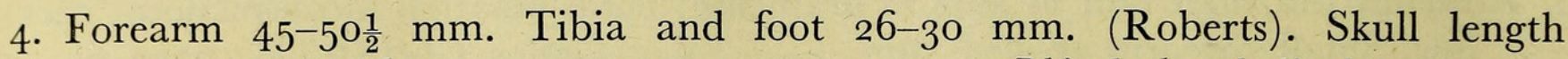
$20.5 \mathrm{~mm}$. and less.

Rhinolophus darlingi, page 57

Forearm (in South African forms) $50 \frac{1}{2}-56 \mathrm{~mm}$. Tibia and foot $30-34.5 \mathrm{~mm}$,

(Roberts). Skull length (in South Africa) 2 I $\mathrm{mm}$. and more.

Rhinolophus clivosus, ${ }^{2}$ page 57

5. Connecting process rises to a narrow and high point.

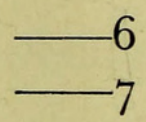

Connecting process with lower end blunt.

6. First phalanx of fourth finger shorter.

First phalanx of fourth finger long, more than half as long as second.

Rhinolophus landeri, ${ }^{3}$ page 59

Rhinolophus blasii, ${ }^{4}$ page 59

7. Larger, forearm 47-5 $\mathrm{I} \mathrm{mm}$. Length of the skull $20 \mathrm{~mm}$. and more.

Rhinolophus capensis, page $5^{8}$

Smaller, forearm about 40-45 $\mathrm{mm}$. Skull length about $18.7 \mathrm{~mm}$. and less.

8. Sella broader. (The only African species with three mental grooves, fide Sanborn).

Length of skull about $17.7 \mathrm{~mm}$. and more.

Sella narrower. Length of skull I $7.6 \mathrm{~mm}$. and less.

Rhinolophus simulator, page 59

9. Front edge of connecting process almost concave, fourth metacarpal longest, lancet with sides almost convex (Sanborn). Rhinolophus denti, page 58

Front edge of connecting process convex, fifth metacarpal longest, lancet pointed, sides concave laterally (Sanborn). Rhinolophus swinnyi, page 58

An eleventh species, $R$. angolensis, is unrepresented in London and not well known. Hill \& Carter's notes suggest it may be allied to landeri and blasii; it appears to be rather smaller than either.

${ }^{1}$ We suggest fumigatus is the prior name for the species usually called aethiops. Although $\mathrm{K}$. Andersen said they differed in forearm length, Angolan specimens referred by Hill \& Carter to aethiops appear from their forearm length to be as fumigatus, showing that the two forms overlap in size.

${ }^{2}$ Dr. Sanborn writes us that the name geoffroyi should be dropped as unidentifiable, and that he proposes to regard augur (referred by Roberts to geoffroyi) as a subspecies of the northern $R$. clivosus. This species is very closely allied to $R$. ferrumequinum. Sanborn states in litt. that the length of the toothrow $\left(\mathrm{C}_{-} \mathrm{M}_{3}\right)$ is slightly greater than the width across the outer edges of $\mathrm{M}_{3}-\mathrm{M}_{3}$ in ferrumequinum and less in clivosus.

${ }^{3}$ We regard the South African form lobatus as a race of the earlier-named landeri.

${ }^{4}$ We see no reason why we should not follow Jentink and regard the South African form empusa as a race of the earlier-named $R$. blasii. 


\section{Rhinolophus ferrumequinum group}

Rhinolophus clivosus Cretzschmar, I 828

Geoffroy's Horseshoe Bat. Geoffroyse Blaarneusvlermuis; Hoefystervlermuis

Distribution: in the Cape Province, Pondoland, Grahamstown, Pirie, Plettenberg Bay, Knysna, Cape Agulhas, Cape Town, Klaver, Little Namaqualand (the Kamiesberg, O'okiep, north of Steinkopf), Kuruman. Vredefort, Orange Free State. Natal (Estcourt, Zululand, etc.). Transvaal; Potchefstroom, Krugersdorp, Johannesburg, Pretoria, near Potgietersrust, Woodbush, Lydenburg, Wakkerstroom, Legogot, etc. The Kruger National Park (Skukuza), (Stevenson-Hamilton). Southern Rhodesia, Northern Rhodesia, Nyasaland. Damaraland and the Kaokoveld, SouthWest Africa. Has been recorded (I887) from Angola. Tanganyika, Pemba and Zanzibar Islands, Kenya, the Belgian Congo. Eritrea, Algeria, Egypt, Arabia ${ }^{1}$.

Rhinolophus GLivosus clivosus Cretzschmar, i828. (Extralimital) 1828. Rhinolophus clivosus Cretzschmar in Rüppell, Atlas Reise Nördl. Afrika, Säugeth. 47. Mohila, Red Sea Coast, approximately $27^{\circ} 49^{\prime}$ N., $35^{\circ} 30^{\prime}$ E., Arabia.

Rhinolophus glivosus augur K. Andersen, igo4

1904. Rhinolophus augur K. Andersen, Ann. Mag. N.H. I4: 380. Kuruman, northern Cape Province.

(1829. Rhinolophus geoffroyii A. Smith, Zool. J. 4: 433. Cape Town (Roberts, I95I). Roberts (I9I9) said "This name apparently takes place over that of Rhinolophus augur" but why this was apparent he did not explain, and there seems to be nothing in the description to identify it. Its type is neither in London nor in Edinburgh, so is apparently lost. We adopt Dr. Sanborn's suggestion and discard this name as unidentifiable.)

Range: western Cape Province to northern Transvaal.

Rhinolophus glivosus zuluensis K. Andersen, igo4

I904. Rhinolophus augur zuluensis K. Andersen, Ann. Mag. N.H. I4: 383. Insuzi (misspelt Jususie) Valley, near Eshowe, Zululand, Natal.

1904. Rhinolophus augur zambesiensis K. Andersen, Ann. Mag. N.H. I4: 383. Fort Hill, northern Nyasaland.

Range: eastern Cape Province, Natal, eastern Transvaal, to Southern Rhodesia, Northern Rhodesia, Nyasaland and, according to Roberts, the adjacent parts of Portuguese East Africa.

Rhinolophus darlingi K. Andersen, I905

Darling's Horseshoe Bat. Darlingse Vlermuis

Distribution: Transvaal; districts of Barberton and Pretoria. Southern Rhodesia (Mashonaland). Damaraland and Great Namaqualand in South-West Africa. Nyasaland. Has been recorded from Benguela, Angola. Tanganyika.

${ }^{1}$ According to Dr. Sanborn, $R$. acrotis (Heuglin, I86 I) should be merged with this species. 
Rhinolophus DARlingi K. Andersen, i905

1905. Rhinolophus darlingi K. Andersen, Ann. Mag. N.H. 15: 70. Mazoe, Mashonaland, north-eastern Southern Rhodesia.

1924. Rhinolophus darlingi barbertonensis Roberts, Ann. Transv. Mus. Io: 59. Louws Creek, Barberton district, south-eastern Transvaal.

I934. Rhinolophus landeri Shortridge, Mamm. S.W. Africa, $1: 5$ I. Not of Martin, I 838 . I946. Rhinolophus darlingi damarensis Roberts, Ann. Transv. Mus. 20: 303. Oserikari, Okahandja district, Damaraland, South-West Africa.

Rhinolophus capensis Lichtenstein, I 823

Cape Horseshoe Bat. Kaapse Hoefystervlermuis

Distribution: in the Cape Province, Grahamstown, Knysna, Dordrecht (Shortridge), Cape Town, Elgin (British Museum), Lamberts Bay, Little Namaqualand (the Kamiesberg, Goodhouse). Nyasaland (Thomas).

RhinOLOPHUS CAPENSIS Lichtenstein, I823

I823. Rhinolophus capensis Lichtenstein, Verz. Doublett. Zool. Mus. Berlin, 4. Cape of Good Hope.

I 86o. Rhinolophus auritus Sundevall in Grill, K. Svenska Vetensk. Akad. Handl. (2) 2: No. I0, I3, footnote. Belvedere, near Knysna, southern Gape Province.

Rhinolophus denti Thomas, I904

Dent's Horseshoe Bat. Dentse Vlermuis

Distribution: in the Cape Province, Kuruman, Louisvale (south bank of Orange River, near Upington). South-West Africa; the Kaokoveld to the southern border of Angola (Rua Cana Falls).

Rhinolophus DENTI Thomas, I904

1904. Rhinolophus denti Thomas, Ann. Mag. N.H. I3: 386. May, i904. Kuruman, northern Cape Province.

Rhinolophus swinnyi Gough, I908

Swinny's Horseshoe Bat. Swinnyse Vlermuis

Distribution: in the Cape Province, Pondoland, Pirie (near King William's Town). Wakkerstroom, south-eastern Transvaal. Southern Rhodesia.

Rhinolophus swinnyi Gough, Igo8

1908. Rhinolophus swinnyi Gough, Ann. Transv. Mus. I: 71. Ngqeleni district, west of Port St. Johns, Pondoland, eastern Cape Province.

I9I3. Rhinolophus swinnyi piriensis Hewitt, Rec. Albany Mus. 2: 402. Pirie, near King William's Town, eastern Cape Province.

1946. Rhinolophus swinnyi rhodesiae Roberts, Ann. Transv. Mus. 20: 304. Bezwe River, a tributary of the Wanetsi (?Nuanetsi) River, Limpopo Valley, southern part of Southern Rhodesia. 
Rhinolophus simulator K. Andersen, I904

Bushveld Horseshoe Bat. Bosveldvlermuis

Distribution: Natal (Dargle district), the Transvaal (Rustenburg district, Klein Letaba, Hectorspruit, etc.). Mashonaland, Southern Rhodesia, Southern Portuguese East Africa, Northern Rhodesia (Lake Bangweulu (if bembanicus is the same)), Nyasaland.

Rhinolophus simulator K. Andersen, igo4.

1904. Rhinolophus simulator K. Andersen, Ann. Mag. N.H. I 4: 384. November, I 904. Mazoe, Mashonaland, north-eastern Southern Rhodesia.

(I9I4. Rhinolophus bembanicus Senna, Ann. Mus. Z.R. Univ. Napoli, (2) 4: No. 9, I. Lake Bangweulu, Northern Rhodesia).

Rhinolophus pusillus group.

Rhinolophus landeri Martin, I 838

Lander's Horseshoe Bat. Kleinhoringvlermuis

Distribution: the eastern Transvaal (Roberts). Portuguese East Africa (Tete included), Northern Rhodesia, Nyasaland. The Belgian Congo, Tanganyika, Zanzibar Island, Kenya, Fernando Po.

RHINOLOPHUS LANDERI LANDERI Martin, I838. (Extralimital) I838. Rhinolophus landeri Martin, P.Z.S. I837: Iо I. Island of Fernando Po.

Rhinolophus landeri lobatus Peters, 1852

I852. Rhinolophus lobatus Peters, Reise nach Mossambique, Säugeth. 4I. Sena, south bank of the Zambezi River, $17^{\circ} 28^{\prime}$ S., $35^{\circ}$ I $^{\prime}$ E., Portuguese East Africa. Restricted by Moreau, Hopkins \& Hayman, i946. Range: as above, excepting Fernando Po.

Rhinolophus blasii Peters, I 866

Peak-saddle Horseshoe Bat. Saalneusvlermuis Distribution: Transvaal (Krugersdorp and Pretoria districts), Southern Rhodesia, Nyasaland; Eritrea; Greece, Italy, Yugoslavia, Cyprus, Palestine, Transcaucasia, Turkmenia.

Rhinolophus blasi blasi Peters, i866. (Extralimital)

I866. Rhinolophus blasii Peters, Mber. Preuss. Akad. Wiss. I 7. New name for clivosus Blasius, I857 (not of Cretzschmar, 1828). The type locality is here restricted to Italy.

Rhinolophus blasi empusa K. Andersen, igo4

1904. Rhinolophus empusa K. Andersen, Ann. Mag. N.H. I4: 378. Zomba, southern Nyasaland. Range: as far south as the Transvaal. 
Rhinolophus angolensis Seabra, 1898

Angolan Horseshoe Bat

Distribution: Hanha, Angola.

Rhinolophus angolensis Seabra, 1898

I 898. Rhinolophus angolensis Seabra, J. Sci. Math. Phys. Nat., Lisboa, 5: 250. Hanha, north of Benguela, western Angola.

Rhinolophus luctus group.

Rhinolophus fumigatus Rüppell, 1842

Damara Horseshoe Bat. Damaralandse Hoefystervlermuis

Distribution: Little Namaqualand (north of Steinkopf), Cape Province. SouthWest Africa; Great Namaqualand, the Kaokoveld. Angola (recorded from many localities, northwards at least to Chitau). Petauke district and Fort Jameson, eastern Northern Rhodesia. Tanganyika, Pemba Island, Kenya, Uganda, Somaliland, Eritrea, Abyssinia. (The form eloquens K. Andersen, I905, is also regarded as a subspecies of fumigatus.)

Rhinolophus fumigatus fumigatus Rüppell, i 842

I842. Rhinolophus fumigatus Rüppell, Abh. Senckenb. Mus. 3: I32. Shoa, Abyssinia.

Some skins bearing this name in the B.M. from Northern Rhodesia.

Rhinolophus fumigatus aethiops Peters, i 869

I 869. Rhinolophus aethiops Peters, Mber. Preuss. Akad. Wiss. I 868: 637. Otjimbingue,

Damaraland, South-West Africa. Range: Little Namaqualand to Angola.

Rhinolophus hildebrandti Peters, 1878.

Hildebrandt's Horseshoe Bat. Hildebrantse Vlermuis

Distribution: Rustenburg district, western Transvaal; Tete, Portuguese East Africa; Southern Rhodesia, including Salisbury and Mazoe; Nyasaland, Northern Rhodesia. Belgian Congo, Tanganyika, Kenya, southern Somaliland.

Rhinolophus hildebrandti hildebrandti Peters, i 878 1878. Rhinolophus hildebrandtii Peters, Mber. Preuss. Akad. Wiss. 195. Ndi, Taita district, Kenya.

\section{Subfamily $\mathrm{H}$ i $\mathrm{p}$ p o s i d e $\mathrm{r}$ i $\mathrm{n}$ a e}

Genus HIPPOSIDEROS Gray, I8 3 I

I831. Hipposideros Gray, Zool. Misc. 37. Vespertilio speoris Schneider, from India. 1837. Phyllorhina Bonaparte, Fauna Ital. pt. 2 I : 3. Rhinolophus diadema E. Geoffroy, from Timor. 
I 866. Macronycteris Gray, P.Z.S. 82. Rhinolophus gigas Wagner (a race of Rhinolophus commersoni E. Geoffroy).

I87 I. Doryrhina Peters, Mber. Preuss. Akad. Wiss., 3 I 4. Phyllorhina cyclops Temminck, from the Gold Coast.

I87 I. Sideroderma Peters, loc. cit. 324. Phyllorhina fuliginosa Temminck, from West Africa.

I87 I. Ptychorhina Peters, loc. cit., 325. Rhinolophus caffer Sundevall.

187 I. Synodesmotis Peters, loc. cit. 329. Phyllorhina megalotis Heuglin, from Eritrea.

For other extralimital generic synonyms see Ellerman \& Morrison-Scott, I95 I, I 23.

For a review of this genus see Tate, I94I, Bull. Amer. Mus. N.H. 78: 353. The large species $H$. commersoni should not be given generic rank under the name Phyllorhina as was done by Roberts and Shortridge; this name was based on an Oriental species and is treated by Tate in quite a different group of the genus. If subgeneric division is desired, then Macronycteris is available for H. commersoni, and Ptychorhina for caffer, which species Tate placed in his galeritus group.

Smaller, forearm about $4^{2-5}$ I $\mathrm{mm}$.

Much larger, forearm about 90-107 $\mathrm{mm}$.
Hipposideros caffer, page 6 I Hipposideros commersoni, page 62

\section{Hipposideros galeritus group}

\section{Hipposideros caffer Sundevall, I 846}

South African Lesser Leafnosed Bat. Kaapse Blaarneusvlermuis Distribution: in the Union, Port St. Johns (Pondoland), Natal including Durban, Zululand, and the eastern Transvaal (Wakkerstroom, Barberton, etc.). Portuguese East Africa (Tete included), Southern Rhodesia, South-West Africa (Damaraland, Ovamboland, the Kaokoveld). Angola, where widely distributed. Northern Rhodesia, Nyasaland. Northwards to Tanganyika, Uganda, Kenya, Eritrea, the Belgian Congo, Gabon district; Morocco; south-western Arabia.

Hipposideros GAFFer caffer, Sundevall, i 846

I 846. Rhinolophus caffer Sundevall, Öfvers. Vetensk. Akad. Förh. Stockholm, 3, 4: I I 8. Near Durban, Natal.

I 852. Phyllorhina gracilis Peters, Reise nach Mossambique, Säugeth. 36. Tete, on the Zambezi, Portuguese East Africa.

Range: the Union as listed above, northwards to Tanganyika and, according to G. Allen, Eritrea.

Hipposideros Gaffer angolensis Seabra, i 898

I898. Phyllorhina angolensis Seabra, J. Sci. Math. Phys. Nat., Lisboa, 5: 256. Benguela, Angola (type locality restricted by Hill \& Carter, I 94I). Ranges southwards to Damaraland.

Hipposideros caffer centralis K. Andersen, igo6

1906. Hipposideros caffer centralis K. Andersen, Ann. Mag. N.H. I7: 275, 277. Entebbe, Uganda. Ranges to Angola. 
Hipposideros commersoni group

Hipposideros commersoni E. Geoffroy, I8 I 3

Commerson's Leafnosed Bat. Commersonse Blaarneusvlermuis

Distribution: South-West Africa (Kaokoveld, Outjo and Grootfontein districts to Damaraland). Northern Rhodesia. Recorded from many localities in Angola, northwards at least to Loanda, southwards to Benguela, Humbe, etc. Nyasaland. Portuguese East Africa (Beira, and includes Ibo Island (Cap Delgado group)). Northwards to Tanganyika, Zanzibar and Pemba Islands, Kenya, the Belgian Congo. Madagascar.

Hipposideros commersoni commersoni E. Geoffroy, i8iz. (Extralimital) I813. Rhinolophus commersoni E. Geoffroy, Ann. Mus. H.N. Paris, 20: 263. Fort Dauphin, Madagascar.

Hipposideros commersoni gigas Wagner, I845

I845. Rhinolophus gigas Wagner, Arch. Naturgesch. II, I: I48. Benguela, southwestern Angola.

1852. Phyllorhina vittata Peters, Reise nach Mossambique, Säugeth., 32. Ibo Island, $\mathrm{I}_{2}{ }^{2} \mathrm{O}^{\prime} \mathrm{S}$., Gap Delgado group, northern Portuguese East Africa.

HIPPOSIDEROS COMMERSONI MARUNGENSIS Noack, I 887

I887. Phyllorhina commersonii var. marungensis Noack, Zool. Jb. 2: 272. Qua Mpala, Marungu, southern Belgian Congo. Ranges southwards to Beira and Damaraland. "There would appear to be no hard and fast line between H.c. marungensis and gigas" (Swynnerton \& Hayman, I95I).

\section{Genus CLOEOTIS Thomas, I9o I}

igor. Cloeotis Thomas, Ann. Mag. N.H. 8: 28. Cloeotis percivali Thomas.

Cloeotis percivali Thomas, I90 I

African Trident Bat. Drietandneusvlermuis

Distribution: the Transvaal, districts of Rustenburg, Krugersdorp, Pretoria, etc., Swaziland, Southern Rhodesia. Kenya.

Cloeotis percivali percivali Thomas, igoi.

I9or. Cloeotis percivali Thomas, Ann. Mag. N.H. 8: 28. Takaungu, north of Mombasa, Kenya. Ranges to Southern Rhodesia.

Cloeotis percivali australis Roberts, 1917

I917. Cloeotis percivali australis Roberts, Ann. Transv. Mus. 5: 264. Mooimeisiesfontein, Rustenburg district, western Transvaal. 


\section{CHIROPTERA - MOLOSSIDAE}

\section{FAMILY M O L O S I D A E}

I. A prominent vertical projection on zygoma. Ears very large, about $38 \mathrm{~mm}$.

Genus OTOMOPS, page 64 Not combining these characters. (In South Africa, ear about $27 \mathrm{~mm}$. and less.) ${ }^{1}$

2. Skull much flattened (depth of braincase only about a third of its width).

Skull not much flattened.

Genus PLATYMOPS, page 63

Genus TADARIDA, page 64

\section{Genus PLATYMOPS Thomas, Igo6}

1906. Platymops Thomas, Ann. Mag. N.H. I7: 499. Platymops macmillani Thomas, from Abyssinia.

I917. Sauromys Roberts, Ann. Transv. Mus. 6: 5. Platymops (Sauromys) haagneri Roberts.

The southern representatives of Platymops differ from the type species in their larger size (forearm $32 \mathrm{~mm}$. in macmillani, $36-42 \mathrm{~mm}$. in petrophilus), but we think that Roberts' two supposed species from South Africa are conspecific, and petrophilus has priority.

\section{Platymops petrophilus Roberts, I9I 7}

Flatheaded Freetailed Bat. Platkop Losstertvlermuis

Distribution: near Rustenburg, western Transvaal; Ceres, the Cedarberg and Goodhouse (Little Namaqualand), western Cape Province; South-West Africa (Great Namaqualand and Damaraland).

Platymops petrophilus petrophilus Roberts, i 9 I 7

I9I 7. Platymops (Sauromys) petrophilus Roberts, Ann. Transv. Mus. 6: 4. Bleskop, near Rustenburg, western Transvaal.

Platymops petrophilus haAgneri Roberts, i 9 i 7

I9I 7. Platymops (Sauromys) haagneri Roberts, Ann. Transv. Mus. 6: 5. Keetmanshoop, Great Namaqualand, South-West Africa. (Damaraland in original description appears to be an error.)

Platymops petrophilus umbratus Shortridge \& Carter, 1938

1938. Platymops haagneri umbratus Shortridge \& Carter, Ann. S. Afr. Mus. 32: 282. Kliphuis, Pakhuis Pass, I I miles north-east of Clanwilliam, western Cape Province.

${ }^{1}$ In specimens and measurements available to us. 
Platymops petrophilus erongensis Roberts, I946

1946. Platymops petrophilus erongensis Roberts, Ann. Transv. Mus. 20: 308. Ombu Farm, Eronga Mountain, Omaruru district, Damaraland, South-West Africa.

Platymops petrophilus fitzsimonsi Roberts, i 946

1946. Platymops petrophilus fitzsimonsi Roberts, Ann. Transv. Mus. 20: 308. Mitchell's Pass, near Ceres, south-western Cape Province.

\section{Genus OTOMOPS Thomas, I9I3}

I9I3. Otomops Thomas, J. Bombay N.H. Soc. 22: 9 I. Nyctinomus wroughtoni Thomas, from Kanara, India.

Otomops martiensseni Matschie, 1897

Large Freetailed Bat. Grootste Losstertvlermuis

Distribution: Durban, Natal; Chitau, Angola; Tanganyika; the Belgian Congo.

Otomops martiensseni martiensseni Matschie, i897. (Extralimital).

1897. Nyctinomus martiensseni Matschie, Arch. Naturgesch. 63 (I): 84. Magrotto plantation, south-eastern Usambara Mountains, west of Tanga, northeastern Tanganyika.

Otomops martiensSeni icarus Chubb, igi 7

i9i 7. Otomops icarus Chubb, Ann. Durban Mus. I: 433. Durban, Natal. Also recorded from Chitau, Angola by Hill \& Carter (I94I).

Genus TADARIDA Rafinesque, I8I 4

I8I4. Tadarida Rafinesque, Précis Som. 55. Cephalotes teniotis Rafinesque, from Sicily.

I8I8. Nyctinomus E. Geoffroy, Description de l'Egypte, 2: I I4. Nyctinomus aegyptiacus E. Geoffroy.

1842. Mops Lesson, Nouv. Tabl. Regn. Anim., i 8. Mops indicus Lesson = Molossus mops Blainville, from Sumatra. Valid as a subgenus.

I865. Mormopterus Peters, Mber. Preuss. Akad. Wiss. 258. Nyctinomus jugularis Peters, from Madagascar $=$ Vespertilio acetabulosus Hermann, from Mauritius. Valid as a subgenus.

I874. Chaerephon Dobson, J. Asiat. Soc. Bengal, 43, 2: I44. Molossus (Nyctinomus) johorensis Dobson, from Johore, Malay States. Valid as a subgenus.

i917. Lophomops J. Allen, Bull. Amer. Mus. N.H. 37: 46o. Chaerephon (Lophomops) chapini J. Allen.

I9I7. Allomops J. Allen, loc. cit., 470. Chaerephon (Allomops) osborni J. Allen, from the Belgian Congo. 
On this genus see Tate, I941, Amer. Mus. Novit., No. I 142 and Thomas, I9I3, 7. Bombay N.H. Soc. 22: 89.

In I95 I we followed Simpson in referring Chaerephon, Mormopterus and Mops to Tadarida as subgenera.

There are apparently fifteen species of this genus in South Africa. Roberts (I95I) reviewed eight of them. He shows that the name condylura antedates angolensis. We are inclined to consider his form rhodesiae as representing the Angolan ansorgei. Hill \& Carter (I94I) reviewed nine of the species (they retained ten, but we are inclined not to give specific rank to the form cristatus). We think that a species for which the first name appears to be chapini (to include also shortridgei and lancasteri), characterized by the long bicoloured crest in the males, is valid, and we think Roberts was wrong in making shortridgei a race of limbatus. Hill \& Carter overlooked the Angolan form T. spillmanni Monard, which was described as near angolensis = condylura, but although approaching the latter in size appears to belong to the subgenus Chaerephon.

I. Only I upper premolar. (M 3 not very reduced; premaxillae with conspicuous emargination).

Tadarida (Mormopterus) acetabulosa, page 70

Normally 2 upper premolars (the small one very reduced, sometimes absent in $T$. condylura which has $\mathrm{M}_{3}$ very reduced, more or less $\mathrm{V}$-shaped).

2. $\mathrm{M}_{3}$ reduced, the cusps more or less forming a V-pattern. $\mathrm{M}_{3}$ less reduced, the cusps forming more than a V-pattern.
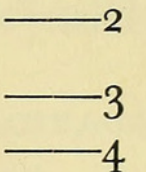

3. Larger, forearm about 59-64 $\mathrm{mm}$. Smaller, forearm about $43-49 \mathrm{~mm}$.

Tadarida (Mops) midas, page 70 Tadarida (Mops) condylura, page 69

4. Palate normally without conspicuous emargination, but a small notch may be present which never extends back to roots of incisors.

Palate with conspicuous median emargination extending back to roots of incisors.

5. Large, forearm about 46-50 mm. Tadarida (Chaerephon) spillmanni, page 67 Smaller, forearm about $42 \mathrm{~mm}$. and less.

6. Males with long bicoloured crest. Not as just described.

Tadarida (Chaerephon) chapini, page 68

7. Wings dark; underparts usually darker.

Wings pale; underparts usually paler.

Tadarida (Chaerephon) pumila, page 67

Tadarida (Chaerephon) limbata, page 68

8. Large species, forearm approximately $64 \mathrm{~mm}$. (length of skull of type circa $25 \mathrm{~mm}$.).

Tadarida africana, page 66

Smaller species, forearm about $42-5 \mathrm{I} \frac{1}{2} \mathrm{~mm}$.

9. Averages larger, forearm about $47^{-}-5^{1} \frac{1}{2} \mathrm{~mm}$. (Length of skull, in South Africa, about I9-2 I mm.).

Tadarida aegyptiaca, page 66

Averages smaller, forearm about $47 \frac{1}{2} \mathrm{~mm}$. and less. (Length of skull about I9 $\mathrm{mm}$. and less.) 
I0. Palatal emargination larger than diameter of canines; pelage abundant; rostrum slender.

Tadarida bocagei, page 67

Palatal emargination smaller than diameter of canine; pelage short, scanty; rostrum broad.

Tadarida ansorgei, page $67^{1}$

\section{Subgenus TADARIDA Rafinesque, I8I4}

Tadarida africana Dobson, 1876

Transvaal Freetailed Bat. Transvaalse Losstertvlermuis

Distribution: the Transvaal, no exact locality.

TADARIDa africana Dobson, i 876

I876. Nyctinomus africanus Dobson, Ann. Mag. N.H. I7: 348. Transvaal.

Tadarida mastersoni Roberts, $\mathrm{I} 946$

Masterson's Freetailed Bat. Mastersonse Losstertvlermuis

Distribution: Southern Rhodesia.

TADARIDA MASTERSONI Roberts, I 946

1946. Nyctinomus mastersoni Roberts, Ann. Transv. Mus. 20: 306. Chikupo Caves, Masembura Native Reserve, Bindura district (near Mazoe), north-eastern Southern Rhodesia.

Tadarida aegyptiaca E. Geoffroy, 18 18

Egyptian Freetailed Bat. Egiptiese Losstertvlermuis

Distribution: Cape Province, recorded from Cape Town, Middelburg, Grahamstown, Peddie, Blythswood, King William's Town. Zululand, Natal. Angola (Quibula, Galanga, Caquindo). Fort Jameson, Northern Rhodesia. Also known from Kenya, Egypt and western India.

Tadarida aegyptiaga aegyptiaga E. Geoffroy, i8i8.

I818. Nyctinomus aegyptiacus E. Geoffroy, Description de l'Egypte, 2: i 28. Egypt. 1826. Dysopes geoffroyi Temminck, Mon. Mamm. I: 226. Substitute for aegyptiacus. I 900. Nyctinomus anchietae Seabra, J. Sci. Math. Phys. Nat., Lisboa, 6: 82. Quibula, western Angola.

Tadarida brunnea, Seabra, Igoo

Seabra's Freetailed Bat

Distribution: Angola (Quissange). The Belgian Congo.

${ }^{1}$ Four other species of Tadarida are named from South Africa, but are not represented in the British Museum. Subgenus Mops: T. brachyptera appears to be smaller than the other species of the subgenus in the present region; $\mathcal{T}$. chitauensis is, from its description, near condylura, but with the upper incisors closer together, and the colour different. Subgenus Tadarida: T. mastersoni is near africana, but smaller, forearm $57 \mathrm{~mm}$.: T. brunnea is nearest aegyptiaca but with the skull less flattened. 


\section{CHIROPTERA - MOLOSSIDAE}

TADARIDA BRUnNea Seabra, igoo

I 900. Nyctinomus brunneus Seabra, J. Sci. Math. Phys. Nat., Lisboa, 6: 83. Quissange, north-east of Benguela, western Angola.

Tadarida bocagei Seabra, I 900

Bocage's Freetailed Bat. Bocagese Losstertvlermuis

Distribution: in the Cape Province, Kuruman, Louisvale (near Upington), Van Wyks Vlei, Klaver, near Lamberts Bay, Grahamstown, Aliwal North, etc. Basutoland (British Museum). Potchefstroom, Pretoria and Florida (near Johannesburg), Transvaal. Great Namaqualand and the Kaokoveld, South-West Africa. Angola (Galanga).

TADARIDA Bocagei Seabra, igoo

1900. Nyctinomus bocagei Seabra, J. Sci. Math. Phys. Nat., Lisboa, 6: 84. Galanga (east of Hanha), western Angola.

Tadarida ansorgei Thomas, I9I3

Ansorge's Freetailed Bat

Distribution: Angola (Malange), Southern Rhodesia (if rhodesiae is the same), the Belgian Congo, Tanganyika.

TADARIDA ANSORgei ANSORgei Thomas, I9I 3

I9I3. Nyctinomus ansorgei Thomas, Ann. Mag. N.H. II: 318. Malange, northern Angola.

TADARIDA (?)ANSORgEI RHODESIAE Roberts, I946

1946. Nyctinomus rhodesiae Roberts, Ann. Transv. Mus. 20: 307. Chikupo Caves, Masembura Native Reserve, Bindura district (near Mazoe), north-eastern Southern Rhodesia.

Subgenus CHAEREPHON Dobson, 1874

Tadarida spillmanni Monard, I 933

Spillmann's Freetailed Bat

Distribution: Southern Angola (Vila da Ponte). Northern Rhodesia (specimens in British Museum).

TADARIDA SPILlmanni Monard, I933

1933. Nyctinomus spillmanni Monard, Bull. Soc. Sci. Nat., Neuchâtel, 57: 51. Vila da Ponte, southern central Angola.

Tadarida pumila Cretzschmar, i830 vel i83 I

Little Freetailed Bat. Cretzschmarse Losstertvlermuis

Distribution: Durban, Natal (specimen in British Museum). Angola (recorded from Catumbela and Cunene districts). Tanganyika, Pemba Island, Kenya, Uganda, Sudan, Eritrea; south-western Arabia. 
TADARIDA PUMila pUmila Cretzschmar, I830 vel I83i ı830 vel г83 . Dysopes pumilus Gretzschmar in Rüppell, Atlas, Reise Nördl. Afrika, Säugeth. 69, pl. 27. Massawa, Eritrea.

\section{Tadarida limbata Peters, $185^{2^{1}}$}

Whitebellied Little Freetailed Bat. Kleinlosstertvlermuis

Distribution: northern Zululand, Natal; Malelane (Barberton district), eastern Transvaal; Portuguese East Africa (Tete and Mozambique Island included); Ngamiland, northern Bechuanaland; Nyasaland; Angola (Benguela, Congulu, Hanha, Loanda, Mossamedes, Quissange, etc.). Tanganyika, including Pemba and Zanzibar Islands, the Belgian Congo, Abyssinia, etc.

Tadarida limbata limbata, Peters, 1852

I852. Dysopes limbatus Peters, Reise nach Mossambique, Säugeth. 56. Mozambique Island ( $15^{\circ}$ S., $40^{\circ} 42^{\prime}$ E.) northern Portuguese East Africa.

I852. Dysopes dubius Peters, loc. cit., 6o. Sena, south bank of Zambezi, Portuguese East Africa. Not of A. Smith, I833.

Range: includes Angola, Tanganyika.

TAdarida (?)Limbata cristata J. Allen, igi 7

I9I 7. Chaerephon (Lophomops) cristatus J. Allen, Bull. Amer. Mus. N.H. 37: 463 . Boma, near mouth of Congo River, western Belgian Congo. Retained as a species by Hill \& Carter (I94I) who record it from Angola, but their characters are not convincing for a valid species.

TADARIDA Limbata ELPHicki Roberts, I926

I926. Chaerephon pumilus elphicki Roberts, Ann. Transv. Mus. II: 245. Malelane Estate, Barberton district, south-eastern Transvaal. Range includes northern Zululand, Nyasaland.

TADARIDA Limbata LANGi Roberts, 1932

1932. Chaerephon (Lophomops) langi Roberts, Ann. Transv. Mus. 15: i 7. Tsotsoroga Pan, Ngamiland, northern Bechuanaland.

Tadarida chapini J. Allen, I9I 7 Longcrested Freetailed Bat

Distribution: Ovamboland, South-West Africa; eastern Northern Rhodesia; Capelongo and Dundo, Angola; the Belgian Congo.

TADARIda GHAPINI Ghapini J. Allen, i9i 7. (Extralimital)

I9I7. Chaerephon (Lophomops) chapini J. Allen, Bull. Amer. Mus. N.H. 37: 46r. Faradje, north-eastern Belgian Congo.

${ }^{1}$ In 195 I we recorded the distribution of $T$. pumila as including Portuguese East Africa, Transvaal and Bechuanaland because we thought we could follow Shortridge (I934) who made limbata a race of pumila, which classification now seems incorrect, as the two species occur together. 


\section{CHIROPTERA - MOLOSSIDAE}

TADARIDA CHAPINI SHORTRIDGEI Thomas, I926

1926. Chaerephon (Lophomops) shortridgei Thomas, P.Z.S., 289. Ukualukasi, northwestern Ovamboland, South-West Africa.

TADARIDA GHAPINI LANGASTERI Hayman, I938

1938. Chaerephon lancasteri Hayman, Ann. Mag. N.H. I: 383. Lunzi River, Lundazi district, Loangwa Valley, eastern Northern Rhodesia. Also recorded from Dundo, north-eastern Angola and Mwinilunga, Northern Rhodesia.

Subgenus MOPS Lesson, I 842

Tadarida condylura A. Smith, I 833

Angola Freetailed Bat. Angolasse Losstertvlermuis

Distribution: the eastern Cape Province (Roberts), Natal, Zululand, Swaziland. Angola (Chitau, Mossamedes district, Cuanza River). Northern Rhodesia, Nyasaland, into Portuguese East Africa (Shire River, north of the Zambezi). Tanganyika, Ruwenzori, French Sudan, Belgian Congo, etc.

TAdarida condylura condylura A. Smith, I833

I833. Nyctinomus condylurus A. Smith, S. Afr. J. 2: 54. "Port Natal" = Durban, Natal.

1870. Nyctinomus angolensis Peters, J. Sci. Math. Phys. Nat., Lisboa, (I) 3: I24. (Quenza River = Cuanza River?), Angola.

TADARida condylura niveiventer Cabrera \& Ruxton, I926.

1926. Mops angolensis niveiventer Cabrera \& Ruxton, Ann. Mag. N.H. I7 : 594. St. Joseph de Luluabourg, southern Belgian Congo. Occurs in Northern Rhodesia.

Tadarida chitauensis Hill, I937

Chitau Freetailed Bat

Distribution: Chitau, Central Angola.

TAdarida Ghitauensis. Hill, I937.

1937. Mops chitauensis Hill, Amer. Mus. Novit., No. 916, 2, 3. Chitau, central Angola.

Tadarida brachyptera Peters, $185^{2}$

Whitebreasted Freetailed Bat

Distribution: Mozambique Island; Zanzibar Island, Tanganyika.

TAdarida BRAGHyptera Peters, I852

I 852. Dysopes brachypterus Peters, Reise nach Mossambique, Säugeth., 59. Island of Mozambique, $15^{\circ}$ S., $40^{\circ} 42^{\prime}$ E., coastal northern Portuguese East Africa. 
Tadarida midas Sundevall, I 843

Sundevall's Freetailed Bat

Distribution: Senegal, Nigeria, the Sudan, Eritrea, Arabia (near northern Yemen border, B.M.), and Nyasaland (Chiromo, B.M.). Madagascar.

TADARIDA midas Sundevall, I843

I843. Dysopes midas Sundevall, K. Svenska Vetensk. Akad. Handl. I842: 207, pl. 2, fig. 7. Bahr-el-Abiad (White Nile), Sudan. Ranges southwards to Nyasaland.

Subgenus MORMOPTERUS Peters, I 865

Tadarida acetabulosa Hermann, 1804

Natal Wrinkle-lipped Bat. Natalse Losstertvlermuis

Distribution: near Durban, Natal; Madagascar, Mauritius.

Tadarida acetabulosa acetabulosa Hermann, i804. (Extralimital)

I 804. Vespertilio acetabulosus Hermann, Obs. Zool. i 9. Port Louis, Island of Mauritius.

Tadarida (?)agetabulosa natalensis A. Smith, i 847

(1833. Nyctinomus dubius A. Smith, S. African J. 2: 54. "Between Cape Colony and Natal."1)

I847. Dysopes natalensis A. Smith, Illustr. Zool. S. Africa, Mamm. pl. 49 and text. Near "Port Natal" = Durban, Natal.

\section{FAMILY V E S P E R T I L I O N I D A E}

Apparently eleven valid genera occur in South Africa.

Miller (1907) gave a key to the genera of this family, but recognized too many. Simpson (1945) has attempted some generic reduction from Miller's list, but in our opinion has gone rather too far and in the present region we follow him only in making Rhinopterus a subgenus of Eptesicus and Scotoecus a subgenus of Nycticeius, except in cases where we followed his classification in our $195^{\mathrm{I}}$ publication. We consider Cistugo to be not more than a subgenus of Myotis. Roberts complicated the classification of the genera south of the Zambezi-Cunene by extreme oversplitting in the division of the family nearest Eptesicus and Pipistrellus, which is precisely the part of the family where any splitting is to be avoided as Pipistrellus itself is only retained as a genus for convenience; it is not, strictly, more than a subgenus of

${ }^{1}$ Roberts (1944) regarded natalensis as a synonym of dubius, but gave no convincing reason why dubius must necessarily be identified with natalensis. The 1847 figure of Smith's Dysopes natalensis suggests a Mormopterus in its clearly separated ears, but the associated tooth formula does not agree with what can be made of the poor skull figure. There are various discrepancies in the original descriptions and we are not satisfied that they are both the same animal. This bat has not been rediscovered since Smith's day. It may be that dubius must be discarded as not certainly identifiable. 


\section{CHIROPTERA - VESPERTILIONIDAE}

Eptesicus which itself might be referred to Vespertilio Linnaeus; for discussion of this problem see Ellerman \& Morrison-Scott ( I95 I, I62). Roberts' classification of these Eptesicus-like bats is typical of the views of zoologists who study only one part of the world and ignore everything else outside that part.

I. Sternum short and broad, its length in middle line not twice as great as breadth of presternum; 4 or 5 ribs connected with sternum; ear slightly but evidently funnel-formed (Miller, who on account of these characters separated the genus as the type of the subfamily Kerivoulinae). Six upper and 6 lower cheekteeth; braincase region of skull elevated.

Genus KERIVOULA, page 88

Sternum slender, its length in middle line more than twice as great as breadth of presternum; 6 or 7 ribs connected with sternum; ear not funnel-formed (Miller).

2. Presternum with median lobe larger than body of bone; scapula with coracoids straight, directed inward; second phalanx of third finger nearly three time as long as first (Miller, who on account of these characters separated the genus as the subfamily Miniopterinae). Braincase region of skull elevated.

Genus MINIOPTERUS, page 86

Presternum with median lobe much smaller than body of bone; scapula with coracoid curved outward; second phalanx of third finger not specially elongated (Miller).

3. Six upper and 6 lower cheekteeth.

Less than 6 upper and 6 lower cheekteeth.

Genus MYOTIS, page 72

4. Normally with 2 upper premolars (and 2 upper incisors).

With I upper premolar.

$$
-4
$$

5. Fifth finger shortened, only a little longer than metacarpal of the fourth and third.

Fifth finger normally not specially shortened.

Genus NYCTALUS, ${ }^{1}$ page 78

Genus PIPISTRELLUS, page 79

6. With I upper incisor.

Two upper incisors.

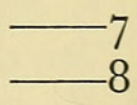

7. First and second upper molars with W-pattern distorted or nearly absent.

Genus SCOTOPHILUS, page 85

First and second upper molars with W-pattern normal.

Genus NYCTICEIUS, page $8_{3}$

8. Ears very enlarged, about $18 \mathrm{~mm}$. and more.

Genus LAEPHOTIS, page 78

Ears normally less enlarged (if not, as in one case in Roberts' measurements for Eptesicus hottentotus, then proportionately considerably shorter).

1 Occurrence in South Africa doubtful. 
9. Braincase very deep, its depth (including bullae) about equal to distance from incisors to posterior zygoma root.

Genus GLAUCONYCTERIS, page 82 Braincase less deep, much less than the above-quoted distance. Io

Io. Skull much flattened. Also characterized by its shortened wings.

Genus MIMETILLUS, page 82

Skull not specially flattened; not combining the characters of the last genus.

Genus EPTESICUS, page 74

Subfamily V e s p e r t i 1 i o $\mathrm{n}$ i $\mathrm{n}$ a e

Genus MYOTIS Kaup, I829

I829. Myotis Kaup, Skizz. Europ. Thierw. I: Io6. Vespertilio myotis Borkhausen, from Germany.

I830. Leuconoe Boie, Isis, Jena, 256. Vespertilio daubentoni Kuhl, from Germany. Valid as a subgenus.

I84I. Selysius Bonaparte, Fauna Ital. I: Introd. 3. Vespertilio mystacinus Kuhl, from Germany. Valid as a subgenus.

i 9 10. Chrysopteron Jentink, Notes Leyden Mus. 32: 74. Kerivoula weberi Jentink, from Celebes. Valid as a subgenus.

I9I 2. Cistugo Thomas, Ann. Mag. N.H. I0: 205. Cistugo seabrae Thomas. Valid as a subgenus.

For other extralimital subgeneric names and synonyms see Ellerman \& MorrisonScott, I95 I, I37-138.

We do not consider Cistugo as more than a subgenus of Myotis, from which it is supposed to differ in having glands in the wings; Roberts stated that he had not been able to see the glands in the only specimen he had examined.

For a review of Eurasian Myotis (and a short note on the African species) see Tate, I94 I, Bull. Amer. Mus. N.H. 78: 537.

Tate divides this large genus into seven subgenera (apart from Cistugo) and refers the South African species welwitschi to Chrysopteron, tricolor and bocagei to Selysius. Dobson (1878) referred $M$. bocagei to the subgenus Leuconoe (characterized by having the feet long, considerably more than half the length of the tibia); but twelve specimens in the British Museum with foot 8-10.5 mm., tibia I 7-2 I mm. show that Tate was correct in referring this species to Selysius. (Eleven skins for M. tricolor with the foot 9-II mm., the tibia $2 \mathrm{I}-23 \mathrm{~mm}$. show that this species, also, is rightly placed in Selysius): Typical Myotis is based on large species, forearm about 52-66 mm., with no dichromatic wing pattern, and the feet not greatly enlarged.

I. Large species, forearm about $47 \mathrm{~mm}$. and more.

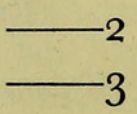


2. With dichromatic wing pattern. Forearm about $5^{2-58} \mathrm{~mm}$.

Wings dark. Forearm about 47-51.7 mm.

Myotis (Chrysopteron) welwitschi, page 73

Myotis (Selysius) tricolor, page 73

3. No glands on wings, so far as known. Forearm about $33-40 \mathrm{~mm}$.

Myotis (Selysius) bocagei, page 73

With glands on wings. Forearm about $32.5-32.9 \mathrm{~mm}$.

Myotis (Cistugo) seabrai, ${ }^{1}$ page 74

Subgenus SELYSIUS Bonaparte, I84I

Myotis bocagei Peters, 1870

Rufous Mouse-eared Bat

Distribution: Northern Angola (Duque de Bragança); Nyasaland; Tanganyika, Kenya, the Cameroons.

Myotis bocagei bogagei Peters, i87o

I870. Vespertilio bocagii Peters, J. Sci. Math. Phys. Nat., Lisboa, (I) 3: i25. Duque de Bragança, northern Angola.

Myotis tricolor Temminck, 1832

Cape Hairy Bat. Kaapse Langhaarvlermuis

Distribution: in the Cape Province, Cape Town, Montagu, East London, King William's Town; Estcourt and near Pietermaritzburg, Natal (B.M.); Potchefstroom district, Transvaal. Mt. Elgon, Uganda (B.M.), Kenya (Coryndon Museum), Abyssinia (B.M.).

MYotis TRICOLOR Temminck, I 832

I832. Vespertilio tricolor Temminck in Smuts, Enum. Mamm. Cap., ıo6. Cape Town, Cape Province.

Subgenus CHRYSOPTERON Jentink, I9 го

Myotis welwitschi Gray, I 866

Welwitsch's Bat. Welwitschse Langhaarvlermuis

Distribution: the Transvaal; near Belfast, and 50 miles from Lydenburg. Melsetter, Southern Rhodesia, Nyasaland, Angola and Tanganyika, the Congo.

Myotis welwitschi welwitschi Gray, i 866

I866. Scotophilus welwitschii Gray, P.Z.S., 2 I I. Angola.

1 There is another species of the subgenus Cistugo (M. lesueuri), which is not represented in London. The glands are said to be in a different position from those of seabrai, and the forearm is about $34 \frac{1}{2} \mathrm{~mm}$. 


\section{Subgenus CISTUGO Thomas, I9I2}

Myotis seabrai Thomas, I912

Angola Wing-gland Bat. Angolasse Vlerkkliervlermuis

Distribution: Mossamedes, Angola; Great Namaqualand, South-West Africa; Goodhouse (on Orange River, Little Namaqualand), Cape Province.

Myotis SEABRAI Thomas, IgI 2

I912. Cistugo seabrae Thomas, Ann. Mag. N.H. Io: 205. Mossamedes, south-western Angola.

Myotis lesueuri Roberts, I9I9

Lesueur's Wing-gland Bat. Lesueurse Vlerkkliervlermuis

Distribution: Paarl district, and near Citrusdal (Shortridge, I942), both western Cape Province.

Myotis Lesueuri Roberts, igi9

I9 19. Cistugo lesueuri Roberts, Ann. Transv. Mus. 6: i I2. Lormarins, Franschhoek Valley, opposite Paarl, south-western Cape Province.

\section{Genus EPTESIGUS Rafinesque, I820}

1820. Eptesicus Rafinesque, Annals of Nature, 2. Eptesicus melanops Rafinesque $=$ Vespertilio fuscus Beauvois, from North America.

I87o. Nyctiptenus Fitzinger, S.B. Akad. Wiss. Wien., 62: 424. Vespertilio smithi Wagner $=$ Vespertilio hottentota A. Smith.

I906. Rhinopterus Miller, Proc. Biol. Soc. Washington 19: 85. Glauconycteris floweri de Winton, from the Sudan. Valid as a subgenus.

I 908. Scabrifer G. M. Allen, Bull. Mus. Comp. Zool. Harvard, 52: 46. Substitute for Rhinopterus, not Rhinoptera Kuhl.

1926. Neoromicia Roberts, Ann. Transv. Mus. II: 245. Eptesicus zuluensis Roberts.

For further extralimital generic synonyms see Ellerman \& Morrison-Scott, I95I.

We consider Rhinopterus is at most a subgenus of the present genus. The species pusillus and zuluensis were regarded as a genus "Neoromicia" by Roberts on account of having the cranium slightly raised above the level of the muzzle, but until every species of Eptesicus from Europe, Asia, Africa, Australia and America is examined it is premature to give that name even subgeneric rank.

Apparently ten valid species in South Africa, but only five of these are represented in the British Museum.

I. Large species, forearm 48-53 mm. Skull strongly built, with "helmet" formed by confluence of lambdoid and sagittal crests. Eptesicus hottentotus, ${ }^{1}$ page 76

Smaller species, forearm $38 \mathrm{~mm}$. and less.

${ }^{1} E$. hottentotus is the South African representative of the Holarctic E. serotinus group. It apparently differs from $E$. serotinus in the structure of its first upper incisor. 
2. Cranial portion of skull raised above muzzle. (Forearm 29-3 I mm., skull about I I $\frac{1}{2}-$ I $2.8 \mathrm{~mm}$., compare $E$. pusillus with forearm $26 \mathrm{~mm}$., skull about Iо $\frac{1}{2} \mathrm{~mm}$. which also occurs in South Africa but is not authentically represented in London).

Eptesicus zuluensis, page 77

Cranium not, or scarcely, raised up above muzzle.

3. Wings dark.

Wings pale.

Eptesicus capensis, page 75

4. Back much darker. Forearm $27 \frac{1}{2}-32 \mathrm{~mm}$.

Back much paler. Forearm $3^{6-} 3^{8} \mathrm{~mm}$.

Eptesicus tenuipinnis, page 77

Eptesicus rendalli, ${ }^{1}$ page 77

\section{Subgenus EPTESICUS Rafinesque, I820}

Eptesicus capensis A. Smith, 1829

Cape Serotine. Kaapse Dakvlermuis

Distribution: in the Union, the Transvaal, Krugersdorp, Pietersburg, Pretoria, Johannesburg, Lydenburg, the Kruger National Park (Skukuza district, StevensonHamilton), Estcourt, Zululand, Natal; Bethlehem, Vredefort, Orange Free State; Maseru, Basutoland (British Museum); in the Cape Province, Kuruman, Deelfontein, Louisvale (near Upington), Little Namaqualand (the Kamiesberg), near Lamberts Bay, east of Clanwilliam, King William's Town, Grahamstown. Portuguese East Africa (Tete); Southern Rhodesia (Bulawayo); northern Bechuanaland; "generally distributed over the whole of South-West Africa" (Shortridge). Many localities in Angola, northwards at least to Chitau; Northern Rhodesia (Broken Hill and Serenje district). Also from the Belgian Congo, Kenya and British Somaliland.

Eptesicus Gapensis Gapensis A. Smith, i 829

I 829. Vespertilio capensis A. Smith, Zool. J. 4: 435. "Cape." Grahamstown, eastern Cape Province, according to Roberts, I95 I, 89. Range: eastern Cape Province to Transvaal.

EPTESICUS GAPENSIS DAMARENSIS Noack, i 889

I889. Vesperus damarensis Noack, Zool. Jb. 4: 2 I 3. Omburu and "Golabu" (Golabie), Damaraland, South-West Africa.

(1932. Eptesicus capensis nkatiensis Roberts, Ann. Transv. Mus. I5: i6. Nkate, northern Bechuanaland.)

Eptesicus Gapensis GRAGilior Thomas \& Schwann, igo5

I905. Vespertilio capensis gracilior Thomas \& Schwann, P.Z.S. I: 257. Eshowe, Zululand, Natal. Ranges to eastern Transvaal.

${ }^{1}$ Five other species of Eptesicus occur which are not represented in London, one of which, pusillus, is noted in the key above, with zuluensis. The species notius belongs to the subgenus Rhinopterus, separated on account of having the forearm, tail and legs sprinkled with small horny outgrowths; E. flavescens is like E. capensis but averages a little larger and occurs with it, and E. melckorum appears to be like flavescens but differs in colour details; it also occurs in the same neighbourhood as capensis (in the Union), and averages rather larger. E. bicolor (Angola) is placed next to tenuipinnis in Hill \& Carter's key, from which it differs in colour. 
Eptesicus flavescens Seabra, I900

Distribution: Angola (Chitau and Galanga).

Eptesicus flavescens Seabra, igoo

I90o. Vesperugo (Vesperus) flavescens Seabra, J. Sci. Math. Phys. Nat., Lisboa, 6: 23. Galanga, north-east of Benguela, Angola.

1937. Eptesicus capensis angolensis Hill, Amer. Mus. Novit. No. 916, I. Chitau, Central Angola.

Eptesicus melckorum Roberts, I9I9

Melck's House Bat. Melckse Dakvlermuis

Distribution: the western Cape Province, Berg River and Riversdale district.

Eptesicus melakorum Roberts, I9I9

I9I9. Eptesicus melckorum Roberts, Ann. Transv. Mus. 6: i I3. Kersfontein, Berg River, south-western Cape Province. Also known from the Riversdale district, south-western Cape Province.

Eptesicus hottentotus A. Smith, I 833

Longtailed House Bat. Langstertdakvlermuis

Distribution: the Natal Drakensberg, and in the Cape Province, Albany district, near Cape Town, near Citrusdal and Goodhouse (Orange River, Little Namaqualand). Damaraland, South-West Africa. Nyasaland.

Eptesicus hottentotus hottentotus A. Smith, i 833

I833. Vespertilio hottentota A. Smith, S. Afr. J. 2: 59. Uitenhage and Albany, eastern Cape Province; type locality here restricted to Uitenhage.

I840. Vespertilio megalurus Temminck, Mon. Mamm. 2: 206. Interior of South Africa.

1849. Vespertilio minutus A. Smith, Illustr. Zool. S. Africa, Mamm. pl. 5I and text. Not of Montagu, i 808 .

I 855. Vespertilio smithii Wagner in Schreber, Säugth. Suppl. 5: 747, footnote. South Africa. For status see Roberts (I95I).

1938. Scotophilus angusticeps Shortridge \& Carter, Ann. S. Afr. Mus. 32: 282. Hex River Estate, Io miles north of Citrusdal, western Cape Province.

Eptesicus hottentotus Pallidior Shortridge, I942

1942. Eptesicus megalurus pallidior Shortridge, Ann. S. Afr. Mus. 36: 37. Goodhouse, on Orange River, Little Namaqualand, north-western Cape Province.

Eptesicus hotTentotus Bensoni Roberts, I946

1946. Eptesicus hottentotus bensoni Roberts, Ann. Transv. Mus. 20: 305. Ncheu, Nyasaland.

Eptesicus pusillus Leconte, I 857

Little Serotine

Distribution: recorded from Cubango, Caquindo, etc., Angola. The Belgian Congo, Tanganyika, ?Gabon. 
Eptesicus Pusillus Leconte, I857

I857. Vespertilio pusillus Leconte, Proc. Acad. Nat. Sci. Philad. io. "Western Africa" (probably Gabon).

I 889. Vesperugo pusillus Noack, Zool. Jb. 4: 2 I6. Boma, mouth of the Congo, Belgian Congo.

Eptesicus zuluensis Roberts, I 924

Aloe Bat. Aalwynvlermuis

Distribution: Zululand, Natal and Leydsdorp, Transvaal; northern Bechuanaland, northern Kaokoveld, Okavango and western Caprivi in South-West Africa.

Eptesicus zuluensis zuluensis Roberts, I924

1924. Eptesicus zuluensis Roberts, Ann. Transv. Mus. Io: 6o. White Umfolosi Game Reserve, Zululand, Natal.

(1840. Vespertilio minuta Temminck, Mon. Mamm. 2: 209. Cape of Good Hope. Not of Montagu, I808.)

Eptesicus zuluensis vansoni Roberts, i932

1932. Neoromicia vansoni Roberts, Ann. Transv. Mus. 15: I5. Zweizwe Waterhole, north of Tsotsoroga Pan, Ngamiland, northern Bechuanaland.

Eptesicus tenuipinnis Peters, 1872

White-winged Serotine

Approximate distribution: has been recorded from Angola (Cotete, Dundo). Belgian Congo, Tanganyika, Lado, etc.; the type locality was on the border of Gabon and the French Congo.

Eptesicus tenuipinnis tenuipinnis Peters, i 872

1872. Vesperus tenuipinnis Peters, Mber. Preuss. Akad. Wiss., 263. Kuilu River, border of Gabon and French Congo (Noack, I889, Zool. Jb. 4: 2 I8).

Eptesicus tenuipinnis ater J. Allen, igi 7

I 9 17. Eptesicus ater J. Allen, Bull. Amer. Mus. N.H. 37: 443. Faradje, north-eastern Belgian Congo. Recorded by Sanborn (1950) from Dundo, north-eastern Angola.

Eptesicus rendalli Thomas, I889

Rendall's Serotine

Distribution: Nyasaland (Shire River); Lumbo, northern Portuguese East Africa. The southern Belgian Congo, Kenya, the Sudan, westwards to Gambia.

Eptesigus Rendalli Thomas, i889

I889. Vesperugo (Vesperus) rendalli Thomas, Ann. Mag. N.H. 3: 362. Bathurst, Gambia.

Eptesicus bicolor Bocage, I889

Bocage's Serotine

Distribution: Angola (Caconda). 
Eptesicus Bicolor Bocage, I 889

I889. Vesperus bicolor Bocage, J. Sci. Math. Phys. Nat., Lisboa, I: 5. Caconda, east of Benguela, Angola.

\section{Subgenus RHINOPTERUS Miller, I906}

Eptesicus notius G. Allen, I908 Horny-skin Bat. Growwevelvlermuis Distribution: only known from Cape Town, South Africa.

Eptesicus notius G. Allen, igo8 i 9o8. Scabrifer notius G. Allen, Bull. Mus. Comp. Zool. Harvard, 52: 46. Cape Town.

\section{Genus LAEPHOTIS Thomas, I90 I}

igo r. Laephotis Thomas, Ann. Mag. N.H. 7: 460. Laephotis wintoni Thomas.

Laephotis wintoni Thomas, Igo I

De Winton's Long-eared Bat

Distribution: Angola (districts of Dala and Dando). Northern Rhodesia. Kenya.

Laephotis Wintoni wintoni Thomas, igoi. (Extralimital)

I9o I. Laephotis wintoni Thomas, Ann. Mag. N.H. 7: 46o. Kitui, 3,500 ft., Kenya.

Laephotis Wintoni angolensis Monard, i935

1935. Laephotis angolensis Monard, Arq. Mus. Bocage, 6: 45. Chiumbe River, I 5 km. west of Dala, eastern Angola. Ranges to Solwezi, Northern Rhodesia.

\section{Genus NYGTALUS Bowdich, 1825}

1825. Nyctalus Bowdich, Excursions in Madeira and Porto Santo, 36 (and footnote). Nyctalus verrucosus Bowdich, from Madeira.

Nyctalus noctula Schreber, I 774

Common Noctule

Distribution: has apparently been recorded from Portuguese East Africa and Algeria. Palaearctic region from England to Japan, southwards to the Malay States.

Nyctalus nogtula nogtula Schreber, I 774

I 774. Vespertilio noctula Schreber, Säugth. I: pl. 52 (text, p. I66). France.

(1852. Vespertilio macuanus Peters, Reise nach Mossambique, Säugeth. 6r. Cabaceira Peninsula, northern Portuguese East Africa.) ${ }^{1}$

1 There is no doubt that the animal described and carefully figured in detail as macuanus is $\mathcal{N} y c t a l u s$, and the author states he collected it himself, in his house at Cabaceira. It was described as being almost identical in all respects with $\mathcal{N}$. noctula, and the author could find only very minor differences, which he stressed must separate his animal from noctula, the geographical separation being so great. But the alleged differences, mainly minor size differences in skull measurements, all break down when applied to the long series of noctula now available. The forearm was $53 \mathrm{~mm}$., the total length of the skull $\mathrm{i} 9 \mathrm{~mm}$. 


\section{CHIROPTERA - VESPERTILIONIDAE}

\section{Genus PIPISTRELLUS Kaup, i 829}

1829. Pipistrellus Kaup, Skizz. Europ. Thierw. I: 98. Vespertilio pipistrellus Schreber, from France.

I838. Romicia Gray, Mag. Zool. Bot. 2: 495. Romicia calcarata Gray = Vespertilio kuhli Kuhl, from Trieste.

I867. Alobus Peters, Mber. Preuss. Akad. Wiss. 707. Vespertilio temmincki Cretzschmar $=$ Vespertilio rüppelli Fischer. Not of Leconte, 1856 .

I875. Scotozous Dobson, P.Z.S., 372. Scotozous dormeri Dobson, from India. Valid as a subgenus.

1926. Eptesicops Roberts, Ann. Transv. Mus. II: 245. Scotophilus rusticus Tomes.

1946. Vansonia Roberts, Ann. Transv. Mus. 20: 304. Pipistrellus vernayi Roberts, a race of Vespertilio rüppelli Fischer.

For further extralimital subgenera and synonyms see Ellerman \& Morrison-Scott, 1951. For a review of the Oriental members of the genus see Tate, 1942, Bull. Amer. Mus. N.H. 8o: $22 \mathrm{I}$.

For discussion of the retention of the genus Pipistrellus, which is not much more than a subgenus of Eptesicus and is also antedated by the related $\mathcal{N} y c t a l u s$, see Ellerman \& Morrison-Scott, I95 I, I62.

Roberts referred the species rusticus and fouriei to his supposed genus "Eptesicops", characterized by having the skull flatter than the other species, and to this group he also referred subtilis, the type of which he had apparently not seen. Thomas did see it, and regarded it as allied to P. kuhli, of which G. Allen (whom we propose to follow) made it a race. Roberts referred kuhli to a genus Romicia which has been ignored by virtually all other authors. The species rueppelli is referred by some authors to the subgenus Scotozous.

I. Second upper incisor very reduced.

Second upper incisor not very reduced.

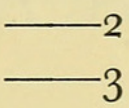

2. First upper incisor markedly bicuspid.

First upper incisor not, or scarcely, bicuspid.

Pipistrellus rueppelli, page 8I

Pipistrellus kuhli, page 8I

3. Braincase flatter, cranium nearly level with muzzle. Pipistrellus rusticus, page 80 Braincase clearly raised up above level of muzzle.

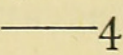

4. Smaller, skull about i I mm. or less. Larger, skull about I I.5 mm. or more, usually more

Pipistrellus culex, ${ }^{1}$ page 80 Pipistrellus nanus, ${ }^{2}$ page 80

${ }^{1} P$. fouriei seems to be a subspecies of the earlier-named $P$. culex. It is not clear why Roberts placed the former with his "Eptesicops" (rusticus group); material examined does not seem to belong there.

${ }_{2}^{2}$ Pipistrellus anchietai from Angola is not authentically represented in the British Museum. The specimens recorded by St. Leger appear to represent $P$. nanus. From descriptions, anchietai is near $P$. rusticus, but the skull is a little larger. 
Subgenus PIPISTRELLUS Kaup, I829

Pipistrellus nanus Peters, 1852

Banana Bat. Piesangvlermuis

Distribution: in the eastern Cape Province, Port St. Johns and East London; Natal, including Durban, Illovo, Malvern, etc.; Barberton district, Transvaal. Inhambane, Portuguese East Africa. Several localities in Angola (at least from Caconda northwards to Duque de Bragança), and several localities in Northern Rhodesia. Lake Ngami. Nyasaland. Further to the north, the Belgian Congo, Tanganyika, Uganda, Kenya.

Pipistrellus nanus Peters, I 852

1852. Vespertilio nanus Peters, Reise nach Mossambique, Säugeth. 63. Inhambane, coastal southern Portuguese East Africa.

I913. Pipistrellus nanus australis Roberts, Ann. Transv. Mus. 4: 67. Port St. Johns, Pondoland, coastal eastern Cape Province.

Pipistrellus culex Thomas, I9 I I

Minute Pipistrelle. Fouriese Dwergvlermuis

Distribution: South-West Africa, the eastern Caprivi, Ovamboland and Grootfontein district. Capelongo, Angola. Northern Nigeria.

Pipistrellus gulex gulex Thomas, igi i. (Extralimital)

igi I. Pipistrellus culex Thomas, Ann. Mag. N.H. 7: 458. "Kabir" (Kabwir), northern Nigeria.

Pipistrellus GUlex fOURIEI Thomas, I926

I926. Pipistrellus fouriei Thomas, P.Z.S. 288. Ukualukasi, north-western Ovamboland, South-West Africa.

Pipistrellus rusticus Tomes, I 86 I

Rusty Bat. Roeskleurvlermuis

Distribution: districts of Pretoria, Tzaneen, Hectorspruit, Transvaal; Damaraland and Grootfontein district, South-West Africa.

Pipistrellus Rusticus Tomes, i 86 I

I86I. Scotophilus rusticus Tomes, P.Z.S. 3I, 35. No locality. Damaraland according to Roberts.

This is the type of Eptesicops Roberts, but until every known species of Pipistrellus from Europe, Asia, Africa, Australia and America has been compared it is premature to recognize it even as a subgenus.

Pipistrellus anchietai Seabra, I90o

Anchieta's Pipistrelle

Distribution: Angola (including Chitau and Humpata). 
Pipistrellus anchietai Seabra, igoo

1900. Vesperugo anchieta Seabra, J. Sci. Math. Phys. Nat., Lisboa, 6: 26, I 20. Cahata $\left(12^{\circ} 20^{\prime}\right.$ S., $14^{\circ} 50^{\prime}$ E. $)$ western Angola.

Pipistrellus kuhli Kuhl, I8 I9

Kuhl's Pipistrelle. Kuhlse Vlermuis

Distribution: in the Cape Province the southern coastal belt in part (Knysna, Pirie, Port St. Johns). Zululand, and near Durban, Natal. The eastern and northern Transvaal, Wakkerstroom district, Legogot (Barberton district), Tzaneen, Zoutpansberg. Specimens in the British Museum perhaps referable to this species from Aberfeldy, Orange Free State and from Southern Rhodesia. Nyasaland. North of the limits of this work, Tanganyika, Kenya; Asben; Egypt, Algeria, Morocco; Europe south of the Baltic, Russian Turkestan, and from Arabia and Asia Minor eastwards to Kashmir and Sind, India.

Pipistrellus kuhli kuhli Kuhl, i8ig. (Extralimital). I 8ı 9. Vespertilio kuhlii Kuhl, Ann. Wetterau Ges. Naturk. 4, 2: i99. Trieste, ItalianYugoslavian border.

Pipistrellus kuhli subtilis Sundevall, i 846

1846. Vesperugo subtilis Sundevall, Öfvers. Vetensk. Akad. Förh. Stockholm, 3: I I 9. "Interior of Caffraria."

Pipistrellus KUhli BROOMI Roberts, I948

1948. Pipistrellus (Romicia) kuhli broomi Roberts, Spec. Publ. Roy. Soc. S. Afr. Broom Commem. Vol. 9. Malvern, near Durban, Natal.

(Roberts proposes this name for the Union specimens formerly referred to Pipistrellus kuhli fuscatus Thomas, I9o I, Ann. Mag. N.H. 8: 34, Naivasha, Kenya.)

Subgenus SCOTOZOUS Dobson, I875

Pipistrellus rueppelli Fischer, I 829

Rüppell's Bat. Grysbontvlermuis

Distribution: Ngamiland, Bechuanaland; Angola, recorded from Gunene River, Cubango and Duque de Bragança. Tanganyika, Belgian Congo, Uganda, Sudan; Egypt; Iraq.

Pipistrellus RUePpelli RUePpelli Fischer, I829

I829. Vespertilio rüppellii Fischer, Synops. Mamm., ıog. Dongola, Anglo-Egyptian Sudan. Recorded by Hill \& Carter from Angola.

1933. Pipistrellus leucomelas Monard, Bull. Soc. Sci. Nat. Neuchâtel, 57: 47. Vila da Ponte, southern Angola.

Pipistrellus RUeppelli vernayi Roberts, I932

1932. Pipistrellus vernayi Roberts, Ann. Transv. Mus. I5: 16. Maun, Ngamiland, northern Bechuanaland. 


\section{SOUTHERN AFRICAN MAMMALS I758-195I}

Genus MIMETILLUS Thomas, I904

1904. Mimetillus Thomas, Abstr. P.Z.S. No. 10: 12. 1905, P.Z.S. 1904, 2: 188. Vesperugo moloneyi Thomas.

Mimetillus moloneyi Thomas, I89 I Moloney's Flatheaded Bat

Distribution: Angola (Vila da Ponte, Chitau, Cahata). Ndola, Northern Rhodesia. The Belgian Congo, Nigeria, Fernando Po, Sierra Leone.

Mimetillus moloneyi moloneyi Thomas, i89i. (Extralimital)

I89i. Vesperugo (Vesperus) moloneyi Thomas, Ann. Mag. N.H. 7: 528. Lagos, southern Nigeria.

Mimetillus moloneyi thomasi Hinton, I920

1920. Mimetillus thomasi Hinton, Ann. Mag. N.H. 6: 240. Ndola (near the Congo border) Northern Rhodesia.

Mimetillus moloneyi Berneri Monard, i 933

1933. Mimetillus berneri Monard, Bull. Soc. Sci. Nat. Neuchâtel, 57: 49. Vila da Ponte, southern Angola.

\section{Genus GLAUCONYGTERIS Dobson, 1875}

1875. Glauconycteris Dobson, P.Z.S., 383. Kerivoula poensis Gray.

This genus is not much more than a subgenus of Chalinolobus Peters, I 866 from Australia, but Miller (1907) gives a few characters in addition to the different dental formula.

Tate (1942, Bull. Amer. Mus. N.H. 8o: 260) is not quite correct in his statement that $\mathrm{P} 2$ in the Australian species Chalinolobus rogersi is absent (thereby weakening the main distinction between Chalinolobus and Glauconycteris). There is nothing in Thomas's original description of $C$. rogersi about the alleged lack of the small $\mathrm{P}_{2}$, and an examination of the type skull of rogersi shows that it has these teeth, although small, and in three other skulls we have of the same species only one lacks the tooth. In view of the extreme shortening of the muzzle and toothrow in Glauconycteris, as well as its tendency to distinctive external characters such as patterns of spots on the body or reticulations of the wings, and its wide geographical separation from Chalinolobus, it is here retained as a valid genus.

Wings pigmented and conspicuously veined Wings plain.
Glauconycteris variegata, page 83

Glauconycteris argentata, page 83

The first named species in this genus, G. poensis, is much darker dorsally than argentata, and is a smaller species. 
Glauconycteris variegata Tomes, I86 I

Butterfly Bat. Vlindervlermuis

Distribution: north-eastern Zululand; Portuguese East Africa (districts of Beira and Inhambane); South-West Africa (Ovamboland, Grootfontein district); recorded from Mupanda, southern Angola; Nyasaland. Northwards to the Belgian Congo, Uganda, Tanganyika, the Sudan and the Gold Coast.

Glauconycteris variegata variegata Tomes, i86 I

I86 I. Scotophilus variegatus Tomes, P.Z.S. 36. Otjoro (in Ovamboland according to Shortridge) South-West Africa.

Glaugonycteris VARIEgata PaPilio Thomas, I905

i905. Glauconycteris papilio Thomas, Ann. Mag. N.H. 15: 77. Entebbe, Uganda. Ranges to northern Zululand, and north-eastern Angola.

Glauconycteris argentata Dobson, 1875

Silvered Bat

Distribution: Recorded from Dundo, north-eastern Angola (Sanborn, I950). Tanganyika, Kenya, Belgian Congo, French Congo, Cameroons.

Glaugonycteris argentata Dobson, 1875

1875. Chalinolobus argentatus Dobson, P.Z.S. 385. Cameroon Mountain, British Cameroons (Moreau, Hopkins \& Hayman, I946).

1889. Chalinolobus congicus Noack, Zool. Jb. Syst. 4: 223. Netonna, near Banana Creek, mouth of Congo River, Belgian Congo.

Genus NYGTICEIUS Rafinesque, I8 I9

I8I9. Nycticeius Rafinesque, J. Physique, 88: 4I7. Nycticeius humeralis Rafinesque, from North America.

I875. Scoteinus Dobson, P.Z.S. 37 I. Nycticejus emarginatus Dobson, thought to be from India. Valid as a subgenus.

igor. Scotoecus Thomas, Ann. Mag. N.H. 7: 263. Scotophilus albofuscus Thomas. Valid as a subgenus.

The characters given by Thomas and Miller for Scotoecus seem more subgeneric than generic, and we follow Simpson in regarding Scotoecus as a subgenus of Nycticeius.

I. Palatal emargination narrow. Palatal emargination broad.

2. Wings dark

Wings light.
Nycticeius (Scoteinus) schlieffeni, page 84

\section{2}

Nycticeius (Scotoecus) hirundo, page 84 Nycticeius (Scotoecus) albofuscus, page 84 
Subgenus SCOTEINUS Dobson, I875

Nycticeius schlieffeni Peters, I 859

Schlieffen's Bat. Kleindakvlermuis

Distribution: northern Zululand; Portuguese East Africa, including districts of Inhambane, Tete, Beira; South-West Africa, the Kaokoveld, Ovamboland, Okavango valley, eastern Caprivi; Ngamiland; Northern Rhodesia; Nyasaland. The Cunene Falls, southern Angolan border. Northwards to Tanganyika, Kenya, Abyssinia, the southern Belgian Congo, northern Sudan, Asben region; Egypt; Arabia.

Nyaticeius sahlieffeni schlieffeni Peters, i859. (Extralimital) I859. Nycticejus schlieffenii Peters, Mber. Preuss. Akad. Wiss., 224. Cairo, Egypt.

Nycticeius schlieffeni australis Thomas \& Wroughton, I9o8 I908. Scoteinus schlieffeni australis Thomas \& Wroughton, P.Z.S., 539. Coguno (Koguno), about 75 miles south-westwards from Inhambane, southern Portuguese East Africa. Ranges to northern Zululand.

Nygticeius SchliefFeni fitzsimonsi Roberts, I932

1932. Scoteinus schlieffeni fitzsimonsi Roberts, Ann. Transv. Mus. I5: i 7. Tsotsoroga Pan, Ngamiland, Bechuanaland.

\section{Subgenus SCOTOECUS Thomas, I90 I}

There appear to be two species (or groups) in this subgenus, for which the first names are respectively albofuscus (with light-coloured wings) and hirundo (with dark wings). Both groups have been recorded from the northern parts of the present region.

Nycticeius albofuscus Thomas, 1890 Light-winged Lesser House Bat

Distribution: Nyasaland; Gambia.

Nycticeius albofuscus albofusgus Thomas, i8go. (Extralimital)

I89o. Scotophilus albofuscus Thomas, Ann. Mus. Stor. Nat. Genova, 29: 84. Bathurst, Gambia.

Nycticeius albofuscus wood Thomas, I9I 7

I9I7. Scotoecus woodi Thomas, Ann. Mag. N.H. 19: 280. Chiromo, southern Nyasaland.

Nycticeius hirundo de Winton, I899

Dark-winged Lesser House Bat

Distribution: recorded from Petauke, Northern Rhodesia, and the Cunene district, southern border of Angola. Kenya, Gold Coast, etc. 


\section{CHIROPTERA - VESPERTILIONIDAE}

Nycticeius HIRUNDo HIRUNDo de Winton, I899. (Extralimital)

I 899. Scotophilus hirundo de Winton, Ann. Mag. N.H. 4: 355. Gambaga, Gold Coast.

Nycticeius HIRUNDO HINDEI Thomas, Igo I

I90 I. Scotoecus hindei Thomas, Ann. Mag. N.H. 7: 264. Kitui, 3,500 ft., Kenya. Recorded by Pitman from Petauke, Northern Rhodesia.

Nygticeius (?)HiRundo albigula Thomas, igo9

I 909. Scotoecus albigula Thomas, Ann. Mag. N.H. 4: 544. Kirui, Mt. Elgon, 6,ooo ft., Kenya. This or an allied form recorded by Monard from the Cunene district, southern Angola.

\section{Genus SCOTOPHILUS Leach, I82 I}

1821. Scotophilus Leach, Trans. Linn. Soc. London, I3: 69, 71. Scotophilus kuhli Leach, from an unknown locality.

I83 I. Pachyotus Gray, Zool. Misc. No. I, 38. Scotophilus kuhli Leach.

The African species were compared with the Asiatic ones by Dobson (1878).

I. Very large, forearm about $85 \mathrm{~mm}$.

Scotophilus gigas, page 85

Medium sized, forearm not over $5^{8} \mathrm{~mm}$.

2. Length of the skull about $20-23 \mathrm{~mm}$.

Length of the skull about $\mathrm{i} 7-\mathrm{r} 9 \mathrm{~mm}$.

Scotophilus nigrita, page 85

Scotophilus viridis, page 86

Scotophilus gigas Dobson, 1875

Giant Yellow Bat

Distribution: Nyasaland, and Southern Rhodesia (Odzi, west of Umtali) (B.M.) Nigeria, the Gold Coast.

Scotophilus gigas Dobson, i 875

I875. Scotophilus gigas Dobson, Ann. Mag. N.H. I6: I22. Lagos, southern Nigeria.

Scotophilus nigrita Schreber, I 774

Yellow House Bat. Geeldakvlermuis

Distribution: in the Union, the eastern Cape Province (Grahamstown, King William's Town, Pondoland); Zululand; in the Transvaal, Pretoria, Leydsdorp, Barberton, Klein Letaba, etc. Portuguese East Africa, (districts of Beira, Inhambane, Gorongoza and Tete); Southern Rhodesia, Nyasaland, Northern Rhodesia (Fort Jameson); in South-West Africa, the Kaokoveld, Grootfontein district, western Caprivi, Ovamboland, Damaraland; Serowe, Bechuanaland; Angola (Mossamedes, Humbé and district in the south). Northwards to Tanganyika, Kenya, the Belgian Congo, the Sudan (Kordofan), and westwards to Senegal.

Scotophilus Nigrita NIGRITA Schreber, I774. (Extralimital)

I 774. Vespertilio nigrita Schreber, Säugth. I: I 7 I, pl. 58. Senegal. 
Scotophilus nigrita dingani A. Smith, i 833

1833. Vespertilio dinganii A. Smith, S. Afr. J. 2: 59. Between "Port Natal" (= Durban) and Delagoa Bay (southern Portuguese East Africa).

I852. Nycticejus planirostris Peters, Reise nach Mossambique, Säugeth. 65. Tete, on the Zambezi, Portuguese East Africa.

I878. Scotophilus borbonicus Dobson, Cat. Chiroptera B.M., 26o. Not of E. Geoffroy, I 806.

Range: Natal to Nyasaland and western Transvaal.

Scotophilus NigRITA HeRERo Thomas, Igo6

I906. Scotophilus nigrita herero Thomas, Ann. Mag. N.H. I7: I 74. Olifants Vlei, about $18^{\circ} \mathrm{S}$., $17^{\circ} 30^{\prime} \mathrm{W}$., apparently in Ovamboland, South-West Africa. Roberts quotes specimens from various localities in South-West Africa, also Serowe, eastern Bechuanaland and Pretoria, Transvaal. Ranges to Angola.

Scotophilus Nigrita pondoensis Roberts, I 946

1946. Scotophilus nigrita pondoensis Roberts, Ann. Transv. Mus. 20: 304. Port St. Johns, Pondoland, eastern Cape Province.

Scotophilus viridis Peters, 1852

Lesser Yellow Bat. Kleingeelvlermuis

Distribution: northern Zululand; Portuguese East Africa (districts of Inhambane, Beira, Tete), Ngamiland, Damaraland and the Grootfontein district in South-West Africa, Nyasaland, north-eastern Angola. Northwards to Tanganyika.

ScOtophilus VIRIDIS VIRIDIS Peters, 1852

I852. Nycticejus viridis Peters, Reise nach Mossambique, Säugeth. 67. Island of Mozambique (north of the Zambezi), $15^{\circ} \mathrm{S} ., 40^{\circ} 42^{\prime}$ E., northern Portuguese East Africa.

Scotophilus VIRIDIS DAMARENsis Thomas, I 906

I906. Scotophilus damarensis Thomas, Ann. Mag. N.H. I7: I75. Olifants Vlei, apparently in Ovamboland, South-West Africa. (Roberts lists the type locality of this and S. nigrita herero as northern Damaraland but if the latitude and longitude given by Thomas are correct, it would seem to be in Ovamboland.)

\section{Subfamily $\mathrm{M}$ i $\mathrm{n}$ i o $\mathrm{p}$ t e $\mathrm{r}$ i $\mathrm{n}$ a $\mathrm{e}$}

Genus MINIOPTERUS Bonaparte, 1837

1837. Miniopterus Bonaparte, Fauna Ital. I: fasc. 20, under Vespertilio emarginatus. Vespertilio ursinii Bonaparte $=$ Vespertilio schreibersii Kuhl.

We regard the South African natalensis as a race of the earlier-named and ubiquitous $M$. schreibersi. Thomas and Roberts thought there were two species, a 
larger one and a smaller one, occurring together in the same caves at Knysna, Cape Province (Roberts also records the smaller one from the Barberton district, Transvaal; Hewitt (I93I) says it occurs from Knysna to Zululand). The differences between the two, however, are very slight; the forearm length of the smaller one, fraterculus, overlaps that of schreibersi natalensis in measurements given by Roberts, and at least the larger members of it are within the range of the forearm length for the schreibersi group given by Tate, I94 I, Bull. Amer. Mus. N.H. 78: 568, who revised the Oriental members of the genus. The skull in Roberts' measurements for schreibersi natalensis is $\mathbf{I} 4.5 \mathrm{~mm}$. and more, the upper toothrow (canine-M 3 ) is $5.6 \mathrm{~mm}$. and more; the same for fraterculus $14.3 \mathrm{~mm}$. and less; $5.5 \mathrm{~mm}$. and less. We submit that it possible that fraterculus is based merely on small individuals of the local $M$. schreibersi.

Miniopterus schreibersi Kuhl, I8 I9

Schreiber's Bat. Schreiberse Vlermuis

Distribution: practically the whole Union (Roberts); Natal, including Zululand, Estcourt, Durban; Transvaal, including Rustenburg, Waterberg, Potchefstroom, Warmbath, Wonderfontein, Pretoria, Klein Letaba, Barberton, Tzaneen, etc. In the Cape Province, Kuruman, Little Namaqualand (north of Steinkopf), Knysna, Plettenberg Bay, Grahamstown, King William's Town, East London, etc. Has been recorded from Delagoa Bay, Portuguese East Africa; Bulawayo and Mashonaland, Southern Rhodesia; the central Kalahari and Ngamiland; in South-West Africa, the districts of Gobabis, Grootfontein, the Kaokoveld, the Etosha Pan. Angola; Golungo Alto, Vila da Ponte, etc. Northern Rhodesia, Nyasaland. North of the limits of this work, the Belgian Congo, Kenya, Tanganyika; Algeria; Europe south of the Baltic, southern Russian Turkestan, Palestine, Persia, Cyprus, Ceylon, India, Burma, China, Japan, Malay States, Sumatra, Java, Borneo, Celebes, Philippine Islands to northern Australia.

Miniopterus SGHREIBERSI SGHREIBERSI Kuhl, i8ig. (Extralimital) I 819. Vespertilio schreibersii Kuhl, Ann. Wetterau Ges. Naturk, 4, 2: i85. Kulmbazer Cave, mountains of southern Bannat, Hungary. Recorded from Angola by Hill \& Carter.

Miniopterus schreibersi natalensis A. Smith, i 833

I833. Vespertilio natalensis A. Smith, S. Afr. J. 2: 59. Natal (type locality nominated by Roberts as Durban).

I840. Vespertilio dasythrix Temminck, Monogr. Mamm. 2: 268. "Interior of Caffraria." I846. Vespertilio scotinus Sundevall, Öfvers. Vetensk. Akad. Förh. Stockholm, 3: I I 9. "Caffraria": Roberts (I95I) nominates Durban, Natal as type locality.

(1906. Miniopterus fraterculus Thomas \& Schwann, P.Z.S. i62. Knysna, southern Cape Province. Recorded also from the Barberton district, Transvaal (Roberts). For discussion see above).

I 909. Miniopterus breyeri Jameson, Ann. Mag. N.H. 4: 47I. Gatkoppies, Waterberg district, western Transvaal.

1927. Miniopterus smitianus Thomas, P.Z.S., 373. Witvlei, 40 miles west of Gobabis, eastern Damaraland, South-West Africa. 


\section{SOUTHERN AFRICAN MAMMALS I 758-I95I}

Subfamily K e $\mathrm{r}$ i v o $\mathrm{u} l \mathrm{i}$ n a e

Genus KERIVOULA Gray, 1842

1842. Kerivoula Gray, Ann. Mag. N.H. 10: 258. Vespertilio pictus Pallas, from India. 1906. Phoniscus Miller, Proc. Biol. Soc. Washington, I8: 229. Phoniscus atrox Miller, from Sumatra. Valid as a subgenus.

\section{Subgenus KERIVOULA Gray, 1842}

The species Kerivoula aerosa Tomes, I858, P.Z.S., 333, was based on (and is only known from) two specimens said to be from Knysna, southern coast of South Africa. Tomes later (I86 I, P.Z.S., 32) said that at Leyden Museum he examined a specimen of his $K$. aerosa labelled "Gorontalo" [which is in Celebes]. Roberts, (I95 I, 76), commented that possibly the type of aerosa never came from Africa. We have examined the type of aerosa, and certainly the proportions of its upper incisors agree more with the majority of the Oriental species, and are unlike those of the two African species here listed. On the other hand, we have also examined the Gorontalo specimen, which does not agree with the type of aerosa, either in size or dentition.

Length of skull $\mathrm{I} 5 \mathrm{~mm}$. and more; forearm 34-39 $\mathrm{mm}$.

Length of skull $\mathrm{I} 3.5 \mathrm{~mm}$. and less; forearm $30-35 \frac{1}{2} \mathrm{~mm}$.

Kerivoula argentata, page 88

Kerivoula lanosa, page 88

Kerivoula lanosa A. Smith, I 847

Lesser Woolly Bat. Kleiner Wolhaarvlermuis

Distribution: southern Cape Province, Knysna and Pirie (near King William's Town); northern Zululand, Natal; Northern Rhodesia (Ndola), Nyasaland. The southern Belgian Congo.

Kerivoula lanosa lanosa A. Smith, i 847

I847. Vespertilio lanosus A. Smith, Illustr. Zool. S. Afr., Mamm. pl. 50 and text. Coast 200 miles east of Cape Town, Cape Province; Knysna (Roberts).

1878. Kerivoula brunnea Dobson, Cat. Chiroptera B.M., 334. "South Africa or Madras."

Kerivoula lanosa lugia Hinton, i920

1920. Kerivoula lucia Hinton, Ann. Mag. N.H. 6: 240. Ndola (near the Congo border), central western Northern Rhodesia. Ranges to Nyasaland and northern Zululand.

Kerivoula argentata Tomes, I86I

Damara Woolly Bat. Damaralandse Wolhaarvlermuis

Distribution: Zululand, Natal; Ovamboland (and Damaraland according to 


\section{PRIMATES}

Roberts), South-West Africa; Boror and the lower Zambezi in Portuguese East Africa; Ndola and Fort Jameson in Northern Rhodesia; Nyasaland; Angola (between Cassange and Bihé, Cuango River, Cazendo); the southern Belgian Congo.

Kerivoula ARgentata argentata Tomes, i86I

I861. Kerivoula argentata Tomes, P.Z.S., 32. Otjoro, Ovamboland, South-West Africa. Ranges eastwards to Nyasaland.

Kerivoula ARgentata Nidicola Kirk, 1865

I 865. Nycticejus nidicola Kirk, P.Z.S. I864: 65 I. Shupanga, on the Zambezi River, $18^{\circ} \mathrm{S}$., Portuguese East Africa.

Kerivoula ARgentata zuluensis Roberts, I 924

1924. Kerivoula nidicola zuluensis Roberts, Ann. Transv. Mus. Io: 6r. White Umfolosi River, Zululand, Natal.

Not identified:

I832. Vespertilio epichrysus Temminck in Smuts, Enum. Mamm. Cap. ıo6. Cape Town.

1832. Vespertilio platycephalus Temminck in Smuts, Enum. Mamm. Cap. io7. Cape Town.

\section{ORDER P R I M A T E S}

(Not including Family Hominidae)

Distinguished by having the hallux or pollex, or both, opposable, the eyes set close together, the orbits ringed by bone and, in the higher members of the group, walled in behind by bone as well; most of the fingers and toes with nails; the canines are the dominant front teeth as a rule, but the dentition is not highly specialized and the diet is usually omnivorous. Size small to relatively large.

See Elliot, I9I3, A Review of the Primates.

The classification of Simpson (1945) is followed here.

Generalized and small species with brain of lower type, the orbits ringed by bone but open behind; second hindtoe with claw.

Family LORISIDAE

(With elongated hindfeet and long tail; Subfamily Galaginae), page 90

Specialized and larger species with brain of higher type, the orbits ringed and walled in behind by bone; all the toes with nails.

Family GERGOPITHEGIDAE, page 93 
SUB-ORDER PROSIMII

\title{
FAMILY L O R I S I D A E
}

\author{
Subfamily $\mathrm{G}$ a $\mathrm{l}$ a $\mathrm{g}$ i $\mathrm{n}$ a $\mathrm{e}$
}

Genus GALAGO E. Geoffroy, I 796

I 796. Galago E. Geoffroy, Mag. Encycl. I: 49. Galago senegalensis E. Geoffroy. I8 I I. Otolicnus Illiger, Prodr. Syst. Mamm. et Avium, 74. Lemur galago Schreber = Galago senegalensis E. Geoffroy.

I8ı 2. Macropus G. Fischer, Mém. Soc. Nat. Moscou, I: i2. New name for Galago; not of Shaw, I790. (The title page has "I8I I" but Sherborn has a note in the B.M. copy that the work was not issued until I8I 2 or possibly early in I 813).

I833. Galagoides A. Smith, S. Afr. J. 2: 32. Galago demidovii Fischer (Elliot, I9I3, Rev. Primates, $I$ : xxix).

I836. Chirosciurus Gervais, Dict. Pittoresque H.N. 4: 6i 7. Nom. nud.

I 857. Hemigalago Dahlbom, Zool. Studier, I: 225. Galago demidovii Fischer.

I859. Otolemur Coquerel, Rev. Zool. Paris, II: 458. Otolemur agisymbanus Coquerel (a race of Galago crassicaudatus E. Geoffroy). Valid as a subgenus.

I863. Otogale Gray, P.Z.S. I32. Type by subsequent designation Otolicnus garnetti Ogilby, a race of Galago crassicaudatus E. Geoffroy.

I 863. Callotus Gray, P.Z.S., I 32. Callotus monteiri Gray (a race of Galago crassicaudatus E. Geoffroy).

I873. Sciurocheirus Gray, P.Z.S. I872: 857. Galago alleni Waterhouse, from Fernando Po.

For revision of this genus see Schwarz, I93 I, Ann. Mag. N.H. 7: 4I.

Schwarz retained four species, three of which occur in the present region. $G$. crassicaudatus is widely separated morphologically from the remainder, and Otolemur Coquerel is available for this species. The name is regarded as a synonym of Galago by Schwarz (I93I), G. Allen (I939), and Swynnerton \& Hayman (I95I) but as a full genus by Shortridge (I934), Roberts (I95I) and Hill \& Carter (I94I). Our view is that subgeneric status is indicated.

I. Larger, total length $600 \mathrm{~mm}$. and more. Adult skulls with sagittal crest. Tail thicker and bushier. Skull rather lower and rostrum strong.

\section{Galago (Otolemur) crassicaudatus, page 92}

Smaller, total length $500 \mathrm{~mm}$. and less. No sagittal crest. Tail thinner, less bushy. Skull higher, rostrum weaker.

2. Small species, total length $250-350 \mathrm{~mm}$. Premaxillae elongated.

Galago demidovi, page $9 \mathrm{I}$

Larger species, total length not under $355 \mathrm{~mm}$., usually $400 \mathrm{~mm}$. and more. Premaxillae not elongated.

Galago senegalensis, page $9 \mathrm{I}$ 
Galago demidovi Fischer, $1806^{1}$

Demidoff's Galago

Distribution: recorded from north-eastern Angola. Tropical Africa from Senegal to Uganda and Tanganyika.

Galago demidovi demidovi Fischer, i806 (Extralimital). I806. Galago demidovii Fischer, Mém. Soc. Nat. Moscou, I: 24. (N.V.) Senegal. I8I 5. Otolicnus demidoffii Illiger, Abh. Preuss. Akad. Wiss. I804-II: 77. Alternative for demidovii.

Galago demidovi phasma Cabrera \& Ruxton, I926

1926. Galagoides demidoff phasma Cabrera \& Ruxton, Ann. Mag. N.H. I7: 596. St. Joseph de Luluabourg, southern Belgian Congo. Recorded from River Kamuanza, near Dundo, north-eastern Angola by Hayman (I95I).

Galago senegalensis E. Geoffroy, I 796

Senegal (or Moholi) Galago, Bushbaby or Night-Ape.

Nagapie

Distribution: in the Union, apparently confined to the Transvaal where it occurs from the Marico, Rustenburg and Pretoria districts to the Zoutpansberg and the Kruger National Park; Shortridge stated it had been recorded from the Vaal River, near Parys. South-West Africa; the northern districts, from northern Damaraland to the Caprivi, Grootfontein district, etc. Ngamiland, and Gaberones, Bechuanaland. Southern Rhodesia, including Bulawayo and Mazoe; Northern Rhodesia, Nyasaland. Angola (occurs locally throughout). Portuguese East Africa; districts of Beira, Gorongoza, Tete, Inhambane, Lourenço Marques and Boror (north of the Zambezi). North of the region dealt with in this work from the Belgian Congo intermittently westwards to the Gold Coast and Senegal, and most of East Africa to the Sudan and Somaliland.

Galago senegalensis senegalensis E. Geoffroy, i 796. (Extralimital). I796. Galago senegalensis E. Geoffroy, Mag. Encycl. I: 38, 49. Senegal.

Galago senegalensis moholi A. Smith, 1836

1836. Galago moholi A. Smith, Rept. Exped. Expl. C. Africa, 42. Banks of Marico River, western Transvaal.

I85I. Galago conspicillatus I. Geoffroy, G.R. Acad. Sci. Paris, 3I: 876. "Port Natal" = Durban, Natal.

I853. Otolicnus galago var. australis Wagner in Schreber, Säugth. Suppl. 5: I58. New name for moholi.

1876. Otolicnus mossambicus Peters, Mber. Preuss. Akad. Wiss., 473, footnote. Tete, south bank of Zambezi, Portuguese East Africa.

${ }^{1}$ Osman Hill (1953) considers that demidovi should be separated generically from the other galagos, and uses the name Galagoides. 
Galago SENEGALENSis moHoli [contd.]

1907. Galago nyasae Elliot, Ann. Mag. N.H. 20: i88. "Mountains south of Lake Nyasa." "Whether it was obtained in what is now the Nyasaland Protectorate or in Portuguese territory seems impossible to determine." (Moreau, Hopkins \& Hayman, I946.)

i93 I. Galago moholi var. intontoi Monard, Bull. Soc. Neuchâtel. Sci. Nat. 55: 67. Type locality here designated as Rio Mbalé, Kuvangu River, Ioo km. S. E. of Vila da Ponte, southern Angola.

I93 I. Galago tumbolensis Monard, loc. cit. 55: 68. Tumbolé River, a tributary of the Kutato, about $40 \mathrm{~km}$. east of Vila da Ponte, Angola.

Galago senegalensis Granti Thomas \& Wroughton, Igo7

I907. Galago granti Thomas \& Wroughton, P.Z.S. 286. Coguno, Inhambane district, southern Portuguese East Africa.

I 924. Galago mertensi Frade, Bull. Soc. Portug. Sci. Nat. 9: I 28. Chibuto, south-west of Inhambane, southern Portuguese East Africa.

Galago SEnegalensis BRAdFIEldi Roberts, I93 I

I93I. Galago moholi bradfieldi Roberts, Ann. Transv. Mus. I 4: 224. Waterberg, Damaraland, South-West Africa.

\section{Subgenus OTOLEMUR Coquerel, I859}

Galago crassicaudatus E. Geoffroy, I8 I 2

Thicktailed (or Large Grey) Bushbaby, Galago or Night-Ape.

Bosnagaap

Distribution: in the Union, Natal (Zululand, Durban), Woodbush and Tzaneen, north-eastern Transvaal (Stevenson-Hamilton, Wild Life in South Africa, states that both species of Galago which occur in the Union occur in the Kruger National Park); Swaziland. Portuguese East Africa, from at least Beira and Gorongoza northwards to Quelimane (north of the Zambezi) and perhaps further. Southern Rhodesia, Salisbury included. Northern Rhodesia, where widely distributed; Nyasaland. Angola, where widely distributed. North of the limits of this work, apparently confined to the eastern side of the continent; Tanganyika, Zanzibar, Kenya and Italian Somaliland.

Galago grassicaudatus grassicaudatus E. Geoffroy, i8 12

I81 2. Galago crassicaudatus E. Geoffroy, Ann. Mus. H.N. Paris, I9: i66. No locality, but fixed by Thomas, I9I7, Ann. Mag. N.H. 20: 48 as Quelimane (north of the Zambezi), eastern coast of Portuguese East Africa.

I 865. Otogale crassicaudata var. kirkii Gray, P.Z.S. I864: 456. Quelimane, Portuguese East Africa.

Range includes Blantyre, southern Nyasaland. 
Galago crassicaudatus Garnetti Ogilby, 1838

I838. Otolicnus garnettii Ogilby, P.Z.S., 6. No locality (described from a living specimen in the Zoological Society's Gardens).

1907. Galago zuluensis Elliot, Ann. Mag. N.H. 20: i 86. Zululand, Natal.

Range: Zululand, Natal coastal districts, Swaziland.

Galago Grassicaudatus monteiri Gray, i863

I863. Callotus monteiri Gray (ex Bartlett MS), P.Z.S. I45. Guio Bay (south of Benguela), western Angola.

Galago grassicaudatus umbrosus Thomas, igi 7

I9I7. Galago crassicaudatus umbrosus Thomas, Ann. Mag. N.H. 20: 49. Woodbush Mountain, Tzaneen Estate, east of Pietersburg, north-eastern Transvaal.

Galago CRassicaudatus lonnbergi Schwarz, i 930

1930. Galago crassicaudatus lönnbergi Schwarz, Ann. Mag. N.H.5: 48. Tambarara, Gorongoza Mountains (south of the Zambezi) in western Portuguese East Africa. Range includes Beira, and westwards to Mount Selinda and Salisbury districts, Southern Rhodesia.

\section{SUB-ORDER ANTHROPOIDEA}

\section{FAMILY G E R G O P I T H E G I D A E}

I. Stomach sacculated for leafeating diet. Thumb vestigial (which character separates the genus from its Asiatic allies). No cheekpouches. In South African species a specialized black and white colour pattern

Subfamily Colobinae: Genus COLOBUS, page 94

Stomach not specialized as above described. Thumb not vestigial. With cheekpouches.

Subfamily Cercopithecinae- -2

2. Face very long, with nostrils terminal. Large animals (the smallest skull quoted by Roberts or by Hill \& Carter is $132.3 \mathrm{~mm}$.). Genus PAPIO, page Ioo

Face short, with nostrils not terminal. Smaller animals (the largest skull quoted by Roberts or by Hill \& Carter is $126 \mathrm{~mm}$.).

Genus CERCOPITHECUS, page 95

In addition, it is possible that the genus Cercocebus E. Geoffroy, i8 12 (Ann. Mus. H.N. Paris, I9: 97, type Cercocebus fuliginosus E. Geoffroy = Simia atys Audebert) occurs in Angola or Northern Rhodesia; from the former Hill \& Carter provisionally list Cercocebus aterrimus and from the latter Pitman provisionally lists C. albigena johnstoni; but so far as we are aware specimens have not yet been taken. 


\section{Subfamily G o 1 o $\mathrm{b}$ i $\mathrm{n}$ a $\mathrm{e}$ \\ Genus COLOBUS Illiger, I 8 I I}

I8 i . Colobus Illiger, Prodr. Syst. Mamm. et Avium, 69. Simia polycomos Schreber = Cebus polykomos. Zimmermann.

I82 I. Colobolus Gray, London Medical Repository, I5: 298. For Colobus.

I870. Guereza Gray, Cat. Monkeys, etc. B.M., 5, ig. Guereza rüppelli Gray = Colobus guereza Rüppell (a race of Colobus polykomos Zimmermann).

I887. Procolobus Rochebrune, Faune de la Sénégambie, Suppl. Mammifères, 95. Colobus verus Van Beneden (a race of Colobus badius Kerr).

1887. Tropicolobus Rochebrune, loc. cit. 96. Colobus rufomitratus Peters.

I887. Piliocolobus Rochebrune, loc. cit. 96. Simia ferruginea Shaw $=$ Colobus badius

Kerr (J. A. Allen, i920, J. Mamm. I: 97).

I887. Stachycolobus Rochebrune, loc. cit. 96. Colobus satanus Waterhouse.

I 887. Pterycolobus Rochebrune, loc. cit. 96. Colobus vellerosus I. Geoffroy.

I895. Lophocolobus Pousargues, Bull. Mus. H.N. Paris, I: 98. Colobus verus Van Beneden.

G. Allen (I 939) retains two species only in this genus, and divides them each into sections of races. One of these species is extralimital to the present region.

Colobus polykomos Zimmermann, I 780

Black and White Colobus, or Guereza Monkey

Approximate distribution: (as understood by G. Allen), Angola, Nyasaland, probably northern parts of Northern Rhodesia; further to the north, Tanganyika to Abyssinia, and the Belgian Congo westwards to Senegal.

All but one of the races here dealt with are referred to the angolensis section of polykomos by G. Allen; but Hill \& Carter, and more lately Swynnerton \& Hayman, give angolensis specific rank. The form occidentalis belongs to the abyssinicus section.

See also Schwarz, I929, On the local races and distribution of the Black and White Colobus Monkeys, P.Z.S., 585 .

Colobus polyкомоs pоlyкомоs Zimmermann, i 780. (Extralimital). I780. Cebus polykomos Zimmermann, Geogr. Gesch. 2: 202. Sierra Leone.

Colobus polykomos angolensis Sclater, i 860

I86o. Colobus angolensis Sclater, P.Z.S. 245. About 300 miles inland from Bembe, northern Angola.

I908. Colobus angolensis sandbergi Lönnberg, Ark. Zool. 4, I5: I. Lufizi River, junction with upper Zambezi River, eastern Angola.

Colobus polykomos palliatus Peters, i 868

1868. Colobus palliatus Peters, Mber. Preuss. Akad. Wiss. 637. Lower reaches of the Ruvu (or Pangani) River, north-eastern Tanganyika. Recorded by Thomas from Nyasaland. 
Colobus polykomos occidentalis Rochebrune, i 887

I887. Guereza occidentalis Rochebrune, Faune Sénégambie, Suppl. Mamm., I 40. Noki, Lower Congo (on south bank, in Angolan territory). Existence in Angola doubtful as there have been no further records.

Colobus polykomos Sharpei Thomas, igo2

I902. Colobus sharpei Thomas, P.Z.S. I: I I8. Fort Hill ( $9^{\circ} 43^{\prime}$ S., $33^{\circ}$ I6' E. $)$, circa 4,00o ft., northern Nyasaland. Ranges to Northern Rhodesia and Tanganyika.

\section{Subfamily $\mathrm{G}$ e $\mathrm{r}$ c o $\mathrm{p}$ i $\mathrm{t} \mathrm{h}$ e $\mathrm{c}$ i $\mathrm{n}$ a e}

\section{Genus CERCOPITHECUS Linnaeus, $175^{8}$}

I758. Cercopithecus ("Cercopitheci") Linnaeus, Syst. Nat. Io, I: 26. Simia diana Linnaeus, from West Africa. (Validated by the International Commission on Zoological Nomenclature on 26 July I948, see Bull. Zool. Nomencl. I950, 4: 3 I I.)

I 77 I. Cercopithecus Brünich, Zool. Fundamenta, 34, 40. Simia mona Schreber, from West Africa (Palmer, I 904). (But suppressed by International Commission on Zoological Nomenclature, see Bull. Zool. Nomencl. i 950, 4: 3 I I.)

I8 I . Lasiopyga Illiger, Prodr. Syst. Mamm. et Avium, 68. Simia nictitans Linnaeus. I 842. Miopithecus I. Geoffroy, C.R. Acad. Sci. Paris, I5: 720. Simia talapoin Schreber. I853. Cercocephalus Temminck, Esquisses Zool. Côte de Guiné, 31. Cercocephalus cephus Temminck = Simia cephus Linnaeus. Lapsus calami for Cercopithecus.

I 862. Petaurista Reichenbach, Völlstand. Naturgesch. Affen, ı 05. Simia petaurista Schreber. Not of Link, I 795.

I862. Diademia Reichenbach, loc. cit. i 07. Type fixed by Pocock, I907, P.Z.S. 678 as Simia leucampyx Fischer = Cercopithecus mitis Wolf.

I862. Mona Reichenbach, loc. cit. iog. Simia mona Schreber.

1862. Callithrix Reichenbach, loc. cit. I I 5. Cercopithecus callitrichus I. Geoffroy = Simia sabaea Linnaeus. Not of Erxleben, I 777.

I870. Chlorocebus Gray, Cat. Monkeys, etc. B.M., 5, 24. Type fixed by Pocock, I907, P.Z.S. 678 as Simia sabaea Linnaeus (a race of Cercopithecus aethiops Linnaeus). I870. Cynocebus Gray, loc. cit. 26. Cercopithecus cynosuros Geoffroy (a race of C. aethiops Linnaeus).

I878. Diana Trouessart, Rev. Zool., Paris, 6: I24. Simia diana Linnaeus. Not of Risso, I 826.

I897. Rhinostictus Trouessart, Cat. Mamm. Viv. Foss. I 7. Simia petaurista Schreber (replaces Petaurista Reichenbach, preoccupied). Simia petaurista is a race of C. nictitans Linnaeus.

I897. Otopithecus Trouessart, loc. cit., 22. Type fixed by Pocock, igo7, P.Z.S. 678 as Cercopithecus pogonias Bennett (a race of $C$. mona Schreber).

I904. Pogonocebus Trouessart, Cat. Mamm. Viv. Foss. Suppl. I4. Type fixed by Pocock, loc. cit., as Simia diana Linnaeus.

I 913. Rhinostigma Elliot, Review of Primates, Monogr. Amer. Mus. N.H. I: xl; 2: 273. Cercopithecus hamlyni Pocock. (For comments see Pocock, I925, Ann. Mag. N.H. I6: 264. Elliot confused the type skull of Cercopithecus hamlyni with that of Cercocebus hamlyni Pocock.) 
Cercopithegus [contd.]

I 9I 3. Allochrocebus Elliot, Review of Primates, Monogr. Amer. Mus. N.H. I: xl; 2: 296. Cercopithecus l'hoesti Sclater.

I9I3. Insignicebus Elliot, loc. cit. Cercopithecus albogularis Sykes (the Zanzibar race of C. mitis Wolf).

I9I3. Melanocebus Elliot, loc. cit. Substitute for Diademia Reichenbach.

I9I3. Neocebus Elliot, loc. cit. Simia cephus Linnaeus.

On this genus see:

Pocock, I907, P.Z.S. 677.

Sahwarz, ig28, Ann. Mag. N.H. I: 649.

Raven \& Hill, i 942, Amer. Mus. Novit. I I77: I.

Four species occur in South Africa.

I. Small monkey, head and body about $400 \mathrm{~mm}$. or less. Facial part of skull shortened (distance from front of orbit to most anterior point of premaxillary less than 40 per cent of zygomatic breadth (Hill \& Carter)).

Cercopithecus talapoin, page Ioo

Larger monkeys. Facial part of skull longer in adults.

2. A white spot on nose.

Cercopithecus nictitans, page 99

No white spot on nose.

$-3$

3. Outer surface of arms black or darker than the back. Limbs and much of the tail predominantly black. Cercopithecus mitis, page 98

Outer surface of arms not black, usually rather paler than body. Limbs not predominantly black, tail if black then only in part, at distal end.

Cercopithecus aethiops, page 96

Cercopithecus aethiops Linnaeus, I $75^{8}$

Vervet Monkey. Blouaap

Distribution: in the Union, the Transvaal; Kruger National Park where widely distributed (Punda Maria, Shingwedzi, Satara, Skukuza, Toulon, ${ }^{1}$ etc., apparently particularly common at Pafuri (north of Punda Maria)), the adjacent portions of the eastern Transvaal (Mariepskop, etc.), and the Rustenburg district, western Transvaal. Natal, including Zululand. In the Cape Province, Port St. Johns, Albany district, Knysna, between Vryburg and Kuruman, along the Vaal River (we are told it occurs west of Kimberley), the Aughrabies Falls, Louisvale (near Upington, western Orange River), and Goodhouse (on Orange River, Little Namaqualand). Hewitt (I93I) states that it "occurs commonly in bush districts near rivers throughout the coastal and adjacent region" of the eastern Cape Province. (This species seems always to occur near banks of rivers.) A monkey (of this species?) is common near Durban. South-West Africa; the districts watered by the Orange River (in the south), and the Cunene, Okavango, Chobe and Zambezi rivers (in the north). Portuguese East Africa; districts of Beira, Gorongoza, Tete, Inhambane included.

\footnotetext{
${ }^{1}$ Toulon is a privately-owned estate situated near but just outside the south-western borders of the Kruger National Park.
} 
Nyasaland; Ndola, etc., Northern Rhodesia. Angola; probably along the rivers throughout Angola, but apparently rare in the western half of the country (Hill \& Carter). Beyond the limits of this work, widely distributed south of the Sahara, to Senegal on the west, Darfur (Sudan) and Abyssinia on the east.

Cercopithegus aethiops aethiops Linnaeus, I758. (Extralimital)

I758. Simia aethiops Linnaeus, Syst. Nat. Ioth ed. I: 28. "Aethiopia." Sennaar, Sudan (Schwarz, I926).

Cercopithegus aethiops cynosuros Scopoli, i 786

I786. Simia cynosuros Scopoli, Deliciae Faunae et Florae Insubricae, I: 44. No locality, but fixed as Banana, Lower Congo, Belgian Congo (Schwarz, I926, Z. Säuget. $I: 46)$.

I 909. Cercopithecus silaceus Elliot, Ann. Mag. N.H. 4: 263. South bank of the Dwanga River, Nyasaland, between $12^{\circ} 35^{\prime} \mathrm{S}$. and I $2^{\circ} 52^{\prime} \mathrm{S} ., 3^{\circ} 2^{\prime}$ E. and $33^{\circ} 45^{\prime} \mathrm{E}$., see Moreau, Hopkins \& Hayman, I946, P.Z.S. I15: 402.

Range also includes Angola.

Cercopithegus aethiops pygerythrus F. Cuvier, i82 I

I82 I. Simia pygerythra F. Cuvier in Geoffroy \& Cuvier, H.N. Mamm. 2: pt. 24: "Vervet," 2. "Africa."

I8 I I. Cercopithecus glaucus Lichtenstein, Reisen Südl. Africa, I: 645, nom. nud.

I822. Cercopithecus pygerithraeus Desmarest, Encycl. Méth. Mamm. 2: 534. Cape of Good Hope.

I825. Cercopithecus pusillus Desmoulins, Dict. Class. H.N. 7: 568. Keiskama, near Great Fish River, Albany district, eastern Cape Province.

I826. Cercopithecus faunus A. Smith, Descript. Cat. S. Afr. Mus. 4. Not of Linnaeus, I 766.

I829. Simia erythropyga G. Cuvier, Règne Anim. ed. 2, I: 92. New name for pygerythrus.

I843. Cercopithecus lalandii I. Geoffroy, Arch. Mus. H.N. Paris, 2: 56r. New name for pusillus.

Range: eastern and southern Cape Province to Natal.

Cercopithegus aethiops RUfoviridis I. Geoffroy, I 843

I 843. Cercopithecus rufo-viridis I. Geoffroy, Arch. Mus. H.N. Paris, 2: 564. "Africa." I 852. Cercopithecus flavidus Peters, Reise nach Mossambique, Säugeth. 3. Quitangonha, I $5^{\circ}$ S. (north of the Zambezi), Mozambique, northern Portuguese East Africa.

1907. Cercopithecus pygerythrus whytei Pocock, P.Z.S. 738. Mount Chiradzulu, Nyasaland. (See Moreau, Hopkins \& Hayman, I946, 402.)

Cercopithegus aethiops helvescens Thomas, i 926

1926. Cercopithecus pygerythrus helvescens Thomas, P.Z.S., 286. Cunene Falls, Angolan border of extreme northern South-West Africa. 
Cercopithegus aethiops cloetei Roberts, i93 I

193 I. Cercopithecus aethiops cloetei Roberts, Ann. Transv. Mus. I4: 223. Mariepskop, Pilgrims Rest district (north-east of Lydenburg), eastern Transvaal. Range includes Zululand and western Transvaal.

Cercopithegus aethiops ngamiensis Roberts, $193^{2}$

1932. Cercopithecus aethiops ngamiensis Roberts, Ann. Transv. Mus. 15: 19. TotenMaun Road, Ngamiland, northern Bechuanaland.

Cercopithegus aethiops marjoriae Bradfield, i 936

1936. Cerpithecus (sic) aethiops marjoriae Bradfield, in a privately-printed leaflet, dated Benoni, South Africa, 26 Sept. 1935. Reprinted in the Auk, 53: I3 I, I936. Zoetvlei, between Kuruman and Vryburg, northern Cape Province. The range perhaps includes the western Orange River.

Cercopithecus mitis Wolf, I 822

Samango Monkey; Diademed Monkey. Samangoaap

Distribution: in the Union, Zululand, Natal, the eastern Transvaal (Woodbush and Pilgrims Rest district), and the eastern Cape Province ("in densest forest at Pirie and in Pondoland, also at the coast near East London" (Hewitt, I93 I)), Stutterheim (British Museum). Eastern parts of Southern Rhodesia; Portuguese East Africa, districts of Beira, Gorongoza, Inhambane; northern Angola; Nyasaland, northwestern Northern Rhodesia. Beyond the limits of this work, the Belgian Congo and Tanganyika to southern Abyssinia and Italian Somaliland.

Cercopithegus mitis mitis Wolf, i 822

I822. Cercopithecus mitis Wolf, Abbildungen u. Beschreibungen merkwürdiger naturg. Gegenstände, 2: I 45. Schwarz (1933, Z. Säugetierk. 8: 279) identified this description of a menagerie specimen as the Angolan form of the Diademed Monkey.

I829. Simia leucampyx Fischer, Synops. Mamm. 20. "In Guinea," but "perhaps, after all, Angola" (Schwarz, I928, Ann. Mag. N.H. I: 653).

I848. Cercopithecus pluto Gray, P.Z.S. 56. Angola.

Cercopithegus mitis labiatus I. Geoffroy, i 843

I843. Cercopithecus labiatus I. Geoffroy, Arch. Mus. H.N. Paris, 2: 555. (South) Africa.

I844. Cercopithecus samango Wahlberg in Sundevall, Öfvers. Vetensk. Akad. Förh. Stockholm, I: I6o. Inland of "Port Natal" (= Durban), Natal.

1853. Cercopithecus chimango Temminck, Esq. Zool. Côte de Guiné, 32. Emendation. Range: eastern Cape Province to Zululand.

Cercopithegus mitis erythrarghus Peters, i 852

1852. Cercopithecus erythrarchus Peters, Reise nach Mossambique, Säugeth. I. Inhambane, coastal southern Portuguese East Africa.

I893. Cercopithecus stairsi Sclater, P.Z.S. I 892: 580. Delta of the Zambezi, Portuguese East Africa. 


\section{PRIMATES - CERCOPITHECIDAE}

I900. Cercopithecus albigularis Sclater, Faun. S. Afr. Mammals, I: 6, I I. Not of Sykes, I83 I.

1907. Cercopithecus albogularis beirensis Pocock, P.Z.S., 70ı. Beira, Portuguese East Africa.

I907. Cercopithecus stairsi mossambicus Pocock, P.Z.S., 705. Mozambique.

Range: northwards to the Zambezi, westwards to Gorongoza and Umtali, Southern Rhodesia.

Cercopithegus mitis moloneyi Sclater, I893

I893. Cercopithecus moloneyi Sclater, P.Z.S., 252. Karonga, north-western shore of Lake Nyasa, $9^{\circ} 5^{6^{\prime}}$ S., $33^{\circ} 56^{\prime}$ E., northern Nyasaland.

1902. Cercopithecus francescae Thomas, Ann. Mag. N.H. Io: 243. Near Mt. Waller, western side of Lake Nyasa, Nyasaland.

Ranges to Northern Rhodesia and south-western Tanganyika.

Cercopithecus mitis opisthostictus Sclater, I894

I894. Cercopithecus opisthostictus Sclater, P.Z.S. I893: 725. Lake Mweru, Northern Rhodesia.

Cercopithegus mitis nyasae Schwarz, i 928

1928. Cercopithecus leucampyx nyasae Schwarz, Ann. Mag. N.H. I: 656. Fort Lister, Mlanje, extreme southern Nyasaland.

Cercopithecus mitis sGhwarzi Roberts, I93 I

1931. Cercopithecus leucampyx schwarzi Roberts, Ann. Transv. Mus. I4: 222. Mariepskop, Pilgrims Rest district, eastern Transvaal. Range includes Woodbush, eastern Transvaal.

Cercopithegus mitis stevensoni Roberts, i 948

1948. Cercopithecus mitis stevensoni Roberts, Ann. Transv. Mus. 21: 63. Mount Selinda, Melsetter district, eastern Southern Rhodesia.

Cercopithecus nictitans Linnaeus, I 766

White-nosed Monkey

Distribution: northern Angola, chiefly in heavy forests, the Mwinilunga district of Northern Rhodesia, and further to the north, from Kenya, Uganda and Tanganyika through tropical West Africa at least to Liberia.

Gercopithegus nictitans nictitans Linnaeus, i 766 . (Extralimital) I 766. Simia nictitans Linnaeus, Syst. Nat. I2th ed. $I$ : 40. "Guinea," West Africa.

Cercopithegus nictitans ascanius Audebert, i 799

I 799. Simia ascanius Audebert, H.N. des Singes, fam. 4, sect. 2, fig. I3. "Guinée." 1845. Cercopithecus melanogenys Gray, Ann. Mag. N.H. I6: 2 I2. Western Africa; probably Angola.

I886. Cercopithecus picturatus Santos, J. Sci. Math. Phys. Nat. Lisboa, II: 98. Quipampala, 6 miles from Ambriz, northern Angola.

Range includes Angola and the Belgian Congo. 
Cercopithecus talapoin Schreber, I 774

Talapoin Monkey

Distribution: northern Angola, as far south as Hanha. Belgian Congo, Cameroons.

Cercopithegus talapoin talapoin Schreber, i774. (Extralimital)

I 774. Simia talapoin Schreber, Säugth. pl. I7; text, I: Io I (vernacular) and I86. Benito River, Spanish Guinea (Pocock).

Cercopithegus talapoin ansorgei Pocock, 1907

1907. Cercopithecus talapoin ansorgei Pocock, P.Z.S. 742. Cambaca (= Canhoca), Angola.

\section{Genus PAPIO Müller, I 773}

I762. Papio Brisson, Regn. Anim. I36. Papio papio Brisson = Simia sphinx Linnaeus (But of doubtful validity; see Ellerman \& Morrison-Scott, I95I, 3).

I773. Papio Müller, Vollständ. Natursyst. I: i I8. Simia sphinx Linnaeus, the West African Mandrill. (Hopwood, I947, P.Z.S. I I 7: 533 dates this name from I 776 , and fixes the type species.)

I824. Mandrillus Ritgen, Nat. Eintheil. Säugeth. 33. (Tafel) (teste Palmer.) Simia maimon Linnaeus and Simia mormon Alströmer, both of which are synonyms of Simia sphinx Linnaeus, according to G. Allen.

1839. Chaeropithecus Gervais, Dict. Pittor. H.N. 8: 90. (Prior to i I May.) Simia cynocephalus Linnaeus. Valid as a subgenus.

1839. Choeropithecus Blainville, Ostéogr. Mamm. Pithecus, 39. (I4 June.) Simia cynocephalus Linnaeus.

I862. Choiropithecus Reichenbach, Vollständ. Nat. Affen, I5 I. Simia porcaria Boddaert = Simia hamadryas ursinus Kerr.

1862. Drill Reichenbach, Vollständ. Nat. Affen., I62. Simia leucophaea F. Guvier, from West Africa.

I925. Comopithecus J. Allen, Bull. Amer. Mus. N.H. 47: 3 12. Simia hamadryas Linnaeus. Valid as a subgenus.

The South African species both have well developed tails, and their. faces are not brightly coloured (compare the typical subgenus), and both lack the heavy mantle of hair on the head and shoulders, compare subgenus Comopithecus.

In the majority of adult male skulls the muzzle length (front of premaxillae to back of nasals) does not reach $123 \mathrm{~mm}$. (two exceptions in eight skulls).

Papio (Chaeropithecus) cynocephalus, page Iо I

In the majority of adult male skulls the muzzle length is not less than I $23 \mathrm{~mm}$. (four exceptions in 62 skulls).

Papio (Chaeropithecus) ursinus, page Iо I

These two species are very difficult to distinguish; $P$. cynocephalus has priority if it is desired to merge them, but they appear to occur together in Tanganyika. Other characters given to divide the species by Roberts and by Hill \& Carter appear 
invalid when all available specimens are examined. A series from Tambarara, Gorongoza district, Portuguese East Africa which was referred to cynocephalus by Thomas \& Wroughton seem to represent $P$. ursinus.

\section{Subgenus CHAEROPITHECUS Gervais, I 839}

Papio cynocephalus Linnaeus, I 766.

Yellow Baboon. Geelbobbejaan

Distribution: Portuguese territory north of the Zambezi; apparently common in Northern Rhodesia; Nyasaland; Central Angola (Chitau, Mombolo, etc.). Further to the north, Tanganyika, Kenya, the Belgian Congo.

Papio gynogephalus cynogephalus Linnaeus, i 766

I766. Simia cynocephalus Linnaeus, Syst. Nat. ed. I2, I: 38. Africa; regarded by Anderson (1902, Zool. of Egypt, Mamm. 64) as having come from inland from Mombasa, Kenya.

1852. Cercopithecus ochraceus Peters, Reise nach Mossambique, Säugeth. 2. "Querimba, Io $0^{\circ}$ to $13^{\circ}$ S.", Mozambique, Portuguese East Africa.

(1928. Papio cynocephalus jubilaeus Schwarz, Z. Säugetierk, 3: 2 I I. Missale, I $4^{\circ}$ S., $33^{\circ}$ IO' E. "north-eastern Rhodesia" but actually in Portuguese East Africa according to Moreau, Hopkins \& Hayman, I946, 405. Roberts (I95I) thought this form might be a synonym of cynocephalus; he states that Schwarz synonymized it with (ursinus) griseipes but was "clearly in error" in doing so.)

Range includes Tanganyika and Nyasaland. For further synonyms, either extralimital to this list or from unknown localities, see G. Allen, I939.

Papio gynocephalus pruinosus Thomas, i 897

I897. Papio pruinosus Thomas, P.Z.S. I896: 789. Fort Johnston $=$ Lesumbwe, Monkey Bay, southern end of Lake Nyasa, Nyasaland.

PAPio Gynogephalus kindae Lönnberg, igi9

I9 19. Papio kindae Lönnberg, Rev. Zool. Afr. 7: I47. Kinda, Lulua district, Belgian Congo. Ranges into Angola.

Papio ursinus Kerr, I 792

Chacma Baboon. Kaapse Bobbejaan

Distribution: widely but sporadically distributed in suitable localities in the Union; in the Transvaal, the Kruger National Park (Punda Maria, Shingwedzi, Satara, Skukuza, Pretorius Kop districts, etc.); districts of Rustenburg, Zoutpansberg, Drakensberg, Vaal River near Potchefstroom; Zululand, Natal (probably also the Giants Castle reserve in Natal). Basutoland. In the Cape Province, the Aughrabies Falls, west of Kimberley, Little Namaqualand (the Kamiesberg and Steinkopf), north of Citrusdal, near Cape Town (Hangklip, Hout Bay, Cape Point reserve), between the Cango Caves and Oudtshoorn, the mountains west of Matjesfontein, Knysna, Queenstown, Albany, Graaff Reinet, and according to Hewitt, Middelburg and Colesberg. The British Museum has specimens from Plettenberg Bay, Kokstad and Deelfontein. Portuguese East Africa; Inhambane and Gorongoza districts. Southern 
Rhodesia (Marandellas, south of Salisbury, Mt. Selinda, Roberts). Northern Bechuanaland; in South West Africa Baboons are "widely distributed over the rocky and mountainous parts ... from the Orange River to the Cunene" (Shortridge, I934). South-western Angola (recorded as far north as Hanha). Nyasaland. Also represented in Tanganyika, Kenya, Uganda, the Sudan, Asben, Abyssinia, etc., under the name anubis (or doguera) and subspecies.

PAPIO URsinus URsinus Kerr, I 792

I792. S(imia) Cercopithecus hamadryas ursinus Kerr, Anim. Kingd. 63. Cape of Good Hope.

I 787. Simia porcaria Boddaert, Naturforscher. 22: I 7. Africa. Not of Brünnich, I 782. I804. Simia sphingiola Hermann, Observ. Zool. $I:$ 2. No locality.

I81 2. Papio comatus E. Geoffroy, Ann. Mus. H.N. Paris, 19: ı03. Cape of Good Hope. Renaming of sphingiola.

I 826. Cynocephalus capensis A. Smith, Descript. Cat. S. Afr. Mus., 3. Cape of Good Hope.

Range: Cape Province from Graaff Reinet and Knysna westwards.

Papio URsinus STRePitus Elliot, ig07

1907. Papio strepitus Elliot, Ann. Mag. N.H. 20: 194. Fort Johnston, southern end of Lake Nyasa, Nyasaland.

PAPIO uRsinus Griseipes Pocock, igi I

I9I I. Papio porcarius griseipes Pocock, Abstr. P.Z.S. No. 93: i 7; P.Z.S., $55^{8}$. Potchefstroom, western Transvaal (?error - see Schwarz, i 934, Ann. Mag. N.H. I4: 26o, who suggests Messina (north of the Zoutpansberg), extreme northern Transvaal).

1927. Choiropithecus porcarius transvaalensis Zukowsky, Carl Hagenbecks Illustrierte Tier-u. Menschenwelt (Hamburg), 2: 57. Messina, northern Transvaal.

Range: Limpopo valley north of Zoutpansberg and Southern Rhodesia to Mount Selinda and Marandellas districts at least (Roberts).

Papio uRsinus RHOdesiae Haagner, I9I8

I9 18. Choiropithecus rhodesiae Haagner, S. African J.N.H. I: 83. Locality not known; "Central Rhodesia."

Papio ursinus occidentalis Goldblatt, 1926

1926. Papio porcarius occidentalis Goldblatt, S. Afr. J. Sci. 23: 782. Rustenburg, western Transvaal. (Schwarz, I934, Ann. Mag. N.H. I 4: 259).

1932. Papio porcarius nigripes Roberts, Ann. Transv. Mus. 15: 19. Magalakuin River (or Magalaqueen River) (north-west of Potgietersrust), western Transvaal.

Papio ursinus orientalis Goldblatt, i 926

1926. Papio porcarius orientalis Goldblatt, S. Afr. J. Sci. 23: 782. Queenstown, eastern Cape Province (Schwarz, I934, Ann. Mag. N.H. I4: 259). Range: eastern Cape Province (Albany, Queenstown, etc.) to Zululand and the Drakensberg. 
Papio URsinus NGAmiensis Roberts, 1932

1932. Papio porcarius ngamiensis Roberts, Ann. Transv. Mus. I5: i8. Maun, Tamalakane River, Ngamiland, northern Bechuanaland.

Papio URSINUs GHobiensis Roberts, 1932

1932. Papio porcarius chobiensis Roberts, Ann. Transv. Mus. I5: 18. Kabulabula, Chobe River, northern Bechuanaland.

Papio URsinus Ruacana Shortridge, I $94^{2}$

1942. Papio comatus ruacana Shortridge, Ann. S. Afr. Mus. 36: 80. Damaraland, the Kaokoveld, and south-western Angola. Type from the Kaokoveld, northern South-West Africa, according to Roberts, I95 I, 537.

\section{ORDER P H O L I D T A}

For the continued use of Pholidota Weber, I904, in spite of its preoccupation in the Reptilia, see Simpson ( 1945; I95).

Medium-sized mammals with no teeth; fingers and toes with claws, body covered with scales, eyes and ears small, zygoma imperfect, face somewhat lengthened. Appearance somewhat reptilian.

\section{FAMILY M A N I D A E}

For a classification of this family and keys to all living subgenera see Pocock, I924, The External Characters of the Pangolins (Manidae) P.Z.S. 707. Simpson (1945), Ellerman \& Morrison-Scott (I95I) and others refer all Pangolins to a single genus.

\section{Genus MANIS Linnaeus, I $75^{8}$}

I758. Manis Linnaeus, Syst. Nat. Ioth ed. $1: 36$. Manis pentadactyla Linnaeus, from Formosa.

I82 I. Phataginus Rafinesque, Ann. Sci. Phys. Brux. 7: 2 I 4. Manis tricuspis Rafinesque. Valid as a subgenus.

1865. Phatagin Gray, P.Z.S., 363. Manis tricuspis Rafinesque.

I865. Smutsia Gray, P.Z.S., 369. Manis temmincki Smuts. Valid as a subgenus.

1872. Triglochinopholis Fitzinger, S.B. Akad. Wiss. Wien, 65, I: 27. Manis tricuspis Rafinesque.

1924. Uromanis Pocock, P.Z.S. 722. Manis longicaudata Brisson (unavailable) = Manis tetradactyla Linnaeus, from West Africa. Valid as a subgenus.

Tail shorter than head and body; scales larger, $40 \mathrm{~mm}$. wide, or wider, in middle of the back; 4-7 scales in the median dorsal line of the tail.

\section{Manis (Smutsia) temmincki, page I04}

Tail longer than head and body; scales smaller, $20 \mathrm{~mm}$. wide, or narrower, in the middle of the back; 30-33 scales in the median dorsal line of the tail. 


\section{Subgenus SMUTSIA Gray, I $86_{5}$}

For characters see Pocock (I924). There are two species in this subgenus, of which the earlier-named is the West African Manis gigantea Illiger, with which M. temmincki has sometimes been regarded as conspecific. But the latter is smaller and has 4-7 scales in the median dorsal line of the tail, as opposed to I I-I 5 in M. gigantea. For an account of other differences between the two see Frechkop, I93 I, Bull. Mus. Hist. Nat. Belg. 7, No. 22.

Manis temmincki Smuts, 1832

Cape Pangolin (Scaly Anteater). Ietermagog Distribution: in the Union, it is known from the Kruger National Park, Transvaal (Toulon, etc.), the Orange Free State, and the region of Upington, Cape Province. Roberts says that it has been reported from northern Zululand, and it has been recorded from as far south as Colesberg (though probably not in recent years). In South-West Africa it apparently occurs intermittently from Great Namaqualand to the Kaokoveld ("in its wide but sporadic distribution it may be compared with the Hedgehog" (Shortridge)). Angola; recent records include Chitau, Mombola, Benguela and between the Kului and Kubango Rivers. Bechuanaland, Ngamiland; Southern Rhodesia, Nyasaland and recorded from Northern Rhodesia. Beyond the limits of this work, Tanganyika where quite widely distributed, also recorded from Uganda, Kenya and the Sudan.

Manis temmincki Smuts, I832

I832. Manis temminckii Smuts, Enum. Mamm. Cap., 54. Beyond "Lataku" (or Litakun), near Kuruman, northern Cape Province.

Subgenus PHATAGINUS Rafinesque, I82 I

Manis tricuspis Rafinesque, I82 I

Tree Pangolin

Distribution: Tropical Africa from Central Angola and Uganda to Liberia.

MANis tricuspis Rafinesque, I82 I

I82 I. Manis tricuspis Rafinesque, Ann. Sci. Phys. Brux. 7: 215. West Africa ("Guinée").

1843. Manis multiscutata Gray, P.Z.S. 22. Western Africa.

I850. Manis tridentata Focillon, Rev. Zool. Paris, 2: 472. Coast of Mozambique. 


\section{ORDER G A R N I V O R A}

Medium-sized or relatively large mammals usually with rather long limbs, the fingers and toes with claws; relatively complex brain structure; usually 3 upper and lower incisors, and canines always present and the dominant front teeth; the main cheekteeth specialized for carnivorous diet; normally the fourth upper premolar and the first lower molar specialized as carnassial, or flesh-tearing, teeth (if not, as in Proteles, then the limbs relatively long).

Simpson (1945) divided living members of this order into two super-families, the Canoidea (containing the Canidae and Mustelidae), and the Feloidea (containing the Viverridae, Felidae, Protelidae and Hyaenidae). He also included the Pinnipedia in this order, but for general reasons (vide Ellerman \& Morrison-Scott, I95I), we prefer to retain that group as a distinct order.

I. All the cheekteeth rudimentary. (Limbs long; 5 fingers and 4 toes; body striped, back maned, ears large and pointed).

The cheekteeth well developed.

$$
\text { Family PROTELIDAE, }{ }^{1} \text { page } \text { I }_{40}
$$

2. The upper carnassial ( $\left.\mathrm{P}_{4}\right)$ the dominant cheektooth; postero-internally to it is one very small, practically functionless molar, which may be shed.

At least one well-developed and functional upper molar.

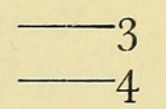

3. Face long; jaws very powerful; usually 34 teeth. Limbs long, with 4 fingers and toes.

Family HYAENIDAE, page I4I

Face relatively short, usually 28 or 30 teeth. Limbs long, with 5 fingers, 4 toes. Family FELIDAE, page I 43

4. Limbs lengthened and adapted for running; 4 toes, 4 or 5 fingers (but the pollex, when present, does not reach the ground). Skull long; molars (in South African genera) at least 2/3. Ears large and erect (8o mm. and more).

Family CANIDAE, page Io6

Limbs not particularly adapted for running, usually rather short. Molars 2/2 or less. Ears rather short (70 mm. and less).

5. Only one upper molar. In South Africa, either considerably modified for aquatic life, or with conspicuous black and white colour pattern. Bullae not divided into two compartments. Five fingers and toes.

Family MUSTELIDAE, page i io

Two upper molars (in South Africa). Bullae either rudimentary or divided into two compartments. Not modified for aquatic life; no black and white colour pattern. Number of fingers and toes vary, but not less than 4 of each.

Family VIVERRIDAE, page iI 7

${ }^{1}$ Simpson (i 945 ) referred Proteles, as the type of a special subfamily, to the Hyaenidae. But we do not agree with this classification. Dentally Proteles and the hyaenas are far apart, the teeth of the latter being amongst the strongest in the order, and those of Proteles being certainly the weakest; in the extreme reduction of the cheekteeth Proteles differs from all other Carnivora of Europe, Asia and Africa. All recent authors on African fauna are agreed in giving Proteles family rank; and because the genus looks like a small hyaena it does not necessarily mean that it is a hyaena. Winge (I924) thought that it was a modified mongoose (Viverridae, Herpestini). 


\section{FAMILY C A N I D A E}

I. Cheekteeth at full dentition $8 / 8$ in number ( $7 / 8$ in most skulls examined), the carnassial teeth scarcely differentiated. Ears much enlarged (I I $4^{-1} 35 \mathrm{~mm}$. although the head and body is $580 \mathrm{~mm}$. and less).

Subfamily Otocyoninae; Genus OTOCYON, page ro6

Cheekteeth not more than $6 / 7$, the carnassials well differentiated. Ears more moderate in size; if the ear is as much as I I $4 \mathrm{~mm}$. (in South Africa) then the head and body is at least $749 \mathrm{~mm}$.

Subfamily Caninae-2

2. No pollex. Large species, skull about I8o-22 I mm. Ears broad and more rounded; body irregularly mottled with black or dark brown, buffy yellow and white. Skull powerful and muscularly developed, with strong sagittal crest.

Genus LYGAON, page 109

With a small pollex. Smaller species, skull about I $75 \mathrm{~mm}$. and less (in South Africa). Colour pattern different, not marked with black, yellow and white. Skull with weaker sagittal crest, less muscularly developed.

3. Frontals flat, postorbital processes concave above. In South Africa (but not always so elsewhere) distinguished by smaller size, skull less than $120 \mathrm{~mm}$. South African species normally with black-tipped tail, and no dark saddlepatch on the back.

Genus VULPES, page Io7

Frontals elevated, postorbital processes convex above. In South African species, skull more than I $30 \mathrm{~mm}$. Externally, in South Africa, distinguished from the local Vulpes either by white-tipped tail or by dark saddlepatch on back.

Genus $C A N I S,{ }^{1}$ page 108

Subfamily O t o c y o $\mathrm{n}$ i $\mathrm{n}$ a e

Genus OTOCYON Müller, I 836

1836. Otocyon Müller, Arch. Anat. Physiol. I836: L. Otocyon caffer Müller = Canis megalotis Desmarest.

I840. Agriodus H. Smith, Jardine's Nat. Library, 28: 258. Agriodus auritus H. Smith $=$ Canis megalotis Desmarest.

Otocyon megalotis Desmarest, 1822

Bat-eared Fox; Delalande's Fox. Draaijakkals; Bakoorjakkals

Distribution: in the Union it now appears to be rare; we are told it still occurs in the Orange Free State (near Wepener), and near Upington, northern Cape Province. Shortridge (1942). recorded it from Port Nolloth, coastal Little Namaqualand, where it was then said to be rare; other possible localities are the western Transvaal and Bushmanland. Hewitt (I93I) stated "found only rarely in the eastern KarrooTafelberg" (= near Middelburg?) South-West Africa; Shortridge (r 934) stated that

${ }^{1}$ Some authors have preferred to refer the Jackals to Thos Oken, but Pocock, Miller and other authors treat this as a synonym. 
it occurs all over this territory, except perhaps along the coastal portion of the Namib desert. Southern Angola. Plentiful in Bechuanaland (Shortridge). Perhaps western Southern Rhodesia. North of the limits of this work, East Africa, where it occurs from Tanganyika northwards to the southern Sudan, Abyssinia and Somaliland.

\section{Otocyon megalotis megalotis Desmarest, i822}

1822. Canis megalotis Desmarest, Enc. Méth. Mamm. Suppl., 538. Cape of Good Hope. (For date of publication see Sherborn \& Woodward, I893, P.Z.S., 584.)

1823. Canis lalandi Desmoulins, Dict. Class. H.N. 4: ı 8. "Cafrerie" = South Africa. 1836. Otocyon caffer Müller, Arch. Anat. Physiol. I836: L. Renaming of megalotis. I840. Agriodus auritus H. Smith, Jardine's Nat. Library, 28: 26o. Cape of Good Hope. 1924. Otocyon steinhardti Zukowsky, Arch. Naturgesch. 9oA, I: 52. Goreis, Ugab region, $45 \mathrm{~km}$. west of Outjo (about $20^{\circ} \mathrm{S}$.), South-West Africa.

\section{Subfamily $\mathrm{G}$ a $\mathrm{n}$ i $\mathrm{n}$ a $\mathrm{e}$}

\section{Genus VULPES Oken, I8 6}

I8ı6. Vulpes Oken, Lehrb. Naturgesch. 3, 2: io33, I034. Vulpes communis Oken = Canis vulpes Linnaeus, from Sweden.

I 822. Vulpes Fleming, Philosophy of Zool. Edinburgh, 2: 184. Canis vulpes Linnaeus. 1839. Cynalopex H. Smith, Jardine's Nat. Library, 25: 222. Canis corsac Linnaeus, from the steppes between the Ural and Irtish rivers, western Siberia.

On the name of this genus see Ellerman \& Morrison-Scott, I95 I, 3. For a key to all species of the genus from Europe, Asia and Africa see Ellerman \& Morrison-Scott, I95 I, 223, 224. The South African species seems most closely allied to Vulpes bengalensis (Shaw, I80o, from India), but differs in having larger ears.

Vulpes chama A. Smith, I 833

Cape Fox. Silwerjakkals

Distribution: Roberts says this species ranges practically all over the dry areas of the west, from the inland plateau of the south to northern South-West Africa, and through the Orange Free State to Transvaal and western Southern Rhodesia, extending over the Drakensberg. Its distribution is however smaller than formerly in the Union. It is thought to be extinct in the Cape Town neighbourhood (though once ranging as far south as Caledon), and it appears to be absent from the Kruger National Park. Shortridge (1942) recorded it from near Clanwilliam, Io miles inland from Lamberts Bay, and Port Nolloth, Little Namaqualand. The British Museum has specimens from Klipfontein, Little Namaqualand, Louisvale (near Upington), also Vredefort and Aberfeldy (near Harrismith), Orange Free State; also a skull collected many years ago at Beaufort West. Hewitt (I93I) said it was comparatively rare on the eastern Karroo. We are told it still occurs near Wepener (Orange Free State). Conway, near Cradock (Shortridge, I 934). South-West Africa; widely distributed (except in the northern parts of the Grootfontein district, the 
Caprivi and perhaps the coastal edge of the Namib desert (Shortridge)). Angola; the British Museum has one specimen from Elephant Bay. Possibly western Southern Rhodesia.

Vulpes ghama A. Smith, i 833

1833. Canis chama A. Smith, S. Afr. J. 2: 89. Namaqualand (and country on both sides of the Orange River).

I839. Megalotis caama H. Smith, Jardine's Nat. Library, 25: 236. South Africa.

I 86I. Canis variegatoides Layard, Cat. Mamm. S. Af. Mus. (N.V., fide Roberts). Not of A. Smith, I834.

I9 Iо. Megalotis hodsoni Noack, Zool. Anz. 35: 46 I. Transvaal. ${ }^{1}$

\section{Genus CANIS Linnaeus, I 758}

I758. Canis Linnaeus, Syst. Nat. ıoth ed. I: 38. Canis familiaris Linnaeus, the domestic Dog.

I816. Thos Oken, Lehrb. Naturgesch, 3, 2: i037. Thos vulgaris Oken = Canis aureus Linnaeus, from Persia.

I 837. Vulpicanis Blainville, Ann. Sci. Nat. Paris, Zool. 8, 2: 279. Canis aureus Linnaeus. I869. Simenia Gray, P.Z.S. I868: 494, 506. Canis simensis Rüppell, from Abyssinia. Valid as a subgenus.

1906. Lupulella Hilzheimer, Zool. Beobachter, 47: 363. Canis mesomelas Schreber. I906. Schaeffia Hilzheimer, Zool. Beobachter, 47: 364. Canis adustus Sundevall.

\section{Subgenus $C A \mathcal{N} I S$ Linnaeus, I $75^{8}$}

Tailtip white. Ears shorter, less than Ioo mm. No dark saddlepatch on the back. Canis adustus, page 109 Tailtip dark. Ears longer, normally more than Iоo $\mathrm{mm}$. On the back is a dark saddlepatch.

Canis mesomelas, page 108

See also Hollister, i918, Bull. U.S. Nat. Mus. 99: го г.

Canis mesomelas Schreber, I 775

Black-backed Jackal. Rooijakkals.

Distribution: still fairly widely distributed in the Union, although they are exterminated where possible outside the game reserves on account of the damage they do to livestock. Transvaal; Kruger National Park (common in the south, near Pretorius Kop, Toulon, etc.). Woodbush. In the Cape Province, De Beers ( 36 miles west of Kimberley), probably the Vryburg district, the Aughrabies Falls, Deelfontein, Little Namaqualand (recorded by Shortridge (1942) from the Kamiesberg), Clanwilliam district (Shortridge, I942); the Cape Flats, near Cape Town, and possibly the Cape Point nature reserve. ?Near Bredasdorp. Hewitt (I93I) said, when writing of the eastern Cape Province, "very common in most parts of our region ... not found near Port St. Johns". It is said there are Jackals in the Addo Bush, near Port Elizabeth. Albany district (Roberts). South-West Africa; "exceedingly

${ }^{1}$ Megalotis Illiger, $18 \mathrm{I}$ i is a synonym of Fennecus Desmarest, 1804 , which genus is restricted to the North African Fennec Fox. 
abundant throughout South-West Africa except in the extreme north-east and the Caprivi" (Shortridge, I934). Eastwards into the Kalahari and Ngamiland region, South-western Angola. North of the region dealt with in this work, from Tanganyika, Uganda, Kenya, Somaliland, the Sudan.

Canis mesomelas mesomelas Schreber, i 775

I 775. Canis mesomelas Schreber, Säugth., pl. 95, text 3: 370 (vernacular), 586 ( I 778). Cape of Good Hope.

I833. Canis variegatoides A. Smith, S. Afr. J. 2: 87. South Africa.

Canis mesomelas arenarum Thomas, i 926

1926. Thos mesomelas arenarum Thomas, P.Z.S. 295. Berseba, central Great Namaqualand, South-West Africa. Ranges into Angola.

Canis mesomelas aGhrotes Thomas, 1926

1926. Thos mesomelas achrotes Thomas, P.Z.S. 295. Rooibank, Kuiseb River, near Walvis Bay, coastal South-West Africa.

Canis adustus Sundevall, I 846

Side-striped Jackal. Grysjakkals; Vaaljakkals; Witkwasjakkals

Distribution: in the Union, the Kruger National Park, Transvaal, where it is said to be commoner in the northern districts, and northern Zululand, Natal. South-West Africa; the northern parts, the Grootfontein district to the Okavango, and the Caprivi. Ngamiland, Southern Rhodesia, recorded from Portuguese East Africa. Angola, where apparently widely distributed throughout. Northern Rhodesia, Nyasaland. Northwards to Tanganyika, Uganda, Kenya, Abyssinia, the southern Sudan, and the region of the Cameroons.

Canis adustus adustus Sundevall, i 846

I846. Canis adustus Sundevall, Öfvers. Vetensk. Akad. Förhandl. Stockholm, 3: 2 I.

"Caffraria Interiore." Magaliesberg (west of Pretoria), Transvaal according to Roberts.

I895. Canis holubi Lorenz, Verh. Zool.-Bot. Ges. Wien, 45: i I . Leshumo Valley, near Victoria Falls, western Matabeleland, Southern Rhodesia.

I897. Canis wunderlichi Noack, Zool. Anz. 20: 5 I9. Probably South-eastern Africa.

\section{Genus LYGAON Brookes, I 827}

1827. Lycaon Brookes in Griffith's Guvier Anim. Kingd. 5: I51. Lycaon tricolor Brookes = Hyaena picta Temminck.

I829. Cynhyaena F. Cuvier, Dict. Sci. Nat. 59: 454. Hyaena picta Temminck. I842. Hyenoides Boitard, le Jardin des Plantes, 2 I 5 . Hyaena picta Temminck. I855. Hyaenoïdes Gervais, H.N. Mamm. 2: 53. For Hyenoides.

Simpson (1945) refers this genus, together with the Asiatic genus Cuon, to a subfamily Simocyoninae which contains also several fossil genera. This classification is not supported by Pocock, I 94I, 2: I46. 
Lycaon pictus Temminck, 1820

Hunting Dog. Wildehond

Distribution: in the Union, the Kruger National Park, Transvaal (Punda Maria district and sometimes wandering as far as the southern borders of the reserve), and in the reserves of Zululand; often straying into the wilds of the northern Transvaal and the vicinity of the Kruger Park in the eastern Transvaal, according to Roberts. The wilder parts of Portuguese East Africa, Southern Rhodesia, northern Bechuanaland, the Kalahari desert (Roberts), and in South-West Africa "widely distributed ... hunting packs may be met with periodically almost anywhere except in the extreme south" (Shortridge, I 934). Angola (most recent records, Chitau (I94I), between Vila da Ponte and Huila, and near Lobito ( I93 I), between Cubango and Capelongo, and Mulando (1935)). Northern Rhodesia and Nyasaland. Northwards to the Sudan and Somaliland on the east, and the Gold Coast and (if not exterminated) southern Algeria on the west.

LyGAON PIGTUS PIGTUS Temminck, I 820

I820. Hyaena picta Temminck, Ann. Gen. Sci. Phys. 3: 54. Coast of Mozambique, Portuguese East Africa.

I822. Hyaena venatica Burchell, Travels in Interior S. Africa, I: 456. 2: 229, I823. North-east of Asbestos Mountains, Griqualand West, Cape Province.

I827. Canis (Lycaon) tricolor Brookes in Griffiths Cuvier Anim. Kingd. 5: I5 I. Cape of Good Hope.

I833. Lycaon typicus A. Smith, S. Afr. J. 2: 91. "Burchell's Lycaon."

I904. Lycaon pictus zuluensis Thomas, Ann. Mag. N.H. I4: 98, footnote. Pongola

River, Zululand, Natal.

I9I5. Lycaon lalandei Matschie, S.B. Ges. Naturf. Fr. Berlin, 3 Io. Between Cape Town and the Great Kei River, Cape Province.

I9I5. Lycaon fuchsi Matschie, loc. cit. 371. Rio Cubal, Benguela, western Angola.

I9I 5. Lycaon cacondae Matschie, loc. cit. 373. Caconda, western Angola.

I9I5. Lycaon gobabis Matschie, loc. cit. 373. Gobabis, eastern Damaraland, SouthWest Africa.

I9I5. Lycaon krebsi Matschie, loc. cit. 376. Near Baviaanskloof, Cape Province (near Steytlerville, in southern central Cape Province).

I915. Lycaon windhorni Matschie, loc. cit. 378. Rustenburg, western Transvaal.

\section{FAMILY M U S T E L I D A E}

For the characters of Ictonyx and allies compared with the northern Mustela and other Mustelinae see Pocock, 1922, P.Z.S. 1921: 803-837, On the external characters and classification of the Mustelidae.

I. Highly modified for aquatic life; tail long, thick and muscular, hindfeet enlarged, much larger than forefeet; colour drab. Upper molar very large and tending to be dominant.

Subfamily Lutrinae-2

Not modified for aquatic life; colour with specialized black and white pattern.

Upper molar not larger than carnassial, and not tending to be dominant. 
2. Claws well developed. In the South African species the skull is smaller, about 94-I Io $\mathrm{mm}$. Postorbital processes vestigial. Genus LUTRA, page I I 5

Nails blunt. In South African species the skull is larger, about I25-I39 mm. Postorbital processes clearly developed in adult.

Genus $A O \mathcal{N} Y X$, page i 6

3. Build heavy and appearance badger-like; claws enlarged; ears small, at most a third of the length of the hindfoot, usually less; tail short. Skull large, exceeding I $20 \mathrm{~mm}$. Colour normally blackish below, whitish above.

Subfamily Mellivorinae; Genus MELLIVORA, page in 4

Build lighter, appearance weasel-like. Claws smaller; ears well over a third of the length of hindfoot. Colour different. Length of skull less than i oo $\mathrm{mm}$.

\section{Subfamily Mustelinae- 4}

4. With 2 lower molars, and 34 teeth. Skull length exceeds $56 \mathrm{~mm}$. Rather thickfurred species, with no very sharply-contrasted whitish patch on head and nape.

Genus ICTON $X X$, page i I

With normally i lower molar, and 28 (rarely 30 ) teeth. Skull length $55.3 \mathrm{~mm}$. and less. Rather short-furred species, with sharply-contrasted whitish patch on nape and head.

Genus POECILOGALE, page I 3

\section{Subfamily $\mathrm{M}$ u s t e $\mathrm{l}$ i $\mathrm{n}$ a $\mathrm{e}$}

\section{Genus ICTONYX Kaup, I $835^{1}$}

1835. Ictonyx Kaup, Das Thierreich, I: 352. Ictonyx capensis = Bradypus striatus Perry.

I838. Rhabdogale Wiegmann, Arch. Naturg. 4, I: 278, footnote. Bradypus striatus Perry here selected as type species.

1846. Ictidonyx Agassiz, Nomenclator Zool. Index. Univ. 194. Emendation of Ictonyx.

1936. Ictomys Roberts, Ann. Transv. Mus. I8: 228. Misprint for Ictonyx.

Ictonyx striatus Perry, I8 10

Zorilla, or Striped Polecat. Stinkmuishond

Distribution: one of the commonest of the small Carnivora in the Union. In the Transvaal, the Kruger National Park (according to Gol. J. A. B. Sandenbergh), districts of Zoutpansberg, Woodbush, Pretoria, Rustenburg, Wakkerstroom; Zululand, Estcourt and Mooi River, Natal; the Orange Free State (Winburg, Aberfeldy, Vredefort, Bothaville, west of Harrismith, etc.), and in the Cape Province, Vryburg district, Upington, Little Namaqualand (Goodhouse, near Steinkopf, Port Nolloth,

${ }^{1}$ Zorilla Oken, I8ı6, Lehrb. Naturg. 3, Zool. 2: xi, "Viverra zorilla" has been used by authors for the African Polecats; not only is it unavailable, but Howell, I906, Proc. Biol. Soc. Washington, I g: 46 in fixing the type species as "Viv. zorilla", also showed that it was indeterminable, but appeared to belong to the New World.

Zorilla I. Geoffroy, I 826 has also been referred to the African Polecats, but it is a Spilogale (see Ellerman \& Morrison-Scott, 1953, F. Mammal. 34: i I4). 
east of Springbok, the Kamiesberg), Lamberts Bay, Citrusdal, Clanwilliam, near Paarl, Durban Road (?near Cape Town; British Museum), Knysna, King William's Town, Grahamstown, Uitenhage, Port St. Johns, near Graaff Reinet, Burghersdorp, Deelfontein, Van Wyk's Vlei, Fourteen Streams, Louisvale, etc. Swaziland. SouthWest Africa; apparently widely distributed, northwards to the Caprivi; Ngamiland, the Kalahari, Gaberones (south-eastern Bechuanaland). Southern Rhodesia (Salisbury, B.M.). Inhambane district, Portuguese East Africa. Probably throughout Angola (Hill \& Carter). Northern Rhodesia, Nyasaland. Beyond the limits of this work, in East Africa northwards to Abyssinia and the Sudan, and also known from northern Nigeria and Senegal.

The form kalaharicus was regarded by Roberts as a species distinct from striatus. But the difference between the two appears to us to be negligible, and to consist chiefly in the colour of the tail. In kalaharicus, black is dominant, and in striatus white. We suggest that this is parallel to the phenomenon found in Ichneumia albicauda, in which black and white tails occur in the same region. In the Gemsbok Pan area of the Kalahari there is Ictonyx striatus ghansiensis, with a white tail, and also a blacktailed form which Roberts distinguished as Ictonyx kalaharicus nigricaudus. We regard them as being the same (see below).

Roberts also subdivided striatus as understood by him, as he thought that his socalled species orangiae and striatus differed in the size of their skulls, but his table of measurements shows that this is not constantly, so. We consider that all these forms are conspecific.

IGtonyx StRiatus striatus Perry, i 8 io

i8 1о. Bradypus striatus Perry, Arcana, or the Museum of Nat. Hist. pt. I I, pl. [4I] and text. Cape of Good Hope. See Hollister, I9 5 , Proc. Biol. Soc. Washington, 28: I 84 on the use of this name.

1826. Mephites capensis A. Smith, Descr. Cat. S. Afr. Mus., 20. Cape of Good Hope. I832. Mustela zorilla Smuts, Enum. Mamm. Cap., I 2. Cape of Good Hope. Not Viverra zorilla Schreber which is a Spilogale.

I838. Mephitis africana Lichtenstein, Abh. Preuss. Akad. Wiss. I836: 284. "Cape of Good Hope, Senegambia, Abyssinia, Barbary."

I84I. Rhabdogale mustelina Wagner in Schreber, Säugth. Suppl. 2: 219. Cape of Good Hope.

I924. Ictonyx striatus pondoensis Roberts, Ann. Transv. Mus. Io: 66. Port St. Johns, Pondoland, eastern Cape Province.

Range: southern Cape Province according to Roberts (who also quoted specimens from Swaziland, Harrismith and Winburg, Orange Free State).

ICTONYX STRIATUS LIMPOPOENSIS Roberts, I9I7

I917. Ictonyx capensis limpopoensis Roberts, Ann. Transv. Mus. 5: 265. Mooivlei, Rustenburg district, western Transvaal.

ICTONYX STRIATUS MAXIMUS Roberts, I924

1924. Ictonyx striatus maximus Roberts, Ann. Transv. Mus. Io: 65. Wakkerstroom, south-eastern Transvaal. Ranges into Zululand, Natal. 


\section{CARNIVORA - MUSTELIDAE}

ICTONYX STRIATUS ORANGIAE Roberts, I 924

1924. Ictonyx orangiae Roberts, Ann. Transv. Mus. 10: 67. Angra Pequina, south of Bothaville, north-western Orange Free State.

ICTONYX STRIATUS PRETORIAE Roberts, I924

I924. Ictonyx orangiae pretoriae Roberts, Ann. Transv. Mus. I0: 67. Boekenhoutfontein, Pretoria district, Transvaal.

ICTONYX STRIATUS ARENARIUS Roberts, I 924

1924. Ictonyx orangiae arenarius Roberts, Ann. Transv. Mus. Io: 67. Lamberts Bay, western Cape Province. Range includes Klaver, Vredendal, Goodhouse, Vryburg, Louisvale, Upington, etc., western Cape Province.

ICTONYX STRIATUS GHANSIEnsis Roberts, I932.

1932. Ictonyx orangiae ghansiensis Roberts, Ann. Transv. Mus. 15: 8. Gemsbok Pan (Kalahari) Bechuanaland.

1932. Ictonyx kalaharicus nigricaudus Roberts, Ann. Transv. Mus. I5: 9. Gemsbok Pan (Kalahari) Bechuanaland.

Ranges westwards to Gobabis, etc., in South-West Africa.

ICTONYX STRIATUS SHORTRIDGEI Roberts, I932

I932. Ictonyx striatus shortridgei Roberts, Ann. Transv. Mus. 15: 8. Maschi River, eastern Caprivi, borders of Ngamiland and South-West Africa. Range includes Angola.

IGTONYX STRIATUS LANGASTERI Roberts, I932

I932. Ictonyx striatus lancasteri Roberts, Ann. Transv. Mus. 15: 8. Choma, (north-east of Victoria Falls), Northern Rhodesia.

IGTONYX STRIATUS KALAHARIGUS Roberts, I932

1932. Ictonyx kalaharicus Roberts, Ann. Transv. Mus. 15: 8. Kuke Pan, central Kalahari, Bechuanaland.

IGTONYX STRIATUS GIGANTEUs Roberts, I932.

1932. Ictonyx kalaharicus giganteus Roberts, Ann. Transv. Mus. 15: 9. Shorobe, 25 miles north of Maun, Ngamiland, northern Bechuanaland.

ICTONYx STRIATUS OVAMBOensis Roberts, I95 I

I95I. Ictonyx kalaharicus ovamboensis Roberts, Mammals of South Africa, 208. Oshikango, Ovamboland, South-West Africa.

\section{Genus POEGILOGALE Thomas, 1883}

1883. Poecilogale Thomas, Ann. Mag. N.H. I I: 370. Zorilla albinucha Gray.

Poecilogale albinucha Gray, I864 White-naped Weasel. Slangmuishond

Distribution: in the Union it seems widely distributed in the eastern parts, but is nowhere common; recorded from Johannesburg, Wakkerstroom district and Tzaneen, 
Transvaal; Natal, including Durban and Zululand; the Orange Free State (Aberfeldy, near Harrismith), and in the Cape Province, Vryburg district, Port St. Johns, Port Alfred, Pirie, Port Elizabeth, Knysna, Deelfontein, Hanover district, and Colesberg (Shortridge). Recorded from Melsetter, Southern Rhodesia and one locality (junction of Molopo and Nossob Rivers) in the Bechuanaland-SouthWest African border region. Sesheke district, Lake Bangweulu, etc., in Northern Rhodesia; Nyasaland. Angola, including Chitau, Capelongo, east of Dando, Caconda, Duque de Bragança, Ambaca, Quindumbo, Jinga country, Pedreira. Beyond the limits of this work, Tanganyika, Uganda and the Belgian Congo.

Poegilogale albinugha albinugha Gray, i 864

I864. Zorilla albinucha Gray, P.Z.S. 69. Locality unknown "but Cape of Good Hope may be assumed" (G. Allen).

I865. Zorilla flavistriata Bocage, P.Z.S. 402. Duque de Bragança district, northern Angola. Proposed as a substitute for albinucha.

I 865. Zorilla africana Peters, P.Z.S. 400, nomen nudum. Golungo Alto, Angola.

Poecilogale albinucha transvaalensis Roberts, I 926

1926. Poecilogale albinucha transvaalensis Roberts, Ann. Transv. Mus. II: 247. Tzaneen, north-eastern Transvaal.

Poegilogale albinucha lebombo Roberts, I93 I

193 I. Poecilogale albinucha lebombo Roberts, Ann. Transv. Mus. I4: 226. Ubombo, northern Zululand, Natal.

Poegilogale albinugha beghuanae Roberts, i93 I

1931. Poecilogale albinucha bechuanae Roberts, Ann. Transv. Mus. I4: 226. Vryburg, northern Cape Province. Also known from Randfontein (west of Johannesburg), Transvaal.

\section{Subfamily $\mathrm{M}$ e $1 \mathrm{l} \mathrm{i}$ v o $\mathrm{r}$ i $\mathrm{n}$ a e}

\section{Genus MELLIVORA Storr, I 780}

I 780. Mellivora Storr, Prodr. Meth. Mamm. 34 and Tab. A., Mamm. Viverra ratel Sparrman = Viverra capensis Schreber.

I836. Ursitaxus Hodgson, Asiat. Res. 19, I: 6r. Ursitaxus inauritus, the Nepal race of Viverra capensis Schreber.

For other synonyms, with the same type species as Mellivora, see Ellerman \& Morrison-Scott, I95 I, 268.

Mellivora capensis Schreber, 1776

Ratel or Honey Badger. Ratel

Distribution: in the Transvaal, the Kruger National Park (including Toulon), the district of Rustenburg. In the Cape Province, near Upington, Little Namaqualand (north of Steinkopf and the Kamiesberg), Knysna, Amatola Mountains (near Grahamstown), Albany district. In South-West Africa, according to Shortridge, 
evenly distributed and comparatively plentiful throughout this region, the Caprivi included, but possibly excepting the coastal edge of the Namib desert. Recorded from the Inhambane district, Portuguese East Africa, and from Southern Rhodesia and Ngamiland. Northern Rhodesia, where common, and Nyasaland. Angola; "probably sparsely but widely dispersed" (Hill \& Carter), recorded from Benguela, Cassinge, Cuvelai River, Cubango Mission, etc. Beyond the limits of this work, virtually throughout East Africa, and on the western side (including the Belgian Congo) westwards to Sierra Leone, northwards to Asben and Morocco. In Asia from Arabia to Russian Turkestan, and eastwards to Nepal and India west of the Bay of Bengal (for details see Ellerman \& Morrison-Scott, I95I).

Mellivora capensis capensis Schreber, i 776

I776. Viverra capensis Schreber, Säugth. pl. I25, also I777, 3: 450, 588. Cape of Good Hope.

I777. Viverra ratel Sparrman, K. Svenska Vetensk. Akad. Handl. 38: 147. Cape of Good Hope.

I 798. Ursus mellivorus G. Cuvier, Tabl. Élém. H.N. Anim. I I 2. Cape of Good Hope. I833. Ratellus typicus A. Smith, S. Afr. J. 2: 83. South Africa.

Mellivora Gapensis Vernayi Roberts, $193^{2}$

1932. Mellivora capensis vernayi Roberts, Ann. Transv. Mus. 15: 7. Kwai, Mababe Flats, Ngamiland, northern Bechuanaland. Ranges into Angola.

\section{Subfamily $\mathrm{L}$ u $\mathrm{t} \mathrm{r}$ i $\mathrm{n}$ a $\mathrm{e}$}

Genus LUTRA Brisson, I 762

I 762. Lutra Brisson, Regn. Anim. I3. Mustela lutra Linnaeus, from Sweden.

I 77I. Lutra Brünnich, Zool. Fundamenta, 34, 42. Mustela lutra Linnaeus. (For date of publication see Bull. Zool. Nomencl. 1950, 4: 307).

I 865. Hydrogale Gray, P.Z.S. I 3 I. Lutra maculicollis Lichtenstein. Not of Kaup, i 829. I92 I. Hydrictis Pocock, P.Z.S. 543. Lutra maculicollis Lichtenstein. Valid as a subgenus.

On the status of Brisson's names see Ellerman \& Morrison-Scott, I95 I, 3.

\section{Subgenus HYDRICTIS Pocock, I92I}

Hydrictis was separated from Lutra on account of details of differences in the webbing of the plantar pads, the hairiness of the rhinarium, smaller ears, shorter muzzle and mesopterygoid region. But by far the clearest character is the reduction of the postorbital processes.

\section{Lutra maculicollis Lichtenstein, I 835}

Spotted-necked Otter. Kleinotter

Distribution: in the Union, recorded from Pretoria, Wakkerstroom, etc., in the Transvaal, Natal, the Orange Free State; the eastern Cape Province (Hewitt (I93 I) quotes the species from the Cathcart district, and the Bushman's, Koonap and 
Buffalo Rivers), Knysna, and the western Orange River (Louisvale and the Upington region). South-West Africa; the Orange, Cunene, Okavango, and rivers and swamps of the eastern Caprivi and Ngamiland. Angola (Chitau, Cunene River, Cubango River, recorded from Benguela, etc.). Southern Rhodesia (Shortridge). Common in Northern Rhodesia; Nyasaland. Beyond the limits of this work, East Africa northwards to Abyssinia and the southern Sudan, and West Africa from the Belgian Congo, Gabon, and (according to Shortridge) Liberia.

LUtra MaGUlicollis MaGulicollis Lichtenstein, I 835

I835. Lutra maculicollis Lichtenstein, Arch. Naturg. I, I : 89. "Am östlichen Abhange der Bambusberge, Kafferland." Bamboos Mountains, $31^{\circ} 30^{\prime} \mathrm{S} ., 26^{\circ} 20^{\prime} \mathrm{E}$. (= near Sterkstroom, eastern Cape Province).

I862. Lutra grayii Gerrard, Cat. Bones Mammalia in B.M., Io I, nom. nud. "Port Natal" = Durban, Natal.

LUtRA MAGULIGOLLIS CHOBIENSIS Roberts, I932

I932. Lutra malculicollis (sic) chobiensis Roberts, Ann. Transv. Mus. I5: 7. Kabulabula, Chobe River, Caprivi (borders of northern Bechuanaland and South-West Africa).

\section{Genus AONYX Lesson, I 827}

I827. Aonyx Lesson, Man. Mamm. I57. Aonyx delalandi Lesson = Lutra capensis Schinz.

1860. Anahyster Murray, Proc. Roy. Phys. Soc. Edinburgh, 2: 157. Anahyster calabaricus Murray = Lutra capensis Schinz.

192 I. Paraonyx Hinton, Ann. Mag. N.H. 7: 195. Paraonyx philippsi Hinton, from Uganda. Valid as a subgenus.

\section{Subgenus $A O \mathcal{N} Y X$ Lesson, I827}

\section{Aonyx capensis Schinz, I $82 \mathrm{I}$}

Cape Clawless Otter. Groototter

Distribution: "anywhere in South Africa where there are large streams and rivers of a permanent nature and with vegetation on the banks to afford adequate shelter" (Roberts, I95I); nevertheless, records seem comparatively few. In the Union, recorded from the Transvaal, Kruger National Park, Pretoria, Mokeetsi in the northeast, White River (south of the Kruger Park). Natal. In the Cape Province, west of Upington, western Orange River (where it is stated by Shortridge to be not so common as Lutra maculicollis), the eastern Province (King William's Town, ?Pondoland, Grahamstown, etc. (common in most of the rivers throughout our region, Hewitt, I93 I) ). Elgin, western Cape Province, and possibly still occurs near Cape Town. South-West Africa; the Orange, Cunene, Okavango and rivers of the Caprivi. Angola; recorded from Chitau, but evidently rare. The Zambezi. Zomba, Nyasaland (British Museum). Northern Rhodesia, including the Bangweulu and Kafue Hook regions. In East Africa known from Abyssinia, Kenya and Tanganyika, and in West Africa from the Belgian Congo, Nigeria, Gold Coast, Liberia, Senegal.

Aonyx CApensis CApensis Schinz, i82 I

I82 I. Lutra capensis Schinz, Guvier's Thierreich, I: 2 I4. Cape of Good Hope. 1823. Lutra inunguis F. Cuvier, Dict. Sci. Nat. 27: 247. Cape of Good Hope. 
1827. Aonyx delalandi Lesson, Man. Mamm. I57. Cape of Good Hope. 1908. Aonyx capensis angolae Thomas, Ann. Mag. N.H. I: 388. Coporole (Coporolo) River, I3 ${ }^{\circ}$ S., western Angola.

1926. Aonyx capensis coombsi Roberts, Ann. Transv. Mus. II: 246. Hennops River, Pretoria, Transvaal.

\section{FAMILY V I V E R R I D A E}

The characters for this family are based on those of Pocock. See particularly i 9 I 9 , Ann. Mag. N.H. 3: 5I 5, Classification of the Mongooses.

The genus Nandinia was considered a member of the Oriental subfamily Paradoxurinae by Simpson (following Gregory \& Hellman); Simpson made it type of a special tribe; it was considered a distinct family, the Nandiniidae, by Pocock, I929, Encyclopaedia Britannica, 4: 898. It was considered a living member of the otherwise extinct family Amphictidae (much better known as Miacidae) by Winge, I924, Pattedyr-Slaegter, 2: I 77. We are of opinion that it is reasonable to give this isolated genus subfamily rank.

I. Feet compressed, with short claws. No bony tube to the auditory orifice.- -2

Feet with freer digits and fossorial claws. With bony tube to auditory orifice.

Subfamily Herpestinae- 4

2. Bullae imperfect, the wall of its posterior portion permanently cartilaginous, the paroccipital process directed backwards away from the bullae. Feet more subplantigrade.

Subfamily Nandiniinae; Genus $\mathcal{N} A \mathcal{N} D I N I A$, page i 20

Bullae normal, the paroccipital process not directed backwards from them. Feet more digitigrade and terrestrial. Subfamily Viverrinae-3

3. Large species, in Africa the length of the skull exceeds I $40 \mathrm{~mm}$. from published measurements available. Skull with strong sagittal crest.

$$
\text { Genus VIVERRA, }{ }^{1} \text { page }{ }^{2} 20
$$

Small species, length of the skull io I mm. and less. Skull with sagittal crest weak or absent.

Genus GENETTA, page I2 I

${ }^{1}$ Viverra Linnaeus, I 758, antedates Civettictis Pocock, I915. Hollister, I918, regarded Civettictis as of subgeneric value only. Pocock separated the African species $V$. civetta from the Oriental species mainly on some external characters, and he compared civetta only with zibetha, the (Indian) type of the genus; the other Oriental species, $V$. megaspila and $V$. tangalunga had not been examined by him. He stated for Civettictis: "each half of the (anal) gland excavated to form a pouch communicating. with the interglandular space by a constricted orifice; a small metatarsal pad above the plantar pad; carpal pad markedly bilobed; sole of foot in front and at the sides of plantar pad quite naked; claws longer, unsheathed, less retractile." And for $V$. zibetha; "Halves of the gland not so excavated; no metatarsal pad; carpal pad not so markedly bilobed; sole of foot partially or wholly hairy; claws shorter, more retractile." Pocock also stated that the prominence of the tympanic bulla and paroccipital process distinguished Civettictis from Oriental Viverra, and that the two upper molars and last lower molar are larger in Civettictis. In V. zibetha, at least, the $3^{\text {rd }}$ and $4^{\text {th }}$ fingers are said by Pocock to have sheaths protecting the claws. Subsequently Pocock examined specimens of $V$. megaspila Blyth from tropical Asia (for which he erected a genus Moschothera which has been ignored or reduced to subgeneric rank by virtually all subsequent authors) which seems to be intermediate in some ways between Civettictis and Viverra. In Moschothera the feet are nearly naked between the pads (as in Civettictis), and there are no skin lobes to protect the claws (as in Civettictis). We consider all the characters given for Civettictis at most of subgeneric value. 
4. No pollex. Hindfoot with 4 digits.

With a functional, clawed pollex.

5. Eyes set rather close together. Face and head somewhat Lemurine. Skull very broad. Bullae very flat, almost as wide as long. Plane of base of skull forms obtuse angle with plane of palate. Foreclaws much enlarged. Back indistinctly transversely banded. Nine upper and 9 lower teeth each side. Dentition of crushing rather than sectorial type.

Genus SURICATA, page I 39

Resembling all other members of the subfamily in not combining the characters of the last genus. Head more Herpestine; bullae less flat and wide, etc. Ten upper and lower teeth each side.

6. Skull much higher (its depth including the bullae about $34-35 \mathrm{~mm}$.). Bullae much larger. Ear usually relatively large (over $40 \mathrm{~mm}$. in B.M. material, but sometimes less than this in Roberts' measurements).

Genus PARACYNICTIS, page 136

Skull considerably lower (its depth including the bullae in the species inhabiting South Africa about $27.7 \mathrm{~mm}$.). Bullae considerably smaller.

Genus BDEOGALE, page 136

7. Hindfoot with 4 digits. Skull relatively high (in this respect similar to Paracynictis which is, however, larger). Ear relatively large; seldom under 9 per cent of the head and body length; in B.M. material usually exceeds io per cent. Ten upper and lower teeth each side. Genus CrNICTIS, page I37

Not combining these characters. Normally with 5 digits to the hindfoot (the hallux is reduced in many species; in Rhynchogale and sometimes in specimens of the subgenus Galerella, it is practically untraceable or absent). Skull normally relatively lower. Ear normally less than 9 per cent of head and body length.

8. Small species; in South Africa the skull is $53 \mathrm{~mm}$. and less, generally less. Nine upper and lower teeth each side. Foreclaws medium-sized. Back not transversely banded.

Genus HELOGALE, page I3 I

Larger species; published measurements show that the skull in South Africa is not under $55 \mathrm{~mm}$. If there are 9 upper and lower teeth either the back is transversely banded or the foreclaws are enlarged, or the length of the skull is about $99 \mathrm{~mm}$. and more. 
9. Foreclaws much enlarged. Nine upper and 9 lower teeth each side. Dentition more or less of the crushing type as described below for Ichneumia and Rhynchogale. Compared with those genera, the soles of the hindfeet are largely naked, and at least in South Africa the length of the skull is less than $80 \mathrm{~mm}$.

Genus MUNGOS, page I 32

Foreclaws not specially enlarged. Not combining the characters of the last genus. (Back never transversely banded).

I O

Io. Dentition more of crushing type, in the upper jaw the lingual parts of crowns of $\mathrm{M} \mathrm{I}_{\mathrm{I}}$ and $\mathrm{M}_{2}$ broad, the space between the inner sides of $\mathrm{P}_{4}$ and $\mathrm{M}_{\mathrm{I}}$ usually appears narrower, the line of the cheekteeth forms a more even curve at junction of $\mathrm{P}_{4}$ and $\mathrm{M}$ I. (In South Africa the length of the skull in published measurements is $88 \mathrm{~mm}$. and more; Io upper and lower teeth each side; soles of hindfeet mostly hairy.)

I I

Dentition more of sectorial type, in the upper jaw the space between the lingual parts of crowns of $\mathrm{P}_{4}$ and $\mathrm{M}$ I usually appears wider; the outer edge of $\mathrm{P}_{4}$ forms more of an angle with that of $\mathrm{M}$ I

I 2

I I. The hallux is vestigial or untraceable. The last upper molar is flatcrowned. The palate does not extend so far behind the toothrows. Length of skull about 88-94 mm. Genus RHYNCHOGALE, page I 35

The hallux is less reduced. The last upper molar is more cuspidate. The palate extends further behind the toothrows. Length of the skull usually exceeds I $00 \mathrm{~mm}$. (98 $\mathrm{mm}$. and more in published measurements available).

Genus ICHNEUMIA, page I 34

I 2. Without webs between digits $2-5$ on all feet (Pocock). Normally 9 upper and lower teeth each side (but not always; the British Museum has a few specimens with ro upper ones, the small first premolar being present). Large species, skull usually exceeds ioo $\mathrm{mm}$. Colour very dark.

Genus ATILAX, page I 30

With digits $2-5$ on all feet united by webs (Pocock). More than 9 upper and 9 lower teeth in normal dentition. Not combining the characters of the last genus.

Genus HERPESTES, ${ }^{1}$ page ${ }^{2} 24$

1 The small species of Herpestes are in Africa usually called "Myonax" Thomas, 1928, which is antedated by Galerella, i 865. Neither Pocock nor Simpson gave Galerella generic rank, and it should be borne in mind that although the small African mongooses appear very distinct from $H$. ichneumon (the type of the genus) there are many more small species of Herpestes in Tropical Asia. Schwarz, I935, Ann. Mag. N.H. 15: 300 has already pointed out that "Myonax" is indistinguishable from Galerella. Myonax seems improperly diagnosed in that Thomas merely said the feet of Galerella differ from those of Myonax, but did not state how they differed, and a perusal of all the type specimens of small African mongooses in the British Museum indicates that they do not differ constantly. There is a tendency in these species for the hallux to become reduced almost to vanishing point, and it seems in some cases to be an individual character. Numerous forms of these small mongooses have been named, and the prior name seems to be $H$. sanguineus Rüppell, which antedates both the betterknown South African names cauui and ratlamuchi. The type species of Galerella would appear to be not more than a subspecies of ratlamuchi, which in itself may be nothing but a reddish colour phase of $H$. sanguineus. 


\section{Subfamily $\mathrm{N}$ a $\mathrm{n}$ d i $\mathrm{n}$ i i $\mathrm{n}$ a $\mathrm{e}$}

Genus NANDINIA Gray, I 843

I843. Nandinia Gray, List Spec. Mamm. B.M., 54. (I865. P.Z.S. I864: 529). Viverra binotata Gray.

Nandinia binotata Gray, I830

Two-spotted Palm Givet. Palmsiwet

Distribution: Beira district, Portuguese East Africa; Mt. Selinda, Melsetter district, eastern Southern Rhodesia; Angola, the northern parts, recorded from Chitau by Hill \& Carter; Nyasaland; Northern Rhodesia (B.M.). North of the limits of this work, Kenya, Uganda, Tanganyika, the Bahr-el-Ghazal (southern Sudan), the Belgian Congo, Fernando Po, Gold Coast, etc.

Nandinia binotata binotata Gray, i83o. (Extralimital). I83o. Viverra binotata Gray, Spicil. Zool., 9. Fernando Po.

NANDinia BINOtATA GerRardi Thomas, I893

I893. Nandinia gerrardi Thomas, Ann. Mag. N.H. I2: 205. Lower Shire River, southern Nyasaland. Ranges to Melsetter district, Southern Rhodesia, and eastwards towards Beira, Portuguese East Africa.

\section{Subfamily $\mathrm{V}$ i $\mathrm{v}$ e $\mathrm{r} \mathrm{r}$ i $\mathrm{n}$ a $\mathrm{e}$}

Genus VIVERRA Linnaeus, $175^{8}$

I758. Viverra Linnaeus, Syst. Nat. Ioth ed. I: 43. Viverra zibetha Linnaeus, from India.

I9I 5. Civettictis Pocock, P.Z.S., I34. Viverra civetta Schreber. Valid as a subgenus.

For discussion of the status of Civettictis see above, page i i 7 , footnote.

\section{Subgenus CIVETTICTIS Pocock, I9I5}

Viverra civetta Schreber, $\mathrm{I} 776$

African Civet. Siwetkat

Distribution: in the Union, known from the Kruger National Park, and the Zoutpansberg and Rustenburg districts, Transvaal, and according to Shortridge the coastal parts of northern Zululand. Portuguese East Africa; districts of Gorongoza and Inhambane. Southern Rhodesia. Ngamiland, and the eastern Caprivi. Angola; widely distributed but relatively rare; more recent records include Hanha, and Cutato River, Central Angola. Northern Rhodesia, where said to be common; Nyasaland. North of the region dealt with in this work, East Africa northwards to the Sudan and parts of Somaliland, and West Africa from the Belgian Congo intermittently to Senegal. 
ViverRa civetTa civetta Schreber, I 776

I 776. Viverra civetta Schreber, Säugeth. pl. I I I, text 3: 419 (I 777). French Guinea. I89I. Viverra civetta orientalis Matschie, Arch. Naturgesch. 57: sect. A, pt. I, 352. Zanzibar (Schwarz, 1934, Ann. Mag. N.H. 14: 26I). Not of Hodgson, I842.

I929. Civettictis civetta schwarzi Cabrera, Mem. Soc. Esp. H.N. i6: 36, footnote, to replace orientalis Matschie, preoccupied. Regarded as a valid.race for the southern localities by Roberts, but a synonym of the typical race according to Swynnerton and Hayman (I95I).

1933. Viverra civetta matschiei Pocock, J. Bombay N. H. Soc. 36: 429 (footnote). To replace orientalis Matschie.

\section{Genus GENETTA Oken, i 8 I 6}

I8ı6. Genetta Oken, Lehrb. Nat. 3, 2: го г. Viverra genetta Linnaeus.

I816. Genetta G. Guvier, Règne Anim. I: I56. Viverra genetta Linnaeus. Published December, 1816, fide Sherborn, I922, Index Anim. I80I-I850, xli.

I. Conspicuous black dorsal line of longer hairs. Spots small, or not well defined. Colour usually greyer.

Genetta genetta, page I 2 I

Hairs of dorsal line not much longer than rest of back. Spots medium or large. Colour usually less grey.

2. Six or 7 pale rings showing on underside of tail. Spots large. Much black on the feet.

Genetta tigrina, page I 22

Usually 8 to ro pale rings showing on the underside of the tail. Spots medium. Little or no black on the feet.

Genetta rubiginosa, page I 23

The above classification is based on the forms occurring in South Africa, and follows the classifications of Roberts and of Hill \& Carter. These authors in each case recognized three species characterized roughly as above in South Africa, and in Angola there appears to be a geographical overlap between rubiginosa and a form (angolensis) which we suggest represents tigrina. Schwarz, I930, Rev. Zool. Bot. Afr. 19, 2: 276 retained only two species in South Africa (genetta and tigrina), and made rubiginosa a synonym of tigrina. But the material we have examined shows that in the south there seem to be three forms. Whether rubiginosa is a colour phase of tigrina we do not know; for the great individual variation in these animals see Stevenson-Hamilton, 1947, Wild Life in South Africa, 202. However, on the evidence before us we have at present no alternative to retaining three nominal species.

Genetta genetta Linnaeus, I $75^{8}$

Small-spotted Genet. Kleinkolmuskejaatkat

Distribution: in the Union, Potchefstroom, Rustenburg, Pretoria, Klein Letaba and the Kruger National Park, Transvaal; in the Cape Province, near Kimberley, Kuruman, Upington, Louisvale, the Aughrabies Falls; Little Namaqualand 
(Goodhouse, Port Nolloth, north of Steinkopf, the Kamiesberg); Lamberts Bay, Clanwilliam, Cape Town, Hout Bay, King William's Town, Port Elizabeth and Deelfontein. ("Fairly common throughout our region" (Hewitt, I93 I, Eastern Province).) South-West Africa; throughout, including the Caprivi and the Namib desert, according to Shortridge. Bechuanaland, south-eastwards to Gaberones; Southern Rhodesia, Northern Rhodesia; Angola, where widely distributed but not common. Beyond the limits of this work, virtually throughout East Africa, westwards to Asben and Senegal; Morocco to Libya; Spain, Balearic Islands, France; Palestine, Arabia.

Genetta genetta genetta Linnaeus, I758. (Extralimital). I 758. Viverra genetta Linnaeus, Syst. Nat. Ioth ed. $1: 45$. Spain.

Genetta genetta felina Thunberg, i 8 i I

I8I I. Viverra felina Thunberg, K. Svenska Vetensk. Akad. Handl. 32: i65. Cape of Good Hope.

I 892. Viverra macrura Jentink, Mus. H.N. Pays Bas Leiden, II: I I 2. (In synonymy of felina.)

Range: mountainous districts of Cape Province.

Genetta genetta pulahra Matschie, 1902

I902. Genetta pulchra Matschie, Verh. Int. Congr. Zool. Berlin, I 9o I, I I 39. Okavango River, northern South-West Africa.

I889. Genetta senegalensis Noack, Zool. Jb. 4: i69. Not of Fischer, I829.

I902. Genetta bella Matschie, Verh. Int. Congr. Zool. Berlin, I9o I, i I40. Loanda (coastal north-western) Angola.

1906. Genetta ludia Thomas \& Schwann, P.Z.S. 579. Klein Letaba (west of the Kruger National Park), north-eastern Transvaal.

Range: northern parts of the Union from the Orange and Crocodile Rivers northwards to the upper Zambezi valley, Angola and apparently Tanganyika.

Genetta Genetta hintoni Schwarz, I929

1929. Genetta genetta hintoni Schwarz, Ann. Mag. N.H. 3: 47. Ndola (near the Congo border), Northern Rhodesia.

Genetta tigrina Schreber, I 776

Large-spotted Genet. Grootkolmuskejaatkat

Distribution: the southern Cape Province, Cape Town district, Rondebosch, Knysna, Cathcart district, King William's Town, Pondoland. Apparently represented in Angola (fairly common throughout western Angola, Hill \& Carter; occurs with rubiginosa at Lobito, Chitau and Capelongo). (Beyond the limits of this work, Schwarz referred forms to tigrina which range from the Sudan and Abyssinia to Senegal, and southwards to Tanganyika and the Belgian Congo; but some of these may represent rubiginosa, which Schwarz did not recognize). 


\section{CARNIVORA - VIVERRIDAE}

Genetta tigrina tigrina Schreber, I776

I 776. Viverra tigrina Schreber, Säugth. pl. I I5; text ( I 777) 3: 425. Cape of Good Hope. Range includes Cape Town district eastwards to Knysna, Cathcart, etc., Cape Province.

Genetta (?)tigrina Angolensis Bocage, i 882

1882. Genetta angolensis Bocage, J. Sci. Math. Phys. Nat., Lisboa, 9: 29. Caconda (south-east of Benguela), Angola.

1902. Genetta gleimi Matschie, Verh. Int. Congr. Zool., Berlin, igo I, i I42. Loanda, north-western Angola.

I930. "Genetta loandae Matschie", Schwarz, Rev. Zool. Bot. Afr. I9: 278. (Lapsus).

Genetta tigrina methi Roberts, I 948

1948. Genetta tigrina methi Roberts, Ann. Transv. Mus. 21: 63. Mouth of Umsigaba (?Umsikaba) River, Pondoland, eastern Cape Province.

Genetta rubiginosa Pucheran, I 855

Rusty-spotted Genet. Rooikolmuskejaatkat

Distribution: Zululand and Mt. Edgecombe (near Durban), Natal; Rustenburg, Zoutpansberg, Woodbush, Klein Letaba, the Kruger National Park (according to Stevenson-Hamilton), Transvaal; Swaziland. Portuguese East Africa, districts of Tete, Inhambane, Beira, Gorongoza, also north of the Zambezi. Southern Rhodesia. Ngamiland. In South-West Africa, near the Cunene and Okavango Rivers, and the Caprivi. Angola (recorded from Lobito, Chitau, Capelongo, Caconda, Benguela, Vila da Ponte and a few other localities). Nyasaland, Northern Rhodesia.

Genetta rubiginosa rubiginosa Pucheran, i 855

I855. Genetta rubiginosa Pucheran, Rev. Zool. Paris, 7: I54. Cape of Good Hope. Roberts thought it might have come from southern Bechuanaland, and regards it as a valid species, quoting specimens from Zoutpansberg and Rustenburg, Transvaal. Hill \& Carter quote it from Angola. Schwarz thought it was a synonym of tigrina.

Genetta (?)Rubiginosa mossambica Matschie, 1902

I902. Genetta mossambica Matschie, Verh. Int. Congr. Zool. Berlin, Igo I, i I38. Mossimboa, I I $^{\circ} 20^{\prime}$ S., $42^{\circ} 22^{\prime}$ E., coast of Portuguese East Africa. (Type locality restricted by Moreau, Hopkins \& Hayman, I946.) Roberts considers this a distinct species.

Genetta rubiginosa zambesiana Matschie, igo2

I902. Genetta zambesiana Matschie, Verh. Int. Congr. Zool. Berlin, I90 I, I I4I. Boror, near Quelimane, north of the Zambezi, Portuguese East Africa. Also recorded from Nyasaland, and as far south as Tete on the Zambezi. Considered a synonym of mossambica by Schwarz, a race of rubiginosa by Roberts. 
Genetta rubiginosa letabae Thomas \& Schwann, igo6

1906. Genetta letabae Thomas \& Schwann, P.Z.S., 578. Klein Letaba (west of the Kruger National Park), eastern Transvaal.

Genetta Rubiginosa zuluensis Roberts, i 924

I924. Genetta rubiginosa zuluensis Roberts, Ann. Transv. Mus. Io: 67. White Umfolosi, Umfolosi Game Reserve, Zululand, Natal. Ranges to Mt. Edgecombe, Natal. Considered a synonym of letabae by Schwarz, but see Roberts (I95I: I34).

Genetta RUbiginosa Albiventris Roberts, $193^{2}$

1932. Genetta rubiginosa albiventris Roberts, Ann. Transv. Mus. 15: i. Maun, Ngamiland, northern Bechuanaland.

\section{Subfamily $\mathrm{H}$ e $\mathrm{r} \mathrm{p}$ e $\mathrm{s} \mathrm{t}$ i $\mathrm{n}$ a e}

Genus HERPESTES Illiger, I8I I

I 799. Ichneumon Lacépède, Tabl. Div. Ord. Gen. Mamm., 7. Not of Linnaeus, I 758.

I8 I I. Herpertes Illiger, Prodr. Syst. Mamm. et Avium, I35 (misprint, corrected to Herpestes, 302). Viverra ichneumon Linnaeus. (Type fixed by Anderson, I878, Anat. Zool. Res. Exped. Yunnan, I: I 7 I.)

1822. Mangusta Horsfield, Zool. Res. Java, unpaged, pt. 5. Ichneumon javanicus E. Geoffroy, from Java.

1865. Calogale Gray, P.Z.S. 1864: 56o. Herpestes nepalensis Gray = Mangusta auropunctatus Hodgson, from Nepal.

I865. Galerella Gray, P.Z.S. I864: 564. Herpestes ochraceus Gray, from Abyssinia. Valid as a subgenus.

1928. Myonax Thomas, Ann. Mag. N.H. 2: 408. Herpestes gracilis Rüppell, the Eritrean race of $H$. sanguineus Rüppell.

For other, extralimital, generic names available, see Ellerman \& Morrison-Scott, I95I, 293.

For discussion on the status of Galerella and its synonym Myonax see above page I I 9 .

It is difficult to say how many species of Galerella there are in South Africa, but we are inclined to regard pulverulentus as possibly valid (though it must be admitted that in East Africa there are forms of sanguineus with an apparently equally large skull), and to regard ratlamuchi and allied forms as representing possible (reddish) colourphases of sanguineus races.

I. Large species, with the skull length exceeding $90 \mathrm{~mm}$., often exceeding Ioo $\mathrm{mm}$. Colour grey, with sharply contrasted black tail tip. Ten upper and io lower teeth each side. Bullae much more weakly developed in front than behind. Herpestes ichneumon, page $\mathrm{I} 25$

Smaller species, the skull in published measurements does not exceed $73.2 \mathrm{~mm}$. If the colour is grey then the black tailtip is usually indistinct or absent. In 
South Africa (but not always so elsewhere within the subgenus), with Io upper and 9 lower teeth each side. Bullae as well developed in front as they are behind.

2. Normally the contrasted dark tailtip is indistinct or absent. In the Union the colour is grey (north of it blackish (?melanistic) forms occur). Averaging larger in size of skull; Roberts' measurements for males give the skull only once under $67 \mathrm{~mm}$., females $63 \mathrm{~mm}$. and more. (British Museum material agrees with these measurements.)

Herpestes (Galerella) pulverulentus, page I 29

With clearly contrasted black tailtip (South Africa). Colour usually reddish or yellowish. Average size not so large; Roberts' measurements for males give the skull only once over $64 \mathrm{~mm}$., the females $62.5 \mathrm{~mm}$. and less. (The British Museum South African skulls do not reach $67 \mathrm{~mm}$.)

Herpestes (Galerella) sanguineus, page 126

\section{Subgenus HERPESTES Illiger, i 8 i I}

\section{Herpestes ichneumon Linnaeus, $\mathrm{I} 75^{8}$}

Egyptian Mongoose or Ichneumon. Grootgrysmuishond

Distribution: in the Union recorded from Satara (Kruger National Park), Transvaal; Natal, Zululand included, and in the Cape Province, Port St. Johns, Komgha, Pirie and Knysna. Portuguese East Africa; Inhambane district, north of Lourenço Marques, also north of the Zambezi (Boror). Southern Rhodesia, Ngamiland, and northern South-West Africa (the Okavango region and the Caprivi). Angola, where rare but widely distributed; Northern Rhodesia, southwards to the Sesheke region; Nyasaland. Beyond the limits of this work, Tanganyika, Uganda, Kenya, Southern Sudan, Abyssinia, the Belgian Congo, Nigeria; Egypt, Algeria, Morocco; Palestine; Spain.

HeRPESTES iGhNeUmon ichneumon Linnaeus, i758. (Extralimital)

I 758. Viverra ichneumon Linnaeus, Syst. Nat. Ioth ed. I: 43. Egypt.

Herpestes ighneumon CAFer Gmelin, i 788

I 788. Viverra cafra Gmelin, Linnaeus Syst. Nat. ed. I3, I: 85. Cape of Good Hope. (1792. Viverra nems Kerr, Linnaeus Anim. Kingd. I6o.)

1832. Herpestes griseus Smuts, Enum. Mamm. Cap., I 9. Not of Geoffroy, i 8 I 8. I 865. Herpestes dorsalis Gray, P.Z.S. I 864: 549. South Africa.

HeRPestes ichneumon ANGOlensis Bocage, i8go

I89o. Herpestes angolensis Bocage, J. Sci. Math. Phys. Nat., Lisboa, 2: 32. Quissange (north-east of Benguela), western Angola.

Herpestes icheumon sabiensis Roberts, I 926

1926. Herpestes caffer sabiensis Roberts, Ann. Transv. Mus. II: 249. Sabi Game Reserve (Kruger National Park), eastern Transvaal. (Type collected at Satara, Roberts, I95I). Ranges to the Lourenço Marques district, southern Portuguese East Africa. 
Herpestes ighneumon mababiensis Roberts, 1932

1932. Herpestes cafer mababiensis Roberts, Ann. Transv. Mus. 15: 4. Tsotsoroga Pan, Mababe Flats, Ngamiland, Bechuanaland. Ranges to Boror, northern Portuguese East Africa.

\section{Subgenus GALERELLA Gray, $\mathrm{I}^{8} 6_{5}$}

Herpestes sanguineus Rüppell, 1836

Slender Mongoose. Rooimuishond

Distribution (as here understood): in the Union, the Transvaal; Kruger National Park (Punda Maria, etc.), near Potgietersrust, Johannesburg, Klein Letaba, Woodbush, Wakkerstroom, the Marico district, Legogot (near White River), etc. Durban, Zululand, etc., Natal. In the eastern Cape Province, Pondoland and in the north-western districts, Vryburg district, Kimberley, Upington, Louisvale. SouthWest Africa; according to Shortridge, occurs more or less plentifully throughout, including the Caprivi, but seems to be scarcer in Great Namaqualand, and perhaps absent from the coastal Namib desert. Ngamiland, and Gaberones, Bechuanaland. District of Tete, and Lumbo (north of the Zambezi), Portuguese East Africa. Southern Rhodesia, including Salisbury and Mount Selinda. Angola, where quite widely distributed. Nyasaland, Northern Rhodesia. Beyond the limits of this work, the greater part of Africa south of the Sahara, northwards to Asben, Senegal, the Sudan and Somaliland.

(sanguineus section):

(All type specimens available in London examined; named forms from the localities listed below are usually nondescript in colouring, with a black tailtip except in the northern Nigerian form phoenicurus.)

Range: Pondoland, Transvaal, Natal, Swaziland, South-West Africa (except the Orange River region), Ngamiland, Southern Rhodesia, Angola, Nyasaland; Tanganyika, Zanzibar, Abyssinia, Eritrea, Kenya, Sudan, Uganda, Cameroons, Northern Nigeria, Senegal.

Herpestes sanguineus sanguineus Rüppell, i836. (Extralimital) I836. Herpestes sanguineus Rüppell, Neue Wirbelth. Abyssin. Pt. 7: 27. Kordofan, Sudan.

The title page bears the date 1835 , but Pt. 7 was published in $18{ }_{3} 6$ (Oken's Isis, I837: I09). This publication date is deemed to be prior to that of cauni since the decision to publish Smith's report was only taken on i9 March, 1836.

Herpestes sanguineus cauui A. Smith, i $8{ }_{3} 6$

1836. Ichneumon cauui A. Smith, Rept. Exped. Explor. C. Africa, 42. Kurrichaine, Marico district, western Transvaal.

1865. Calogale venatica Gray, P.Z.S. I 864: 563. "East Africa."

Range: southern Bechuanaland, Transvaal, Southern Rhodesia. 
Herpestes sanguineus punctulatus Gray, i 849

I 849. Herpestes punctulatus Gray, P.Z.S. i I. "Port Natal" = Durban, Natal. Ranges to Zululand and probably Swaziland.

Herpestes sanguineus ornatus Peters, 1852 I 852. Herpestes ornatus Peters, Ber. Preuss. Akad. Wiss. 81. Tete, on the Zambezi, Portuguese East Africa.

Herpestes sanguineus flavescens Bocage, i 889

I889. Herpestes gracilis var. flavescens Bocage, J. Sci. Math. Phys. Nat., Lisboa, I: I79. Benguela, Angola.

Hill \& Carter made this a queried synonym of bocagei, but this name would take priority.

Herpestes sanguineus bocagei Thomas \& Wroughton, ig05

1905. Herpestes bocagei Thomas \& Wroughton, Ann. Mag. N.H. I6: i 70. Caconda, Benguela, south-western Angola.

I889. Herpestes gracilis var. punctulatus Bocage, J. Sci. Math. Phys. Nat., Lisboa, I: I 79. Caconda, Angola. Not of Gray, I849.

1935. Myonax melanurus lundensis Monard, Arq. Mus. Bocage, No. 6, 2 I3. Chiumbé River I I $^{\circ}$ S. $20^{\circ}$ i $5^{\prime}$ E., Angola.

Herpestes sanguineus zombae Wroughton, ig07

1907. Mungos melanurus zombae Wroughton, Ann. Mag. N.H. 20: i I5. Zomba, southern Nyasaland.

Herpestes sanguineus swinnyi Roberts, i 9 I 3

I9I3. Mungos caaui (sic) swinnyi Roberts, Ann. Transv. Mus. 4: 75. Ngqeleni district (west of Port St. Johns), Pondoland, eastern Cape Province.

Herpestes sanguineus swalius Thomas, I 926

1926. Herpestes cauni swalius Thomas, P.Z.S., 292. Great Brukaros Mountain, 3,500 ft., near Berseba, southern Great Namaqualand, South-West Africa.

Herpestes sanguineụs caldatus Thomas, I 927

1927. Herpestes cauui caldatus Thomas, P.Z.S., 374. Sandfontein, Gobabis-Bechuanaland border, South-West Africa. Ranges northwards to the Waterberg district, South-West Africa.

Herpestes sanguineus Kalaharigus Roberts, I932

1932. Myonax cauui kalaharicus Roberts, Ann. Transv. Mus. 15: 2. Gemsbok Pan, Kalahari desert, Bechuanaland.

Herpestes SANGuineus Kaokoensis Roberts, I932

1932. Myonax cauui kaokoensis Roberts, Ann. Transv. Mus. I5: 2. Okorosave, Kaokoveld, northern South-West Africa. Ranges into southern Angola. 
HeRPESTES SANGUINEUS BRADFIELDI Roberts, I932

1932. Myonax cauui bradfieldi Roberts, Ann. Transv. Mus. 15: 2. Quickborn Farm, 60 miles north of Okahandja, Damaraland, South-West Africa.

Herpestes SANGuineus OKaVAngensis Roberts, I932

1932. Myonax cauui okavangensis Roberts, Ann. Transv. Mus. 15: 3. Karakuwise, Grootfontein district, north-eastern South-West Africa.

Herpestes sanguineus khanensis Roberts, I932

1932. Myonax cauui khanensis Roberts, Ann. Transv. Mus. 15: 3. Khan Mountains, east of Swakopmund, South-West Africa.

Herpestes SAnguineus ngamiensis Roberts, I932

1932. Myonax cauui ngamiensis Roberts, Ann. Transv. Mus. 15: 3. Maun, Ngamiland, northern Bechuanaland.

Herpestes SANGuineus lancasteri Roberts, i $93^{2}$.

1932. Myonax cauui lancasteri Roberts, Ann. Transv. Mus. 15: 4. Kafue River, southern Northern Rhodesia.

Herpestes Sanguineus Dasilvai Roberts, 1938

1938. Calogale cauui dasilvai Roberts, Ann. Transv. Mus. I9: 235. Ondjiwa, southern Angola.

Herpestes SANGuineus erongensis Roberts, I946

1946. Myonax cauui erongensis Roberts, Ann. Transv. Mus. 20: 313. Ombu Farm, Eronga Mountain, Omdaruru district, South-West Africa.

(ratlamuchi section):

(All type specimens available in London examined; includes forms from Tanganyika (granti), Abyssinia and Somaliland (ochracea, the type of Galerella and related forms), Uganda (galbus) and Asben (saharae); normally reddish in colour; with a dark tailtip except in saharae and granti.)

South African range: Western Transvaal (Vaal River region), northern Cape Province (Vryburg and Griqualand West to Upington and Louisvale, western Orange River), Portuguese East Africa, Gaberones (south-eastern Bechuanaland).

Herpestes sanguineus ratlamuchi A. Smith, i 836

1836. Ichneumon ratlamuchi A. Smith, Rept. Exped. Expl. G. Africa, 42. "Between Latakoo (near Kuruman) and the Tropic," South Africa.

I838. Herpestes badius A. Smith, Illustr. Zool. S. Africa, Mamm. pl. 4 and text. "Near Old Latakoo" (= Kuruman) and between that and Kurrichane.

Herpestes Sanguineus auratus Thomas \& Wroughton, igo8

1908. Mungos auratus Thomas \& Wroughton, P.Z.S. 543. Tete, on the Zambezi, Portuguese East Africa. Ranges to Mount Selinda, Southern Rhodesia. 
Herpestes SAnguineus ignitus Roberts, I9I3

I9I3. Mungos ignitus Roberts, Ann. Transv. Mus. 4: 76. Malava, Boror, north of the Zambezi, Portuguese East Africa.

Herpestes sanguineus mossambigus Matschie, igi 4

I9I4. Calogale mossambica Matschie, S.B. Ges. Naturf. Fr. Berlin, 438. Cabaceira, north-eastern coastal Portuguese East Africa.

HeRpestes SANGuineus ignitoides Roberts, I932.

1932. Myonax auratus ignitoides Roberts, Ann. Transv. Mus. I5: 2. Macequece, Portuguese East Africa. (This is south of the Zambezi, near Umtali (Southern Rhodesia).)

Herpestes SANGuineus upingtoni Shortridge, i934.

I934. Myonax ratlamuchi upingtoni Shortridge, Mamm. S.-W. Africa, I: I 24, footnote. Between Upington and Louisvale, western Orange River, northern Cape Province.

Herpestes pulverulentus Wagner, I 839

Cape Grey Mongoose. Kleingrysmuishond

(Probably the form nigratus is a melanistic variety of this species, and probably the form shortridgei is an erythristic variety.)

Distribution: the Orange Free State, the Maluti Mountains in Basutoland; in the Cape Province, the Aughrabies Falls, Louisvale (near Upington), Little Namaqualand (Goodhouse, north of Steinkopf, Port Nolloth, the Kamiesberg), Klaver, Lamberts Bay, Clanwilliam, Rondebosch (near Cape Town), the Cape Point nature reserve, south of Cape Town (where it is common), Knysna, Plettenberg Bay, King William's Town, Albany, Alexandria, Grahamstown, Bathurst, Tarkastad district, Deelfontein. In South-West Africa, from Helmeringshausen (Great Namaqualand) to Damaraland, the Kaokoveld and the Cunene Falls (Angolan border), eastwards to Waterberg and Grootfontein districts.

Herpestes pulverulentus pulverulentus Wagner, i 839

I 839. Herpestes pulverulentus Wagner, Gelehrte Anzeigen, 9: 426. Cape of Good Hope. I 826. Herpestes caffra A. Smith. Descript. Cat. S. Afr. Mus. 2 I. Not of Gmelin, I 788. 1865. Herpestes apiculatus Gray, P.Z.S. I 864: 55 I. Cape of Good Hope.

I9I9. Mungos pulverulentus maritimus Roberts, Ann. Transv. Mus. 6: i i4. Lamberts Bay, western Cape Province.

Range: southern Cape Province.

Herpestes PUlverulentus RUdDi Thomas, ig03.

I903. Herpestes ruddi Thomas, Ann. Mag. N.H. I2: 465. Klipfontein (north of Steinkopf), Little Namaqualand, north-western Cape Province. Ranges into South-West Africa, and to Aughrabies Falls district. 
Herpestes pulverulentus nigratus Thomas, I 928

1928. Myonax nigratus Thomas, Ann. Mag. N.H. 2: 408. Okorasave, northern Kaokoveld, South-West Africa. Recorded also from Windhoek, etc.

Herpestes PUlverulentus SHORTRIDGei Roberts, I 932

I932. Myonax shortridgei Roberts, Ann. Transv. Mus. 15: I. Cunene Falls, southern Angola (near South-West African border).

Herpestes pulverulentus basuticus Roberts, I 936

1936. Myonax pulverulentus basuticus Roberts, Ann. Transv. Mus. I 8: 253. Senqunyane Valley, Maluti Mountains, western Basutoland.

\section{Genus ATILAX F. Cuvier, I 826}

I826. Atilax F. Guvier in Geoffroy \& Cuvier, H.N. Mamm. livraison 54, text on the "Vansire": 2. "The Vansire" of F. Cuvier = Herpestes paludinosus G. Cuvier. (See J. Allen, I924, Bull. Amer. Mus. N.H. 47: I 7 I.) 1837. Athylax Blainville, Ann. Sci. Nat. 8: 272. Alternative for Atilax.

Atilax paludinosus G. Cuvier, 1829

Water Mongoose; Marsh Mongoose. Kommetjiegatmuishond

Distribution: this species is well known in the Kruger National Park, Transvaal, and its borders (Mokeetsi, Woodbush, Tzaneen, etc.). Natal, including Mooi River and Zululand. Shortridge ( I 934) quotes it from the Orange Free State. In the Cape Province, they may occur in the Cape Point nature reserve (near Cape Town), and one was recently killed at Hout Bay (Dr. S. H. Skaife, in litt). Near Lamberts Bay; Vredendal (Roberts); Louisvale (near Upington); Kuruman, where it is (or was) rare. Knysna, King William's Town, Port Elizabeth. Recorded by Hewitt (I93 I) from as far inland as Burghersdorp. South-West Africa; the Orange, Cunene and Okavango Rivers and the eastern Caprivi. Northern Ngamiland, Bechuanaland. Southern Rhodesia (Shortridge). Portuguese East Africa, recorded from districts of Inhambane, Beira and Gorongoza. Angola, including the Cubango River region, Hanha, western coastal districts, Chitau, etc. Northern Rhodesia, Nyasaland. In East Africa northwards to the Sudan and Abyssinia, and in West Africa from the Belgian Congo about to Sierra Leone.

Atilax paludinosus paludinosus G. Cuvier, 1829

(1776. Mustela galera Schreber, Säugth. pl. I 35; text, 3: 493 (I 778). Madagascar. The name is regarded as unidentifiable (J. Allen, I924, Bull. Amer. Mus. N.H. 47: 163$)$.)

(1777. Mustela voang-shire Zimmermann, Spec. Zool. Geogr. 487 (= Mustela galera Schreber according to J. A. Allen, I902, Bull. Amer. Mus. N.H. I6: I6. But Zimmermann, 1777 , is in any case an unavailable work, see Bull. Zool. Nomencl. I950, 4: 547).)

I829. Herpestes paludinosus G. Cuvier, Règne Anim. 2, I : I 58. Cape of Good Hope. I829. Mangusta urinatrix A. Smith, Zool. J. 4: 437. South Africa. (May, I829.) 
I841. Herpestes atilax Wagner in Schreber, Säugth. Suppl. 2: 305. South Africa. I842. Atilax vansire F. Cuvier in Geoffroy \& Guvier, H.N. Mamm., Table gén. 3 (naming the "Vansire", see under Atilax above).

I865. Athylax paludosus Gray, P.Z.S. I864: 557.

Range: Cape Province, Natal, Zululand, south-eastern Transvaal; also South-West Africa to Angola?

Atilax paludinosus Rubellus Thomas \& Wroughton, I908 I908. Mungos paludinosus rubellus Thomas \& Wroughton, P.Z.S., i66. Tambarara, Gorongoza district (south of the Zambezi), western Portuguese East Africa.

Atilax paludinosus mordax Thomas, igi 2

I912. Mungos paludinosus mordax Thomas, Ann. Mag. N.H. Io: 588. "Rombashi River" = Mbasi Creek, I,6oo ft., north-western corner of Lake Nyasa, south-western Tanganyika (Swynnerton \& Hayman, I95I). Roberts quotes specimens from Ncheu, southern Nyasaland.

Atilax paludinosus transvaalensis Roberts, I 933

I933. Atilax paludinosus transvaalensis Roberts, Ann. Transv. Mus. I5: 266. Mokeetsi (north of Tzaneen), north-eastern Transvaal.

\section{Genus HELOGALE Gray, I862}

I862. Helogale Gray, P.Z.S. I86r: 308. Herpestes parvulus Sundevall.

Helogale parvula Sundevall, I 846

Dwarf Mongoose. Dwergmuishond

Distribution: in the Union, the Transvaal, Kruger National Park (Skukuza, Toulon and other localities), northwards to the Zoutpansberg, Klein Letaba, westwards to the Rustenburg district; Natal, Zululand included. South-West Africa; the Kaokoveld, parts of Damaraland; northern Bechuanaland, Southern Rhodesia. It occurs north of the Zambezi in Portuguese East Africa (Lumbo). Angola, fairly common throughout, at least south of the Cuanza River (Hill \& Carter). Northern Rhodesia (southwards to the Sesheke-Kafue region), Nyasaland. North of the limits of this work, this or closely allied species occur in the Belgian Congo, and in East Africa northwards to Abyssinia and Somaliland.

Helogale parvula parvula Sundevall, i 846 I 846. Herpestes parvulus Sundevall, Öfvers. Vetensk. Akad. Förh. Stockholm, 3: I 2 I. "Caffraria superiore juxta tropicum." Roberts nominated Zoutpansberg, northern Transvaal.

1906. Helogale brunnula Thomas \& Schwann, Abstr. P.Z.S. No. 33, го; P.Z.S., 58 I. Klein Letaba (west of Kruger National Park) eastern Transvaal.

Range: Natal northwards to Southern Rhodesia. 
Helogale parvula undulata Peters, $185^{2}$

I 852. Herpestes undulatus Peters, Ber. Preuss. Akad. Wiss., 8 I. Mossimboa, i I ${ }^{\circ} \mathrm{o}^{\prime} \mathrm{S}$., $40^{\circ} 22^{\prime}$ E., northern coast of Portuguese East Africa. Ranges to Tanganyika. Recorded also from the Sesheke-Kafue district of Northern Rhodesia (Shortridge).

Helogale parvula varia Thomas, igo2

I902. Helogale varia Thomas, P.Z.S. I: I I9. "Northern Nyasaland." Should be corrected to Mweru District, Northern Rhodesia (Moreau, Hopkins \& Hayman, I946). Range includes Ndola and Msofu River, Northern Rhodesia.

Helogale parvula ivori Thomas, igi9

I919. Helogale ivori Thomas, Ann. Mag. N.H. 4: 31. Lumbo, mainland opposite Mozambique Island, $15^{\circ} I^{\prime}$ S., $40^{\circ} 40^{\prime}$ E., sea level, Portuguese East Africa. Recorded also from Tanganyika.

Helogale parvula RUficeps Kershaw, I 922

1922. Helogale brunnula ruficeps Kershaw, Ann. Mag. N.H. Io: Io3. Monze, 200 miles south of Ndola, Northern Rhodesia.

Helogale parvula mimetra Thomas, i926

1926. Helogale mimetra Thomas, Ann. Mag. N.H. I7: I83. (January, I926.) Ganguela, Angola.

1926. Helogale brunetta Thomas, P.Z.S. 293. (April, i926). Rua Cana Falls (= Cunene Falls), Cunene River, extreme southern Angola.

Helogale parvula nero Thomas, I 928

1928. Helogale parvula nero Thomas, Ann. Mag. N.H. 2: 408. (November, 1928.) Okorosave, Kaokoveld, northern South-West Africa.

1928. Helogale bradfieldi Roberts, Ann. Transv. Mus. 12: 323. (December, 1928). Waterberg Police Post, Damaraland, South-West Africa.

Genus MUNGOS E. Geoffroy \& G. Cuvier, I 795

I795. Mungos E. Geoffroy \& G. Guvier, Mag. Encycl. 2: 184, 187. Viverra mungo Gmelin.

1825. Crossarchus F. Cuvier, in Geoffroy \& Cuvier, H.N. Mamm. 3: pt. 47: "Mangue," 3. Crossarchus obscurus F. Guvier, from West Africa. Valid as a subgenus.

I865. Ariela Gray, P.Z.S. I864: 565. Herpestes taenianotus A. Smith, the Natal race of Viverra mungo Gmelin.

On the use of the name Mungos see J. Allen, 1924, Bull. Amer. Mus. N.H. 47: 157.

It should be noted that at one time (as for instance by Hollister, I918, and other authors) the name Mungos was transferred to what is now called Herpestes, and the 
present genus was called Crossarchus or Ariela. Later, it was shown that the present genus, which is the prior name in the subfamily, was the Banded Mongoose.

We follow Hill \& Carter in regarding Crossarchus as being congeneric with Mungos. Back conspicuously transversely banded. Back not transversely banded.

Mungos mungo, page I 33 Mungos (Crossarchus) ansorgei, ${ }^{1}$ page ${ }^{\mathrm{I}} 34$

\section{Subgenus MUNGOS E. Geoffroy \&. G. Guvier, I 795}

Mungos mungo Gmelin, i 788

Banded Mongoose. Gebande Muishond

Distribution: in the Union, known from Zululand, the coast of Natal, the Kruger National Park (it is said to be common in the Skukuza district), and the Rustenburg district. Shortridge (1934) says that it occurs, as a great rarity, in the north-eastern Cape Province. Portuguese East Africa; districts of Beira, Gorongoza, Tete, Inhambane, also Lumbo (north of the Zambezi). Southern Rhodesia, Salisbury included. Ngamiland, Bechuanaland; in South-West Africa, the northern portions "from a little beyond the Tropic of Capricorn northwards to the Cunene and Okavango Rivers, and eastwards to the Bechuanaland border and through the Caprivi" (Shortridge, 1934). Angola; probably throughout, according to Hill \& Carter. Northern Rhodesia, Nyasaland. North of the region dealt with in this work, in East Africa northwards to the Sudan and Somaliland, and in West Africa from the Belgian Congo to Nigeria and Portuguese Guinea.

\section{Mungos mungo mungo Gmelin, i 788 . (Extralimital)}

I 788. Viverra mungo Gmelin, Linnaeus Syst. Nat. ed. I3, I: 84. "Asia," but type locality fixed as Gambia, West Africa (Ogilby, i835, P.Z.S. Iо I).

i 823. Herpestes fasciatus Desmarest, Dict. Sci. Nat. 29: 58. Renaming of mungo.

Mungos mungo taenianotus A. Smith, I 834

I834. Ichneumon taenianotus A. Smith, S. Afr. J. 2: i I 4. Natal.

Mungos Mungo senescens Thomas \& Wroughton, I907

I907. Crossarchus fasciatus senescens Thomas \& Wroughton, P.Z.S. 29I. Coguno, Inhambane district, southern Portuguese East Africa. Roberts quotes specimens from Beira, and from Mt. Selinda, Southern Rhodesia.

1 The earliest name in the subgenus Crossarchus is M. obscurus, F. Cuvier, i 825, from West Africa, but the Angolan species ansorgei is distinct from that species and its ally, or race, alexandri from the Congo; it is smaller and has a shorter palate, shorter postdental palate, and shorter toothrow, as will be shown by these figures:

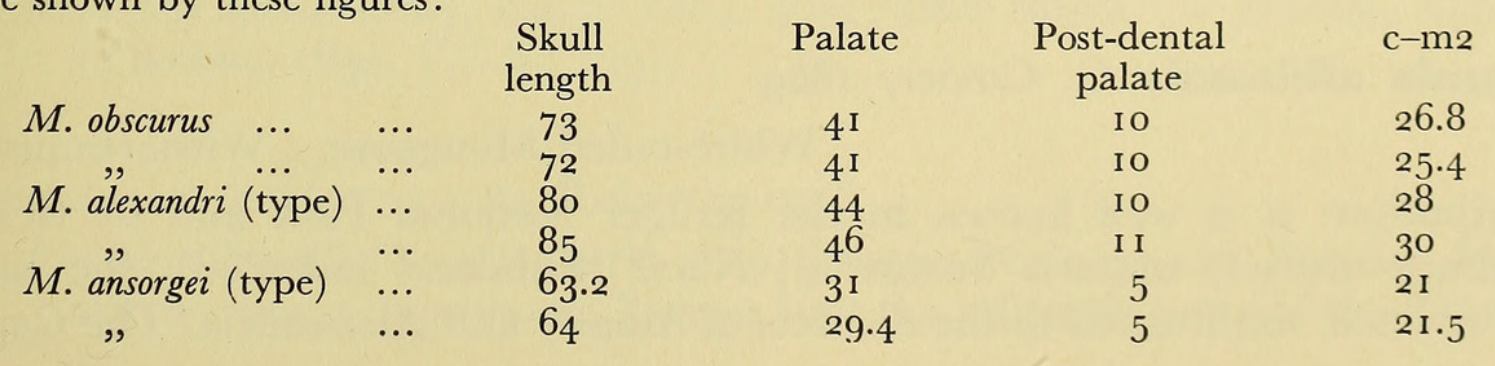


Mungos mungo grisonax Thomas, I926

1926. Mungos mungo grisonax Thomas, P.Z.S. 294. Otjumbumbi, I5 miles above Cunene Falls, northern South-West Africa (or extreme southern Angola); but Shortridge (1934) says the type came from Ekandua, north-western Ovamboland, South-West Africa.

Mungos Mungo BOROREnsis Roberts, I929

1929. Mungos mungo bororensis Roberts, Ann. Transv. Mus. I3: 88. Buruma's Village, Boror, north of the Zambezi, Portuguese East Africa.

Mungos mungo Rossi Roberts, I929

1929. Mungos mungo rossi Roberts, Ann. Transv. Mus. 13: 89. Lake Bangweulu, Northern Rhodesia.

Mungos mungo pallidipes Roberts, I 929

1929. Mungos mungo pallidipes Roberts, Ann. Transv. Mus. I3: 89. Mooivlei, Rustenburg district, western Transvaal.

Mungos mungo ngamiensis Roberts, I $93^{2}$

1932. Mungos mungo ngamiensis Roberts, Ann. Transv. Mus. 15: 5. Maun, Ngamiland, northern Bechuanaland.

Subgenus CROSSARCHUS F. Cuvier, 1825

Mungos ansorgei Thomas, I9I0

Angolan Kusimanse

Distribution: north-western Angola, and Belgian Congo (British Museum).

Mungos Ansorgei Thomas, I9io

i910. Crossarchus ansorgei Thomas, Ann. Mag. N.H. 5: 195. Dala Tando, northwestern Angola.

Genus ICHNEUMIA I. Geoffroy, I 837

1835. Lasiopus I. Geoffroy in Gervais, Résumé des Leçons de Mamm. professées au Mus. Paris, I: 37 . Herpestes albicaudus G. Guvier. Not of Dejean, I833.

1837. Ichneumia I. Geoffroy, Ann. Sci. Nat. Zool. 8: 251. Replaces Lasiopus, preoccupied. Herpestes albicaudus G. Cuvier.

Ichneumia albicauda G. Cuvier, I 829

White-tailed Mongoose. Witstertmuishond

Distribution: it is well known in the Kruger National Park and its vicinity; Rustenburg district, western Transvaal; Natal (Zululand included), the eastern Cape Province, southwards to the districts of Albany and Alexandria. The Caprivi, 
northern South-West Africa, Ngamiland, Southern Rhodesia, the Inhambane district of Portuguese East Africa. Angola; "doubtless found throughout Angola" (Hill \& Carter). Northern Rhodesia, Nyasaland. North of the limits of this work, most of East Africa northwards to the Sudan and Somaliland; Belgian Congo, Nigeria, Gold Coast, Senegal. Southern Arabia.

IGhneumia albicauda albicauda G. Cuvier, i829. (Extralimital) I 829. Herpestes albicaudus G. Cuvier, Règne Anim. 2, I : I 58. Senegal.

ICHNEUmia ALBIGAUDA GRANDIS Thomas, I890

I 890. Herpestes grandis Thomas, P.Z.S. I 889: 622. "Believed to have been collected either on the Limpopo or in Zululand." Roberts (I95I) nominates Hectorspruit (near the south-eastern border of the Kruger National Park) as the type locality.

1924. Ichneumia grandis haagneri Roberts, Ann. Transv. Mus. Io: 68. Bridgewater, Rustenburg district, western Transvaal.

ICHNEUmia Albigauda LOANDAE Thomas, I904 I904. Herpestes albicaudus loandae Thomas, Ann. Mag. N.H. I3: 408. Pungo Andongo (south-east of Loanda), northern Angola.

\section{Genus RHYNCHOGALE Thomas, I 894}

1865. Rhinogale Gray, P.Z.S. I864: 573. Rhinogale melleri Gray. Not of Gloger, I 84 I. 1894. Rhynchogale Thomas, P.Z.S., I 39. To replace Rhinogale Gray, preoccupied. Rhinogale melleri Gray.

Rhynchogale melleri Gray, ${ }^{8} 86_{5}$

Meller's Mongoose. Mellerse Muishond

Distribution: the south-eastern Transvaal, Swaziland, the Gorongoza district, Portuguese East Africa; Nyasaland, Northern Rhodesia, with a closely allied form or subspecies in Tanganyika.

RHYNCHOGALE MELLERI MELLERI Gray, I 865

I 865. Rhinogale melleri Gray, P.Z.S. I 864: 575. "East Africa" = Zomba, Nyasaland (Thomas, I894, P.Z.S., I 39).

Rhynghogale MELlERI LANGi Roberts, I938

1938. Rhynchogale melleri langi Roberts, Ann. Transv. Mus. I9: 243. Ranches Limited, north-eastern Swaziland. Ranges into the adjacent parts of the Transvaal. 
Genus BDEOGALE Peters, I $85^{\circ}$

I850. Bdeogale Peters, Spenersche Z., 25 June; i 852. Mber. Preuss. Akad. Wiss. 8I. Bdeogale crassicauda Peters (Thomas, I882, P.Z.S. 8I).

I 894. Galeriscus Thomas, Ann. Mag. N.H. 13: 522. Galeriscus jacksoni Thomas, from Kenya. Valid as a subgenus. ${ }^{1}$

\section{Subgenus BDEOGALE Peters, I850}

Bdeogale crassicauda Peters, 1852

Bushy-tailed Mongoose; Four-toed Mongoose. Dikstertmuishond

Distribution: Portuguese East Africa, including Tete, Gorongoza district, Boror, etc.; Nyasaland; Fort Jameson, Northern Rhodesia (B.M.), northwards to Zanzibar, Tanganyika and Kenya.

Bdeogale Grassicauda Grassicauda Peters, 1852

1852. Bdeogale crassicauda Peters, Mber. Preuss. Akad. Wiss. 8I. Tete (on the Zambezi), Portuguese East Africa. (Restricted by Moreau, Hopkins \& Hayman, 1946.) Recorded also from Boror, north of the Zambezi, and Gorongoza.

Bdeogale Grassicauda puisa Peters, 1852

I852. Bdeogale puisa Peters, Mber. Preuss. Akad. Wiss. 82. Mossimboa, i I ${ }^{\circ} 2 \mathrm{o}^{\prime} \mathrm{S}$., $40^{\circ} 22^{\prime}$ E., north-eastern coast of Portuguese East Africa. Ranges into Tanganyika.

\section{Genus PARACYNICTIS Pocock, Igi 6}

I9 6. Paracynictis Pocock, Ann. Mag. N.H. i7: i 77. Cynictis selousi de Winton.

We do not agree with Simpson (1945) that this genus should be merged with Cynictis.

Paracynictis selousi de Winton, 1896

Selous' Meerkat. Kleinwitstertmuishond

Distribution: in the Union, Zululand and the north-eastern Transvaal (Zoutpansberg, Woodbush, Mokeetsi). South-West Africa; the central and eastern Caprivi; eastern and northern Bechuanaland; Northern Rhodesia, Southern Rhodesia, Nyasaland. Angola, where Hill \& Carter say that it is moderately common, and probably found throughout, south of the Congo district.

${ }^{1}$ The earliest name in the subgenus Galeriscus is Bdeogale nigripes Pucheran, 1855, Rev. Mag. Z. 7: I I I, Gabon. Hill \& Carter (I94I) include it in the Angolan mammals, but from their remarks it appears that its occurrence there is rather doubtful; "reported several times from Angola ... possibly some of the specimens are Paracynictis selousi, but Galeriscus probably occurs in northern Angola." 
Paracynictis selousi selousi de Winton, i 896

I896. Cynictis selousi de Winton, Ann. Mag. N.H. I8: 469. Essex Vale (near Bulawayo), Matabeleland, western Southern Rhodesia. Ranges to Zoutpansberg, northern Transvaal (Roberts).

Paracynictis selousi sengaAni Roberts, I93 I

I93 I. Paracynictis sengaani Roberts, Ann. Transv. Mus. 14: 227. Maputa, northeastern Zululand, Natal.

Paragynictis Selousi ngamiensis Roberts, i932.

1932. Paracynictis selousi ngamiensis Roberts, Ann. Transv. Mus. I5: 5. 30 miles northwest of Maun, Ngamiland, northern Bechuanaland. Range (according to Roberts) Ngamiland to Ovamboland and southern Angola, probably also Northern Rhodesia and Nyasaland.

Paracynictis selousi Bechuanae Roberts, i932.

1932. Paracynictis selousi bechuanae Roberts, Ann. Transv. Mus. 15: 5. Tsessebe Siding, Tati district, eastern Bechuanaland.

Genus CYNICTIS Ogilby, I833

I833. Cynictis Ogilby, P.Z.S. 48. Cynictis steedmanni Ogilby $=$ Herpestes penicillatus G. Cuvier.

Cynictis penicillata G. Cuvier, I 829

Red Meerkat or Bushy-tailed Meerkat; Yellow Mongoose Geelmeerkat; Rooimeerkat

Distribution: in the Union, a large part of the Transvaal, including the Marico River, near Schweizer-Reneke, near Wolmaransstad, near Johannesburg, Pretoria, Potchefstroom, Pietersburg, Zoutpansberg, Carolina, Wakkerstroom. Newcastle, Natal (British Museum). Vredefort, Harrismith, etc., in the Orange Free State. In the Cape Province, Vryburg, Kuruman and west of it, Upington, Louisvale; in Little Namaqualand, Klipfontein (north of Steinkopf), also Bitterfontein and Nieuwerust; Klaver, Lamberts Bay; east of Ladismith, Oudtshoorn, Port Elizabeth, Uitenhage, Grahamstown, west of Queenstown, near Graaff Reinet, near Cradock, south of Richmond, Deelfontein. Tembuland (according to Hewitt). The Kalahari, and Gaberones in south-eastern Bechuanaland. South-West Africa; from Great Namaqualand to Damaraland, the Kaokoveld, western Ovamboland, and northwards into southern Angola.

It is probable that too many races are recognized in this species.

Cynictis penicillata penicillata G. Cuvier, i 829

I 829. Herpestes penicillatus G. Cuvier, Règne Anim. ed. 2, I: I 58. (April, I 829). Cape of Good Hope; Uitenhage, eastern Cape Province according to Roberts ( I 95 I). 
Cynictis Penicillata penicillata [contd.]

I829. Mangusta Le Vaillantii A. Smith, Zool. J. 4: 437 (May, i829). South Africa.

I 833. Cynictis steedmanni Ogilby, P.Z.S. 49. Uitenhage, eastern Cape Province.

I834. Cynictis typicus A. Smith, S. Afr. J. 2: i I6. Renaming of Le Vaillantii.

Cynictis penicillata ogilbyi A. Smith, i 834

I834. Cynictis ogilbyii A. Smith, S. Afr. J. 2: I I 7. "Bushman Flat and northern parts of Graaff-Reynet district." Range: eastern Karroo and western and southern Orange Free State (Fauresmith, Rouxville).

Cynictis penicillata leptura A. Smith, i 839

I839. Cynictis lepturus A. Smith, Illustr. Zool. S. Africa, Mamm. pl. I 7 and text. "Arid plains towards the Tropic of Capricorn"; Marico district, western Transvaal (Roberts).

Cynictis penicillata pallidion Thomas \& Schwann, igo4.

I904. Cynictis penicillata pallidior Thomas \& Schwann, Abstr. P.Z.S. No. 2, 5; P.Z.S. I: I 75. Klipfontein (north of Steinkopf), Little Namaqualand, north-western Cape Province. Ranges to the Olifants River, western Cape Province.

Cynictis Penicillata intensa Schwann, igo6 I906. Cynictis penicillata intensa Schwann, P.Z.S. I04. Deelfontein (north of Richmond) Cape Province. Also recorded by Roberts from the Oudtshoorn district.

Cynictis penicillata BRAGHyura Roberts, I924

1924. Cynictis penicillata brachyura Roberts, Ann. Transv. Mus. Io: 68. Boschkop, near Johannesburg, Transvaal.

Cynictis Penicillata BRAdFieldi Roberts, I924

I924. Cynictis penicillata bradfieldi Roberts, Ann. Transv. Mus. Io: 69. Quickborn Farm, Okahandja district, Damaraland, South-West Africa.

Cynictis penicillata cinderella Thomas, i927

1927. Cynictis bradfieldi cinderella Thomas, P.Z.S. 375. Ondongwa, central Ovamboland, northern South-West Africa. Ranges into Angola.

Cynictis penicillata coombsi Roberts, ig29

1929. Cynictis penicillata coombsi Roberts, Ann. Transv. Mus. I3: 90. Swarthoek, Zoutpansberg, northern Transvaal.

Cynictis penicillata beghuanae Roberts, i932.

1932. Cynictis penicillata bechuanae Roberts, Ann. Transv. Mus. 15: 4. Gaberones, south-eastern Bechuanaland. Also recorded by Roberts from Vryburg and Fourteen Streams, northern Cape Province. 
Cynictis penicillata kalaharica Roberts, I932

1932. Cynictis penicillata kalaharica Roberts, Ann. Transv. Mus. 15: 4. Kaotwe Pan, central Kalahari, Bechuanaland. Ranges northwards to Lake Ngami.

Cynictis penicillata karasensis Roberts, i 938

1938. Cynictis penicillata karasensis Roberts, Ann. Transv. Mus. 19: 235. Kochena, Great Karas Mountains, Great Namaqualand, South-West Africa. Also recorded from Upington and Aughrabies Falls, north-western Cape Province.

\section{Genus SURICATA Desmarest, 1804}

I804. Suricata Desmarest, Nouv. Dict. H.N. (I) 24: Tabl. Méth. Mamm. I5. Suricata capensis Desmarest = Viverra suricatta Schreber.

I8 I I. Ryzaena Illiger, Prodr. Syst. Mamm. et Avium, i34. Viverra tetradactyla Pallas and Viverra zenik Gmelin (=Viverra suricatta Schreber).

I81 7. Rizaena Blainville, Nouv. Dict. H.N. 9: 339. (No species given).

1827. Rysaena Lesson, Man. Mamm. i 78 (lapsus).

1841. Rhyzaena Wagner in Schreber, Säugth. Suppl. 2: 330. Viverra tetradactyla Pallas $=$ Viverra suricatta Schreber.

Simpson makes Suricata the type of a special tribe, contrasted with all other Mongooses.

Suricata suricatta Schreber, ${ }_{7} 776$

Grey Meerkat; Slendertailed Meerkat; Suricate Graatjiemeerkat; Stokstertmeerkat

Distribution: the southern Transvaal (Wakkerstroom, Pretoria districts), the Orange Free State, including Aberfeldy (near Harrismith), Vredefort district; and in the Cape Province, about roo miles west of Kuruman, west of Kimberley (De Beers), Louisvale (near Upington), Little Namaqualand (where common, including Port Nolloth, Klipfontein (north of Steinkopf), north of Springbok, the Kamiesberg etc.), Lamberts Bay, Klaver, Vredendal, Ceres district (Shortridge, I934); west of Graaff Reinet, Fort Beaufort, Nelspoort, between Richmond and Three Sisters, Deelfontein; recorded from Grahamstown, Uitenhage, Alexandria and according to Hewitt (I93I) districts of Cradock, Aliwal North, Burghersdorp and Griqualand East. South-West Africa; southern Damaraland, eastwards to the Gobabis district. The Kalahari.

Suricata suricatta suricatta Schreber, i 776

I 776. Viverra suricatta Schreber, Säugth. pl. i i 7. Cape of Good Hope (restricted to Deelfontein (north of Richmond, Cape Province) by Thomas \& Schwann, I905, P.Z.S. $r$ : I33).

I 777. Viverra tetradactyla Pallas in Schreber, Säugth. 3: 434. Cape of Good Hope.

I 786. Mus zenik Scopoli, Deliciae Faunae et Florae, Insubricae, 2: 84. "In terra Hottentotarum." 
SURIGATA SURICATTA SURICATTA [contd.]

i 804. Suricata capensis Desmarest, Nouv. Dict. H.N. (I) 24: Tabl. Méth. Mamm. I5. Cape of Good Hope.

I8I9. Surikata viverrina Desmarest, Nouv. Dict. H.N. (2) 32: 297. Cape of Good Hope.

I826. Ryzaena suraktta (sic) A. Smith, Descript. Cat. S. Afr. Mus. 32.

I834. Rhyzaena typicus A. Smith, S. Afr. J. 2: I I 7. South Africa.

Suricata suricatta hamiltoni Thomas \& Schwann, igo5

I905. Suricata suricatta hamiltoni Thomas \& Schwann, P.Z.S. I: I 33. Wakkerstroom, south-eastern Transvaal. Ranges to the Orange Free State (Harrismith, Fauresmith, etc.).

SURICATA SURIGATtA LOPHURUS Thomas \& Schwann, I905

I905. Suricata suricatta lophurus Thomas \& Schwann, P.Z.S. I: I33. Near Grahamstown, eastern Cape Province.

Suricata suricatta NAmaQuensis Thomas \& Schwann, I905

1905. Suricata suricatta namaquensis Thomas \& Schwann, P.Z.S. I: I34. Klipfontein, north of Steinkopf, Little Namaqualand, north-western Cape Province. Ranges southwards to Klaver and Vredendal.

SuRicata SURICATta HAHNI Thomas, I927

1927. Suricata suricatta hahni Thomas, P.Z.S. 376. Gobabis, eastern South-West Africa. Range includes the Kalahari.

Suricata suricatta marjoriae Bradfield, I936

1936. Suricata marjoriae Bradfield, Descr. of New Races of Kalahari Birds and Mamm. (privately printed and dated Benoni, 26 Sept. 1935). Reprinted in The Auk, 53: 131, Jan. 1936. Saltpan, io miles north of Swakopmund, SouthWest Africa.

FAMILY P R O T E L I D A E

Genus PROTELES I. Geoffroy, I824

I824. Proteles I. Geoffroy, Bull. Soc. Philom. Paris, I39. Proteles lalandii I. Geoffroy $=$ Viverra cristata Sparrman.

1830. Geocyon Wagler, Naturl. Syst. Amphib., 30. Proteles lalandii I. Geoffroy $=$ Viverra cristata Sparrman.

Proteles cristatus Sparrman, I 783 Aardwolf. Maanhaarjakkals; Erdwolf Distribution: in the Union, known from the Kruger National Park (according to Col. J. A. B. Sandenbergh), the Pretoria district and Potchefstroom, Transvaal (specimen from the latter locality in the British Museum). Estcourt, Natal. The Orange Free State (for instance, near Wepener; and the B.M. has specimens from 
Vredefort district). In the Cape Province, De Beers ( 36 miles west of Kimberley), Vryburg, Little Namaqualand (the Kamiesberg, near Steinkopf, Port Nolloth), Klaver, Clanwilliam; the Albany district and according to Hewitt, Pirie (near King William's Town). Other possible localities are the neighbourhood of Bredasdorp, and Graaff Reinet. Deelfontein (British Museum). South-West Africa; "widely distributed throughout South-West Africa; nowhere very abundantly. It is apparently rather scarce along the valley of the Orange River, and northwards in the neighbourhood of the Okavango and the Caprivi. I did not hear of its occurrence in the Namib coastal belt" (Shortridge, I934). The Kalahari; Southern Rhodesia. Rare in southern Angola, records include Humpata and Capelongo. Recorded from Northern Rhodesia (Batoka Province), where not common. Beyond the limits of this work, East Africa, as far north as British Somaliland and Suakin, northern Sudan.

Proteles Gristatus Gristatus Sparrman, I 783

I 783. Viverra cristata Sparrman, Resa Goda Hopps-Udden, I: 58I. Near Little Fish River, Somerset East, eastern Cape Province.

I822. Viverra hyenoides Desmarest, Encycl. Méth. Mamm. 538. Cape of Good Hope. i 824. Proteles lalandii I. Geoffroy, Bull. Soc. Philom. Paris, i39. Near Algoa Bay, eastern Cape Province.

I833. Proteles typicus A. Smith, S. Afr. J. 2: 96. Renaming of lalandii.

Proteles Gristatus harrisoni Rothschild, igo2.

1902. Proteles cristatus harrisoni Rothschild, Novit. Zool. 9: 443. Umpata (= Humpata), Mossamedes district, south-western Angola.

Proteles Gristatus transvaAlensis Roberts, I932

1932. Proteles cristata transvaalensis Roberts, Ann. Transv. Mus. I5: 6. Roodekuil, Pretoria district, Transvaal. Ranges to Southern Rhodesia.

Proteles Gristatus Ganescens Shortridge \& Carter, i938

1938. Proteles cristatus canescens Shortridge \& Carter, Ann. S. Afr. Mus. 32: 285. Eselfontein (Kamiesberg), Little Namaqualand, north-western Cape Province.

\section{FAMILY H Y A E N I D A E}

Ears pointed; back heavily maned; upper molar less reduced; body either striped or (in South African species) unicolor.

Genus HYAENA, page I4I

Ears rounded; back not maned; upper molar much reduced, often shed in adult; body spotted.

Genus CROCUTA, page $\mathrm{I}_{4}^{2}$

Genus HYAENA Brisson, I 762

I 762. Hyaena Brisson, Regn. Anim. ed. 2, I3 and i68. Canis hyaena Linnaeus.

I77I. Hyaena Brünnich, Zool. Fundamenta, 34, 42, 43. Canis hyaena Linnaeus.

On the nomenclature of this genus see Ellerman \& Morrison-Scott, I95 I, 3, 4 . 
There are two species, only one of which occurs in South Africa. This, $H$. brunnea, is a thoroughly distinct species; the skull and teeth are larger than in H. hyaena and the colour and general appearance are entirely different.

Hyaena brunnea Thunberg, I 820

Brown Hyaena. Strandwolf; Strandjut

Distribution: in the Union becoming rare, but is known to occur in the Kruger National Park, Transvaal and according to Roberts in the game reserves of Zululand. Both G. Allen and Shortridge note the Upington district as a locality for this species, and Mr. Hollings, the ranger at De Beers, west of Kimberley, has informed us that occasionally one is killed there. We have heard of no other recent records from the Union. South West Africa; according to Shortridge (1934) practically the whole of the territory, being generally plentiful except in those portions of Great Namaqualand where game is scarce, and in the Caprivi. Range includes the Namib desert. The Kalahari desert. It has apparently been recorded from Portuguese East Africa and Rhodesia. Its occurrence in Angola seems very doubtful.

Hyaena bRunnea Thunberg, i820.

I820. Hyaena brunnea Thunberg, K. Svenska Vetensk. Akad. Handl. 59. Cape of Good Hope.

I825. Hyaena fusca E. Geoffroy, Dict. Glass. H.N. 8: 444. No locality.

I 826. Hyaena striata A. Smith, Descript. Cat. S. Afr. Mus. I4. Southern Africa. Not of Zimmermann, i 780 .

I827. Hyaena villosa A. Smith, Trans. Linn. Soc. London, 15:46r. South Africa.

1935. Hyaena brunnea melampus Pocock, P.Z.S. 1934: 824. Otjitundua, central Kaokoveld, northern South-West Africa.

\section{Genus CROGUTA Kaup, I 828}

1828. Crocuta Kaup, Oken's Isis, 21: column i I45. Canis crocuta Erxleben. 1829. Crocotta Kaup, Skizz. Europ. Thierwelt, 1: 78. Canis crocuta Erxleben.

Crocuta Kaup is antedated by Crocuta Meigen, I8oo, Nouvelle classification des mouches à deux ailes, 39, a name which does not appear to be in current use by entomologists. Meigen's I 800 work was declared available by Opinion No. I 52 of the International Commission on Zoological Nomenclature, but it now appears (Bull. Zool. Nomencl. 6: I 30, I $\left.95^{2}\right)$ that this work may be suppressed.

It is to be hoped, from the mammalogist's point of view at all events, that this will be the case; if not, then Crocotta Kaup, I829, would be the name of the Spotted Hyaena.

Crocuta crocuta Erxleben, I 777

Spotted Hyaena. Gevlekte Hiëna; Weerwolf

Distribution: in the Union, the Kruger National Park, Transvaal (Skukuza, Toulon and in all probability common throughout most of the reserve). The game reserves of Zululand. South-West Africa; the northern districts (rare or absent 
south of the Tropic of Capricorn), including the Caprivi, the Kaokoveld, Gobabis district, Damaraland. Northern Bechuanaland; Southern Rhodesia; Portuguese East Africa (recorded from near Beira, Tete, etc.). Northern Rhodesia, Nyasaland. Angola (Hill \& Carter record it from Chitau and Chimpora, southern Angola). North of the limits of this work, virtually throughout East Africa, to the Sudan and Somaliland, and from the Belgian Congo intermittently westwards to Senegal.

\section{Crocuta Grocuta Erxleben, I 777}

I777. Canis crocuta Erxleben, Syst. Regn. Anim. 578. "Guinea, Aethiopia, ad Caput bonae spei." Cabrera (I9I I, P.Z.S. 95) selected Senegambia.

I 8 I I. Hyaena maculata Thunberg, Mém. Acad. Sci. St. Pétersb. 3: 302. South Africa. I 8 I 7. Hyaena capensis Desmarest, Nouv. Dict. H.N. (2) 15: 499. Cape of Good Hope. I8 1 7. Hyaena rufa Desmarest, loc. cit. Cape of Good Hope.

I826. Hyaena croacuta A. Smith, Descript. Cat. S. Afr. Mus. I2.

1827. Hyaena encrita A. Smith, Trans. Linn. Soc. London, 15: 46 I. Misprint. 1842. Hyaena cuvieri Boitard, Le Jardin des Plantes, 233. Cape of Good Hope.

I9oo. Hyaena (Crocotta) wissmanni Matschie, S.B. Ges. Naturf. Fr. Berlin, 22. Epukiro, South-West Africa.

I90o. Hyaena (Crocotta) gariepensis Matschie, loc. cit. 25. "In the region of the Bamboo Mountains, between the Orange and Graaff Reynett and Cradock, north of the Liqua River." The Bamboos Mountains are $3 \mathrm{I}^{\circ} 3 \mathrm{O}^{\prime} \mathrm{S} ., 26^{\circ} 20^{\prime} \mathrm{E}$. We do not know why Roberts said they were the same as the Amatola Mtns., which are between Grahamstown and Cathcart.

1904. Hyaena weissmanni Trouessart, Cat. Mamm. Viv. Foss. Suppl. 243.

I9I I. Crocuta nyasae Cabrera, P.Z.S. 99. Mlanje, southern Nyasaland.

\section{FAMILY F E L I D A E}

I. The claws when retracted are not covered by sheaths. Body spotted; face with a dark stripe down each side of nose. Long-legged, and well adapted to running. Skull length about $\mathrm{I}_{4}{ }^{6-203} \mathrm{~mm} .{ }^{1}$ Face short, profile of skull short and high. Hyoidean apparatus unspecialized, and resembling that of Felis.

Genus $A C I N O \mathcal{N} X X$, page I $5 \mathrm{I}$

The claws with sheaths to cover them when they are retracted. Profile of skull less arched. Not combining the above characters.

2. Hyoidean apparatus modified by conversion of median part of suspender into a long elastic tendon. Large species, skull $\mathrm{I} 75 \mathrm{~mm}$. and more.

\section{Genus PANTHERA, page I 49}

Hyoidean apparatus of normal mammalian type, the suspender consisting of a chain of bones joined end to end. Smaller species (the largest skulls (of South African species) about $150 \mathrm{~mm}$.).

Genus FELIS, page I 44

1 Measurements quoted for Felidae include all published measurements available to us from Europe, Asia and Africa. 
Genus FELIS Linnaeus, I $75^{8}$

I758. Felis Linnaeus, Syst. Nat. Ioth ed. I: 4I. Felis catus Linnaeus, the domestic Cat.

I792. Lynx Kerr, Anim. Kingd. Cat. Mamm. Nos. 288-299. Felis lynx Linnaeus, from Sweden. Valid as a subgenus.

1843. Caracal Gray, List Mamm. B.M. 46. Caracal melanotis Gray = Felis caracal Schreber. Valid as a subgenus.

I858. Leptailurus Severtzov, Rev. Zool. Paris, Io: 389. Felis serval Schreber. Valid as a subgenus.

1858. Urolynchus Severtzov, loc. cit. 389. Felis caracal Schreber.

I864. Serval Brehm, Führer Z. Garten Hamburg, 6th ed. 53. Serval maculatus Brehm. (N.V.).

I866. Galeopardus Heuglin \& Fitzinger, S.B. Akad. Wiss. Wien. 54, I : 557. Felis serval Schreber.

I894. Servalina Grevé, Nova Acta Leop. Carol, 63: 76. Felis serval Schreber. 1926. Microfelis Roberts, Ann. Transv. Mus. II: 250. Felis nigripes Burchell.

For the numerous other Old World subgeneric names and synonyms see Ellerman \& Morrison-Scott, I95I, 30 I.

I. Ear tufted; pattern tawny or reddish, unicolor. Skull about rog-I50 mm. Felis (Caracal) caracal, page 148

Ear not heavily tufted; pattern usually spotted or banded.

2. Ears large and broad, 82-99 $\mathrm{mm}$. long in specimens from South Africa. Limbs rather long. Body spotted. Rather large species, skull about Io I-I $35 \mathrm{~mm}$.

$$
\text { Felis (Leptailurus) serval, page } 4^{6} 6
$$

Ears smaller (published measurements and B.M. specimens from South Africa give $78 \mathrm{~mm}$. and less). Limbs rather shorter. The largest recorded skull (Pocock, I95I, Catalogue of the genus Felis) is I $12 \mathrm{~mm}$., but usually the skull is below $100 \mathrm{~mm}$.

3. Tail less than half length of head and body. Bullae enlarged. Skull not more than $87 \mathrm{~mm}$. Spotted pattern usually better developed.

Felis nigripes, page 146

Tail more than half length of head and body. Bullae less enlarged. Skull 8II $2 \mathrm{~mm}$.

Felis libyca, page 144

Subgenus FELIS Linnaeus, I $75^{8}$

We follow the classification of Pocock, 195 I, Catalogue of the genus Felis. That author, who classified the cats of the world, regarded Roberts' supposed genus Microfelis as a synonym of restricted Felis.

Felis libyca Forster, I 780

African Wild Cat. Vaalboskat

Distribution: in the Transvaal, the Kruger National Park, near Wakkerstroom, Klein Letaba, near Pietersburg, and northwards to the Limpopo. Natal, including Estcourt and Newcastle. In the Cape Province, Fourteen Streams, Upington 
district, Louisvale, Little Namaqualand (where it is common; including Klipfontein (north of Steinkopf), near Springbok, Goodhouse, the Kamiesberg), Clanwilliam, Lamberts Bay, Wolseley, Tulbagh (?the Cape Point reserve), Cape Agulhas region; Port Elizabeth, King William's Town, Albany district, Deelfontein. ("Common throughout our region" Hewitt, I93I, eastern Province.) South-West Africa; plentiful throughout, including the Namib desert and the Caprivi (Shortridge). Northern Bechuanaland, and the Kalahari. Southern Rhodesia, including Bulawayo. Inhambane district, Portuguese East Africa. Throughout Angola. Nyasaland and many parts of Northern Rhodesia (northwards to Lake Mweru, southwards to the Sesheke and Kafue districts, etc.). Beyond the limits of this work, most of East Africa, northwards to the Sudan and Somaliland, and in West Africa, Nigeria, Asben, the Belgian Congo. Morocco to Egypt; Sardinia, Corsica, Majorca; Transcaucasia, Russian and Chinese Turkestan, Persia, Afghanistan, into Arabia and the deserts of north-western India.

The species is very closely allied to the earlier-named European $F$. silvestris Schreber, I 777 .

Felis libyca libyca Forster, i 780 . (Extralimital) I 780. Felis lybica (sic) Forster in Buffon's Nat. Vierf. Thiere, 6: 313. Gafsa, Tunis. "The original spelling of this name was adopted by Pocock and G. Allen, but we think Forster made a mistake which comes under the heading of a lapsus" (Ellerman \& Morrison-Scott, 195I).

Felis libyca Gafra Desmarest, i 822

1822. Felis cafra Desmarest, Encyclop. Méth. Mamm. 540. Caffraria.

1826. Felis caffra A. Smith, Descript. Cat. S. Afr. Mus. Io.

1824. Felis caligata Temminck, Mon. Mamm. I: I23 (in part); Smuts, I832, Enum. Mamm. Cap. 30.

1902. Felis lybica obscura Anderson \& de Winton, Mamm. Egypt, I75. Not of Desmarest, I820.

1926. Felis ocreata namaquana Thomas, Ann. Mag. N.H. I7: I80. Klipfontein, (north of Steinkopf), Little Namaqualand, north-western Cape Province.

1928. Felis ocreata rusticana Thomas, Ann. Mag. N.H. I: 319. Zuurbron, near Wakkerstroom, south-eastern Transvaal.

Range: the Union, where according to Pocock there is only the one valid race.

Felis Libyca mellandi Schwann, I904

1904. Felis ocreata mellandi Schwann, Ann. Mag. N.H. 13: 423. Mpika, eastern Northern Rhodesia. Ranges to Nyasaland and the southern Belgian Congo.

Felis libyca Griselda Thomas, I 926

1926. Felis ocreata griselda Thomas, Ann. Mag. N.H. I7: i8o. Fifty miles south of Dombe Grande, Benguela, south-western Angola.

1926. Felis ocreata xanthella Thomas, P.Z.S. 29i. Ukualukasi, north-western Ovamboland, South-West Africa.

1932. Felis ocreata vernayi Roberts, Ann. Transv. Mus. 15: 6. Tsotsoroga Pan, Ngamiland, northern Bechuanaland. 
Felis libyga Pyrrhus Pocock, I944

1944. Felis libyca pyrrhus Pocock, Ann. Mag. N.H. II: I3I. Sogera, on the road from Bokoio to Luimbale, Benguela, about $12^{\circ} \mathrm{S}$., $16^{\circ}$ E., southern Angola.

Felis nigripes Burchell, 1823

Blackfooted Cat. Swartpootwildekat

Distribution: in the Union, recorded from Potchefstroom, western Transvaal; the Orange Free State (Vredefort Road (British Museum)), the Kuruman region, Deelfontein (north of Richmond), the Fort Beaufort and Albany districts, eastern Cape ("now very uncommon", Hewitt, I93I). South-West Africa; Damaraland, Gobabis district (but rare there), to the Kalahari.

FELIS NIGRIPES NIGRIPES Burchell, I 823

1823. Felis nigripes Burchell, Travels in Inter. S. Africa, 2: 592, footnote. "Bachapin country" = near Kuruman, northern Cape Province.

FeLis NIGRIPES THOMASI Shortridge, I93 I

I93 I. Felis (Microfelis) nigripes thomasi Shortridge, Rec. Albany Mus. 4: I I9. Thorn Kloof (Carlisle Bridge), Albany division (near Grahamstown), eastern Cape Province.

\section{Subgenus LEPTAILURUS Severtzov, I858}

Felis serval Schreber, I 776

Serval. Tierboskat

It was thought at one time that $F$. serval and $F$. brachyura (servalina) ${ }^{1}$ were two separate species. Pocock thought so in 1907 , but subsequently changed his mind: "The two styles of pattern, with variations, are found practically all over Africa, south of the Sahara, frequently in the same locality. Although as lately as I924 they were mostly regarded as of specific significance, I asserted in I9I 7 (Ann. Mag. Nat. Hist. 20: 337) that there is but one species of Serval, the so-called "servaline cats" being merely pattern-phases or mutants of the normal type. Since that date considerably more evidence in confirmation of that conclusion has come to hand" (Pocock, I944, Ann. Mag. N.H. II: 696). Pocock then used the name Leptailurus serval brachyura Wagner for the Sierra Leone race of the Serval.

J. A. Allen, I924, Bull. Amer. Mus. N.H. 47: 265, 272, seems to have been the last strongly to support the separate species theory. His conviction was based on the fact that in his Congo collections the two forms occurred side by side but without intergradation; and he did not admit dimorphism in cats (though this is now well established in more than one species). Hill \& Carter (I94I : I37) admit brachyura as a species though they comment on the fact that Angolan skins are very variable and that the variation seems to be unconnected with geographical position.

Pitman (1934: I60) in Northern Rhodesia, found every stage of variation in size of spots between "serval" type and "servalina" type, which indicates that the Serval is not really dimorphic, but has a wide range of individual variation.

${ }^{1}$ Felis brachyura Wagner, 1841, in Schreber, Säugth. Suppl. 2: 547. Sierra Leone. 
Schouteden (1947: 185), dealing with the Belgian Congo, described the Serval as exhibiting two colour patterns, but adds that in the Lulua and Albert Park regions there is intergradation.

There seems little doubt that brachyura (servalina) is the same species as serval, and that the name is valid only in the sense of the Sierra Leone race of serval, should such be required to be distinguished.

Distribution: the western and eastern Transvaal, including the Kruger National Park and Rustenburg district; Zululand, Natal; Swaziland. Hewitt (I93I) said it was then rare in the eastern Cape Province, but said it occurs at Port St. Johns and Pirie, with records from near East London and near Aliwal North. South-West Africa; the northern parts, northern and central Damaraland, eastwards to the Waterberg, Etosha Pan and Grootfontein districts, also the neighbourhood of the Okavango, and throughout the Caprivi (Shortridge, I934). Ngamiland, northern Bechuanaland; recorded from Southern Rhodesia; Portuguese East Africa, districts of Tete, Beira, etc. Angola (probably occurs throughout, Hill \& Carter). Northern Rhodesia (including Ndola and Sesheke district). Nyasaland. North of the limits of this work, much of East Africa northwards to the Sudan and Abyssinia, the Belgian Congo, westwards to Senegal and recorded from Algeria.

Felis Serval SeRval Schreber, I 776

I 776. Felis serval Schreber, Säugth. pl. 108 and text, 3: 407, I777. Cape of Good Hope.

I78I. Felis capensis Forster, Philos. Trans. 7I: 4. Cape of Good Hope.

(1820. Felis galeopardus Desmarest, Ency. Méth. Mamm. 227. No locality; unidentifiable according to Allen.)

Range: Cape Province, according to Roberts.

Felis SeRval Liposticta Pocock, I907

1907. Felis servalina liposticta Pocock, P.Z.S. 666. Mombasa, Kenya.

I9I3. Felis servalina larseni Thomas, Ann. Mag. N.H. I2: 91. Near Bembe, Congo district of northern Angola.

(This belongs to the $F$. brachyura type; see discussion above).

Felis serval beirae Wroughton, igio

igı. Felis capensis beirae Wroughton, Ann. Mag. N.H. 5: 206. Beira (south of the Zambezi), coastal Portuguese East Africa. Range: St. Lucia (Zululand) to the Zambezi.

Felis serval lonnbergi Cabrera, igio

I897. Felis (Serval) togoensis niger Lönnberg, Zool. Jb. Syst. Io: 57 I. Cunene River, opposite mouth of the Kakulovar, south-western Angola. Not Felis nigra Erxleben, I 777 .

I910. Felis serval lönnbergi Cabrera, Bol. Soc. Esp. H.N. IO: 427. To replace niger Lönnberg, preoccupied. 
Felis SeRval hamiltoni Roberts, I93 I

193 I. Leptailurus serval hamiltoni Roberts, Ann. Transv. Mus. 14: 227. " 'Mabbat River" (= Umbabat River, a south-western tributary of the Olifants River, in the Satara area), Kruger National Park, eastern Transvaal.

Felis Serval mababiensis Roberts, 1932

1932. Leptailurus serval mababiensis Roberts, Ann. Transv. Mus. 15: 7. Mababe Flats, Ngamiland, northern Bechuanaland.

Felis SeRVAl ROBERTSI nom. nov.

1926. Leptailurus capensis limpopoensis Roberts, Ann. Transv. Mus. II: 248. Fairfield, Rustenburg district, western Transvaal. Not Lynx caracal limpopoensis Roberts, I926, loc. cit., described on the same page, and with line priority. If, following Simpson and others, Caracal and Leptailurus are both regarded as subgenera of Felis, then the name limpopoensis can be used only once in the latter genus, and robertsi is therefore proposed here to replace Leptailurus capensis limpopoensis Roberts.

\section{Subgenus CARACAL Gray, 1843}

Felis caracal Schreber, 1776

Caracal Lynx. Rooikat

Distribution: in the Union, the Kruger National Park, the Drakensberg, Zoutpansberg, etc., Transvaal. According to Mr. Hollings of De Beers Estate $(36$ miles west of Kimberley) it occurs there, and we are told that it has been killed at least within living memory in the Orange Free State, and might still occur there. Shortridge (I942) recorded it at Clanwilliam and Little Namaqualand (near Springbok, rare in the Kamiesberg), western Cape Province. Albany district (Roberts); Deelfontein (British Museum); Hewitt (I93I) said it was not uncommon in mountainous districts of the eastern Cape Province. South-West Africa; "widely distributed throughout" (Shortridge, I934) and extending to the Caprivi. Ngamiland. Shortridge says it has been recorded from Muncha in Portuguese East Africa. The British Museum has it from Hanha, Angola. Northern Rhodesia. Beyond the limits of this work, Tanganyika, Kenya, the Sudan, Somaliland; Asben; Morocco, Algeria, Egypt; from southern Arabia northwards into Russian Turkestan and from Palestine to the deserts of north-western India.

Felis Caracal Garacal Schreber, i 776

1776. Felis caracal Schreber, Säugth. pl. I Io; text, I777, 3: 413, 587. Table Mountain, Cape Town (where now extinct).

1867. Caracal melanotis Gray, P.Z.S. 277.

1913. Caracal caracal nubica Roberts, Ann. Transv. Mus. 4: 103, nom. nud. Not of Fischer, I829.

1926. Caracal caracal coloniae Thomas, Ann. Mag. N.H. 17: i8I. Deelfontein, north of Richmond, Cape Province.

I926. Lynx caracal roothi Roberts, Ann. Transv. Mus. II: 247. Elandshoek, Drakensberg, Barberton district, eastern Transvaal. 
Felis Garacal Limpopoensis Roberts, i 926

1926. Lynx caracal limpopoensis Roberts, Ann. Transv. Mus. II: 248. Njellele River, north of Zoutpansberg (and near the Limpopo River), northern Transvaal. Ranges to Ngamiland.

Felis Garacal Damarensis Roberts, I 926

1926. Lynx caracal damarensis Roberts, Ann. Transv. Mus. II: 248. Quickborn, Okahandja district, Damaraland, South-West Africa.

Not certainly identifiable: Felis pardella Pallas, i 784, Acta Acad. Sci. Imp. Petrop. $I 78 I, I: 281$. Cape of Good Hope?

\section{Genus PANTHERA Oken, I8I6}

1816. Panthera Oken, Lehrb. Naturgesch, 3, 2: 1052. Panthera vulgaris Oken $=$ Felis pardus Linnaeus.

ı116. Tigris Oken, loc. cit. ı o66. Felis tigris Linnaeus, from Bengal. Valid as a subgenus.

I8ı6. Leo Oken, loc. cit. io7o. Felis leo Linnaeus. Valid as a subgenus.

I829. Leo Brehm, Isis (Oken) 637. Leo asiaticus Brehm = Felis leo Linnaeus. (Type designated by Swynnerton \& Hayman, I95 I.)

I868. Pardus Fitzinger, S.B. Akad. Wiss. Wien, 58, I : 459. Felis pardus Linnaeus. I894. Leonina Grevé, Nova Acta Leop. Carol. 63: 6o. Felis leo Linnaeus.

On the nomenclature of this genus see Ellerman \& Morrison-Scott, I95 I, 3 and 3 I 5.

Body spotted in adult; no tail tuft; no mane in male; averaging smaller, skull about I 75-26o mm.

Panthera pardus, page I 49

Body tawny, not spotted in adult (although the young are usually spotted); end of tail tufted; normally a mane on head and neck in the male; larger on average, skull length about 253-40 I $\mathrm{mm}$.

Panthera (Leo) leo, page I50

\section{Subgenus PANTHERA Oken, I8ı6}

Panthera pardus Linnaeus, I 758

Leopard. Luiperd; Afrikaanse Tier

Distribution: in the Union, the Transvaal (Kruger National Park, Shingwedzi, Toulon, and probably throughout the Reserve); Potchefstroom district (Rand Daily Mail, January, I952). Natal, Zululand included, according to Roberts. ?Near Vryburg and north of Upington? Little Namaqualand; recorded from the Kamiesberg by Shortridge ( I $94^{2}$ ); that author stated that it occurs in the Cedarberg range, western Cape Province. Inland from Cape Town (Bains Kloof, Cape Times, I952), and perhaps the Stellenbosch region. We are told that they are occasionally killed in the Gamka district, near Oudtshoorn. Riviersonderend (near Bredasdorp) (die Landstem, July, I952). Near Swellendam (die Landstem, October, I952). Hewitt (I93I) quoted it from Albany to Port St. Johns, but said it was rather rare in the Eastern Province. We are told that there are still a few in the mountains of Basuto- 
land. South-West Africa; widely distributed over the territory according to Shortridge. ?Southern Rhodesia. The British Museum has it from Portuguese East Africa (Angoche). Common in Northern Rhodesia. Nyasaland. Angola (recent records include Chitau and (I93 I) Rio Mbalé, Chimporo, etc.). North of the limits of this work, nearly throughout East Africa, and from the Belgian Congo to Senegal; Morocco, Algeria, Egypt (where rare). For the Asiatic range see Ellerman \& Morrison-Scott (I95I); it is a very wide one, and includes roughly from Arabia, Ceylon and Java northwards to the Amur district of eastern Siberia, Tibet, Kashmir, Persia and the Caucasus.

PANTHERA PARDUS PARDUS Linnaeus, I $75^{8}$

I 758. Felis pardus Linnaeus, Syst. Nat. Ioth ed. I: 41. Egypt.

I 826. Felis leopardus A. Smith, Descript. Cat. S. Afr. Mus. 7. Southern Africa. Not of Schreber, I 775 .

I885. Felis leopardus var. melanotica Günther, P.Z.S. 243, pl. i6. Forty miles from Grahamstown, eastern Cape Province.

1908. Felis pardus melanosticta Lydekker, Game Anim. Africa, 430 (error).

I932. Panthera pardus shortridgei Pocock, Abstr. P.Z.S. No. 347, 33; P.Z.S. 584 . Gangongo, Okavango River, western Caprivi, South-West Africa.

1932. Panthera pardus puella Pocock, Abstr. P.Z.S. No. 347, 33; P.Z.S., 588. Okorosave, central Kaokoveld, northern South-West Africa.

Subgenus LEO Oken, I8ı6; (Brehm, 1829)

Panthera leo Linnaeus, I $75^{8}$

Lion. Leeu

Distribution: in the Union survives in the Kruger National Park (Shingwedzi, Satara, Skukuza, Toulon, etc.) and in the Mkuzi reserve in Zululand (Roberts). Occasionally still occurs along the northern border of the Cape Province (for instance, near the Molopo River in the Vryburg district (Cape Times, January, I950) and according to Shortridge (I934) periodically to within 50-100 miles north of Upington). South-West Africa; Shortridge (I934) said that lions were steadily retreating before European settlement, and occurred mainly in the northwest, north-east and eastern districts, and that in the Namib desert a certain number managed to hold their own in the more remote parts. The Kalahari, Ngamiland, Southern Rhodesia (Mashonaland, etc.), parts of Portuguese East Africa, Nyasaland, Northern Rhodesia; in Angola Hill \& Carter (I94I) state that they were formerly common throughout but with the destruction of the larger game they have become greatly reduced in number. Beyond the limits of this work, widely distributed south of the Sahara (where not exterminated), through most of East Africa, and from the Belgian Congo to Senegal. Also in Kathiawar, India and (doubtfully) in Persia.

\section{Panthera leo Linnaeus, $175^{8}$}

1758. Felis leo Linnaeus, Syst. Nat. Ioth ed. I: 4I. Constantine, Algeria, where now extinct. Type locality fixed by J. Allen, 1924, Bull. Amer. Mus. N.H. 47: 222 . 
I830. Felis leo capensis Fischer, Syn. Mamm., addenda, 365. Not of Forster, I 781. 1842. Felis (Leo) melanochaitus H. Smith, Jardine's Nat. Library, 35 (Introd. to Mamm.) I 77. Cape of Good Hope. Spelt melanochoetus on pl. Io.

I9I4. Felis leo bleyenberghi Lönnberg, Rev. Zool. Afr. 3: 273. Katanga, southern Belgian Congo.

1929. Leo leo krugeri Roberts, Ann. Transv. Mus. I3: 91. Brixton, Sabi Game Reserve (Kruger National Park), eastern Transvaal.

1948. Leo leo vernayi Roberts, Ann. Transv. Mus. 21: 65. Matapa Pan, near Kuke Pan, central Kalahari, Bechuanaland.

\section{Genus AGINONYX Brookes, I 828}

1828. Acinonyx Brookes, Cat. Anat. Zool. Mus. J. Brookes, I6, 33. Acinonyx venator Brookes $=$ Felis venatica Griffith, the Indian race of Felis jubata Schreber. I830. Cynailurus Wagner, Nat. Syst. Amphib. 30. Felis jubata Schreber. 1842. Guepar Boitard, Le Jardin des Plantes, 234. Felis jubata Schreber.

Acinonyx jubatus Schreber, I 775

Cheetah. Jagluiperd

Distribution: well known in the Kruger National Park, Transvaal; occurs in the game reserves of Zululand, and according to Roberts the wilder parts of Swaziland and the eastern and northern Transvaal. It is thought to be extinct elsewhere in the Union. South-West Africa; apparently more or less throughout the territory according to Shortridge (but perhaps not the coastal desert strip, and noted by that author as scarce near the Orange River, the western and south-western parts of Great Namaqualand, and the highlands of western Damaraland; range includes the Caprivi). Evidently widely distributed in Bechuanaland. Southern Rhodesia. Angola (widely distributed but rare in central and southern Angola (Hill \& Carter)). Northern Rhodesia, Nyasaland. In East Africa northwards to the Sudan and Somaliland, apparently quite widely distributed. Senegal; Morocco; Egypt. Its present status in Asia is obscure, but it occurs in Russian Turkestan and Arabia.

Acinonyx jubatus jubatus Schreber, i 775

I 775. Felix jubata Schreber, Säugth. 3: pl. I05; text, 393 ( I 777). Cape of Good Hope. I834. Felis fearonii A. Smith, S. Afr. J. 2: 245. North-east of Natal.

I 869. Felis fearonis Fitzinger, S.B. Akad. Wiss. Wien, 59, I : 664. Cape of Good Hope. Substitute for fearonii.

I877. Felis lanea Sclater, P.Z.S. 532. Beaufort West, western central Cape Province. I9I3. Acinonyx guttatus obergi Hilzheimer, S.B. Ges. Naturf. Fr. Berlin, 289. Keetmanshoop, Great Namaqualand, South-West Africa.

1927. Acinonyx rex Pocock, Abstr. P.Z.S. No. 283, I8. P.Z.S., 250. Umvukwe Range, north-west of Salisbury, Southern Rhodesia. (Regarded by Cabrera, I932, Mamm. de Marruecos, I9I, as an individual variation of the usual type of cheetah found in Rhodesia. See also Pocock, I939, Fauna Brit. India, Mamm. I: 325, who came to the same conclusion.) 


\section{ORDER P I N N I P E D I A}

An offshoot of the Carnivora modified for semi-marine life; mammals of large size, with short limbs in form of flippers, very short tail, ears very short or absent; no carnassial teeth.

There is only one family which habitually breeds on South African coasts, the Otariidae. Two genera of the family Phocidae from the Antarctic occasionally become stranded on the southern shores of the Cape.

The key is based on the three South African forms only.

I. The hindlimbs capable of forward rotation. In South Africa, skull with postorbital processes; normally 3 upper and 2 lower incisors; relatively smaller species, overall length of the skull approximately $280 \mathrm{~mm}$.

Family OTARIIDAE: Genus ARCTOCEPHALUS, page I 52

The hindlimbs not capable of forward rotation. In South African genera, skull lacks postorbital processes; less than 3 upper incisors; relatively larger species, overall length of the skull approximately $38 \mathrm{o} \mathrm{mm}$. and more.

$$
\text { Family PHOGIDAE:- } 2
$$

2. Much larger, overall length of the skull approximately $500 \mathrm{~mm}$. Nasals very short, nasal aperture very large. Normally 2 upper I lower incisors. Nose of adult males produced into short tubular proboscis, capable of dilation.

Genus MIROUNGA, page I 53

Medium in size, overall length of the skull approximately $380-390 \mathrm{~mm}$. Nasals medium, and nasal aperture medium. Normally 2 upper and 2 lower incisors. Nose not abnormal.

Genus HYDRURGA, ${ }^{1}$ page ${ }^{\text {I }} 54$

Simpson refers the two genera of Phocidae to two distinct subfamilies (Mirounga to the Cystophorinae, Hydrurga to the Lobodontinae).

For the characters of Arctocephalus compared with the other genera of Otariidae see J. A. Allen, I88o, History of North American Pinnipeds.

\section{FAMILY O T A R I I D A E}

\section{Genus ARGTOGEPHALUS F. Cuvier, 1826}

1826. Arctocephalus F. Cuvier, Dict. Sci. Nat. 39: 554. The type of this genus is not "Phoca ursinus" Linnaeus (as quoted by G. Allen and Roberts, and which is the type of the northern genus Callorhinus), but it is Phoca ursina Cuvier, I826 (not of Linnaeus) $=$ Arctocephalus delalandii Gray $=$ Phoca pusilla Schreber.

1866. Halarctus Gill, Proc. Essex Inst. Salem, Communications, 5: 7. Arctocephalus delalandii Gray $=$ Phoca pusilla Schreber.

${ }^{1}$ Differs from Monachus which usually has a similar incisor formula in larger skull, much narrower zygomatic width (about 55 per cent of length of skull; in Monachus this width is nearly 70 per cent of the length of the skull); and much shorter postdental palate. 
Arctocephalus pusillus Schreber, I 775

Cape Sea-Lion (or Fur Seal). Seeleeu; Rob

Distribution: Shortridge (1934) listed the localities of this species in some detail, which included near the Orange River mouth, the Olifants River mouth, near Saldanha Bay, Table Bay, False Bay, off the Caledon coast, Mossel Bay and Algoa Bay (he also stated they were sometimes stranded as far east as East London); and, in South-West Africa, certain islands between the Orange River mouth and Lüderitz, certain islands and rocks between Lüderitz and Walvis Bay, and northwards to Cape Cross (about roo miles north of Walvis Bay). (The species is still well known near Cape Town, near Mossel Bay, and probably elsewhere.)

Arctocephalus pusillus Schreber, I 775

I 775. Phoca pusilla Schreber, Säugth., pl. 85; text 3: 314 (vernacular) and 585 ( 1778 ). Type locality presumed to be off South Africa.

I785. Phoca parva Boddaert, Elench. Anim. I: I72. "Mediterranean Sea." This is an error, since parva is a renaming of pusilla.

I8I I. Phoca antarctica Thunberg, Mém. Acad. Sci. St. Pétersb. 3: 32 I, nom. nud. I8 1 7. Otaria peronii Desmarest, Nouv. Dict. Hist. Nat. (2) 25: 598. Cape of Good Hope.

1859. Arctocephalus delalandii Gray, P.Z.S. io7. Substitute for pusilla.

I 868. Arctocephalus nivosus Gray, Ann. Mag. N.H. I: 2 I 9. Cape of Good Hope.

I 868. Arcto-cephalus schist-hyperöes Turner, J. Anat. Physiol. 3: i I5. Cape of Good Hope.

I874. Euotaria compressa Gray, Handlist Seals, etc. B.M., 38. South Africa?

\section{FAMILY P H O G I D A E}

\section{Genus MIROUNGA Gray, I827}

I826. Macrorhinus F. Guvier, Dict. Sci. Nat. 39: 552. Phoca proboscidea Péron. Not of Latreille, I 825 .

I827. Mirounga Gray in Griffith's Guvier Anim. Kingd. 5: I79. Phoca proboscidea Péron = Phoca leonina Linnaeus (see Miller, I923, List North Amer. Recent Mamm., i66).

1830. Rhinophoca Wagler, Naturl. Syst. Amphib. 27. Phoca proboscidea Péron $=$ Phoca leonina Linnaeus.

I843. Morunga Gray, List Spec. Mamm. B.M., xxiii, ı3. M. proboscidea = Phoca leonina Linnaeus.

Mirounga leonina Linnaeus, I 758

Elephant Seal

Distribution: the Antarctic; in South Africa, has occasionally been taken off the Cape coast in recent years (Simonstown, Algoa Bay and, according to Hewitt (I 93 I), has been recorded as far east as Pondoland).

Mirounga Leonina Linnaeus, i $75^{8}$

I 758. Phoca leonina Linnaeus, Syst. Nat. Ioth ed. I: 37. Antarctic. For other, extralimital, synonyms see G. Allen (I939: 249). 
Genus HYDRURGA Gistl, I 848

1826. Stenorhinchus F. Cuvier, Dict. Sci. Nat. 39: 549. Phoca leptonyx Blainville. Not Stenorhynchus Lamarck, I8I8.

I848. Hydrurga Gistl, Nat. Thierr., xi. For Stenorhinchus Cuvier, preoccupied. Phoca leptonyx Blainville.

I875. Ogmorhinus Peters, Mber. Preuss. Akad. Wiss., 393.. For Stenorhinchus Cuvier, preoccupied.

Hydrurga leptonyx Blainville, I820

Leopard Seal

Distribution: the Antarctic. A specimen was taken in South Africa in 1946, about 40 miles north of East London, see Roberts (I95I).

HydRuRga LEPTONyx Blainville, I820

I820. Phoca leptonyx Blainville, J. Physique, 9I: 298. Falkland Islands (east of Patagonia).

\section{ORDER T UBU L I D E N T A T A}

Relatively large mammals with abnormal dentition; the front teeth are absent and the main cheekteeth are $3 / 3$ rootless molars which lack enamel, in addition to which there are usually $2 / 2$ premolars (and further premolars may be present in front of these, but if so they are vestigial). The body is nearly naked, the tail thick and rather long, the ears large, and the 4 fingers and 5 toes bear thick nails. Zygomatic arch complete. Habits subterranean, and (like the Pholidota) the diet consists of ants and termites. (The characters just outlined for the Tubulidentata are not combined elsewhere.)

\section{FAMILY O R Y G T E R O P O D I D A E}

Genus ORYGTEROPUS G. Cuvier, I $79^{8}$

1798. Orycteropus G. Cuvier, Tabl. Élém. H.N. Anim. I44. Myrmecophaga capensis Gmelin = Myrmecophaga afra Pallas.

I799. Orycteropus Lacépède, Tabl. Mamm. I I. Orycteropus capensis Gmelin = Myrmecophaga afra Pallas.

I803. Orycteropus E. Geoffroy, Bull. Soc. Philom. Paris, I: I02. Myrmecophaga capensis Gmelin = Myrmecophaga afra Pallas.

See Swynnerton \& Hayman ( 95 I : 336) on the above dates.

Orycteropus afer Pallas, i 766

Aardvark or Antbear. Erdvark

Distribution: this species is probably more numerous than records show, but as it is subterranean and nocturnal it is seldom seen; it is also difficult to catch, and few specimens find their way into museums. In the Union it is known in the Kruger 
National Park, Transvaal, and we are told that it still occurs in the Orange Free State. It is also thought to occur in the region of Kimberley, and westwards from Kuruman, and Roberts quotes burrows of these animals at Maputa (Zululand). Shortridge ( 1942$)$ recorded the species from north of Steinkopf in Little Namaqualand. Roberts quoted specimens from Grahamstown; (Hewitt (I93I) said it was widespread in the eastern Province wherever termite heaps occur). It is also likely that it occurs near Richmond, Cape Province. The British Museum has specimens from Deelfontein and near Vryburg. Shortridge says it occurs throughout SouthWest Africa, from Great Namaqualand northwards, except along the coastal Namib desert. Probably occurs throughout most of Angola (Hill \& Carter, I 94I). Northern Rhodesia and Nyasaland. (We have not seen it recorded from Southern Rhodesia nor Portuguese East Africa.) North of the limits of this work, through most of Africa south of the Sahara, and northwards to Asben, Senegal, the Sudan and British Somaliland.

Oryateropus Afer AfER Pallas, i 766

I 766. Myrmecophaga afra Pallas, Misc. Zool. 64. Cape of Good Hope.

I 788. Myrmecophaga capensis Gmelin, Linn. Syst. Nat. ed. I3, I: 53. Cape of Good Hope.

Orycteropus AFER Albicaudus Rothschild, I907

I907. Orycteropus afer albicaudus Rothschild, Novit. Zool. I4: 506. South-West Africa. (Damaraland, fide Roberts.)

ORYGTEROPUS AFER WARDI Lydekker, I 908

1908. Orycteropus afer wardi Lydekker, Game Animals of Africa, 467. North-Eastern Rhodesia. (North-Eastern and North-Western Rhodesia were united in I 9 I I as Northern Rhodesia.)

\section{ORDER P R O B O S G I D E A}

Largest of living land mammals, with the limbs heavy and adapted for bearing weight, five fingers and toes; nose elongated to form a prehensile trunk. The front teeth absent except for (usually) one pair of enlarged upper incisors (tusks). Ears enlarged.

\section{FAMILY E L E P H A N T I D A E}

The two living genera in this family are the Asiatic Elephas Linnaeus, I 758, and the African Loxodonta. The latter is distinguished by its much larger ears, simpler molars, differently shaped skull with less domed forehead, the presence of two "fingers" on the end of the trunk as opposed to one in the Asiatic form; the general shape of the body is also different, and in typical africana there are only 4 nails on the forefeet and 3 on the hind, as opposed to 5 and 3 respectively in the Asiatic elephant (but see Morrison-Scott, 1947: 521). 
Genus LOXODONTA F. Cuvier, I 827

1827. Loxodonta F. Cuvier, Zool. J. 3: 140. Elephas capensis F. Cuvier = Elephas africanus Blumenbach.

I 857. Loxodon Falconer, Quart J. Geol. Soc. London, I3: 315. Emendation. Not of Mueller \& Henle, 1838.

Loxodonta africana Blumenbach, I 797

African Elephant. Olifant

Distribution: in the Union, the Kruger National Park (commoner north of the Olifants River; Punda Maria, Shingwedzi, Letaba, Satara and occasionally wandering southwards from the last named); the Addo Bush (near Port Elizabeth) and the Knysna forest, southern Cape Province. According to Roberts they rarely wander into Zululand. In South-West Africa, quoted by Shortridge (I934) from the Kaokoveld and the Caprivi (east of the Okavango), also as occasional migrants in the Outjo district, north-eastern and north-western Ovamboland, etc. Angola. Ngamiland, Southern Rhodesia, Portuguese East Africa, Northern Rhodesia, Nyasaland. Beyond the limits of this work, through most of East Africa to the Sudan and Somaliland (unless exterminated there) and westwards to Sierra Leone with outliers in Mauretania and Portuguese and French Guinea.

Loxodonta AFricana AFricana Blumenbach, i797. Bush Elephant

I 797. Elephas africanus Blumenbach, Handb. Naturgesch. ed. 5, I25. Central and Southern Africa. Orange River, South Africa nominated by Pohle, I926, Z. Säugetierk, $1: 63$.

I 798. Elephas capensis G. Guvier, Tabl. Élém. H.N. Anim. I49. Orange River region, South Africa.

I 907. Elephas africanus toxotis Lydekker, P.Z.S. 385, 388. "Mossel Bay" but actually the Addo Bush, near Port Elizabeth, eastern Cape Province.

I907. Elephas africanus selousi Lydekker, P.Z.S. 387 (in legend to text fig. 108, of type), 389. Mashonaland, Southern Rhodesia.

1924. Loxodonta africana zukoweskyi Strand, Arch. Naturgesch. 9oA, I: 68, footnote. Kaokoveld, northern South-West Africa.

1924. Elephas africanus moçambicus Frade, Bull. Soc. Portug. Sci. Nat. 9: I33. Maputo, southern Portuguese East Africa.

1928. Loxodonta africana angolensis Frade, Titulos e Trabalhos Scientificos (Curriculum vitae), Lisboa, I6. Cunene River region, extreme southern Angola.

This form and cyclotis are sometimes regarded as separate species, on the ground that in areas where the Congo Forest abuts on savannah country herds of each form have been seen in the same locality, but not intermingling. But this fact is not necessarily significant since it is conceivable that herds (or large family parties) of elephants of the same form, if normally living some distance from one another, might avoid each other when their wanderings brought them to the same district. 


\section{HYRACOIDEA}

Loxodonta Africana gyclotis Matschie, igoo. Forest Elephant I900. Elephas cyclotis (or Elephas capensis cyclotis) Matschie, S.B. Ges. Naturf. Fr. Berlin, I94. Yaunde, southern Cameroons. Range in area covered by this work: Northern Angola, in Cuanzo and Bembe districts and on the rivers Mebrige, Cuilo, Lungo, Zaza, Mococola and Cugo, also in the plateau of Mazenquelle and the plains of Suá Escomba, Zaïre, etc. (Frade, I936).

\section{ORDER HY R A G O I D E A}

Rather small mammals with I upper and 2 lower pairs of incisors which are enlarged, the other front teeth being absent; a considerable space between these front teeth and the cheekteeth, which in pattern are not unlike those of Rhinoceroses. Tail and ears short; 4 functional fingers and 3 toes, bearing flattened nails. (Skull and dentition of "ungulate" type rather than rodent type; palate well developed and normal, ascending ramus of mandible straight.)

\section{FAMILY P R O G A V I I D A E}

See Hahn, 1934, Z. Säuget., 9: 207-358, also Ellerman \& Morrison-Scott, I 95 I $; 334$.

Molars hypsodont; in fully adult skulls, in the upper jaw, the 3 molars are clearly longer than the 4 premolars.

Genus PROCAVIA, page I57

Molars brachyodont; in fully adult skulls, in the upper jaw, the 3 molars are about equal to, or a little shorter than the 4 premolars.

Genus DENDROHYRAX, page I6o

\section{Genus PROCAVIA, Storr, i 780}

I 78o. Procavia Storr, Prodr. Meth. Mamm. 40, pl. B. Cavia capensis Pallas. I 783. Hyrax Hermann, Tabl. Affin. Anim. I I 5. Cavia capensis Pallas.

1868. Euhyrax Gray, Ann. Mag. N.H. I: 46. Hyrax habessinicus Ehrenberg, from Abyssinia.

Procavia capensis Pallas, i 766

Dassie; Hyrax. Klipdas

Distribution: one of the commonest mammals in the Union. The Transvaal; Kruger National Park, Mokeetsi, Legogot (near White River), Wakkerstroom, Pretoria, Zoutpansberg, Rustenburg district, etc. Natal, including Newcastle, Mooi River, Pietermaritzburg and Zululand. The Orange Free State, including Fauresmith and Meadows (about 46 miles south-east of Bloemfontein). Basutoland. Cape Province; Vryburg, Kuruman, Griquatown, Upington, Louisvale, Aughrabies Falls, Little Namaqualand (north of Steinkopf, north of Springbok, the Kamiesberg, etc.), Klaver, Lamberts Bay, Clanwilliam, the Cape Point Nature Reserve, Oudtshoorn 
(the Cango Caves), near George, Knysna, Albany district, Plettenberg Bay, Grahamstown, King William's Town, Mount Fletcher (Griqualand East), Pondoland, between Laingsburg and Ladismith, near Richmond, Deelfontein, Seven Weeks Poort, north of Colesberg, Graaff Reinet, where they are particularly common. Swaziland. In South-West Africa, Great Namaqualand and Damaraland northwards about to the Waterberg district (Shortridge). Western Angola, mainly in the districts near the coast. Nyasaland, the Kafue district of Northern Rhodesia. Plumtree (near Bulawayo) Southern Rhodesia (Roberts, I95 I, 57 I). Northwards to British Somaliland, the Sudan, Asben and Senegal, also southern Egypt (B.M.), Libya, Algeria, and from southern Arabia to Syria.

Procavia capensis capensis Pallas, i 766

I 766. Cavia capensis Pallas, Zool. Misc. 30, pl. 3. Cape of Good Hope.

(1869. Dendrohyrax semicircularis Gray, Cat. Carnivorous, Pachyderm. and Edentate Mamm. B.M., 285. No locality.)

Range: southern Cape Province, Gape Town, Cape Agulhas, Knysna, etc.

Progavia Gapensis welwitschi Gray, i868

I 868. Hyrax welwitschii Gray, Ann. Mag. N.H. I: 43. Rocky banks of River Maiomba, Mossamedes district, south-western Angola.

(1917. Procavia flavimaculata Brauer, S.B. Ges. Naturf. Fr. Berlin, 303. Kaokoveld, northern South-West Africa.)

(Roberts (I95I) and Shortridge (I934) listed welwitschi under Heterohyrax. But we have one of Bocage's specimens, and others labelled welwitschi collected by Shortridge. These are Procavia, the 3 upper molars being clearly longer than the 4 upper premolars. Also, the teeth increase in size regularly from the anterior ones to the posterior ones, whereas in Dendrohyrax (with Heterohyrax) they are much more of a size. Hahn (I934) and Hill \& Carter (I94I) treat welwitschi as a race of Procavia capensis. There is a plate by Bocage, I889, J. Sci. Math. Phys. Nat., Lisboa, I (plate which goes with text on p. I86).)

Procavia Gapensis johnstoni Thomas, 1894

I894. Procavia johnstoni Thomas, P.Z.S., I42. Fort Lister, Nyasaland. Given specific rank by Hahn; races referred by that author to johnstoni are the largest in the genus, but there is individual overlap between the johnstoni group and the other groups regarded as species by Hahn.

Procavia Capensis windhuki Brauer, igi 4

I9I4. Procavia capensis windhuki Brauer, S.B. Ges. Naturf. Fr. Berlin, 3o. Dobra and neighbouring localities near Windhoek, central South-West Africa.

I9I4. Procavia capensis reuningi Brauer, loc. cit. 31. Furstenwalde, Lichtenstein and neighbourhood, near Windhoek, South-West Africa. Considered a valid subspecies by Roberts (I95I).

I9I4. Procavia capensis waterbergensis Brauer, loc. cit. 33. Waterberg, South-West Africa. Considered a valid subspecies by Roberts (I95I). 
Progavia gapensis schultzei Brauer, igi4

I9I4. Procavia capensis schultzei Brauer, S.B. Ges. Naturf. Fr. Berlin, 32. Chamis (north-east of Aus), Great Namaqualand, South-West Africa.

Progavia gapensis marlothi Brauer, i9i 4

I9I4. Procavia capensis marlothi Brauer, S.B. Ges. Naturf. Fr. Berlin, 33. Kranshoek, Clanwilliam district, western Cape Province. Range: the central Karroo plateau from Clanwilliam and Vanrhynsdorp districts, north of the southern mountains, to Uitenhage, Cape Province.

Progavia (?) capensis volkmanni Brauer, igi 4

I9I4. Procavia volkmanni Brauer, S.B. Ges. Naturf. Fr. Berlin, 35. Franzfontein, $20^{\circ} \mathrm{S}$. in north-western South-West Africa.

Procavia capensis natalensis Roberts, I924

1924. Procavia capensis natalensis Roberts, Ann. Transv. Mus. Io: 76. Piggs Peak, Swaziland. Range includes Wakkerstroom district, south-eastern Transvaal.

Progavia capensis coombsi Roberts, i 924

I924. Procavia capensis coombsi Roberts, Ann. Transv. Mus. Io: 76. Hennops River, Pretoria, Transvaal. Range: western and north-western Transvaal, ?eastwards to Woodbush and Legogot, northwards into Southern Rhodesia.

Procavia capensis chiversi Roberts, 1937

1937. Procavia capensis chiversi Roberts, Ann. Transv. Mus. 19: Iо I. Mount Fletcher, Griqualand East, eastern Cape Province.

Progavia capensis orangiae Roberts, 1937

1937. Procavia capensis orangiae Roberts, Ann. Transv. Mus. I9: ro I. Meadows (about 46 miles south-east of Bloemfontein), Orange Free State.

Progavia capensis letabae Roberts, i 937

1937. Procavia capensis letabae Roberts, Ann. Transv. Mus. 19: I02. Mokeetsi (north of Tzaneen) in the eastern Transvaal low-country.

Procavia capensis albaniensis Roberts, i 946

1946. Procavia capensis albaniensis Roberts, Ann. Transv. Mus. 20: 326. Fir Glen, Albany district, eastern Cape Province.

Progavia capensis vanderhorsti Roberts, i 946

1946. Procavia capensis vanderhorsti Roberts, Ann. Transv. Mus. 20: 326. Graaff Reinet, eastern Karroo, Cape Province.

Procavia capensis griquae Roberts, i 946

1946. Procavia capensis griquae Roberts, Ann. Transv. Mus. 20: 326. Fauresmith, western Orange Free State. Range: to Griqualand West; Hopetown, Campbell, Vryburg. 
Procavia Gapensis klaverensis Roberts, I 946

1946. Procavia capensis klaverensis Roberts, Ann. Transv. Mus. 20: 327. Klaver, western Cape Province. Roberts thinks Little Namaqualand specimens may belong to this race.

\section{Genus DENDROHYRAX Gray, I 868}

1868. Dendrohyrax Gray, Ann. Mag. N.H. I: 48. Hyrax arboreus A. Smith (Sclater, I900, Mamm. S. Africa, I: 310).

I868. Heterohyrax Gray, Ann. Mag. N.H. I: 50. Dendrohyrax blainvillei Gray = Hyrax brucei Gray. Valid as a subgenus.

Outer surface of parietals and intertemporal region with weak ridges closer together, or absent. Orbit usually not ringed by bone.

Dendrohyrax (Heterohyrax) brucei, page 160

Outer surface of parietals and intertemporal region with strong ridges widely separated. Orbit usually ringed by bone.

Dendrohyrax arboreus, page $\mathrm{I} 6 \mathrm{I}$

Other characters used by Roberts to distinguish these species, particularly the length of the diastema and the width between the incisors, seem more average than absolute. It should be noted that occasionally the orbit can be ringed by bone in Heterohyrax (Angola).

\section{Subgenus HETEROHYRAX Gray, I 868}

G. Allen, Roberts and others use syriacus as the first named species in this subgenus. But as we have already shown (Ellerman \& Morrison-Scott, I95 I : 335) syriacus was named from Syria, and no Heterohyrax occurs there, or anywhere else in Asia. The earliest named species in the subgenus Heterohyrax is therefore brucei.

Dendrohyrax brucei Gray, I 868

Yellow-spotted Dassie. Geelkoldas

Distribution: Zoutpansberg to Pilgrims Rest district, northern Transvaal, and part of the Limpopo valley; northern parts of South-West Africa (owing to authors confusing Procavia and Heterohyrax (see note under welwitschi above) it is a little difficult to arrive at the details of the distribution of these two species); Angola, where widely distributed in the plateau region, northwards at least to Pungo Andongo; Southern Rhodesia; Gorongoza district of Portuguese East Africa, and also north of the Zambezi; Northern Rhodesia, Nyasaland. Beyond the limits of this work, northwards to the Belgian Congo, Abyssinia and Somaliland.

Dendrohyrax brugei brugei Gray, i868. (Extralimital)

I868. Hyrax brucei Gray, Ann. Mag. N.H. I: 44. Abyssinia.

Dendrohyrax brugei bocagei Gray, i 869

1869. Hyrax bocagei Gray, Ann. Mag. N.H. 3: 243. Angola.

1889. Dendrohyrax grayi Bocage, J. Sci. Math. Phys. Nat., Lisboa, I: I9o. Quissange, Benguela district, western Angola. 


\section{HYRACOIDEA}

Dendrohyrax bRUGei mossambicus Peters, i 869

I 869. Hyrax mossambicus Peters, S.B. Ges. Naturf. Fr. Berlin, 25. Cabaceira Peninsula, about $15^{\circ}$ S. (north of the Zambezi), coastal Portuguese East Africa.

DENDROHYRAX BRUGeI RUDDI Wroughton, I9IO

I9 Io. Procavia brucei ruddi Wroughton, Ann. Mag. N.H. 5: io8. Tambarara, Gorongoza Mountains, southern Portuguese East Africa.

DendRohyrax BRUGeI GRANTI Wroughton, igio

I9I0. Procavia brucei granti Wroughton, Ann. Mag. N.H. 5: iog. Woodbush, northeastern Transvaal. Range: Zoutpansberg to Pilgrims Rest district, north-eastern Transvaal.

Dendrohyrax BRUGeI manningi Wroughton, igio

I9 I0. Procavia brucei manningi Wroughton, Ann. Mag. N.H. 5: iog. Mlanje, southern Nyasaland.

DendRohyrax BRUGeI TSUMEBENSIS Roberts, I938

1938. Heterohyrax welwitschii tsumebensis Roberts, Ann. Transv. Mus. 19: 236. Guinas waterhole, west of Tsumeb (north of Grootfontein), north-eastern SouthWest Africa.

Dendrohyrax BRUGei RHODESIAE Roberts, I 946

1946. Heterohyrax syriacus rhodesiae Roberts, Ann. Transv. Mus. 20: 327. Matibi district, north of Malala Drift on the Limpopo River, Southern Rhodesia. Range: the upper Limpopo valley in northern Transvaal (southwards to Waterberg district) and Southern Rhodesia.

DendRohyrax BRUGEI OTJIWARONGENSIS Roberts, I 946

1946. Heterohyrax welwitschii otjiwwarongensis Roberts, Ann. Transv. Mus. 20: 328. Tweekopjes Farm, Otjiwarongo district (south of Outjo), northern Damaraland, South-West Africa.

\section{Subgenus DENDROHYRAX Gray, I 868}

Dendrohyrax arboreus A. Smith, 1827 Tree-Dassie. Bosdas

Distribution: in the eastern Cape Province, Port St. Johns and Notinsila, Pondoland; King William's Town, Albany and according to Hewitt (I93 I) Bedford, Pirie, Alexandria, etc. Known to occur in the Natal midlands (Roberts). In South-West Africa, Shortridge quoted it from the eastern Caprivi. That author also quoted it from parts of Portuguese East Africa and Southern Rhodesia. Nyasaland; the Kafue Hook region of Northern Rhodesia (Pitman, I934). Thence northwards to Tanganyika, Kenya and the Belgian Congo. 
Dendrohyrax arboreus arboreus A. Smith, i 827

1827. Hyrax arboreus A. Smith, Trans. Linn. Soc. London, 15: 468. Forests, South Africa.

Dendrohyrax arboreus mimus Thomas, igoo

I90o. Procavia mima Thomas, Ann. Mag. N.H. 6: 387. Nyasa-Tanganyika plateau, northern Nyasaland.

\section{ORDER PER ISSOD A G T Y L A}

The living members of this order are large mammals superficially specialized in much the same way as the Artiodactyla (below), but are not cloven-hoofed; the fourth digits when present are shorter than the third, which are dominant. In living members of the order, none of the front teeth is much enlarged.

The two families which occur in South Africa are referred to two suborders, which are so distinct that they do not require special comparison.

Lightly-built animals; slender limbs, with I digit; the orbit ringed by bone, and the cheekteeth complex. In South African species the body, neck and limbs are striped.

Family EQUIDAE, page $6_{4}$ Heavily-built species; heavy limbs with 3 digits; the orbit not ringed by bone, and the cheekteeth relatively simple. African forms have 2 horns on the nose. Family RHINOGEROTIDAE, page ${ }^{6} 62$

SUb-ORDER GERATOMORPHA

\section{FAMILY R H I N O G E R O T I D A E}

For key to all living members of this family see Pocock, I945, P.Z.S., I I4: 437. Pocock (loc. cit.) divided the living rhinoceroses into two subfamilies, one for the Asiatic, and one for the African forms. For our reasons for agreeing with this view, rather than that of Simpson (1945) and others, see Ellerman \& Morrison-Scott (195I).

\section{Subfamily D i c e r o t i n a e}

Genus DICEROS Gray, I82 I

1821. Diceros Gray, London Medical Repository, 15: 306. Rhinoceros bicornis Linnaeus. 1841. Opsiceros Gloger, Hand-u. Hilfsbuch Naturgesch. I: I25 (xxxii, I842). Rhinoceros bicornis Linnaeus.

1862. Rhinaster Gray in Gerrard, Cat. Bones Mamm. Brit. Mus. 282. Rhinoceros bicornis Linnaeus. 
I868. Keitloa Gray, P.Z.S. I867: I025. Rhinoceros keitloa A. Smith $=$ Rhinoceros bicornis Linnaeus.

I868. Ceratotherium Gray, P.Z.S. I867: 1027. Rhinoceros simus Burchell. Valid as a subgenus.

Ceratotherium has been treated as a full genus by many authors, but we do not regard the differences between this and Diceros as being of more than subgeneric value.

Upper lip squared.

Upper lip narrow, its tip prehensile.
Diceros (Ceratotherium) simus, page 164 Diceros bicornis, page 163

\section{Subgenus DICEROS Gray, I82 I}

Diceros bicornis Linnaeus, I 758

Black Rhinoceros. Swartrenoster

Distribution: this species is becoming rare in South Africa, and in the Union seems now to be restricted to the reserves in Zululand. (It appears to have become extinct in the Kruger National Park.) South-West Africa; Shortridge (I934) quoted the species from the Kaokoveld (where rare) and said that it occurred rarely in the Caprivi district, and as an occasional visitor in western Ovamboland. Parts of Portuguese East Africa, Southern Rhodesia and northern Bechuanaland (Roberts). Southern Angola; parts of Northern Rhodesia. Apparently has been recorded from Nyasaland. Beyond the limits of this work, occurs in most parts of East Africa, and westwards probably as far as the general neighbourhood of Lake Chad, but it is likely that it is nowhere common.

Diceros BICORNIS BICORNIS Linnaeus, I $75^{8}$

I 758. Rhinoceros bicornis Linnaeus, Syst. Nat. Ioth ed. I: 56. "India", but Cape of Good Hope according to Thomas (I9I I : I44).

I803. Rhinoceros africanus Blumenbach, Man. Hist. Nat. I: I 56. Cape of Good Hope. I836. Rhinoceros keitloa A. Smith, Rept. Exped. Expl. Central Afr., 44. "Country north and south of Kurrichaine" (Marico district, western Transvaal).

I837. Rhinoceros ketloa A. Smith, Cat. S. Afr. Mus. 7. "I8o miles N.E. of Lattakoo." I842. Rhinoceros bicornis Var. B. Rhinoceros gordoni Lesson, Nouv. Tabl. Règne Anim. Mamm. I 59, nom. nud.

I845. Rhinoceros niger Schinz, Synops. Mamm. 2: 335. Chuntop, near Mt. Mitchell, Kuiseb district, South-West Africa (Shortridge, I934, Mamm. S.W. Africa, I: 4 I 2, footnote).

I845. Rhinoceros camperi Schinz, loc. cit. Cape of Good Hope.

I898. Rhinoceros bicornis capensis Trouessart, Cat. Mamm. Viv. Foss. 757. Cape of Good Hope.

1922. Opsiceros occidentalis Zukowsky, Arch. Naturgesch. 88A, 7: i62. KaokoveldCunene region, northern South-West Africa.

1947. Diceros bicornis punyana Potter \& Mitchell, Field, 190: 385. Hluhluwe Game Reserve, Zululand, Natal. 
Diceros simus Burchell, i8 77

White Rhinoceros. Witrenoster

Distribution: so far as is known, in South Africa the species is now confined to the game reserves in Zululand (where it is the commoner of the two species). There is another race in the region of the southern Sudan and Uganda, probably extending into the adjacent parts of the Congo.

Diceros simus simus Burchell, i8i 7

I8 17. Rhinoceros simus Burchell, Bull. Soc. Philom. Paris, 97. Interior of South Africa, near lat. $26^{\circ}$ S. (near Kuruman, northern Cape Province, fide Shortridge, I934).

1827. Rhinoceros camus (sic) Griffith, Cuvier's Anim. Kingd. 5: 292. Southern Africa. I827. Rhinoceros burchellii Lesson, Man. Mamm. 332. Substitute for simus.

I854. Rhinoceros oswellii Gray, P.Z.S. I853: 46. Interior of South Africa.

SUB-ORDER HIPPOMORPHA

FAMILY E Q U I D A E

Genus EQUUS Linnaeus, I $75^{8}$

I758. Equus Linnaeus, Syst. Nat. Ioth ed. I: 73. Equus caballus Linnaeus, the domestic Horse.

I84I. Hippotigris H. Smith, Jardine's Naturalist's Library, 3I: 32 I. Equus zebra Linnaeus (Sclater, I 900, Mamm. of S. Africa, $I: 282$ ). Valid as a subgenus. i 9o9. Zebra J. Allen, Bull. Amer. Mus. N.H. 26: I63, in legend to text-f. 7, 8. Zebra burchelli granti de Winton = Equus burchelli boehmi Matschie. Not of Shuttleworth, i 856 , a mollusc.

I912. Dolichohippus Heller, Smiths. Misc. Coll. 6o, 8: I. Equus grevyi Oustalet, from Abyssinia. Valid as a subgenus.

1934. Quagga Shortridge, Mamm. S.W. Africa, I: 397. Quagga quagga greyi Lydekker = Equus quagga Gmelin.

Pocock (I902, I904, I907), Shortridge (1934) and Rzasnicki (I95I) considered that $E$. burchelli was conspecific with the extinct E. quagga Gmelin, ( I 788, Syst. Nat. I: 213 , South Africa) and at first sight this seems a logical conclusion. The races of the Burchell group of Zebras show a progressive reduction of the stripes on the legs and belly from boehmi and selousi in the northern part of the range to the now extinct typical burchelli in the south: quagga, still further south, seemed merely to carry the process further. But recent investigations into the cranial characters of quagga tend to show that the skull is different from that of the Burchell Zebras (Lundholm, r 95 I) and that this difference is greater than that existing between the Burchell Zebras themselves. This in itself does not, of course, mean that the difference between the Quagga and the Burchell Zebras is necessarily of specific order, but, taken together with the evidence for quagga and burchelli having been sympatric, we are inclined to 
agree with Cabrera (1936) and Allen (in Harper, 1945) in regarding quagga as a species on its own. The evidence just referred to is to be found in Harris (I840). Of Equus quagga he says "Inhabits the open plains south of the Vaal river in immense herds" (p. 5) and "although never intermixing with its own more elegant congeners (Burchell's Zebra), is almost invariably to be found ranging with the White-tailed Gnoo, and with the Ostrich, for the society of which bird, especially, it evinces the most singular predilection" (p. 7). Of Equus burchelli Harris says: "inhabits the plain country beyond the Gareep or Orange River, in immense herds, but is never found to the southward of that stream" (p. I 7) and "occupying the same regions, and delighting in the same pastures, as the Brindled Gnoo, rarely is it to be seen unless in the companionship of that fantastic animal, whose presence would appear to be almost indispensable to its happiness" (p. I8). From this it appears that quagga and burchelli both inhabited the regions between the Vaal and the Orange River, but that they did not mix, and even that they associated with different species of Gnu (Wildebeest).

Shortridge's subgenus or genus Quagga is usually rejected. The two South African species of Zebra are closely related, and Roberts (I95I) in dealing with the two species states "no cranial differences are indicated and those which are said to be found in the dentition are slight".

\section{Subgenus HIPPOTIGRIS H. Smith, I84I}

Stripes on croup form a "gridiron" pattern. A dewlap present. Ears larger. Equus (Hippotigris) zebra, page I 65 Stripes on croup not forming "gridiron" pattern. No dewlap. Ears smaller. Equus (Hippotigris) burchelli, page I66

Equus zebra Linnaeus, I $75^{8}$

Mountain Zebra. Bergkwagga

Distribution: the typical race exists in very small numbers on a private property near Cradock, and near Oudtshoorn, Cape Province. E. z. hartmannae; South-West Africa, the chain of arid mountains that form the eastern boundary of the sandy coastal strip known as the Namib desert (Shortridge, 1934), northwards into Angola (to about roo miles north of Mossamedes (Shortridge)), southwards to Great Namaqualand.

EQUUS ZEBRA ZEBRA Linnaeus, I 758

I758. Equus zebra Linnaeus, Syst. Nat. Ioth ed. I: 74. "In India, Africa." Type locality fixed by Roberts (I95I) as Paardeberg, near Malmesbury, southwestern Cape Province, where it is now extinct.

1822. Equus montanus Burchell, Travels in Interior S. Africa, I: I39. No locality, but mentions Paardeberg, near Malmesbury, south-western Cape Province, as a locality where it used to be found.

1852. Hippotigris campestris Gray, Cat. Mamm. Brit. Mus. pt. 3: 277. Not of H. Smith, I84I. Mountains of South Africa.

I898. Equus indica Trouessart, Cat. Mamm. Viv. Foss., 797. 
EQUUS ZEBRA ZEBRA [contd.].

I905. Equus zebra frederici Trouessart, Cat. Mamm. Viv. Foss. Suppl. 646. Northern part of Cape Colony.

I9ı. Equus wardi Ridgeway, P.Z.S. Igog: 799. Believed to be a menagerie hybrid between $E$. zebra and $E$. burchelli chapmani.

Present range: near Cradock and near Oudtshoorn, Cape Province.

EquUs zebra hartmannae Matschie, i 898

I 898. Equus hartmannae Matschie, S.B. Ges. Naturf. Fr. Berlin, I 74. Between Hoanib and Unilab Rivers, I $9^{\circ}$ S., I $3^{\circ}$ E., Kaokoveld, northern South-West Africa.

I90o. Equus penricei Thomas, Ann. Mag. N.H. 6: 465. Providencia, Moninho valley, $70 \mathrm{~km}$. north-east of Mossamedes, Angola.

I924. Hippotigris hartmannae matschiei Zukowsky, Arch. Naturgesch. 9oA, I: 90. Namib, near Swakopmund, Damaraland, South-West Africa.

Range: South-West Africa and Angola.

Equus burchelli Gray, I 824

Burchell's Zebra. Bontkwagga

Distribution: in the Union, now apparently confined to Zululand, and the Kruger National Park, Transvaal, where it is widely distributed (Punda Maria, Shingwedzi, Letaba, Satara, Skukuza, Pretorius Kop, Toulon, etc.). Swaziland. In South-West Africa, Shortridge quoted the species from northern Damaraland, the Etosha Pan area, the Kaokoveld, Ovamboland, the Okavango region and the Caprivi. Northern Bechuanaland; Southern Rhodesia; parts of Portuguese East Africa. Southern Angola; local in Northern Rhodesia; Nyasaland. Northwards through much of East Africa, to the southern parts of the Sudan, Abyssinia and southern Somaliland.

On this species see Cabrera, I936, 7. Mamm. I7: 89.

We do not agree with the classification of Roberts (I95I) of the Burchell zebras, and for the benefit of those who may not have access to Cabrera's revision, we include here his key to the races.

I. Legs never wholly striped; shadow stripes generally numerous.

Legs wholly striped to the hoofs; shadow stripes very few and frequently absent.

2. Limbs without stripes below the elbow and stifle, a few traces of them on the hock sometimes excepted.

E. b. burchelli

Limbs more or less striped below elbow and stifle, but never completely so.

E. b. antiquorum

3. Stripes and interspaces on neck and body narrow and numerous; cervical stripes Io-13, vertical stripes 4-8. E. b. selousi

Stripes and interspaces on neck and body wider and less numerous; cervical stripes 7-10, vertical stripes $3-4$.

E. b. boehmi 
EquUS BURGhelli bURGhelli Gray, I 824

I 824. Asinus burchellii Gray, Zool. J. I: 247. "The flat parts near the Cape (Burchell)."

Burchell, W. J., I825, A list of quadrupeds brought by Mr. Burchell from Southern Africa, and presented by him to the British Museum, says that he shot the animal which Gray used for his description at Little Klibbolikhoni Fontein $\left(27^{\circ} 50^{\prime}\right.$ S., $24^{\circ} 25^{\prime}$ E. $)$.

I827. Equus zebroides Lesson, Man. Mamm. 346. Substitute for burchelli.

I834. Equus festivus Wagner, Schreber Säugth. 6: 2 I 6. Interior of Cape of Good Hope. I84I. Hippotigris campestris H. Smith, Jardine's Naturalist's Library, 3I: 329. Substitute for burchellii.

(1878. Equus markhami Tichomirow, Diary of journey to west European zoological gardens (N.V. Rzasnicki, I943, Zool. Gart. 15: 54, says that this name refers to a specimen in which the stripes on the rump are broken up into spots).)

I899. Equus burchelli typicus Selous in Bryden, Great and Small Game of Africa, 79. Now extinct. Former range: southern Bechuanaland and Orange River Colony (= northern Cape Province and Orange Free State).

EquUs burchelli antiQuorum H. Smith, i84i. Chapman's Zebra

1841. Hippotigris antiquorum H. Smith, Jardine's Naturalist's Library, 3I: 327. Angola (Cabrera, 1936: 94).

1865. Equus chapmanni Layard, P.Z.S. 4I7. Between the Zambezi and Botletle Rivers, South Africa.

1897. Equus burchelli wahlbergi Pocock, Ann. Mag. N.H. 20: 44. Zululand, Natal. I 897. Equus burchelli transvaalensis Ewart, Veterinarian (London) 70: 622. Transvaal. (1909. Equus burchelli pococki Brasil \& Pennetier, Mém. Soc. Linn. de Normandie, Caen, 23: 97, (April). Actes Mus. H.N. Rouen, I 2: 31, (December). "An almost indeterminable name, based on a museum specimen without locality. It may have been park-reared and even from parents of different subspecies" (Cabrera (1936: 98).)

I91 2. Equus (Hippotigris) kaufmanni Matschie, Deutsche Jäger-Zeitung, 59: I 20, 209. Caprivi-Zipfel, between Botletle and Zambezi Rivers, northern South-West Africa.

1924. Hippotigris chapmani kaokensis Zukowsky, Arch. Naturgesch. 9oA, i: 82. Kaoko plains, near south bank of Cunene River, northern South-West Africa.

Range: from Benguela and Damaraland, across the Bechuanaland Protectorate to Transvaal and Zululand.

EQUUS BURGhelli boehmi Matschie, i892. Grant's Zebra.

I892. Equus böhmi Matschie, S.B. Ges. Naturf. Fr. Berlin, I3 I. Pangani River, north-eastern Tanganyika.

I896. Equus burchelli crawshaii de Winton, Ann. Mag. N.H. I7: 319. Henga, highlands west of Lake Nyasa, Nyasaland.

1897. Equus burchelli crawshayi Pocock, Ann. Mag. N.H. 20: 46. Emendation.

I898. Equus burchelli zambeziensis Prazak, Wild Horses, I: pl. i6 (N.V. But see Trouessart, I 898, Bull. Mus. H.N. Paris, 4: 64, which may antedate). Barotseland, north bank of Upper Zambezi, Northern Rhodesia.

Range: from Northern Rhodesia and Nyasaland to southern Abyssinia, Somaliland and the southern Sudan. 
EquUs BURGhelli selousi Pocock, I897 I897. Equus burchelli selousii Pocock, Ann. Mag. N.H. 20: 45. Manyami River, Mashonaland, north-eastern Southern Rhodesia.

I899. Equus (Hippotigris) foai Prazak \& Trouessart, Bull. Mus. H.N. Paris, 5: 350. Mountainous region south of Angoniland, north bank of lower Zambezi, opposite Tete (Portuguese East Africa).

I906. Equus annectens Rothschild, P.Z.S. 69i. Near Fort Jameson, eastern Northern Rhodesia.

1908. Equus burchelli annectans Lydekker, Game Animals of Africa, $5^{8 .}$

Range: Lower Zambezi basin, from Victoria Falls; Southern Rhodesia; Mozambique; northwards to southern Nyasaland.

\section{ORDER A R T IO D A G T Y L A}

Medium-sized or large mammals with the dentition adapted for vegetarian diet, the fingers and toes bearing hoofs, the limbs usually lengthened and specialized either for running or bearing weight, the fourth digit being as long as the third with the weight taken equally on these two (cloven-hoofed mammals). The canines may be enlarged, but not the incisors (except in the Hippopotamus).

See particularly:

Lydekker, R. I9I3-I5, Catalogue of Ungulate Mammals in the British Museum, I-4.

Sclater \& Thomas, I894-I9oo. The Book of Antelopes, I-4.

Simpson (1945) classified the four South African families as follows:

Suborder: SUIFORMES

Infraorder: SuINA

Family: Suidae

Infraorder: ANGODONTA

Superfamily: Anthracotherioidea

Family: Hippopotamidae

Suborder: RUMINANTIA

Infraorder: PECORA

Superfamily: Giraffoidea

Family: Giraffidae

Superfamily: Bovoidea

Family: Bovidae

I. Lower and upper canines caniniform and enlarged; at least I upper incisor present; stomach simple; no horns.

Lower canine incisoriform, upper canine absent; no upper incisors; stomach divided into four compartments for ruminating; male with 2 horns on head. 
2. Orbit ringed by bone and raised; upper canine straighter; muzzle much widened; lateral digits reach the ground. Central lower incisors enlarged and projected forwards. The typical genus very large in size, with relatively short limbs and much enlarged head. Third upper molar not enlarged.

Family HIPPOPOTAMIDAE, page I 72

Orbit not ringed by bone; upper canines more or less curved; muzzle narrow; lateral digits not reaching the ground. Central lower incisors not much enlarged. Smaller animals. Third upper molar much enlarged.

Family SUIDAE, page 169

3. Lower canine bilobed. Horns, present in both sexes (in the typical subfamily), simple skin-covered bony projections. In the typical genus, neck and limbs abnormally elongated.

Family GIRAFFIDAE, page I 73

Lower canine not bilobed. Horns, present in male, present or absent in female, in form of nondeciduous unbranched horny sheaths supported on bony cores.

Family BOVIDAE, page I74

\section{SUB-ORDER SUIFORMES}

\section{FAMILY S U I D A E}

In adult normally less than 30 teeth; the body mainly naked except for a mane on the back; last molars much larger, and upper canines of males much enlarged and dominant. Skull much wider between the orbits. With warts on side of head and in front of eye. Orbit somewhat raised.

Genus PHACOCHOERUS, page I 7 I

Normally 42 teeth; body more hairy; last molars relatively smaller and upper canines of males less dominant. No warts on side of head. Skull much narrower between the orbits.

Genus POTAMOCHOERUS, page I69

\section{Genus POTAMOCHOERUS Gray, I 854}

I 854. Potamochoerus Gray, P.Z.S. I 852: I 29, I 30 (published 27th June, I854). Choiropotamus pictus Gray (the Cameroons race of Sus porcus Linnaeus).

I843. Koiropotamus and Choiropotamus Gray, List. Mamm. B.M. xxvii and i85. Choiropotamus africanus Gray $=$ Sus koiropotamus Desmoulins. These have been held to be homonyms of Chaeropotamus Desmarest, I822, a genus of extinct ungulate from France, but according to the Commission's revised rules (August I 953) this is not the case. In view, however, of the long usage of Potamochoerus, we are asking the Commission to place this name on the Official List, and to set aside Koiropotamus and Choiropotamus.

I 863. Nyctochoerus Heuglin, Nova Acta Leop. Carol. 3o, suppl. to sect. 2: 7. Nyctochoerus hassama Heuglin, the Abyssinian race of Sus porcus Linnaeus.

See Lönnberg, igro, Ark. Zool. 7, 6: I.

It is customary to regard all forms of this genus as belonging to one species. The genus is near Sus Linnaeus, but normally has 6 (instead of 7) lower cheekteeth, with more tendency for the ear to be tufted, and with two pairs of osseous tuberosities on and above sheaths of upper canines, which are absent in Sus. 
Potamochoerus porcus Linnaeus, I $75^{8}$

Bush-Pig; Red River Hog (West Africa). Bosvark

Distribution: in the Union survives in the Kruger National Park, Transvaal (where it is said to be quite common in the extreme north, near Pafuri), according to Roberts Zululand, and the Knysna forest and the Albany district (Fish River), eastern Cape Province. Shortridge quoted it from the eastern Caprivi in the north of South-West Africa; eastern Southern Rhodesia, parts of southern Portuguese East Africa. Northern Rhodesia (southwards to the Zambezi, Sesheke and Kafue districts), Nyasaland. Angola (recent records include Andulu, Namba and Vila da Ponte). Beyond the limits of this work, north-eastwards to Abyssinia and Italian Somaliland, westwards to the Gold Coast and Liberia (according to Ingoldby). A closely allied form occurs in Madagascar.

Potamoghoerus porgus porgus Linnaeus, i 758. (Extralimital) I758. Sus porcus Linnaeus, Syst. Nat. Ioth ed. I: 50. Guinea, West Africa.

Potamochoerus porgus kotropotamus Desmoulins, i83 I

I83 I. Sus koiropotamus Desmoulins, Dict. Class. H.N. I7: pl. I46 (referred to on p. I39). South Africa (a specimen collected by Lalande).

1832. Sus larvatus Smuts, Enum. Mamm. Cap. 59. Not of F. Cuvier, I822.

1868. Sus capensis Gray, P.Z.S., 35. South Africa.

I897. Potamochoerus choeropotamus Major, P.Z.S., 366. Emendation.

(179I. Sus africanus Schreber, Säugth. pl. 327; text, 6: $45^{8}$ (I835). No locality (Schreber left this plate without any data and Wagner included it under Sus larvatus (1835) in his completion of Schreber's work). Not Sus africanus Gmelin, I 788, which was based on a Wart Hog (Phacochoerus).)

Range: Cape Province.

Potamochoerus porgus Johnstoni Forsyth Major, I897

I897. Potamochoerus johnstoni Forsyth Major, P.Z.S., 367. Ngarawi River, Nkana, North Nyasa district, north-western Nyasaland.

Potamochoerus porcus nyasae Forsyth Major, I897

I897. Potamochoerus choeropotamus nyasae Forsyth Major, P.Z.S., 367. Zomba (northeast of Blantyre), southern Nyasaland. Has been recorded from Northern Rhodesia.

Potamochoerus porgus maschona Lönnberg, igio

I910. Potamochoerus choeropotamus maschona Lönnberg, Ark. Zool. 7, 6: 20. Mashonaland, Southern Rhodesia. Ranges to northern Zululand, south-eastern Transvaal, southern Portuguese East Africa, western Northern Rhodesia.

Potamochoerus porcus cottoni Pinfold, i 928

1928. Potamochoerus choeropotamus cottoni Pinfold, Ann. Mag. N.H. 2: 99. Tunda (=Funda), Quanza district, north-western Angola.

In addition, Pitman (1934) queries Potamochoerus porcus albinuchalis (Lönnberg, I920, Rev. Zool. Afric. 7: 245, Lake Léopold II, Belgian Congo) from Northern Rhodesia. 


\section{Genus PHACOGHOERUS F. Cuvier, 1826}

I766. Aper Pallas, Misc. Zool. i6. Aper aethiopicus Pallas. "Although Aper may be regarded as merely the masculine form of Sus, it is perhaps here used as a distinct generic term" (G. Allen, I939: 459).

I8I6. "Phaco choerus" G. Cuvier, Règne Anim. I: 236. This "name", usually misquoted as "Phaco-choerus" or "Phacochoerus", and wrongly attributed to F. Cuvier, is in current use for the Wart Hogs, and has been for a long time. But the fact is that, on page 236 of the work quoted, the Wart Hogs are termed "Les Phaco-Choeres. (Fred. Cuv.) (I)". The "I" refers to a footnote: (I) "Phaco choerus; cochon portant une verrue."

This is merely an etymological note by G. Cuvier, to explain to readers the derivation of his brother's term "Les Phaco-Choeres", but is in no nomenclatural sense a "name".

All this has already been pointed out by Lyon, I9I5, Proc. Biol. Soc. Washington, 28: I4I, but for some reason nothing was ever done about it, and Phacochoerus continued to be used.

i8ı 7. Eureodon G. Fischer de Waldheim, Mém. Soc. Nat. Moscou, 5: 417. Sus aethiopicus Linnaeus.

I820. Phascochoeres et Phascochoerus Ranzani, Elem. Zool. 2: 536, 537.

I822. Phascochaerus Desmarest, Encycl. Meth. (Mamm.) 393.

1826. Phacochoerus F. Cuvier, Dict. Sci. Nat. 39: 383. Sus aethiopicus Gmelin = Aper aethiopicus Pallas.

I828. Phascochaeres Cretzschmar, in Rüppell, Atlas, Reise nördl. Afr., Säugeth. 6I. I841. Dinochoerus Gloger, Hand-u. Hilfsbuch Naturgesch, I: I 3 I (xxxii, I842). Aper aethiopicus Pallas.

I904. Macrocephalus Palmer, Index Genera Mammalium, 39 I (ex Frisch, I 775, Das Natur-system Vierf. Thiere, 3 (unavailable)). Aper aethiopicus Pallas.

In view of the longstanding usage of the name Phacochoerus, we have asked the International Commission on Zoological Nomenclature to place Phacochoerus F. Cuvier, I 826, on the Official List and to reject Eureodon, Aper, and Phascochoeres and its variants.

See Lönnberg, I909, P.Z.S. 1908: 936 for review.

Phacochoerus aethiopicus Pallas, i 766

Wart Hog. Vlakvark

Distribution: in the Union, survives in the Kruger National Park, Transvaal (Shingwedzi, Letaba, Satara, Skukuza, Toulon; common south of the Olifants River), and Zululand, Natal. South-West Africa: "throughout the northern and central parts ... and wherever there are vleis and waterholes" (Shortridge, I934) who also quoted the species from as far south as the Maltahohe district in Great Namaqualand. Angola. Ngamiland and northern Bechuanaland. Recorded from Southern Rhodesia and Portuguese East Africa. Nyasaland, Northern Rhodesia. Further to the north, East Africa as far as the Sudan and Somaliland, and westwards to Nigeria, the Gold Coast and apparently Senegal.

Most of the subspecies of this species seem to be based on cranial characters, and as it is known that great individual variation exists in the species their status seems obscure. 
Phacochoerus aethiopicus aethiopicus Pallas, i 766

I 766. Aper aethiopicus Pallas, Misc. Zool. i6. Cape of Good Hope.

1828. Phacochoerus edentatus I. Geoffroy, Dict. Class. H.N. 13: 320. Cape of Good Hope.

I 834. Phascochaerus typicus A. Smith, S. Afr. J. 2: i 78. Interior of Cape Colony.

1839. Phacochoerus pallasi van der Hoeven, Nova Acta Leop. Carol. 19: i 73. Substitute for aethiopicus.

The typical race is now regarded as extinct.

Phacochoerus aethiopigus sundevalli Lönnberg, i 908

1908. Phacochoerus sundevallii Lönnberg, Wiss. Ergebn. schwed. Zool. Exped. Kilimandjaro, etc. $I, 2: 54$. Natal.

Phacochoerus aethiopicus shortridgei St. Leger, $193^{2}$

1932. Phacochoerus aethiopicus shortridgei St. Leger, Ann. Mag. N.H. Io: 86. Numkaub, Grootfontein district, northern South-West Africa. Ranges to Angola.

\section{FAMILY H I P P O P O T A M I D A E}

Genus HIPPOPOTAMUS Linnaeus, I $75^{8}$

I758. Hippopotamus Linnaeus, Syst. Nat. Ioth ed. I: 74. Hippopotamus amphibius Linnaeus.

Hippopotamus amphibius Linnaeus, $175^{8}$

Hippopotamus. Seekoei

Distribution: in the Union survives in the Kruger National Park, Transvaal (Pafuri (north of Punda Maria), Letaba, near Skukuza, Crocodile Bridge, etc.) and in northern Zululand. Limpopo River, Zambezi, etc., in Portuguese East Africa (also Inhambane district, (British Museum)). Southern Rhodesia. In northern South-West Africa and adjacent territories, the Cunene, Okavango, Chobe and Zambezi rivers. Angola (recent records include Rio Mbalé district (I93I) and Bihé district (I94I) ). Rowland Ward quoted specimens from Nyasaland and Northern Rhodesia. Beyond the limits of this work, in suitable localities northwards to Abyssinia and probably parts of the Sudan (the Nile), and from the Belgian Congo to (at least formerly) Gambia.

(Became extinct in the western Orange River in 1925 according to Shortridge, I934.)

Hippopotamus amphibius amphibius Linnaeus, i 758. (Extralimital)

1758. Hippopotamus amphibius Linnaeus, Syst. Nat. roth ed. I: 74. Nile River.

Hippopotamus amphibius capensis Desmoulins, i825

1825. Hippopotamus capensis Desmoulins, Dict. Class. H.N. 8: 220. Lower Berg River (northwards from Cape Town), western Cape Province (where now extinct).

1846. Hippopotamus australis Duvernoy, G.R. Acad. Sci. Paris, 23: 650. Cape of Good Hope. 
I 910. Hippopotamus constrictus Miller, Smithson. Misc. Coll. 54, 7: 1. Angola. 1924. Hippopotamus constrictor Zukowsky, Arch. Naturgesch. 9oA, I : 99. (Lapsus for constrictus).

\section{SUB-ORDER RUMINANTIA}

\section{FAMILY G I R A F F I D A E}

Two distinct living genera, referred by Simpson to two subfamilies, belong to this family. Only one of them occurs in South Africa.

\section{Subfamily $\mathrm{G}$ i $\mathrm{r}$ a $\mathrm{f} f \mathrm{i} \mathrm{n}$ a $\mathrm{e}$}

Genus GIRAFFA Brisson, I 762

I 762. Giraffa Brisson, Regn. Anim. i 2, 37. Giraffa giraffa Brisson = Cervus camelopardalis Linnaeus. On the status of Brisson's names see Ellerman \& Morrison-Scott, I95 I : 3 .

I 77 I. Giraffa Brünnich, Zool. Fundamenta, 36, 46. Cervus camelopardalis Linnaeus. (For date of Brünnich see Bull. Zool. Nomencl. I950, 4: 307.)

I 784. Camelopardalis Schreber, Säugth. pl. 255; text, 5: I I39 (I8I 7). Camelopardalis giraffa Schreber $=$ Cervus camelopardalis Linnaeus.

i 8ı6. Orasius Oken, Lehrb. Naturgesch, 3, 2: 744. Cervus camelopardalis Linnaeus. (Unavailable.)

I848. Trachelotherium Gistl, Nat. Thierr., 8 I. New name for Camelopardalis Schreber.

Giraffa camelopardalis Linnaeus, $\mathrm{I} 75^{8}$

Giraffe. Kameelperd; Giraf

Distribution; in the Union, survives in the Kruger National Park, Transvaal (Satara, Skukuza, Toulon, etc.; particularly common at Satara). (Col. J. A. B. Sandenbergh informs us that they have been introduced in the Hluhluwe Reserve, Zululand.) Occurs in Portuguese territory along the eastern border of the Kruger National Park. Southern Rhodesia, part. The central Kalahari (Roberts). In South-West Africa Shortridge (1934) quoted the species from northern localities, the Kaokoveld, the Grootfontein district, and the Caprivi (east of the Okavango). Roberts says that the distribution of the race capensis (= giraffa) is "in all cases only in isolated areas where certain tall açacias are found". Southern Angola. ?Rare in Northern Rhodesia. Beyond the limits of this work, northwards in East Africa about to the Sudan and Abyssinia, and from parts of the Belgian Congo to Nigeria and apparently Senegal.

On the races of the Giraffe see Lydekker, I904, P.Z.S. I: 202. It may be mentioned here that the form reticulata de Winton, 1899, from the Loroghi Mountains, Kenya, which is sometimes listed as a species, appears to be nothing more than a form of the one and only species $G$. camelopardalis. We have seen a photograph of a herd on the Loroghi plateau which contained both forms.

Giraffa Gamelopardalis Gamelopardalis Linnaeus, I758. (Extralimital) I 758. Cervus camelopardalis Linnaeus, Syst. Nat. Ioth ed. $I: 66$. Aethiopia and Sennar (Sudan). 
Giraffa Gamelopardalis girafFa Boddaert, I 785

I 785. Camelopardalis giraffa Boddaert, Elenchus Animalium, i 33. Cape of Good Hope. 1842. Camelopardalis capensis Lesson, Nouv. Tabl. Règne Anim. Mamm. i68. Cape of Good Hope.

1896. Giraffa camelopardalis australis Rhoads, Proc. Acad. Nat. Sci. Philadelphia, 5 I8. South Africa.

1904. Giraffa camelopardalis wardi Lydekker, P.Z.S. I: 22 I. Northern Transvaal.

I908. Giraffa infumata Noack, Zool. Anz. 33: 356. Barotse, middle Zambezi region, Northern Rhodesia.

I9I I. Giraffa camelopardalis thornicrofti Lydekker, Nature, London, 87: 484. Petauke, Eastern Province, Northern Rhodesia.

GirafFa CAMElopardalis ANGOlEnsis Lydekker, I903

1903. Giraffa camelopardalis angolensis Lydekker, Hutchinson's Anim. Life, 2: I22; P.Z.S.1904, I : 22 I (1904). Cunene River, I50 miles south-west of Humbe, extreme southern Angola.

\section{FAMILY B O V I D A E}

Twenty genera occur in the present region. Simpson ( 1945 ) classified these genera as follows: 1

Subfamily: Bovinae

Tribe: "Strepsicerotini" = Tragelaphini.

Tragelaphus (Simpson used the name Strepsiceros Frisch, I 775 for this genus, but it is not available).

Taurotragus.

Tribe: Bovini.

Syncerus.

Subfamily: Gephalophinae.

Cephalophus, Sylvicapra.

Subfamily: Hip Pot RAGINAE

Tribe: Reduncini.

Kobus, Redunca, Pelea.

Tribe: Hippotragini.

Hippotragus, Oryx.

Tribe: Alcelaphini.

Damaliscus, Alcelaphus, Connochaetes.

Subfamily: AntilopinaE

Tribe: Neotragini.

Oreotragus, Ourebia, Raphicerus, Nesotragus, Madoqua.

Tribe: Antilopini.

Aepyceros, ${ }^{2}$ Antidorcas.

${ }^{1}$ Simpson retained more genera than we list here.

${ }^{2}$ Although Simpson and others refer Aepyceros to the Antilopinae it seems probable that it is more nearly allied to Kobus and Redunca. 
We are not convinced that Simpson's classification is a natural one, and for the present we list no subfamilies in this family.

I. Horns poorly developed, present or absent in female, relatively short, straight, spike-shaped and simple. The largest horns quoted by Rowland Ward (I935) are little over 7 inches in length, and below 8 inches. Facegland present, and preorbital pit on the skull for its reception.

Horns well developed, usually somewhat curved (but straight in Oryx and Pelea), not spikeshaped, and in measurements quoted by Rowland Ward (1935) exceed 7 inches in length (except Redunca fulvorufula, in which they curve forwards).

2. Hoofs short, truncated, as an adaptation to rock or mountain habitat. Coat thick and coarse, almost bristly, its colour and texture distinguishable at a glance from that of the other small genera.

Genus OREOTRAGUS, page I88

Hoofs not particularly shortened; coat without the peculiarities and colour of the last genus.

3. Nasals much reduced in size; nostrils large and inflated.

Nasals and nostrils not abnormal.

Genus $M A D O Q U A,{ }^{1}$ page 189

4. Facegland specialized, prominent, opening in long slit down the face.

Facegland less prominent and specialized, not forming long opening.

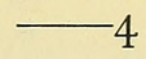

5. Horns (usually absent in female) directed upwards, forming obtuse angle with plane of face. Ears long, pointed. Genus SYLVICAPRA, page i8 I

Horns (usually present in both sexes), directed backwards in plane of face; ears medium or short, rounded.

Genus CEPHALOPHUS, page I 77

6. Normally with vacuity between premaxilla and maxilla (so in all South African skulls examined). Horns heavily ridged for much of their length.

Genus NESOTRAGUS, page I 87

No vacuity between premaxilla and maxilla. Horns not ridged, or ridged more lightly and for less of their length.

7. With bare patch below ear; with "knee" tufts; horns ridged at base.

Genus OUREBIA, page I 86

No bare patch below ear; no "knee" tufts; horns not or little ridged at base.

Genus RAPHICERUS, ${ }^{2}$ page 183

${ }^{1}$ Rhynchotragus (characterized by the presence of a third hind lobe to the last lower molar and by the more curved premaxillae) is here considered a subgenus of Madoqua, following Roberts.

2 Thomas \& Schwann (I go6) separated Raphicerus melanotis as the genus Nototragus on account of its retention of small lateral hoofs, its close ally sharpei being left in Raphicerus (type species campestris). Shortridge (1934) and Roberts (I95I) agreed in regarding sharpei as being nearer to melanotis than to campestris, and in including the two former in Nototragus. But apart from some minor cranial details pointed out by Roberts and the colour of the fur there are no differences of importance between these two groups and we think it best to follow Swynnerton \& Hayman (I 95 I, 353) who synonymize Nototragus with Raphicerus. 
8. Horns normally present in male only. (No faceglands.) Horns normally present and well developed in both sexes.

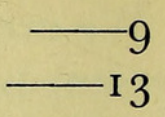

9. Horns quite straight, medium in length $\left(8 \frac{1}{4}-\mathrm{I} I \frac{1}{2}\right.$ inches in specimens quoted by Rowland Ward (1935)). ${ }^{1}$ Coat woolly. With footglands.

Genus PELEA, page igo

Horns considerably curved; not combining the characters of the last genus; footglands normally absent.

Io. Horns twisted in a more or less open spiral, and not heavily ringed. Usually the body has at least signs of stripes. Genus TRAGELAPHUS, page 206

Horns either more or less lyrate in shape, or in the form of a forwardly-directed arc of a circle, and usually ringed. Body without stripes.

I I. No lateral hoofs; no supraorbital pits nor lachrymal vacuities; with premaxillomaxillary vacuity. Horns more or less lyrate; a vertical black streak on each hindquarter and white between them. Genus AEPYCEROS, page I95

With lateral hoofs; with supraorbital pits and lachrymal vacuities; no premaxillomaxillary vacuity.

I 2

I2. Tail short and bushy; bare patch below ear; on average smaller; horns in form of forwardly-directed arc of a circle and rarely as much as I 7 inches (Rowland Ward).

Genus REDUNCA, page I9I

Tail not bushy; no bare patch below ear; on average larger, in South Africa horns not under I7 inches (Rowland Ward).

Genus $K O B U S,{ }^{2}$ page 192

I3. Horns in the male more or less lyrate in shape, ridged and usually hooked inwards at the tips; in the female smoother, much shorter and thinner. Cheekteeth reduced, only 5 in the lower jaw, and 5 or 6 in the upper. Colour distinctive, pale sandy with black band along flank, white underparts and dark streak on face. A line of long, white, erectile hairs along the spine from the middle of the back to the tail. Facegland present and corresponding preorbital pit in the skull. Genus ANTIDORCAS, page Ig6

Little or less difference in size between the horns of males and females. Not combining the characters of the last genus, and as a general rule of larger size.

I4. Horns long and more or less straight (about 26-48 inches in length in species now under consideration). Colour of body pale, with whitish limbs and dark marks on the face. (No facegland.)

Genus ORYX, page 197

Horns curved.

${ }^{1}$ These are "record" measurements, and Pelea may have the horn under 7 inches in length. The genus may still be distinguished, however, from the short-horned forms listed under 2-7 above by the lack of faceglands, woolly fur, the relatively large rhinarium and the small bullae.

${ }^{2}$ The Lechwes are usually treated as belonging to a separate genus Onotragus, but the differences between them and the Kobs and the Puku (subgenus Adenota) do not seem to be sufficiently clear-cut to warrant subgeneric distinction. Onotragus is here regarded as a synonym of Adenota, and Adenota is here, following many earlier authors, regarded as a subgenus of Kobus. 
I5. Horns rising from above the orbits, and curving back. (No facegland.)

Horns of different shape.

Genus HIPPOTRAGUS, page 198

I6. Horns spirally twisted, thinner in female than male. Usually with at least traces of stripes on body. Male with dewlap, and tufted forehead. (No facegland.)

Genus TAUROTRAGUS, page 209

Horns not spirally twisted; colour different; not combining the characters of the last genus.

I 7. Build massive and ox-like. Horns not ringed, in South and East Africa usually tending to meet in middle line of skull, at first directed outwards. Nasals short and broad (in Roberts figures only once over $200 \mathrm{~mm}$.). Tail not very longhaired, and not nearly reaching the ground. No facegland.

Genus SYNGERUS, page 2 I I

Build less massive; antelopine or almost horselike. (Connochaetes taurinus, which has horns of similar shape to Syncerus, has the nasals long and narrow (only once under $200 \mathrm{~mm}$. in Roberts' figures, although all the skulls are smaller in condylobasal length than Syncerus) and the tail is very longhaired and nearly reaches the ground). With facegland, and at least a small pit in the skull for its reception. I 8

I8. Horns smooth and curving downwards then upwards, directed either forwards or outwards. Back with mane. (Tail very long-haired, the hairs nearly reaching the ground).

Genus CONNOCHAETES, page 204

Horns ringed and of a different shape; back without mane.

I9

I9. Horns usually roughly S-shaped, and on pedicle; occiput about level with or in front of base of horns; face very long.

Genus ALCELAPHUS, page 202

Horns more lyrate, less specialized, not situated on pedicle; occiput behind base of horns; face rather less long.

Genus DAMALISCUS, page 200

\section{Genus CEPHALOPHUS H. Smith, I 827}

I 827. Cephalophus H. Smith, Griffith's Cuv. Anim. Kingd. 5: 344. Type fixed as Antilope silvicultrix Afzelius by Sclater \& Thomas, 1895, Book of Antelopes, I: I 2 I.

I840. Philantomba Blyth in Cuvier's Anim. Kingd. I40. Antilope philantomba H. Smith = Antilope maxwelli H. Smith. (Swynnerton \& Hayman (I95I) dropped Philantomba on the ground that it was possibly not used in a generic sense, and that no type species was specified. But the name appears to us to be used in a generic sense and the type by absolute tautonomy is philantomba.) Valid as a subgenus.

I842. Cephalophorus Gray, Ann. Mag. N.H. Io: 267. Antilope ogilbyi Waterhouse, from Fernando Po.

1843. Cephalolophus Wagner in Schreber, Säugth. Suppl. 4: 445. Emendation. 
Cephalophus [contd.]

1852. Guevei Gray, Cat. Mamm. B.M., pt. 3: 86. Antilope maxwelli H. Smith.

I871. Terpone Gray, P.Z.S., 592. Cephalophus longiceps Gray = Antilope silvicultrix Afzelius.

I872. Potamotragus Gray, Cat. Ruminant Mamm. B.M., 25. Cephalophus melanoprymnus Gray = Antilope silvicultrix Afzelius.

I907. Cephalophia Knottnerus-Meyer, Arch. Naturgesch. 73, I: 44. Cephalophus ogilbyi Waterhouse (here selected).

I907. Cephalophidium Knottnerus-Meyer, loc. cit. 45. Cephalophus niger Gray, from West Africa.

I907. Cephalophella Knottnerus-Meyer, loc. cit. 45. Cephalophus callipygus Peters, from Gabon.

I907. Cephalophops Knottnerus-Meyer, loc. cit. 46. Cephalophus dorsalis Gray, from Sierra Leone.

1907. Cephalophula Knottnerus-Meyer, loc. cit. 46. Antilope doria Ogilby = Antilope zebra Gray, from Sierra Leone.

I. No inguinal glands. Skull approximately $127 \mathrm{~mm}$. and less.

Cephalophus (Philantomba) monticola, page $179^{1}$

With inguinal glands. Published measurements for the typical subgenus indicate that the skull is usually more than I $30 \mathrm{~mm}$.

2. Large species, skull usually over $240 \mathrm{~mm}$.

Small species, skull normally under $200 \mathrm{~mm}$.

Cephalophus silvicultor, page I 79

Cephalophus natalensis, page 178

Subgenus CEPHALOPHUS H. Smith, I827

Cephalophus natalensis A. Smith, 1834

Red or Natal Duiker. Rooiduiker

Distribution: in the Union, Natal coastal bush (Zululand and originally named from Durban), Barberton and Legogot (near White River), south-eastern Transvaal. Portuguese East Africa, districts of Gorongoza and Inhambane, also Boror (north of the Zambezi). Nyasaland, Northern Rhodesia. Much of East Africa to the southern borders of the Sudan, and the Belgian Congo (Rowland Ward treats the East African harveyi, etc., as races of this species).

Cephalophus natalensis natalensis A. Smith, I834

1834. Cephalophus natalensis A. Smith, S. Afr. J. 2: 2 I 7. About "Port Natal" = Durban, Natal.

Cephalophus natalensis harveyi Thomas, i 893

1893. Cephalolophus harveyi Thomas, Ann. Mag. N.H. II: 48. Kahe forest, south-east of Kilimanjaro, northern Tanganyika (Swynnerton, 1945). Occurs Nyika Plateau, Nyasaland (Loveridge in litt). ${ }^{1}$ All forms of the subgenus Philantomba are regarded as conspecific, and the prior name appears
to be monticola Thunberg, i 789 . 
Cephalophus natalensis walkeri Thomas, igo6

1906. Cephalophus walkeri Thomas, Abstr. P.Z.S. No. 3 I : I; P.Z.S., 464. Tuchila River, about 25 miles from Blantyre, southern Nyasaland.

(I9I I. Cephalophus natalensis bradshawi Wroughton, Ann. Mag. N.H. 8: 277. Chiromo, Shire valley, southern Nyasaland. St. Leger, I936, P.Z.S., 2 19, thought it was possible that walkeri is a melanistic form of bradshawi.)

Cephalophus natalensis robertsi Rothschild, igo6

ı go6. Cephalophus robertsi Rothschild, P.Z.S., 69ı. N. Makualand, Portuguese East Africa.

1906. Cephalophus natalensis vassei Trouessart, Bull. Mus. H.N. Paris, 445. Guenguère, Portuguese East Africa.

Range: Portuguese East Africa, north of the Limpopo, at least to Quelimane district.

Cephalophus natalensis amoenus Wroughton, igi I

I9I I. Cephalophus natalensis amoenus Wroughton, Ann. Mag. N.H. 8: 277. Legogot ( 3 miles from Nelspruit, north of White River), south-eastern Transvaal.

Cephalophus natalensis lebombo Roberts, 1936

1936. Cephalophus natalensis lebombo Roberts, Ann. Transv. Mus. I8: 248. Mkusi River below Ubombo Magistracy, Zululand, Natal.

Cephalophus silvicultor Afzelius, I 8 I 5

Yellow-backed Duiker

Distribution: Central Angola and Northern Rhodesia, thence through the Belgian Congo to Sierra Leone, and recently recorded from Kenya.

Cephalophus silvigultor silvigultor Afzelius, i8 I5

I8I 5. Antilope silvicultrix Afzelius, Nova Acta Soc. Sci. Upsal. 7: 265. Sierra Leone. 1827. Antilope sylvicultrix Lesson, Man. Mamm. 378 (alternative spelling).

I869. Cephalophus ruficrista Bocage, J. Sci. Math. Phys. Nat., Lisboa, 2: 22 I. Loanda, Angola. Regarded by Hill \& Carter (I94I) as a valid race.

I892. Cephalophus sylvicultor Thomas, P.Z.S. 4I6 (alternative spelling).

1906. Cephalophus coxi Jentink, Notes Leyden Mus. 28: I I7. "North-Western Rhodesia."

I939. Cephalophus silvicultor G. Allen, Checklist Afr. Mamm. 488. (Afzelius seems to be using the feminine Latin adjective "silvicultrix" meaning "inhabiting woods", and we agree with using its masculine form in conjunction with the generic name Cephalophus.)

\section{Subgenus PHILANTOMBA Blyth, I 840}

We prefer to follow Hollister and other authors and regard this group as a subgenus of Cephalophus rather than a distinct genus.

Cephalophus monticola Thunberg, I 789 .

Blue Duiker. Bloubokkie

Distribution: in the Union, part of the forests of the southern Cape Province, recorded from the Outeniqua forests (Jonkersberg in the George district eastwards) 
by Roberts, Knysna, and the Bathurst district (Hewitt, I93 I). Zululand; Swaziland. Melsetter district of eastern Southern Rhodesia; Portuguese East Africa, districts of Beira, Gorongoza, etc. Angola; western mountainous districts. Nyasaland, Northern Rhodesia. Northwards to Kenya, and thence westwards to Senegal.

Cephalophus monticola monticola Thunberg, i789

I789. Capra monticola Thunberg, Resa uti Europa, Africa, Asia, etc. 2: 66. Lange

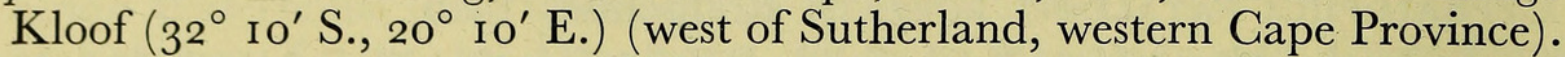
(Schwarz, I9I4, Ann. Mag. N.H.I3: 35, was responsible for a change of name: "This specific name [caerulus] replaces monticola, which, as will be shown in a subsequent paper, is a clear synonym of Ourebia ourebi." But later on (I920, Zweite Deutsche Zentralafrika Expedition, I9IO-II, I: 949) Schwarz had second thoughts and decided to retain monticola for the Blue Duiker after all. Admittedly Thunberg's original description is difficult, but his amplification in I8 I , K. Svenska Vetensk. Akad. Handl. 32: 93, and plate 5 , makes the position reasonably clear).

1821. Antilope pygmea Schinz, Cuvier's Thierreich, I: 393. South Coast of Africa.

Not pygmaea Pallas, I $777=$ Neotragus pygmaeus Linnaeus.

I827. Antilope caerula H. Smith, Griffith's Guv. Anim. Kingd. 4: 268. Galgebosch, Uitenhage district, eastern Cape Province.

I 827. Antilope perpusilla H. Smith, loc. cit.: 269. "Interior of Caffraria."

I844. Antelope minuta Forster, Descript. Anim. 383. Forster says this is a synonym of pygmaea Pallas, but it cannot be since minuta is included in a list of animals from the Cape of Good Hope.

Cephalophus monticola bicolor Gray, i 863

I863. Cephalophus bicolor Gray, P.Z.S. I 862: 263. "Natal." Umgoye forest, between Umlalazi and Umhlatuzi Rivers, Zululand. (See Roberts, I95 I, 323.)

I869. Cephalophus pygmaeus caffer Fitzinger, S.B. Akad. Wiss. Wien, 59, I: 166. "Kaffirland"; nom. nud.

1922. Cephalophus monticola ruddi Blaine, Ann. Mag. N.H. 9: I75. Sibedeni (= Sibudeni), N.W. Eshowe, Zululand, Natal.

Cephalophus monticola anchietae Bocage, i 879

1879. Cephalophus anchietae Bocage, P.Z.S. I 878: 743. Bibala, near Capangombe, south-western Angola.

Cephalophus monticola hegki Matschie, i 897

1897. Cephalolophus hecki Matschie, S.B. Ges. Naturf. Fr. Berlin, I58. Coast of Mozambique, Portuguese East Africa. Ranges southwards to Beira.

Cephalophus monticola nyasae Thomas, igo2.

1902. Cephalophus nyasae Thomas, Ann. Mag. N.H. 9: 58. Mlanje, extreme southern Nyasaland.

Cephalophus monticola Defriesi Rothschild, igo4

1904. Cephalophus nyasae defriesi Rothschild, Abstr. P.Z.S. No. 3, 9; P.Z.S. I: 229. "Itambe" (= Itawa), between Lakes Mweru and Tanganyika, Northern Rhodesia. 
Cephalophus monticola ludlami Blaine, ig22

1922. Cephalophus monticola ludlami Blaine, Ann. Mag. N.H. 9: i 74. Junction of Lunga with Kafue River, western Northern Rhodesia.

Cephalophus monticola fuscicolor Blaine, 1922

1922. Cephalophus monticola fuscicolor Blaine, Ann. Mag. N.H. 9: i 75. Chirinda Forest, Melsetter district, eastern Southern Rhodesia.

\section{Genus SYLVICAPRA Ogilby, I 837}

1837. Sylvicapra Ogilby, P.Z.S. I836: I38. Antilope mergens Desmarest $=$ Capra grimmia Linnaeus.

1841. Grimmia Laurillard in d'Orbigny's Dict. Univ. H.N. I: 623. Capra grimmia Linnaeus. (For date of publication see Sherborn \& Palmer, I899, Ann. Mag. N.H. 3: 350.)

I842. Cephalophora Gray, Ann. Mag. N.H. I o: 266. Cephalophora coronata Gray, one of the western African races of Capra grimmia Linnaeus.

Sylvicapra grimmia Linnaeus, I 758

Grey Duiker. Duikerbok

Distribution: one of the commoner small buck in the Union; the Transvaal; Kruger National Park (Skukuza, Toulon and other districts) Wakkerstroom, Woodbush, Tzaneen, Klein Letaba, Pretoria district (Roberts), Potgietersrust, Rustenburg district, etc. Natal and Zululand. In the Cape Province, west of Kuruman, De Beers Estate (36 miles west of Kimberley), ?Vryburg district, the Aughrabies Falls, Little Namaqualand (east of the Kamiesberg (Shortridge, I942), Port Nolloth (B.M.)), Lamberts Bay, perhaps near Cape Town, probably Bredasdorp district, Albany district and, according to Hewitt (I93 I), Grahamstown, Bedford, Cradock, Tarkastad, Cathcart, Port St. Johns. Other possible localities are the Addo Bush (near Port Elizabeth), near Graaff Reinet, and the mountains to the west of Matjesfontein. In South-West Africa, from Great Namaqualand northwards (Shortridge, 1934) who says the species is more numerous in the northern and north-eastern districts than in the arid regions south of the Tropic of Capricorn; the Kalahari and Ngamiland; Southern Rhodesia; in Portuguese East Africa from both sides of the Zambezi, and recorded from districts of Beira, Tete, Inhambane, etc. Angola; evidently quite widely distributed in the central parts, and recorded as far west as Hanha. Nyasaland, Northern Rhodesia. North of the limits of this work, northwards to Abyssinia and the southern Sudan, thence westwards to Senegal.

Sylvigapra Grimmia Grimmia Linnaeus, I $75^{8}$

I758. Capra grimmia Linnaeus, Syst. Nat. ioth ed. I: 70. "Africa." Type locality fixed as Cape Town by Thomas (I9I I : I53).

I8I I. Antilope nictitans Thunberg, Mém. Acad. Sci. St. Pétersb. 3: 312. Cape of Good Hope.

i8ı6. Antilope mergens Desmarest, Nouv. Dict. H.N. 2: i93. Cape of Good Hope. I816. Cemas cana Oken, Lehrb. Naturgesch. 3, 2: 743. (Unavailable.) 
SylvicAPra Grimmia GRIMmia [contd.]

1827. Antilope platous H. Smith, Griffith's Guv. Anim. Kingd. 4: 260. "Vicinity of the Gareep" (= Orange River).

I 827. Antilope ptoox H. Smith, loc. cit. 265. Cape of Good Hope.

I836. Antilope platyotis Lesson, Complément de Buffon, I0: 293. For platous.

I892. Cephalolophus grimmii Thomas, P.Z.S. 428. Emendation of grimmia.

Range: southern and western Cape Province.

Sylvicapra grimmia bURGhelli H. Smith, i 827

1827. Antilope burchellii H. Smith in Griffith's Guvier Anim. Kingd. 4: 262. "West side of Caffraria"; Zwartwater Poort near borders of Caffraria, Albany district, according to Roberts (I95I). Range: eastern Cape Province, to Natal?

Sylvicapra grimmia orbicularis Peters, $185^{2}$

1852. Antilope (Cephalophus) orbicularis Peters, S.B. Ges. Naturf. Fr. Berlin, for I7 February, I852 (published in the Spenersche Z. of 22 February, I852). Plains at Sena, Tete, Macanga and Boror ( $16^{\circ}-18^{\circ} \mathrm{S}$.). Sena here selected. 1852. Antilope altifrons Peters, Reise nach Mossambique, Säugeth. I84. Sena and Boror, Portuguese East Africa.

I852. Antilope ocularis Peters, loc. cit. I86. Substitute for orbicularis.

SylvicaPra Grimmia GAFFra Fitzinger, i 869

ı 869. Sylvicapra mergens caffra Fitzinger, S.B. Akad. Wiss. Wien. 59, I : I67. "Kaffirland" (probably Natal, according to Roberts).

I871. Grimmia irrorata Gray, P.Z.S. 590. Natal.

1926. Sylvicapra altifrons noomei Roberts, Ann. Transv. Mus. I I: 263. Maputa River, extreme southern Portuguese East Africa.

Range includes Zululand, Wakkerstroom district, Klein Letaba and Woodbush, eastern Transvaal, and into Southern Rhodesia.

Sylvicapra GRImmia sPlendidula Gray, i87i

I871. Grimmia splendidula Gray, P.Z.S. 590. St. Paul de Loanda, northern Angola (but Hill \& Carter think it came from the interior).

I894. Cephalophus grimmia flavescens Lorenz, Ann. Naturh. Hofmus. Wien, 9: Notizen, 6o. Matabeleland, near Victoria Falls, Southern Rhodesia.

1899. Cephalolophus leucoprosopus Neumann, S.B. Ges. Naturf. Fr. Berlin, I8. Angola, sent from St. Paul de Loanda.

I 9 1о. "Cephalolophus grimmii fulvescens Lorenz", Wroughton, Ann. Mag. N.H. 4: 274. (Error for flavescens.)

Sylvicapra GRIMMia SHIRENSIS Wroughton, I9Io

I910. Cephalophus abyssinicus shirensis Wroughton, Ann. Mag. N.H. 5: 274. Zomba, southern Nyasaland.

SYlvicAPra Grimmia STEINHARdti Zukowsky, ig24.

1924. Sylvicapra grimmia steinhardti Zukowsky, Arch. Naturgesch, 9oA, I: I I3. Otjikuara, source of the Hoamib, South-West Africa. 
I924. Sylvicapra grimmia ugabensis Zukowsky, loc. cit. I I5. Goreis, $45 \mathrm{~km}$. west of Outjo, northern Damaraland, South-West Africa.

1924. Sylvicapra grimmia cunenensis Zukowsky, loc. cit. I I 7. Otjonganga, south-east of Omuhonga mountains, northern Kaokoveld, South-West Africa.

I924. Sylvicapra grimmia omurambae Zukowsky, loc. cit. I I8. Otjomikambo, on the Omuraba u'Omatako, Grootfontein district, South-West Africa.

1926. Sylvicapra grimmia bradfieldi Roberts, Ann. Transv. Mus. II: 262. Quickborn Farm, north of Okahandja, Damaraland, South-West Africa.

1942. Sylvicapra grimmia vernayi Hill, Amer. Mus. Novit, No. I I 7o. Kaotwe Pan $\left(22^{\circ} 30^{\prime}\right.$ S., $23^{\circ} 20^{\prime}$ E. $)$, Kalahari Desert, Bechuanaland.

Sylvicapra Grimmia transvaAlensis Roberts, I 926

1926. Sylvicapra grimmi transvaalensis Roberts, Ann. Transv. Mus. I I: 262. Rustenburg district, western Transvaal. Ranges into southern Bechuanaland and western Southern Rhodesia.

Genus RAPHICERUS H. Smith, I 827

1827. Raphicerus H. Smith, Griffith's Guvier Anim. Kingd. 5: 342. Antilope acuticornis Blainville $=$ Antilope campestris Thunberg (Sclater \& Thomas, I8g6, Book of Antelopes, 2: 33).

1846. Rhaphocerus Agassiz, Nomenclator Zool. Index. Univ. 321. Emendation of Raphicerus.

I846. Calotragus Sundevall, K. Svenska Vetensk. Akad. Handl. I844: i92. "Calotragus tragulus (Forster)" = Antilope campestris Thunberg.

I 86 I. Pediotragus Fitzinger, S.B. Akad. Wiss. Wien, 42: 396. Antilope tragulus Forster $=$ Antilope campesiris Thunberg.

I897. Raphiceros Thomas, P.Z.S. I896: 796.

I 897. Rhaphiceros Lydekker, Zool. Record, 33: 28.

1906. Nototragus Thomas \& Schwann, Abstr. P.Z.S. No. 27, ı; P.Z.S. i68. Antilope melanotis Thunberg.

1907. Grysbock Knottnerus-Meyer, Arch. Naturgesch. 73, I: 55. Antilope melanotis Thunberg.

I908. Rhaphicerus Lönnberg, Sjöstedt's Kilimandjaro Meru Exped. Mamm. 40.

On the status of $\mathcal{N o t o t r a g u s ~ s e e ~ a b o v e , ~ p a g e ~ I ~ 7 5 , ~ f o o t n o t e ~} 2$.

I. Coat uniform, reddish. (No lateral hoofs; from published measurements of South African forms, ear I05-I $35 \mathrm{~mm}$.)

Raphicerus campestris, page $\mathrm{I} 84$

Coat speckled, with numerous whitish hairs interspersed amongst the reddish ones.

2. Ear (from the few published measurements and skins available) i I 7-I $28 \mathrm{~mm}$. With small lateral hoofs.

Raphicerus melanotis, page 185 Ear (from the few published measurements and skins available) $84^{-1}$ I $5 \mathrm{~mm}$. Normally no lateral hoofs. Raphicerus sharpei, page 186 
Raphicerus campestris Thunberg, I 8 I I

Steenbok (Steinbok). Vlakbokkie; Steenbok

Distribution: probably the most widely distributed member of the family in the Union. Transvaal; Kruger National Park (Punda Maria, Shingwedzi, Letaba, Satara, Skukuza, Toulon); the western Transvaal, also Klein Letaba. Natal Drakensberg, and Zululand. The British Museum has it from Vredefort district, Orange Free State. In the Cape Province, west of Kuruman, ?near Vryburg, west of Kimberley (De Beers Estate), neighbourhood of Graaff Reinet, Little Namaqualand (north of Steinkopf), near Lamberts Bay, north of Van Rhynsdorp; near Bredasdorp (the Bontebok National Park). Albany district, and according to Hewitt, districts of Cathcart, Grahamstown, Cradock, Tarkastad, Queenstown, Hanover, Colesberg, Fort Beaufort and Bedford. Deelfontein (British Museum). (It is not certain whether it occurs now near Cape Town, where the common small buck is the Grysbok.) In South-West Africa, evidently all districts from the Orange River to the Cunene, Okavango and Caprivi. Southern and south-eastern Angola. The Kalahari, Ngamiland and Gaberones in Bechuanaland. Parts of Southern Rhodesia, and west of Inhambane in Portuguese East Africa. The area between the Zambezi and Kafue Rivers in Northern Rhodesia (Shortridge). Has been recorded from Nyasaland. Northwards to Tanganyika and Kenya.

RAPHICERUS CAMPESTRIS CAMPESTRIS Thunberg, I8I I

I 8 I . Antilope campestris Thunberg, Mém. Acad. Sci. St. Pétersb. 3: 313. Cape of Good Hope.

I81 2. Antilope tragulus Lichtenstein, Mag. Ges. Naturf. Fr. Berlin, 6: i 76. Near Cape Town.

I8 1 2. Antilope tragulus var. rupestris Lichtenstein, loc. cit. I 77. Cape.

I81 2. Antilope tragulus var. pallida Lichtenstein, loc. cit. Cape.

I8I5. Antilope capensis Afzelius, Nova Acta Soc. Sci. Upsal. 7: 254. Cape of Good

Hope (Groene Kloof, Saldanha Bay and Cold Bokkeveld).

I8 15. Antilope pediotragus Afzelius, loc. cit. 26o. Cape of Good Hope.

I8I5. Antilope ibex Afzelius, loc. cit. 263. Cape of Good Hope.

I8ı6. Cerophorus (Cervicapra) acuticornis Blainville, Bull. Soc. Philom. Paris, 75, 79.

I8I6. Cerophorus (Cervicapra) stenbock Blainville, loc. cit. 75, nom. nud.

(1827. Antilope subulata H. Smith, Griffith's Cuv. Anim. Kingd. 4: 253. "East Indies.") I869. Pediotragus tragulus grayi Fitzinger, S.B. Akad. Wiss. Wien, 59, г : i63. SouthWest Africa. Nom. nud.

I 90o. Pediotragus horstockii Jentink, Notes Leyden Mus. 22: 36. Cape of Good Hope. Range: southern and south-western Cape Province.

Raphicerus Campestris fulvorubescens Desmoulins, i 822

1822. Antilope fulvo-rubescens Desmoulins, Dict. Class. H.N. I: 446. "Plains of Caffraria."

1827. Antilope rufescens H. Smith, Griffith's Guv. Anim. Kingd. 4: 249. Cape of Good Hope.

I95I. Antilope rupescens Roberts, Mamm. S. Africa, 34I. Lapsus for rufescens.

Name revived by Roberts for eastern Cape Province specimens; Albany district to Graaff Reinet. 
RAPHicerus GAMPESTRIS KELleni Jentink, igoo

I90o. Pediotragus kelleni Jentink, Notes Leyden Mus. 22: 41. Cahama, Kakulovar River, a northern tributary of the Cunene, Mossamedes, southern Angola.

I930. Raphicerus campestris bourquii Monard, Bull. Soc. Sci. Nat. Neuchâtel, 54: 82. Calundungu, Angola.

RAPHICERUS CAMPESTRIS GAPRICORNIS Thomas \& Schwann, igo6

I906. Raphicerus neumanni capricornis Thomas \& Schwann, P.Z.S., 584. Klein Letaba (west of the Kruger National Park), eastern Transvaal. Range includes Southern Rhodesia, Coguno (Inhambane district), Portuguese East Africa, Zululand (Limpopo to Zambezi).

RAPHIGERUS GAMPESTRIS NATALENSIS Rothschild, I907

1907. Rhaphiceros (sic) horstocki natalensis Rothschild, P.Z.S., 237. Drakensberg, Natal.

RAPHICERUS GAMPESTRIS STEINHARDTI Zukowsky, I924

1924. Pediotragus kelleni steinhardti Zukowsky, Arch. Naturgesch. 9oA, I: I29. Cheiros, north-east of Franzfontein, southern Kaokoveld, South-West Africa. (G. Allen regards this and its synonyms as further synonyms of R. c. kelleni.)

I924. Pediotragus kelleni cunenensis Zukowsky, loc. cit. I3 I. Ombepera, southern Omuhonga Mountains, Kaokoveld, South-West Africa.

I924. Pediotragus kelleni ugabensis Zukowsky, loc. cit. I32. Okuvakuatjivi, near Omaruru, upper Omaruru River, Damaraland, South-West Africa.

1924. Pediotragus kelleni hoamibensis Strand, Arch. Naturgesch. 90A, I: I33, footnote. Otjonduno, near source of the Hoamib, south of Ombombo, Kaokoveld, South-West Africa.

1924. Pediotragus kelleni zukowskyi Strand, loc. cit. Bubos, I 8 km. north-east of Grootfontein, South-West Africa.

RAPHIGERUS CAMPESTRIS ZULUENSIS Roberts, I946

I946. Raphicerus campestris zuluensis Roberts, Ann. Transv. Mus. 20: 325. Umfolosi Game Reserve, Zululand, Natal. Ranges into the eastern Transvaal (recorded from Carolina district).

Raphicerus melanotis Thunberg, I8 I I

Grysbok. Grysbok

Distribution: the southern Cape Province; it is common in the Cape Point nature reserve (south of Cape Town), and on the western coast occurs (including Elgin) northwards about to the Cedarberg. It is said to occur in the Bontebok reserve near Bredasdorp, and in the Addo Bush (near Port Elizabeth) and is recorded from Knysna, Grahamstown, Alexandria and Bathurst, eastwards about to Komgha (Hewitt, I93I). There is a Grysbok reported from the Giants Castle, Natal, which may, however, be $R$. sharpei. The British Museum has skulls from Zululand (but these also may represent sharpei). 
RAPHIGERUS MELANOTIS Thunberg, I8I I

i8 I r. Antilope melanotis Thunberg, Mém. Acad. Sci. St. Pétersb. 3: 312. Cape of Good Hope.

I804. Antilope grisea G. Cuvier, Dict. Sci. Nat. 2: 244. Cape of Good Hope. Not of Boddaert, I 785 .

I822. Antilope rubro-albescens Desmoulins, Dict. Class. H.N. $I: 446$. No locality.

Raphicerus sharpei Thomas, I897 Sharpe's Grysbok. Tropiese Grysbok

Distribution: in the Union, the Transvaal; the Kruger National Park, Klein Letaba and the Rustenburg district. (?Natal; see under $R$. melanotis.) Shortridge says that it occurs in the Caprivi, on the north-eastern borders of South-West Africa. Southern Rhodesia, and recorded from Tete, Portuguese East Africa. Nyasaland and Northern Rhodesia, thence northwards to Tanganyika.

RAPHICERUS SHARPEI SHARPEI Thomas, I 897

I 897. Raphicerus sharpei Thomas, P.Z.S. I896: 796. Southern Angoniland, Nyasaland.

Raphicerus Sharpei colonicus Thomas \& Schwann, igo6

1906. Raphicerus sharpei colonicus Thomas \& Schwann, P.Z.S., 583. Klein Letaba, west of the Kruger National Park, eastern Transvaal. Range: southern part of the distribution of the species.

\section{Genus OUREBIA Laurillard, I 84 I}

I84I. Ourebia Laurillard, D’Orbigny's Dict. Univ. H.N. I: 622 Ourebia scoparia Schreber = Antilope ourebi Zimmermann (Sclater \& Thomas, I896, Book of Antelopes, 2: I3).

(For date of publication of Laurillard see Sherborn \& Palmer, I899, Ann. Mag. N.H. 3: 350.)

I846. Scopophorus Gray, Ann. Mag. N.H. I8: 232. Antilope ourebi Zimmermann.

1869. Quadriscopa Fitzinger, S.B. Akad. Wiss. Wien, 59, I: 167. Quadriscopa smithii Fitzinger = Antilope quadriscopa $\mathrm{H}$. Smith, the Senegal race of $A$. ourebi Zimmermann.

I899. Oribia Kirby in Bryden, Great and Small Game of Africa, 238.

Ourebia ourebi Zimmermann, I 783

Oribi. Oorbietjie

Distribution: in the Union Roberts (195I) gave "Uitenhage district eastwards to Natal and northwards through the grassveld districts of eastern Orange Free State, Natal, Zululand ... Transvaal," also quoting the species from southern Portuguese East Africa, Swaziland, Southern Rhodesia to the Zambezi. But this buck is now very scarce (if it occurs at all) in the Cape Province, Orange Free State and Transvaal; at the time of writing it is absent from the Kruger National Park; Hewitt (I93I) said there were then still a small number in Albany, Bathurst and Alexandria districts, and at Cathcart, but that their numbers had been sadly reduced by poachers; Shortridge (1934) said they were then tending to disappear in many parts 
of South Africa. South-West Africa; the northern parts; the Caprivi, Okavango valley (very local), etc. (Shortridge, I 934). Northern Rhodesia, Nyasaland. Angola. Beyond the limits of this work, north-eastwards to the Sudan and Abyssinia, and westwards to Senegal.

Ourebia ourebi OuREBI Zimmermann, I 783

I 783. Antilope ourebi Zimmermann, Geogr. Gesch. 3: 268. Cape of Good Hope; Uitenhage district according to Roberts.

I 799. Antilope scoparia Schreber, Säugth. pl. 26 I ; 5: I 244 (published I 824) (Plate 26 I is sometimes dated from I785, but Poche (I9I2) has shown that it was published between Easter and Michaelmas, I 799). "Cape Colony."

I 799. Antilope melanurus Bechstein, Ubers. Vierf. Thiere, I: 73.

I 869. Scopophorus ourebi greyi Fitzinger, S.B. Akad. Wiss. Wien, 59, I : i65. Cape of Good Hope. Nom. nud.

Ourebia ourebi hastata Peters, 1852

1852. Antilope hastata Peters, S.B. Ges. Naturf. Fr. Berlin for I 7 February, I 852 (published in the Spenersche Z. for 22 February, 1852). Reise nach Mossambique, Säugeth., I88. Sena, south bank of Zambezi River, Portuguese East Africa. (Recorded from Nyasaland by Thomas (i 897).)

Ourebia ourebi Rutila Blaine, I922

I922. Ourebia rutilus Blaine, P.Z.S., 325. Between the Quanza and Luando Rivers, central Angola.

I930. Ourebia leucopus Monard, Bull. Soc. Sci. Nat. Neuchâtel, 54: 78. Chimporo, west of Caiundo, southern Angola. (Retained as a valid race by Hill \& Carter (I94I).)

Genus NESOTRAGUS Von Dueben, 1846

I846. Nesotragus Von Dueben in Sundevall, Öfvers. Vetensk. Akad. Förh. Stockholm, 3: 22 I. Nesotragus moschatus Von Dueben.

Closely allied to the West African genus Neotragus H. Smith, I 827, and regarded as a subgenus of it by Lydekker, I9I4, Cat. Ungulate Mamm. 2: I59, who compares these two with the closely-allied genus Hylarnus.

The prior name in this genus is $\mathcal{N}$. moschatus, and although it is customary to regard $\mathcal{N}$. livingstonianus as a species, we suggest that, as there is no evidence that they occur together, and as the differences between them are not in any way marked, they might well be regarded as conspecific.

Nesotragus moschatus Von Dueben, I 846

Suni. Soenie

Distribution: Zululand; Portuguese East Africa, including Tete and Coguno (Inhambane district); Nyasaland; Northern Rhodesia; Zanzibar, Tanganyika and Kenya. 
Nesotragus moschatus moschatus Von Dueben, i846. (Extralimital) I846. Nesotragus moschatus Von Dueben in Sundevall, Ofvers. Vetensk. Akad. Förh. Stockholm, 3: 22 I. Chapani Islet, west of Zanzibar Island.

Nesotragus moschatus livingstonianus Kirk, i 865 I 865. Nesotragus livingstonianus Kirk, P.Z.S. I864: 657. Shupanga, south bank of Zambezi, $18^{\circ} 2^{\prime}$ S., $35^{\circ} 30^{\prime}$ E., Portuguese East Africa. (See Moreau, Hopkins \& Hayman, I946: $43^{6}$.)

Nesotragus moschatus zuluensis Thomas, i 898 I898. Nesotragus livingstonianus zuluensis Thomas, Ann. Mag. N.H. 2: 31 7. Unkuja (Umkuzi) Valley, Zululand, Natal. Range: from Lake St. Lucia district, Zululand northwards to the Zambezi.

\section{Genus OREOTRAGUS A. Smith, 1834}

I834. Oreotragus A. Smith, S. Afr. J. 2: 2 I2. Antilope (Oreotragus) typicus A. Smith = Antilope oreotragus Zimmermann.

I84I. Oritragus Gloger, Hand-u. Hilfsbuch Naturgesch. I: I54 (xxxiii, I842). For Oreotragus.

Oreotragus oreotragus Zimmermann, I 783

Klipspringer. Klipbokkie; Klipspringer

Distribution: in the Union, the Kruger National Park (Punda Maria, near Skukuza), and Rustenburg district, Transvaal. Zululand (Roberts). In the Cape Province, the Aughrabies Falls, Little Namaqualand (Goodhouse, Klipfontein (near Steinkopf), the Kamiesberg), near Clanwilliam, near Elgin; Roberts quotes it from the Uitenhage district along the southern mountains of the Cape Province to the Swartberg and Doorn River (near George), Hewitt (I93I) quoted it from mountainous parts of the Transkei and Cradock districts, and Shortridge (I 934) said it was rare in Griqualand West. (This buck was once common in the mountains or rocky parts of the Union, but has been much shot because of the demand for its hide.) South-West Africa; in suitable (rocky) localities from Great Namaqualand and Damaraland to the Kaokoveld, east of Grootfontein, etc. (Shortridge, 1934). Western Southern Rhodesia. Recorded from northern Bechuanaland. Northern Rhodesia and Nyasaland. Southern Angola, northwards to Hanha and Bimbe. Beyond the limits of this work, East Africa northwards to the Sudan and Somaliland; also northern Nigeria.

Oreotragus oreotragus oreotragus Zimmermann, i 783 1783. Antilope oreotragus Zimmermann, Geogr. Gesch. 3: 269. Cape of Good Hope (the Cape Peninsula according to Roberts).

I785. Antilope saltatrix Boddaert, Elench. Anim. I: I4 I. Cape of Good Hope. 1802. Antilope klippspringer Daudin in Buffon, Hist. Nat. (Didot's ed). Quad. I4: I83. Cape of Good Hope. 
I834. Oreotragus typicus A. Smith, S. Afr. J. 2: 2 I 2.

1865. Oreotragus saltator Kirk, P.Z.S. I864: 657.

Range: southern Cape Province.

Oreotragus oReotragus transvaAlensis Roberts, I9I 7

I9I 7. Oreotragus oreotragus transvaalensis Roberts, Ann. Transv. Mus. 5: 276. Rooikrans, Rustenburg district, western Transvaal. Ranges to eastern Transvaal and Zululand.

Oreotragus oreotragus centralis Hinton, ig2 I

I92 I. Oreotragus oreotragus centralis Hinton, Ann. Mag. N.H. 8: I3 I. Southern Chinsali district, north-eastern Northern Rhodesia.

Oreotragus oreotragus tyleri Hinton, i92 I

I92 I. Oreotragus oreotragus tyleri Hinton, Ann. Mag. N.H. 8: I3 I. Esquimina, south of Benguela, on the coast of Angola.

1924. Oreotragus oreotragus cunenensis Zukowsky, Arch. Naturgesch. 9oA, I: I24. Kambele Falls, north bank of Cunene River, in extreme southern Angola. "Kambele Falls are at about I4 ${ }^{\circ}$ I5' E" (Moreau, Hopkins \& Hayman, I946).

I924. Oreotragus oreotragus steinhardti Zukowsky, Arch. Naturgesch. 9oA, I : I27. Otjongombe, west of Kaoko-Otavi, Kaokoveld, northern South-West Africa.

Oreotragus oreotragus stevensoni Roberts, i 946

I946. Oreotragus oreotragus stevensoni Roberts, Ann. Transv. Mus. 2.7 325. Matopo Hills, south of Bulawayo, western Southern Rhodesia.

\section{Genus MADOQUA Ogilby, I 837}

I 837. Madoqua Ogilby, P.Z.S. I 836: 137. Antilope saltiana Desmarest, from Abyssinia. 1905. Rhynchotragus Neumann, S.B. Ges. Naturf. Fr. Berlin, 88. Madoqua guentheri Thomas, from Abyssinia. Valid as a subgenus.

The difference outlined by Lydekker (I9I4) to separate the supposed southern species $M$. damarensis from $M$. kirki from Italian Somaliland, the "size larger" and "size smaller" given in the key, p. I83, is not apparent when all forms which he refers to kirki are considered, and it would seem that kirki and damarensis might well be regarded as conspecific. The former has priority.

\section{Subgenus RHYNCHOTRAGUS Neumann, I905}

Madoqua kirki Günther, I88o.

(In South Africa) Damara Dikdik. Damaralandse Bloubokkie; Neusbok Distribution: Damaraland and the Kaokoveld, to the Cunene River, South-West Africa; south-western Angola (where rare). Also Tanganyika, Kenya, Uganda, Italian Somaliland. 
MADOQUA KIRKI KIRKI Günther, I88o. (Extralimital) I88o. Neotragus kirkii Günther, P.Z.S., I 7. Brava, Italian Somaliland.

MADOQUa KIRKI DAMAREnSIS Günther, I 880 I88o. Neotragus damarensis Günther, P.Z.S., 20. Omaruru, Damaraland. I887. Cephalophus hemprichianus Jentink, Notes Leyden Mus. 9: I72. Not of Ehrenberg, I832. Otjipompenima, Mossamedes, south-western Angola.

I9I3. Rhynchotragus damarensis variani Drake-Brockman, Ann. Mag. N.H. I2: 48I. Lobito (near Benguela, western coast) Angola.

\section{Genus PELEA Gray, I85 I}

I851. Pelea Gray, P.Z.S. I850: 126. Antilope capreolus Bechstein = Antilope capreolus Forster.

This genus is curiously isolated, both from a geographical and a morphological point of view. Roberts (I95I) who divided South African Bovidae into eleven subfamilies, referred the genus to a separate subfamily, and for authors who wish to subdivide the Bovidae into many subfamilies this is probably the correct classification.

Pelea capreolus Forster, I 790.

Vaal Rhebok. Vaalribbok

Distribution: practically confined to the Union, although Shortridge quotes it from Gaberones near the Transvaal border of southern Bechuanaland. In the Cape Province, well known in the Cape Point Nature Reserve (south of Cape Town), and in the Bontebok Reserve near Bredasdorp. ?Near Elgin. Rare in mountains near Clanwilliam (mainly on private property (Shortridge)). Hewitt (I93I) quoted districts of Graaff Reinet, Fort Beaufort, Bedford, Albany (and then scarce in a few other localities, Burghersdorp, Cradock, Cathcart) eastern Cape Province; the British Museum has it from Deelfontein. We are told it still occurs in the mountains of Basutoland. Roberts quoted it from the Transvaal Drakensberg, and the mountains of the Orange Free State, and said it is rare in Griqualand West. (The British Museum has it from near Wakkerstroom, south-eastern Transvaal.) Giants Castle Reserve, Natal (Shortridge, 1934, included Zululand in the range).

"It is deserving of special protection on scientific grounds, as it is one of the most peculiar antelopes of the Union, apparently not directly related to any others and a relic of the distant past" (Roberts, I95I).

Pelea capreolus Forster, i 790

1790. Antilopa capreolus Forster in Levaillant, Erste Reise Afrika, 7 I. Cape of Good Hope.

(Usually quoted as I 799. Bechstein, Uebers. Vierf. Thiere, $I: 98$. 1822. Antilope lanata Desmoulins, Dict. Class. H.N. $I$ : 445. Cape of Good Hope. 1823. Antilope villosa Burchell, Travels in Int. S. Africa, 2: 302, footnote. Cotypes from Zoetmilks Valley, Swellendam and Mossel Bay, southern Cape Province. 


\section{Genus REDUNCA H. Smith, I827}

1827. Redunca H. Smith, Griffith's Cuvier Anim. Kingd. 5: 337. Antilope redunca Pallas, from West Africa.

I8ı6. Cervicapra Blainville, Bull. Soc. Philom. Paris, 75. Antilope redunca Pallas. Not of Sparrman, I 780.

I84I. Nagor Laurillard in d'Orbigny's Dict. Univ. H.N. I: 62 I. Antilope redunca Pallas. (For date of publication see Sherborn \& Palmer, I899, Ann. Mag. N.H. 3: 350.)

I 843. Eleotragus Gray, List Spec. Mamm. B.M., xxvi, i65. Antilope isabellina Afzelius = Antilope arundinum Boddaert. (Sclater \& Thomas, i 897, Book of Antelopes, 2: I 55.)

1865. Heleotragus Kirk, P.Z.S., I864: 657, emendation.

191 2. Oreodorcas Heller, Smithson. Misc. Coll. 6o, 8: i3. Antilope fulvorufula Afzelius.

On this genus see Blaine, I9I3, Some notes on the Reedbucks, with a description of two new subspecies, Ann. Mag. N.H. II: 287.

Larger, horns usually 2 inches long or over. One pair of inguinal glands (Lydekker). Shoulder height about $30-36$ inches. Redunca arundinum, page 192 Smaller, horns about 5-9 inches long. Two pairs of inguinal glands (Lydekker). Shoulder height about 27-3I inches.

Redunca fulvorufula, page igi

The latter is apparently rather closely allied to Redunca redunca Pallas, i 767 , type of the genus, but differs in some colour details and usually has shorter horns; according to Lydekker also distinguished by the relatively greater interorbital width of the skull, shorter rostrum and larger orbits.

Redunca fulvorufula Afzelius, i 8 i 5

Mountain Reedbuck. Rooiribbok

Distribution: the mountains of Basutoland (where rare at present), the Orange Free State, Transvaal, Griqualand West and Zululand. We are told that it is still likely to occur in the mountains near Graaff Reinet, Middelburg and Kokstad, eastern Cape Province. (Hewitt (I93 I) quoted the species from several places in the Eastern Province (Albany, Alexandria, Bedford, Fort Beaufort, Cathcart and Cradock districts, and near Grahamstown).) Swaziland. Southern Rhodesia. Also in East Africa, Tanganyika, Kenya, southern Abyssinia. (The British Museum has both species of Reedbuck from Deelfontein, but it is not likely that they still occur there.)

Redunaa fulvorufula fulvorufula Afzelius, i 8 i 5

I 81 5. Antilope fulvorufula Afzelius, Nova Acta Soc. Sci. Upsal. 7: 250. Eastern Cape. I822. Antilope lalandia Desmoulins, Dict. Class. H.N. I: 445. Cape of Good Hope. 1822. Antilope landiana Desmarest, Encycl. Méth. Mamm. 462. Cape of Good Hope. I846. Cervicapra eleotragus Sundevall, K. Svenska Vetensk. Akad. Handl. I844: I94. Not of Schreber, I 787 . South Africa.

189o. Cervicapra redunca Günther, P.Z.S. 604. Not of Pallas, i 767.

1898. Cervicapra fulvorufula subalbina Kirby, P.Z.S. I 897: 897. Steenkamp Mountain, I 2 miles west of Kruger's Post, Lydenburg district, eastern Transvaal. 
Redunca arundinum Boddaert, I 785

Reedbuck. Rietbok

Distribution: in the Union, the Kruger National Park (between Satara and Skukuza, Toulon and other localities) Klein Letaba, and Rustenburg district, Transvaal; Natal, Zululand. Hewitt (I93I) stated "about 70 remain in the Komgha district" (eastern Cape Province). South-West Africa; the northern districts, Caprivi, Okavango valley and northern Ovamboland. Angola, recorded from Central districts (Chitau, Chissonque, Namba), and the Upper Cubango River in the south. Ngamiland; Southern Rhodesia. Portuguese East Africa; Inhambane, Beira, Gorongoza districts. Northern Rhodesia, Nyasaland. North of the limits of this work, Tanganyika and recorded from the Bahr-el-Ghazal, southern Sudan.

REDUNGA ARUNDINUM ARUNDINUm Boddaert, I 785

I785. Antilope arundinum Boddaert, Elench. Anim. I: I4I. Cape of Good Hope.

(Bathurst division according to Roberts, I95I.)

I 787. Antilope eleotragus Schreber, Säugth. pl. 266; text (I82 I) 5: I 225.

I 795. Antilope coerulescens Link, Beytr. Naturgesch. I, 2: 99. Nom. nud.

I 799. Antilope arundinacea Bechstein, Uebers. Vierf. Thiere, $I: 8 \mathrm{I}$. I 00 miles north of Cape of Good Hope.

I80o. Antilope cinerea Bechstein, loc. cit. 2: 643. "Africa." (There is a lapsus calami earlier in the work $(I: 80)$ where Bechstein refers to oreotragus when he clearly meant eleotragus.)

I815. Antilope isabellina Afzelius, Nova Acta Soc. Sci. Upsal. 7: 250. Mountains, Cape of Good Hope.

I822. Antilope oleotragus Desmoulins, Dict. Class. H.N. I: 446. Reeds bordering rivers and in marshes in "Cafrerie".

I869. Redunca isabellina multiannulata Fitzinger, S.B. Akad. Wiss. Wien, 59, I : i6g. "Port Natal" = Durban, Natal.

I869. Redunca isabellina caffra Fitzinger, loc. cit. "Kaffirland".

I869. Redunca isabellina algoënsis Fitzinger, loc. cit. Algoa Bay, southern Cape Province.

190o. Cervicapra thomasinae Sclater, P.Z.S. 429. Songwé River, 6 miles from Lake Nyasa, Nyasaland.

I910. Cervicapra penricei Lydekker, The Field, London, II6: 498. Accidental renaming of thomasinae.

Range: the Union northwards to Nyasaland and Angola.

Redunca arundinum occidentalis Rothschild, i907

1907. Cervicapra arundineum occidentalis Rothschild, P.Z.S., 237. Near Fort Jameson, Eastern Province, $13^{\circ} 37^{\prime}$ S., $32^{\circ} 4 I^{\prime}$ E., Northern Rhodesia. Range includes the Bangweulu Flats, Northern Rhodesia, and Tanganyika.

\section{Genus KOBUS A. Smith, I840}

1840. Kobus A. Smith, Illustr. Zool. S. Africa, Mamm. pt. i2, pl. 28 and text. Antilope ellipsiprymnus Ogilby.

1843. Kolus Gray, List Spec. Mamm. B.M., xxvi, I 59. Lapsus for Kobus.

1847. Adenota Gray, List Osteol. Spec. B.M. xv, I46. Antilope kob Erxleben, from West Africa. Valid as a subgenus. 
I 866. Hydrotragus Fitzinger, S.B. Akad. Wiss. Wien, 54, I : 596. Adenota lechè Gray. (Sclater \& Thomas, I896, Book of Antelopes, 2: 95 for some reason give "Adenota kul Heuglin" as the type species, but leche Gray is the type by monotypy.)

I869. Pseudokobus Fitzinger, S.B. Akad. Wiss. Wien, 59, I: I73. Antilope forfex H. Smith = Antilope kob Erxleben.

I872. Onotragus Gray, Cat. Ruminant Mamm. B.M., I7. Adenota lechè Gray (Sclater \& Thomas, I896, Book of Antelopes, 2: 95).

1876. Cobus Buckley, P.Z.S., 284. Emendation.

I9I3. Onototragus Heller, Smithson. Misc. Coll. 6I, No. 7: 12. Error for Onotragus.

As explained above, page I 76 , we consider that Adenota is a subgenus only of Kobus, and that Onotragus (apparently antedated by Hydrotragus) is a synonym of Adenota.

Apparently these three supposed genera will breed together in captivity (Hindle, i 95 I, Abstr. P.Z.S. No. 2: 8), and the differences between Adenota and Onotragus, when all forms are taken into account, seem more average than absolute.

I. No inguinal glands. Coat grizzled and harsh. Horns curved forwards (about 23-39 inches long (Rowland Ward)). Shoulder height more than 42 inches.

A single pair of inguinal pouches. Coat not grizzled, less coarse. Horns inclined to be more lyrate. Shoulder height from published measurements $4 \mathrm{I}$ inches and less.

2. A white elliptical rumpband.

No white rumpband.

Kobus ellipsiprymnus, page 193

Kobus defassa, page I94

3. Skull markedly broader in measurements given by Roberts. Average rather larger; from published measurements shoulder height about 36-4I inches, length of horn about 19-34 inches. Kobus (Adenota) leche, page I95

Skull markedly narrower in measurements given by Roberts. Average rather smaller; from published measurements shoulder height about $32-40$ inches, length of horn about $\mathrm{I}^{-20}$ inches.

Kobus (Adenota) vardoni, ${ }^{1}$ page 194

\section{Subgenus KOBUS A. Smith, I840}

Kobus ellipsiprymnus Ogilby, I833 Waterbuck. Waterbok; Kringgat

Distribution: in the Union, survives in northern Zululand, the western Transvaal border? and the Kruger National Park (districts of Punda Maria, Shingwedzi, Letaba, Satara, Skukuza, Toulon, etc.). In South-West Africa, the northern districts (the Caprivi, east of the Okavango). Ngamiland, and according to Roberts southern Bechuanaland. Portuguese East Africa, Gorongoza district (B.M.); Southern Rhodesia; Nyasaland, Northern Rhodesia. Thence northwards to Tanganyika, Kenya and the Webi Shebeli River (southern Abyssinia or Italian Somaliland).

${ }^{1} K$. vardoni differs from the northern and earlier-named $K$. kob by lacking the black line on the front of the forelegs. 
KOBUS ELLIPSIPRYMNUS ELLIPSIPRYMNUS Ogilby, I833

I 833. Antilope ellipsiprymnus Ogilby, P.Z.S., 47. " 25 days journey north of the Orange River between Lataku (= near Kuruman) and the west coast of Africa", (presumably on the Molopo River (Roberts)).

Kobus defassa Rüppell, I $835^{1}$

Defassa or Sing-sing Waterbuck. Tropiese Waterbok

Distribution: Angola (fairly widely distributed in southern and central districts and recorded as far north as the Guanzo River), rarely wandering into the Okavango region of extreme northern South-West Africa (for details see Shortridge, 1934). Northern Rhodesia (as far as the Sesheke district); recorded from Nyasaland.

Kobus defassa defassa Rüppell, i835. (Extralimital) I835. Antilope defassa Rüppell, Neue Wirbelth. Abyssin. Pt. I : 9. Abyssinia (about Dembea Lake and in the Kulla).

Kobus Defassa crawshayi Sclater, I 894 1894. Cobus crawshayi Sclater, P.Z.S. I893: 726. Northern shore of Lake Mweru (near the Congo border) Northern Rhodesia. Ranges to Tanganyika.

Kobus DEFASSA PENRigei Rothschild, I895 1895. Cobus penricei Rothschild, Novit. Zool. 2: 52. Bongo, banks of the Kuvali River, roo miles south-east of Benguela, western Angola.

\section{Subgenus ADENOTA Gray, I 847}

Kobus vardoni Livingstone, 1857

Puku. Poekoe

Distribution: the neighbourhood of the Victoria Falls, the junction of the Chobe and Zambezi Rivers; Northern Rhodesia, where evidently quite common, as far north as Lakes Bangweulu and Mweru, Nyasaland and into south-western Tanganyika.

(Occurrence in Angola evidently doubtful, see Hill \& Carter, I94I.)

KOBUS VARDONI VARDONI Livingstone, I 857

1857. Antilope vardonii Livingstone, Missionary Travels and Researches in S. Afr., 256, and pl. opp. 71. Barotseland, Northern Rhodesia, at about $14^{\circ} 30^{\prime} \mathrm{S}$, $23^{\circ}$ I $5^{\prime}$ E. (See Moreau, Hopkins \& Hayman, I946, 437.)

1899. Cobus vardoni typicus Selous in Bryden, Great and Small Game Africa, 294.

Kobus vardoni SEnganus Sclater \& Thomas, I897

I897. Cobus senganus Sclater \& Thomas, Book of Antelopes, 2: 145. Asenga country, upper Luangwa River Valley, Northern Rhodesia (see Moreau, Hopkins \& Hayman, I946, 437). Ranges into Tanganyika.

${ }^{1}$ G.H.E. Hopkins (in litt.) tells us that according to V.G.L. van Someren ellipsiprymnus and defassa interbreed in Kenya, and form intermediate herds. If this is so then the latter should be regarded as a race of the former. 
Kobus leche Gray, I 850

Lechwe Waterbuck. Basterwaterbok

Distribution: northern South-West Africa, the Okavango valley and the Caprivi, and adjacent parts of Angola (Cubango river region); Northern Rhodesia (Lakes Bangweulu, Mweru, Barotseland, etc.), thence into the southern Belgian Congo.

Kobus LeGhe LeGhe Gray, I850

I850. Kobus lechè Gray, Gleanings Menagerie Knowsley Hall, 2: 23. "River Zoaga, lat. $2 \mathrm{I}^{\circ}$." Botletle River, Lake Ngami, Bechuanaland.

1852. Adenota lechèe Gray, Cat. Mamm. B.M., pt. 3: 98.

I876. Cobus leechi Buckley, P.Z.S., 29 I.

1903. Adenota amboellensis Sokolowsky in Baum, Kunene-Sambesi Exped. 535. The

Kubango River, between the Kueio and the Quatiri (approximately I $7^{\circ} \mathrm{S}$., $18^{\circ} 30^{\prime}$ E.), southern Angola (here selected).

1907. Cobus lechwe Rothschild, P.Z.S. 237.

I907. Cobus robertsi Rothschild, P.Z.S. 237. Between Lakes Mweru and Bangweulu, Northern Rhodesia.

I9I2. Onotragus lechè notatus Matschie, Deutsche Jäger-Zeitung, 59: i I9. Caprivi Zipfel, northern South-West Africa.

Kobus LeGhe smithemani Lydekker, igoo

I900. Cobus smithemani Lydekker, P.Z.S., I899: 982. Borders of Lake Mweru, Northern Rhodesia.

\section{Genus AEPYGEROS Sundevall, I 847}

1847. Aepyceros Sundevall, K. Svenska Vetensk. Akad. Handl. I845: 27 I. Antilope melampus Lichtenstein.

I893 Aepiceras Zittel, Handb. Pal. 4, 2: 4 I 7.

Aepyceros melampus Lichtenstein, I8 12

Impala. Rooibok

Distribution: in the Union, northern Zululand, and the Kruger National Park, Transvaal (Punda Maria, Shingwedzi, Letaba, Satara, Skukuza, Pretorius Kop, Toulon; easily the commonest buck in the Reserve). South-West Africa, the Okavango district and the Caprivi, the Kaokoveld to the Cunene. Angola, northwards to Benguela. Ngamiland, and southern Bechuanaland (Roberts). Southern Rhodesia; parts of Portuguese East Africa. Nyasaland, Northern Rhodesia. North of the limits of this work, Tanganyika, Uganda, Kenya and parts of the Belgian Congo.

Aepyceros melampus melampus Lichtenstein, i8 12

I8I 2. Antilope melampus Lichtenstein, Reisen Südl. Africa, 2, pl. 4, opposite p. 544 . Mag. Ges. Naturf. Fr. Berlin, 6: I67 (1812). Klipfontein in southern Bechuanaland. (The type locality is not Klipfontein in Little Namaqualand.) Koossi mentioned on p. 543 is evidently Kosis, east of Olifantshoek (which is south of Kuruman in the northern Cape Province, the part which used to be called British Bechuanaland). 
Aepyceros melampus melampus [contd.]

I 893. Aepyceros melampus typicus Thomas, P.Z.S. I892: 553.

Range: Zululand and Transvaal northwards to the Zambezi and to Ngamiland and the south-eastern corner of Angola.

Aepyceros melampus petersi Bocage, i879.

I 879. Aepyceros petersi Bocage, P.Z.S. I878: 741. Capangombe, Mossamedes district, southern Angola. Range: from the Kaokoveld to Benguela district, western Angola.

Aepyceros melampus johnstoni Thomas, i 893

I893. Aepyceros melampus johnstoni Thomas, P.Z.S. I892: 553. Zomba, circa 3,000 ft., I $5^{\circ} 24^{\prime}$ S., $35^{\circ}$ I $7^{\prime}$ E., southern Nyasaland.

I894. Aepiceros melampus holubi Lorenz, Ann. Naturh. Hofmus. Wien, 9: Notizen, 62. North of the Zambezi.

\section{Genus ANTIDORGAS Sundevall, I 847}

1847. Antidorcas Sundevall, K. Svenska Vetensk. Akad. Handl. I845: 271. Antilope euchore Forster $=$ Antilope marsupialis Zimmermann.

This is the South African representative of the genus Gazella, from which it differs in having only two pairs of lower premolars, and in the specialized erectile hairs along the lower part of the spine.

Antidorcas marsupialis Zimmermann, I 780

Springbuck or Springbok. Springbok

Distribution: in the Union the species exists at present mainly on fenced farms or private property, although some of these are of very large size and the animals appear at liberty to jump the fences. There are a considerable number at De Beers estate, 36 miles west of Kimberley; near Graaff Reinet, and in the Orange Free State (north of Philippolis, the Sommerville Reserve (Winburg district)), etc. Other localities (I95I) are Kruidfontein (near Nelspoort), north of Colesberg, near Hanover, and between Deelfontein and Richmond, all Cape Province. Shortridge stated that they occur in the Waterberg district, western Transvaal. They may also occur (in a wild state) along the northern central borders of the Cape Province. South-West Africa; the whole of South-West Africa except the north-eastern districts (N.E. Ovamboland, Grootfontein district and the Caprivi) (Shortridge, 1934). South-western Angola, between the Cunene River and Benguela. The Kalahari to Ngamiland (Roberts).

ANTIDORCAS MARSUPIALIS MARSUPIALIS Zimmermann, I780

1780. Antilope marsupialis Zimmermann, Geogr. Gesch. 2: 427. Cape of Good Hope.

I785. Antilope saccata Boddaert, Elench. Anim. I: i42. Cape of Good Hope.

I 788. Capra pygargus Thunberg, Resa uti Europa, Africa, Asia, etc. 2: 28. Cape of Good Hope. 
I 790. Antilope euchore Forster in Levaillant, Erste Reise Afrika, I 59. South Africa. I 792. Antilope saltans Kerr, Anim. Kingd. 31 2. Cape of Good Hope.

I 795. Antilope saltatrix Link, Beytr. Naturgesch, I, 2: 99. Not of Boddaert, I 785.

I802. Antilope dorsata Daudin in Buffon, Hist. Nat. (Didot's ed.) Quad. I4: I82. Cape of Good Hope.

I802. Antilope saliens Daudin, loc. cit. I82. Cape of Good Hope.

I9I4. Antidorcas marsupialis centralis Lydekker \& Blaine, Cat. Ruminant Mamm.

B.M. 3: I I I, I I 2. Deelfontein, north of Richmond, Cape Province.

Range: the Union.

Antidorcas marsupialis angolensis Blaine, 1922

1922. Antidorcas angolensis Blaine, P.Z.S. 335. Coastal belt between Benguela and Mossamedes, southern Angola. Range: southwards to the Kaokoveld and northern Namib desert, South-West Africa.

ANTIDORGas Marsupialis hofmeyri Thomas, 1926

I926. Antidorcas angolensis hofmeyri Thomas, P.Z.S. 3 I I. Berseba, Great Namaqualand, South-West Africa. Range: Great Namaqualand to the Kalahari and Ngamiland.

\section{Genus ORYX Blainville, I8 6}

I8I6. Oryx Blainville, Bull. Soc. Philom. Paris, 75. Antilope oryx Pallas, I777 (not A. oryx Pallas, I766, which is the Eland) = Capra gazella Linnaeus.

1918. Aegoryx Pocock, Ann. Mag. N.H. 2: 221. Cemas algazel Oken = Antilope tao H. Smith, from the Sudan.

Oryx gazella Linnaeus, I $75^{8}$

Gemsbok; Beisa Oryx (in East Africa). Gemsbok; Gensbok

Distribution: if Gemsbok still survive in the Union, they would probably be in the district of Vryburg, or along the northern central border of the Cape Province, although Roberts thought it was possible that they might exist in Bushmanland, and states that the species is given to wandering, and sometimes reappears in areas from which it had formerly disappeared. South-West Africa; recorded from all districts except the eastern Caprivi (Shortridge). The Kalahari desert (there is a Gemsbok National Park near the Nossob River region of the southern Kalahari); recorded from as far north as Ngamiland, and at least formerly to Matabeleland, Southern Rhodesia. South-western Angola, where local and rather rare. In East Africa $(O$. beisa Rüppell, I 835 is probably the same species), Tanganyika, Kenya, Abyssinia, Somaliland.

Oryx GAZElla Gazella Linnaeus, I $75^{8}$

I758. Capra gazella Linnaeus, Syst. Nat. Ioth ed. I: 69. "India" (= South Africa, Thomas, I9I I, P.Z.S. I 52).

I 766. Antilope bezoartica Pallas, Misc. Zool. 8. No locality.

I 769. Gazella recticornis Pallas, Nov. Comment. Petrop. I3: 648. Africa. 
Oryx Gazella gazella [contd.]

I777. Antilope oryx Pallas, Spic. Zool. pt. i 2: i6. "Aegypti, Aethiopiae, Arabiae inquilina." Not of Pallas, I 766 which is the Eland.

I802. Antilope pasan Daudin in Buffon, Hist. Nat. (Didot's ed.) Quad. I4: i 82. Cape of Good Hope.

I 82 I. Onyx onyx Gray, London Med. Repository, 15: 307. (Lapsus).

I 837. Oryx capensis Ogilby, P.Z.S. I 836: I 39. Substitute for oryx Pallas, I 777 .

I92 I. Oryx gazella blainei Rothschild, Ann. Mag. N.H. 8: 209. 20 miles inland from

Elephant Bay, south of Benguela, western Angola.

I924. Oryx aschenborni Strand, Arch. Naturgesch. 9oA, I: I46, footnote. Between Goshas, Kalkfontein and Arahoah, South-West Africa.

\section{Genus HIPPOTRAGUS Sundevall, ı 846}

I 822. Egocerus Desmarest, Encycl. Méth. Mamm. 2: 475. Antilope leucophaea Pallas, I 766, the extinct Blue Buck, from the Cape Province. (Type fixed by

Sclater \& Thomas, I899, Book of Antelopes, 4: 3.)

I827. Aegocera Berthold in Latreille, Nat. Fam. Thierr., 6r. For Egocerus.

I 827. Aigocerus H. Smith, Griffith's Guv. Anim. Kingd. 5: 324. For Egocerus.

I842. Oegocerus Lesson, Nouv. Tabl. Règne An. Mamm. I 79. For Egocerus.

I844. Aegocerus Wagner in Schreber, Säugth. Suppl. 4: 482. For Egocerus.

I845. Ozanna Reichenbach, Vollständ. Naturgesch. Säugeth. 3: i 26. Aigocerus niger

Harris (Sclater \& Thomas, I899, Book of Antelopes, 4: 3).

i 846. Hippotragus Sundevall, K. Svenska Vetensk. Akad. Handl. I844: ig6. Antilope leucophaea Pallas.

I 859. Aegocoerus Gervais, Zool. et Paléontol. Franç. I 39. For Egocerus.

(The name Hippotragus Sundevall, I846, was placed on the Official List of Generic Names by the Commission, and Egocerus Desmarest, I 822 and Ozanna Reichenbach, I 845 were suppressed-see Opinion I og. Sundevall, however, also published the name Hippotragus in I 845, Öfvers. Vetensk. Akad. Förh., Stockholm, 2: 31, with A. equina as the type by monotypy.)

Colour black or chestnut, the underparts well defined white. Shoulder height up to about 54 inches; horns average longer (about 33-64 inches, Rowland Ward).

Hippotragus niger, page I 99

Colour pale brown, the whitish of underparts less defined; shoulder height about 56-63 inches; horns average shorter, about $24 \frac{3}{4}-39$ inches ( $R$. Ward).

Hippotragus equinus, page $9^{8}$

Hippotragus equinus Desmarest, I804 Roan Antelope. Bastergemsbok

Distribution: in the Union now survives only in the Kruger National Park, Transvaal (Shingwedzi, etc., but mainly or wholly north of the Olifants River). Roberts quoted the species from Swaziland. South-West Africa; the northern districts, northern and eastern Ovamboland, Grootfontein district, and the Caprivi. Northern Bechuanaland, Southern Rhodesia, southern Portuguese East Africa. Angola; probably throughout the interior, south of the Congo region (Hill \& Carter). Northern Rhodesia, Nyasaland. Beyond the limits of this work, north-eastwards to the Sudan, and thence to Senegal. 
Hippotragus equinus equinus Desmarest, i804

I804. Antilope equina Desmarest, Nouv. Dict. H.N. (I) 24: 4. Locality unknown. (I82 I. Capra aethiopica Schinz, Cuvier's Thierreich, I: 403. Based on "The Tackhaitse" of Daniell, I805, African scenery and animals, pl. 24, the locality of which is given as "On the edge of the Karroo plains ... and in the parallel of latitude under which Latakoo is situated"'. Roberts (I95 I : 303) treats this, jubata and barbata, which were founded on the same plate, as being a separate, extinct species related to the Roan and the Blue Buck.)

(1824. Capra jubata Goldfuss in Schreber, Säugth. pl. 287C; text 5: I47 I (I836) (where it is treated as a synonym of truteri).)

(1827. Antilope barbata H. Smith, Griffith's Cuvier Anim. Kingd. 4: i 8o. Based on Danniell's "Tackhaitse".)

I827. Antilope aurita H. Smith in Griffith's Cuvier Anim. Kingd. 5: 325.

(1829. Antilope truteri Fischer, Synops. Mamm. 478. Renaming of aethiopica.)

1899. Hippotragus equinus typicus Sclater \& Thomas, Book of Antelopes, 4: I3.

Range: Transvaal, Rhodesia, Portuguese East Africa (part).

Hippotragus equinus cottoni Dollman \& Burlace, ig28

I928. Hippotragus equinus cottoni Dollman \& Burlace, Rowland Ward's Records Big Game, 9th ed., 265. Cuanza River, northern Angola. Range includes Ngamiland, and according to Roberts, Beira, Portuguese East Africa.

Hippotragus niger Harris, 1838

Sable Antelope. Swartwitpens

Roberts calls this species Ozanna grandicornis (Antilope grandicornis Hermann, I804, Obs. Zool. 87). This name does not seem to have been based on a Sable Antelope, and should be regarded as not certainly identifiable. Hermann gives a description of some horns which might well be Sable (curved back and measuring $2 \frac{1}{2}$ feet in a straight line and $3 \frac{1}{2}$ feet on the outside of the curve), but he described the body as having a white stripe round the neck, another right round the body just behind the front legs, and a third right round the body just in front of the back legs. Also there is a beard. He refers to a plate in Kolbe, I7 I9, Caput Bonae Spei hodiernum, which pictures this curious beast (but gives it straight horns about a foot long) and says that his grandicornis is this plate, but with the horns modified in accordance with H. Hop, I 778, Fournal d'un voyage de terre dans l'intérieur d'Afrique, 44. But this animal is simply Kolbe's with the horns longer and curved. The white bands and the beard are still there. Roberts adopted grandicornis without even having seen the original description.

We see no reason to upset the name niger for the Sable Antelope, which name is well described in the P.Z.S. of 1838 .

Distribution: in the Union survives in the Kruger National Park, Transvaal, where it is moderately widely distributed (Punda Maria, Shingwedzi, Skukuza, Toulon districts, etc.). South-West Africa; the northern portions, the Caprivi and Okavango Valley, to the north-eastern corner of the Grootfontein district (Shortridge). Ngamiland. Angola; the typical race occurs in the south-eastern corner, and $H$. n. variani between the Cuanza and Luando rivers in the north-central 
region. Southern Rhodesia, Northern Rhodesia, Nyasaland, Portuguese East Africa. North of the limits of this work, Tanganyika, Kenya and Katanga, southern Belgian Congo (Shortridge).

Hippotragus Niger Niger Harris, ${ }^{8} 838$

I838. Aigocerus niger Harris, P.Z.S., 2. Cashan Mountains, near Pretoria (Magaliesberg, west of Pretoria, according to Shortridge), Transvaal. (The animal is now extinct in the region of the type locality.)

I839. Aigocerus harrisi Harris, Wild Sports of Southern Africa, 264, 378. Mountain range of eastern Matabeleland, Southern Rhodesia.

I872. Aegocerus niger var. kirkii Gray, Cat. Ruminant Mamm. B.M., 35. South Africa. Batoka Hills, Livingstone Falls, Northern Rhodesia (Roberts, who regarded this form as a valid race).

I91 2. Hippotragus (Ozanna) niger kaufmanni Matschie, Deutsche Jäger-Zeitung, 59: I 19. Caprivi Zipfel, between the Chobe and Zambezi Rivers, South-West Africa.

Hippotragus niger variani Thomas, igi6. (Giant Sable)

I916. Hippotragus niger variani Thomas, Abstr. P.Z.S. No. I5I, I; P.Z.S., 300. Luando River (an eastern tributary of the Cuanza River) northern central Angola.

Genus DAMALISGUS Sclater \& Thomas, I894

1846. Damalis Gray, Ann. Mag. N.H. I8: 233. Damalis lunatus Burchell (Sclater \& Thomas, I894, Book of Antelopes, I: 5I). Not of Fabricius, I805 (Diptera). I894. Damaliscus Sclater \& Thomas, Book of Antelopes, I: 51. Antilope pygarga Pallas = Antilope dorcas Pallas.

I91 2. Beatragus Heller, Smithson. Misc. Coll. 6o, 8: 8. Damalis hunteri Sclater, from Kenya. Valid as a subgenus.

Face not white; limbs dark. Larger, shoulder height about $46-48$ inches.

Damaliscus lunatus, page 200

Face white; limbs partly white. Smaller, shoulder height about 40 inches or less. Damaliscus dorcas, page 201

\section{Subgenus DAMALISCUS Sclater \& Thomas, I894}

For the use of the name dorcas in place of the more familiar D. pygargus see Harper, I940, J. Mamm. 2I: 328. The Blesbok and Bontebok are here considered conspecific.

Damaliscus lunatus Burchell, I823 Sassaby, or Tsesseby. Basterhartbees

Distribution: in the Union, survives in the Kruger National Park, Transvaal (Shingwedzi, etc.; now either confined to the region north of the Olifants River, or at least very rare to the south of it). South-West Africa; the northern parts; the 
Okavango region, Grootfontein district, and the Caprivi. South-eastern Angola, where evidently not well known. Ngamiland, Southern Rhodesia, parts of Portuguese East Africa. Northern Rhodesia and Nyasaland, as far north as the southern end of Lake Tanganyika and the southern Belgian Congo. It is possible that $D$. korrigum Ogilby, I837 (Senegal to Italian Somaliland and Tanganyika) is a further northern extension of this species.

Damaliscus lunatus lunatus Burchell, i 823

1823. Antilope lunata Burchell, Travels in Interior S. Africa, 2: 334. (The title page has "I 824 " but, according to Sherborn, published November, I 823.) "Makkwarin River" ( $27^{\circ} 20^{\prime}$ S., $24^{\circ} 30^{\prime}$ E. on Burchell's map). Mathlowing River, a little north-east of Kuruman, northern Cape Province (Roberts, I95 I), and where now extinct.

I912. Damaliscus lunatus reclinis Matschie, Deutsche Jäger-Zeitung, 59: i I9 (77 of reprint). Caprivi Zipfel, South-West Africa.

Damaliscus dorcas Pallas, I 766

Bontebok; Blesbok. Bontbok; Blesbok

Distribution: confined to reserves or private property in the Union. A large herd (approximately Iоo) exists in the Bontebok Reserve near Bredasdorp, southern Cape Province, and there are a few introduced specimens in the Cape Point Nature Reserve (south of Cape Town), in paddocks at Groote Schuur, Cape Town, and in a reserve near Lamberts Bay, western Cape Province. The Blesbok exists in the Sommerville Game Reserve in the Winburg district of the Orange Free State, and on private property north of Kroonstad, between Ventersburg and Winburg, etc., in the Orange Free State, and near Pretoria, Transvaal.

Damalisgus dorgas dorgas Pallas, i 766 . Bontebok

I 766. Antilope dorcas Pallas, Misc. Zool., 6. No locality, but nominated by Harper (1940, 329) as Caffer Kuyls River, between Mossel Bay and Swellendam, south-western Cape Province.

I 767. Antilope pygargus Pallas, Spic. Zool. I: io. Cape of Good Hope (restricted to Swart River, near Caledon, by Bigalke, I948, J. Mammal, 29: 442).

I773. Capra cervicapra Müller, Vollständ. Natursyst. I: 4I 4. Not of Linnaeus, I 758. I 785. Antilope grisea Boddaert, Elench. Anim. I: I 39. Cape of Good Hope.

I 788. Capra scripta Thunberg, Resa uti Europa, Africa, Asia, etc. 2: 50. Cape of Good Hope.

I 8 I I. Antilope maculata Thunberg, Mém. Acad. Sci. St. Pétersb. 3: 3 I 5. Swellendam, Cape Province.

I823. [Antilope] albifrons Burchell, Travels in Int. South Africa, 2: 335. Substitute for pygargus.

I829. Antilope personata Woods, Zool. J. 5: 2. Vicinity of Cape of Good Hope.

Damaliscus doRGas Phillipsi Harper, i939. Blesbok

I840. Gazella albifrons Harris, Portraits of the game and wild animals of southern Africa, pl. 2 I et auctorum. Not of Burchell, I823.

1939. Damaliscus phillipsi Harper, Proc. Biol. Soc. Washington, 52: 90. Orange Free State. (Harper also discusses the identity of albifrons Burchell.) 
Genus ALCELAPHUS Blainville, I8 6

18 6. Alcelaphus Blainville, Bull. Soc. Philom. Paris, 75. Antilope bubalis Pallas = Antilope buselaphus Pallas. Type fixed by Sclater \& Thomas, I894, Book of Antelopes, $1: 5$.

I820. Bubalis Goldfuss, Handb. Zool. 2: 367. Antilope buselaphus Pallas. (This name has been quoted as Rafinesque (18I5) where it is a nomen nudum; Frisch ( I 775) an unavailable work; and Lichtenstein (18I4) where it occurs in the plural only-Bubalides. See Lyon, I9I4, Proc. Biol. Soc. Washington, 27: 228.)

I827. Damalis H. Smith, Griffith's Cuvier Anim. Kingd. 4: 343. Not of Fabricius, I 805 (Diptera).

I 827. Acronotus H. Smith, loc. cit. 346. Substitute for Alcelaphus.

1837. Bubalus Ogilby, P.Z.S. I 836: I 39. Not of H. Smith, I827.

I 91 2. Sigmoceros Heller, Smithson. Misc. Coll. 6o, 8: 4. Antilope lichtensteinii Peters.

Apart from A. lichtensteini, for which Sigmoceros is available if subgeneric division is required, there seem to be three main types of horn structure in the remainder of the genus, as typified respectively by the races buselaphus, tora and lelwel; G. Allen (1939) lists all named forms as races of A. buselaphus except the South African caama which apparently resembles lelwel except for some colour details. It seems logical, if one follows the classification of G. Allen, to make caama an outlying southern race of buselaphus.

Horn pedicle short and broad, occiput about level with base of horns; horns flat and curved inwards towards each other before being bent back. Forehead convex. Alcelaphus lichtensteini, page 203

Horn pedicle long, occiput in front of base of horns; and the horns not curving inwards as in the last. Forehead flat. Alcelaphus buselaphus, page 202

Alcelaphus buselaphus Pallas, i 766

Hartebeest. Rooihartbees

Distribution: in the Union, at De Beers Estate, 36 miles west of Kimberley. There are also said to be herds on private property at Moes Rest, New Hanover, Natal and the Buckland Downs, Harrismith district, Orange Free State. Apparently there are now no Hartebeests in the Kruger National Park, and if they survive in the Transvaal at all it would be on the western (Bechuanaland) border. Perhaps the western Molopo River region on the northern borders of the Cape Province. South-West Africa; according to Shortridge, mostly east of a diagonal line between Nakop (about 86 miles from Upington on the border, where the railway enters South-West Africa) and the Rua Cana Falls on the Cunene River in the north, but they do not occur in the northern half of Grootfontein district and along the Caprivi. Southern Angola. Northwards about to Ngamiland. North of the limits of this work, from Tanganyika to the Sudan and Somaliland, and thence westwards to Senegal.

Algelaphus buselaphus buselaphus Pallas, i 766 . (Extralimital) i 766. Antilope buselaphus Pallas, Misc. Zool. 7. Probably Morocco, where now extinct. 
Algelaphus buselaphus gaama G. Cuvier, I804

I804. Antilope caama G. Cuvier, Dict. Sci. Nat. 2: 242. Cape of Good Hope.

I785. Antilope dorcas Sparrman, Voyage to Cape of Good Hope (Engl. Tr.) 2: 2 I 9. Agter Bruintjes-Hoogte (headwaters of the Little Fish River, Cape Province).

Not of Pallas, i 766.

I 899. Bubalus cama Bryden, Great and Small Game of Africa, I33.

I 937. Bubalis caama obscurus Frechkop, Bull. Mus. H.N. Belg. I3, 39: I I, 22. Locality unknown.

This race is now considered to be extinct.

Algelaphus buselaphus selbornei Lydekker, i 9 I 3

I9I3. Bubalis caama selbornei Lydekker, Abstr. P.Z.S. No. i I9: i9. P.Z.S., 820. Kimberley Game Farm, the herd there having apparently been imported from the western Transvaal. Ranges northwards to Bechuanaland and South-West Africa.

Algelaphus buselaphus evalensis Monard, i 933.

1933. Bubalis caama evalensis Monard, Bull. Soc. Sci. Nat. Neuchâtel, 57: 64. Evale, southern Angola.

Alcelaphus lichtensteini Peters, I 849

Lichtenstein's Hartebeest. Mofhartbees

Distribution: though formerly occurring in the Transvaal it is probably now extinct in the Union. Portuguese East Africa, Southern Rhodesia, Northern Rhodesia, Nyasaland and Tanganyika.

Algelaphus lichtensteini Peters, i 849

I849. Antilope lichtensteinii Peters, S.B. Ges. Naturf. Fr. Berlin, I 8 December, I 849, published in the Spenersche Z. for 23 December, I849; I852. Reise nach Mossambique, Säugeth. I90. Tete, Zambezi River, Portuguese East Africa.

I9 I0. Bubalis lichtensteini shirensis Zukowsky, Zool. Beob. 5I: 26 I. Boundary between Shiré and lower Loangwa regions, Portuguese East Africa.

ı 9 о. Bubalis lichtensteini basengae Zukowsky, loc. cit. Boundary between Shiré and lower Loangwa regions, Portuguese East Africa.

I916. Sigmoceros gorongozae Matschie \& Zukowsky, S.B. Ges. Naturf. Fr. Berlin, ig6. Northern Gorongoza district, $60 \mathrm{~km}$. west of Urema River, Portuguese East Africa.

I9I6. Sigmoceros godonga Matschie \& Zukowsky, loc. cit, i97. Urema River, a branch of the Pungwe, Cheringoma district, Portuguese East Africa.

I916. Sigmoceros inkulanondo Matschie \& Zukowsky, loc. cit. I97. Unzeilas Kingdom, upper Sabi, south-eastern Mashonaland, Southern Rhodesia.

19i6. Sigmoceros wiesei Matschie \& Zukowsky, loc. cit. 199. West of Chifumbazi, on the Luia, tributary of the Kapotche, Portuguese East Africa.

I9 I6. Sigmoceros senganus Matschie \& Zukowsky, loc. cit. 200. Mussenda Luz, on the Zambezi between the Loangwa and the Kebrabassa Falls, Portuguese East Africa.

I916. Sigmoceros heuferi Matschie \& Zukowsky, loc. cit. 202, substitute for basengae. 
Alcelaphus lichtensteini [contd.]

I9 6. Sigmoceros konzi Matschie \& Zukowsky, loc. cit. 203. North of the middle Kafue, $50 \mathrm{~km}$. south of Broken Hill, Northern Rhodesia.

igi6. Sigmoceros niediecki Matschie \& Zukowsky, loc. cit. 205. Not of Neumann, igo5. Baunza, north of middle Kafue, $33 \mathrm{~km}$. east of where the river turns east, north of Victoria Falls, Northern Rhodesia.

I9i6. Sigmoceros bangae Matschie \& Zukowsky, loc. cit. 206. Banga, south-east of Baunza, and north of the Kafue River, Northern Rhodesia.

I9 6. Sigmoceros niedieckianus Matschie, loc. cit. 295. Substitute for niediecki, preoccupied.

I9 18. Sigmoceros petersi Matschie \& Zukowsky, S.B. Ges. Naturf. Fr. Berlin, I9I7: 530. Near Sena, Portuguese East Africa.

igi8. Sigmoceros kangosa Matschie \& Zukowsky, loc. cit. 532. Makjusa's Land, north-west end of Lake Nyasa, near Ipiana, Nyasaland.

I925. Sigmoceros rendalli Matschie \& Zukowsky, S.B. Ges. Naturf. Fr. Berlin, I922: 8o. Kambwe, southern end of Lake Nyasa, Nyasaland.

\section{Genus GONNOGHAETES Lichtenstein, I8I 2}

I8I 2. Connochaetes Lichtenstein, Mag. Ges. Naturf. Fr. Berlin, 6: I52. Antilope gnu Gmelin = Antilope gnou Zimmermann.

i8i6. Cemas Oken, Lehrb. Naturgesch. 3, 2: 727. Cemas gnu Oken = Antilope gnou Zimmermann (Sclater \& Thomas, I895, Book of Antelopes, I: 93). Unavailable.

I82 I. Catablepas Gray, London Medical Repository, I5: 307. Antilope gnu Gmelin = Antilope gnou Zimmermann.

I827. Catoblepas H. Smith, Griffiths Cuvier Anim. Kingd. 4: 366. Antilope gnu Gmelin = Antilope gnou Zimmermann.

I850. Gorgon Gray, Gleanings Menagerie Knowsley Hall, 20. I85I. P.Z.S. I850: I39. Antilope gorgon H. Smith $=$ Antilope taurina Burchell. Valid as a subgenus.

I872. Butragus Gray, Cat. Ruminant Mamm. B.M., 43. Butragus corniculatis (Blyth MS) = Antilope taurinus Burchell.

Horns directed at first outwards; tail black; nasals long; forehead convex.

Connochaetes (Gorgon) taurinus, page 205

Horns directed forwards; tail white; nasals shorter; forehead flat.

Connochaetes gnou, page 204

\section{Subgenus CONNOCHAETES Lichtenstein, I8I 2}

\section{Connochaetes gnou Zimmermann, I 780}

Black Wildebeest or Whitetailed Gnu. Swartwildebees

Distribution: extinct as a wild animal; there is a moderate-sized herd in paddocks at Groote Schuur, Cape Town, and there are also said to be herds in the Sommerville Game Reserve, Winburg district, Orange Free State, near Kroonstad, Orange Free State, and on one of the farms owned by De Beers, west of Kimberley. Shortridge ( I934) quoted a few introduced specimens at a farm at Colenso, Natal. 
Connoghaetes Gnou Zimmermann, i $780^{1}$

I780. Antilope gnou Zimmermann, Geogr. Gesch. 2: 102. Cape of Good Hope (nominated as Colesberg, Cape Province, by Harper, I940, J. Mamm. 2 I: 329).

I 780. Antilope capensis Gatterer, Brev. Zool. I: 8o. Cape of Good Hope.

I 788. Antilope gnu Gmelin, Linn. Syst. Nat. ed. I 3, I: I89.

1828. Catablepas operculatus Brookes, Cat. Anat. Zool. Mus. J. Brookes, 64 .

1844. Bos connochaetes Forster, Descript. Anim. 392. Cape of Good Hope.

\section{Subgenus GORGON Gray, I850}

Connochaetes taurinus Burchell, I823

Blue Wildebeest, or Brindled Gnu. Blouwildebees

Distribution: in the Union, the Kruger National Park (Shingwedzi, Satara, Skukuza, Pretorius Kop, Toulon, etc. Very common south of the Olifants River). Zululand. Possibly the northern borders of the Cape Province (north of Vryburg? 50-IOo miles north of Upington (Shortridge)). South-West Africa; Shortridge (I 934) states that its distributional area is similar to that of Alcelaphus buselaphus (caama) (q.r.), but that it extends to the Okavango and the Caprivi; that author quoted it as far south as Great Namaqualand (Aroab district), but Roberts (I95I) says that it has been exterminated in the south though still plentiful in the Etosha Pan and other districts in the north. The greater part of Bechuanaland. Southern Rhodesia, southern Portuguese East Africa. Southern Angola. Northern Rhodesia and Nyasaland. Northwards to Tanganyika and Kenya.

Connochaetes taurinus taurinus Burchell, i 823

1823. Antilope taurina Burchell, Travels in Inter. S. Africa, 2: 278, footnote. (The title page has "I 824 ", but, according to Sherborn, published November, I 823.) Khosi Fountain, about 30 miles S. by W. from Kuruman, northern Cape Province.

1827. Catoblepas gorgon H. Smith, Griffith's Cuvier Anim. Kingd. 4: 371. Interior of South Africa.

1872. Gorgon fasciatus Gray, Gat. Ruminant Mamm. B.M. 43. Substitute for gorgon. I872. Butragus corniculatus Gray, loc. cit. 43. South Africa.

I 893. Catoblepas reichei Noack, Zool. Anz. I6: I 54. Limpopo, northern Transvaal.

1925. Connochaetes taurinus mattosi Blaine, Ann. Mag. N.H. I5: I 29. Chiacusse, Huilla district, Gunene River, extreme southern Angola.

1933. Connochaetes taurinus borlei Monard, Bull. Soc. Sci. Nat. Neuchâtel, 57: 64. Rio Mbalé, southern Angola.

Connochaetes taurinus johnstoni Sclater, i 896

I896. Connochaetes taurinus johnstoni Sclater, P.Z.S. 6i6. Mlanje Plain, southern end of Lake Shirwa, southern Nyasaland. Ranges into Tanganyika.

${ }^{1}$ (Zimmermann, I 777, Spec. Zool. Geograph. 372 (Bos gnou) is unavailable.) 
Connochaetes taurinus cooksoni Blaine, I9I4

I9I4. Connochaetes taurinus cooksoni Blaine, Ann. Mag. N.H. 13: 337. East bank of Luanga River, Lundazi district, eastern Northern Rhodesia. (See Moreau, Hopkins \& Hayman, 1946, 435.)

\section{Genus TRAGELAPHUS Blainville, $\mathrm{I} 8 \mathrm{i} 6$}

I8I5. Strepsiceros Rafinesque, Analyse de la Nature, 56, nomen nudum. ${ }^{1}$

I8ı6. Tragelaphus Blainville, Bull. Soc. Philom. Paris, 75. Antilope sylvatica Sparrman (Sclater \& Thomas, 1900, Book of Antelopes, 4: 103).

I827. Strepsiceros H. Smith, Griffith's Cuv. Anim. Kingd. 5:365. Antilope strepsiceros Pallas. Valid as a subgenus.

1837. Calliope Ogilby, P.Z.S. 1836: 138. Antilope strepsiceros Pallas. Not of Gould, I836.

1872. Hydrotragus Gray, Cat. Ruminant Mamm. B.M., 49. Tragelaphus spekei Sclater. Not of Fitzinger, I 866.

I 90o. Limnotragus Sclater \& Pocock in Sclater \& Thomas, Book of Antelopes, 4: I 49. Tragelaphus spekei Sclater. (For authorship see Lydekker, I9I4, Cat. Ung. Mamm. B.M. 3: 185, footnote.)

1903. Strepsicerastes Knottnerus-Meyer, Arch. Naturgesch. 69, 2, pt. I, Jahresber. Mamm. for I 902: I I3. Strepsiceros imberbis Blyth, from Abyssinia.

1910. Strepsicerella Zukowsky, Wild und Hund, I6: No. I2, 206. (N.V.) Strepsiceros imberbis Blyth.

I9 1 2. Ammelaphus Heller, Smithson. Misc. Coll. 6o, 8: i5. Strepsiceros imberbis Blyth. 19 1 2. Nyala Heller, Smithson. Misc. Coll. 6o, 8: i6. Tragelaphus angasi Gray.

Schwarz, Simpson and others have regarded Strepsiceros, Limnotragus and Tragelaphus as congeneric, and on account of some East African intermediate species this seems the correct classification. The prior name for the genus is Tragelaphus Blainville, 1816 , as is shown in the above synonymy.

I. Hoofs elongated (over 3 inches in length).

Hoofs not specially elongated.

Tragelaphus spekei, page 208

2. Large species, height of shoulder over 45 inches, with longer horns which have one and a half twists; males with small mane on hindneck and shoulders and fringe of hairs on throat; males usually only a little darker than females; both sexes banded with white. Tragelaphus (Strepsiceros) strepsiceros, page 209

Smaller species, height at shoulder not over 45 inches, with smaller horns which have one complete twist.

${ }^{1}$ Strepsiceros Frisch, I 775, has been used for the Kudu, but the work in which it is published is unavailable under the Commission's ruling (Bull. Zool. Nomencl. I950, 4: 549). In any case Palmer (I904) was in error in saying that the type species is Antilope strepsiceros Pallas; it is "Ovis strepsiceros", the Zackelschaf from Crete. 
3. A mane of long hairs on neck and back, and males with fringe of hairs on throat. Males much darker than females which are more markedly banded. Shoulder height between 36 and 45 inches. Horns longer.

Tragelaphus angasi, page 208

Mane less developed, and no fringe on throat. Normally the sexual difference in colour is less marked. Shoulder height below 36 inches. Horns shorter. ${ }^{1}$

Tragelaphus scriptus, page 207

Subgenus TRAGELAPHUS Blainville, I8 6

Tragelaphus scriptus Pallas, I 766

Bushbuck. Bosbok

Distribution: in the Union, the Kruger National Park (Punda Maria, Shingwedzi, Letaba, Skukuza, Toulon, etc.), probably suitable localities elsewhere in the wilder parts of the Transvaal, to the Zoutpansberg, Rustenburg district, etc. Natal, Zululand and in the Cape Province, districts of George, Knysna, the Addo Bush (near Port Elizabeth) and "in deep kloofs and dense shady forests throughout the Eastern Province" (Hewitt, I 93I). Swaziland. South-West Africa; northern parts, the Okavango valley and the Caprivi. Central and southern Angola. Ngamiland. Southern Rhodesia, where evidently quite widely distributed. Portuguese East Africa, including Gorongoza district. Northern Rhodesia, Nyasaland. Beyond the limits of this work through East Africa to the southern Sudan and Abyssinia, and from the Belgian Congo westwards to Gambia.

Tragelaphus sGriptus sGriptus Pallas, i 766 . (Extralimital)

I 766. Antilope scripta Pallas, Misc. Zool., 8. Senegal.

TRAgelaphus sGriptus sylvatigus Sparrman, i 780

I 780. Antilope sylvatica Sparrman, K. Svenska Vetensk. Akad. Handl. 197. Grootvadersbosch, Swellendam district, south-western Cape Province. Range: the Union localities listed above.

Tragelaphus SGriptus roualeyni Gray, i 852

I 852. Antilopus rouáleynei Gray, Cat. Mamm. B.M., pt. 3, Ungulata, I 40. Bakalahari country, near sources of the Limpopo, Bechuanaland.

I850. Antelopus roualeynei Cumming, A Hunter's Life in S. Africa, 2: 169, nomen nudum.

I89I. Tragelaphus scriptus roualeyni Thomas, P.Z.S. 389. Emendation; (roualeyni is right since Cumming's christian name was Roualeyn).

I900. Tragelaphus roualeyni typicus Sclater \& Thomas, Book of Antelopes, 4: I 23.

Range: North-eastern Zululand to the Limpopo and westwards up that valley to the lower Crocodile River; in Southern Rhodesia to the Melsetter district (Roberts).

${ }^{1}$ Horn, length on front curve, quoted by Rowland Ward; for $T$. scriptus, IO $\frac{1}{2}-2 \mathrm{I} \frac{3}{4}$ inches $T$. angasi $27 \frac{1}{2}-31 \frac{1}{2}$ inches; $T$. spekei $20-36 \frac{3}{8}$ inches; $T$. strepsiceros $43-7 \mathrm{I} \frac{1}{2}$ inches. 
Tragelaphus SGRIPtus ornatus Pocock, I900.

1900. Tragelaphus scriptus ornatus Pocock, Ann. Mag. N.H. 5: 94. Linyanti, swamps of the Chobe, between Lake Ngami and the Zambezi, northern Bechuanaland. Range: Ngamiland to Angola, and eastwards to Nyasaland and Mashonaland, Southern Rhodesia.

\section{Tragelaphus spekei Sclater, I $864^{1}$}

Marshbuck or Sitatunga. Waterkoedoe

Distribution: South-West Africa, northern parts, the upper Okavango (west of the Kwito), the southern border of the western Caprivi, and the eastern Caprivi (Shortridge, 1934). Ngamiland. (Has been recorded from north-western Southern Rhodesia, and R. Ward quotes a specimen from Chinde, mouth of the Zambezi, Portuguese East Africa.) Angola. Northern Rhodesia (Zambezi and Kafue and their tributaries, to Lakes Bangweulu, Mweru, southern end of Lake Tanganyika, etc. (Shortridge) ). Has been recorded from Nyasaland. North of the limits of this work, in suitable localities in Tanganyika, Kenya, the Belgian Congo, Uganda, the southern Sudan, Nigeria, Gambia.

Tragelaphus Spekei spekei Sclater, i864. (Extralimital) I 864. Tragelaphus spekii Sclater in Spekes J. Discovery of Source of Nile, 223, footnote. Lake Lwelo, in Bukoba district (about $2^{\circ}$ S., $30^{\circ} 57^{\prime}$ E.), Tanganyika. See Moreau, Hopkins \& Hayman, I 946, 44I.

Tragelaphus SPekei selousi Rothschild, I 898

I898. Tragelaphus selousi Rothschild, Novit. Zool. 5: 206. Zambezi Valley (according to Roberts, from the Lake Ngami swamps).

I86I. Tragelaphus eurycerus Layard, Cat. Mamm. S. Afr. Mus. (N.V., fide Roberts). Not of Ogilby, I 837

1903. Limnotragus baumii Sokolowsky in Baum, Kunene-Sambesi Exped. 533. Cuito (= Kwito) River, below the Longa (approximately $17^{\circ}$ S., $20^{\circ}$ E.), south-eastern Angola.

Tragelaphus spekei inornatus Cabrera, igi 8

I918. Limnotragus spekei inornatus Cabrera, Bol. Soc. Esp. H.N. I8: 276. Lake Young, eastern Northern Rhodesia.

Tragelaphus angasi Gray, I 849

Inyala; Nyala. Nyalabosbok

Distribution: the Kruger National Park, Transvaal (districts of Punda Maria and Shingwedzi; very common at Pafuri, northwards from Punda Maria; sometimes known from the southern parts of the Reserve); Zululand (St. Lucia district and according to Roberts, introduced into the Hluhluwe Game Reserve). Portuguese East Africa; Nyasaland.

Tragelaphus angasi Gray, i849

1849. Tragelaphus angasii Gray in Angas, P.Z.S. I848: 89. St. Lucia Bay, Zululand, Natal.

${ }^{1}$ This species is often separated subgenerically as Limnotragus, but see Hopkins, I949, P.Z.S. I I9: 526. 
Tragelaphus strepsiceros Pallas, i 766

Kudu. Koedoe

Distribution: in the Union, the Kruger National Park, Transvaal, where common (districts of Punda Maria, Shingwedzi, Letaba, Satara, Skukuza, Toulon, etc.). Zululand, and Giants Castle Reserve, Natal. In the Cape Province, reported to occur still in the Uitenhage district (but evidently not the Addo Bush), and on private property in the Prince Albert and Riversdale districts, and according to Hewitt (I93I) the Albany district. There are a few introduced Kudu at De Beers, west of Kimberley, and, it is said, on one of the farms near Graaff Reinet. On private property in Swaziland (Roberts.) South-West Africa; recorded by Shortridge (1934) throughout South-West Africa, where suitable cover exists, except the coastal part of the Namib desert, and southwards to Warmbad; that author said that Kudu occur sparsely along the Orange River, to as far east as the Aughrabies Falls (we do not know their present status in that region). The Kalahari Gemsbok National Park? Southern Rhodesia, Portuguese East Africa, Bechuanaland. Angola, Northern Rhodesia, Nyasaland. Thence northwards to Somaliland and the Sudan, but rare in West Africa although known from the Chad Territory, French Congo.

Tragelaphus strepsiceros strepsigeros Pallas, i 766

I 766. Antilope strepsiceros Pallas, Misc. Zool., 9. Cape of Good Hope. ("Gammafluss", Matschie, I9I4.)

I 834. Strepsiceros capensis A. Smith, S. Afr. J. 2: 223. South Africa.

I836. Strepsiceros koodoo H. Smith, Jardine's Naturalists Libr. I2: I 80. "Woody parts of Caffraria and the Karoo Mountains", South Africa.

I843. Strepsiceros kudu Gray, List Spec. Mamm. B.M., I55.

I846. Strepsiceros excelsus Sundevall, K. Svenska Vetensk. Akad. Handl. I844: I96. Africa south of the Sahara.

1894. Strepsiceros strepsiceros zambesiensis Lorenz, Ann. Naturh. Hofmus. Wien. 9: Notizen, 63. Leschumo Forest, south-eastern border of Marutseland and north-western Matabeleland.

"Lancaster writes 'This is obviously Leshuma on the old waggon road from Tati to Kasungula on the Zambezi R. at the Chobi R. mouth, about I 5 miles from Kasungula (about I $7^{\circ} 44^{\prime}$ S., $25^{\circ}$ I $9^{\prime}$ E.) just inside the Bechuanaland Protectorate'." (Moreau, Hopkins \& Hayman, I946.)

I910. Strepsiceros capensis typicus Lydekker in Ward, Rec. Big Game, 6: 3 I9.

I9I4. Strepsiceros hamiltoni Matschie, S.B. Ges. Naturf. Fr. Berlin, 387. New name for Damalis strepsiceros H. Smith, not Antilope strepsiceros Pallas. Sources of the Gariep or Orange River.

\section{Genus TAUROTRAGUS Wagner, I 855}

I855. Taurotragus Wagner in Schreber, Säugth. Suppl. 5: 438. Antilope oreas Pallas = Antilope oryx Pallas ( I 766).

1822. Oreas Desmarest, Encycl. Méth. Mamm. 47 I. Antilope oreas Pallas = Antilope oryx Pallas. Not of Hübner, i 806. 
TAurotragus [contd.]

I850. Euryceros Gray, Gleanings Menagerie Knowsley Hall, 2: 27. Antilope eurycerus Ogilby. Not of Lesson, I830.

I89. Doratoceros Lydekker, The Field, London, 78: I30. Antilope triangularis Günther = Antilope oryx Pallas.

I 894. Orias Lydekker, Royal Nat. Hist. 2: 267.

I902. Boocercus Thomas, Ann. Mag. N.H. IO: 309. Renaming of Euryceros Gray. Valid as a subgenus.

I905. Boocerus Trouessart, Cat. Mamm. Viv. Foss. Suppl. 73 I.

\section{Subgenus TAUROTRAGUS Wagner, I 855}

\section{Taurotragus oryx Pallas, i 766}

Eland. Eland

Distribution: survives in the Union in the northern parts of the Kruger National Park, Transvaal (north of the Olifants River), and in the Giants Castle Reserve, Natal. (A few specimens have been reintroduced into the Cape Point reserve, south of Cape Town.) South-West Africa; according to Shortridge (I934) south about to the Tropic of Capricorn, sometimes wandering to as far south as latitude $24^{\circ} \mathrm{S}$. along the Nosob River; northwards to the Caprivi, and the Kaokoveld-Ovamboland border (not occurring much to the west of a line between the Rua Cana Falls, Cunene and the Nosob River region in the south). Bechuanaland, Ngamiland, the northern Kalahari. Parts of Southern Rhodesia, and western Portuguese East Africa. Northern Rhodesia, Nyasaland. Angola. Beyond the limits of this work, Tanganyika, Kenya to the southern Sudan, with a closely-allied form (?group of subspecies) from the Bahr-el-Ghazal, Chad district, and Senegal.

\section{TAurotragus oryx oryx Pallas, i 766}

I 766. Antilope oryx Pallas, Misc. Zool. 9. Cape of Good Hope.

I 777. Antilope oreas Pallas, Spic. Zool. pt. I 2: i 7. Mountains of South Africa.

I792. Bos barbatus Kerr, Anim. Kingd., 340. "Country of the Namaques" north from the Cape of Good Hope.

I8 i6. Cemas alces Oken, Lehrb. Naturgesch. 3, 2: 735. "South Africa, especially to the east of the Cape of Good Hope." (Unavailable.)

I827. Damalis canna H. Smith, Griffith's Cuvier Anim. Kingd. 4: 357. "Beyond the Gareep [= the Orange River], upon the Great Desert," South Africa. (This is the first use of the name in a technical sense; Desmarest, I 822, Enc. Meth. Mamm. 2: 47 I is a vernacular name.)

I889. Antilope triangularis Günther, The Field, London, 73: 260. I889, P.Z.S. 74 . The Zambezi. Based on the abnormal horns of a female $T$. oryx.

I 899. Taurotragus oryx typicus Selous in Bryden, Great and Small Game of Africa, 426.

TAurotragus ORYX Livingstonei Sclater, I 864

I864. Oreas livingstonii Sclater, P.Z.S. I 05. Left bank of the Zambezi River, near the Kafue, Northern Rhodesia. (Near Sekhosi, Zambezi River, upstream from Sesheke, about I I 5 miles north-west of Victoria Falls, Northern Rhodesia; Harper, I 940, J. Mamm. 21: 33 I.) 
I9I2. Oreas oreas kaufmanni Matschie, Deutsche Jäger-Zeitung, 58: I I9. Caprivi Zipfel, South-West Africa.

I9I3. Oreas oryx niediecki Matschie, S.B. Ges. Naturf. Fr. Berlin, 249. Banga, Kafue River (Mashukulumbwe Country), Northern Rhodesia.

Range includes Nyasaland and Angola.

TAUROTRAGUS ORYX SELOUSi Lydekker, IgIo

I9 10. Taurotragus oryx selousi Lydekker in Ward, Records Big Game, 6: 328. Rugawé Valley, Mashonaland, eastern Southern Rhodesia.

\section{Genus SYNGERUS Hodgson, I 847}

I 847. Syncerus Hodgson, J. Asiat. Soc. Bengal, I6: 709. Bos brachyceros Gray = Bos nanus Boddaert (Hollister, I9I I, Proc. Biol. Soc. Washington, 24: I92).

1872. Planiceros Gray, Cat. Ruminant Mamm. B.M., io. Bos planiceros Blyth = Bos nanus Boddaert.

1872. Synceros Gray, loc. cit. 12. Bubalus caffer Gray = Bos caffer Sparrman.

Lydekker (1913) separated the Buffaloes from the typical Oxen, Yak, Bison, etc., by stating that the horns were triangular, or partly so, in section in the Buffaloes, but oval or circular in section in the Oxen. He referred all Buffaloes to Bubalus (which antedates Syncerus) and distinguished the African Buffaloes (Syncerus) by their large and heavily-fringed ears, their relatively shorter and broader skulls, and by the fact that the vomer is free from the palatines.

Syncerus caffer Sparrman, I 779

African Buffalo. Buffel

Distribution: in the Union survives in the Kruger National Park, Transvaal (districts of Shingwedzi, near Crocodile River in the Skukuza region where it occurs in large numbers), Toulon, etc., Zululand, and the Addo Bush (near Port Elizabeth). Portuguese East Africa, recorded from districts of Beira, Gazaland, Lourenço Marques, etc. Southern Rhodesia, Ngamiland. In South-West Africa the central and eastern Caprivi, and irregularly migratory into the extreme north-west of Grootfontein district and the north-east of Ovamboland (Shortridge). Northern Rhodesia, Nyasaland. Angola (the typical race locally south of the Cuanza River and said to be greatly reduced in number; $S$. c. nanus in the northern districts (recorded in 1935 from $150 \mathrm{~km}$. east of Loanda) ). Beyond the limits of this work, northwards to the Sudan and Abyssinia, westwards to Senegal.

See Christy, I 929, P.Z.S., 445 for a review of this species.

Syncerus Gaffer Gaffer Sparrman, I 779

I 779. Bos caffer Sparrman, K. Svenska Vetensk. Akad. Handl. 40: 79. Near Sundays River, Algoa Bay, eastern Cape of Good Hope.

I898. Bos caffer typicus Lydekker, Wild Oxen, Sheep and Goats of all Lands, 97. 1906. Bubalus gariepensis Matschie, S.B. Ges. Naturf. Fr. Berlin, i66. Liqua Valley (= Vaal River, Roberts). 
SyNGerus GAFFER CAFFer [contd.]

I906. Bubalus limpopoensis Matschie, loc. cit. I67. Limpopo Valley.

I906. Bubalus wiesei Matschie, loc. cit. I68. North of the Zambezi between the Loangwa and the Revugu.

I9 о. Bubalus caffer cunenensis Zukowsky, Zool. Beobachter, 5I: 266. Benguela district, Angola.

I9 10. Bubalus caffer cubangensis Zukowsky, loc. cit. Benguela district, Angola.

I918. Bubalus gazae Matschie, S.B. Ges. Naturf. Fr. Berlin, I36. Lebombo Mountains, southern Gazaland, extreme southern Portuguese East Africa.

I9 8. Bubalus pungwensis Matschie, loc. cit. I36. Beira, Portuguese East Africa.

I9ı. Bubalus niediecki Matschie, loc. cit. I38. Baunza, north of middle Kafue, about $33 \mathrm{~km}$. east of where the river turns east, north of Victoria Falls, Northern Rhodesia.

I929. Bubalus niediecus Christy, P.Z.S. 459. (For niediecki.)

Syncerus GAFfer NANus Boddaert, I 785. Dwarf Forest Buffalo

I 785. Bos nanus Boddaert, Elench. Anim. I: I52. "Morocco" doubtless brought from Equatorial West Africa (Christy).

1827. Bos pegasus H. Smith, Griffith's Cuv. Anim. Kingd. 4: 386. Angola.

ı906. Bubalus mayi Matschie, S.B. Ges. Naturf. Fr. Berlin, I7 I. Bengo, Loanda, Angola.

Considered a valid species by Christy and G. Allen, a race of caffer by Hill \& Carter.

\section{ORDER L A G O MOR P H A}

Like the Rodentia (below) but jaw muscles less specialized, the masseter muscles not modifying the region of the infraorbital foramen, and the ascending ramus of the mandible is straight, not curved as in the Rodentia. Palate usually much shortened. There is a second, vestigial, upper incisor placed behind the enlarged front one. Cheekteeth rootless and simple. In South Africa (family Leporidae), medium-sized mammals combining very long ears and short tail, and skull with large postorbital processes.

\section{FAMILY L E P O R I D A E}

For a comparison of all genera and species of European, Asiatic and African Leporidae see Ellerman \& Morrison-Scott, Checklist Palaearctic and Indian Mammals, 4i 9 , key, 424 .

Mesopterygoid region narrow, the width of space immediately behind palate much shorter than the least longitudinal diameter of palatal bridge (palatal bridge averages more than I 40 per cent of mesopterygoid width just mentioned).

Genus PRONOLAGUS, page 2 I 9

Mesopterygoid region wider; the width of space immediately behind palate a little shorter than, or subequal to, but most often longer than length of palatal bridge (which averages less than I 30 per cent, usually less than I 20 per cent. of mesopterygoid width).

Genus LEPUS, page 2 I 3 
Genus LEPUS Linnaeus, I $75^{8}$

I 758. Lepus Linnaeus, Syst. Nat. Ioth ed. 1 : 57. Lepus timidus Linnaeus, from Sweden. 1867. Eulagos Gray, Ann. Mag. N.H. 20: 222. Lepus mediterraneus Wagner, the Sardinia race of Lepus capensis Linnaeus.

1929. Bunolagus Thomas, P.Z.S. I09. Lepus monticularis Thomas.

I. Tail wholly brown. (Skull length less than $80 \mathrm{~mm}$.)

Tail normally clearly contrasted black and white above.

Lepus monticularis, page 2 I 8

2. Larger animals; always averaging larger in size of skull than members of the capensis group where the two groups occur together. South of the Sahara (in British Museum material) the occipitonasal length averages about $86 \mathrm{~mm}$. and more.

Smaller animals; always averaging smaller in size of skull than members of the europaeus group where the two groups occur together. South of the Sahara (in British Museum material) the occipitonasal length averages $85 \mathrm{~mm}$. and less. ${ }^{1}$

3. Palate usually clearly longer than mesopterygoid space immediately behind it.

Lepus whytei, page 2 I 6

Palate averages shorter than mesopterygoid space immediately behind it, or only a little longer (under I Io per cent with a few individual exceptions).

Lepus europaeus, page 2 i 6

4. Palate normally exceeds width of mesopterygoid space immediately behind it. Bullae large, their length $\mathrm{I} 2.7 \mathrm{~mm}$. and more.

Lepus salai, page 2 I 5

Palate normally shorter than mesopterygoid space immediately behind it (the sole exception being L. capensis aquilo, Portuguese East Africa), which has distinctly smaller bullae than salai, their length I I.5 mm. and less (and has a smaller skull than $L$. whytei).

Lepus capensis, page 2 I 3

\section{Subgenus LEPUS Linnaeus, I $75^{8}$}

Lepus capensis Linnaeus, I $75^{8}$

Cape Hare. Kaapse Vlakhaas; Rooipootjie

Distribution: in the Union, Transvaal; Potchefstroom, Pretoria, Pietersburg, Ermelo, Woodbush, Wakkerstroom, etc. Near Kroonstad, and other localities, Orange Free State. In the Cape Province, Vryburg, Fourteen Streams, Little

${ }^{1}$ It may be that Roberts measured his skulls in a slightly different way from the method which gave the above results. North of the Sahara the average minimum for europaeus is about $88 \mathrm{~mm}$., and the average maximum for capensis is about $87 \mathrm{~mm}$. Roberts' results agree more with these figures. Thus in his specimens of europaeus from the Union there is only one specimen below $89 \mathrm{~mm}$., whereas in his capensis this figure is only exceeded in three individuals and $89.7 \mathrm{~mm}$. is the maximum. Roberts' figures for L.europaeus herero are below the figures quoted above for $L$. europaeus, but the British Museum has nineteen skulls for this race, which give an average of $88 \mathrm{~mm}$. in occipitonasal length. 
Namaqualand (Steinkopf district, Port Nolloth, the Kamiesberg), near Lamberts Bay, Eendekuil, Vredendal, near Cape Town, Oudtshoorn, Albany, Calvinia, Deelfontein, Burghersdorp, Hanover, Middleburg, Graaff Reinet. (A hare occurs in the Kruger National Park (Shingwedzi, Toulon), near Wepener (Orange Free State), near Springbok (Little Namaqualand), west of Kimberley, and near Matjesfontein, but it was not ascertained whether they were capensis or europaeus.) South-West Africa; Great Namaqualand, Damaraland and the Namib desert (Shortridge (1934) said it had not been recorded north of $20^{\circ} \mathrm{S}$.) The Kalahari and parts of Bechuanaland. Inhambane district, Portuguese East Africa. Reported from Northern Rhodesia. North of the limits of this work, the Belgian Congo, virtually throughout East Africa, the Gold Coast, northern Nigeria, Senegal; Morocco, Algeria, Egypt; Spain, Sardinia; much of Asia from Palestine and north-western Arabia to Kashmir, the plains of Russian Asia, and thence to Mongolia and China (mainly north of the Yangtse River) (for Asiatic details see Ellerman \& Morrison-Scott, I95I).

LePUS CAPENSIS GAPENSIS Linnaeus, I $75^{8}$

I 758. Lepus capensis Linnaeus, Syst. Nat. Ioth ed. I: 58. Cape of Good Hope.

1826. Lepus arenarius I. Geoffroy, Dict. Class. H.N. 9: 383. "Dans les sables du pays des Hottentots."

I86o. Lepus capensis var. major Grill, K. Svenska Vetensk. Akad. Handl. (2) 2: No. Io, I9. Roodeval, Karroo (in Oudtshoorn district?).

The range of this race is given by Roberts as the western Cape Province from near Cape Town to the Olifants River (and eastwards to Oudtshoorn if major Grill is a synonym).

LEPUS GAPENSIS OGHROPUS Wagner, I 844

1844. Lepus ochropus Wagner in Schreber, Säugth. Suppl. 4: 96. "Cape of Good Hope." Range: southern Transvaal (to Pretoria) and northern Orange Free State, southwards to Ventersburg and Fauresmith.

Lepus Gapensis centralis Thomas, I903

1903. Lepus capensis centralis Thomas, Ann. Mag. N.H. 12: 344. Deelfontein, north of Richmond, Cape Province. Range: the central Karroo, from Deelfontein to Albany district.

Lepus Gapensis GRANTI Thomas \& Schwann, I904

1904. Lepus capensis granti Thomas \& Schwann, Abstr. P.Z.S. No. 2, 6: P.Z.S. I: I82. Port Nolloth, Little Namaqualand. Range includes the plateau around Calvinia, western Cape Province.

Lepus Capensis aQuilo Thomas \& Wroughton, I907

1907. Lepus capensis aquilo Thomas \& Wroughton, P.Z.S. 297. Coguno, Inhambane district, southern Portuguese East Africa. 
Lepus Gapensis kalaharicus Dollman, igio

i9io. Lepus ochropus kalaharicus Dollman, Ann. Mag. N.H. 6: 400. Lehutitung, Kalahari, Bechuanaland. Ranges to northern Great Namaqualand and eastern Damaraland.

Lepus Gapensis NARRAnus Thomas, 1926

1926. Lepus capensis narranus Thomas, P.Z.S., 309. Rooibank, Kuiseb River, near Walvis Bay, South-West Africa.

Lepus Gapensis mandatus Thomas, 1926

1926. Lepus capensis mandatus Thomas, P.Z.S., 309. Berseba (north-west of Keetmanshoop), Great Namaqualand, South-West Africa.

LEPUS GAPENSIS OCHROPOIDES Roberts, I 929

1929. Lepus capensis ochropoides Roberts, Ann. Transv. Mus. I3: I2 I. Burghersdorp, eastern Cape Province.

LEPUS CAPENSIS VERNAYI Roberts, $193^{2}$

I932. Lepus capensis vernayi Roberts, Ann. Transv. Mus. 15: I3. Geluk, south-west of Kroonstad, Orange Free State. Range includes the north-western Orange Free State, to Hoopstad district.

Lepus CAPENSIS ERMELOensis Roberts, I932

1932. Lepus capensis ermeloensis Roberts, Ann. Transv. Mus. I5: I4. Ermelo, southeastern Transvaal. Range includes Carolina and Wakkerstroom districts, south-eastern Transvaal.

LePUS GAPENSIS HARTENSIS Roberts, I 932

1932. Lepus capensis hartensis Roberts, Ann. Transv. Mus. 15: I4. Fourteen Streams, Cape Province. (This locality is on the Vaal River, on the Cape Province side of the border, and near where the Transvaal, Orange Free State and Cape Province meet.) Ranges northwards to the Molopo River.

LEPUS GAPENSIS BEDFORDI Roberts, I932.

1932. Lepus capensis bedfordi Roberts, Ann. Transv. Mus. 15: I4. Kalkbank, Pietersburg district, northern Transvaal.

Lepus Gapensis LANGi Roberts, I 932

1932. Lepus capensis langi Roberts, Ann. Transv. Mus. I5: I 5. Nkate River, northern Bechuanaland.

Lepus salai Jentink, I 880 Sala's Hare

Distribution: south-western desert district of Angola.

Lepus SAlai Jentink, I88o

I880. Lepus salae Jentink, Notes Leyden Mus. 2: 57. Mossamedes, south-western coast of Angola. 
Lepus whytei Thomas, I894

Whyte's Hare

Distribution: Nyasaland; the Petauke district, Northern Rhodesia; Cabaceira, northern Portuguese East Africa; Tanganyika.

Lepus WhyteI Thomas, I 894

I894. Lepus whytei Thomas, P.Z.S. I42. Palombi River, Shirwa plain, borders of Mlanje and Zomba districts, $15^{\circ} 35^{\prime}$ S., $35^{\circ} 35^{\prime}$ E., circa 2,00o ft., southern Nyasaland.

Lepus europaeus Pallas, 1778

(In South Africa) Southern Bush or Scrub Hare. Ribbokhaas; Kolhaas

Distribution: in the Union, Transvaal; districts of Potchefstroom, Wolmaransstad, Rustenburg, Bloemhof, Klein Letaba, Sabi River, Woodbush, Barberton, Legogot (near White River), Wakkerstroom, Carolina. Natal, including Estcourt and Zululand. Rouxville, Hoopstad and other localities, Orange Free State. In the Cape Province, Vryburg, Louisvale (near Upington), Little Namaqualand (near Steinkopf, the Kamiesberg), Van Rhynsdorp, Clanwilliam, Lamberts Bay, near Cape Town, Bredasdorp, Knysna, Albany, King William's Town, Grahamstown, Uitenhage, Middelburg, Murraysburg, Deelfontein, etc. Swaziland. South-West Africa, throughout, from the Orange River to the Caprivi (Shortridge). Northern Bechuanaland, Ngamiland and Gaberones in south-eastern Bechuanaland. Southern Rhodesia, where evidently quite widely distributed. West of Beira, Portuguese East Africa. Northern Rhodesia (Sesheke district). Probably throughout most of Angola except in true desert. Beyond the limits of this work, through much of East Africa, northwards to the southern Sudan and Eritrea; Europe south of the Baltic, Britain included, Asia Minor, Persia, Palestine, Cyprus and Transuralia.

Lepus europaeus europaeus Pallas, i 778 . (Extralimital)

I778. Lepus europaeus Pallas, Nov. Sp. Quad. Glir. Ord. 30. Burgundy, France.

Lepus europaeus saxatilis F. Cuvier, 1823

I823. Lepus saxatilis F. Cuvier, Dict. Sci. Nat. 26: 309. Cape of Good Hope.

I829. Lepus rufinucha A. Smith, Zool. J. 4: 440. "Rocky and mountainous situations in South Africa."

(1837. Lepus longicaudatus Gray, Mag. N.H.J. Zool. I: 586. "Magellan Land" but doubtless South Africa (G. Allen).)

I 844. Lepus fumigatus Wagner in Schreber, Säugth. Suppl. 4: 98. "Kaffernland."

Range, according to Roberts: Knysna to the Cape Peninsula, thence northwards to

Van Rhynsdorp, Cape Province.

Lepus europaeus ANGOlensis Thomas, I904

1904. Lepus angolensis Thomas, Ann. Mag. N.H. I3: 420. Ambaca, 800 m., northern Angola.

1905. Lepus ansorgei Thomas \& Wroughton, Ann. Mag. N.H. I6: i 76. Caiala, near Bihé, central Angola. 
1933. Lepus angolensis meridionalis Monard, Bull. Soc. Sci. Nat. Neuchâtel, 57: 6r. Rio Mbalé, Vila da Ponte, and Caquindo, all in the Kubango region, south-eastern Angola.

In I95 I we treated this as a race of $L$. capensis because the two measurable skulls in the British Museum agree in size with that species; but Hill \& Carter state that the average for eleven specimens is $87 \mathrm{~mm}$., so it is here transferred to L. europaeus.

Lepus europaeus zuluensis Thomas \& Schwann, ig05

I905. Lepus saxatilis zuluensis Thomas \& Schwann, P.Z.S. I: 270. Umfolosi, Zululand, Natal. The range includes eastern and northern Transvaal.

Lepus europaeus megalotis Thomas \& Schwann, ig05

1905. Lepus saxatilis megalotis Thomas \& Schwann, P.Z.S. I: 271. Klipfontein, north of Steinkopf, Little Namaqualand, north-western Cape Province. The range includes the Upper Karroo, as far east as Murraysburg.

Lepus europaeus micklemi Chubb, igo8

I908. Lepus zuluensis micklemi Chubb, Ann. Mag. N.H. I: 466. Bulawayo, Southern Rhodesia. Range: highlands of Southern Rhodesia from Plumtree and Wankie eastwards to the Birchenough Bridge (Melsetter district).

LePUS EURopaeus SUbRUfus Roberts, I9I 3

I9I3. Lepus zuluensis subrufus Roberts, Ann. Transv. Mus. 4: Ioo. Wakkerstroom, south-eastern Transvaal. Ranges westwards to Potchefstroom, Rustenburg, Wolmaransstad, etc., in the western Transvaal.

Lepus europaeus gungunyanae Roberts, I9I4

I9I4. Lepus gungunyanae Roberts, Ann. Transv. Mus. 4: I84. Jabwielu, between Bubye and Nuanetsi Rivers, Southern Rhodesia. Apparently based on young specimens.

Lepus europaeus aURANti Thomas \& Hinton, I 923

1923. Lepus saxatilis aurantii Thomas \& Hinton, P.Z.S. 497. Louisvale (opposite Upington, south bank of Orange River), north-western Cape Province. Ranges through Great Namaqualand to Rehoboth district, South-West Africa.

Lepus Europaeus herero Thomas, I926

1926. Lepus capensis herero Thomas, P.Z.S. 308 (29th April). Lukualukasi, Ovamboland, South-West Africa. Range: "Ovamboland and Kaokoveld, southwards to Eronga mountain in Omaruru district, eastwards through Grootfontein district, and southwards through the dry Kalahari Desert" (Roberts).

Lepus eURopaeus DamaRensis Roberts, I 926

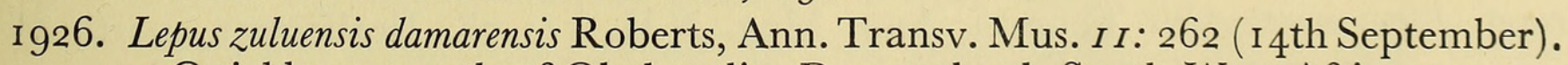
Quickborn, north of Okahandja, Damaraland, South-West Africa. 
Lepus EUROPAEUS CHIVERSI Roberts, I929

1929. Lepus saxatilis chiversi Roberts, Ann. Transv. Mus. I3: I I9. Rouxville, southern Orange Free State.

Lepus europaeus bechuanae Roberts, 1932

1932. Lepus saxatilis bechuanae Roberts, Ann. Transv. Mus. I5: 12. Gaberones (near the Transvaal border) south-eastern Bechuanaland. Roberts also quoted this form from Zeerust, north-western Transvaal.

Lepus europaeus NGamiensis Roberts, $193^{2}$

1932. Lepus saxatilis ngamiensis Roberts, Ann. Transv. Mus. 15: 12. Maun, Ngamiland, northern Bechuanaland.

Lepus europaeus chobiensis Roberts, I932

1932. Lepus saxatilis chobiensis Roberts, Ann. Transv. Mus. 15: 12. Kabulabula, Chobe River, northern Bechuanaland.

Lepus eURopaeus albaniensis Roberts, 1932

1932. Lepus saxatilis albaniensis Roberts, Ann. Transv. Mus. 15: 12. Kleinpoort, Fish River Valley, Albany district, eastern Cape Province. Ranges to King William's Town, and inland to Middelburg, Cape Province.

LePUS EUROPAEUS NIGRESCENS Roberts, I932

1932. Lepus saxatilis nigrescens Roberts, Ann. Transv. Mus. 15: I3. Vila Pery, west of Beira, southern Portuguese East Africa.

LEPUS EUROPAEUS KHANENSIS Roberts, I946

1946. Lepus saxatilis khanensis Roberts, Ann. Transv. Mus. 20: 324. Onguati Farm, the foot of Eronga Mountain, Khan River, near Karibib, South-West Africa.

LePus eUROPAEUS ORANGensis Kolbe, I 948

1948. Lepus saxatilis orangensis Kolbe, Ann. Transv. Mus. 21: 71. Beestekraal, Hoopstad district, north-western Orange Free State.

Lepus monticularis Thomas, 1903

Bushman Hare. Vleihaas

Distribution: known from Deelfontein and the region east of Calvinia in the Karroo district of central Cape Province.

LePUS MONTIGULARIS Thomas, I903

1903. Lepus monticularis Thomas, Ann. Mag. N.H. II: 78. Deelfontein, north of Richmond, Cape Province. 


\section{Genus PRONOLAGUS Lyon, I904}

I 904. Pronolagus Lyon, Smithson. Misc. Coll. 45: 4i 6. Lepus crassicaudatus I. Geoffroy. I932. Poëlagus St. Leger, P.Z.S. i I 9. Lepus marjorita St. Leger, from Uganda. Valid as a subgenus.

Roberts is of opinion that the name crassicaudatus Geoffroy was based on the large eastern species formerly called $P$. ruddi. This is accepted, and consequently $P$. rupestris A. Smith, I834, seems the prior name for the smaller species.

I. Occipitonasal length of skull usually below $80 \mathrm{~mm}$. (the largest skull quoted by Roberts is $84.6 \mathrm{~mm}$.). (Bullae not very reduced.)

Pronolagus rupestris, page 22 I

Occipitonasal length rarely below $85 \mathrm{~mm}$. (only one skull quoted by Roberts is under $87 \mathrm{~mm}$.).

2. Bullae very small; normally less than one tenth of the occipitonasal length.

Pronolagus crassicaudatus, page 2 I 9

Bullae more normal, more than one tenth of the occipitonasal length on average.

Pronolagus randensis, page 220

Subgenus PRONOLAGUS Lyon, I904

Pronolagus crassicaudatus I. Geoffroy, 1832

Natal Red Hare. Natalse Rooihaas

Distribution: Natal, including Durban, Dargle, Zululand; Legogot (near White River) south-eastern Transvaal, the eastern Cape Province, Albany district, the Amatola Mountains (near Stutterheim), Griqualand East and Bathurst district.

Pronolagus grassigaudatus grassicaudatus I. Geoffroy, I8 32

I832. Lepus crassicaudatus I. Geoffroy, Mag. Zool. Paris, 2: cl. I, pl. 9 and text. "Port Natal" (= Durban), Natal.

Pronolagus grassicaudatus Ruddi Thomas \& Schwann, igo5

I905. Pronolagus ruddi Thomas \& Schwann, Abstr. P.Z.S., No. I8, 23: P.Z.S. I: 272. Sibudeni (about 20 miles north-west of Eshowe), Zululand. Ranges to Legogot, south-eastern Transvaal.

Pronolagus Grassicaudatus kariegae Hewitt, 1927

1927. Pronolagus ruddi kariegae Hewitt, Rec. Albany Mus. 3: 433. Kariega River, Bathurst district, eastern Cape Province. Probable range includes Griqualand East and Albany district.

Pronolagus (?) Grassicaudatus bowkeri Hewitt, i 927

1927. Pronolagus crassicaudatus bowkeri Hewitt, Rec. Albany Mus. 3: 437. Gaika's Kop, Amatola Mountains, near Stutterheim, eastern Cape Province. 
Pronolagus Grassicaudatus lebombo Roberts, 1936

1936. Pronolagus ruddi lebomboensis Roberts, Ann. Transv. Mus. I8: I73. Misspelling of lebombo, but a nomen nudum.

1936. Pronolagus ruddi lebombo Roberts, Ann. Transv. Mus. I 8: 240. Ubombo, Lebombo Mountains, north-eastern Zululand, Natal.

Pronolagus randensis Jameson, 1907

Rand Red Hare. Johannesburgse Rooihaas

Distribution: the Transvaal, from Parys (extreme northern Orange Free State) to the Zoutpansberg, including Rustenburg district, Johannesburg, Potgietersrust, etc. (There is said to be a Pronolagus at Shingwedzi, Kruger National Park.) North of the Union, Gaberones in south-eastern Bechuanaland; South-West Africa, from Damaraland to Grootfontein, the Kaokoveld, etc.

Pronolagus Randensis Randensis Jameson, igo7 1907. Pronolagus ruddi randensis Jameson, Ann. Mag. N.H. 20: 404. Observatory, Johannesburg, Transvaal. Range: from Parys to Pretoria and westwards to Koster, Transvaal.

Pronolagus Randensis powelli Roberts, i 924 1924. Pronolagus randensis powelli Roberts, Ann. Transv. Mus. IO: 75. Rooikrans, Rustenburg district, western Transvaal. Ranges to Gaberones, southeastern Bechuanaland.

Pronolagus Randensis makapani Roberts, I924

1924. Pronolagus randensis makapani Roberts, Ann. Transv. Mus. Io: 75. Makapan's Caves, near Potgietersrust, northern central Transvaal.

Pronolagus RANDENSis GAPRIGornis Roberts, I 926

1926. Pronolagus randensis capricornis Roberts, Ann. Transv. Mus. II: 262. Newgate, on the Zoutpansberg above Wylie's Poort, northern Transvaal.

Pronolagus randensis gaucinus Thomas, 1929

1929. Pronolagus caucinus Thomas, P.Z.S. ıog. Karibib, roo miles N.W. of Windhoek, South-West Africa. Ranges to Windhoek.

Pronolagus Randensis ковosensis Roberts, 1938

1938. Pronolagus caucinus kobosensis Roberts, Ann. Transv. Mus. 19: 242. Kobos, south-west of Rehoboth, central South-West Africa.

Pronolagus (?) Randensis fitzsimonsi Roberts, 1938

1938. Pronolagus caucinus fitzsimonsi Roberts, Ann. Transv. Mus. 19: 242. Barby Farm, 25 miles west of Helmeringshausen, Great Namaqualand, South-West Africa.

Possibly a form of rupestris: based apparently on one specimen, the skull of which is smaller than is normal in randensis. 
Pronolagus Randensis Kaokoensis Roberts, I 946

I946. Pronolagus kobosensis kaokoensis Roberts, Ann. Transv. Mus. 20: 324. Kamanjab, Kaokoveld, northern South-West Africa.

Pronolagus rupestris A. Smith, I834

Smith's Red Hare. Smithse Rooihaas

Distribution: Natal, including Ladysmith and Estcourt; the Transvaal, near Wakkerstroom; Orange Free State, Boshof, Fauresmith, etc. In the Cape Province, Vryburg, the Aughrabies Falls, Louisvale (near Upington), Little Namaqualand (near Steinkopf, Springbok, the Kamiesberg), Klaver, Van Rhynsdorp, Clanwilliam, Wolseley, Grahamstown, Rosmead (near Middelburg), Deelfontein, etc. South-West Africa; there is a specimen in London from Great Brukaros Mountain, near Berseba, Great Namaqualand. Vumba, Southern Rhodesia. Nyasaland. (A Pronolagus has been recorded from Northern Rhodesia.) Beyond the limits of this work Kenya (and Swynnerton \& Hayman think there is a Pronolagus in Tanganyika).

Pronolagus Rupestris Rupestris A. Smith, i 834

I834. Lepus rupestris A. Smith, S. Afr. J. 2: I 74. "South Africa, rocky situations." Locality uncertain; Roberts thinks from near Van Rhynsdorp, western Cape Province, in which case mulleri will probably be a synonym.

Pronolagus Rupestris melanurus Rüppell, i 842

I842. Lepus melanurus Rüppell. Mus. Senckenberg. 3: I37. "Cape Colony"; type locality restricted to Klipfontein (north of Steinkopf), Little Namaqualand by Roberts, I95I.

Pronolagus Rupestris nyikae Thomas, igo2

I902. Oryctolagus crassicaudatus nyikae Thomas, Ann. Mag. N.H. IO: 244. Nyika Plateau, at 7,000 ft., northern Nyasaland.

Pronolagus RUPestris curryi Thomas, igo2

1902. Oryctolagus crassicaudatus curryi Thomas, Ann. Mag. N.H. Io: 245. Boshof, western Orange Free State. Range: western Orange Free State from Fauresmith and Boshof to Vryburg and probably Upington district, northern Cape Province.

Pronolagus rupestris saundersiae Hewitt, i 927

1927. Pronolagus crassicaudatus saundersiae Hewitt, Rec. Albany Mus. 3: 434. Albany district, eastern Cape Province. (Roberts gives the type locality as Grahamstown, and suggests the Deelfontein specimens may belong with this race.)

Pronolagus Rupestris australis Roberts, i 933

I933. Pronolagus crassicaudatus australis Roberts, Ann. Transv. Mus. I5: 270. Clanwilliam, western Cape Province. Ranges southwards to Wolseley. 
Pronolagus RUPestris mulleri Roberts, I938

1938. Pronolagus crassicaudatus mulleri Roberts, Ann. Transv. Mus. 19: 243. Klaver, western Cape Province.

Pronolagus RUPestris Whitei Roberts, 1938

1938. Pronolagus whitei Roberts, Ann. Transv. Mus. 19: 244. Vumba (south of Umtali), eastern Southern Rhodesia.

Pronolagus RUPestris barretti Roberts, i 949

1949. Pronolagus barretti Roberts, Ann. Transv. Mus. 21: I 79. Near Matiwane, Ladysmith, Natal. Probably also this race ranges to Wakkerstroom district, south-eastern Transvaal.

\section{ORDER R O D E N T I A}

Small to medium-sized mammals with brain of rather primitive type, the first upper and lower incisors rootless and enlarged, the other front teeth being absent; a long space separates the incisors from the cheekteeth. Fingers and toes normally with claws. Palate well developed. Jaw muscles highly specialized for gnawing, the ascending ramus of the mandible not straight, the masseter muscles reaching and modifying the region of the infraorbital foramen in the skull. The pollex mostly (though not invariably) vestigial. The diet mainly vegetarian.

On this Order see:

Tullberg, 1899, Ueber das System der Nagethiere, Nova Acta Reg. Soc. Sci. Upsaliensis, I8, I.

Ellerman, The Families and Genera of Living Rodents, I940, I; I94I, 2; and I949, 3.

Miller \& Gidley, I9I8, Synopsis of the supergeneric groups of Rodents, $\mathcal{F}$.

Washington Acad. Sci. 8, I3: 43 I.

Some previous classifications of the Rodents which occur in South Africa:

TUllberg, I 899

Tribus: HYSTRIGOGNATHI

Subtribus: BATHYERGOMORPHI

Subtribus: HYSTRICOMORPHI

Family: Bathyergidae.

Family: Hystricidae.

Family: "Aulacodidae" = Thryonomyidae.

Family: Petromyidae.

Tribus: SGIUROGNATHI

Subtribus: MYOMORPH I

Sectio: ANOMALUROIDEA

Family: Anomaluridae.

Family: Pedetidae. 


\section{RODENTIA}

Sectio: MYOIDEA

Subsectio: "Myoxiformes"

Family: "Myoxidae" = Muscardinidae.

Subsectio: Muriformes

Family: Cricetidae (but South African genus not dealt with).

Family: Muridae.

Subfamily: Murini (included Dendromus and Steatomys).

Subfamily: Otomyini.

Family: Gerbillidae.

Subtribus: SGIUROMORPHI

Family: Sciuridae.

Miller \& Gidley, igi 8

Superfamily: SCIUROIDAE

Family: Sciuridae

Superfamily: MUROIDAE

Family: Cricetidae.

Subfamily: Cricetinae.

Subfamily: Gerbillinae.

Family: Muridae.

Subfamily: Dendromyinae.

Subfamily: Murinae.

Subfamily: Otomyinae.

Superfamily: DIPODOIDAE

Family: Graphiuridae (Graphiurus only).

Family: Anomaluridae.

Family: Pedetidae.

Superfamily: BATHYER GOIDAE

Family: Bathyergidae.

Superfamily: HYSTRICOIDAE

Family: Hystricidae.

Family: Petromyidae.

Family: Thryonomyidae.

Ellerman, i 940

HYSTR I COMORPH I

Bathyergomorph Series

Superfamily: Bathyergoidae.

Family: Bathyergidae.

Hystricomorph Series

Superfamily: Hystricoidae.

Family: Echimyidae. ${ }^{1}$

Subfamily: Petromyinae.

Subfamily: Thryonomyinae.

Family: Hystricidae.

${ }^{1}$ Simpson, I945, prefers Octodontidae for this group. 
Ellerman, 1940 [contd.]

SGIUROGNATHI

Saiuromorph Series

Superfamily: Sciuroidae.

Family: Sciuridae.

Myomorph Series

Superfamily: Anomaluroidae.

Family: Anomaluridae.

Superfamily: Pedetoidae.

Family: Pedetidae.

Superfamily: Muroidae.

Family: Muscardinidae.

Subfamily: Graphiurinae.

Family: Muridae.

Subfamily: Murinae.

Subfamily: Dendromyinae.

Subfamily: Otomyinae.

Subfamily: Cricetinae.

Subfamily: Gerbillinae.

Simpson, I 945

Suborder: SGIUROMORPHA

Superfamily: Sciuroidea.

Family: Sciuridae.

?SCIUROMORPHA incertae sedis.

Superfamily: Anomaluroidea.

Family: Anomaluridae.

?ANOMALUROIDEA incertae sedis.

Family: Pedetidae.

Suborder: MYOMORPHA

Superfamily: Muroidea.

Family: Cricetinae.

Subfamily: Cricetinae.

Subfamily: Gerbillinae.

Family: Muridae.

Subfamily: Murinae.

Subfamily: Dendromurinae.

Subfamily: Otomyinae.

Superfamily: Gliroidea.

Family: Gliridae. ${ }^{1}$

Subfamily: Graphiurinae.

Suborder: HYSTRICOMORPHA

Superfamily: Hystricoidea.

Family: Hystricidae.

${ }^{1}$ Here called Muscardinidae. 
Superfamily: Octodontoidea.

Family: Thryonomyidae.

Family: Petromyidae.

?HYSTRICOMORPHA incertae sedis.

Superfamily: Bathyergoidea.

Family: Bathyergidae.

ROBERTS, I95 I

Suborder: HYSTRICOMORPHA

Family: Hystricidae.

Family: Thryonomyidae.

Family: Pedetidae. ${ }^{1}$

Family: Petromyidae.

Suborder: SCIUROMORPHA

Family: Sciuridae.

Suborder: DIPODOMORPHA

Family: Muscardinidae.

Suborder: BATHYERGOMORPHA

Family: Bathyergidae.

Subfamily: Bathyerginae.

Subfamily: Georychinae.

Suborder: MYOMORPHA

Family: Gerbillidae.

Family: Otomyidae.

Family: Muridae.

Subfamily: Cricetinae.

Subfamily: Saccostomurinae.

Subfamily: Cricetomyinae.

Subfamily: Dendromurinae.

Subfamily: Petromyscinae.

Subfamily: Murinae.

It is presumed that the characters given for his "suborders" are meant to be for forms south of the Zambezi-Cunene only, because north of that area his key to suborders would not hold for a moment. He has erected a subfamily for each of three aberrant Muridae, Cricetomys, Saccostomus and Petromyscus, but it is premature to accept classification of this nature, distinct as those three genera may be, until the whole subfamily Murinae is revised from all parts of the world.

Some American authors, and others, dislike referring the Thryonomyinae and Petromurinae to an otherwise South American family Octodontidae (or Echimyidae), on account of the fact that they feel African and South American genera cannot be closely allied. Thryonomys is a distinct genus and perhaps merits family rank, but the

${ }^{1}$ Follows Thomas, 1896 in placing Pedetidae among the Hystricomorpha (Anomaluridae not dealt with as extralimital to the region covered by him). 
same cannot be said of Petromus, which is essentially morphologically an Octodont, and these authors usually ignore the fact that if Petromus is separable on a subfamily level from South American Octodontidae, it is hard to separate the South African Cricetine genus Mystromys even on a generic level from some South American forms which it resembles closely.

I. Lower jaw with the angular process distorted outwards by specialized limb of masseter lateralis superficialis.

Lower jaw essentially normal, not as just described.

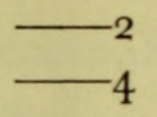

2. Infraorbital foramen not or scarcely transmitting muscle. Animals modified for subterranean life; eyes, ears and tail reduced. Cheekteeth rooted, but relatively simple. Fibula fused with tibia. Zygomatic plate below the small infraorbital foramen. Five hindtoes.

Family BATHYERGIDAE, page 227

Infraorbital foramen much enlarged for muscle transmission. Animals not modified for subterranean life. Fibula not fused with tibia. Zygomatic plate below the large infraorbital foramen, not tilted upwards. (Cheekteeth $4 / 4$.)

3. Body covered with long quills and spines, and tail with many hollow rattling quills. Bullae and paroccipital processes small. In South Africa, nasals enlarged and broadened; tail short; a long crest of hairs on the head. Cheekteeth rooted, with isolated narrow enamel folds on flat crowns in adult. Five hindtoes.

Family HYSTRICIDAE, page 236

Body not covered with spines or quills; tail normal. Either bullae or paroccipital processes enlarged. Nasals less enlarged. Cheekteeth either with thick isolated enamel folds in adult, or relatively simple in pattern. Four or 5 hindtoes.

Family OCTODONTIDAE, page 237

4. Cheekteeth rootless and simple. Animal modified for bipedal saltatorial life, with long hindlimbs and tail; four hindtoes; fibula fused with tibia. Infraorbital foramen very much enlarged, the zygomatic plate below it. Skull specialized, with wide frontals, large mastoids, thickened zygomata. Cheekteeth $4 / 4$.

Family PEDETIDAE, page 25I

Cheekteeth rooted and complex. Animals not modified for bipedal saltatorial life, or less so, and with 5 hindtoes (except in the Murine genus Malacothrix). Not combining the characters just described.

5. Infraorbital foramen not or scarcely transmitting muscle, the zygomatic plate tilted upwards. Skull with postorbital processes. Tail bushy. Fibula not fused to tibia. Cheekteeth $5 / 4$ or $4 / 4$, their pattern in the upper jaw typically a series of transverse ridges and with cusps at corners.

Family SCIURIDAE, page 240

Infraorbital foramen well open for muscle transmission. Skull with no postorbital processes.

6. Fibula (so far as known) not fused with tibia. Animal arboreal, with (in South Africa) flying membrane attached to sides of body; underside of tail with scaly 
outgrowths near base. Upper cheekteeth with wide re-entrant folds. Zygomatic plate below the infraorbital foramen. 4/4 cheekteeth. Jugal long. Family ANOMALURIDAE, page 250

Fibula (so far as known) fused with tibia. No flying membrane, and no scaly outgrowths on underside of tail. (In the Muscardinidae, Ethiopian members of which resemble the last family in possessing $4 / 4$ cheekteeth and a long jugal, and in having the zygomatic plate below the infraorbital foramen, the pattern of the cheekteeth is entirely different.)

7. Cheekteeth (in Africa) 4/4, crown basin-shaped, usually with cusps at corners, and with weak transverse ridges. South of the Sahara the zygomatic plate is not tilted upwards, and the infraorbital foramen is not very large. Tail bushy. Jugal usually long. Bullae (African forms) large.

$$
\text { Family MUSCARDINIDAE, page } 253
$$

Cheekteeth not exceeding $3 / 3$ (except in rare individual abnormalities), their pattern variable but not as just described. Zygomatic plate tilted upwards to a greater or lesser degree. Jugal usually short. Tail usually not bushy.

Family MURIDAE, page 259

\section{FAMILY B A T H Y E R G I D A E}

Roberts (I95I) divided this family into two subfamilies, restricting the typical one to Bathyergus and erecting a subfamily Georychinae to which he referred the other South African genera and to which Heliophobius would belong. There is much to be said in favour of this classification, as Bathyergus is a relatively generalized form, whereas the excessively long upper incisor roots of the other genera, which extend into the pterygoid region, seem unique in the Rodentia. But if subfamilies are admitted in this family then the aberrant East African Heterocephalus should probably be regarded as the type of a third subfamily.

I. Upper incisors heavily grooved, not extending backwards into pterygoid region. foreclaws much enlarged. Angular process of mandible much drawn backwards. Cheekteeth $4 / 4$.

Genus BATHYERGUS, page 228

Upper incisors not heavily grooved, extending backwards into pterygoid region. Foreclaws not much enlarged. Angular process of mandible not much drawn backwards.

2. Cheekteeth at full dentition $6 / 6$, but the teeth are usually not all in place together, the anterior premolars shed before the posterior molars are cut.

Genus HELIOPHOBIUS, page 228

Cheekteeth $4 / 4$. 3

3. Cheekteeth with one fold each side in the upper series; hindmost molar cut late in life. Black cap on head, white ring round ear, cheeks black, nose white.

Genus GEORYCHUS, page 229

Cheekteeth more or less simple, ringshaped in adult; hindmost molar cut earlier. Colour of face different.

Genus CRYPTOMYS, page 230 
Genus BATHYERGUS Illiger, I 8 I I

ı 1 п. Bathyergus Illiger, Prodr. Syst. Mamm. 86. Mus maritimus Gmelin = Mus suillus Schreber.

I829. Orycterus F. Cuvier, Dict. Sci. Nat. 59: 481. Mus maritimus Gmelin = Mus suillus Schreber.

All forms are here tentatively regarded as conspecific. The form janetta is smaller than other named races of which adults are known.

Bathyergus suillus Schreber, $\mathrm{I} 782$

Cape Sand-Mole or Mole-Rat. Duinmol

Distribution: coastal districts of western Cape Province extending to both sides of the Orange River mouth. Knysna, Cape Town, Franschhoek (near Paarl), Lamberts Bay, Klaver, Little Namaqualand (the Kamiesberg, Port Nolloth), just extending into Great Namaqualand.

Bathyergus SUILlus suillus Schreber, 1782 I 782. Mus suillus Schreber, Säugth. 4: 7 I5, pl. 204B. Cape of Good Hope.

I 788. Mus maritimus Gmelin, Linn. Syst. Nat. ed. I3, I: I40. Cape of Good Hope. I 788. Marmota africana Thunberg, Resa uti Europa, Africa, Asia, etc. I: 293, 318, pl. I. Cape of Good Hope.

Bathyergus suillus Janetta Thomas \& Schwann, I904 1904. Bathyergus janetta Thomas \& Schwann, Abstr. P.Z.S. No. 2 : 6; P.Z.S. I: I8o. Port Nolloth, coastal Little Namaqualand, north-western Cape Province.

BAthyergus SUILlus INTERmedius Roberts, I926 1926. Bathyergus suillus intermedius Roberts, Ann. Transv. Mus. II: 26I. Klaver (northern part of Olifants River), western Cape Province.

BAthyergus Suillus inselbergensis Shortridge \& Carter, I938

1938. Bathyergus janetta inselbergensis Shortridge \& Carter, Ann. S. Afr. Mus. 32: 290. Eselfontein, approximately 4,400 ft., Kamiesberg, central Little Namaqualand, north-western Cape Province.

Bathyergus suillus Plowesi Roberts, 1946

1946. Bathyergus janetta plowesi Roberts, Ann. Transv. Mus. 20: 315. Orangemund, north of the mouth of the Orange River, Great Namaqualand, South-West Africa.

\section{Genus HELIOPHOBIUS Peters, I 846}

1846. Heliophobius Peters, Ber. Preuss. Akad. Wiss. 259. Heliophobius argenteocinereus Peters.

I89o. Myoscalops Thomas, P.Z.S. 448. Proposed to replace Heliophobius which was thought to be preoccupied by Heliophobus Boisduval, I829. 


\section{RODENTIA - BATHYERGIDAE}

Heliophobius argenteocinereus Peters, 1846

Silvery Mole-Rat

Distribution: Tete, Portuguese East Africa; Nyasaland, Northern Rhodesia; Tanganyika, Kenya and into the Belgian Congo.

Heliophobius argenteocinereus argenteocinereus Peters, i 846

I846. Heliophobius argenteocinereus Peters, Ber. Preuss. Akad. Wiss. 259. Tete, on the Zambezi, Portuguese East Africa.

Heliophobius argenteocinereus robustus Thomas, igo6

I906. Heliophobius robustus Thomas, Ann. Mag. N.H. I7: I 79. Mpika (east of Lake Bangweulu), eastern Northern Rhodesia.

Heliophobius argenteocinereus angonigus Thomas, i9i 7

I9I 7. Heliophobius angonicus Thomas, Ann. Mag. N.H. 20: 314. Bua River, Central Angoniland, Nyasaland. "The Bua River rises on the watershed forming the Nyasaland-Northern Rhodesia boundary, and its course is wholly in Nyasaland. That part of the river which is in the former District of Central Angoniland is between I $3^{\circ} 20^{\prime}$ and $13^{\circ} 55^{\prime}$ S." (Moreau, Hopkins \& Hayman, I946).

\section{Genus GEORYGHUS Illiger, I 8 I I}

I8 I I. Georychus Illiger, Prodr. Syst. Mamm. 87. Mus capensis Pallas.

I843. Georhychus Wagner, in Schreber, Säugth. Suppl. 3: 369. Alternative spelling. I844. Fossor Lichtenstein in Forster's Descript. Anim. (edited by Lichtenstein), 364. Fossor leucops Lichtenstein $=$ Mus capensis Pallas.

Georychus capensis Pallas, I 779

Blesmol or Cape Mole-Rat. Blesmol

Distribution: confined to the Union, mainly to the coastal parts of Cape Province. In the Transvaal known from Belfast, and, according to Shortridge, has been taken at Nottingham Road, Natal. In the Cape Province, Port Elizabeth, Knysna, George, Cape Agulhas, Gape Town district (Hout Bay, Tokai, Rondebosch, etc.), Stellenbosch, Wolseley, the Cedarberg, Citrusdal, Nieuwoudtville. (Shortridge also quotes it from the Bathurst district.)

Georyahus capensis capensis Pallas, I 779

I779. Mus capensis Pallas, Nov. Spec. Quad. Glir. Ord., 76, I72. Cape of Good Hope. ${ }^{1}$

I834. Mus buffonii F. Cuvier, Ann. Sci. Nat. Zool. (2) I: I 96. Cape of Good Hope.

1844. Fossor leucops Lichtenstein in Forster's Descript. Anim. (ed. by Lichtenstein) 364. Cape of Good Hope.

Range: western Cape Province.

${ }^{1}$ For date of publication see Sherborn, I891, Ann. Mag. N.H. 7: 236. 
Georychus capensis canescens Thomas \& Schwann, igo6

I906. Georychus capensis canescens Thomas \& Schwann, P.Z.S. i65. Knysna, southern Cape Province.

Georychus Gapensis yatesi Roberts, I9I 3

I913. Georychus yatesi Roberts, Ann. Transv. Mus. 4: 92. Belfast, eastern Transvaal.

\section{Genus GRYPTOMYS Gray, 1864}

1864. Cryptomys Gray, P.Z.S., I 24. Georychus holosericeus Wagner.

I 864. Coetomys Gray, P.Z.S., I 25. Type here designated as Bathyergus caecutiens Brants. I 867. Typhloryctes Fitzinger, S.B. Akad. Wiss. Wien, 55, I : 502. Type here designated as Bathyergus caecutiens Brants.

I. On average large species; head and body length $175 \mathrm{~mm}$. and more, but only twice under $180 \mathrm{~mm}$. in considerable series. No clear white headspot. Skull length (with incisors) in adult $45^{-66} \mathrm{~mm}$. (the smallest specimens are from Northern Rhodesia; the species is confined to that country, Angola and the southern Congo). Cryptomys mechowi, page 235

On average smaller species; head and body length only reaches $180 \mathrm{~mm}$. twice in a very long series of skins, both in the form damarensis, which has a distinct white headspot. Greatest length of skull with incisors very rarely reaches $45 \mathrm{~mm}$. (only in two races in the measurements given by Roberts, from the Union; both of these have the head and body not exceeding $164 \mathrm{~mm}$.). -2

2. On average smaller species. In the Union, where it occurs with the next, the greatest length of the male skull (including incisors) only reaches $4 \mathrm{I} \mathrm{mm}$. once (vandami) and rarely $40 \mathrm{~mm}$. In South-West Africa, where this length may reach $43 \mathrm{~mm}$. (although on average it appears to be below $40 \mathrm{~mm}$.), there is always a distinct white headspot. In the Union, female skulls rarely reach $38 \mathrm{~mm}$. in length.

Cryptomys hottentotus, ${ }^{1}$ page $23 \mathrm{I}$

1 The Cryptomys hottentotus group is much oversplit by Roberts in South Africa. There is evidence that in the Union there are two species which may occur together in the Carolina district, the Pretoria district, at Cradock and near Bloemfontein, but the differences are average rather than absolute and difficult to define when all forms are taken into account. The specimens from the Union do not have a white headspot, except in rare individual abnormalities. In South-West Africa there is a very well-marked form damarensis (which antedates holosericeus), which always has a distinct white headspot. This form seems also to combine the size of hottentotus and holosericeus in different individuals. But the average seems nearer the former. The white headspot is known to be very variable individually in bocagei from Angola. Hill \& Carter say it is usually present in that form, but in the British Museum it is usually absent in bocagei (distinct in four specimens, vestigial or absent in seventeen). In the original series of molyneuxi it is present; but some recently received material of this form (if rightly identified) from the Kabompo district, Northern Rhodesia, shows considerable individual variation in this character. It is present in beirae and darlingi, according to descriptions in ovamboensis and zimbitiensis, and in the type of stellatus; normally absent in other forms. But this character seems too individually variable to base a species (damarensis) on in the absence of correlated cranial characters. We therefore very tentatively define holosericeus as above, and restrict it to the Union (and southern Portuguese East Africa), referring the other named forms, all of which in British Museum material have the skull length less than $40 \mathrm{~mm}$. except some individuals of damarensis as noted above, to the earliest named hottentotus as races. We take no responsibility for the validity of those races of Roberts which we have not placed in synonymy; where that author had several forms occurring close together we have assumed he was dealing with one individually variable form, 
On average larger species (practically confined to the Union, and occurring there with the last); the greatest length of male skull is under $40 \mathrm{~mm}$. only in three individuals in the British Museum (two of these, from Estcourt, Natal, may in reality represent the last species). Normally there is no white headspot. Female skull length rarely below $3^{8} \mathrm{~mm}$.

Cryptomys holosericeus, page 234

Cryptomys hottentotus Lesson, 1826

Common Mole-Rat, or Hottentot Mole-Rat Hotnotse Grysmol

Distribution: in the Union, the Transvaal, districts of Waterberg, Pretoria, Johannesburg, Carolina, Hectorspruit, Tzaneen, Woodbush, Leydsdorp, Legogot (near White River), etc. Natal, including west of Durban and Zululand. Bloemfontein district, Orange Free State. In the Cape Province, the Molopo River, Kuruman, Kimberley, Little Namaqualand (near Steinkopf, the Kamiesberg), Nieuwoudtville, many places in the western Province southwards to Paarl, Belville (near Cape Town); George, Knysna, Plettenberg Bay, Uitenhage, King William's Town, Grahamstown, near Kokstad, Cradock, Deelfontein, Matjesfontein. SouthWest Africa; widely distributed from about the latitudes of Rehoboth and Gobabis northwards; the Kalahari desert; most of the interior of Angola. Salisbury, Vumba, etc. Southern Rhodesia. Beira and Gorongoza districts, Portuguese East Africa. Northern Rhodesia, Nyasaland. Similar forms occur in Tanganyika, Uganda, the Belgian Congo, southern Sudan, northern Nigeria, Togoland. ${ }^{1}$

CRyptomys hotTentotus hottentotus Lesson, I 826

I826. Bathyergus hottentotus Lesson, Voyage autour du monde, Zool. I: i66. Near Paarl (east of Cape Town), south-western Cape Province. ("Vingt lieues de la ville du Cap, près le village de la Pearl, non loin des montagnes de Drackenstein.")

I829. Bathyergus ludwigii A. Smith, Zool. J. 4: 439. South Africa. Cape Town nominated by Roberts (I95I, 39I).

Range: western Cape Province.

Cryptomys hottentotus Caegutiens Brants, i 827

I 827. Bathyergus caecutiens Brants, Het Geslacht der Muizen, 37. Cape of Good Hope (Knysna, fide Roberts, I95I). Melanistic form.

1899. Georychus exenticus Trouessart, Cat. Mamm. Viv. Foss. I338. Error for caecutiens.

I906. Georychus hottentottus (sic) talpoides Thomas \& Schwann, P.Z.S., i66. Knysna, southern Cape Province.

(1924. Cryptomys cradockensis Roberts, Ann. Transv. Mus. I0: 73. Cradock, eastern Cape Province. (Not melanistic).)

Range: Cradock, Grahamstown, Plettenberg Bay and Knysna (at the last locality it would appear to occur in two colour phases).

and have placed certain names in synonymy. It is even possible that there is only one very variable species in the Union. It should be borne in mind that the mammary formula is often individually variable in rodents.

${ }^{1}$ It should be noted that (with the exception of Rattus natalensis which Mr. D. H. S. Davis tells us occurs there), the small rodents of the Kruger National Park, Transvaal, are not known. 
Cryptomys hottentotus damarensis Ogilby, i 838

1838. Bathyergus damarensis Ogilby, P.Z.S., 5. Damaraland, South-West Africa.

I898. Georychus lugardi de Winton, Ann. Mag. N.H. I: 253. Kalahari desert, between Palapye and Lake Ngami, northern Bechuanaland.

1909. Georychus micklemi Chubb, Ann. Mag. N.H. 3: 35. Kataba River, Upper Zambezi, western Northern Rhodesia.

Ranges also into Southern Rhodesia (Matetsi) (Roberts), and southwards to the Molopo River.

CRyptomys hotTentotus DaRlingi Thomas, I895

I895. Georychus darlingi Thomas, Ann. Mag. N.H. I6: 239. Salisbury, Southern Rhodesia. Ranges southwards to Mt. Selinda, eastern Southern Rhodesia.

Cryptomys hottentotus nimrodi de Winton, i 897

1897. Georychus nimrodi de Winton, P.Z.S. I896: 808. Essex Farm, near Bulawayo, Matabeleland, western Southern Rhodesia. On p. 806 de Winton says "a collection of nearly 50 specimens made at Essex Vale, about I, $500 \mathrm{ft}$., near Bulawayo, Matabeleland"'. De Winton quotes Selous' (collector's) label as "Essex Farm, Matabeleland" but Essex Farm must be in Essex Vale since Selous' collection was made there.

CRyptomys hottentotus bocagei de Winton, i 897

I897. Georychus bocagei de Winton, Ann. Mag. N.H. 20: 323. Hanha, western Angola.

I933. Georhychus (sic) kubangensis Monard, Bull. Soc. Sci. Nat. Neuchâtel, 57: 58. Type specimen not designated, probably from Rio Mbalé, southern Angola (Hill \& Carter, I94I).

Said to range to the Kaokoveld, South-West Africa.

CRyptomys hottentotus whytei Thomas, i 897

I 897. Georychus whytei Thomas, P.Z.S., 432. Karonga, north-western corner of Lake Nyasa ( $9^{\circ} 56^{\prime}$ S., $33^{\circ} 56^{\prime}$ E., I, $600 \mathrm{ft}$.), northern Nyasaland.

CRyptomys hottentotus amatus Wroughton, ig07

1907. Georychus amatus Wroughton, Manchester Mem. 5I, 5:28. Road to Chiwali's, Alala plateau, 4 , ooo ft. (about $13{ }^{\circ} 46^{\prime}$ S., $30^{\circ} 5^{\prime}$ E., fide Moreau, Hopkins \& Hayman), Northern Rhodesia.

CRyptomys hottentotus beirae Thomas, igo8

1908. Georychus beirae Thomas, P.Z.S. 1907: 780. Beira (south of the Zambezi), coastal Portuguese East Africa.

CRyptomys hottentotus molyneuxi Chubb, igo8

1908. Georychus molyneuxi Chubb, Ann. Mag. N.H. 2: 45 I. Loano valley, western Northern Rhodesia. "Loano Valley is the valley of the Lunsemfwa River, extending east from the neighbourhood of Broken Hill to the lowest reaches of the Luangwa River, in an area, that is to say, that no one inspecting the 
map would call 'north-western'. Nevertheless the latter, which was just within the border of the obsolete administrative division called 'Northwestern Rhodesia' (see introduction), is the type-locality intended. Lancaster concurs." (Moreau, Hopkins \& Hayman, I946.)

CRyptomys hotTentotus JoRisseni Jameson, igo9

I 909. Georychus jorisseni Jameson, Ann. Mag. N.H. 4: 466. Waynek, Waterberg district, western Transvaal. (Named after Mr. E. Jorissen of Johannesburg.)

(1924. Cryptomys transvaalensis Roberts, Ann. Transv. Mus. Io: 73. Boekenhoutfontein Farm, 20 miles north of Pretoria, Transvaal.)

Range includes the Rustenburg district, western Transvaal.

CRyptomys hottentotus Jamesoni Roberts, igi3

I9I3. Georychus jamesoni Roberts, Ann. Transv. Mus. 4: 95. Houghton Estate, near Johannesburg, Transvaal.

I9I3. Georychus arenarius Roberts, Ann. Transv. Mus. 4: 96. Rietondale (East), Pretoria, Transvaal.

(1926. Cryptomys montanus Roberts, Ann. Transv. Mus. II: 260. Klapperkop, Pretoria, Transvaal.)

CRyptomys hottentotus komatiensis Roberts, I9I 7

I9I7. Georychus komatiensis Roberts, Ann. Transv. Mus. 5: 272. Arnhemburg, Carolina, south-eastern Transvaal.

(1917. Georychus rufulus Roberts, Ann. Transv. Mus. 5: 272. Tzaneen, eastern Transvaal.)

(1917. Georychus vandami Roberts, Ann. Transv. Mus. 5: 273. Griffin Mine, Leydsdorp, eastern Transvaal.)

(19I7. Georychus natalensis pallidus Roberts, Ann. Transv. Mus. 5: 278. Manetsi River, near Malala, Zoutpansberg district, northern Transvaal. Not of Gray, I864. (Roberts (I95I) makes it a synonym of vandami).)

(1926. Cryptomys melanoticus Roberts, Ann. Transv. Mus. I I: 260. Balloon Farm, Makoetsi River, Leydsdorp district, north-eastern Transvaal.)

(1939. Cryptomys natalensis nemo G. Allen, Checklist Afr. Mamm. 429. To replace pallidus Roberts, preoccupied.)

Range: eastern Transvaal and near Durban, Natal.

Cryptomys hottentotus stellatus Roberts, igi 7

I9I 7. Georychus stellatus Roberts, Ann. Transv. Mus. 5: 272. Komatipoort (near the Portuguese border), eastern Transvaal.

CRyptomys hottentotus bigalkei Roberts, I924

1924. Cryptomys bigalkei Roberts, Ann. Transv. Mus. Io: 73. Glen, north of Bloemfontein, Orange Free State. Range: northwards to Parys, and also in the western Orange Free State. 
CRyptomys hotTentotus STREeteri Roberts, I 946

1946. Cryptomys natalensis streeteri Roberts, Ann. Transv. Mus. 20: 316 . Hectorspruit (near the southern border of the Kruger National Park) eastern Transvaal. Probable synonym of komatiensis.

Cryptomys hottentotus ovamboensis Roberts, 1946

1946. Cryptomys ovamboensis Roberts, Ann. Transv. Mus. 20: 315. Ondongwa, Ovamboland, northern South-West Africa.

CRyptomys hottentotus zimbitiensis Roberts, I 946

1946. Cryptomys zimbitiensis Roberts, Ann. Transv. Mus. 20: 315. Zimbiti, about 20 miles inland from Beira, Portuguese East Africa.

CRyptomys hottentotus zuluensis Roberts, I95 I

I95 I. Cryptomys komatiensis zuluensis Roberts, Mamm. S. Africa, 396. Lake St. Lucia, Zululand, Natal.

Incertae sedis:

Cryptomys albus (Georychus albus Roberts, I9I3, Ann. Transv. Mus. 4: 100). An albino specimen bearing a torn label with the words "... nberg, K.K., Jan. I899". . . most likely Wynberg in the Cape Province.

Cryptomys holosericeus Wagner, I 843

Greater Grey Mole-Rat. Groter Grysmol

Distribution: Bloemhof, Krugersdorp, Pretoria district, Johannesburg, Wakkerstroom, Transvaal; Natal, including Estcourt, Zululand, and Howick district; Vredefort district, Bothaville, Bloemfontein district, Vet River, Modder River, etc., Orange Free State; in the Cape Province, Vryburg, Fourteen Streams, Cradock, Graaff Reinet, and Port St. Johns (Pondoland). Swaziland. Southern Portuguese East Africa. Gaberones, south-eastern Bechuanaland (Transvaal border).

CRyptomys holoserigeus holosericeus Wagner, i 843

I843. Georhychus holosericeus Wagner in Schreber, Säugth. Suppl. 3: 373. Graaff Reinet district (on the eastern Karroo), Cape Province. Roberts quotes a specimen from Cradock, eastern Cape Province.

Cryptomys holoseriaeus natalensis Roberts, i9i 3

I9I3. Georychus natalensis Roberts, Ann. Transv. Mus. 4: 94. Wakkerstroom, southeastern Transvaal. Ranges into the upland districts of Natal, Swaziland, and Carolina, eastern Transvaal.

CRyptomys holosericeus aberrans Roberts, I9I 3

I9I 3. Georychus aberrans Roberts, Ann. Transv. Mus. 4: 97. Port St. Johns, Pondoland, coastal eastern Cape Province. 
CRyptomys holoserigeus anomalus Roberts, I 9 I 3

I913. Georychus anomalus Roberts, Ann. Transv. Mus. 4: 96. Skinners Court Valley, Pretoria, Transvaal.

I9I3. Georychus pretoriae Roberts, Ann. Transv. Mus. 4: 99. Skinners Court Valley, Pretoria, Transvaal. (An immature specimen.)

I9I 7. Georychus palki Roberts, Ann. Transv. Mus. 6: 5. Venterskroon, Vaal River, Potchefstroom district, western Transvaal.

Cryptomys holosericeus mahali Roberts, igi 3

I913. Georychus mahali Roberts, Ann. Transv. Mus. 4: io8. Rosslyn, some 5 miles along the railway line N.W. of Pretoria North, Pretoria district, Transvaal. Ranges northwards to Nylstroom, Transvaal.

Cryptomys holosericeus vRyburgensis Roberts, igi 7

I9I7. Georychus vryburgensis Roberts, Ann. Transv. Mus. 5: 274. Vryburg, northern Cape Province.

Gryptomys holosericeus orangiae Roberts, i 926

I926. Cryptomys orangiae Roberts, Ann. Transv. Mus. II: 259. Glen, north of Bloemfontein, Orange Free State.

Cryptomys holosericeus vetensis Roberts, i 926

1926. Cryptomys vetensis Roberts, Ann. Transv. Mus. II: 259. Taaiboschspruit, Vet River, northern Orange Free State. Roberts (I95I) also quotes specimens from Bloemhof, western Transvaal, Fourteen Streams, northern Cape Province, and Gaberones, south-western Bechuanaland.

CRyptomys holosericeus Junodi Roberts, I 926

I926. Cryptomys junodi Roberts, Ann. Transv. Mus. II: 26o. Masiene (a little to the north of the mouth of the Limpopo River), southern Portuguese East Africa. Ranges to northern Zululand.

Gryptomys holosericeus langi Roberts, i 929

1929. Cryptomys langi Roberts, Ann. Transv. Mus. 13: i 19. Karkloof, Howick district, central Natal.

GRYPTOMys holosericeus VAlschensis Roberts, 1946

I946. Cryptomys holosericeus valschensis Roberts, Ann. Transv. Mus. 20: 3 I6. Bothaville, northern Orange Free State.

Gryptomys mechowi Peters, I 88 I

Angolan Giant Mole-Rat

Distribution: Angola (all known localities are in the northern two-thirds of Angola according to Hill \& Carter) and Northern Rhodesia (Mpika, Ndola, Balovale, south of Lake Bangweulu, etc.) Katanga, southern Belgian Congo. 
Cryptomys mechowi mechowi Peters, i $88 \mathrm{I}$

I88ı. Georychus mechowii Peters, S.B. Ges. Naturf. Fr. Berlin, I33. Malange, northern Angola.

1905. Georychus ansorgei Thomas \& Wroughton, Ann. Mag. N.H. I6: i75. Coquema (Kukema) River, near Bihé, central Angola.

192 I. Crytomys blainei Hinton, Ann. Mag. N.H. 7: 372. Chisongwe, Luando River, 4, ooo ft., central Angola.

CRyptomys meghowi mellandi Thomas, igo6

I906. Georychus mellandi Thomas, Ann. Mag. N.H. I7: i 78. Mpika (between Lakes Bangweulu and Nyasa), eastern Northern Rhodesia.

\section{FAMILY H Y S T R I C I D A E}

\section{Genus HYSTRIX Linnaeus, $175^{8}$}

I758. Hystrix Linnaeus, Syst. Nat. Ioth ed. 1 : 56. Hystrix cristata Linnaeus, from Italy.

Hystrix africaeaustralis differs from the related $H$. cristata $^{1}$ Linnaeus in having the nasals shorter (average about 53 per cent of the occipitonasal length), although much broadened; from $H$. indica Kerr, 1792 in having the nasals broader. The skull length is about $\mathrm{I} 27-\mathrm{I} 62 \mathrm{~mm}$.

\section{Subgenus HYSTRIX Linnaeus, I $75^{8}$}

Hystrix africaeaustralis Peters, $185^{2}$

Cape Porcupine. Ystervark

Distribution: in the Union, the Transvaal, Rustenburg district and the Kruger National Park (Toulon, etc.). Natal, including Estcourt and Zululand. Mr. S. Roche writes us, "I have seen porcupine quills in many places on Orange Free State farms." In the Cape Province, De Beers ( 36 miles west of Kimberley), near Upington, Louisvale, Little Namaqualand (near Steinkopf and the Kamiesberg), near Citrusdal, near Cape Town, Bredasdorp, Deelfontein, Knysna, Plettenberg Bay, Albany district, etc. ("widely distributed in our region but nowhere abundant", Hewitt, I93 I, Eastern Province). (These animals are not very common in museums, and perhaps have a wider distribution than is here indicated.) South-West Africa; "everywhere widely distributed except possibly along the coastal edge of the Namib desert" (Shortridge, I934). Angola; "probably throughout most of Angola" (Hill \& Carter); recorded from Chitau, Benguela, Huila, Vila da Ponte, Chimporo, Humbe, Mulondo. Roberts records it from the Chobe River (northern Bechuanaland) and the Matibi district of Southern Rhodesia. Portuguese East Africa; Tete, and north of the Zambezi. Nyasaland. Northern Rhodesia ("ubiquitous, but absent from areas of swamp and marsh" (Pitman, I934)). Northwards to Tanganyika.

${ }^{1}$ In B.M. material for typical $H$. cristata the nasals average 62 per cent of the occipitonasal length. 236 
Hystrix africaeaustralis africaeaustralis Peters, i 852

1852. Hystrix africae australis Peters, Reise nach Mossambique, Säugeth. I 70. Querimba coast (about $10^{\circ} 30^{\prime}-12^{\circ}$ S., $40^{\circ} 30^{\prime}$ E., sea level), northern Portuguese East Africa. Type locality restricted by Moreau, Hopkins \& Hayman, 1946.

I860. Hystrix capensis Grill, K. Svenska Vetensk. Akad. Handl. (2), 2: No. Io, I 9. Salt River, near Knysna, southern Cape Province.

1936. Hystrix africae-australis zuluensis Roberts, Ann. Transv. Mus. I8: 240. White Umfolosi River, Zululand, Natal.

\section{FAMILY O G T O D O N T I D A E}

The name Echimyidae was formerly (following Miller \& Gidley) used for this family by one of us (Ellerman, I940), but Simpson (1945) although recognizing both a family Echimyidae and a family Octodontidae in his somewhat oversplit classification of the group, prefers the superfamily name Octodontoidea, and as Octodontidae was the name used by Flower \& Lydekker, I89I, and other authors, we here revert to the use of that name.

Cheekteeth simplified, outer side of upper molars with one re-entrant fold. Bullae enlarged, paroccipital processes not so. Five hindtoes. Tail more or less bushy. Incisors not heavily grooved. Skull not heavily ridged.

subfamily Petromurinae: Genus PETROMUS, page 239

Cheekteeth complex, outer side of upper molars with more than one fold. Bullae small, paroccipital processes enlarged. Four hindtoes. Tail not bushy. Incisors thick, the upper ones heavily 3-grooved. Skull massive and powerfully ridged. SUBFAMILY Thryonomyinae: Genus THRYONOMYS, page 237

For comparison with extralimital subfamilies see Ellerman, I940, I: I03. Thryonomys is a considerably larger animal than Petromus.

Subfamily Thryonomyinae

Genus THRYONOMYS Fitzinger, 1867

I827. Aulacodus Temminck, Mon. Mamm. I: 245. Aulacodus swinderianus Temminck. Not of Eschscholtz, I 822.

I867. Thryonomys Fitzinger, S.B. Akad. Wiss. Wien, 56, I : I41. Aulacodus semipalmatus Heuglin = Aulacodus swinderianus Temminck.

I 896. Triaulacodus Lydekker, Geogr. Hist. Mamm. 9I and 240, footnote. Substitute for Aulacodus, preoccupied.

I922. Choeromys Thomas, Ann. Mag. N.H. 9: 390. Thryonomys gregorianus Thomas. I924. Chaeromys Sclater, Zool. Record, Mamm. 59: 50. Misprint.

Skull considerably arched anteriorly.

Skull not much arched anteriorly.
Thryonomys swinderianus, page 238

Thryonomys gregorianus, page 238 
Thryonomys swinderianus Temminck, 1827

Great Cane-Rat. Rietrot; Rietmuis

Distribution: in the Union, the Kruger National Park (Toulon and other localities) Pretoria, Woodbush, the Limpopo, Transvaal; Zululand; and parts of the eastern Cape Province westwards at least to Albany and Bathurst districts. Portuguese East Africa, districts of Beira, Gorongoza, Tete, and north of the Zambezi; Southern Rhodesia, Ngamiland and in South-West Africa, the swamps of the Okavango, the eastern Caprivi, and the reedbeds of the Upper Cunene, above the Rua Cana Falls (Shortridge, 1934). Angola ("it is an animal of the swamp and riverbank and probably occurs wherever these environments are found in Angola" (Hill \& Carter)). Nyasaland, Northern Rhodesia. In East Africa northwards to Kenya, Uganda and the southern Sudan, and in West Africa from the Belgian Congo to Senegal.

Thryonomys SWINDERIANus Temminck, 1827

1827. Aulacodus swinderianus Temminck, Mon. Mamm. I: 248. Sierra Leone, West Africa (Thomas, I922, Ann. Mag. N.H. 9: 391).

1922. Thryonomys swinderianus variegatus Thomas, Ann. Mag. N.H. 9: 39I. Tete, on the Zambezi, Portuguese East Africa (restricted by Roberts, I95 I : 348). (Thomas quoted Aulacodus variegatus Peters, 1852, Reise nach Mossambique, I 38 , but the name was stillborn since Peters himself says that it was a name which he had in his manuscript but realized before publication that it was a synonym of swinderianus, in the synonymy of which he publishes it.)

1922. Thryonomys swinderianus angolae Thomas, Ann. Mag. N.H. 9: 392. Junction of the Luando and Cuje rivers, northern central Angola.

Thryonomys gregorianus Thomas, 1894

Lesser Cane-Rat. Kleinrietrot

Approximate distribution: Nyasaland, Mount Selinda in eastern Southern Rhodesia; further to the north, the Belgian Congo, Kenya, Tanganyika, Uganda to Darfur (Sudan).

Thryonomys GRegorianus Gregorianus Thomas, i894. (Extralimital) I894. Aulacodus gregorianus Thomas, Ann. Mag. N.H. I3: 202. Luiji Reru River (about IO-I 5 miles north of Fort Hall, fide Moreau, Hopkins \& Hayman), 5,700 ft., Kikuyu Country, Kenya.

Thryonomys Gregorianus SGLATERI Thomas, I 897

I897. Thryonomys sclateri Thomas, P.Z.S., 432. Nyika Plateau, 6,00o-7,00o ft., northern Nyasaland. Range includes Mount Selinda, eastern Southern Rhodesia. (G. Allen (1939) made this form a race of harrisoni which it antedates by ten years. We think it probable that all these lesser Cane-Rats belong to one species.) 


\section{RODENTIA - OGTODONTIDAE \\ SUBFAmily $\mathrm{P}$ e $\mathrm{t} \mathrm{r}$ o $\mathrm{m}$ u $\mathrm{r}$ i $\mathrm{n}$ a $\mathrm{e}$}

Genus PETROMUS A. Smith, I 83 I

I83 I. Petromus A. Smith, S. Afr. J. I: No. 5, io. Petromus typicus A. Smith.

I834. Petromys A. Smith, S. Afr. J. 2: I46. Alternative spelling of Petromus.

We do not agree with Simpson (1945, 99), who suggests that Petromus in the original publication "may well have been a misprint correctable under the Rules".

Petromus typicus A. Smith, I83 I Dassie Rat, or Rock Rat. Dassierot

Distribution: Little Namaqualand (Goodhouse, Klipfontein (north of Steinkopf), O'okiep, Springbok, the Kamiesberg, Garies, Bitterfontein), Kenhardt (British Museum) and the Aughrabies Falls district, north-western Cape Province. SouthWest Africa; from Great Namaqualand northwards and evidently widely distributed, northwards to the Cunene (or Rua Cana) Falls on the southern border of Angola.

There is a great number of named races based mainly on rather minor colour details. Shortridge thought that there were two species, typicus and cunealis occurring together in northern South-West Africa; although the latter averages rather larger in size of skull than typicus, the colour distinctions between them seem bridged by forms named as races of typicus and it seems doubtful if there is a real specific difference between them.

Petromus typigus typicus A. Smith, I83 I

I83 I. Petromus typicus A. Smith, S. Afr. J. I: No. 5, I I. Mountains of Little Namaqualand.

Petromus typicus tropicalis Thomas \& Hinton, i925

1925. Petromys typicus tropicalis Thomas \& Hinton, P.Z.S., 24I. Karibib (northwestwards of Windhoek), South-West Africa.

Petromus typicus gunealis Thomas, 1926

1926. Petromys cunealis Thomas, P.Z.S., 307. Cunene (or Rua Cana) Falls, Cunene River, extreme southern Angola. Range includes the Kaokoveld, part of Ovamboland, etc.

Petromus typicus marjoriae Bradfield, i 936

1936. Petromys typicus marjoriae Bradfield, Descr. of new races of Kalahari Birds and Mammals (privately printed and dated Benoni, 26th September, I935). Reprinted in The Auk, 53: I3 I, 1936. Khan River (presumably west of Usakos according to Roberts), Namib desert (inland from Walvis Bay), South-West Africa.

Petromus typigus guinasensis Roberts, 1938

1938. Petromys typicus guinasensis Roberts, Ann. Transv. Mus. I9: 240. Guinas Lake, Tsumeb district (north of Grootfontein), Ovamboland, South-West Africa. 
Petromus typicus windhoekensis Roberts, I938

1938. Petromys typicus windhoekensis Roberts, Ann. Transv. Mus. 19: 240. Neudamm, Government Karakul Farm, Windhoek district, central South-West Africa.

Petromus typicus ковosensis Roberts, 1938

1938. Petromys typicus kobosensis Roberts, Ann. Transv. Mus. 19: 240. Kobos, 45 miles S.W. of Rehoboth, central South-West Africa.

Petromus typigus barbiensis Roberts, 1938

1938. Petromys typicus barbiensis Roberts, Ann. Transv. Mus. 19: 241. Barby Farm, Helmeringshausen district, Great Namaqualand, South-West Africa. Roberts also refers specimens from Brukkaros Mountain, near Berseba, Great Namaqualand to this race.

Petromus typicus ausensis Roberts, 1938

1938. Petromys typicus ausensis Roberts, Ann. Transv. Mus. 19: 241. Aus (on the border of the Namib desert) (inland from Lüderitz), Great Namaqualand, SouthWest Africa.

Petromus typicus namaquensis Roberts, 1938

1938. Petromys typicus namaquensis Roberts, Ann. Transv. Mus. 19: 241. Fifteen miles south-west of Warmbad, southern Great Namaqualand, South-West Africa. Ranges to the Aughrabies Falls district, western Orange River.

Petromus typicus karasensis Roberts, I946

1946. Petromus typicus karasensis Roberts, Ann. Transv. Mus. 20: 314. Kochina Farm, Great Karas Mountains (north of Karasburg), south-eastern Great Namaqualand, South-West Africa.

Petromus typigus cinnamomeus Roberts, I 946

1946. Petromus typicus cinnamomeus Roberts, Ann. Transv. Mus. 20: 314. Ariamsvlei, north of the Aughrabies Falls, on road from Upington to Karasburg, near the Cape Province border in South-West Africa.

\section{FAMILY S G I U R I D A E}

Five genera occur in South Africa. The North American species Sciurus carolinensis has been introduced in the Cape Town neighbourhood.

I. Fur bristly. In the hand the middle finger $\left(\mathrm{D}_{3}\right)$ is normally dominant. A pale stripe on each side of the body. Occipitonasal length $55^{-62.9} \mathrm{~mm}$. Lachrymal enlarged. Palate well over half the occipitonasal length (these characters are based on the South African subgenus Geosciurus). ${ }^{1}$

Genus XERUS, page 249

\footnotetext{
1 The subgenus Geosciurus agrees with typical Xerus in having only 4 upper cheekteeth, but differs in possessing a flankstripe on each side, also in its more hypsodont molars and possibly larger average size. Xerus seems distinguishable from the Palaearctic Ground-Squirrels (Citellus) mainly by its enlarged lachrymals, wide frontals and bristly fur.
} 
Fur not bristly. In the hand usually the fourth finger (D 4 ) is dominant (or sometimes $\mathrm{D}_{3}$ and $\mathrm{D}_{4}$ are about equal). Lachrymal not enlarged. Palate normally clearly less than half the occipitonasal length. Not combining the characters of the last genus.

2. The infraorbital foramen does not form a canal, and is round and more open than is normal for the family. Large; occipitonasal length (in Angola) $63-67 \mathrm{~mm}$.

Genus PROTOXERUS, page 248

The infraorbital foramen is narrow and forms a canal. Occipitonasal length (in region now under discussion) $57.4 \mathrm{~mm}$. and less.

3. The pattern of the cheekteeth is essentially normal, not very different from that figured by Miller, 1912, Cat. Mamm. W. Europe, 903, for Sciurus vulgaris.

Genus HELIOSCIURUS, ${ }^{1}$ page $24 \mathrm{I}$

The pattern of the cheekteeth is abnormal; the molars tend to become flatcrowned, with isolated deep re-entrant folds in the adult.

4. The cheekteeth more specialized, with both upper and lower molars more or less flatcrowned in the adult (as figured in Ellerman, I940, Fam. Gen. Liv. Rodents, I: 4I I).

Genus FUNISCIURUS, page 247

The cheekteeth less specialized; usually the lower cheekteeth are cuspidate in the adult (but the upper ones are flatcrowned).

Genus PARAXERUS, page 243

It should be noted that in the area now under consideration, with the single exception of Xerus inauris, it is normal for the orbit (measured from the lachrymal to a point on the posterior zygomatic root just after it leaves the side of the braincase) to be at least one third of the occipitonasal length, and in the majority of specimens of all species more than a third of this length. In this character the South African genera resemble the Flying-Squirrels and Palaearctic Ground-Squirrels, but are quite different from the majority of the Palaearctic and Indomalayan Tree-Squirrels (except Lariscus hosei). See also Ellerman, I949, Fam. Gen. Liv. Rodents, 3: 5.

\section{Genus HELIOSGIURUS Trouessart, I88o}

I 880. Heliosciurus Trouessart, Le Naturaliste, I: 292. Sciurus gambianus Ogilby. 1916. Aethosciurus Thomas, Ann. Mag. N.H. I7: 27I. Sciurus poensis A. Smith, from Fernando Po. Valid as a subgenus.

Trouessart designated Sciurus annulatus Desmarest as the type. Thomas, I898, P.Z.S. I897: 933, basing himself on Trouessart, and "without making prolonged nomenclatural investigations", also gave annulatus as the type. But Thomas later ( I 909, Ann. Mag. N.H. 3: 470) rejected annulatus, on the grounds that the description is insufficient to identify it with the Gambian Squirrel, that the locality is unknown,

${ }^{1}$ Heliosciurus is said to differ from Sciurus by the complete or almost complete suppression of the baculum. In South Africa the orbit is clearly longer than in Palaearctic species of Sciurus. 
and that the type no longer exists. Thomas thereupon selected gambianus as the type of Heliosciurus. In view of this and the fact that gambianus is in current use, and annulatus is not, we follow Thomas (I909) and have applied to the International Commission on Zoological Nomenclature for Heliosciurus to be placed on the Official List in this sense.

Cheekteeth 5/4. Colour above light red, with blackish central dorsal patch. Cheekteeth $4 / 4$. Colour different and much less striking.

\section{Heliosciurus (Aethosciurus) lucifer, ${ }^{1}$ page 243}

Heliosciurus gambianus, page $24^{2}$

\section{Subgenus HELIOSCIURUS Trouessart, I88o}

Heliosciurus gambianus Ogilby, 1835

Sun-Squirrel. Soneekhorinkie

On this species see Ingoldby, 1927. Some notes on the African squirrels of the genus Heliosciurus, P.Z.S., $47 \mathrm{I}$.

Distribution: Portuguese East Africa, districts of Beira, Gorongoza, also north of the Zambezi, south-eastern Southern Rhodesia, Northern Rhodesia, Nyasaland, Angola (Hill \& Carter state that it is present in most of the interior savannah area, but records indicate that it is abundant only in restricted localities). North of the limits of this work, to Abyssinia and the Sudan, and thence westwards to Gambia.

Heliosciurus gambianus gambianus Ogilby, i835. (Extralimital) ı 835. Sciurus gambianus Ogilby, P.Z.S., I03. Gambia, probably near Fort St. Mary.

Heliosaiurus gambianus mutabilis Peters, i 852

I 852. Sciurus mutabilis Peters, Ber. Preuss. Akad. Wiss. 273; Reise nach Mossambique, Säugeth., I3 I. Boror, I $7^{\circ}$ S., north of the Zambezi, northern Portuguese East Africa. Also recorded from the Petauke district, Northern Rhodesia.

Heliosciurus gambianus shirensis Gray, i 867

I867. Macroxus shirensis Gray, Ann. Mag. N.H. 20: 327. Shire River, southern Nyasaland.

Heliosciurus gambianus Rhodesiae Wroughton, ig07

1907. Funisciurus annulatus rhodesiae Wroughton, Manchester Mem. 5I, 5: I5. Road to Chewalla's (= Chiwale?) 'approximately $13^{\circ} 46^{\prime} \mathrm{S}$., $30^{\circ} 5^{\prime} \mathrm{E}$., 4,000 ft., on the path from Serenje Boma to Mkushi Boma, crossing the Alala plateau, which is in Serenje district," Northern Rhodesia. (Moreau, Hopkins \& Hayman, 1946.)

1 The colour distinguishes this species also from other species of its subgenus which were named before it. 
Heliosaiurus gambianus beirae Roberts, igi 3

I9I3. Heliosciurus mutabilis beirae Roberts, Ann. Transv. Mus. 4: 78. Zimbiti, near Beira (south of the Zambezi), Portuguese East Africa.

Heliosaiurus gambianus GHiRindensis Roberts, I9I 3

1913. Heliosciurus mutabilis chirindensis Roberts, Ann. Transv. Mus. 4: 78. Chirinda Forest, Melsetter district, eastern Southern Rhodesia.

Heliosciurus gambianus loandigus Thomas, ig23

1923. Heliosciurus rhodesiae loandicus Thomas, Ann. Mag. N.H. II: 52 I. N'Dalla Tando, northern Angola.

Heliosciurus gambianus brauni St. Leger, I935

I935. Heliosciurus rufobrachiatus brauni St. Leger, Novit. Zool. 39: 252. Fazenda Congulu, $800 \mathrm{~m}$. , about 65 miles east of Porto Amboin, western central Angola.

Heliosciurus gambianus vumbae Roberts, i 937

1937. Heliosciurus mutabilis vumbae Roberts, Ann. Transv. Mus. I9: 1oo. Vumba, near the Portuguese border, south-eastern Southern Rhodesia.

\section{Subgenus AETHOSCIURUS Thomas, I9I6}

Heliosciurus lucifer Thomas, I 897

Nyasa Black and Red Squirrel

Distribution: Nyasaland and Tanganyika.

Heliosaiurus Luaifer Thomas, i 897

I897. Xerus (Paraxerus) lucifer Thomas, P.Z.S., 430. Kombe Forest, Masuku Mountains, 5,500 ft., northern Nyasaland. (On the altitude see Swynnerton \& Hayman, I95 I, 307.)

Genus PARAXERUS Forsyth Major, I 893

I893. Paraxerus Forsyth Major, P.Z.S., I89. Sciurus cepapi A. Smith (Thomas, I898, P.Z.S. I 897: 933).

I9I8. Tamiscus Thomas, Ann. Mag. N.H. I: 33. Sciurus emini Stuhlmann, from Uganda.

There are 5 upper cheekteeth in this genus and the related Funisciurus.

I. A white flankstripe each side of body. (Small species, occipitonasal in South Africa $4 \mathrm{I} \mathrm{mm}$. or less).

Paraxerus flavovittis, page 246

No white flankstripes. 
2. Tail either deep red or deep orange or with these colours in it. Underparts red or orange. (Skull length about $45-52 \mathrm{~mm}$, in adult).

Tail grey, drab or dull.

Paraxerus palliatus, page 245

3. Underparts without deep coloration. Skull about $39-45 \mathrm{~mm}$. (rarely as much as $45 \mathrm{~mm}$.) Underparts coloured, rufous orange. Skull about $50 \mathrm{~mm}$.

Paraxerus cepapi, page 244 Paraxerus vincenti, ${ }^{1}$ page 245

Paraxerus cepapi A. Smith, 1836

Bush Squirrel. Geelpooteekhorinkie

Distribution: in the Union, the Transvaal, Kruger National Park (Punda Maria, Shingwedzi, Satara, Skukuza, Toulon, etc.), also Klein Letaba, Olifants River, Sabi River (B.M.), and according to Roberts the Rustenburg district. Northern South-West Africa (to about $20^{\circ} \mathrm{S}$. (Shortridge, I934)), northwards to Capelongo, south-western Angola. Northern Bechuanaland; Southern Rhodesia; Portuguese East Africa, districts of Tete, Gorongoza, Beira. Nyasaland, Northern Rhodesia. North of the limits of this work, Tanganyika, the Belgian Congo, and (as nominal races of the form ochraceus) Kenya and Abyssinia.

Paraxerus gepapi Gepapi A. Smith, 1836

1836. Sciurus cepapi A. Smith, Report Exped. Explor. G. Africa, 43. Marico River, Rustenburg district, western Transvaal.

1843. Sciurus cepate Gray, List Spec. Mamm. B.M., I 40. Lapsus for cepapi. Range: the Transvaal and into the southern part of Southern Rhodesia.

Paraxerus Gepapi yulei Thomas, igo2

1902. Funisciurus yulei Thomas, P.Z.S. I: I 20. Mwenzo, Northern Province, northeastern Northern Rhodesia (see Swynnerton \& Hayman, I95I, 308). Ranges into Tanganyika.

Paraxerus cepapi sindi Thomas \& Wroughton, i908

I908. Funisciurus cepapi sindi Thomas \& Wroughton, P.Z.S., 543. Tete, on the Zambezi, Portuguese East Africa.

Paraxerus cepapi socgatus Wroughton, Igo9

I909. Paraxerus cepapi soccatus Wroughton, Ann. Mag. N.H. 3: 5I5. Vwaza, Hewe River, northern Angoniland, $10^{\circ} 5^{\prime}$ S., $33^{\circ} 27^{\prime}$ E., northern Nyasaland.

1 The forms "Aethosciurus" vexillarius (Kershaw, 1923, Tanganyika), Paraxerus byatti (Kershaw, 1923, Tanganyika) and Paraxerus vincenti, though unquestionably racially distinct from each other, may ultimately be united as a single species. The form vexillarius has priority; unfortunately no examples are known with unworn molars. $P$. vincent $i$ is the only one which has the underparts coloured; the others are most reminiscent of $P$. cepapi, but are distinctly larger (type skull of byatti about $53.5 \mathrm{~mm}$.). 


\section{RODENTIA - SCIURIDAE}

Paraxerus cepapi QuOTuS Wroughton, Igog.

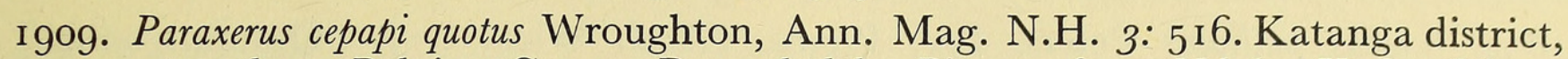
southern Belgian Congo. Recorded by Pitman from Ndola, Kafue River, etc., Northern Rhodesia.

Paraxerus cepapi phalaena Thomas, i 926

1926. Paraxerus cepapi phalaena Thomas, P.Z.S. 296. The forest between Ukuambi and Ondongwa (or Ondonga), Ovamboland, South-West Africa.

Paraxerus cepapi chobiensis Roberts, i 932

1932. Paraxerus cepapi chobiensis Roberts, Ann. Transv. Mus. 15: 9. Kabulabula, Chobe River, northern Bechuanaland.

Paraxerus cepapi maunensis Roberts, $193^{2}$

1932. Paraxerus cepapi maunensis Roberts, Ann. Transv. Mus. 15: 9. Maun, Tamalakane River, Ngamiland, northern Bechuanaland.

Paraxerus cepapi kalaharicus Roberts, 1932

1932. Paraxerus cepapi kalaharicus Roberts, Ann. Transv. Mus. 15: io. Mabeleapudi, south of Lake Ngami, northern Bechuanaland.

Paraxerus cepapi tsumebensis Roberts, I938

1938. Paraxerus cepapi tsumebensis Roberts, Ann. Transv. Mus. 19: 236. Guinas waterhole, Tsumeb district (north of Grootfontein), northern South-West Africa.

Paraxerus GePAPI GePAPOIDES Roberts, I 946

I946. Paraxerus cepapi cepapoides Roberts, Ann. Transv. Mus. 20: 3 16. Zimbiti, near Beira (south of the Zambezi), Portuguese East Africa.

Paraxerus Gepapi bororensis Roberts, I946

1946. Paraxerus cepapi bororensis Roberts, Ann. Transv. Mus. 20: 31 7. Namabieda, Boror, north of the Zambezi, Portuguese East Africa.

Paraxerus vincenti Hayman, I950 Vincent's Squirrel

Distribution: Northern Portuguese East Africa.

Paraxerus vincenti Hayman, i950

I950. Paraxerus vincenti Hayman, Ann. Mag. N.H. 3: 263. Namuli Mtn., I $5{ }^{\circ} 2$ I $^{\prime}$ S., $37^{\circ} 4^{\prime}$ E., north of the Zambezi, Portuguese East Africa.

Paraxerus palliatus Peters, 1852

South African Red Squirrel. Rooieekhorinkie

Distribution: Zululand (St. Lucia Bay and Eshowe); Portuguese East Africa, districts of Inhambane and Beira; Southern Rhodesia (Melsetter); Nyasaland; further to the north Tanganyika, Zanzibar, Kenya and Italian Somaliland. 
Paraxerus palliatus palliatus Peters, 1852

1852. Sciurus palliatus Peters, Ber. Preuss. Akad. Wiss., 273. "Quintangonha." Mainland near Mozambique Island (Moreau, Hopkins \& Hayman, 1946), Portuguese East Africa.

Paraxerus palliatus ornatus Gray, 1864

I864. Sciurus ornatus Gray, P.Z.S., I3. Ngoye Forest, Eshowe district, Zululand, Natal.

Paraxerus palliatus sponsus Thomas \& Wroughton, 1907

1907. Funisciurus sponsus Thomas \& Wroughton, P.Z.S., 292. Coguno, Inhambane district, southern Portuguese East Africa. Ranges northwards to Beira district.

Paraxerus palliatus swynnertoni Wroughton, igo8

I 908. Funisciurus palliatus swynnertoni Wroughton, Ann. Mag. N.H. I: 305. Chirinda Forest, Melsetter district, eastern Southern Rhodesia.

Paraxerus palliatus bridgemani Dollman, igi 4

I9I4. Paraxerus bridgemani Dollman, Ann. Mag. N.H. I4: I52. Induk (or Indook), $700 \mathrm{ft}$. , Panda, Portuguese East Africa. (Panda is a region inland from Inhambane.) Also recorded from Tanganyika.

Paraxerus palliatus auriventris Roberts, I926 1926. Paraxerus cepapi auriventris Roberts, Ann. Transv. Mus. II: 250. Magudi, lower Limpopo area, southern Portuguese East Africa.

Paraxerus palliatus tongensis Roberts, i93 I

193 I. Paraxerus sponsus tongensis Roberts, Ann. Transv. Mus. I4: 229. Mangusi Forest, north-eastern Zululand, Natal.

Paraxerus flavovittis Peters, 1852 Eastern Striped Squirrel

Distribution: northern Portuguese East Africa, Tanganyika, Kenya.

Paraxerus flavovittis flavovittis Peters, i 852

I 852. Sciurus flavovittis Peters, Ber. Preuss. Akad. Wiss., 274. Mossimboa, i I ${ }^{\circ}$ S., coast of northern Portuguese East Africa (designated by Thomas, I919, Ann. Mag. N.H. 4: 32).

I 852. Sciurus flavivittis Peters, Reise nach Mossambique, Säugeth., I 29. (Emendation or lapsus.)

Paraxerus flavovittis mossambicus Thomas, igig

1919. Paraxerus flavivittis mossambicus Thomas, Ann. Mag. N.H. 4: 31. Lumbo (about $15^{\circ} \mathrm{S}$.), coast of northern Portuguese East Africa. 
I880. Funisciurus Trouessart, Le Naturaliste, I: 293. Sciurus isabella Gray, the Cameroon Mountains race of Sciurus lemniscatus Leconte, from Gabon.

The type species, $F$. lemniscatus, differs from the species here dealt with in its longitudinally striped back.

I. Limbs reddish.

Limbs not reddish.

2. A bright whitish flankstripe on each side. The flankstripes obsolete.
Funisciurus pyrrhopus, page 248

$-2$

Funisciurus congicus, page 247

Funisciurus bayoni, ${ }^{1}$ page 248

Funisciurus congicus Kuhl, I 820

Western Striped Squirrel. Gestreepte Eekhorinkie

Distribution: northern South-West Africa, from Kovares (about the latitude of the Etosha Pan) and western Ovamboland (the forest belt between Ondongwa and Ukuambi) northwards (Shortridge, I934). Western Angola, where apparently widely distributed. The Belgian Congo, Gabon.

Funisciurus congigus congicus Kuhl, i 820

I820. Sciurus congicus Kuhl, Beitr. Zool. 2: 66. "Congo." Thomas, igi6, Ann. Mag. N.H. I8: 237, notes that Kuhl's type agrees absolutely with the form in northern Angola.

I843. Sciurus praetextus Wagner in Schreber, Säugth. Suppl. 3: 2 I6. No locality. I904. Funisciurus congicus olivellus Thomas, Ann. Mag. N.H. I3: 410. Cunga (south of Loanda) north-western Angola.

Funisciurus congigus flavinus Thomas, igo4

1904. Funisciurus congicus flavinus Thomas, Ann. Mag. N.H. I3: 4I I. Capangombe (near Mossamedes), south-western Angola.

Funisciurus congicus oenone Thomas, i 926

1926. Funisciurus congicus oenone Thomas, P.Z.S., 297. Cunene (or Rua Cana) Falls, extreme southern Angola. Range includes the Kaokoveld, South-West Africa.

Funisciurus Gongigus DAMAREnsis Roberts, I 938

1938. Heliosciurus (sic) congicus damarensis Roberts, Ann. Transv. Mus. I9: 236. Guinas waterhole, Tsumeb district (north of Grootfontein), northern South-West Africa.

${ }^{1}$ In a general way this may represent $F$. leucogenys Waterhouse, I842 (Fernando Po), several forms of which are thought to occur with pyrrhopus in many parts of western and central Africa. But some recently received material for bayoni suggests that it is too small to be placed as a race of leucogenys (occipitonasal length $40.6-42.5 \mathrm{~mm}$. in bayoni, $(49.4 \mathrm{~mm}$. in a specimen of leucogenys from Fernando Pọ)). 
Funisciurus bayoni Bocage, I89o

Bayon's Squirrel

Distribution: northern Angola.

Funisciurus bayoni Bocage, i8go

I89o. Sciurus bayoni Bocage, J. Sci. Math. Phys. Nat., Lisboa, 2: 3. Duque de Bragança, northern Angola. Recently recorded by Hayman from the Dundo district, north-eastern Angola (about $7^{\circ} 20^{\prime}$ S., $20^{\circ} 45^{\prime}$ E.).

Funisciurus pyrrhopus F. Cuvier, 1842

Red-footed Squirrel

Distribution: northern Angola; and from the Belgian Congo approximately westwards to Sierra Leone.

Funisciurus Pyrrhopus Pyrrhopus F. Cuvier, i 842. (Extralimital)

I842. Sciurus pyrrhopus F. Cuvier, in Geoffroy \& Cuvier, H.N. Mamm. 4: Tab. Gén. 4. Fernando Po.

Funisciurus PYRRHOPUS PEMBERTONI Thomas, I904

I904. Funisciurus pembertoni Thomas, Ann. Mag. N.H. I4: 20I. Dondo, Cuanza River, north-western Angola. The type and only specimen available for examination is juvenile, and looks like an immature specimen of $F . p$. akka (de Winton, I899, from the Belgian Congo).

\section{Genus PROTOXERUS Forsyth Major, I893}

I893. Protoxerus Forsyth Major, P.Z.S. I89. Sciurus stangeri Waterhouse (Thomas, I898, P.Z.S. I897: 933).

I909. Myrsilus Thomas, Ann. Mag. N.H. 3: 470. Macroxus aubinnii Gray, from the Gold Coast. Not of Stål, I 865 .

1953. Allosciurus Conisbee, Genera and subgenera of recent mammals, 7. Replaces Myrsilus Thomas. Valid as a subgenus.

\section{Subgenus PROTOXERUS Forsyth Major, I893}

Protoxerus stangeri Waterhouse, 1843

African Giant Squirrel

Distribution: Northern Angola, recorded as far southwards as Hanha. North of the limits of this work, Kenya, Uganda, the Belgian Congo and thence westwards to Sierra Leone.

This species has 4 upper cheekteeth.

Protoxerus stangeri stangeri Waterhouse, i843. (Extralimital) 1843. Sciurus stangeri Waterhouse, P.Z.S., I842: I27. Fernando Po.

Protoxerus stangeri loAndae Thomas, igo6

I906. Sciurus stangeri loandae Thomas, Ann. Mag. N.H. I8: 295. Canhoca, western Angola. 


\section{Genus XERUS Ehrenberg, I 833}

I 833. Xerus Ehrenberg in Hemprich \& Ehrenberg, Symb. Phys. Mamm. I: folio ee. Sciurus (Xerus) brachyotis Ehrenberg $=$ Sciurus rutilus Cretzschmar, from Abyssinia.

1834. Geosciurus A. Smith, S. Afr. J. 2: I28. Xerus capensis (Kerr) = Sciurus inauris Zimmermann. Valid as a subgenus.

i842. Spermosciurus Lesson, Nouv. Tabl. Règne Anim. Mamm. i io. Sciurus rutilus Gretzschmar.

I909. Euxerus Thomas, Ann. Mag. N.H. 3: 473. Sciurus erythropus Desmarest ${ }^{1}$ probably from Senegal. Valid as a subgenus.

\section{Subgenus GEOSCIURUS A. Smith, I834}

The characters of this subgenus have already been pointed out, page 240 .

Orbit normally rather less than a third of the occipitonasal length. Incisors white. Xerus (Geosciurus) inauris, page 249 Orbit normally more than a third of the occipitonasal length. Incisors pigmented. Xerus (Geosciurus) princeps, page 250

\section{Xerus inauris Zimmermann, I 780}

Cape Bristly Ground Squirrel. Waaierstertmeerkat

Distribution: in the Union, the western Transvaal (near Schweizer Reneke, near Christiana); the Orange Free State, near Wepener, between Ventersburg and Winburg, Vredefort district, Renoster River district and other localities; in the Cape Province, near Vryburg, De Beers estate (west of Kimberley) where it is very common, around Kuruman, near Upington, the Aughrabies Falls, Louisvale, between Kakamas and Pofadder, west of Graaff Reinet, Cradock, Deelfontein, Victoria West, Van Wyk's Vlei, near Middelburg, Aliwal North, Burghersdorp, etc. South-West Africa; apparently locally but widely distributed; parts of Great Namaqualand, the Kalahari desert, Gobabis district, parts of Damaraland, to Ngamiland and, according to Roberts, western Southern Rhodesia.

Xerus INAURIS Zimmermann, I 780

I780. Sciurus inauris Zimmermann, Geogr. Gesch. 2: 344. Kaffirland, Ioo miles north of the Cape of Good Hope (based on Pennant).

I 788. Sciurus dschinschicus Gmelin, Linn. Syst. Nat. ed. I3, I: I5I. Probably from South Africa. "In Provincia Indiae Dschinschi" (based, as is Shaw's (I80 I) name, on the "écureuil de Gingi" of Sonnerat).

I 792. Sciurus capensis Kerr, Anim. Kingd. 266. Karroo north of Sneeuwberg, near Graaff Reinet, eastern Cape Province.

${ }^{1}$ Sciurus erythropus Desmarest, I8I 7, Nouv. Dict. H. N. IO: I I0. This name has been dated from E. Geoffroy, I8o3 (Cat. Mamm. Mus. H.N. Paris) but the work was never published, see I. Geoffroy, I839, Mag. Zool. Paris, I: 5 . 
Xerus inAuris [contd.]

I 793. Sciurus namaquensis Lichtenstein, Cat. Rer. Nat. 2. Great Namaqualand, west of Fish River, South-West Africa.

I80 I. Sciurus ginginianus Shaw, Gen. Zool. 2: I47. "Gingi, East Indies" = South Africa.

I8ог. Myoxus africanus Shaw, Gen. Zool. 2: i72. In mountains of Sneeburgh, 800 (sic) miles north of Cape of Good Hope.

I8 1 7. Sciurus albovittatus. Desmarest, Nouv. Dict. H. N. io: i ro. "Le Cap de BonneEspérance", see Desmarest, I 822, Encycl. Méth., Mammalogie, 338.

1820. Sciurus levaillantii Kuhl, Beitr. Zool. 2: 67. "In Africa meridionali.",

1822. Sciurus setosus Smuts, Enum. Mamm. Cap. 33. Southern part of Cape of Good Hope.

\section{Xerus princeps Thomas, I929}

Kaokoveld Bristly Ground Squirrel. Kaokoveld Waaierstertmeerkat

Distribution: South-West Africa, from Great Namaqualand (Berseba) and Damaraland to the Kaokoveld, and south-western Angola, whence recorded from I o $\mathrm{km}$. east of Mossamedes.

Xerus PRINGeps Thomas, I929

1929. Geosciurus princeps Thomas, P.Z.S., Io6. Otjitundua, central Kaokoveld, northern South-West Africa.

\section{FAMILY A N O M A L U R I D A E}

\section{Genus ANOMALURUS Waterhouse, I 843}

I 843. Anomalurus Waterhouse, P.Z.S. I 842: i 24. Anomalurus fraseri Waterhouse, the Fernando Po race of Pteromys derbianus Gray.

I843. Aroaethrus Waterhouse, loc. cit. Provisional substitute for Anomalurus.

I9I4. Anomalurodon Matschie, S.B. Ges. Naturf. Fr. Berlin, 350. Anomalurus auzembergeri Matschie, a probable synonym of Pteromys (Anomalurus) peli Schlegel \& Müller, from the Gold Coast.

I9I4. Anomalurella Matschie, loc. cit. 35 I. Anomalurus pusillus Thomas, from the Belgian Congo.

See Rümmler, I 933, S.B. Ges. Naturf. Fr. Berlin, 389.

The correct name for the common species in this genus would appear to be Anomalurus derbianus Gray (December, I 842 ), which antedates $A$. fraseri Waterhouse (January, i 843).

Anomalurus derbianus, Gray, 1842

Common Scalytail

Distribution: north-western Angola, Northern Rhodesia, and Boror (north of the Zambezi in Portuguese East Africa (Transvaal Museum)). North of the limits of this work, Tanganyika, Uganda and thence westwards to Sierra Leone. 
Anomalurus derbianus derbianus Gray, i842. (Extralimital)

I842. Pteromys derbianus Gray, Ann. Mag. N.H. I0: 262. (December, I842.) Sierra Leone.

Anomalurus derbianus Ginereus Thomas, i 895

I 895. Anomalurus cinereus Thomas, Ann. Mag. N.H. 15: i88. Upper Rovuma River, towards Lake Nyasa, Songea district, southern Tanganyika. Specimens in the Transvaal Museum from Boror (north of the Zambezi) Portuguese East Africa.

Anomalurus derbianus neavei Dollman, igo9

I909. Anomalurus neavei Dollman, Ann. Mag. N.H. 3: 351. Kambove, Katanga, southern Belgian Congo. Recorded from Ndola, Northern Rhodesia and Lunda, N. E. Angola (Hayman).

AnOmalurus DeRbianus JORDANi St. Leger, I 935

I935. Anomalurus jacksoni jordani St. Leger, Novit. Zool. 39: 25 I. Congulu, inland from Porto Amboim, north-western Angola (See Hill \& Carter, I94I).

\section{FAMILY P E D E T I D A E}

Genus PEDETES Illiger, I 8 I I

I 778. Yerbua Forster, K. Svenska Vetensk. Akad. Handl. 39: I 08, in part. We have asked the International Commission on Zoological Nomenclature to suppress this name, since it is not in current use and antedates one of six well-known generic names, depending on which of its species is selected as being the type species.

I8 I I. Pedetes Illiger, Prodr. Syst. Mamm. 8ı. Dipus cafer Gmelin $=$ Mus cafer Pallas = Terbua capensis Forster.

I8ı. Helamys G. Guvier, Régne Anim., ed. I, I: 202, footnote. Mus cafer Pallas= Yerbua capensis Forster.

I82 I. Helamis F. Guvier, Dict. Sci. Nat. 20: 34I.

I843. Pedestes Gray, List Spec. Mamm. B.M., I 30.

Pedetes capensis Forster, $1778^{1}$

Springhaas or Spring Hare. Springhaas

Distribution: in the Union, the Transvaal (Kruger National Park, Shingwedzi, etc., Woodbush, Tzaneen, Pietersburg district), the highlands of Natal (Shortridge, I934), the Orange Free State, including near Wepener, Vredefort district and Aberfeldy (near Harrismith), etc.; Maseru, Basutoland (British Museum); in the Cape Province, De Beers (36 miles west of Kimberley), Kuruman, Louisvale (near Upington), near Graaff Reinet, Deelfontein, Grahamstown, Albany district and Port Elizabeth according to Shortridge (I934). (Hewitt (I93I) stated, "very common in sandy districts almost throughout our region (= the Eastern Province); unknown in coastal parts of the Transkei and Pondoland.") South-West Africa;

1 Yerbua capensis Forster, I 778 antedates Mus cafer Pallas, I 779 for this species. 
distributed throughout the Territory except along the coastal edge of the Namib desert and apparently scarce in central Great Namaqualand (Shortridge, r934). Ngamiland; Southern Rhodesia (according to Shortridge); the Inhambane district of Portuguese East Africa. Apparently widely distributed in the interior of Angola (Hill \& Carter). Northern Rhodesia (Sesheke district, Kafue, etc., British Museum). Beyond the limits of this work, Tanganyika and Kenya.

There seem far too many named subspecies in South Africa.

Pedetes Gapensis capensis Forster, 1778

I 778. Yerbua capensis Forster, K. Svenska Vetensk. Akad. Handl. 39: ro8. Cape of Good Hope.

I779. Mus cafer Pallas, Nov. Spec. Quad. Glir. Ord., 87. Cape of Good Hope. (Pages I -70 of this work were published in I 778 , the rest in I 779 ). (Sherborn, I89 I, Ann. Mag. N.H. 7: 236.) Cape of Good Hope.

1834. Pedetes typicus A. Smith, S. Afr. J. 2: i69. Eastern districts of Cape Colony. (Renaming of capensis).

Pedetes capensis orangiae Wroughton, i907 1907. Pedetes cafer orangiae Wroughton, Ann. Mag. N.H. 20: 32. Aberfeldy district (near Harrismith), north-eastern Orange Free State.

Pedetes Capensis Salinae Wroughton, i907

1907. Pedetes cafer salinae Wroughton, Ann. Mag. N.H. 20: 32, 33. Woodbush, Pietersburg district, eastern Transvaal.

Pedetes capensis angolae Hinton, i920

1920. Pedetes angolae Hinton, Ann. Mag. N.H. 6: 102. Cholinde (= Cholende), 20 miles north-east of Bihé, central Angola.

Pedetes Gapensis Damarensis Roberts, 1926

1926. Pedetes caffer damarensis Roberts, Ann. Transv. Mus. II: 26I. Quickborn Farm, Okahandja district, Damaraland, South-West Africa. Ranges to the Gordonia district (north-western Cape Province), to Ngamiland, and has been recorded from Northern Rhodesia.

Pedetes Gapensis fouriei Roberts, 1938

1938. Pedetes cafer fourei Roberts, Ann. Transv. Mus. 19: 242 and 1946, loc. cit. 20: 3 I 4 (described as a new subspecies in both places). Itota Pan, 40 miles south of Ondonga, Ovamboland, northern South-West Africa.

Pedetes gapensis albaniensis Roberts, 1946

1946. Pedetes cafer albaniensis Roberts, Ann. Transv. Mus. 20: 313. Committees Drift, Great Fish River, Albany district, south-eastern Cape Province. 


\section{FAMILY M U S G A R D I N I D A E}

For continued use of this name instead of Gliridae for this family see Ellerman \& Morrison-Scott, I95 I, 54 I. One valid genus occurs south of the Sahara.

SUbFAmily Graphiurina e

\section{Genus GRAPHIURUS Smuts, 1832}

1832. Graphiurus Smuts, Enum. Mamm. Cap., 32. Graphiurus capensis Smuts = Sciurus ocularis A. Smith.

I888. Claviglis Jentink, Notes Leyden Mus. 10: 4I. Claviglis crassicaudatus Jentink, from Liberia. Valid as a subgenus.

1925. Gliriscus Thomas \& Hinton, P.Z.S., 232. Graphiurus platyops Thomas.

I936. Aethoglis G. Allen, J. Mamm. I7: 292. Graphiurus nagtglasii Jentink, the Liberian race of Graphiurus hueti Rochebrune, from Senegal.

The subfamily Graphiurinae differs from the typical subfamily by having the zygomatic plate not tilted upwards.

On the status of Aethoglis see Ellerman, i 940, 606-6o7.

Thomas \& Hinton erected a genus Gliriscus in 1925 for the species G. platyops. This was based primarily on the skull being flattened. We doubt if it is anything but a synonym of Claviglis. G. platyops is distinguishable from G. murinus (typical Claviglis) by its larger size; but Roberts has recently named a form of restricted Claviglis (the smaller subgenus) with a flattened skull (schneideri); and the form angolensis from Angola is the size of platyops, but its skull does not seem to be specially flattened. Therefore it becomes impossible to separate "Gliriscus" from Claviglis in a satisfactory manner; in fact it is by no means easy, when all forms of the genus are taken into account, to separate $G$. platyops from $G$. murinus, the differences between these two species being much less than hitherto supposed; murinus has priority. The only cranial difference between the two groups in Roberts' measurements, the width of the braincase (which is constantly wider in platyops) is not borne out in B.M. material. There seem to be two species, one on average larger and the other smaller, that occur in South Africa, sometimes together (as for instance near Pretoria, and at least in one locality in Angola).

I. Colour pattern specialized; underside of tail with striking black line running down the middle, and with white hairs each side of this. A black stripe from eye to ear. Upper premolar very small. Large species, head and body length I 29-I 44 mm., skull length 32.8-37. I mm.

Graphiurus ocularis, page 259

Colour pattern less specialized; underside of tail less strikingly coloured; dark eye-ring may be present, but the general colour, including the face, much drabber. Upper premolar usually less reduced. 
2. Large species, length of skull $32-36.6 \mathrm{~mm}$. Head and body about $\mathrm{I}_{30-1} 5^{0} \mathrm{~mm}$. Hindfoot $2 \mathrm{I}-22 \mathrm{~mm}$.

Graphiurus (Claviglis) monardi, page $25^{8}$ Smaller species, length of skull reaches $32 \mathrm{~mm}$. in only four individuals in a considerable series (B.M., Roberts, Hill \& Carter). Head and body $124 \mathrm{~mm}$. and less.

3. Averages larger; hindfoot $\mathrm{I} 8-23 \mathrm{~mm}$.; the majority of skulls exceed $29 \mathrm{~mm}$.

Graphiurus (Claviglis) platyops, page 257

Averages smaller; hindfoot $14-20 \mathrm{~mm}$. (but rarely over $18 \mathrm{~mm}$. in South Africa, and only once over $19 \mathrm{~mm}$. in measurements available); the majority of the skulls fail to reach $29 \mathrm{~mm}$. Graphiurus (Claviglis) murinus, page 254

\section{Subgenus CLAVIGLIS Jentink, I 888}

When we read a key to the South African forms like that of Roberts (I95I) which starts off "tail thickly haired" or "tail thinly haired" or "tail not so thickly or so thinly haired" it is small wonder that this author listed ten species in the murinus group, all of which appear to be conspecific.

Graphiurus murinus Desmarest, 1822

Forest Dormouse. Boswaaierstertmuis

Distribution: in the Union, the Transvaal, including districts of Zoutpansberg, Rustenburg, Pretoria, Klein Letaba, Tzaneen, Barberton, Hectorspruit, Wakkerstroom. Zululand, Durban and Estcourt, Natal. Leribe, Basutoland. In the Cape Province, Kuruman, the Molopo region, Pondoland (Port St. Johns and Ngqeleni), King William's Town, Grahamstown, Knysna and near George. The southern parts of Portuguese East Africa; Southern Rhodesia; the Kalahari, and south-eastern Bechuanaland (Gaberones). In South-West Africa from about the latitude of Gobabis northwards to the Caprivi. South-western and central Angola. Northern Rhodesia and Nyasaland. Beyond the limits of this work similar forms occur in East Africa northwards to the Sudan and British Somaliland, and in West Africa from the Belgian Congo to Asben and probably Senegal.

GRAPhiURUS MURINUS MURINUS Desmarest, I 822

1822. Myoxus murinus Desmarest, Encycl. Méth. Mamm. Suppl. 542. Cape of Good Hope.

1825. Myoxus lalandianus Schinz, Cuvier's Thierreich, 4: 393. Renaming of murinus. I829. Myoxus erythrobronchus A. Smith, Zool. J. 4: 438. South Africa.

I842. Myoxus cineraceus Rüppell, Mus. Senckenberg. 3: I 36. "Port Natal" = Durban, Natal.

1845. Myoxus cinerascens Schinz, Synops. Mamm. 2: 8o. (Emendation). Range: southern Cape Province to Natal. 
GRAPHIURUS MURINUS MICROTIS Noack, I 887

I887. Eliomys microtis Noack, Z. Jahrb. 2: 248. Mpala's, west shore of Lake Tanganyika, in Marungu, 3,900 ft. Belgian Congo. Many specimens, bearing this name in British Museum from Ndola, Northern Rhodesia and Nyasaland.

GRAPHiURUS MURINUS KELleni Reuvens, i 890

I890. Eliomys kelleni Reuvens, Die Myoxidae oder Schlaefer, 35. Damaraland, South-West Africa (but Hill \& Carter say it came from the interior of Mossamedes district, south-western Angola).

(1897. Myoxus (Eliomys) nanus de Winton, P.Z.S. I896: 799.Mazoe, Mashonaland, eastern Southern Rhodesia).

G. nanus recorded from Petauke by Pitman, and G. murinus subsp. stated to be common in huts and houses throughout Northern Rhodesia.

Graphiurus murinus Johnstoni Thomas, i 898 I898. Graphiurus johnstoni Thomas, P.Z.S. I897: 934. Zomba, southern Nyasaland.

GraphiURUS MURINUS GRISElda Schwann, igo6

I906. Graphiurus griselda Schwann, P.Z.S. 105. Kuruman, northern Cape Province. Has also been recorded from Bulawayo, Southern Rhodesia and Damaraland (but we doubt if it is distinguishable from nanus which Roberts makes a synonym of kelleni).

Graphiurus murinus woosnami Dollman, igio

i910. Graphiurus woosnami Dollman, Ann. Mag. N.H. 6: 393. North of Okwa, Kalahari $\left(22^{\circ} 30^{\prime} \mathrm{S} ., 2 \mathrm{I}^{\circ} 30^{\prime} \mathrm{E}\right.$., in Bechuanaland). Ranges in part of South-West Africa (Gobabis, Damaraland, etc.), southwards to the Molopo River.

Graphiurus murinus ANSORgei Dollman, I9I 2

191 2. Graphiurus ansorgei Dollman, Ann. Mag. N.H. 9: 317. Tala Kilau, 3,00o ft., Donguena, Mossamedes, south-western Angola.

Graphiurus murinus tZaneenensis Roberts, i 9 I 3

I9I3. Graphiurus murinus tzaneenensis Roberts, Ann. Transv. Mus. 4: 79. Tzaneen, eastern Transvaal. Ranges northwards to Zoutpansberg, northern Transvaal.

GraphiURUs mURINUS PRETORIAe Roberts, I9I 3

I9I3. Graphiurus pretoriae Roberts, Ann. Transv. Mus. 4: 79. Little Wonderboom, Pretoria, Transvaal. Range includes Rustenburg district, western Transvaal and Gaberones, south-eastern Bechuanaland.

Graphiurus murinus Streeteri Roberts, I9I3

I913. Graphiurus streeteri Roberts, Ann. Transv. Mus. 4: 8o. Hectorspruit, near southern border of Kruger National Park, eastern Transvaal. 
GraphiURUs mURINUS TASMANi Roberts, 1929

1929. Claviglis tasmani Roberts, Ann. Transv. Mus. 13: 95. Driefontein Mission Station, near Gwelo, central Southern Rhodesia. Based on one specimen.

GraphiURUS murinus LitToRalis Roberts, 1929

1929. Claviglis littoralis Roberts, Ann. Transv. Mus. 13: 97. Masiene, a little north of the mouth of the Limpopo River, southern Portuguese East Africa. Based on one specimen.

GRAPHIURUS MURINUS VANDAMI Roberts, I929

1929. Claviglis vandami Roberts, Ann. Transv. Mus. 13: 97. Guija, lower Olifants River, southern Portuguese East Africa.

Graphiurus murinus alticola Roberts, i 929

1929. Claviglis alticola Roberts, Ann. Transv. Mus. I3: 98. "Kastrol Nek," Wakkerstroom, south-eastern Transvaal. Roberts (I95I) also quoted a specimen from Leribe, Basutoland.

Graphiurus murinus zUluensis Roberts, I93 I

1931. Claviglis zuluensis Roberts, Ann. Transv. Mus. 14: 229. Ubombo Bush, altitude about I,500 ft., northern Zululand, Natal. Based on one specimen.

Graphiurus murinus Guanzensis Hill \& Carter, 1937

1937. Claviglis ansorgei cuanzensis Hill \& Carter, Amer. Mus. Novit. No. 913: 9 . Chitau, 4,930 ft., Central Angola.

GraphiURUs MURINUS SELINDEnsis Roberts, I937

1937. Claviglis murinus selindensis Roberts, Ann. Transv. Mus. 19: roo. Mt. Selinda, Melsetter district, eastern Southern Rhodesia. Based on one specimen.

GraphiURUS MURINUS SGHNEIDERI Roberts, I938

1938. Claviglis schneideri Roberts, Ann. Transv. Mus. 19: 237. Okosongomingo, Waterberg, north-central South-West Africa. Based on one specimen, which is the size of murinus but has the relatively flattened skull of typical platyops and related forms.

Graphiurus murinus etoschae Roberts, $193^{8}$

1938. Claviglis woosnami etoschae Roberts, Ann. Transv. Mus. 19: 238. Itota Dune, 40 miles south of Ondonga, Etosha Pan district, Ovamboland, northern South-West Africa.

GraphiURUS MURINUS DASILVAI Roberts, 1938

1938. Claviglis woosnami dasilvai Roberts, Ann. Transv. Mus. 19: 238. Ondjiwa, Southern Angola. 


\section{RODENTIA - MUSCARDINIDAE}

Graphiurus platyops Thomas, 1897

Rock Dormouse. Klipwaaierstertmuis

Distribution: in the Union, the Transvaal, including Koster, Pretoria, Woodbush, Carolina; and Little Namaqualand (north of Steinkopf and Port Nolloth). SouthWest Africa; mountains of Great Namaqualand, Damaraland and the Kaokoveld. Mashonaland, eastern Southern Rhodesia. Angola (common throughout the interior plateau (Hill \& Carter)). Northern Rhodesia.

The forms angolensis and eastwoodae have the skull less flattened than platyops, rupicola, etc., but it seems reasonable to regard them all as conspecific.

Graphiurus platyops platyops Thomas, i 897

I897. Graphiurus platyops Thomas, Ann. Mag. N.H. 19: 388. Enkeldorn (or Enkeldoorn), Mashonaland, Southern Rhodesia. April, I897.

Graphiurus platyops angolensis de Winton, i 897

I897. Graphiurus angolensis de Winton, Ann. Mag. N.H. 20: 320. Caconda (inland from Benguela), south-western Angola. September, 1897 .

Graphiurus platyops eastwoodae Roberts, I9I 3

1913. Graphiurus eastwoodae Roberts, Ann. Transv. Mus. 4: 8o. Woodbush, eastern Transvaal. Range includes Transvaal localities listed above.

Graphiurus platyops rupigola Thomas \& Hinton, I925

1925. Gliriscus rupicola Thomas \& Hinton, P.Z.S. 232. Karibib, 3,842 ft. (northwestwards from Windhoek), central South-West Africa.

Graphiurus platyops montosus Thomas \& Hinton, I925

1925. Gliriscus rupicola montosus Thomas \& Hinton, P.Z.S. 233. Great Brukkaros Mountain, 3,60o-5,00o ft., near Berseba in central Great Namaqualand, South-West Africa.

GRAPHIURUS PLATYOPS JORDANI Roberts, I 929

1929. Gliriscus angolensis jordani Roberts, Ann. Transv. Mus. I3: 95. Isoka, northeastern Northern Rhodesia.

Graphiurus platyops parvulus Monard, i 933

I933. Graphiurus parvulus Monard, Bull. Soc. Sci. Nat. Neuchâtel, 57: 54. Hill \& Carter (I94I) restricted the type locality to Vila da Ponte, southern Angola. (Other localities, Rio Mbalé and Tumbolé, southern Angola.)

Graphiurus platyops KaOKoensis Roberts, 1938

1938. Gliriscus kaokoensis Roberts, Ann. Transv. Mus. 19: 237. Kamanjab, Kaokoveld, northern South-West Africa. 
Graphiurus platyops aUstralis Shortridge \& Carter, $193^{8}$ 1938. Gliriscus rupicola australis Shortridge \& Carter, Ann. S. Afr. Mus. 32: 286. Eenriet (about 3,300 ft.), 7 miles north of Steinkopf, Little Namaqualand, north-western Cape Province. Also known from Port Nolloth, Little Namaqualand.

Graphiurus monardi St. Leger, 1936

Monard's Dormouse

Distribution: north-eastern Angola, and Mwinilunga district, Northern Rhodesia.

G. Allen (1939) listed this as a race of hueti. But G. hueti is a very well-defined species, and $G$. monardi shows no affinity with it at all, but rather appears to be a giant species in the murinus group. The character of the comparative shortening of the nasals in hueti so that they do not project behind the posterior upper edge of the maxilla is alone sufficient sharply to distinguish hueti from all other species in the subgenus Claviglis, except crassicaudatus. In this respect monardi differs markedly from hueti.

Skull characters:

\section{G. hueti \\ G. monardi}

Nasals parallel, not spatulate. Not extending behind posterior edge of maxillary bone.

Bullae short and low, length 7.5-8.4 mm.

Palatal foramina shorter, $3.2-3.5 \mathrm{~mm}$.

Toothrow longer, length $5 \cdot 5-5.9 \mathrm{~mm}$.

Upper incisors flatfronted.

Nasals spatulate as in murinus. Long, extending well behind posterior edge of maxillary bone.

Bullae long and well inflated, length I0.3-I I mm.

Palatal foramina longer, $4-4.6 \mathrm{~mm}$.

Toothrow short, teeth small, length 4-4.3 mm.

Upper incisors turned inward.

\section{External characters:}

Colour of tail; no white in a long series of skins.

Hands and feet proportionately large, with long digits and big claws; hindfoot 27-30 mm., longest digit $8 \mathrm{~mm}$.

Forefoot $14.5^{-17} 7.5 \mathrm{~mm}$., longest digit $7 \mathrm{~mm}$.
Tail; much white, with conspicuous white tip in six skins known.

Hands and feet proportionately small, with short digits and small claws; hindfoot $2 \mathrm{I}-22 \mathrm{~mm}$., longest digit $5.4 \mathrm{~mm}$.

Forefoot I I.4-I $2.5 \mathrm{~mm}$., longest digit $4 \mathrm{~mm}$.

Graphiurus monardi St. Leger, I 936

1936. Claviglis monardi St. Leger, Ann. Mag. N.H. I7: 465. Fifteen km. above Dala, Chiumbe River, north-eastern Angola. 


\section{RODENTIA - MURIDAE}

\section{Subgenus GRAPHIURUS Smuts, I832}

Graphiurus ocularis A. Smith, 1829

Black and White Dormouse. Gemsbokmuis

Distribution: has been recorded from north-west of Zeerust, Transvaal; the Orange Free State; in the Cape Province, Little Namaqualand (Klipfontein (north of Steinkopf), the Kamiesberg), Clanwilliam, Klaver, Citrusdal. In I 948 a specimen was caught at Betty's Bay, near Hangklip, east of Cape Town. Deelfontein, Alicedale and Middelburg (Hewitt, I93I). This is a rare species in museums.

Graphiurus ogularis A. Smith, i829.

I829. Sciurus ocularis A. Smith, Zool. J. 4: 439. (May, i 829.) Near Plettenberg Bay east of Knysna), southern Cape Province.

I832. Graphiurus capensis Smuts, Enum. Mamm. Cap. 32.

I834. Graphiurus typicus A. Smith, S. Afr. J. 2: 145. Renaming of ocularis.

I838. Graphiurus elegans Ogilby, P.Z.S., 5. Said to be from Damaraland. Cape of Good Hope?

\section{FAMILY M U R I D A E}

I. Skull specialized by enlargement of braincase and bullae, and weakening of rostrum, zygoma and mandible; upper incisors (in South African genera) usually grooved. Upper cheekteeth either biserially cuspidate or simple prismatic in pattern (cuspidate in the South African genera). Externally, mostly modified for life in plains or deserts.

SUBFAMILy Gerbillinae, page 3I4

Skull not specialized exactly in the manner described above; not combining these characters. If the bullae are enlarged and the incisors grooved, then the molars are a series of transverse plates.

2. The upper molars with their laminae separated by folds and the cusps arranged in two longitudinal rows (in Europe, Asia and Africa).

\section{SUBFAMILy Cricetinae, page 3i3}

The upper molars not as just described; their laminae normally tightly packed together; the cusps when present arranged in three longitudinal rows. $-3$

3. The molars simply laminate, without traces of cusps; in the upper jaw the third molar is the dominant (and most variable tooth), in the lower jaw the first molar remains dominant. Subfamily Otomyinae, page 306

The molars usually cuspidate; the third upper molar is not, or scarcely, the dominant tooth. 
4. The inner row of cusps of the upper molars much reduced, so that there is only one functional inner cusp in the first and second upper molars. ${ }^{1} \mathrm{M}_{3 / 3}$ much reduced. Except in the genus Petromyscus, the upper incisors are grooved.

Subfamily Dendromurinae, page 296 At least two functional inner cusps in the first and second upper molars. SUBfamily Murinae, page 260

SUBFAmily $\mathrm{M}$ u ri n a e

Eighteen genera in South Africa, only nine of which reach the Union.

I. Very large, head and body length $240 \mathrm{~mm}$. and more, hindfoot $63 \mathrm{~mm}$. and more. Tail wholly dark proximally, wholly pale distally. Cheekpouches present. The inner row of cusps of the upper molars (said by Roberts not to be homologous with those of other Murinae) is reduced, and in M I with wear the anterointernal cusp is transferred to the second lamina. No posterointernal cusp in $\mathrm{M}_{\mathrm{I}}$ and $\mathrm{M}_{2}$. Bullae small, palatal foramina very short, far in front of the toothrows. In South Africa, skull length $65^{-80} \mathrm{~mm}$.

Genus CRICETOMYS, page 295

Considerably smaller, head and body below $200 \mathrm{~mm}$., hindfoot not over $43 \mathrm{~mm}$. Colour of the tail different. Not combining the above cranial and dental characters.

2. The foremost space between the pterygoid bones is roofed in by bone. The foremost space between the pterygoid bones is not roofed in by bone.

3. Fur spiny. Upper incisors not proodont; condylobasal length shorter than occipitonasal length.

Genus ACOMYS, page 292

Fur not spiny. Upper incisors proodont; condylobasal length at least as long as, usually longer than occipitonasal length. Genus URANOMYS, page 292

4. Upper cheekteeth abnormal; M I lacks the anterointernal cusp; the posterointernal cusp in $\mathrm{M}_{\mathrm{I}}$ and $\mathrm{M}_{2}$ is well developed. Cheekpouches are present.

The anterointernal cusp in $\mathrm{M}_{\mathrm{I}}$ is retained. Not known to possess cheekpouches, and not combining the characters as just outlined above. 6

5. Tail short, normally less than half head and body length. Cusps of cheekteeth in adult weak or obsolete, the pattern tending to simplification. Palatal foramina long, average 20 per cent and more of occipitonasal length. (The hindfoot is short, rarely exceeding $20 \mathrm{~mm}$. although the head and body usually exceeds $\mathrm{I} 00 \mathrm{~mm}$.)

Genus SACCOSTOMUS, page 294

${ }^{1}$ Dendromurinae; the antero-internal cusp in $\mathbf{M}_{\mathrm{I}}$ is absent. This subfamily is perhaps of less importance than the others recognized here, and is more comparable with the divisions called "tribes" by Simpson (1945). Members of this subfamily are small mice, Steatomys being the only one in South Africa which may sometimes have the head and body as much as $100 \mathrm{~mm}$. 
Tail not reduced (in South Africa about 82 per cent of head and body). Cusps of cheekteeth in adult strong and angular, the pattern remaining complex. Palatal foramina shortened, I I per cent of occipitonasal length (South Africa).

Genus BEAMYS, page 294

6. Fifth finger so reduced that the manus has only three functional digits.

Fifth finger clawed and not so reduced.

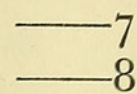

7. Upper incisors grooved.

Upper incisors plain.

Genus PELOMYS, page 289 Genus LEMNISCOMYS, page 290

8. The condylobasal length is normally either approximately equal to or exceeds the occipitonasal length.

The condylobasal length is shorter than the occipitonasal length.

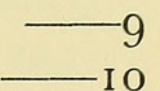

9. Occipitonasal length (South Africa) $31.5 \mathrm{~mm}$. and less. Zygomatic plate with anterior border not concave. Tail relatively short, averaging about 82 per cent or less of head and body. Toothrow $6 \mathrm{~mm}$. and less. M 3 small. Hindfoot $26 \mathrm{~mm}$. and less. Genus ZELOTOMYS, page 287

Occipitonasal length $33.4 \mathrm{~mm}$. and more. Zygomatic plate with anterior border concave. Frontals very constricted. Tail normally less shortened (though most often rather shorter than head and body). Toothrow $6.7 \mathrm{~mm}$. and more. Hindfoot usually over $30 \mathrm{~mm}$. $\mathrm{M}_{3}$ tends to be as large as $\mathrm{M}_{2}$.

Genus DASYMYS, page 288

Io. Upper toothrow specialized by enlargement of $\mathrm{M}$ I combined with considerable backward distortion of its anterointernal cusp combined with marked reduction of $\mathrm{M}_{3}$. Small species (south of the Zambezi-Cunene, hindfoot I $5 \mathrm{~mm}$. and less, head and body $75 \mathrm{~mm}$. and less in wild species native to South Africa, but in Angola larger forms occur). Occipitonasal length about $24.6 \mathrm{~mm}$. at highest.

Genus $M U S$, page 284

Upper toothrow not specialized exactly in the manner just described. (South of the Zambezi-Cunene, head and body at least $79 \mathrm{~mm}$., hindfoot at least $16 \mathrm{~mm}$., usually more.) Occipitonasal length (South Africa) $24.7 \mathrm{~mm}$. and more, usually more.

I I

I I. Dentition abnormal; cusps of molars unusual: uniform in size, columnar, and distinctly separated from each other (except for the outer cusps of $\mathrm{M}_{3}$ which are more or less obliterated).

Genus OENOMYS, page 287

Dentition less abnormal, cusps of molars not so unusual.

I 2

I 2. Back with four dark stripes. (The manus has the $5^{\text {th }}$ finger small but clawed and functional; the $5^{\text {th }}$ hindtoe is relatively short.)

Genus RHABDOMYS, page 280

Back normally unstriped.

13. Palatal foramina short (in a few extralimital skulls about i5 per cent of the occipitonasal length), considerably in front of toothrows. Hindfoot long, 
averages $24^{-26}$ per cent of the head and body length. Occipitonasal length usually over $40 \mathrm{~mm}$. Cusps of molars obsolete.

Genus MALACOMYS, page 287

Palatal foramina long, very rarely under 20 per cent of the occipitonasal length, in South African species usually reaching toothrows. Hindfoot normally shorter except in Colomys, which has long palatal foramina as just indicated, and a smaller skull, usually about 32-35 mm., with molar cusps much more strongly marked, etc.

I 4

I4. Hindfoot long, about 27-29 per cent of head and body length.

Genus COLOMYS, page 286

Hindfoot proportionately shorter, in adult normally below a quarter of head and body length.

- I5

I5. Interorbital region of skull unusually broad, scarcely any interorbital constriction evident; interorbital region broader than rostrum. In South Africa tail short, roughly $54^{-6}$ I per cent of head and body.

\section{Genus LOPHUROMYS, page 283}

Interorbital region of skull more clearly constricted. Tail not specially short, normally over three-quarters of head and body length. - 6

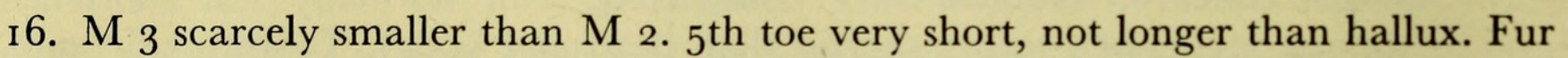
grey speckled dorsally.

Not combining the characters just described.

Genus ARVICANTHIS, page 264

I7. A much reduced posterointernal cusp normally present in unworn first and second upper molars. Genus GRAMMOMYS, page 262

Posterointernal cusp normally absent in first and second upper molars.

Genus RATTUS, ${ }^{1}$ page 264

\section{Genus GRAMMOMYS Thomas, I9I 5 .}

1915. Grammomys Thomas, Ann. Mag. N.H. i6: i5o. Mus dolichurus Smuts.

Fifth hindtoe long, hindfoot arboreal. This genus should not be merged with Thamnomys Thomas, as is sometimes done; see Ellerman, I941, 2: 105, for details.

Tail averages about 127 per cent of head and body. Bullae large, $6.4 \mathrm{~mm}$. and more (more than 20 per cent of the occipitonasal length).

Grammomys ruddi, page 263

Tail averages over I 40 per cent (up to over I6o per cent) of head and body. Bullae rarely over $6 \mathrm{~mm}$. (6.2 mm. and less in South Africa), about 17 per cent of the occipitonasal length.

Grammomys dolichurus, page 263

It is necessary to note that apparently the palatal foramina in $G$. ruddi are a little shorter than is normal in these Rattus-like Rats (more like the subgenus Hylomyscus; the foramina average 2 I per cent of the occipitonasal length in ruddi; more than 22 per cent in South African dolichurus).

${ }^{1}$ In this work, the introduced European species Rattus rattus, Rattus norvegicus and Mus musculus are not included. 
Grammomys dolichurus Smuts, 1832

Forest Mouse. Bosmuis

Distribution: in the Union, the eastern Transvaal (Woodbush), Zululand, and Pondoland and King William's Town district, eastern Cape Province. Portuguese East Africa, including Inhambane district and Lumbo (north of the Zambezi), Southern Rhodesia, Northern Rhodesia, Nyasaland, central and northern Angola. Similar forms also occur in East Africa northwards to the Sudan and Abyssinia, and in West Africa as far as Liberia and Timbuktu.

Grammomys dolichurus dolichurus Smuts, i 832

I832. Mus dolichurus Smuts, Enum. Mamm. Cap., 38. The type locality is usually quoted as near Cape Town, where we do not think the animal occurs. A. Smith, $1834, S$. Afr. F. 2: 156 gave Uitenhage, in the eastern Cape Province, to which the type locality is here restricted. Range: eastern Cape Province to southern Zululand.

Grammomys Dolichurus cometes Thomas \& Wroughton, igo8 I908. Thamnomys cometes Thomas \& Wroughton, P.Z.S., 549. Inhambane, coastal southern Portuguese East Africa. Ranges to north-eastern Zululand.

Grammomys Doliahurus SURDaster Thomas \& Wroughton, I908.

I908. Thamnomys surdaster Thomas \& Wroughton, P.Z.S., 550. Zomba, about 3,00o ft., southern Nyasaland. Ranges to Tanganyika.

Grammomys Doliahurus Baliolus Osgood, igio

i910. Thamnomys baliolus Osgood, Ann. Mag. N.H. 5: 278. Woodbush Hills, north-east of Pietersburg, eastern Transvaal.

Grammomys dolichurus tongensis Roberts, I93 I

I93 I. Grammomys tongensis Roberts, Ann. Transv. Mus. I4: 234. Manaba, northern Zululand.

Grammomys dolichurus ANGolensis Hill \& Carter, 1937

1937. Grammomys surdaster angolensis Hill \& Carter, Amer. Mus. Novit. No. 913: 4. Chitau, 4,930 ft., central Angola.

Grammomys Dolichurus silindensis Roberts, $193^{8}$

1938. Grammomys silindensis Roberts, Ann. Transv. Mus. 19: 245. Mount Selinda, south-eastern Southern Rhodesia.

(1938. Grammomys vumbaensis Roberts, loc. cit.: 245. Vumba (near Portuguese border) south-eastern Southern Rhodesia.)

Grammomys ruddi Thomas \& Wroughton, 1908

Rudd's Forest Mouse. Ruddse Bosmuis

Distribution: Tete, Portuguese East Africa and Chiromo, southern Nyasaland.

GRAmmomys RUdDi Thomas \& Wroughton, igo8

I908. Thamnomys ruddi Thomas \& Wroughton, P.Z.S., 549. Tete, on the Zambezi, Portuguese East Africa. 


\section{Genus ARVICANTHIS Lesson, 1842}

I842. Arvicanthis Lesson, Nouv. Tabl. Règne Anim. Mamm., I47. Lemmus niloticus Geoffroy = Arvicola niloticus Desmarest.

Arvicanthis niloticus Desmarest, 1822

Nile Rat or Kusu Rat

Distribution: Northern Rhodesia, and northwards, the greater part of East Africa, westwards to Asben and Senegal; Egypt; Arabia.

Arvicanthis niloticus niloticus Desmarest, i822. (Extralimital) 1822. Arvicola niloticus Desmarest, Mammalogie, 2: 281. Egypt.

Arviganthis niloticus Rhodesiae St. Leger, I932

1932. Arvicanthis abyssinicus rhodesiae St. Leger, Ann. Mag. N.H. 10: 85. Sichili River Sesheke district (near the Caprivi border) extreme southern Northern Rhodesia. Also known from Kasempa district, Northern Rhodesia (B.M.).

\section{Genus RATTUS Fischer, 1803}

I803. Rattus Fischer, Das Nationalmuseum der Naturgeschichte zu Paris, 2: I 28 (misprinted Ruttus). Mus decumanus Pallas = Mus norvegicus Berkenhout. I88 I. Epimys Trouessart, Bull. Soc. Études Sci. Angers, I0: i I 7. Mus rattus Linnaeus. I9I 5. Aethomys Thomas, Ann. Mag. N.H. I6: 477. Epimys hindei Thomas, one of the Kenya races of Epimys kaiseri Noack. Valid as a subgenus.

I9I 5. Praomys Thomas, Ann. Mag. N.H. I6: 477. Epimys tullbergi Thomas, the Ashanti race of Mus morio Trouessart. Valid as a subgenus.

I9I5. Myomys Thomas, Ann. Mag. N.H. 16: 477. Epimys colonus A. Smith $=$ Mus colonus Brants, which is here regarded as not certainly identifiable.

I9I5. Mastomys Thomas, Ann. Mag. N.H. 16: 477. Mus coucha A. Smith = Mus marikquensis A. Smith, a race of Mus natalensis A. Smith. Valid as a subgenus.

1920. Thallomys Thomas, Ann. Mag. N.H. 5: I41. Mus nigricauda Thomas. I920. Ochromys Thomas, Ann. Mag. N.H. 5: 142. Mus woosnami Schwann. I926. Stochomys Thomas, Ann. Mag. N.H. I7: i 76. Dasymys longicaudatus Tullberg, from the Cameroons. Valid as a subgenus.

1926. Dephomys Thomas, Ann. Mag. N.H. I7: i 77. Mus defua Miller, from Liberia. I926. Hylomyscus Thomas, Ann. Mag. N.H. I7: i78. Epimys aeta Thomas, the Cameroons race of Mus carillus Thomas. Valid as a subgenus.

I94I. Micaëlamys Ellerman, Fam. Gen. Liv. Rodents, 2: I 70. Mus granti Wroughton. 1942. Myomyscus Shortridge, Ann. S. Afr. Mus. 36: 93. Mus verroxi A. Smith. I95I. Michaelomys Roberts, Mamm. S. Afr., 473. Error.

For other extralimital subgeneric names and synonyms see Ellerman \& MorrisonScott, I95 I.

(The introduced European Rattus rattus and Rattus norvegicus are not included.) 


\section{Discussion on African Rattus}

In I9I5 Thomas proposed four subgenera (not genera) of Epimys, I88 I (= Rattus, 1803), based upon mammary formula. These were Aethomys, Praomys, Myomys and Mastomys. Myomys was improperly diagnosed, in that Thomas merely said it had Io mammae, which formula is quite common elsewhere within the genus, and it was based on Mus colonus Brants (see Roberts, I95 I, 469, who thought colonus the same as Mus verreauxi A. Smith, whereas we hold it to be not certainly identifiable). In order to identify Mus colonus Brants as being one of the ro-mammate small Rats $(R$. verreauxi group), Roberts has had to shift the accepted type locality from Algoa Bay to Plettenberg Bay, and has had to alter the measurements given in the original description, stating that Brants must have measured his specimens in a different way from the method used today. According to Roberts, Brants merely said that colonus came from the eastern parts of Cape Colony, which would seem to be outside the distribution of $R$. verreauxi anyway. It seems that colonus may well be the prior name for the multimammate rats but that it would be better to regard it as not certainly identifiable, and the name "Myomys" as therefore having no status.

The three remaining subgenera were all given generic rank and were further split by Thomas until every valid species of Rattus-like rat south of the Sahara, and perhaps even some that were not valid, were given generic rank. Ellerman (I94I) retained Aethomys and also Thallomys Thomas, I920, as valid genera, but referred Mastomys, Praomys and others to Rattus. The erection of Thallomys and its retention seemed reasonable because its type species, and the western members of the genus, look very distinct from Aethomys as restricted (kaiseri group), and give the appearance of being at least a valid subgenus. But neither Thomas nor his followers in the British Museum had seen Roberts' eastern Transvaal forms of Thallomys, moggi, etc., which were not represented in the British Museum until after I 94 I. $R$. moggi is intermediate between the kaiseri group and typical Thallomys (nigricauda, etc.); it lacks the thick fur, dark hairy tail and tendency to face markings of nigricauda and looks very like members of the kaiseri group (chrysophilus, etc.), merely differing from them in its long fifth toe. This intermediate group of forms now seems to make Thallomys a synonym of Aethomys, which itself is not so distinct from Rattus that it need be given generic rank. It may be borne in mind that all these South African species are very closely allied to each other and that their characters grade into one another to a certain degree, and that in a very large group like this one will always get a certain individual overlap in characters which affect a key to the species.

Later researches lead us to the opinion that in South Africa, apart from Hylomyscus, here restricted to relatively small species with proportionately shorter palatal foramina than is normal in African members of the genus, there are three subgenera of Rattus. All members of these three subgenera have average longer palatal foramina than the Asiatic (and European) species, the subgenus Cremnomys excepted. These subgenera may be roughly diagnosed as follows:

AETHOMYS Thomas, I915: (synonyms, Thallomys Thomas, 1920; Ochromys Thomas, 1920). Large rats, in adults the majority of specimens have the head and 
body length $130 \mathrm{~mm}$. and more. ${ }^{1}$ Skull usually with well-marked supraorbital ridges (excepting $R$. woosnami), large bullae, heavy molars and long palatal foramina. Tail rarely more than I 30 per cent of head and body, averaging less than I40 per cent; sometimes shorter than head and body. Mammae typically 4 or 6 , individually in chrysophilus can be 8 , and in woosnami io. (For the individual variation in mammary formula elsewhere within the subfamily see Ellerman, 1949, Fam. Gen. Liv. Rodents, 3: i89.)

MASTOMYS Thomas, I9I5: (to include the species $R$. angolensis). Smaller species, the majority of specimens have the head and body $130 \mathrm{~mm}$. and less. ${ }^{2}$ Tail short, mostly shorter than head and body, very rarely averages only a little longer. Mammae io (angolensis), rarely io (a specimen of natalensis in the British Museum from King William's Town), more often in natalensis more than 12 and up to 24 . Usually the skull has the supraorbital ridges rather weak, the bullae moderate in size, the palatal foramina very long, and the molars lightly built.

PRAOMYS Thomas, I915: (synonym: Dephomys Thomas, 1926; to include also the species verreauxi and namaquensis, both of A. Smith). Small species, the head and body very rarely over i $30 \mathrm{~mm}^{3}$ Tail very long, mostly averaging over i 20 per cent of the head and body, and may be over $5_{5}$ o per cent. Mammae, where known, 4,6 or io (South Africa), 4, 6, 8 or io north of the Zambezi-Cunene line. Skull mostly with rather weak supraorbital ridges (which may be absent) (but more marked in $R$. namaquensis); molars usually lightly built (but heavier in namaquensis); palatal foramina long, and bullae medium in size.

A note on the status of "Mus" granti Wroughton.

1908. Mus granti Wroughton, Ann. Mag. N.H. I: 257. Deelfontein, Cape Province. I939. Myomys granti Wroughton, G. Allen, Checklist African Mamm., 406.

I94I. Rattus (Micaëlamys) granti (Wroughton) Ellerman, Fam. Gen. Liv. Rodents, 2: 2 I3.

195I. Mastomys natalensis natalensis (part) Roberts, Mamm. S. Afr. 473.

Apparently three species of South African Rattus represented in the British Museum collections occur together at Deelfontein:

Rattus natalensis, molars lightly built, tail relatively short, and not black and hairy; mammae usually more than 12.

${ }^{1}$ In Aethomys, in B.M. material (205 specimens) 40 were under $130 \mathrm{~mm}$. (perhaps some of them not adult). In Roberts' figures, I 3 specimens in 71 were under I $30 \mathrm{~mm}$. In Shortridge (1934), 28 specimens out of about 204 were under I $30 \mathrm{~mm}$. In Hill \& Carter (I94I), 2 in 28 were under I $30 \mathrm{~mm}$.

${ }^{2}$ In Mastomys, in B.M. material (about $3^{1} 6$ specimens), 32 reached ${ }^{3} 30 \mathrm{~mm}$. In Roberts' figures, I 4 specimens out of I I o reached this figure. In Shortridge (I 934) 20 out of I 29 skins reached I 30 mm. In Hill \& Carter (I94I) 2 out of I I specimens reached I $30 \mathrm{~mm}$.

${ }^{3}$ In Praomys, as here understood, in B.M. material ( 78 specimens), 2 specimens reached ${ }^{3} 30 \mathrm{~mm}$. In Roberts' figures, 3 specimens out of 57 reached I $30 \mathrm{~mm}$. In Shortridge's figures, no specimen reached I $30 \mathrm{~mm}$. out of I 45 . In Hill \& Carter (I $94 \mathrm{I}$ ), one exception in 9 (avunculus, which seems to represent namaquensis). 
Rattus namaquensis, molars heavily built; tail very long, black and hairy; mammae 4 or 6.

Rattus granti, molars heavily built; tail relatively short, black and hairy; mammae 10.

We are not sure that specimens subsequently collected by Shortridge and referred to Micaëlamys granti are authentic.

Roberts was wrong in referring granti to the synonymy of Mastomys natalensis natalensis, and he had not seen the original series on which the name was based. One of this original series is labelled as having ro mammae. Roberts stated "its dental characters do not appear to differ very much from Mastomys", but actually they are much closer to those of $R$. namaquensis. It also agrees with namaquensis in its black, hairy tail. It differs from $R$. namaquensis centralis, with which it occurs, in darker underparts and relatively shorter tail (averaging about 107 per cent of the head and body in the original series). (As Roberts says, its measurements are those of a Mastomys natalensis). The suggestion we now put forward is that the original series might possibly have been hybrids between $R$. natalensis and $R$. namaquensis, both of which occur in the same locality, as it seems so precisely intermediate between them in a number of ways, and not to be known authentically from other localities than Deelfontein. Shortridge had other specimens from east of Calvinia which he identified as granti, but although the tail is short in the ones he sent to London, the foot is consistently larger than in the original series of granti; moreover one of them is labelled as having 6 mammae.

Rattus paedulcus the prior name for the species hitherto referred to Thallomys.

The British Museum has a syntype skull of Rattus paedulcus Sundevall, which name has hitherto not been certainly identified. According to descriptions the name was based on a species with the head and body I $30 \mathrm{~mm}$., the tail $120 \mathrm{~mm}$. Our syntype skin bears no measurements, but the skull, which has the unusually large bullae characteristic of most members of the group referred by Thomas to Thallomys, and the shape of the hindfoot with its relatively long fifth toe enables us to suggest that paedulcus is in reality the prior name for the group to which nigricauda, damarensis and moggi, all here considered conspecific, belong. The only difficulty in adopting this classification is that according to the original description the tail (which might have been based on an incomplete specimen) is shorter than the head and body. This is rare in the nigricauda group, although one of Roberts' types (molopensis) shows the character. Probably one of the forms named as representatives of moggi by Roberts is in reality a synonym of paedulcus; in a considerable series noted in the Transvaal Museum a few have the tail a little shorter than the head and body, although the majority do not. Without direct comparison it is not possible to synonymize Roberts' names with certainty. The occipitonasal length of our syntype skull of paedulcus is $3 \mathrm{I} \mathrm{mm}$., length of palate from front of incisors $\mathrm{I} 4.9 \mathrm{~mm}$., palatal foramina $8.2 \mathrm{~mm}$. (somewhat damaged), bullae $6.7 \mathrm{~mm}$., upper toothrow $4.6 \mathrm{~mm}$. 


\section{Status not sure:}

Mus colonus Brants, I 827, Het Geslacht der Muizen, I 24. Algoa Bay, south-eastern Cape Province. Possibly the prior name for natalensis, but here regarded as unidentifiable. See discussion, page 265 .

Mus granti Wroughton, I908, Ann. Mag. N.H. I: 257. Deelfontein, north of Richmond, Cape Province. For remarks on status see above, page 266.

Mus albiventer Jentink, I909, Zool. Jahrb. Syst. 28: 246. Mossel Bay, coast of southwestern Cape Province. Mus albiventris Jentink, loc. cit., 247. G. Allen lists it as a race of $R$. chrysophilus, but that species is not known to occur in the Cape Province.

I. Larger species, the head and body in the majority of specimens exceeds $\mathrm{I} 30 \mathrm{~mm}$. (see page 266 , footnote).

Smaller species, the head and body in the majority of specimens is below I $30 \mathrm{~mm}$. (see page 266 , footnote).

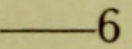

2. Tail short, averages 85 per cent of head and body, its colour white. Io mammae (Roberts). Supraorbital ridges of skull relatively weak.

Rattus (Aethomys) woosnami, page 274

The colour of the tail is different; shorter or longer than head and body, but usually longer south of the Zambezi-Cunene line (where woosnami is restricted). Mammae, so far as known, 4 or 6 or 8 . Normally supraorbital ridges are more marked.

3. Hindfoot of arboreal type, the fifth hindtoe relatively long. (See discussion on status and nomenclature, page 267 ).

Rattus (Aethomys) paedulcus, ${ }^{1}$ page 273

Hindfoot terrestrial, fifth hindtoe relatively short.

$-4$

4. Tail relatively longer, normally approximately i io per cent of head and body, often more. ${ }^{2}$ Rattus (Aethomys) chrysophilus, page $27 \mathrm{I}$

Tail relatively shorter, averages about I03 per cent or less of head and body, often shorter than head and body.

5. Zygomatic width not under $19 \mathrm{~mm}$., in South African skulls averaging 54 per cent of occipitonasal length. (Tail shorter than head and body.)

Rattus (Aethomys) nyikae, ${ }^{3}$ page 270

1 The bullae usually exceed 20 per cent of the occipitonasal length in $R$. paedulcus, the race shortridgei excepted. This is rarely the case in related species, but exceptions can occur (vernayi, hintoni).

${ }^{2}$ There is little essential difference between $R$. kaiseri and $R$. chrysophilus, but there are geographical overlaps in Angola and perhaps Nyasaland between two species, a short-tailed and a long-tailed. Tentatively, chrysophilus is retained as the longer-tailed species (tail normally approximately I Io per cent of the head and body (Iog per cent minimum); often more than I Io per cent) and kaiseri is used for the species with the tail averaging about Io3 per cent or less, often shorter than head and body. Hollister's figures for East African races of kaiseri are in general agreement with this except for the race norae which may have to be transferred to chrysophilus.

${ }^{3} R$. nyikae is better known as walambae; but apparently nyikae belongs to what has hitherto been regarded as walambae, and it is the prior name. 
Zygomatic width rarely reaching $\mathrm{I} 9 \mathrm{~mm}$., but if so then averages $5^{\mathrm{I}}$ per cent, or usually less, of occipitonasal length in the forms occurring in South Africa. (Tail usually shorter than head and body in South Africa).

$$
\text { Rattus (Aethomys) kaiseri, page } 270
$$

6. Tail relatively short, only rarely as long as or a little longer than head and body. Mammae typically more than io, usually in continuous series and not separated into sets. Supraorbital ridges can be present, but are often rather weak.

Tail relatively considerably longer (in South Africa averaging over I 20 per cent of head and body length; the lowest extralimital percentage known to us is I I I per cent). Mammae io or less. 8

7. (Where it occurs with the next) either interpterygoid wider (Angola) or colour usually darker (South-West Africa).

\section{Rattus (Mastomys) angolensis, ${ }^{1}$ page 276}

(Where it occurs with the last) either interpterygoid region relatively narrow (Angola) or colour usually paler (South-West Africa).

Rattus (Mastomys) natalensis, page 275

8. Palatal foramina very long, averaging at least 22 per cent of the occipitonasal length.

Palatal foramina less elongated, averaging under 22 per cent of the occipitonasal length.

9. Molars wide, the width of M I about I.6-2 mm. (Mammae 4 or 6.) Rattus (Praomys) ${ }^{2}$ namaquensis, page 277

Molars narrower, the width of $\mathrm{M}$ I about I.4-I.5 $\mathrm{mm}$.

I0. Mammae I0. Tail averaging I 38 per cent or more of head and body.

Rattus (Praomys) verreauxi, page 277

Mammae 6 (according to records). Tail in South African specimens (and in Hatt's figures from the Congo) averaging less than i 30 per cent of head and body. Rattus (Praomys) morio, ${ }^{3}$ page 279

1 There is in Angola and South-West Africa a species (angolensis, with its southern race shortridgei which is preoccupied and here renamed legerae) which has usually been given specific rank on account of having Io mammae (whereas natalensis is supposed to have more than io mammae) and which may occur with natalensis. It is very hard to define characters to retain angolensis. Hill \& Carter gave a few cranial details for Angola, of which the one quoted above seems the least likely to break down through individual variation. Shortridge stated that the hindfoot of legerae is longer than the local natalensis, but this is certainly not constant. Although natalensis usually has more than Io mammae this is not always the case; we have a specimen in the British Museum from King William's Town with io mammae.

${ }^{2}$ Cremnomys Wroughton, I 9 I 2, based on the Indian species $R$. cutchicus, antedates Praomys I9I 5 and might well be used instead of it. It is difficult in fact to suggest characters which can separate $R$. cutchicus even specifically from the much earlier named South African species $R$. namaquensis, except that when the type specimens of $R$. cutchicus and races were compared with the type specimens of $R$. namaquensis and races, the cutchicus group was more greyish dorsally, the namaquensis group generally more yellowish.

${ }^{3}$ Hatt (1940) thought there were two species in the morio group, jacksoni and morio, differing principally in the size of their ears and bullae. But a few extralimital skulls measured for both indicate that there is no difference in the size of the bullae, and there is certainly no constant difference in the size of the ear in B.M. specimens. We suggest therefore that these two are in reality conspecific. 
I I. Skull length (in South Africa) $26.4 \mathrm{~mm}$. and less.

Occipitonasal length (type skull) $27.3 \mathrm{~mm}$.

Rattus (Hylomyscus) carillus, ${ }^{1}$ page 280

Rattus (Hylomyscus) delectorum, ${ }^{2}$ page 279

\section{Subgenus AETHOMYS Thomas, I9I5}

Rattus kaiseri Noack, 1887

The Kaiser's Rat

Distribution: as here understood, central and western Angola; also the Belgian Congo, Tanganyika, Kenya, Uganda and the southern Sudan.

RATTUS KAISERI KAISERI Noack, I887. (Extralimital)

1887. Epimys kaiseri Noack, Zool. Jb. Syst. 2: 228. Qua Mpala (Marungu) southern Belgian Congo.

RATtUS KAISERI THOMASI de Winton, I 897

1897. Mus thomasi de Winton, Ann. Mag. N.H. 20: 32 I. Galanga, western Angola. Also recorded from Chitau and Humpata, Angola.

Rattus (?)Kaiseri vernayi Hill \& Carter, I937

1937. Aethomys vernayi Hill \& Carter, Amer. Mus. Novit. No. 913, I. Chissonque, $20 \mathrm{~km}$. east of Dando, central Angola.

Rattus nyikae Thomas, 1897

Nyika Rat

Distribution: Nyasaland, Northern Rhodesia; the Belgian Congo, Tanganyika, Kenya, Uganda. (Better known as $R$. walambae and races.)

Rattus NyikaE NyikaE Thomas, I897

I897. Mus nyikae Thomas, P.Z.S. 431 (October, I897). Nyika plateau, northern Nyasaland.

${ }^{1}$ Hylomyscus is retained as a subgenus because, at least in South Africa, it is the only group here referred to Rattus which does not have the unusually long palatal foramina which seems to divide these species from their Asiatic allies, the subgenus Cremnomys excepted. British Museum skulls of $H$. carillus and type specimens measurable from other parts of Africa do not exceed $25.8 \mathrm{~mm}$. in length, but the subgenus does not necessarily include the larger extralimital species denniae, the type skull of which suggests it would be referable to Praomys as here understood. The skull in Hylomyscus as here understood seems to be smaller than that of any of the Asiatic species of Rattus. The first species to be named in Hylomyscus was $R$. alleni Waterhouse, 1838 , from Fernando Po. But Hatt, 1940, Bull. Amer Mus. N.H. 76: 536 , treats carillus as a distinct species, and uses it as the prior name for the species better known as aeta (Thomas, I9I2), which apparently occurs with forms (stella, etc.) which Hatt regards as races of alleni. The chief distinction between these two species seems to be in the shape of the skull; the supraorbital ridges are more apparent in carillus, and the frontals more evenly divergent backwards. Tentatively Hatt's classification is accepted.

${ }^{2} R$. delectorum has hitherto been grouped with morio, the restricted Praomys of Thomas. It is very little known, but the type skull seems to show that it has the relatively short foramina of the smaller species, carillus, etc. Further specimens are really needed to show its exact status. 
Rattus Nyikae Walambae Wroughton, ig07

I907. Mus walambae Wroughton, Manchester Mem. 5I, 5: 21. "Msofu River, Rhodesia." "We have not found the Msofu River named, but the type locality can be placed with certainty in Northern Rhodesia, close to $13^{\circ} 30^{\prime}$ S., $29^{\circ}$ E.; Walamba is a railway station about 60 miles south of Ndola and Msofu Mission is marked 30 miles east of Walamba" (Moreau, Hopkins \& Hayman, I946).

Rattus Nyikae hintoni Hatt, I934

1934. Aethomys walambae hintoni Hatt, Amer. Mus. Novit. No. 708: 7. Kambove, Katanga, 4,400 ft., Belgian Congo. Occurs in Northern Rhodesia (British Museum).

Rattus chrysophilus de Winton, I 897

Red Veld Rat. Rooiveldrot

Distribution: in the Union, Durban, Zululand, etc., in Natal, and in the Transvaal, Rustenburg, Pretoria, Zoutpansberg, Woodbush, Tzaneen, Klein Letaba, Legogot (near White River), Carolina, etc. Swaziland. South-West Africa; "widely distributed north of the Tropic of Capricorn" (Shortridge); parts of Bechuanaland; Southern Rhodesia (Matabeleland, Mashonaland), districts of Tete, Beira, Inhambane and Gorongoza, Portuguese East Africa. Nyasaland. Kafue and Petauke districts, etc., Northern Rhodesia. Angola, where known from several localities. Northwards to Tanganyika, the Belgian Congo and Kenya.

Rattus GHrysophilus GHrysophilus de Winton, I 897

ı 897. Mus chrysophilus de Winton, P.Z.S. I896: 8o I. April, i897. Mazoe, Mashonaland, eastern Southern Rhodesia. Range: various places in Southern Rhodesia, Bulawayo included (B.M.). Recorded from Gorongoza district, Portuguese East Africa.

RAtTus GHRysophilus Bocagei Thomas, I904

1904. Mus bocagei Thomas, Ann. Mag. N.H. 13: 4I6. Pungo Andongo, I, 200 m., northern Angola. Recorded by Hill \& Carter from Hanha and Dala, Angola. Although the type specimen is short-tailed the majority of Hill \& Carter's specimens and the majority of specimens in the British Museum appear to have the relatively longer tail of chrysophilus.

RATtus GHRysophilus ineptus Thomas \& Wroughton, I908

I908. Mus chrysophilus ineptus Thomas \& Wroughton, P.Z.S., 546. Tete, on the Zambezi, Portuguese East Africa.

Rattus GHRysophilus acticola Thomas \& Wroughton, igo8

I908. Mus chrysophilus acticola Thomas \& Wroughton, P.Z.S., 547. Beira (south of the Zambezi), coastal Portuguese East Africa.

I9 10. Mus chrysophilus alticola Lydekker, Zool. Record, I9o8: Mamm. 74. Accidental renaming. Recorded also from the Inhambane district, Portuguese East Africa. 
RATtus GHRYSOPHILUS TZANEENENSIS Jameson, I909

1909. Mus chrysophilus tzaneenensis Jameson, Ann. Mag. N.H. 4: 46o. Tzaneen, eastern Transvaal. Range: the low country, east of the Drakensberg escarpment, from Carolina district northwards to Zoutpansberg (Roberts).

RATtus GHRYSOPHILUS PRETORIAE Roberts, I9I3

1913. Mus chrysophilus pretoriae Roberts, Ann. Transv. Mus. 4: 85. Fountains valley, Pretoria, Transvaal.

1926. Aethomys chrysophilus magalakuini Roberts, Ann. Transv. Mus. II: 254. Wilhanshohe, Magalakuin (or Magalaqueen) River, western Transvaal.

Ranges to Gaberones, south-eastern Bechuanaland.

RATTUS GHRYSOPHILUS GAPRICORNIS Roberts, I926

1926. Aethomys chrysophilus capricornis Roberts, Ann. Transv. Mus. II: 254. Newgate, Zoutpansberg, northern Transvaal. Range: southwards on the foothills of the Drakensberg to Barberton district, eastern Transvaal.

RatTus GHRYSOPHILUS IMAGo Thomas, 1927

1927. Aethomys chrysophilus imago Thomas, P.Z.S., 387. Stampriet, Gobabis district, eastern-central South-West Africa. Recorded from Mulondo, Angola, by Hill \& Carter.

RATTUS GHRYSOPHILUS TONGENSIS Roberts, I93 I

I93 I. Aethomys chrysophilus tongensis Roberts, Ann. Transv. Mus. 14: 235. (Type:

T.M. No. 6ris8 from Mangusi Forest, north-eastern Zululand) and described as new for a second time, 1936, Ann. Transv. Mus. I8: 235. (Type: T.M. No. 7202 from Otobotini, northern Zululand). Range: from Durban to Portuguese East Africa, south of the Olifants River, and Swaziland.

RatTus Chrysophilus dollmani Hatt, I 934

1934. Aethomys chrysophilus dollmani Hatt, Amer. Mus. Novit. No. 708, 8. Upper Lufira River, Katanga, Belgian Congo. Recorded from Dundo, northeastern Angola.

RatTus GHRYSOPHILUS PHIPPSI Hill \& Carter, I 937

1937. Aethomys avunculus phippsi Hill \& Carter, Amer. Mus. Novit. No. 913: 3 . Humpata, 6,30o ft., south-western Angola. (The form avunculus is here considered as the Angolan representative of Rattus namaquensis.)

Rattus GHRYSOPHILUS SILINDENSIS Roberts, I938

1938. Aethomys silindensis Roberts, Ann. Transv. Mus. 19: 245. Mt. Selinda, eastern Southern Rhodesia.

RAtTus GHRYsophilus FOURIEI Roberts, I 946

1946. Aethomys chrysophilus fouriei Roberts, Ann. Transv. Mus. 20: 319. Oshikanga, Ovambo-Angola border. 
RatTus (?)Chrysophilus haRei Roberts, I946

1946. Aethomys chrysophilus harei Roberts, Ann. Transv. Mus. 20: 320. Waterberg, Otjiwarongo district, northern-central South-West Africa. Perhaps a form of $R$. namaquensis, as the figures given by Roberts are too small for this species.

Rattus paedulcus Sundevall, 1846

Blacktailed Tree Rat. Swartstertrot

Distribution: in the Union, the Transvaal, districts of Rustenburg, Pretoria, Zoutpansberg, Woodbush, etc., Newcastle and Zululand, Natal; in the Cape Province, the Molopo River and the western Orange River, Upington region, Louisvale, and Goodhouse (Little Namaqualand). Swaziland. Apparently in suitable localities more or less throughout South-West Africa. In Angola most records are from the Mossamedes district, but it is recorded from Pungo Andongo in the north. Part of the Kalahari; Ngamiland. Southern Rhodesia. Northern Rhodesia, Nyasaland. North of these limits, Kenya and Tanganyika.

Rattus paedulaus paedulgus Sundevall, i 846

I 846. Mus paedulcus Sundevall, Öfvers. Vetensk. Akad. Förh. Stockholm, 3: I20. "In Caffraria interiore, prope tropicum."

Rattus Paedulgus Nigrigauda Thomas, 1882

I882. Mus nigricauda Thomas, P.Z.S., 266. Hountop (Hudup or Hutop) River, west of Gibeon, Great Namaqualand, South-West Africa.

Rattus paedulgus damarensis de Winton, i 897

I897. Mus damarensis de Winton, Ann. Mag. N.H. 19: 349. Damaraland, but exact locality of the type unknown; one of the other three specimens of the same collection is endorsed Otjimbingue, Damaraland (South-West Africa).

Rattus paedulgus Rhodesiae Osgood, igio

19 10. Mus damarensis rhodesiae Osgood, Ann. Mag. N.H. 5: 277. Petauke, East Loangwa district, eastern Northern Rhodesia.

Rattus paedulgus kalaharigus Dollman, igi I.

I9I I. Epimys nigricauda kalaharicus Dollman, Ann. Mag. N.H. 8: 544. Molopo River, Kalahari (border of northern Cape Province and Bechuanaland). A synonym of nigricauda, fide Shortridge ( 1934).

1933. Thallomys leuçonoe molopensis Roberts, Ann. Transv. Mus. 15: 269. Midway between Setlagoli and the Molopo River at Pitsani location, southern Bechuanaland.

Rattus Paedulgus moggi Roberts, I9I 3

I9I3. Mus moggi Roberts, Ann. Transv. Mus. 4: 85. Zoutpan, Pretoria district, Transvaal. Ranges westwards to Gaberones, south-eastern Bechuanaland.

Rattus paedulgus agagiae Roberts, i9 5

I9I5. Mus moggi acaciae Roberts, Ann. Transv. Mus. 5: r20. Woodbush, eastern Transvaal. Ranges northwards to the Zoutpansberg, northern Transvaal. 
Rattus Paedulgus Shortridgei Thomas \& Hinton, I923

1923. Thallomys shortridgei Thomas \& Hinton, P.Z.S., 492. Louisvale, southern bank of Orange River, near Upington, north-western Cape Province. Ranges westwards to Goodhouse, Little Namaqualand.

Rattus paedulgus nitela Thomas \& Hinton, 1923

1923. Thallomys nitela Thomas \& Hinton, P.Z.S., 493. Bomboné, Mossamedes, 3,200 ft., south-western Angola.

Rattus paedulgus leuconoe Thomas, 1926

1926. Thallomys leuconoe Thomas, P.Z.S., 303. Osohama, Etosha Pan, Ovamboland, northern South-West Africa.

Rattus Paedulgus herero Thomas, I926

1926. Thallomys herero Thomas, P.Z.S., 303. Ondongwa (or Ondonga), Ovamboland, northern South-West Africa. Range: Kaokoveld and Cunene River areas, eastwards to Okavango and Ngamiland, reported from extreme southern Angola, northwards to Mupa.

Rattus paedulcus Lebomboensis Roberts, I93 I

I93 I. Thallomys moggi lebomboensis Roberts, Ann. Transv. Mus. I4: 234. Mkuzi River, Ubombo district, northern Zululand. Range includes northern Natal and Swaziland.

Rattus paedulgus stevensoni Roberts, i 933

1933. Thallomys stevensoni Roberts, Ann. Transv. Mus. 15: 269. Bembesi, 30 miles north of Bulawayo, Southern Rhodesia.

RATTUS PAEDUlGUS ROBERTSI nom. nov.

1933. Thallomys leuconoe bradfieldi Roberts, Ann. Transv. Mus. 15: 268. Quickborn Farm, Okahandja district, Damaraland, South-West Africa. Evidently a doubtful form, based on an immature specimen. Not of Roberts, I926 (a Mastomys).

Rattus woosnami Schwann, I906.

Woosnam's Desert Rat. Woosnamse Bleekrot

Distribution: Kuruman and Molopo districts, northern Cape Province; Ngamiland, and Gobabis in eastern South-West Africa.

Rattus woosnami Schwann, igo6

1906. Mus woosnami Schwann, P.Z.S., I08. Molopo River, border of the northern Cape Province, southern Bechuanaland. 
Subgenus MASTOMYS Thomas, I9I5

Rattus natalensis A. Smith, I 834

Multimammate Rat. Vaalveldmuis

Distribution: in the Union, the Transvaal; the Marico River, Potchefstroom, near Krugersdorp, Zoutpansberg, Potgietersrust, Pietersburg, Pretoria, Woodbush, Klein Letaba, Carolina, Legogot (near White River), the Kruger National Park (D. H. S. Davis), Wakkerstroom. Zululand, Durban, Illovo, Estcourt, etc., in Natal. In the Orange Free State, Aberfeldy (near Harrismith), Heilbron, Bothaville, Parys, etc. Maseru, Basutoland. In the Cape Province, Molopo district, Kuruman, near Louisvale, the Aughrabies Falls, Deelfontein, Port Elizabeth, King William's Town, Grahamstown, Port St. Johns, etc. Swaziland. South-West Africa; according to Shortridge, throughout the territory except the Namib desert and perhaps some of the more arid parts of Great Namaqualand. Ngamiland; several localities in Southern Rhodesia; districts of Inhambane, Beira, Tete, Gorongoza, etc., Portuguese East Africa. Apparently common in Angola. Nyasaland, Northern Rhodesia. North of the limits of this work, very widely distributed, the northern limit being roughly Abyssinia-Sudan-Asben-Morocco.

For use of the name natalensis see Roberts, I944, Bull. S. Afr. Mus. Assoc. 3: 239.

Rattus natalensis natalensis A. Smith, I834

I834. Mus natalensis A. Smith, S. Afr. J. 2: i56. "About Port Natal" = Durban, Natal.

I834. Mus caffer A. Smith, loc. cit., I 57. "Cafferland."

1843. Mus muscardinus Wagner in Schreber, Säugth. Suppl. 3: 430. Kaffraria.

ı89o. Mus sp. var albinus Bocage, J. Sci. Math. Phys. Nat., Lisboa, 2: I4. Caconda, Angola.

I89o. Mus fuscus Bocage, J. Sci. Math. Phys. Nat., Lisboa, 2: I4. Huilla and Quissange, Angola. Not of Fitzinger, I 867.

I 89o. Mus rufa Bocage, loc. cit., I 4. Gambos and Quillenges, Angola.

1905. Mus coucha zuluensis Thomas \& Schwann, P.Z.S. I: 268. Umfolosi, Zululand, Natal.

I 909. Mus illovoensis Jentink, Zool. Jahrb. Syst. 28: 248. Lower Illovo, Natal.

I926. Mastomys coucha komatiensis Roberts, Ann. Transv. Mus. I I: 259. Arnhemburg, Komati River, Carolina district, eastern Transvaal.

Range: Roberts quotes specimens from Port St. Johns, Zululand, Natal, Swaziland, and in the eastern Transvaal from the Carolina district to Tzaneen and Zoutpansberg. The British Museum has specimens from near Wakkerstroom, Transvaal.

Rattus natalensis marikquensis A. Smith, i 836

I836. Mus marikquensis A. Smith, Rept. Exped. Explor. C. Africa, 43. "Country beyond Kurrichaine" (taken by Roberts as Marico River, western Transvaal).

I836. Mus coucha A. Smith, loc. cit. 43. "Between the Orange River and the Tropic"; type locality taken by Roberts as Kuruman, northern Cape Province.

1913. Mus socialis Roberts, Ann. Transv. Mus. 4: 88. Wonderfontein, Potchefstroom, western Transvaal. Not of Pallas, I 773. 
RATTUS NATALENSIS MARIKQUENSIS [contd.]

19I 5. Mus breyeri Roberts, Ann. Transv. Mus. 5: 1 20. Moorddrift, near Potgietersrust, Transvaal. (Status fide G. Allen, I939).

1934. Mastomys coucha sicialis Shortridge, Mamm. S.W. Africa, I: 303. (Misprint.)

Range: Roberts quotes specimens from northern Orange Free State, Pretoria,

Potchefstroom, etc., in the western Transvaal, and states that it occurs in western

Southern Rhodesia and the southern Kalahari.

Rattus natalensis silaceus Wagner, i 842

I 842. Mus silaceus Wagner, Arch. Naturgesch. 8, I : I I. Cape of Good Hope. Range:

Port Elizabeth and Grahamstown, Cape Province (Roberts).

Rattus natalensis microdon Peters, i 852

I852. Mus microdon Peters, Reise nach Mossambique, Säugeth. I49. Tete, on the Zambezi, Portuguese East Africa (type locality restricted by Roberts; also recorded by Peters from Boror, north of the Zambezi, Portuguese East Africa).

I9 4. Mus limpopoensis Roberts, Ann. Transv. Mus. 4: i83. Sand River, north-eastern Transvaal.

Range: eastern Transvaal low country, southern Portuguese East Africa, eastern

Southern Rhodesia, and according to Roberts to Nyasaland and Ndola in Northern Rhodesia.

RAtTus NATALENSIS BRADFIELDI Roberts, I926

1926. Mastomys coucha bradfieldi Roberts, Ann. Transv. Mus. II: 257. Quickborn, Okahandja, Damaraland, South-West Africa.

1926. Mastomys coucha ovamboensis Roberts, loc. cit.: 258. Namutoni (Etosha Pan), Ovamboland, northern South-West Africa. Status fide Thomas, I927, P.Z.S., 388.

Range: South-West Africa, and (perhaps this form) into southern Angola.

Rattus angolensis Bocage, I 890

Angola Rat

Distribution: Angola (Chitau, Luimbale, Humpata, Capangombe, Caluquembe, Pungo Andongo, Dundo, etc.), and the Okavango region of northern South-West Africa.

This species is doubtfully distinguishable from $R$. natalensis, but occurs with it.

Rattus angolensis Angolensis Bocage, i89o

I89o. Mus angolensis Bocage, J. Sci. Math. Phys. Nat., Lisboa, 2: I2. Capangombe. (near Mossamedes), south-western Angola.

RAtTus ANGOlensis LEgERAe nom. nov.

I933. Myomys shortridgei St. Leger, P.Z.S., 4I I. Okavango-Omatako junction, Grootfontein district, northern South-West Africa. Not of Thomas \& Hinton, I923 (a "Thallomys"). 


\section{Subgenus PRAOMYS Thomas, I9I5}

Rattus verreauxi A. Smith, I 834

Verreaux's Rat. Kaapse Muis

Distribution: the south-western coastal Cape Province; Knysna, near George, Simonstown, Cape Town, Hout Bay, Paarl, Wolseley, Citrusdal, Eendekuil, Klaver. There are two specimens in the British Museum from Umfolosi, Zululand, with Io mammae and rather long tails (head and body I08-IOg mm., tail I22-I $23 \mathrm{~mm}$.) which might possibly represent a form of this species.

Rattus verreauxi A. Smith, I 834

1834. Mus verroxii A. Smith, S. Afr. J. 2: i56. Near Cape Town. (Named after Verreaux).

I90 I. Mus verreauxi Sclater, Mamm. S. Africa, 2: 45.

Rattus namaquensis A. Smith, I834.

Namaqua Rock Rat. Namakwalandse Klipmuis

Distribution: in the Union, the Transvaal, including Pretoria, Johannesburg, Zoutpansberg, Magalaqueen River. Natal, including Utrecht and Zululand. Orange Free State (Bethulie). In the Cape Province, Vryburg, Kuruman, westwards from Upington, Louisvale, the Aughrabies Falls, the Molopo River; Bushmanland, Matjesfontein, Deelfontein, the Swartberg (Seven Weeks Poort); Little Namaqualand (Goodhouse, north of Steinkopf, the Kamiesberg, Garies), Klaver, Wolseley, near Paarl; Grahamstown, King William's Town, Lady Grey, Carnarvon, Middelburg, Aliwal North, etc. Swaziland. South-West Africa, evidently widely distributed throughout (the only districts ... where it does not occur are the plains of Ovamboland and around the Etosha Pan, Grootfontein district... and the Caprivi) (Shortridge, I934). The Kalahari, northwards to Ngamiland. Recorded from several places in Southern Rhodesia, including near Bulawayo, Salisbury, etc. Districts of Tete and Inhambane, Portuguese East Africa. Northern and western Angola.

Rattus namaquensis namaquensis A. Smith, i834

I834. Gerbillus namaquensis A. Smith, S. Afr. J. 2: i6o. Little Namaqualand, northwestern Cape Province.

Rattus namaquensis Lehocla A. Smith, 1836

I836. Mus lehocla A. Smith, Report Exped. Expl. C. Africa, 43. "Latakoo" (Litakun), near Kuruman, northern Cape Province.

Rattus namaquensis arborarius Peters, I 852

1852. Mus arborarius Peters, Reise nach Mossambique, Säugeth. I52. Tete, on the Zambezi, Portuguese East Africa.

I897. Mus auricomus de Winton, P.Z.S. I896: 802. Mazoe, Mashonaland, eastern Southern Rhodesia. (Roberts makes this a synonym of arborarius.)

(1908. Mus avarillus Thomas \& Wroughton, P.Z.S. 547. Tete, on the Zambezi, Portuguese East Africa. Apparently based on one specimen.)

Range includes part of the Magalaqueen River region, western Transvaal. 
Rattus namaquensis avunculus Thomas, 1904

1904. Mus avunculus Thomas, Ann. Mag. N.H. 13: 417. Pungo Andongo, northern Angola. Recorded by Hill \& Carter also from Hanha and Caporolo, Angola.

RAtTus NAmaQUensis centralis Schwann, igo6

1906. Mus auricomis centralis Schwann, P.Z.S., I07. Deelfontein, north of Richmond, central Cape Province. Ranges on the Karroo to Matjesfontein, and eastwards to Aliwal North, and Bethulie, southern Orange Free State.

RatTuS NAMAQUENSIS MONTIGUlaRis Jameson, I909

I909. Mus namaquensis monticularis Jameson, Ann. Mag. N.H. 4: 46r. Johannesburg, Transvaal. Ranges to Pretoria, Transvaal.

Rattus NAMAQUensis GRAHAmi Roberts, I9I5

191 5. Mus namaquensis grahami Roberts, Ann. Transv. Mus. 5: i i8. Godwin's Kloof, Grahamstown, eastern Cape Province. Range includes the Seven Weeks Poort (between Oudtshoorn and Ladismith). A distinct, very long-tailed form.

Rattus NamaQuensis Galarius Thomas, I 926

1926. Aethomys namaquensis calarius Thomas, Ann. Mag. N.H. I7: I84 (January). Lehutitung, Kalahari Desert, Bechuanaland. Range: Upington district to Ngamiland, Great Namaqualand and southern Damaraland, South-West Africa.

Rattus namaquensis siccatus Thomas, 1926

1926. Aethomys namaquensis siccatus Thomas, P.Z.S., 304 (April). Cunene (or Rua Cana) Falls, extreme southern Angola. Range includes the Kaokoveld and parts of northern South-West Africa.

Rattus namaquensis Gapensis Roberts, I926

1926. Praomys namaquensis capensis Roberts, Ann. Transv. Mus. II: 254 (September) Lormarins, Franschhoek Valley, opposite Paarl, south-western Cape Province.

Rattus namaquensis Klaverensis Roberts, I926

I926. Praomys namaquensis klaverensis Roberts, Ann. Transv. Mus. II: 254. Klaver, on the Olifants River, western Cape Province.

Rattus NAMAQUENSIS DRAKENSBERgi Roberts, I926

I926. Praomys namaquensis drakensbergi Roberts, Ann. Transv. Mus. II: 255. Klipspruit, Utrecht, northern Natal. Ranges to Swaziland and the Lebombo Mountains, Zululand. 
Rattus namaQuensis Lehochloides Roberts, I 926

I926. Praomys namaquensis lehochloides Roberts, Ann. Transv. Mus. II: 255. Wilhanshohe, Magalakuin (Magalaqueen) River, western Transvaal. Range: western Transvaal in Waterberg and Zoutpansberg districts.

Rattus NAMAQUensis WATERbergensis Roberts, I938

1938. Aethomys namaquensis waterbergensis Roberts, Ann. Transv. Mus. 19: 239, and I 946, 20: 320 (described as a new subspecies in both places). Okosongomingo, Waterberg, in Otjiwarongo district, north central South-West Africa.

Rattus NAMAQUensis NAmibensis Roberts, I 946

1946. Aethomys namaquensis namibensis Roberts, Ann. Transv. Mus. 20: 320. Karub, Namib desert between Usakos and Swakopmund, western South-West Africa.

Rattus morio Trouessart, I88 I

Soft-furred Rat

Distribution: Dundo and Amboim, Angola (British Museum), Lwakera, Northern Rhodesia. Northwards to the Gold Coast, Liberia, the Belgian Congo, Tanganyika, Kenya, etc.

RAtTus MORIO MORIo Trouessart, I88I. (Extralimital)

I862. Mus maura Gray, P.Z.S., i8 I. Not of Waterhouse, i839. Cameroon Mountain, Cameroons.

I88 I. Mus morio Trouessart, Bull. Soc. Études Sci. Angers, IO: I 2 I. Replaces maura Gray, preoccupied.

Rattus morio tUllbergi Thomas, i 894

I892. Mus burtoni Thomas, Ann. Mag. N.H. I0: 182. Ankober River, Wasa, Ashanti, West Africa. Not of Ramsay, 1887.

I894. Mus tullbergi Thomas, Ann. Mag. N.H. I3: 205. New name for burtoni Thomas, preoccupied. Occurs at Amboim, Angola (British Museum).

Rattus moRio JAGKSONi de Winton, i897

I897. Mus jacksoni de Winton, Ann. Mag. N.H. 20: 3 I 8. Entebbe, Uganda. Occurs at Dundo, north-eastern Angola, and in Northern Rhodesia.

\section{Subgenus HYLOMYSCUS Thomas, I926}

Rattus delectorum Thomas, igio

Mlanje Rat

Distribution: southern Nyasaland.

Rattus Delegtorum Thomas, igio

i 9 Iо. Epimys delectorum Thomas, Ann. Mag. N.H. 6: 430. Mlanje Plateau, 5,500 ft., southern Nyasaland. 
Rattus carillus Thomas, 1904

Climbing Wood Mouse

Distribution: Angola, recorded from Pungo Andongo, Chitau and Hanha; Belgian Congo, Cameroons, Tanganyika.

RatTus Garillus Garillus Thomas, I904

1904. Mus carillus Thomas, Ann. Mag. N.H. 13: 418. Pungo Andongo, I,200 m., northern Angola.

\section{Genus RHABDOMYS Thomas, I9i 6}

I916. Rhabdomys Thomas, Ann. Mag. N.H. i8: 69. Mus pumilio Sparrman.

Rhabdomys pumilio Sparrman, I 784

Four-striped Rat. Streeprot; Streepmuis

Distribution: in the Union, the Transvaal, Bloemhof, Krugersdorp, Potchefstroom, Pretoria, Pietersburg, Woodbush, Tzaneen, Legogot (near White River), Wakkerstroom, etc. Estcourt, Zululand, etc., Natal. The Orange Free State, including Bethulie, Modder River (Abrahams Kraal), Aberfeldy (near Harrismith); Maseru, Basutoland. In the Cape Province, Fourteen Streams, Kuruman, Kimberley, Vryburg, Louisvale (near Upington); Little Namaqualand (north of Steinkopf, Goodhouse, Port Nolloth, Springbok, the Kamiesberg, Garies); Van Rhynsdorp, Lamberts Bay, Nieuwoudtville, Citrusdal, Clanwilliam; Cape Town (Kirstenbosch, Rondebosch, etc.), Elgin, Simonstown, Hermanus; Matjesfontein, Oudtshoorn, George, Knysna; Port Elizabeth, Uitenhage, Grahamstown, Pondoland; Prieska, Deelfontein, Cradock, Queenstown, east of Calvinia, Van Wyk's Vlei, etc.; one of the commonest mammals of the Union. South-West Africa; throughout, except in the north-eastern districts (eastern Ovamboland, Etosha Pan region, Grootfontein district and the Caprivi (Shortridge, 1934)). The Kalahari, and Gaberones in south-eastern Bechuanaland. Southern Rhodesia. Angola, where it apparently ranges throughout the southern and central parts. Nyasaland. North of these limits, Tanganyika, Kenya, Uganda.

Rhabdomys pUmilio pUmilio Sparrman, i 784

I 784. Mus pumilio Sparrman, K. Svenska Vetensk. Akad. Handl., 236. Sitzicamma forest, on Slang Rivier, east of Knysna, southern Cape Province.

I827. Mus pumilio var. major Brants, Het Geslacht der Muizen, I05. Not of Pallas, I 779. Cape of Good Hope.

I829. Mus lineatus F. Cuvier in Geoffroy \& Cuvier, H.N. Mamm. 4: pt. 61 : "Rat à dos rayé", 2. Renaming of pumilio.

1845. Mus septemvittatus Schinz, Synops. Mamm. 2: I55. Cape of Good Hope. Range: Roberts restricts this race to the southern Cape Province from the region of the type locality to Paarl district, Wolseley and Tulbagh. 
Rhabdomys pumilio vittatus Wagner, $184^{2}$

1842. Mus vittatus Wagner, Arch. Naturgesch. 8, I : i I. Cape of Good Hope.

(1827. Mus donavani Lesson, Man. Mamm., 268. Cape of Good Hope. Perhaps a synonym of the typical race.)

1905. Arvicanthis pumilio meridionalis Wroughton, Ann. Mag. N.H. I6: 632. Tokai Retreat, Cape Town.

Roberts quotes specimens from Lamberts Bay, Matjesfontein and Oudtshoorn, Cape Province.

Rhabdomys pumilio bechuanae Thomas, I 893

I 893. Isomys pumilio bechuanae Thomas, P.Z.S. I892: 55 I. Originally thought to have been from Bechuanaland, but type locality later fixed as Rooibank, Walvis Bay, South-West Africa. (Shortridge, I934: 280). Hill \& Carter quote a specimen from Pico Azevedo, south-western Angola. A distinct, pale and large race.

Rhabdomys pumilio dilegtus de Winton, 1897

I897. Arvicanthis pumilio dilectus de Winton, P.Z.S. I896: 803. Mazoe, Mashonaland, eastern Southern Rhodesia. Recorded also from Matabeleland (including near Bulawayo), and the north-eastern Transvaal (Woodbush, Tzaneen).

Rhabdomys pumilio cinereus Thomas \& Schwann, I904

I904. Arvicanthis pumilio cinereus Thomas \& Schwann, Abstr. P.Z.S. No. 2: 5. P.Z.S., I 79. Klipfontein (north of Steinkopf), Little Namaqualand, north-western Cape Province. Recorded also by Roberts from Van Rhynsdorp, Klaver and Calvinia, western Cape Province.

RHABDOMYS PUmilio GRIQUAE Wroughton, I905

I905. Arvicanthis pumilio griquae Wroughton, Ann. Mag. N.H. I6: 632. Kuruman, northern Cape Province.

I910. Arvicanthis pumilio deserti Dollman, Ann. Mag. N.H. 6: 399. Lehutitung, Kalahari, Bechuanaland.

Ranges to Upington, Mafeking, Gaberones (south-eastern Bechuanaland), etc.

RhABdomys PUMILIO INTERMEdiUs Wroughton, I905

1905. Arvicanthis pumilio intermedius Wroughton, Ann. Mag. N.H. I6: 635. Deelfontein, north of Richmond, Cape Province.

The following two forms recently named by Roberts are likely to be synonyms, as the characters given by Roberts for differentiating intermedius do not hold good in all specimens in the British Museum.

1946. Rhabdomys pumilio cradockensis Roberts, Ann. Transv. Mus. 20: 323. Cradock, eastern Cape Province.

I946. Rhabdomys pumilio algoae Roberts, loc. cit., 323. Centlivres, near Port Elizabeth, eastern Cape Province; specimens also quoted from Grahamstown, eastern Cape Province. 
Rhabdomys pUmilio angolae Wroughton, i905

1905. Arvicanthis pumilio angolae Wroughton, Ann. Mag. N.H. ${ }_{\text {I6: }} 6{ }_{3} 6$. Caconda, inland from Benguela, Angola.

Rhabdomys pUmilio chaKaE Wroughton, I905

I905. Arvicanthis pumilio chakae Wroughton, Ann. Mag. N.H. I6: 636. Sibudeni, Zululand, Natal. Probable synonym of dilectus. Roberts says it occurs in Pondoland, eastern Cape Province.

RHABDOMYS PUMILIO MOSHESH Wroughton, I905

I905. Arvicanthis pumilio moshesh Wroughton, Ann. Mag. N.H. I6: 638. Maseru, 5,00o ft., western Basutoland. Probable synonym of dilectus. Roberts gives the range as including Orange Free State and Johannesburg, Pretoria, Potchefstroom, Pietersburg, etc., Transvaal.

Rhabdomys pumilio nyasae Wroughton, 1905

I905. Arvicanthis pumilio nyasae Wroughton, Ann. Mag. N.H. I6: 639. Mlanje Plateau, 6,ooo ft., southern Nyasaland.

RhaBdomys pUmilio NAMibensis Roberts, I926

1926. Rhabdomys pumilio namibensis Roberts, Ann. Transv. Mus. II: 255. Swakopmund (near Walvis Bay) South-West Africa.

In 1946 Roberts described nine more races of this species, most of which are probably of doubtful validity. Two of them are dealt with above under intermedius. The others are:

1946. Rhabdomys pumilio orangiae Roberts, Ann. Transv. Mus. 20: 32 I. Goodhouse, Lower Orange River, Little Namaqualand, north-western Cape Province. Probable synonym of cinereus.

1946. Rhabdomys pumilio namaquensis Roberts, Ann. Transv. Mus. 20: 32 I. Fish River, near Berseba, southern central Great Namaqualand, South-West Africa. Possible synonym of griquae.

I946. Rhabdomys pumilio prieskae Roberts, Ann. Transv. Mus. 20: 322. Prieska, middle Orange River, northern Cape Province. Probable synonym of orangiae.

1946. Rhabdomys pumilio fouriei Roberts, Ann. Transv. Mus. 20: 322. Ondonga, Ovamboland, South-West Africa.

1946. Rhabdomys pumilio vaalensis Roberts, Ann. Transv. Mus. 20: 322. Bloemhof, Vaal River, south-western Transvaal.

1946. Rhabdomys pumilio griquoides Roberts, Ann. Transv. Mus. 20: 322. Fourteen Streams, on the Vaal River, northern Cape Province. The last two probably = griquae.

1946. Rhabdomys pumilio bethuliensis Roberts, Ann. Transv. Mus. 20: 323. Bethulie, southern Orange Free State. Probable synonym of vittatus, if that itself is separable from the typical race. 


\section{RODENTIA - MURINAE \\ Genus LOPHUROMYS Peters, 1874}

I866. Lasiomys Peters, Mber. Preuss. Akad. Wiss., 409. Lasiomys afer Peters = Mus sikapusi Temminck. Not of Burmeister, I854.

1874. Lophuromys Peters, Mber. Preuss. Akad. Wiss., 234. Lasiomys afer Peters = Mus sikapusi Temminck. To replace Lasiomys Peters, preoccupied.

Fur finely speckled.

Fur dark, not speckled.
Lophuromys flavopunctatus, page 283

Lophuromys sikapusi, page 283

It is customary to recognize two species of the short-tailed group of Lophuromys, which may be distinguished roughly as above. They may occur together, and although some individuals have been examined which are not easily allocated to either group, for the time being we retain two species. L. sikapusi is the prior name in this genus, and flavopunctatus is the prior name for the speckled group.

Lophuromys sikapusi Temminck, I 853 Harsh-furred Rat

Distribution: Angola, Tanganyika, Kenya, westwards to the Gold Coast.

LOPHUROMYs SIKAPUSI SIKAPUSI Temminck, I 853

ı853. Mus sikapusi Temminck, Esq. Zool. Côte de Guiné, r6o. Dabacrom, Gold Coast. Occurs Angola (Duque de Bragança, Chitau).

Lophuromys flavopunctatus Thomas, I 888

Speckled Harsh-furred Rat

Distribution: Nyasaland, Northern Rhodesia, northern Portuguese East Africa, Belgian Congo, Tanganyika, Kenya, Abyssinia.

LophuRomys flavopunctatus flavopunctatus Thomas, i888. (Extralimital) I888. Lophuromys flavo-punctatus Thomas, P.Z.S., I4, footnote. Shoa, Abyssinia (probably obtained at Ankober, about Ioo miles N.E. of Addis Ababa, Thomas, 1903, P.Z.S. 1902, 2: 314).

Lophuromys flavopunctatus aQuilus True, 1892 1892. Mus aquilus True, Proc. U.S. Nat. Mus. 15: 46o. Mt. Kilimanjaro, 8,00o ft. Tanganyika. Occurs Nyika Plateau, northern Nyasaland, Zomba, southern Nyasaland.

Lophuromys flavopunctatus Rita Dollman, igio

I 9 10. Lophuromys rita Dollman, Ann. Mag. N.H. 5: I 79. Lufupa River, Katanga, 4,00o ft., Belgian Congo. Recorded from Dundo, north-eastern Angola; also Namuli Mt., northern Portuguese East Africa, Mlanje, southern Nyasaland (B.M.). 


\section{Genus MUS Linnaeus, I $75^{8}$}

I 758. Mus Linnaeus, Syst. Nat. Ioth ed. I: 59. Mus musculus Linnaeus, from Sweden. 1837. Leggada Gray, Charlesworth's Mag. N.H. I: 586. Mus booduga Gray, from India.

I876. Nannomys Peters, Mber. Preuss. Akad. Wiss., 48o. Mus setulosus Peters $=$ Mus musculoides Temminck, from the Cameroons.

I896. Pseudoconomys Rhoads, Proc. Acad. Nat. Sci. Philadelphia, 53 I. Mus proconodon Rhoads, from south-eastern Abyssinia.

1925. Hylenomys Thomas, Ann. Mag. N.H. 15: 667. Hylenomys callewaerti Thomas.

For other, extralimital, subgeneric names and synonyms see Ellerman \& MorrisonScott, 195I, 602.

The introduced European Mus musculus is not included: synonym: Mus modestus Wagner, 1842, Arch. Naturgesch. 8, I : I 4. Cape of Good Hope.

I. Large, skull length exceeds $23 \mathrm{~mm}$. Smaller, skull length below $23 \mathrm{~mm}$.

Mus callewaerti, page 286

2. Skull length about 2 I-22 mm.

$-2$

Skull length $20 \mathrm{~mm}$. at most, but less than $20 \mathrm{~mm}$. in almost all individuals

(Roberts gives one specimen $20.4 \mathrm{~mm}$; all other specimens noted to date below $20 \mathrm{~mm}$ ).

Mus minutoides, page 284

Roberts' statement that "Leggada" differs from Mus in smaller size and shorter tail is completely erroneous and based on too limited a view. Asiatic "Leggada" can be larger than Mus musculus and have the tail longer than the head and body.

\section{Subgenus MUS Linnaeus, $175^{8}$}

\section{Mus minutoides A. Smith, I 834}

Pygmy Mouse. Dwergmuis

Distribution: in the Union, the Transvaal, known from districts of Rustenburg, Pietersburg, Pretoria, Johannesburg, Legogot (near White River), Wakkerstroom; Zululand, Estcourt, Durban, etc., in Natal. Swaziland. In the Orange Free State,

${ }^{1}$ Mus triton; an unsatisfactory species from all points of view. Revision of the African Mus species is long overdue, and they should be compared in detail with the Indian ones. Thomas stated that Mus (musculus) has a short snout, and that species formerly referred to "Leggada" have a long snout. Whereas this is true with one exception (at least on average) in the Indian species, it does not seem to hold good in the African ones. For instance, Mus minutoides averages smaller in size of skull than is usual in wild races of Mus musculus, but the ratio of its diastema/occipitonasal length in B.M. material is the same as musculus (i.e. less than 25 per cent), the reverse being the case in the equally small species in India (booduga). Mus triton is nearly extralimital to this list, and cannot at the present time be worked out in detail, but the diastema in five specimens from Kenya, the Congo and Northern Rhodesia, the type included, give an average short diastema, as in Mus musculus, from wild races of which it does not seem easy to separate it. Hill \& Carter's measurements (two specimens) do not agree with this, but should the species prove to have a longer diastema, as might be expected, then it is quite indistinguishable from the Indian Mus cervicolor (which antedates it by many years) and its races. Pending a general revision the question is left open. $M$. callewaerti seems to have a very short tail, only about half the head and body length, or a little less in the type, and this, together with its somewhat specialized dentition, should separate it from species of similar size in India. But it is little known. The underparts may be noted as grey in triton, normally white in minutoides. 
Aberfeldy (near Harrismith), Bothaville, Heilbron, Viljoensdrift, etc. In the Cape Province, Molopo River district, Deelfontein, de Aar, Pondoland, King William's Town, Port Alfred, Port Elizabeth, Knysna, Elgin, Cape Town, Citrusdal, Wolseley, Klaver, Clanwilliam, Van Rhynsdorp, Lamberts Bay, Nieuwoudtville, Little Namaqualand (the Kamiesberg, Goodhouse). In Portuguese East Africa, Beira and Inhambane districts; Mashonaland, Southern Rhodesia; Ngamiland; in South-West Africa, widely but sparsely distributed over the central and northern parts from about the Tropic of Capricorn northwards (not met with south of Gobabis and Karibib (Shortridge, I934)). South-western Angola, Chitau (central) and Dundo (northeastern Angola). Nyasaland, Northern Rhodesia. North of these limits, in East Africa (usually under the name bellus) to Abyssinia, the Belgian Congo, Northern Nigeria, etc.

Mus minutoides minutoides A. Smith, I 834

I 834. Mus minutoides A. Smith, S. Afr. J. 2: I 57. Cape Town.

I 852. Mus minimus Peters, Ber. Preuss. Akad. Wiss., 274. Not of White, I 789. Tete, on the Zambezi, Portuguese East Africa (here restricted).

Range: western, southern and eastern Cape Province to Zululand.

Mus minutoides umbRatus Thomas, igio

i 9io. Leggada minutoides umbrata Thomas, Ann. Mag. N.H. 5: 86. Wakkerstroom, 5,900 ft., south-eastern Transvaal. Ranges to Swaziland, and northwards to Pietersburg district, Transvaal.

Mus minutoides marica Thomas, igio

I9 10. Leggada bella marica Thomas, Ann. Mag. N.H. 5: 88. Beira, coastal Portuguese East Africa. Range: includes the low country of the eastern Transvaal, Nyasaland and Northern Rhodesia.

Mus Minutoides indutus Thomas, igio

i 9 Iо. Leggada bella induta Thomas, Ann. Mag. N.H. 5: 89. Molopo, west of Morokwen, extreme northern Cape Province.

I910. Leggada deserti Thomas, Ann. Mag. N.H. 5: 9o. Molopo, west of Morokwen, extreme northern Cape Province.

Range: the Kalahari desert from the Molopo River to Ngamiland, westwards to Ovamboland, South-West Africa; deserti is recorded from Capelongo, south-western Angola by Hill \& Carter.

Mus minutoides neAvei Thomas, igio

i 9i o. Leggada neavei Thomas, Ann. Mag. N.H. 5: 9o. Petauke, 2,400 ft., eastern Loangwa district, eastern Northern Rhodesia.

Mus minutoides sybilla Thomas, I9I8

I 9 18. Leggada bella sybilla Thomas, Ann. Mag. N.H. 2: 484. Usolo River, Benguela, south-western Angola. Also recorded from Chitau, central Angola. 
Mus minutoides Kasaigus Cabrera, I924

1924. Leggada bella kasaica Cabrera, Bol. Real Soc. Esp. H.N. Madrid, 24: 222. St. Joseph de Luluabourg, Kasai, Belgian Congo. Recorded from Dundo, Angola by Sanborn.

Mus minutoides oRAngiae Roberts, I926

1926. Leggada orangiae Roberts, Ann. Transv. Mus. II: 25I. Kreusementfontein, Viljoensdrift, near Vereeniging, northern Orange Free State.

Mus minutoides VAlschensis Roberts, I926

1926. Leggada deserti valschensis Roberts, Ann. Transv. Mus. II: 25I. Bothaville, north-western Orange Free State.

Mus Minutoides PRETORIAe Roberts, I926

1926. Leggada deserti pretoriae Roberts, Ann. Transv. Mus. II: 252. Pretoria, Transvaal. Ranges to Rustenburg district, Moorddrift, Johannesburg, etc., Transvaal.

Mus triton Thomas, 1909

Larger Pygmy Mouse

For remarks on the status of this species see above, page 284 , footnote.

Distribution: Chitau and Dundo, Angola, Northern Rhodesia (Solwezi), the Belgian Congo, Uganda, Tanganyika, Kenya.

Mus TRITON Thomas, Igo9

i 909. Leggada triton Thomas, Ann. Mag. N.H. 4: 548. Kirui, Mt. Elgon, 6,ooo ft. Kenya. Range: as above.

Mus callewaerti Thomas, I925

Callewaert's Mouse

Distribution: recorded from Chitau and Dundo districts, Angola. Southern Belgian Congo.

Mus Gallewaerti Thomas, i 925

1925. Hylenomys callewaerti Thomas, Ann. Mag. N.H. 15: 668. Luluabourg, Lulua River, southern Belgian Congo. Range: as above.

Genus COLOMYS Thomas \& Wroughton, I907

1907. Colomys Thomas \& Wroughton, Ann. Mag. N.H. 19: 379. Colomys goslingi Thomas \& Wroughton.

Colomys goslingi Thomas \& Wroughton, I907 Gosling's Swamp Rat

Distribution: Dundo district, north-eastern Angola; Kenya, the Belgian Congo, the Cameroons. 
RODENTIA - MURINAE

Colomys goslingi goslingi Thomas \& Wroughton

1907. Colomys goslingi Thomas \& Wroughton, Ann. Mag. N.H. I9: 380. Gambi, Uele River, Belgian Congo.

Genus MALACOMYS Milne-Edwards, 1877

I 877. Malacomys Milne-Edwards, Bull. Soc. Philom. Paris, I3: 9. Malacomys longipes Milne-Edwards.

Malacomys longipes Milne-Edwards, I 877

Milne-Edwards' Swamp Rat

Distribution: Dundo district, northern Angola. Belgian Congo westwards to Liberia.

Malacomys Longipes LONGipes Milne-Edwards, I877. (Extralimital)

I877. Malacomys longipes Milne-Edwards, Bull. Soc. Philom. Paris, I3: 9. Gaboon River, West Africa.

Malagomys longipes wilsoni Thomas, igi 6

I916. Malacomys wilsoni Thomas, Ann. Mag. N.H. I8: 238. Inkongo, Belgian Congo. Recorded from Dundo, Angola.

Genus OENOMYS Thomas, I904

igo4. Oenomys Thomas, Ann. Mag. N.H. I3: 416. Mus hypoxanthus Pucheran.

Oenomys hypoxanthus Pucheran, I 855

Rufous-nosed Rat

Distribution: northern Angola; Uganda, Kenya, Belgian Congo, to the Gold Coast.

Oenomys hypoxanthus hypoxanthus Pucheran, I 855

I855. Mus hypoxanthus Pucheran, Rev. Zool. Paris, 7: 206. Gabon, West Africa.

Recorded from Dundo, north-eastern Angola.

Oenomys hypoxanthus anchietae Bocage, i 890

I 89o. Mus anchietae Bocage, J. Sci. Math. Phys. Nat., Lisboa, 2: I I. Ambaca, northern Angola. Records also include Chitau, Dondo, Luimbale, Pungo Andongo, Mombolo.

\section{Genus ZELOTOMYS Osgood, I9Io}

I910. Zelotomys Osgood, Field Mus. Publ. Zool. Io: 7. Mus hildegardeae Thomas.

Zelotomys hildegardeae Thomas, I902

Broad-headed Rat

Distribution: southern and central Angola (Chitau, Humpata, near Mupa), Northern Rhodesia; Belgian Congo, Kenya.

It is doubtful if there is more than one valid species in this genus. 
Zelotomys hildegardeae hildegardeae Thomas, ig02. (Extralimital) 1902. Mus hildegardeae Thomas, Ann. Mag. N.H. 9: 219. Machakos, Kenya.

Zelotomys HildegardeAe SHORTRIDGei Hinton, i920

1920. Zelotomys shortridgei Hinton, Ann. Mag. N.H. 6: 242. Ndola, near the Belgian Congo border, Northern Rhodesia.

Zelotomys hildegardeae kUvelaiensis St. Leger, I936

1936. Zelotomys shortridgei kuvelaiensis St. Leger, Ann. Mag. N.H. I7: 470. Cuvelai River, $50 \mathrm{~km}$. north of Mupa, southern Angola.

\section{Genus DASYMYS Peters, 1875}

1875. Dasymys Peters, Mber. Preuss. Akad. Wiss. 12. Dasymys gueinzii Peters = Mus incomtus Sundevall.

Dasymys incomtus Sundevall, $\mathrm{I} 846$

African Water Rat. Waterrot

Distribution: in the Union, the Transvaal, including Pretoria, Zoutpansberg, Woodbush, Tzaneen, Hectorspruit, near Carolina, etc. Natal (Durban, Zululand). In the Cape Province, Pondoland in the south-eastern and Wolseley in the southwestern coastal districts. South-West Africa; the marshes and reedbeds of the Okavango, Zambezi and Chobe rivers in the north. Eastern Southern Rhodesia (Mazoe, Melsetter). Apparently widespread in Angola, recorded as far north as Duque de Bragança. Northern Rhodesia, Nyasaland. (Shortridge mentions Portuguese East Africa, but its status there is obscure.) North of the limits of this work, on the western side from the Belgian Congo to Liberia, and on the eastern side northwards to Abyssinia and the southern Sudan.

Dasymys incomtus incomtus Sundevall, i 846

I846. Mus incomtus Sundevall, Ofvers. Vetensk. Akad. Förh. Stockholm, 3: I20. "E Caffraria prope Port Natal" (= Durban, Natal).

I875. Dasymys gueinzii Peters, Mber. Preuss. Akad. Wiss., I3. Interior of "Port Natal" (= Durban), Natal.

I897. Dasymys incomtus fuscus de Winton, P.Z.S. I896: 804. Mazoe, Mashonaland, north-eastern Southern Rhodesia.

Dasymys incomtus nudipes Peters, 1870

I870. Mus (Isomys) nudipes Peters, J. Sci. Math. Phys. Nat., Lisboa, 3: I 26. Huilla (Huila), south-western Angola.

Dasymys incomtus bentleyae Thomas, I892

I892. Mus (Dasymys) bentleyae Thomas, Ann. Mag. N.H. Io: i 79. Ngombi, Lower Congo, Belgian Congo. Recorded from Dundo and district, north-eastern Angola. 
Dasymys incomtus Gapensis Roberts, I936

1936. Dasymys incomtus capensis Roberts, Ann. Transv. Mus. I 8: 254. La Plisante, Wolseley, south-western Cape Province. (The type locality is between Tulbagh and Ceres, but to the south of that line.)

\section{Genus PELOMYS Peters, $185^{2}$}

I 852. Pelomys Peters, Ber. Preuss. Akad. Wiss., 275. Mus (Pelomys) fallax Peters.

I9I0. Desmomys Thomas, Ann. Mag. N.H. 5: 284. Pelomys harringtoni Thomas, from Abyssinia. Valid as a subgenus.

1924. Komemys de Beaux, Ann. Mus. Stor. Nat. Genova, 5I: 207. Komemys isseli de Beaux, from Kome Island, Lake Victoria, Uganda. Valid as a subgenus.

\section{Subgenus PELOMYS Peters, I 852}

I. Hindfoot $24 \mathrm{~mm}$. and less. Skull length in B.M. material is $29.6 \mathrm{~mm}$. and less. Pelomys minor, page 290

Hindfoot $28 \mathrm{~mm}$. and more. Skull length in B.M. material exceeds $3 \mathrm{I} \mathrm{mm}$.

2. Teeth larger, upper toothrow (crowns) normally exceed $6 \mathrm{~mm}$. (not under 6. I mm. in B. M. material). Pelomys fallax, page 289 Teeth smaller, upper toothrow (crowns) $6 \mathrm{~mm}$. at highest, usually less. Pelomys campanae, page 290

$P$. campanae is very close to $P$. fallax, but occurs with it in Angola. See also Hill $\&$ Carter. These authors only give the alveoli measurement for the upper molars but from their figures it will be seen that the length of the toothrow is the clearest division between the two species. The figures given above for $P$. fallax include only interlimital specimens.

\section{Pelomys fallax Peters, 1852}

Groove-toothed Swamp Rat; Creek Rat. Tropiese Groeftandrot

Distribution: Portuguese East Africa, including districts of Beira and Gorongoza, also north of the Zambezi. Mashonaland, Southern Rhodesia. The Caprivi strip, extreme northern South-West Africa. Angola (probably distributed throughout most of Angola wherever there are streams, Hill \& Carter). Nyasaland and Northern Rhodesia. Beyond the limits of this work, the Belgian Congo, Tanganyika, Kenya, Uganda.

Pelomys fallax fallax Peters, 1852

I852. Mus (Pelomys) fallax Peters, Ber. Preuss. Akad. Wiss., 275. Caya district, Zambezi River and Boror, Licuare River, Portuguese East Africa, of which the first is here designated the type locality. 
Pelomys fallax frater Thomas, I904.

I 904. Pelomys frater Thomas, Ann. Mag. N.H. I3: 415. Duque de Bragança, northern Angola.

Pelomys fallax insignatus Osgood, igio

I910. Pelomys fallax insignatus Osgood, Ann. Mag. N.H. 5: 276. Fort Hill, northern Nyasaland.

Pelomys fallax australis Roberts, I9I3

I9I3. Pelomys australis Roberts, Ann. Transv. Mus. 4: 9o. Mazambeti, Beira, coastal southern Portuguese East Africa.

Pelomys fallax Rhodestae Roberts, 1929

1929. Pelomys fallax rhodesiae Roberts, Ann. Transv. Mus. 13: i i8. Machile River (a northern tributary of the upper Zambezi), southern part of western Northern Rhodesia.

Pelomys fallax vumbae Roberts, 1946

1946. Pelomys fallax vumbae Roberts, Ann. Transv. Mus. $20: 320$. Vumba, southeastern Southern Rhodesia.

Pelomys campanae Huet, i 888.

Huet's Groove-toothed Swamp Rat

Distribution: the northern two-thirds of Angola, and the western Congo, according to Hill \& Carter.

Pelomys gampanae Huet, i 888.

I888. Golunda campanae Huet, Le Naturaliste, I0: I43. Landana (north of the Congo mouth), Cabinda. Occurs in Angola as just noted.

Pelomys minor Cabrera \& Ruxton, 1926

Lesser Creek Rat

Distribution: north-eastern Angola (Dundo and district), and the Belgian Congo.

Pelomys minor Cabrera \& Ruxton, I926

1926. Pelomys minor Cabrera \& Ruxton, Ann. Mag. N.H. I7: 6o I. St. Joseph de Luluabourg, Belgian Congo.

\section{Genus LEMNISCOMYS Trouessart, I 88 I}

I88ı. Lemniscomys Trouessart, Bull. Soc. Études Sci. d'Angers, 10, 2: 124. Mus barbarus Linnaeus, from Morocco.

Back with one dark stripe.

Lemniscomys griselda, page $29 \mathrm{I}$

Back with a middorsal stripe on either side of which are several rows of spots.

Lemniscomys striatus, page 29I 
Lemniscomys striatus Linnaeus, I $75^{8}$

Spotted Grass Rat

Distribution: northern Angola, also most of East Africa northwards to the Sudan and Abyssinia, and West Africa from the Belgian Congo to Sierra Leone.

LEMNISCOMYS STRIATUS STRIATUS Linnaeus, I 758

I758. Mus striatus Linnaeus, Syst. Nat. Ioth ed., I: 62. "India" = Sierra Leone (Thomas, I9 I I, P.Z.S., I 48).

I864. Golunda pulchella Gray, P.Z.S., 57. West Africa.

Has been recorded from Pungo Andongo, Duque de Bragança, and Jinga country, northern Angola.

\section{Lemniscomys griselda Thomas, I904}

Single-striped Grass Rat. Eenstreepmuis

Distribution: in the Union, the Transvaal; districts of Rustenburg, Pretoria, Leydsdorp, Klein Letaba, Tzaneen, Legogot (near White River). Natal (near Durban, Zululand). Swaziland. Portuguese East Africa, districts of Inhambane, Tete, Beira, Gorongoza, etc. Southern Rhodesia (Melsetter and Bulawayo, B.M.). The central Kalahari. In South-West Africa, according to Shortridge, "widely but apparently sparsely distributed north of the Tropic of Capricorn, the southern recorded limit of its range is Sandfontein (Gobabis-Bechuanaland border)". In Angola appears quite widely distributed, from Chitau and Hanha northwards, and includes Dundo. Nyasaland, Northern Rhodesia. Beyond the limits of this work, Tanganyika, Kenya, and an outlying form in Gambia.

LEMniscomys GRISELDA GRISELDA Thomas, I904

I904. Arvicanthis dorsalis griselda Thomas, Ann. Mag. N.H. I3: 4I4. Muene Coshi, Jinga country, northern Angola.

For the use of the name griselda instead of dorsalis see Thomas, I927, P.Z.S., 385.

LEMNiscomys GRISELDA GALIDIOR Thomas \& Wrougthon, I908

1908. Arvicanthis dorsalis calidior Thomas \& Wroughton, P.Z.S., 545. Tambarara, Gorongoza Mountains (north-westwards from Beira), western Portuguese East Africa. Ranges to Mashonaland, Southern Rhodesia, and Beira and Inhambane, southern Portuguese East Africa.

Lemniscomys GRISELDA SPINALIS Thomas, I 9 i 6

I845. Mus dorsalis A. Smith, Illustr. Zool. S. Africa, Mamm. pl. 46, fig. 2. "North of the Great Orange River"; western Transvaal, according to Roberts. Not of Fischer, I8I 4 .

I916. Lemniscomys griselda spinalis Thomas, Ann. Mag. N.H. I8: 69, footnote. To replace dorsalis A. Smith, preoccupied.

Range: Rustenburg and Pretoria districts, Transvaal, also Bulawayo, Southern Rhodesia. 
LEMNISCOMYS GRISELdA SABUlatus Thomas, I927

1927. Lemniscomys griselda sabulata Thomas, P.Z.S., 385. Sandfontein, Gobabis district, eastern South-West Africa.

LEMNISCOMYS GRISELDA ZULUENSIS Roberts, I93 I

193 I. Lemniscomys griselda zuluensis Roberts, Ann. Transv. Mus. I4: 235. Manaba, north-eastern Zululand, Natal.

LEMNISGOMYS GRISELDA FITZSIMONSI Roberts, I932

1932. Lemniscomys griselda fitzsimonsi Roberts, Ann. Transv. Mus. 15: i I. Kaotwe Pan, central Kalahari, Bechuanaland.

LEMNISCOMYS GRISELDA SABIENSIS Roberts, I946

1946. Lemniscomys griselda sabiensis Roberts, Ann. Transv. Mus. 20: 32 I. Gravellote, Leydsdorp district, north-eastern Transvaal.

\section{Genus URANOMYS Dollman, I909}

I909. Uranomys Dollman, Ann. Mag. N.H. 4: 551. Uranomys ruddi Dollman.

Uranomys ruddi Dollman, I9o9

Rudd's Rat

Distribution: Nyasaland; Kenya, Uganda, Northern Nigeria, Gold Coast, French Guinea.

URANOMYs RUDDI RUDDI Dollman, I909. (Extralimital)

I909. Uranomys ruddi Dollman, Ann. Mag. N.H. 4: 552. Kirui, Mt. Elgon, 6,ooo ft., Kenya.

URANOMYS RUDDI wOodi Hinton, I92 I

I92 I. Uranomys woodi Hinton, Ann. Mag. N.H. 7: 369. Cholo (south-east of Blantyre), southern Nyasaland.

URANOMYS RUDDI TENEBRosus Hinton, I92 I

I92 I. Uranomys tenebrosus Hinton, Ann. Mag. N.H. 7: 370. Mkhoma, Dowa district, Nyasaland ( fide K. H. Barnard, in litt. The type locality given by Hinton is really the native name).

For description of another form from Likabula, foot of Mt. Mlanje, Nyasaland, see Hayman, 1953, Ann. Mag. N.H. 6: 317.

\section{Genus ACOMYS I. Geoffroy, I 838}

I838. Acomys I. Geoffroy, Ann. Sci. Nat. Paris, Zool. I0: i26. Mus cahirinus Desmarest.

A large number of species is recognized in Africa in this genus. Nearly all of them can probably be considered as subspecies of the earliest-named $A$. cahirinus, 
which was based on a commensal form from Egypt. But $A$. russatus (Egypt and Arabia), A. wilsoni (East Africa), and A. subspinosus (Cape Province) seem valid.

The last is remarkable for its small teeth. It is not a common species, but a certain number of specimens have been obtained and it seems that the characters we outline for it in the key are likely to prove constant enough to justify its retention as a species.

Teeth very small; the upper toothrow known to reach $3.5 \mathrm{~mm}$. in one specimen only. Acomys subspinosus, page 293

Teeth less reduced, the upper toothrow normally $3.7 \mathrm{~mm}$. and more. Acomys cahirinus, page 293

Acomys cahirinus Desmarest, I8 I9 Common Spiny Mouse. Stekelmuis Distribution: in the Union, the Transvaal (Magalaqueen River, Zoutpansberg, Leydsdorp district). Portuguese East Africa, districts of Tete, Beira and Gorongoza south of the Zambezi and Boror north of that river. Southern Rhodesia (near Bulawayo, Melsetter district, etc.). Nyasaland; Northern Rhodesia (Ndola, Petauke district, etc.). Beyond the limits of this work, practically the whole of East Africa; northern Nigeria, Asben; Egypt, Libya, Algeria; Crete, Cyprus, Arabia, Palestine, southern Persia, western Sind (India).

Acomys GahiRinus Gahirinus Desmarest, i8 8 ig. (Extralimital) I8 I9. Mus cahirinus Desmarest, Nouv. Dict. H.N. 29: 70. Cairo, Egypt.

Acomys gahirinus spinosissimus Peters, 1852 1852. Mus (Acomys) spinosissimus Peters, Ber. Preuss. Akad. Wiss., 274; Reise nach Mossambique, Säugeth. i6o. Tete, on the Zambezi, Portuguese East Africa (Moreau, Hopkins \& Hayman, I946).

Acomys Gahirinus Selousi de Winton, I897

I897. Acomys selousi de Winton, P.Z.S. I896: 807. Essex Farm, near Bulawayo, Matabeleland, western Southern Rhodesia. Probable synonym of spinosissimus? Recorded by Roberts from Nyasaland, Northern Rhodesia and parts of Portuguese East Africa.

Acomys Gahirinus transvaalensis Roberts, ig26

1926. Acomys transvaalensis Roberts, Ann. Transv. Mus. II: 252. Newgate Farm, Zoutpansberg, northern Transvaal. Range: Transvaal as listed above. One of the smaller races of $A$. cahirinus.

Acomys subspinosus Waterhouse, $18{ }_{3} 8$

Cape Spiny Mouse. Kaapse Stekelmuis

Distribution: the south-western Cape Province; Knysna, Cape Town, Simonstown, Citrusdal, Eendekuil, Clanwilliam district.

Acomys subspinosus Waterhouse, , 1838

1838. Mus subspinosus Waterhouse, P.Z.S. I837: io4. Cape of Good Hope (from Table Mountain, Cape Town, fide Roberts). 
Genus BEAMYS Thomas, I909

1909. Beamys Thomas, Ann. Mag. N.H. 4: 107. Beamys hindei Thomas, from Kenya.

There are two species, one which is smaller, from Kenya, and the other which is larger, from Nyasaland. So far no intermediate forms are known either in size or from the intervening region.

Beamys major Dollman, I9I4

Larger Longtailed Pouched Rat

Distribution: Nyasaland.

Beamys major Dollman, I9I4

I 9 I 4. Beamys major Dollman, Ann. Mag. N.H. I 4: 428. Mlanje, southern Nyasaland.

\section{Genus SACCOSTOMUS Peters, 1846}

I 846. Saccostomus Peters, Ber. Preuss. Akad. Wiss. 258. Saccostomus campestris Peters. I903. Eosaccomys Palmer, Science, I7: 873, to replace Saccostomus which was supposed to be preoccupied by Saccostoma Fitzinger, I843, in reptiles.

We do not think there is more than one valid species in this genus. Roberts (I95 I, 439) thought two occurred together in Zululand, campestris and fuscus, the latter stated to be a "much larger species" but his table of measurements does not bear this out. We think it far more probable that fuscus, with its synonym mashonae is a synonym of the typical race.

\section{Saccostomus campestris Peters, 1846}

Cape Pouched Mouse. Wangsakmuis

Distribution: in the Union, the Transvaal, near Rustenburg, Moorddrift, near Pietersburg, Zoutpansberg district, Woodbush, Hectorspruit, etc. Zululand. The Modder River region. In the Cape Province, Kuruman, Molopo district, Louisvale (near Upington), Goodhouse (on Orange River, Little Namaqualand), Cradock, Grahamstown, Port Elizabeth, and according to Hewitt (I93I) Rosmead (near Middelburg), Bedford and King William's Town. South-West Africa: "Pouched Mice range throughout South-West Africa, except possibly along the coastal desert" (Shortridge, 1934). The Kalahari, Bechuanaland, to Ngamiland. Southern Rhodesia (Bulawayo district, Mashonaland, etc.). Portuguese East Africa, recorded from districts of Beira, Tete, Inhambane and Gorongoza. Nyasaland, and Northern Rhodesia. Most of the interior of Angola, south of Hanha and west of the Cubango River; also recorded from Dundo. North of the limits of this work, Tanganyika, Uganda, Kenya and according to Shortridge the southern Belgian Congo.

Far too many subspecies appear to be named. 
Sagcostomus Gampestris Gampestris Peters, i 846

i 846. Saccostomus campestris Peters, Ber. Preuss. Akad. Wiss. 258. Tete, on the Zambezi, Portuguese East Africa.

I852. Saccostomus lapidarius Peters, Reise nach Mossambique, Säugeth., i67. Substitute for campestris.

( I 852. Saccostomus fuscus Peters, Reise nach Mossambique, Säugeth., I68. Inhambane, coastal southern Portuguese East Africa.)

(1897. Saccostomus mashonae de Winton, P.Z.S. I896: 804. Mazoe, Mashonaland, eastern Southern Rhodesia. Roberts makes this a synonym of fuscus.)

Range: Eastern Cape Province, Zululand, Portuguese East Africa, Southern

Rhodesia to Nyasaland and Northern Rhodesia.

Sagcostomus gampestris elegans Thomas, i 897

I897. Saccostomus elegans Thomas, P.Z.S., 431. Karonga, north-western corner of Lake Nyasa, Northern Nyasaland. Ranges into Tanganyika.

Saccostomus Gampestris anderssoni de Winton, i 898

I898. Saccostomus anderssoni de Winton, Ann. Mag. N.H. 2: 6. Damaraland, SouthWest Africa.

(1923. Saccostomus pagei Thomas \& Hinton, P.Z.S., 495. Lehutitung, Kalahari, Bechuanaland.)

1938. Saccostomus anderssoni angolae Roberts, Ann. Transv. Mus. 19: 240. Ondjiwa, southern Angola.

SAGcostomus Gampestris hildae Schwann, igo6

I 906. Saccostomus hildae Schwann, P.Z.S., i io. Kuruman, northern Cape Province.

Range includes near Upington (southern bank of the Orange River),

Goodhouse (Little Namaqualand), and has been recorded from near

Bulawayo, Southern Rhodesia.

SAccostomus GAmpestris Limpopoensis Roberts, I9I4

I9I4. Saccostomus limpopoensis Roberts, Ann. Transv. Mus. 4: i83. Sand River, Zoutpansberg district, northern Transvaal (Mapogone, Roberts, I95 I, 628). Roberts also quoted a specimen from the Modder River (most of which is in the Orange Free State).

Saccostomus campestris STReeteri Roberts, igi 4

I9I4. Saccostomus streeteri Roberts, Ann. Transv. Mus. 4: i83. Hectorspruit, near southern border of the Kruger National Park, eastern Transvaal. Range includes Tzaneen, Rustenburg district, Moorddrift, etc., in the Transvaal. Probable synonym of the typical race.

\section{Genus CRICETOMYS Waterhouse, I840}

I840. Cricetomys Waterhouse, P.Z.S., 2. Cricetomys gambianus Waterhouse.

Gricetomys gambianus Waterhouse, I 840

African Giant Rat. Reuserot

Distribution: in the Union, Zoutpansberg district, northern Transvaal (and reported from the Hluhluwe reserve, Zululand (African Wild Life, Vol. 5, No. 3, 
p. I85)). Portuguese East Africa; districts of Inhambane, Beira and Gorongoza. Melsetter district, eastern Southern Rhodesia. Angola (western Angola southwards at least to Humpata, and the regions of Chitau and Dala in the central and eastern portion). Nyasaland, Northern Rhodesia (Ndola included). North of the limits of this work, East Africa as far north as Kenya and the Sudan; and from the Belgian Congo westwards to Gambia.

Grigetomys gambianus gambianus Waterhouse, i84o. (Extralimital) I840. Cricetomys gambianus Waterhouse, P.Z.S., 2. River Gambia, West Africa.

Crigetomys gambianus ansorgei Thomas, igo4

1904. Cricetomys ansorgei Thomas, Ann. Mag. N.H. 13: 412. Pungo Andongo, northern Angola.

CRicetomys gambianus viator Thomas, I904

1904. Cricetomys gambianus viator Thomas, Ann. Mag. N.H. 13: 413. Likangala River, Zomba district, $15^{\circ} 25^{\prime}$ S., $35^{\circ} 30^{\prime}$ E., southern Nyasaland.

Cricetomys gambianus adventor Thomas \& Wroughton, 1907 1907. Cricetomys gambianus adventor Thomas \& Wroughton, P.Z.S., 295. Coguno, Inhambane district, southern Portuguese East Africa. Ranges to Beira and the mouth of the Limpopo, southern Portuguese East Africa.

CRicetomys gambianus gunctator Thomas \& Wroughton, igo8 I908. Cricetomys gambianus cunctator Thomas \& Wroughton, P.Z.S., I 7 I. Tambarara, Gorongoza district (south of the Zambezi), western Portuguese East Africa.

Cricetomys gambianus haAgneri Roberts, 1926

I926. Cricetomys gambianus haagneri Roberts, Ann. Transv. Mus. II: 252. Ten miles north of Louis Trichardt, Zoutpansberg, northern Transvaal.

Cricetomys gambianus vaughanjonesi St. Leger, I937

1937. Cricetomys emini vaughan-jonesi St. Leger, Ann. Mag. N.H. 20: I48. Balovale, upper Zambezi (above the junction of the Kabompo River with the Zambezi), western Northern Rhodesia.

Gricetomys gambianus selindensis Roberts, i 946

1946. Cricetomys gambianus selindensis Roberts, Ann. Transv. Mus. 20: 3 19. Mt. Selinda, Melsetter district, eastern Southern Rhodesia.

\section{Subfamily $\mathrm{D}$ e $\mathrm{n} \mathrm{d} \mathrm{r}$ o $\mathrm{m}$ u $\mathrm{r}$ i $\mathrm{n}$ a e}

I. Four hindtoes only, the hallux absent. Tail short, usually less than half head and body length. Ear nearly as long as, or as long as, hindfoot. (Four functional digits on forefeet.)

Hindfoot with 5 toes.

Genus MALACOTHRIX, page 305 
2. Manus with 3 functional digits. Hallux lacks claw. Tail longer than head and body, prehensile. (Often or usually with mid-dorsal stripe, but according to Roberts this is sometimes less marked or absent in females and young animals.)

Genus DENDROMUS, page 301

Manus with 4 functional digits. Hallux clawed. No stripe on back.

$-3$

3. Tail short, about 6 o per cent of head and body at longest, usually less. Infraorbital foramen enlarged, its outer border prominently ridged, and with large masseter knob at its lower border. Pattern of cheekteeth more distinct. Upper incisors grooved.

Genus STEATOMYS, page 298

Tail long, minimum about 90 per cent of head and body length. Infraorbital foramen more normal, without strong masseter knob at its lower border. Cheekteeth usually with pattern obscure. Upper incisors not grooved.

Genus PETROMYSCUS, page 297

\section{Genus PETROMYSGUS Thomas, I926}

I926. Petromyscus Thomas, Ann. Mag. N.H. i7: i 79. Praomys collinus Thomas.

P. monticularis seems to be known only by two specimens, but differs rather sharply from the other named forms and is tentatively retained as a species.

Tail shorter than head and body; ear about I I-I $2 \mathrm{~mm}$.

Petromyscus monticularis, page 298

Tail averages longer than head and body. Ear I3 mm. and more.

Petromyscus collinus, page 297

Petromyscus collinus Thomas \& Hinton, I 925

Pygmy Rock Mouse. Kleinklipmuis

Distribution: Little Namaqualand (the Kamiesberg, north of Steinkopf, Goodhouse). South-West Africa; mountains of Great Namaqualand, Damaraland, the Kaokoveld, etc., northwards to Caporolo (south of Benguela) south-western Angola.

Petromysaus collinus collinus Thomas \& Hinton, I925

1925. Praomys collinus Thomas \& Hinton, P.Z.S., 237. Karibib (north-west of Windhoek), Damaraland, South-West Africa.

Petromysaus collinus Brughus Thomas \& Hinton, I925

1925. Praomys collinus bruchus Thomas \& Hinton, P.Z.S., 238. Great Brukkaros Mountain, near Berseba, Great Namaqualand, South-West Africa.

Petromysaus collinus shortridgei Thomas, ig26

I926. Petromyscus shortridgei Thomas, P.Z.S., 302. Cunene (or Rua Cana) Falls, extreme southern Angola. Range includes the Kaokoveld, eastwards to Tsumeb district, north to Caporolo, Angola. 
Petromyscus collinus Kaokoensis Roberts, 1938

1938. Petromyscus shortridgei kaokoensis Roberts, Ann. Transv. Mus. 19: 239. Kamanjab, Kaokoveld, north-western South-West Africa.

Petromysgus collinus barbouri Shortridge \& Carter, 1938

1938. Petromyscus barbouri Shortridge \& Carter, Ann. S. Afr. Mus. 32: 288. Witwater, Kamiesberg, 3,500-3,800 ft., Little Namaqualand, north-western Cape Province.

Petromysaus collinus capensis Shortridge \& Carter, 1938

1938. Petromyscus collinus capensis Shortridge \& Carter, Ann. S. Afr. Mus. 32: 289. Goodhouse (Raman's Drift), south bank of Orange River, Little Namaqualand, north-western Cape Province.

Petromyscus collinus namibensis Roberts, i 948

1948. Petromyscus collinus namibensis Roberts, Ann. Transv. Mus. 21: 65. Okombahe, lower Omaruru River, borders of the Namib desert (north of Walvis Bay), South-West Africa.

Petromyscus monticularis Thomas \& Hinton, 1925

Berseba Rock Mouse. Bersebase Klipmuis

Distribution: Berseba district of Great Namaqualand, South-West Africa.

Petromysaus monticularis Thomas \& Hinton, 1925

1925. Praomys monticularis Thomas \& Hinton, P.Z.S. 238. Great Brukkaros Mountain, near Berseba, Great Namaqualand, South-West Africa.

\section{Genus STEATOMYS Peters, 1846}

I846. Steatomys Peters, Ber. Preuss. Akad. Wiss., 258. Steatomys pratensis Peters.

Although members of this genus vary very much individually in bodily size, there seems to be fair evidence that there are two species, a larger one and a smaller one, in Angola.

Average larger; skull usually about $28 \mathrm{~mm}$. and more (averages $28 \mathrm{~mm}$. in Hill \&

Carter's measurements).

Average smaller; skull usually below $27 \mathrm{~mm}$.
Steatomys bocagei, page $30 \mathrm{I}$

Steatomys pratensis, page 298

\section{Steatomys pratensis Peters, 1846}

Fat Mouse. Vetmuis

Distribution: in the Union, the Transvaal, including Randfontein (west of Johannesburg), Witwatersrand, Tzaneen, Klein Letaba, Hectorspruit, Legogot (near White River). Natal, including Blood River, Bergville, Zululand, etc. Bothaville, 298 
Orange Free State. In the Cape Province, Mafeking; also near Cape Town, Eendekuil, Wolseley, Tulbagh, Citrusdal and Klaver. Portuguese East Africa; recorded from Tete, and Lumbo (north of the Zambezi). Southern Rhodesia (Mashonaland), Ngamiland, the Kalahari; in South-West Africa, the northern and north-eastern parts, north of the Tropic of Capricorn (Shortridge). South-western and central Angola, also recorded from Dundo. Nyasaland; common in Northern Rhodesia. North of the limits of this work, similar forms occur in the Sudan, northern Nigeria, the Belgian Congo, Tanganyika and probably Kenya.

Steatomys PRatensis pratensis Peters, i 846

I846. Steatomys pratensis Peters, Ber. Preuss. Akad. Wiss. 258. Tete, on the Zambezi, Portuguese East Africa.

I 852. Steatomys edulis Peters, Reise nach Mossambique, Säugeth. i63. Substitute for pratensis.

Ranges to Zululand, and into the Transvaal (in part), and Southern Rhodesia.

Steatomys pratensis krebsi Peters, 1852

I852. Steatomys krebsii Peters, Reise nach Mossambique, Säugeth. i65. Interior of Kaffraria. Roberts thought from Graaff Reinet, eastern Cape Province, where the species is apparently unknown, or has not subsequently been taken.

Steatomys PRAtensis Pentonyx Sclater, i 899

I 899. Malacothrix pentonyx Sclater, Ann. S. Afr. Mus. I: 202. Cape Flats, near Cape Town. Range: western Cape Province, northwards to Klaver.

Steatomys PRATensis minutus Thomas \& Wroughton, ig05

I905. Steatomys minutus Thomas \& Wroughton, Ann. Mag. N.H. I6: I 74. Quillenges, Benguela district, south-western Angola.

Steatomys PRAtensis loveridgei Thomas, igi9

igr 9. Steatomys loveridgei Thomas, Ann. Mag. N.H. 4: 33. Lumbo, mainland opposite Mozambique Island, I $5^{\circ} \mathrm{I}^{\prime} \mathrm{S} ., 4^{\circ} 4 \mathrm{O}^{\prime} \mathrm{E}$., sea level, northern Portuguese East Africa. Ranges into Tanganyika.

Steatomys PRatensis swalius Thomas, i 926

1926. Steatomys swalius Thomas, P.Z.S. 300. Ondongwa, Ovamboland, northern South-West Africa.

1926. Steatomys swalius umbratus Thomas, P.Z.S. 30 I. Cunene (or Rua Cana) Falls, extreme southern Angola.

Steatomys PRAtensis orangiae Roberts, I 929

I 929. Steatomys krebsi orangiae Roberts, Ann. Transv. Mus. I3: i I6. "Angra Pequina" Farm, Bothaville district, north-western Orange Free State. 
Steatomys PRATEnsis transvaAlensis Roberts, 1929

1929. Steatomys krebsi transvaalensis Roberts, Ann. Transv. Mus. 13: i 17. Witfontein, Randfontein district (west of Johannesburg), western Transvaal. Ranges to Mafeking, northern Cape Province.

Steatomys PRatensis natalensis Roberts, i929

I929. Steatomys natalensis Roberts, Ann. Transv. Mus. 13: i I7. Bergville (below the Drakensberg), western Natal.

SteAtomys PRATENSIS GHIVERSI Roberts, I93 I

I93 I. Steatomys chiversi Roberts, Ann. Transv. Mus. I4: 233. Blood River, Newcastle district, northern Natal.

Steatomys PRATENSIS TONGensis Roberts, I93 I

I931. Steatomys chiversi tongensis Roberts, Ann. Transv. Mus. 14: 233. Manaba, northern Zululand, Natal.

STEATOMYS PRATENSIS KALAhaRICus Roberts, I $93^{2}$

1932. Steatomys krebsi kalaharicus Roberts, Ann. Transv. Mus. 15: i I. Twenty-five miles west of Damara Pan, central Kalahari, Bechuanaland.

Steatomys pRatensis maunensis Roberts, I932

1932. Steatomys pratensis maunensis Roberts, Ann. Transv. Mus. 15: I I. Shorobe, Maun district, Ngamiland, northern Bechuanaland.

Steatomys PRATENSis Kasaigus Hatt, I934

1934. Steatomys pratensis kasaicus Hatt, Amer. Mus. Novit. No. 708: I 5. Luluabourg, Kasai district, southern Belgian Congo. Has been recorded from Dundo district, north-eastern Angola.

Steatomys pratensis LeUcorhynchus Hill \& Carter, I937

1937. Steatomys minutus leucorhynchus Hill \& Carter, Amer. Mus. Novit. No. 913: 4 . Capelongo, Huilla district, south-western Angola.

Steatomys pratensis angolensis Hill \& Carter, 1937

1937. Steatomys angolensis Hill \& Carter, Amer. Mus. Novit. No. 913: 5. Chitau, 4,930 ft., central Angola.

Steatomys PRATEnsis bRAdleyi Hill \& Carter, 1937

1937. Steatomys angolensis bradleyi Hill \& Carter, Amer. Mus. Novit. No. 913: 5 . Humpata, 6,300 ft., Huilla district, south-western Angola.

The last two forms are little known, each apparently being based on a single specimen. 
Steatomys bocagei Thomas, 1892

Bocage's Fat Mouse

Distribution: Angola, throughout most of the central interior region (Hill \& Carter); records include Chitau, Caconda, Chissonque, east of Dando, Quindumbo, Bihé district, Duque de Bragança, etc.

Steatomys bocagei Thomas, I892

I 892. Steatomys bocagei Thomas, Ann. Mag. N.H. Io: 264 . Caconda, east of Benguela, Angola.

Genus DENDROMUS A. Smith, I 829

I 829. Dendromus A. Smith, Zool. J. 4: 438. Dendromus typus A. Smith $=$ Mus mesomelas Brants.

I 832. Dendromys Smuts, Enum. Mamm. Cap., 39. Emendation.

I9I6. Poemys Thomas, Ann. Mag. N.H. I8: 238. Dendromus melanotis A. Smith.

I916. Chortomys Thomas, Ann. Mag. N.H. I8: 238. Dendromus lovati de Winton, from Abyssinia.

On this genus see Bohmann, I942, Die Gattung Dendromus A. Smith, Zool. Anz. I39: 33 .

The differences between the two species groups (mesomelas group and melanotis) of Dendromus seem far less than some authors, who have separated them subgenerically, would have us believe.

We follow Bohmann's classification, who recognized two species in the mesomelas group, a larger one and a smaller one, occurring together through most of Africa south of the Sahara, although the difference between these two species is average rather than absolute.

Bohmann called the smaller species Dendromus pumilio Wagner, I84I, but Wagner later stated that this name was based on a young specimen of $D$. mesomelas, and as it has no exact locality, and the description is not very helpful, we prefer to regard it as not certainly identifiable, and we adopt the next available name, mystacalis.

I. General colour normally grey. Fifth hindtoe with nail. (Skull small, about as in D. mystacalis).

Dendromus melanotis, page 303

General colour normally brown. Fifth hindtoe with claw.

2. Average larger, normally adult skulls $22 \mathrm{~mm}$. and more. Hairs of underparts usually slaty at base.

Dendromus mesomelas, page $30 \mathrm{I}$

Average smaller, adult skulls 2 I $\mathrm{mm}$. and less. Hairs of underparts either white to base or tinged with ochraceous.

Dendromus mystacalis, page 302

Dendromus mesomelas Brants, I 827

Chestnut Tree-Mouse or Climbing Mouse. Rooiboommuis; Klimmuis Distribution: in the Union, the eastern Transvaal (Tzaneen, Woodbush, Mariepskop, Barberton district, near Wakkerstroom); Estcourt and Durban, Natal; in the 
Cape Province, Port St. Johns and Notinsila, Pondoland; Port Alfred (Hewitt), Knysna; and in the western Province, Wolseley, Tulbagh and Eendekuil. The Okavango district of northern South-West Africa. Angola (Chitau). N. Rhodesia. To the north Tanganyika, Belgian Congo, Kenya, Abyssinia, southern Nigeria.

Dendromus mesomelas mesomelas Brants, I 827

I827. Mus mesomelas Brants, Het Geslacht der Muizen, I 22. "Near Zondags River"; (Sundays River, just east of Port Elizabeth, eastern Cape Province).

I 829. Dendromus typus A. Smith, Zool. J. 4: 439. South Africa.

1834. Dendromys typicus A. Smith, S. Afr. J. 2: I 58 . Renaming of typus.

(184I. Dendromys pumilio Wagner, Gelehrte Anzeigen, I2: 437. Cape of Good Hope. (Juvenile D. mesomelas?').)

I9I3. Dendromus longicaudatus Roberts, Ann. Transv. Mus. 4: 83. Tzaneen, eastern Transvaal.

I9I3. Dendromus ayresi Roberts, Ann. Transv. Mus. 4: 83. Port St. Johns, eastern Cape Province.

Range: Union localities listed above.

Dendromus mesomelas major St. Leger, i 930

1930. Dendromus mesomelas major St. Leger, Ann. Mag. N.H. 6: 622. Ssanukanu Village, Grootfontein district, northern South-West Africa.

Dendromus mesomelas vernayi Hill \& Carter, 1937

1937. Dendromus mesomelas vernayi Hill \& Carter, Amer. Mus. Novit. No. 913: 4 . Chitau, 4,930 ft., central Angola.

Dendromus mystacalis Heuglin, 1863

Lesser Climbing Mouse. Kleinklimmuis

Distribution: in the Union, Tzaneen, eastern Transvaal, Estcourt and Zululand, Natal, in the Cape Province, Ngqeleni (Pondoland), Pirie (near King William's Town), and, according to Roberts, Knysna. Swaziland. Chirinda Forest, Southern Rhodesia. Northern Rhodesia. East Loangwa district, near the western border, northern Portuguese East Africa (British Museum). Nyasaland. Angola (as below). Further to the north, Tanganyika, Kenya, Abyssinia, the Cameroons.

Dendromus mystagalis mystagalis Heuglin, i863. (Extralimital) I 863. Dendromys mystacalis Heuglin, Nova Acta Leop. Carol. 30, 2, suppl.: 5 . Bäschlo region, Abyssinia: (= Bashilo River?)

Dendromus mystacalis messorius Thomas, I903

1903. Dendromys messorius Thomas, Ann. Mag. N.H. I2: 340. Efulen, Cameroons. Recorded from Dundo, north-eastern Angola. 


\section{RODENTIA - DENDROMURINAE}

Dendromus mystaGalis ansorgei Thomas \& Wroughton, i905.

I 905. Dendromus ansorgei Thomas \& Wroughton, Ann. Mag. N.H. i6: i 73. Caconda, east of Benguela, Angola. Recorded also from Chitau and Caiala (Bihé district), Angola.

Dendromus mystaGalis Whytei Wroughton, igog

I909. Dendromus whytei Wroughton, Ann. Mag. N.H. 3: 247. Fort Hill, northern Nyasaland.

Dendromus mystagalis jamesoni Wroughton, igo9

I909. Dendromus jamesoni Wroughton, Ann. Mag. N.H. 3: 247. Tzaneen, eastern Transvaal. (Originally cited as Zoutpansberg; Tzaneen is about 50 miles south-east of that range.)

I93 I. Dendromus jamesoni pongolensis Roberts, Ann. Transv. Mus. I4: 232. Pongola River, I 5 miles west of Manaba, north-eastern Zululand, Natal.

DendRomus mystaGalis NyiKaE Wroughton, igog

I909. Dendromus nyikae Wroughton, Ann. Mag. N.H. 3: 248. Nyika Plateau, northern Nyasaland.

I916. Dendromus nyasae Thomas, Ann. Mag. N.H. I8: 24I. Nyika Plateau, northern Nyasaland.

(These two forms have been referred to different subgenera (!); Bohmann referred them to melanotis, but they seem to belong more with mystacalis.)

Dendromus melanotis A. Smith, I 834

Grey Pygmy Tree-Mouse. Grysboommuis; Swartoorklimmuis

Distribution: in the Union, in the Transvaal known from Pretoria, Legogot (near White River) and Wakkerstroom district. Estcourt, Durban, Mooi River, Zululand, etc., in Natal. Parys, extreme northern Orange Free State. Basutoland. In the Cape Province, Vryburg, Molopo district; Grahamstown, King William's Town, Blythswood, Port Elizabeth, Knysna, near Cape Town (Kirstenbosch, British Museum), Wolseley, Tulbagh, Citrusdal, and the Kamiesberg (Little Namaqualand). Northern South-West Africa (the Okavango, Caprivi and Ovamboland). Southern Rhodesia (eastern districts, Mazoe and Melsetter). Northern Rhodesia, Nyasaland. Angola (the south-western districts, Ghitau and Golungo Alto). Thence northwards to Kenya, Abyssinia and northern Nigeria.

Dendromus melanotis melanotis A. Smith, i 834

I834. Dendromys melanotis A. Smith, S. Afr. J. 2: I 58. Near "Port Natal" = Durban, Natal.

I846. Dendromys subtilis Sundevall, Öfvers. Vetensk. Akad. Förh. Stockholm, 3: I 20. South Africa.

1927. Dendromus melanotis basuticus Roberts, Rec. Albany Mus. 3: 484. Thaba Putsua Mountain, Basutoland. 
DendRomus melanotis melanotis [contd.]

1929. Dendromus (Poemys) melanotis chiversi Roberts, Ann. Transv. Mus. I3: I 6. Vlakfontein, Parys district, northern Orange Free State.

I931. Dendromus melanotis thorntoni Roberts, Ann. Transv. Mus. I4: 231. Port Elizabeth, eastern Cape Province.

I93 I. Dendromus melanotis capensis Roberts, Ann. Transv. Mus. I4: 232. Wolseley, south-western Cape Province.

1938. Poemys melanotis insignis Shortridge \& Carter, Ann. S. Afr. Mus. 32: 287. Not of Thomas, I903. Eselfontein, Kamiesberg, Little Namaqualand, northwestern Cape Province.

Dendromus melanotis PeCilei Milne-Edwards, i 886.

I 886. Dendromys pecilei Milne-Edwards, Rev. Sci. Paris, I2: I6. "Lower Congo to Ogowe River." A specimen in B.M. bearing this name from Golungo Alto, northern Angola.

Dendromus melanotis NigRifrons True, I 892

I 892. Dendromys nigrifrons True, Proc. U.S. Nat. Mus. I5: 462. Mount Kilimanjaro, Tanganyika. Recorded from Northern Rhodesia by Pitman. Specimens in B. M. (Ansell).

Dendromus melanotis vulturnus Thomas, igi 6

i9i6. Dendromus (Poemys) nigrifrons vulturnus Thomas, Ann. Mag. N.H. I8: 242. Chirinda Forest, Melsetter district, south-eastern Southern Rhodesia. Ranges to eastern Transvaal and north-eastern Zululand.

DendROMUS MELANOTIS ARENARIUS Roberts, I924

1924. Dendromus (Poemys) arenarius Roberts, Ann. Transv. Mus. 10: 71. "Angra Pequina" Farm, Bothaville, north-western Orange Free State (see Roberts, I95 I : 448). Ranges to Molopo River region, northern Cape Province.

Dendromus melanotis conainnus Thomas, I 926

1926. Dendromus (Poemys) concinnus Thomas, P.Z.S. 299. Otjumbumbi, Cunene River, extreme southern Angola. Ranges in Ovamboland, northern SouthWest Africa.

Dendromus melanotis angolensis Roberts, i929

1929. Dendromus (Poemys) angolensis Roberts, Ann. Transv. Mus. I3: I I 5. Mombolo (= Namba), central western Angola. Also recorded from Chitau by Hill \& Carter.

Dendromus melanotis SHORTRIDGei St. Leger, I930

I930. Dendromus (Poemys) nigrifrons shortridgei St. Leger, Ann. Mag. N.H. 6: 622. Ssanukanu Village, Grootfontein district, northern South-West Africa.

I93 I. Dendromus melanotis pretoriae Roberts, Ann. Transv. Mus. I4: 232. Rietondale, Pretoria, Transvaal.

Range includes Ngamiland and Okavango district. 
Dendromus melanotis leucostomus Monard, i 933

1933. Dendromus leucostomus Monard, Bull. Soc. Sci. Nat. Neuchâtel, 57: 55. Caluquembe, western Angola.

\section{Genus MALACOTHRIX Wagner, I 843}

I843. Malacothrix Wagner, Schreber's Säugth. Suppl. 3: 496. Otomys typicus A. Smith. ${ }^{1}$

Malacothrix typica A. Smith, I 834

Mouse Gerbil. Grootoormuis

Distribution: in the Union, the western and southern Transvaal, Krugersdorp district, Bloemhof, and Volksrust (near the Natal border). The Orange Free State (Vredefort district); Basutoland. In the Cape Province, Kimberley, Mafeking, Fourteen Streams, Molopo district; near Queenstown, Deelfontein, Vredendal, Klaver, Graaff Reinet, and (according to Shortridge) Beaufort West and Cradock. South-West Africa; Ovamboland, and Gobabis. The Kalahari. Extreme southern Angola (Mupanda).

Malagothrix typiga typiga A. Smith, i 834

I834. Otomys typicus A. Smith, S. Afr. J. 2: I48. Near Graaff Reinet, eastern Cape Province.

MALAGOTHRIX TYPIGA FRYI Roberts, I9I7

I9I7. Malacothrix typicus fryi Roberts, Ann. Transv. Mus. 5: 268. Klipriviersoog, Krugersdorp district (west of Johannesburg), Transvaal.

I95 I. Malacothrix typicus harveyi Roberts, Mamm. S. Africa, 455. ("harveyi" appears to be a lapsus for fryi.)

Ranges into the northern Orange Free State and to Mafeking.

Malacothrix typica egeria Thomas, ig26

1926. Malacothrix egeria Thomas, P.Z.S., 30г. Ondongwa (Ondonga), central Ovamboland, South-West Africa. Ranges into southern Angola.

MALAGOTHRIX TYPIGA KALAhARIGUS Roberts, I932

1932. Malacothrix typicus kalaharicus Roberts, Ann. Transv. Mus. I5: io. Kuke Pan, central Kalahari, Bechuanaland.

Malacothrix typiga Damarensis Roberts, I932

1932. Malacothrix typicus damarensis Roberts, Ann. Transv. Mus. I5: io. Gobabis, on western border of the Kalahari desert, eastern South-West Africa.

Malagothrix tÝpica molopensis Roberts, I933

1933. Malacothrix typicus molopensis Roberts, Ann. Transv. Mus. 15: 266. Eight miles west of Pitsani, Molopo River, in southern Bechuanaland.

${ }^{1}$ Otomys A. Smith, 1834, was not Otomys Cuvier, 1824. Smith used Euryotis for that genus. 


\section{Subfamily $\mathrm{O} \mathrm{t}$ o $\mathrm{m}$ y $\mathrm{i} \mathrm{n}$ a $\mathrm{e}$}

Although much less specialized cranially and less aberrant dentally the Otomyinae seem to take the place of the Holarctic subfamily Microtinae which is absent south of the Sahara.

Bullae much enlarged (10.8 mm. minimum in adult); the basioccipital between them narrowed.

Genus PAROTOMYS, page 312 Bullae not or less enlarged $(9.5 \mathrm{~mm}$. maximum), the basioccipital between them less narrowed.

Genus OTOMYS, page 306

\section{Genus OTOMYS F. Guvier, I 824}

I 824. Otomys F. Cuvier, Dents Mamm. i68 (vernacular, I823), 255 (scientific, I824), pl. 6o. Euryotis irrorata Brants.

1827. Euryotis Brants, Het Geslacht der Muizen, 93. Euryotis irrorata Brants.

I877. Oreomys Heuglin, Reise in Nordost-Afrika, 2: 76. Oreomys typus Heuglin, from Abyssinia.

I88I. Oreinomys Trouessart, Bull. Soc. Études Sci. Angers, IO: i i I. Substitute for Oreomys Heuglin, thought to be preoccupied by Orenomys Aymard, I855.

1918. Myotomys Thomas, Ann. Mag. N.H. 2: 204, 206. Otomys unisulcatus Brants = Otomys unisulcatus F. Cuvier.

I9I8. Anchotomys Thomas, Ann. Mag. N.H. 2: 204, 208. Otomys anchietae Bocage.

I 918. Lamotomys Thomas, Ann. Mag. N.H. 2: 208. Otomys laminatus Thomas \& Schwann.

1937. Metotomys Broom, S. Afr. J. Sci. 33: 765. Otomys turneri Wroughton, a race of Otomys sloggetti Thomas.

F. Cuvier, I82 I-I825, Dents des Mammifères, is an available work. Otomys is, however, described without mention of any species by name. Euryotis Brants contained only one species, E. irrorata and is a synonym of Otomys (the identity of these genera was suggested as early as 1830 by Lichtenstein in his Darstellung Säugethiere and recognized by Smuts, I832, Enumerationem Mammalium Capensium, 45). Otomys has stood as a generic name for I 20 years and should be placed on the official list. The type of Otomys was fixed by W. L. Sclater, 1899, Ann. S. Afr. Mus. I: I95-198.

On this genus see Wroughton, I906, Notes on the genus Otomys, Ann. Mag. Nat. Hist. I8: 264, and Dollman, I915, On the Swamp-Rats (Otomys) of East Africa. Ann. Mag. N.H. I5: I 49 .

On Thomas's supposed genera and subgenera see Ellerman, i94 I, Fam. Gen. Liv. Rodents, 2: 319-320.

I. Lamination of molars at maximum; the first lower with normally 6-7 laminae, the third upper with 9 or Io. (Upper and lower incisors well grooved).

Otomys laminatus, page 307

Lamination of molars less marked; the first lower with $4_{-5}^{-5}$, the third upper with $4^{-7}$ (South Africa, or rarely with 8 north of the region now under consideration). 
2. First lower molar with 5 laminae. (Upper and lower incisors grooved).

First lower molar with 4 laminae.

Otomys anchietai, page 308

3. Lower incisors (as well as the upper ones) well grooved. (Third upper molar with 5-7 laminae.)

Lower incisors usually plain (and the upper ones may become so).

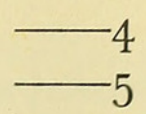

4. The width of the nasals is $6.3 \mathrm{~mm}$. and less. Otomys saundersiae, page 3 ro The width of the nasals (South Africa) is $6.5 \mathrm{~mm}$. and more.

Otomys irroratus, ${ }^{1}$ page 308

5. Tail short, less than half head and body length. (Third upper molar with 4 or 5 laminae.)

Otomys sloggetti, page 3 I I

Tail longer, on average more than half head and body length, usually over 60 per cent of it. (Third upper molar usually with 4 laminae.)

Otomys unisulcatus, page 3 I

Otomys laminatus Thomas \& Schwann, I905

Laminate Vlei Rat. Bergvleimuis

Distribution: The eastern Transvaal (Mariepskop (near Lydenburg)), Natal (Dargle (near Howick) and Zululand), the eastern Cape Province, Pondoland, and the western Cape Province, near Paarl.

Отомуs Laminatus Laminatus Thomas \& Schwann, I905

1905. Otomys laminatus Thomas \& Schwann, Abstr. P.Z.S. No. I8: 23; P.Z.S., I: 267. Sibudeni, Zululand, Natal.

OtOMYS LAminatus SILBERbaUeRI Roberts, I9I9

I919. Otomys silberbaueri Roberts, Ann. Transv. Mus. 6: i I4. Lormarins, Franschoek Valley, opposite Paarl, south-western Cape Province.

Otomys Laminatus pondoensis Roberts, I 924

I924. Otomys (Lamotomys) laminatus pondoensis Roberts, Ann. Transv. Mus. Io: 7 I. Ngqeleni, western Pondoland, Eastern Cape Province. Probable synonym of the typical race.

OTOMys LAminatus MARIEPSI Roberts, I 929

1929. Otomys (Lamotomys) laminatus mariepsi Roberts, Ann. Transv. Mus. I3: i io. Mariepskop, Lydenburg district, eastern Transvaal. Probable synonym of the typical race.

1 We do not accept Roberts' subdivision of the irroratus group into two species based, apparently, on whether the nasals have or have not a sharp angle at the base of the expansion; this seems altogether too slight a character on which to base species, and as there seem no other characters or measurements which will divide his species in cases of apparent geographical overlap, we have thought it best to synonymize forms where necessary. 
Otomys Laminatus FanNini Roberts, I95 I

1951. Lamotomys laminatus fannini Roberts, Mamm. S. Africa, 426. Kilgobbin Farm, near Dargle Rail Station, central Natal. Probable synonym of the typical race.

Otomys anchietai Bocage, 1882

Anchieta's Swamp Rat

Distribution: Angola (according to Hill \& Carter, probably restricted to the northern two-thirds of Angola and the adjacent part of the Congo). Tanganyika.

Otomys ANchietai ANGhietai Bocage, i 882

I882. Euryotis anchietae Bocage, J. Sci. Phys. Math. Nat., Lisboa, 9: 26. Caconda, east of Benguela, Angola.

Otomys irroratus Brants, 1827

Vlei Rat. Vleirot; Vleimuis

Distribution: in the Union, the Transvaal; Zoutpansberg, Pietersburg, Woodbush, Tzaneen, Klein Letaba, Lydenburg district, Wakkerstroom, Pretoria, Johannesburg, Rustenburg, Krugersdorp, Potchefstroom, etc. Natal, including Estcourt, Utrecht, Dargle district, Zululand. Orange Free State; Aberfeldy (near Harrismith), Vredefort, Kroonstad, Bethlehem, Fouriesburg, etc. Basutoland; Maseru, and Maluti Mountains. In the Cape Province, Kuruman, Vryburg, the Kamiesberg in Little Namaqualand, Citrusdal, Clanwilliam, near Lamberts Bay, Van Rhynsdorp, Tulbagh, Wolseley, Worcester, Paarl, Cape Town, Elgin, Simonstown, George, Knysna, Grahamstown, Uitenhage, King William's Town, Griqualand East, Pondoland. Inhambane district, Portuguese East Africa. Southern Rhodesia; in South-West Africa, the reedbeds and marshes of the Okavango and the rivers of the Caprivi, and in swampy sections of the Omurambe-Omatako as far south as Ssanukanu Village (Shortridge, I934). Angola, where apparently widely distributed. Nyasaland, Northern Rhodesia. Similar forms occur northwards to Kenya and southern Nigeria.

OTOMYS IRRORATUS IRRORATUS Brants, I 827

1827. Euryotis irrorata Brants, Het Geslacht der Muizen, 94. Near Constantia (Cape Town district) (A. Smith, I834).

I 829. Otomys capensis G. Cuvier, Règne Anim. ed. 2, I: 208.

(In his additions and corrections, on p. $5^{8} \mathrm{I}$, Cuvier says that capensis is a synonym of irrorata).

I834. Euryotis typicus A. Smith, S. Afr. J. 2: I49. Near Constantia (Cape Town district). Renaming of irrorata.

1842. Otomys bisulcatus F. Cuvier in Geoffroy \& Cuvier, H.N. Mamm. 4: Tab. Gén. 4. Namaqualand.

I842. Euryotis obscura Lichtenstein, Verz. Samml. Kaffernlande, ı. "Kaffirland."

Range: western and southern coastal belt of the Cape Province, eastwards to Pondoland. 


\section{RODENTIA - OTOMYINAE}

OtOMYs IRroratus aURATus Wroughton, I906

1906. Otomys irroratus auratus Wroughton, Ann. Mag. N.H. I8: 272. Vredefort, northern Orange Free State.

OTOMYS IRRORATUS GUPREUS Wroughton, Igo6

1906. Otomys irroratus cupreus Wroughton, Ann. Mag. N.H. I8: 273. Woodbush, Pietersburg district, Transvaal. (Originally given as Zoutpansberg, in error.)

Otomys (?)IRRoRAtus ANGONIENSIS Wroughton, I906

I 906. Otomys irroratus angoniensis Wroughton, Ann. Mag. N.H. I8: 274. M'Kombhuie, Angoniland, 8,0oo ft., Nyasaland.

OtOMYS (?) IRRORATUS NYIKAE Wroughton, Igo6

1906. Otomys irroratus nyikae Wroughton, Ann. Mag. N.H. I8: 276. Nyika Plateau, $6,500 \mathrm{ft} .$, northern Nyasaland.

OTOMYS IRRORATUS coenosus Thomas, I9I 8

I9I8. Otomys irroratus coenosus Thomas, Ann. Mag. N.H. 2: 208. Kuruman, northern Cape Province.

OTOMYS IRRORATUS ROWLEYI Thomas, I9I8

I 9 8. Otomys rowleyi Thomas, Ann. Mag. N.H. 2: 209. Coguno, Inhambane district, Portuguese East Africa. Roberts also quotes specimens from eastern Southern Rhodesia.

OTOMYS IRRORATUS MASHONA Thomas, IgI 8

I918. Otomys mashona Thomas, Ann. Mag. N.H. 2: 210. Mazoe, Mashonaland, north-eastern Southern Rhodesia.

OtOMYS IRRORATUS MAXIMUS Roberts, I924

I924. Otomys irroratus maximus Roberts, Ann. Transv. Mus. I0: 70. Machile River (tributary of the Zambezi), southern part of western Northern Rhodesia. Ranges to the Okavango and Chobe rivers, and western and southern Angola.

OtOMYS IRRORATUS NATALENSIS Roberts, I 929

1929. Otomys irroratus natalensis Roberts, Ann. Transv. Mus. I3: i i . Kilgobbin, Dargle district, central Natal. Range includes Wakkerstroom, south-eastern Transvaal.

OTOMYS IRRORATUS RANDENSIS Roberts, I929

I929. Otomys irroratus randensis Roberts, Ann. Transv. Mus. I3: i I2. Fontainebleau, Johannesburg, Transvaal.

(1929. Otomys tugelensis pretoriae Roberts, Ann. Transv. Mus. I3: i I4. Fountains Valley, Pretoria, Transvaal.

Ranges to Marico district and Vryburg, northern Cape Province (pretoriae).) 
OTOMYS IRRORATUS TUGELENSIS Roberts, I929

1929. Otomys tugelensis Roberts, Ann. Transv. Mus. 13: I I3. Klipspruit, Utrecht, northern Natal. Range includes Zululand, and Carolina district, southeastern Transvaal.

OtOMYS IRRORATUS SABIENSIS Roberts, I929

1929. Otomys tugelensis sabiensis Roberts, Ann. Transv. Mus. I3: I I4. Mariepskop, Lydenburg district, eastern Transvaal.

(1946. Otomys cupreus cupreoides Roberts, Ann. Transv. Mus. 20: 318. Newgate Farm, Zoutpansberg, northern Transvaal.)

Otomys IRroRatus GuAnzensis Hill \& Carter, 1937

1937. Otomys cuanzensis Hill \& Carter, Amer. Mus. Novit. No. 913: 7. Chitau, $4930 \mathrm{ft}$, , central Angola. Northern Angolan records may refer to this form.

OTOMYS IRRORATUS ORIENTALIS Roberts, I 946

1946. Otomys irroratus orientalis Roberts, Ann. Transv. Mus. 20: 318. Umzimkulu, Griqualand East, near the Natal border, eastern Cape Province.

Otomys saundersiae Roberts, I929

Saunders' Vlei Rat. Kleinvleirot

Distribution: Cape Province; Grahamstown, King William's Town, near Citrusdal, Wolseley, Tulbagh, Eendekuil.

Отомys SAUNDERSIAE Roberts, I929

i929. Otomys tugelensis saundersiae Roberts, Ann. Transv. Mus. I3: i I5. Grahamstown, eastern Cape Province.

I93 I. Otomys karoensis Roberts, Ann. Transv. Mus. I4: 231. Tulbagh, south-western Cape Province (see Roberts, I95I, 425. "Wolseley" in the original description is an error).

Otomys unisulcatus F. Cuvier, I 829

Bush Karroo Rat. Boskarorot; Boskaromuis

Distribution: Cape Province; Little Namaqualand (Port Nolloth, north of Steinkopf, Springbok, the Kamiesberg, Garies), Vredendal (near Van Rhynsdorp), Lamberts Bay, near Clanwilliam, Saldanha Bay, east of Calvinia, Van Wyk's Vlei, Brandvlei (Bushmanland), Hanover, Cradock, Deelfontein, Albany district, Bedford, Grahamstown, Matjesfontein, Oudtshoorn, probably near Ladismith, Victoria West, and according to Shortridge, George and Port Elizabeth.

Отомys unisulgatus unisulgatus F. Cuvier, 1829

I829. Otomys unisulcatus F. Guvier in Geoffroy \& Cuvier, H.N. Mamm. 3: livraison 60 (pl. and text on "Otomys cafré"). South Africa; type locality nominated as Matjesfontein, on the south-western Karroo, south-west of Laingsburg, Cape Province by Roberts. 
Отомys Unisulgatus GRANTI Thomas, I902

1902. Otomys unisulcatus grantii Thomas, Ann. Mag. N.H. IO: 312. Deelfontein, north of Richmond, central Cape Province. Ranges to Cradock, Hanover, Oudtshoorn and Bushmanland.

Отомys UNisulgatus BRoomi Thomas, I902

I902. Otomys broomi Thomas, Ann. Mag. N.H. I0: 31 3. Port Nolloth, coastal Little Namaqualand, north-western Cape Province.

Отомys unisulgatus BeRgensis Roberts, I 929

1929. Myotomys unisulcatus bergensis Roberts, Ann. Transv. Mus. I3: io8. Lamberts Bay (west of Clanwilliam), western Cape Province.

Отомys unisulgatus albaniensis Roberts, I946

1946. Myotomys unisulcatus albaniensis Roberts, Ann. Transv. Mus. 20: 3 I8. Kleinpoort, near Committees Drift, Albany district, south-eastern Cape Province.

Otomys sloggetti Thomas, I902

Sloggett's Karroo Rat; Ice Rat. Sloggettse Karorot; Ysrot

Distribution: Wakkerstroom, south-eastern Transvaal; Aberfeldy (near Harrismith), Orange Free State; northern and southern Basutoland; and in the Cape Province, Deelfontein, Jamestown (south of Aliwal North), Hanover, Lady Frere (north-east of Queenstown), Beaufort West and Victoria West.

Отомys SLOGgetti SLOGgetti Thomas, 1902

1902. Otomys sloggetti Thomas, Ann. Mag. N.H. IO: 3I I. Deelfontein, north of Richmond, central Cape Province.

OTOMYS SLOGgetTI TURNERI Wroughton, ig07

I907. Otomys turneri Wroughton, Ann. Mag. N.H. 20: 31. Aberfeldy, near Harrismith, north-eastern Orange Free State. Ranges to Wakkerstroom, south-eastern Transvaal.

Отомys Sloggetti Robertsi Hewitt, i927. (Ice Rat)

I 927. Otomys robertsi Hewitt, Rec. Albany Mus. 3: 430. Summit of Mont-aux-Sources, I I, $500 \mathrm{ft}$., borders of north-eastern Basutoland and Orange Free State. Range includes Maluti Mountains, Basutoland.

Отомys SLOGgetti JePPEi Roberts, I929

1929. Myotomys sloggetti jeppei Roberts, Ann. Transv. Mus. I3: io9. Jamestown (south of Aliwal North), eastern Cape Province.

Отомys SLOGGetti Basuticus Roberts, i 929

1929. Myotomys sloggetti basuticus Roberts, Ann. Transv. Mus. I3: I Io. Bolepeletsa, $5,800 \mathrm{ft}$., southern Basutoland (this is a small trading station between Telle Drift and Quthing, 93 miles S.E. of Wepener (Orange Free State) and 48 miles S.E. of Zastron). 


\section{SOUTHERN AFRICAN MAMMALS I758-1951}

Genus PAROTOMYS Thomas, I9I8

1918. Parotomys Thomas, Ann. Mag. N.H. 2: 204. Euryotis brantsi A. Smith. 1918. Liotomys Thomas, Ann. Mag. N.H. 2: 204. Parotomys (Liotomys) littledalei Thomas. Valid as a subgenus.

Upper incisors grooved. Tail in British Museum material averages 59-64 per cent of head and body.

Parotomys brantsi, page 312

Upper incisors plain. Tail in British Museum material averages 77 per cent of head and body.

Parotomys (Liotomys) littledalei, page $3 \mathrm{I} 3$

\section{Subgenus PAROTOMYS Thomas, I918}

Parotomys brantsi A. Smith, I 834 Brants' Karroo Rat. Brantse Karorot

Distribution: Cape Province; Kuruman district, Little Namaqualand (Port Nolloth, north of Steinkopf, Springbok, near the Kamiesberg, N.W. of Garies, Nieuwerust), Vredendal (near Van Rhynsdorp), Tulbagh, Matjesfontein, Oudtshoorn (fide D. H. S. Davis), Deelfontein, Cradock, Middelburg, Calvinia district.

Parotomys brantsi brantsi A. Smith, 1834

1834. Euryotis brantsii A. Smith, S. Afr. J. 2: I50. "Common in certain places towards mouth of Orange River" (A. Smith, I840, Illustr. Zool. S. Africa, pl. 24, text). Thomas \& Schwann (I904) restrict the type locality to Port Nolloth, coastal Little Namaqualand, north-western Cape Province.

PAROTOMYS BRANTSI PALLIDA Wagner, I84I

I84I. Euryotis pallida Wagner, Arch. Naturgesch. 7, I: I34. South Africa. Type locality fixed as Van Rhynsdorp (Western Cape Province) by Roberts, I929, Ann. Transv. Mus. 13: i08. Probable synonym of the typical race.

PAROTOMYS BRANTSI RUfifrons Wagner, I 843

I842. Otomys ruffifons Rüppell, Verz. Mus. Senckenberg, I: 28, nomen nudum.

I843. Euryotis rufifrons Wagner in Schreber, Säugth. Suppl. 3: 507. Cape of Good Hope. Roberts nominates Cradock, eastern Cape Province, as type locality.

Parotomys BRANTSI Luteolus Thomas \& Schwann, i904

I904. Otomys brantsii luteolus Thomas \& Schwann, P.Z.S. 1 : I78. Deelfontein, north of Richmond, central Cape Province. Probable synonym of rufifrons.

PAROtomys BRANTSI Deserti Roberts, I933

1933. Parotomys brantsi deserti Roberts, Ann. Transv. Mus. 15: 267. Bushman Pits, Kuruman River $\left(22^{\circ}\right.$ E.) northern Cape Province. 


\section{Subgenus LIOTOMYS Thomas, I918}

Parotomys littledalei Thomas, I 9 I 8

Littledale's Karroo Rat. Boesmanlandse Karorot; Geelbosrot

Distribution: in the Union, Little Namaqualand (Goodhouse, north of Steinkopf, Port Nolloth), Louisvale (near Upington, south bank of Orange River), Kenhardt, Calvinia, Van Wyk's Vlei, and west of the Molopo River near the South-West African border. South-West Africa; Great Namaqualand, and south-western Damaraland (near the coast).

Parotomys littledalei littledalei Thomas, i 9 i 8

I9I8. Paratomys (Liotomys) littledalei Thomas, Ann. Mag. N.H. 2: 205. Tuin, Kenhardt, Bushmanland, north-western Cape Province.

Parotomys littledalei molopensis Roberts,' i 933

I933. Parotomys (Liotomys) littledalei molopensis Roberts, Ann. Transv. Mus. 15: 267. Hakscheen Pan, near Rietfontein police post, northern Cape Province (near the South-West African border).

Parotomys littledalei namibensis Roberts, i 933

1933. Parotomys (Liotomys) littledalei namibensis Roberts, Ann. Transv. Mus. 15: 268. Swakopmund (near Walvis Bay), South-West Africa.

\section{Subfamily $\mathrm{G} r$ i $\mathrm{c}$ e $\mathrm{t}$ i $\mathrm{n}$ a $\mathrm{e}$}

Genus MYSTROMYS Wagner, I84I

I84I. Mystromys Wagner, Gelehrte Anzeigen, I2: 434. Mystromys albipes Wagner = Otomys albicaudatus A. Smith.

This genus is separated from the Palaearctic genera Cricetus and immediate allies by lacking the deep pit between each pair of cusps which is characteristic of Cricetus, etc.; ?by the lack of cheekpouches. The skull is very constricted in the interorbital region in Mystromys, the tail is short (about 52 per cent of head and body length or less, but more often less than half head and body length); the head and body is about I36-I $84 \mathrm{~mm}$. Resembles very closely the South American genus Phyllotis and its allies; for distinguishing characters see Ellerman (I94I).

Mystromys albicaudatus A. Smith, 1834 White-tailed Rat. Witstertrot

Distribution: confined to the Union; Johannesburg, Wakkerstroom, Potchefstroom in the southern Transvaal; Estcourt, Natal; Vredefort district and Aberfeldy (near Harrismith), Orange Free State; in the Cape Province, Grahamstown, Blythswood, Griqualand East, Hanover (Shortridge, I934), Peddie (eastern Province), and in the western coastal belt, Vredendal (near Van Rhynsdorp) and Tulbagh. 
Mystromys albicaudatus A. Smith, 1834

I834. Otomys albicaudatus A. Smith, S. Afr. J. 2: I48. Albany district, eastern Cape Province.

(1822. Arvicola albicaudatus Desmarest, Ency. Méth. Mamm: 281. No locality. ?Unidentifiable.)

I84I. Mystromys albipes Wagner, Gelehrte Anzeigen, I2: 435. South Africa.

(1842. Euryotis lanuginosa Lichtenstein, Verz. Samml. Kaffernlande, Io. "Kaffirland".)

(1905. Mystromys albicaudatus fumosus Thomas \& Schwann, P.Z.S. I: i37. Wakkerstroom, south-eastern Transvaal.)

\section{Subfamily G e $\mathrm{r}$ b i $11 \mathrm{i} \mathrm{n}$ a e}

I. Bullae very much enlarged (in London material averaging 39 per cent of the occipitonasal length, their length in adult specimens (not including the swollen mastoid portion) I 2.9-I $4.4 \mathrm{~mm}$.). Tail short, averages about 8I per cent at most of head and body, its length only rarely as much as $100 \mathrm{~mm} .^{1}$

Genus DESMODILLUS, page $3{ }^{1} 4$

Bullae less enlarged (in London material their length, not including the mastoid portion if swollen), does not reach $\mathrm{I} 2 \mathrm{~mm}$. and averages not more than 34 per cent of the occipitonasal length, usually less. Tail not specially shortened, longer than head and body in Gerbillus, and exceeds Ioo mm. in Tatera.

2. Soles of hindfeet (in South Africa) at least partly hairy. Small species, head and body length rarely reaches I IO $\mathrm{mm}$. Nasals, usually proportionately shorter, reach $13 \mathrm{~mm}$. only once in Roberts' measurements. Zygomatic plate less thrown forward.

Genus GERBILLUS, page 3I 5

Soles of hindfeet naked. Larger species, head and body in adult rarely under I $20 \mathrm{~mm}$. Nasals, usually proportionately longer, in adult not under $\mathrm{I} 3 \mathrm{~mm}$. Zygomatic plate thrown well forward. Genus TATERA, page 317

Genus DESMODILLUS Thomas \& Schwann, I904

I904. Desmodillus Thomas \& Schwann, Abstr. P.Z.S., No. 2: 6; P.Z.S. I: 177. Gerbillus auricularis A. Smith.

Desmodillus auricularis A. Smith, 1834

Cape Short-tailed Gerbil; Namaqualand Gerbil Kortstertnagmuis; Namakwalandse Nagmuis

Distribution: in the Union, the western Transvaal and the western Orange Free State (including near Bloemfontein); in the Cape Province, Vryburg, Kuruman, Upington, Louisvale; Little Namaqualand (Goodhouse, Port Nolloth, near Stein-

${ }^{1}$ Desmodillus was separated from the North African genus Pachyuromys Lataste, I880; it is less specialized than that genus, having less enlarged bullae and a considerably longer tail. 
kopf, O'okiep, the Kamiesberg), Klaver, Van Rhynsdorp, Lamberts Bay, Citrusdal, Oudtshoorn district (D. H. S. Davis), near Port Elizabeth (British Museum); Deelfontein, near Middelburg, Calvinia, Prieska, Bushmanland. South-West Africa; "widely distributed except in the north-east (the forest regions of Ovamboland, the Etosha Pan region, Grootfontein and the Caprivi") (Shortridge, I934). Ngamiland (Roberts).

Desmodillus auricularis A. Smith, I 834

I834. Gerbillus auricularis A. Smith, S. Afr. J. 2: i6o. Little Namaqualand.

I838. Gerbillus brevicaudatus F. Cuvier, Trans. Zool. Soc. London, 2: I44. Cape of Good Hope.

I842. Meriones caffer Wagner, Arch. Naturgesch. 8, I : I8. South Africa.

i 9 I0. Desmodillus auricularis pudicus Dollman, Ann. Mag. N.H. 6: 395. Lehutitung (or Lehututu), Kalahari, Bechuanaland.

\section{Genus GERBILLUS Desmarest, I 804}

I804. Gerbillus Desmarest, Nouv. Dict. H.N. 24, Tabl. Méth.: 22. Gerbillus aegyptius Desmarest $=$ Dipus gerbillus Olivier.

I88 I. Dipodillus Lataste, Le Naturaliste, Paris, I: 506. Gerbillus simoni Lataste, the Algerian race of Meriones dasyurus Wagner, from Sinai. Valid as a subgenus. i9ı. Microdillus Thomas, Ann. Mag. N.H. 5: 197. Gerbillus peeli de Winton, from Somaliland. Valid as a subgenus.

1942. Gerbillurus Shortridge, Ann. S. Afr. Mus. 36, I : 52. Gerbillus vallinus Thomas. Valid as a subgenus.

Gerbillus gerbillus Olivier, I80o, antedates Gerbillus paeba Smith, I834, and no characters of specific value have been found which will separate $G$. paeba and related forms from $G$. gerbillus and related forms, when all subspecies are compared.

Soles of hindfeet poorly haired. Bullae more enlarged, in London material average 34 per cent of the occipitonasal length, their length over io $\mathrm{mm}$. Tail $124 \mathrm{~mm}$. and more.

Gerbillus (Gerbillurus) vallinus, page 3 I 7

Soles of hindfeet well haired, but usually with a bare patch. Bullae less enlarged, on average less than 30 per cent of the occipitonasal length, their length in London material not reaching $9 \mathrm{~mm}$. In South Africa the tail very rarely reaches $\mathrm{I} 24 \mathrm{~mm}$. Gerbillus gerbillus, page 3 I 5

Subgenus GERBILLUS Desmarest, I804

Gerbillus gerbillus Olivier, I 800

Lesser Gerbil. Kleinnagmuis; Dwerg Springhaasmuis

Distribution: in the Union, Zoutpansberg (northern Transvaal); in the Cape Province, Molopo district, Vryburg, Kuruman, near Upington; Little Namaqualand (Goodhouse, Port Nolloth, near Steinkopf, the Kamiesberg), Klaver, Van 
Rhynsdorp, Nieuwoudtville, near Lamberts Bay, Citrusdal, Eendekuil; Oudtshoorn district (D. H. S. Davis), Alexandria (coastal eastern Cape Province); east of Calvinia, Middelburg, Deelfontein, Prieska, de Aar, Molteno (near Aliwal North), Colesberg. South-West Africa; apparently widely distributed north of the Tropic of Capricorn (approximately Gobabis district and Swakopmund northwards); the Kalahari and probably Gaberones district, Bechuanaland; Pico Azevedo in southwestern Angola. Further to the north, the Sudan, Kenya, Asben, northern Nigeria; Algeria to Egypt, Palestine.

Gerbillus gerbillus gerbillus Olivier, i8oo. (Extralimital) I8oo. Dipus gerbillus Olivier, Bull. Soc. Philom. Paris (Publ. "Messidor, An. VIII" = June-July, I800) 2: I 2 I. Giza Province, Egypt.

Gerbillus gerbillus Paeba A. Smith, 1836

I836. Gerbillus paeba A. Smith, Rept. Exped. Explor. C. Africa, 43. "Country beyond Latakoo," type locality nominated by Roberts (I95I) as Vryburg, northern Cape Province.

1842. Gerbillus tenuis A. Smith, Illustr. Zool. S. Africa, Mamm. pl. 36, fig. 2. North of "Latakoo".

Range includes the central Karroo.

Gerbillus gerbillus Galidus Thomas, i9 18

i9 18. Gerbillus calidus Thomas, Ann. Mag. N.H. 2: 63. Molopo, west of Morokwen, extreme northern Cape Province.

Gerbillus Gerbillus broomi Thomas, igi 8

1918. Gerbillus paeba broomi Thomas, Ann. Mag. N.H. 2: 64. Port Nolloth, coastal Little Namaqualand, north-western Cape Province.

Gerbillus gerbillus swalius Thomas \& Hinton, I925

1925. Gerbillus swalius Thomas \& Hinton, P.Z.S., 235. Karibib (north-westwards of Windhoek), South-West Africa. Ranges northwards to the Kaokoveld, eastwards to Gobabis, South-West Africa.

Gerbillus Gerbillus oralis Thomas \& Hinton, I925

1925. Gerbillus swalius oralis Thomas \& Hinton, P.Z.S., 236. Rooibank, inland from Walvis Bay, South-West Africa.

Gerbillus gerbillus leuaAnthus Thomas, 1927

1927. Gerbillus swalius leucanthus Thomas, P.Z.S., 382. Ondongwa, Ovamboland, South-West Africa.

Gerbillus Gerbillus coombsi Roberts, 1929

1929. Gerbillus paeba coombsi Roberts, Ann. Transv. Mus. 13: 98. Swarthoek, near Waterpoort, Zoutpansberg, northern Transvaal. 
Gerbillus Gerbillus Kalaharicus Roberts, I 932

1932. Gerbillus calidus kalaharicus Roberts, Ann. Transv. Mus. 15: io. Gomodimo Pan, central Kalahari, Bechuanaland. Range: the central Kalahari, also Okahandja district, South-West Africa.

Gerbillus Gerbillus exilis Shortridge \& Carter, $193^{8}$ 1938. Gerbillus paeba exilis Shortridge \& Carter, Ann. S. Afr. Mus. 32: 290. Paardevlei, Sundays River mouth, Alexandria district, eastern Cape Province.

Gerbillus Gerbillus mulleri Roberts, I946

1946. Gerbillus paeba mulleri Roberts, Ann. Transv. Mus. 20: 317. Eendekuil (north of Piquetberg), south-western Cape Province.

Gerbillus Gerbillus sWAKopensis Roberts, I95 I

I95I. Gerbillus paeba swakopensis Roberts, Mamm. S. Africa, 404. Swakopmund, coastal South-West Africa.

Subgenus GERBILLURUS Shortridge, I942

Gerbillus vallinus Thomas, I9I 8 Brushtailed Gerbil. Borselstertnagmuis

Distribution: near Kenhardt (north-western Cape Province), and Great Namaqualand, northwards to Swakopmund (South-West Africa).

Gerbillus vallinus Thomas, igi 8

I918. Gerbillus vallinus Thomas, Ann. Mag. N.H. 2: i48. Tuin, Kenhardt, Bushmanland, north-western Cape Province.

\section{Genus TATERA Lataste, 1882}

1882. Tatera Lataste, Le Naturaliste, Paris, 2: i 26. Dipus indicus Hardwicke, from India.

I 897. Gerbilliscus Thọmas, P.Z.S., 433. Gerbillus boehmi Noack. Valid as a subgenus. I 9 1 7. Taterona Wroughton, J. Bombay N.H. Soc. 25, I : 40. Gerbillus afra Gray.

See Davis, I949, The affinities of the South African Gerbils of the genus Tatera, P.Z.S. I I 8: 1002 .

I. Upper incisors faintly grooved (rarely plain), normally traces of two grooves. Skull in Southern Africa in British Museum material exceeds $40 \mathrm{~mm}$. Tail long with white tip, usually tufted.

Tatera (Gerbilliscus) boehmi, page 3 I 8

Upper incisors normally one-grooved (rarely plain in the forms valida, liodon and immediate allies). Tail not tufted. 
2. Average larger; fully adult skulls rarely below $40 \mathrm{~mm}$. in length (in British Museum material twice in thirteen specimens). Tatera valida, ${ }^{1}$ page 318 Average smaller; the majority of the skulls do not reach $40 \mathrm{~mm}$. (in British Museum material, sixteen exceptions in one hundred and fifty-five specimens). Tatera afra, ${ }^{1}$ page $3^{\text {I } 9}$

\section{Subgenus GERBILLISCUS Thomas, 1897}

Tatera boehmi Noack, 1887

Böhm's Gerbil

Distribution: has been recorded from southern central Angola by Monard, I 935 (Hill \& Carter). Serenje, Ndola, etc., in Northern Rhodesia. Northern Nyasaland. Also the Belgian Congo, Tanganyika and Kenya.

TAtera boehmi boehmi Noack, i 887

I 887. Gerbillus böhmi Noack, Zool. Jb. Syst. 2: 24I. Qua Mpala, Marungu, southern Belgian Congo. Has been recorded from Angola, northern Nyasaland, Northern Rhodesia.

\section{Subgenus TATERA Lataste, 1882}

Tatera valida Bocage, i 890

Bocage's Gerbil

Distribution: Angola (northwards to Dundo district, "distributed throughout northern Angola" (Hill \& Carter)), Northern Rhodesia, probably Nyasaland, if fraterculus is the same; Gorongoza district of Portuguese East Africa, into Southern Rhodesia. The Belgian Congo. Represented in Kenya and Uganda.

TAtera VAlida VAlida Bocage, i 890 ı89o. Gerbillus validus Bocage, J. Sci. Math. Phys. Nat., Lisboa, 2: 6. Type locality restricted by Hill \& Carter (I94I) to Rio Cuando, western Angola.

TATERA VALIDA LIODON Thomas, I902

I902. Tatera liodon Thomas, Ann. Mag. N.H. 9: 441. Lake Mweru, Congo border of Northern Rhodesia.

1907. Tatera neavei Wroughton, Manchester Mem. 5I, 5: i8. Ndola, near Congo border, Northern Rhodesia.

1 The African species differ from the Asiatic one in the less specialized colour of the tail (for details see Ellerman, I94I, 5I2).

Tatera afra is evidently the prior name for a member of this genus in Africa. There are some distinct races within the afra group in South Africa (brantsi, schinzi, etc.) but characters of a really specific nature seem to be absent. In Angola and Northern Rhodesia, however, the species seems to occur with another for which the prior name is evidently valida, and which averages larger. With reference to the above key, of the sixteen exceptions noted for afra, only one occurs in the region where the two species occur together. There is a distinct tendency for the incisors to lose the groove in valida and liodon; of thirteen skulls examined, four had plain incisors. The types (? and only known specimens) of fraterculus and neavei have plain incisors. The latter is currently regarded as a young specimen of liodon, and it may well be that fraterculus is also based on a young specimen of liodon, in which case, however, fraterculus takes priority. It has been found necessary provisionally to transfer the form inclusa to $\mathcal{T}$. valida, as this alone of the forms south of the Zambezi-Cunene seems constantly to have the skull exceeding $40 \mathrm{~mm}$. But it is not a well-known form. 
TAtera Valida inclusa Thomas \& Wroughton, igo8

igo8. Tatera inclusa Thomas \& Wroughton, P.Z.S., i69. Tambarara, Gorongoza district (south of the Zambezi), western Portuguese East Africa. Also recorded from Mt. Selinda, south-eastern Southern Rhodesia.

Incertae sedis:

TAtera Fratergulus Thomas, I 898

I898. Gerbillus (Gerbilliscus) fraterculus Thomas, P.Z.S., 392. Songwe, northern Nyasaland. (Possibly based on a young specimen of $T$. v. liodon, but antedates that name.)

Tatera afra Gray, 1830

Cape Greater Gerbil. Kaapse Nagmuis

Distribution: in the Union, the Transvaal; Christiana, Bloemhof, Rustenburg district, near Johannesburg, Pretoria, Nylstroom, Magaliesberg, Zoutpansberg district, Klein Letaba, Woodbush, Tzaneen, Wakkerstroom district, etc. Natal (including Dargle (near Howick) and Zululand). The Orange Free State, including Bothaville, Aberfeldy (near Harrismith), Vredefort, etc. Basutoland. In the Cape Province, the Molopo district, Kuruman, Goodhouse (northern Little Namaqualand), Louisvale (near Upington), Nieuwoudtville, Van Rhynsdorp, Lamberts Bay, the Cedarberg, Tulbagh, near Cape Town (Wynberg, etc.), Mossel Bay, Bredasdorp; Deelfontein, Molteno, Sterkstroom, Queenstown, Dordrecht, the Transkei. SouthWest Africa; widely distributed north of the Tropic of Capricorn (except the coastal Namib desert). Western and southern Angola. The Kalahari northwards to Ngamiland, Bechuanaland. Southern Rhodesia, where widely distributed; Portuguese East Africa, districts of Beira, Inhambane, Tete, also north of the Zambezi. Nyasaland, Northern Rhodesia. Thence apparently northwards to the southern Sudan and Senegal.

Of the earlier named races, generally the molars are wider (width of $\mathrm{M}_{\mathrm{I}}$ 2.3- $^{-}$ $2.8 \mathrm{~mm}$.) in the forms afra, brantsi, ruddi, perpallida and mashonae, and usually the molars are narrower (width M I $2.2 \mathrm{~mm}$. and less) in leucogaster (4 specimens including one from Peters' collection), schinzi (with "bechuanae"), miliaria, salsa, panja and beirensis. There is, however, considerable individual overlap between the two groups. The bullae average relatively larger in schinzi (and immediate allies), griquae, miliaria and angolae than in the other races represented in the B. M. The typical race afra (with its ally gilli) averages larger ears than the other races. In London material the most distinct form is ruddi from Zululand which has an unusually long tail (over $200 \mathrm{~mm}$.), but Mr. D. H. S. Davis informs us that he has further material from its type locality which shows that this character is not constant.

TATERA AFra AFra Gray, I830

I83o. Gerbillus afra Gray, Spic. Zool. ı. Cape of Good Hope.

(1832. Meriones schlegelii Smuts, Enum. Mamm. Cap., 41. Port Elizabeth, Cape Province, where the animal probably does not occur.) 
TATERA AFRA AFRA [contd.]

I 838. Gerbillus africanus F. Cuvier, Trans. Zool. Soc. London, 2: pl. 26. Renaming of afra.

Large-eared and broad-toothed race.

Range: the south-western Cape Province, approximately Bredasdorp to Tulbagh.

TAtera AFra BRANTsi A. Smith, ${ }_{1} 836$

I836. Gerbillus brantsii A. Smith, Rept. Exped. Expl. C. Africa, 43. "Tops of hills towards sources of Caledon River" (in Basutoland, fide Roberts).

842. Meriones montanus A. Smith, Illustr. Zool. S. Africa, Mamm. pl. 36, fig. I. "Summits of hills in the country to the north of the Orange River towards its sources."

Much like afra but normally with smaller ears.

Range includes the Orange Free State and the eastern Karroo, Cape Province.

TAtera AFra macGalinus Sundevall, i 846

I846. Meriones (Rhombomys) maccalinus Sundevall, Öfvers. Vetensk. Akad. Förh. Stockholm, 3: I 20. Magaliesberg, western Transvaal.

igo6. Tatera draco Wroughton, Ann. Mag. N.H. I7: 479. Wakkerstroom, southeastern Transvaal.

Probable synonym of brantsi.

Ranges into northern Orange Free State, Drakensberg, Griqualand East.

TAtera Afra Leucogaster Peters, i 852

I852. Meriones leucogaster Peters, Ber. Preuss. Akad. Wiss. 274; Reise nach Mossambique, Säugeth. I 45. Mesuril and Boror, north of the Zambezi, Portuguese East Africa. Specimens from Lumbo, northern Portuguese East Africa, in British Museum.

Apparently a narrow-toothed race.

TATERA AFRA SGHINZI Noack, i 889

I889. Gerbillus tenuis var. schinzi Noack, Zool. Jb. 4: I34. Kalahari Desert.

Igo6. Tatera lobengulae bechuanae Wroughton, Ann. Mag. N.H. I7: 482. Molopo, border of northern Cape Province and Bechuanaland.

Near leucogaster but with larger bullae on average.

Range: approximately Upington and Molopo to Ngamiland, Gobabis district,

Etosha Pan, Kaokoveld, Ovamboland, Cunene districts, South-West Africa.

TAtera AFra lobengulai de Winton, i 898

I898. Gerbillus (Tatera) lobengulae de Winton, Ann. Mag. N.H. 2: 4. Essex Vale, Matabeleland, western Southern Rhodesia.

Probably near brantsi; the type specimen is broad-toothed.

TATERA AFRA RUDDI Wroughton, Igo6

I 9o6. Tatera ruddi Wroughton, Ann. Mag. N.H. I7: 478. Umfolosi, Zululand, Natal.

Broad-toothed and very long-tailed form. 
TATERA AFRA GRIQUAE Wroughton, Igo6

i 906. Tatera lobengulae griquae Wroughton, Ann. Mag. N.H. I7: 483. Kuruman, northern Cape Province.

1906. Tatera miliaria stellae Wroughton, Ann. Mag. N.H. I7: 485. Kuruman, northern Cape Province.

Probable synonym of schinzi.

TAtera AFra mashonae Wroughton, igo6

Igo6. Tatera lobengulae mashonae Wroughton, Ann. Mag. N.H. I7: 483. Mazoe, Mashonaland, eastern Southern Rhodesia. Has been recorded from Northern Rhodesia.

Evidently nearest brantsi (from British Museum material).

TATERA AFra miliaria Wroughton, igo6

I 906. Tatera miliaria Wroughton, Ann. Mag. N.H. I7: 484. Deelfontein, north of Richmond, central Cape Province.

Near schinzi; with the relatively large bullae of that form.

TATERA AFra SAlsa Wroughton, igo6

I906. Tatera miliaria salsa Wroughton, Ann. Mag. N.H. I7: 485. Klein Letaba, eastern Transvaal. Range includes Woodbush, etc., low country east of the Drakensberg, from the Letaba River to the Grocodile River (Roberts).

Probably nearest leucogaster, but with rather longer tail.

TATERA AFra PANJA Wroughton, Igo6

I906. Tatera panja Wroughton, Ann. Mag. N.H. I7: 486. Chicosta, south bank of Zambezi, 6o miles above Tete, Portuguese East Africa.

I852. Meriones tenuis Peters, Reise nach Mossambique, Säugeth. I49. Tete, Portuguese East Africa. Not of A. Smith, 1842.

Near the last race, but differing in colour.

TAtera AFra ANgolae Wroughton, igo6

I 906. Tatera angolae Wroughton, Ann. Mag. N.H. I7: 488. Fort Quilenges, southwestern Angola.

1933. Gerbillus nigrotibialis Monard, Bull. Soc. Sci. Nat. Neuchâtel, 57: 54. Vila da Ponte, vicinity of Cubango, southern Angola.

Evidently related to schinzi.

TAtera Afra nyasae Wroughton, igo6

I 906. Tatera nyasae Wroughton, Ann. Mag. N.H. I7: 490. Mwanembe, northern Nyasaland (10 $5^{\prime}$ S., $33^{\circ} 4^{\prime}$ E.) see Davis (1949: 1007, 1008).

Placed by Davis in his schinzi division.

TAtera AFra shiRensis Wroughton, igo6

I906. Tatera nyasae shirensis Wroughton, Ann. Mag. N.H. I7: 490. "Mt. Malosa, Upper Shiré" southern Nyasaland, but Davis (I 949) thinks Mt. Malosa is an error for Mt. Mlanje. 
TAtera Afra perpallida Dollman, igio

i9 10. Tatera brantsi perpallida Dollman, Ann. Mag. N.H. 6: 394. Eastern bank of the Tamalakan River, Ngamiland, northern Bechuanaland.

(1926. Tatera joanae Thomas, P.Z.S., 299. Ukuambi, Ovamboland, northern SouthWest Africa. Specimens also in B.M. from Sandfontein, South-West Africa.)

In British Museum material the molars average a little wider than those of schinzi; bullae enlarged in a similar manner.

TAtera AFRA NDOLAe Kershaw, I922

1922. Taterona lobengulae ndolae Kershaw, Ann. Mag. N.H. Io: 105. Ndola, near the Congo border, $12^{\circ} 50^{\prime}$ S., $28^{\circ} 40^{\prime}$ E., Northern Rhodesia.

Except for beirensis and perhaps tzaneenensis the remaining forms, mainly of Roberts, are not represented in London. Davis and also Roberts distributed most of these forms between brantsi and schinzi (but it must be borne in mind that the western schinzi forms usually have larger bullae than the eastern forms, which may more resemble leucogaster).

TATERA AFRA BREYeri Roberts, I 926

1926. Tatera breyeri Roberts, Ann. Transv. Mus. II: 250. Nylstroom, about 70 miles north of Pretoria, Transvaal.

Davis places this form in his brantsi division.

TATERA AFra GiLli Roberts, I929

1929. Tatera afra gilli Roberts, Ann. Transv. Mus. I3: ioo. Lamberts Bay, coast of western Cape Province. Ranges northwards to Klaver. Nearest the typical race.

TAtera AFra natalensis Roberts, 1929

1929. Tatera natalensis Roberts, Ann. Transv. Mus. 13: го . Kilgobbin, Dargle district, central Natal.

Davis places this form in his brantsi division.

TATERA AFRA PESTis Roberts, I929

1929. Tatera lobengulae pestis Roberts, Ann. Transv. Mus. 13: 103. Bothaville, northern Orange Free State. Ranges to Bloemhof and Christiana districts, western Transvaal.

Davis places this form in his schinzi division.

TATERA AFRA Mitchelli Roberts, I929

1929. Tatera lobengulae mitchelli Roberts, Ann. Transv. Mus. 13: 103. Wonderfontein, west of Johannesburg, Transvaal. Range: highveld from Johannesburg westwards to Zeerust district, Transvaal.

Davis places this form in his schinzi division. 
TATERA AFra PRETORIAE Roberts, I929

1929. Tatera lobengulae pretoriae Roberts, Ann. Transv. Mus. I3: 104. Pretoria North, Pretoria district, Transvaal. Ranges westwards to the southern part of the

Rustenburg district.

Davis places this form in his schinzi division.

TATERA AFRA Limpopoensis Roberts, I 929

1929. Tatera lobengulae limpopoensis Roberts, Ann. Transv. Mus. I3: io4. Njellele River, Zoutpansberg district, northern Transvaal. Range includes northern Rustenburg and Marico districts, also lower ground in Waterberg and Zoutpansberg districts.

Davis places this form in his schinzi division.

TATERA AFRA TZAneenensis Roberts, I 929

I929. Tatera lobengulae tzaneenensis Roberts, Ann. Transv. Mus. 13: I05. Tzaneen Estates, foothills of the Drakensberg, north-eastern Transvaal.

Davis places this form in his schinzi division.

TATERA AFRA LITTORALIS Roberts, I 929

1929. Tatera lobengulae littoralis Roberts, Ann. Transv. Mus. I3: 105. Masiene, near mouth of Limpopo River, southern Portuguese East Africa.

Davis places this form in his schinzi division.

TATERA AFRA BeIREnsis Roberts, I929

I929. Tatera lobengulae beirensis Roberts, Ann. Transv. Mus. I3: io6. Six and a half miles from Beira, coast of Portuguese East Africa.

I95I. Tatera schinzi beirae Roberts, Mamm. S. Africa, 6i6 (error).

Near salsa and panja, but rather larger on average or at extreme development.

TATERA AFRA TONGENSIS Roberts, I93 I

I93 I. Tatera ruddi tongensis Roberts, Ann. Transv. Mus. I4: 230. Maputa, northern Zululand, Natal.

1936. Tatera maputa Roberts, Ann. Transv. Mus. I8: 238. Maputa, northern Zululand, Natal.

Davis placed this form in his brantsi division.

TATera AFRA zULUensis Roberts, I93 I

I93I. Tatera lobengulae zuluensis Roberts, Ann. Transv. Mus. I4: 230. Manaba, 30 miles from Kosi Bay, northern Zululand, Natal.

Davis placed this form in his schinzi division.

TAtera AFRa humpatensis Hill \& Carter, I937

1937. Taterona humpatensis Hill \& Carter, Amer. Mus. Novit. No. 913: 5. Humpata, 6,30o ft., south-western Angola.

Davis placed this form in his brantsi division. 
TAtera Afra namaquensis Shortridge \& Carter, 1938

1938. Taterona brantsi namaquensis Shortridge \& Carter, Ann. S. Afr. Mus. 32: 287. (July, 1938.) Goodhouse (Raman's Drift), south bank of Orange River, Little Namaqualand, north-western Cape Province.

TATERA AFra WATERbergensis Roberts, I938

1938. Tatera schinzi waterbergensis Roberts, Ann. Transv. Mus. 19: 239 (3 Ist October), and $1946,20: 318$ (described as a new subspecies in both places). Waterberg, Otjiwarongo district $\left(20^{\circ} 30^{\prime}\right.$ S., $17^{\circ}$ E. $)$, central South-West Africa.

\section{MAR I N E O D E R S}

The Cetacea and Sirenia of Africa have been listed in great detail by G. Allen (1939). For the sake of completeness we include here a nominal list of forms which have been recorded from the region now under discussion. For further synonymy G. Allen should be consulted.

\section{ORDER S I R E N I A}

\section{FAMILY T R I C H E C H I D A E}

Genus TRICHEGHUS Linnaeus, $175^{8}$

I 758. Trichechus Linnaeus, Syst. Nat. ed. I0, I: 34. Trichechus manatus Linnaeus, from the West Indies.

Trichechus senegalensis Link, I 795

African Manatee

I 795. Trichechus senegalensis Link, Beytr. Naturgesch, I, 2: Iog. Senegal.

Distribution: western coast of Africa from Senegal to the Qwanza River, Angola, following up the larger rivers where possible (G. Allen).

\section{FAMILY D U G O N G I D A E}

Genus DUGONG Lacépède, I 799

I799. Dugong Lacépède, Tabl. Mamm. I7. Dugong indicus Lacépède = Trichechus dugon Müller.

Dugong dugon Müller, I 776

Dugong

I 776. Trichecus (sic) dugon Müller, Linné's Vollständ. Natursyst. Suppl., 2 I. Cape of Good Hope to the Philippines.

Distribution: Portuguese East Africa to Lourenço Marques. East Africa, Madagascar, the Red Sea, Indian seas, Malaysian seas, Formosa, the Philippine Islands, northern Australia, etc., where not exterminated. 


\section{ORDER GE T A G E A}

SUB-ORDER MYSTICETI

\section{FAMILY B A L A E N O P T E R I D A E}

Genus BALAENOPTERA Lacépède, I804

I804. Balaenoptera Lacépède, H.N. des Cétacés, xxxvi and I I4. Balaena rostrata Fabricius = Balaenoptera acutorostrata Lacépède.

I 849. Pterobalaena Eschricht, K. Dansk Vidensk. Selsk. Skr. I: i 88. Balaena physalus Linnaeus.

I864. Sibbaldus Gray, P.Z.S. 222. Sibbaldus borealis (Gray not Lesson) = Balaena musculus Linnaeus.

1866. Rudolphius Gray, Gat. Seals, Whales B.M., ed. 2, I 7o. Sibbaldius laticeps Gray = Balaenoptera borealis Lesson.

Balaenoptera acutorostrata Lacépède, I804

Little Piked Whale;. Lesser Rorqual I804. Balaenoptera acuto-rostrata Lacépède, H.N. des Cétacés, xxxvii and I34. Cherbourg, France.

Distribution: Cosmopolitan. Has been stranded near Cape Town (K. H. Barnard, in litt).

Balaenoptera borealis Lesson, I 828

Sei Whale I828. Balaenoptera borealis Lesson, H. N. Mamm. et Ois. depuis i 788, Cétacés, 342. Grömitz, Lübeck Bay, Schleswig-Holstein, Germany.

Distribution: Cosmopolitan; recorded from Cape and Natal seas.

Balaenoptera brydei Olsen, I 9 I 2

Cape Rorqual I912. Balaenoptera brydei Olsen, Tidens Tegn, I2 November, I9I2 (Norwegian newspaper) (N.V.); I9I3, P.Z.S. I074. Saldanha Bay, western Cape Province.

Distribution: South African seas, including Natal and Angola, and reported from the West Indies (Fraser in Norman \& Fraser, I937).

Balaenoptera physalus Linnaeus, I 758

Common Rorqual. Finback

I758. Balaena physalus Linnaeus, Syst. Nat. ioth ed. I: 75. European seas (Spitzbergen according to Thomas, I9II).

Distribution: Cosmopolitan; recorded from South African seas, Natal included. 
Balaenoptera musculus Linnaeus, I $75^{8}$

Great Blue Whale

I 758. Balaena musculus Linnaeus, Syst. Nat. ioth ed. 1 : 76. Firth of Forth, Scotland.

Distribution: Cosmopolitan; recorded from Durban, Natal, etc.

\section{Genus MEGAPTERA Gray, I846}

1846. Megaptera Gray, Zool. Voy. Erebus \& Terror, I: Mamm. I6. Balaena nodosa Bonnaterre = Balaena novaeangliae Borowski.

Megaptera novaeangliae Borowski, I78I

Humpback Whale I 78 I. Balaena novae angliae Borowski, Gemeinn. Naturgesch. des Thierreichs, Berlin, 2, I : 2 I. New England coast.

I 788. Balaenoptera australis Lesson, H.N. Mamm. et Ois. depuis I 788, I, Cétacés, 372.

Cape of Good Hope.

I829. Balaena lalandii Fischer, Synops. Mamm. 525. Cape of Good Hope.

I834. Balaenoptera capensis A. Smith, S. Afr. J. 2: 242. Cape of Good Hope.

Distribution: Cosmopolitan, South African seas included.

\section{FAMILY B A L A E N I D A E}

Genus EUBALAENA Gray, 1864

I864. Eubalaena Gray, P.Z.S. 201. Balaena australis Desmoulins.

Eubalaena australis Desmoulins, I $822 .^{1}$

Southern Right Whale I822. Balaena australis Desmoulins, Dict. Class. H.N. 2: I6 I. Algoa Bay, eastern Cape Province.

I84I. Balaena mysticetus antarctica Schlegel, Abh. aus dem Gebiete Zool. I: 37. Cape of Good Hope.

I864. Hunterus temminckii Gray, Ann. Mag. N.H. I4: 349. Cape of Good Hope. I866. Hunterius temminckii Gray, Cat. Seals, etc., B.M., ed. 2 : 98.

Distribution: formerly the southern hemisphere, but now apparently approaching extinction.

\section{Genus CAPEREA Gray, I 864}

I864. Caperea Gray, P.Z.S. 202. Balaena antipodarum Gray = Balaena marginata Gray. I870. Neobalaena Gray, Ann. Mag. N.H. 6: i 54. Balaena marginata Gray.

${ }^{1}$ It is customary to list three species of the genus Eubalaena, two of which are from the northern hemisphere, but the differences between them are very obscure. The first to be named was $E$. glacialis Borowski, I 781, from the North Sea. 
Caperea marginata Gray, 1846

Pygmy Right Whale i846. Balaena marginata Gray, Zool. Voy. Erebus and Terror, 48, pl. I, fig. I. Western Australia.

Distribution: Australia, New Zealand, South America and South Africa; occasionally taken off the coast of Cape Province (there is a specimen from Simonstown, False Bay, in the South African Museum, Cape Town).

SUB-ORDER ODONTOCETI

FAMILY P H Y S E T E R I D A E

Subfamily $\mathrm{K}$ o g i i $\mathrm{n}$ a $\mathrm{e}$

Genus KOGIA Gray, I 846

I846. Kogia Gray, Zool. Voy. Erebus and Terror, I, Mamm.: 22. Physeter breviceps Blainville.

Kogia breviceps Blainville, 1838

Pygmy Sperm Whale

1838. Physeter breviceps Blainville, Ann. franç. étr. Anat. Phys. 2: 337. Cape of Good Hope.

Distribution: South African seas, and has been recorded from all continents, but apparently nowhere very common and not in Arctic latitudes.

\section{Subfamily $\mathrm{P} h$ y $\mathrm{s}$ e $\mathrm{t}$ e $\mathrm{r}$ i $\mathrm{n}$ a $\mathrm{e}$ \\ Genus PHYSETER Linnaeus, I 758}

I 758. Physeter Linnaeus, Syst. Nat. I oth ed. I: 76. Physeter catodon Linnaeus.

Physeter catodon Linnaeus, $175^{8}$

Sperm Whale

I 758. Physeter catodon Linnaeus, Shyst. Nat. rot ed. 1 : 76. Kairston, Orkney Islands (Thomas, I9I I, P.Z.S. I57).

Distribution: Cosmopolitan, but more common in tropical and subtropical seas. Has been recorded from Natal and Cape Province.

\section{FAMILY Z I P H I I D A E}

Genus ZIPHIUS G. Cuvier, I 823

I823. Ziphius G. Guvier, Rech. Oss. Foss. 5, I : 350. Ziphius cavirostris G. Cuvier.

Ziphius cavirostris G. Cuvier, I 823

Guvier's Beaked Whale I823. Ziphius cavirostris G. Cuvier, Rech. Oss. Foss. 5, i : 352. Near Fos, Bouches-duRhône, France. 
ZipHIUS GAVIROSTRIs [contd.]

I864. Ziphius indicus Van Beneden, Mém. Couronnés et Autres Mém. Acad. Roy.

Sci. Lettres et Beaux-Arts Belgiques, Bruxelles, I6: art. I ; 23. Cape of Good

Hope, probably on Indian Ocean side.

I 865. Hyperoodon capensis Gray, P.Z.S. 359. Cape of Good Hope.

Distribution: Cape Seas; virtually cosmopolitan, has been recorded from all continents.

\section{Genus MESOPLODON Gervais, I 850}

I 850. Mesoplodon Gervais, Ann. Sci. Nat. Zool. I 4: I6. Delphinus sowerbiensis Blainville $=$ Physeter bidens Sowerby, from Scotland.

I850. Dioplodon Gervais, G.R. Acad. Sci. Paris, 31: 512. Delphinus densirostris Blainville. Valid as a subgenus.

One South African species belongs to the typical subgenus, and two to the subgenus Dioplodon which is characterized by its much enlarged lower tooth. Good figures of most of the better-known species are published in Fraser, 1937, Giant Fishes, Whales and Dolphins, 279.

\section{Subgenus MESOPLODON Gervais, 1850}

Mesoplodon grayi Von Haast, ${ }_{1} 876$

Gray's Beaked Whale I 876. Mesoplodon grayi von Haast, P.Z.S. 9. Waitingi beach, Chatham Islands, east of New Zealand.

Distribution: recorded from Holland, New Zealand, Australia, Patagonia; a specimen recorded in Table Bay, Cape Province, I9 2

Subgenus DIOPLODON Gervais, 1850

Mesoplodon densirostris Blainville, $\mathrm{I} 8 \mathrm{I} 7$

Blainville's Beaked Whale I 8 i 7. Delphinus densirostris Blainville, Nouv. Dict. H.N. 9: i 78. Locality unknown.

Distribution: recorded from Algoa Bay, Cape Province, also Madeira, Japan, eastern United States, northwards to Canada, Seychelles (off East Africa), Lord Howe Island (east of Australia).

Mesoplodon layardi Gray, ${ }^{8} 86_{5}$

Strap-toothed Whale I 865. Ziphius layardii Gray, P.Z.S. 358. Cape of Good Hope.

Distribution: New Zealand, Australia, South Africa, the Falkland Islands (Fraser).

\section{FAMILY D E L P H I N I D A E}

Genus DELPHINUS Linnaeus, I $75^{8}$

I 758. Delphinus Linnaeus, Syst. Nat. Ioth ed. I: 77. Delphinus delphis Linnaeus. 
Delphinus capensis Gray, 1828 Cape Dolphin I828. Delphinus capensis Gray, Spic. Zool., 2. Cape of Good Hope.

Distribution: Cape Seas; Japan (Kuroda, I938). ?Palestine.

Delphinus delphis Linnaeus, $175^{8}$

Common Dolphin

I758. Delphinus delphis Linnaeus, Syst. Nat. Ioth ed. I: 77. European seas.

Distribution: temperate and warm seas throughout the world. Has been recorded from Table Bay (see Roberts, I95I: 228).

\section{Genus STENELLA Gray, i 866}

I866. Stenella Gray, P.Z.S. 2 I3. Steno attenuatus Gray.

1877. Prodelphinus Van Beneden \& Gervais, Ost. des Cétacés, 6o4. Type not specified.

This genus is much in need of revision. Three species are listed by Roberts from South Africa.

Stenella longirostris Gray, 1828 Longbeaked Dolphin I828. Delphinus longirostris Gray, Spic. Zool. I. Locality unknown.

Distribution: the type skull is said to have been from the Cape of Good Hope (Roberts); has been recorded from Japan by Kuroda, and according to Roberts from Australia and near the Galapagos Islands.

Stenella styx Gray, 1846

Euphrosyne Dolphin

i846. Delphinus styx Gray, Zool. Voy. Erebus \& Terror, I, Mamm.: 39, pl. 2 I. Western coast of Africa.

I846. Delphinus euphrosyne Gray, loc. cit., 40, pl. 22. Locality unknown.

I868. Clymene similis Gray, P.Z.S. I46. Cape of Good Hope.

Distribution: has been recorded from South Africa; the Atlantic northwards to Greenland.

Stenella attenuata Gray, I $846 .^{1}$

Narrow-snouted Dolphin I846. Steno attenuatus Gray, Zool. Voy. Erebus and Terror, I: Mamm., 44. No locality.

I865. Steno capensis Gray, P.Z.S. 522. Cape of Good Hope.

Distribution: includes Cape of Good Hope.

Genus SOTALIA Gray, I 866

1866. Sotalia Gray, Cat. Seals and Whales, B.M., 393, 40 r. Sotalia guianensis Van Beneden, from British Guiana.

${ }^{1}$ Possible synonym of Stenella malayana Lesson, I 826 (from between Java and Borneo). 
Sotalia lentiginosa Owen, I 866

Speckled Dolphin 1866. Delphinus (Steno?) lentiginosus Owen, Trans. Zool. Soc. London, 6, I: 20. Waltair, Vizagapatam, Madras, India.

Distribution: India, Ceylon, and False Bay, western Cape Province.

\section{Genus STENO Gray, 1846}

I846. Steno Gray, Zool. Voy. Erebus \& Terror, I, Mamm.: 43. Delphinus rostratus Desmarest $=$ Delphinus bredanen sis Lesson.

1936. Stenopontistes Miranda-Ribeiro, Bol. Mus. Nac. Rio de Janeiro, 12, I : 19, $4^{2}$. Stenopontistes zambezicus Miranda-Ribeiro $=$ Delphinus bredanensis, Lesson.

Steno bredanensis Lesson, 1828

Rough-toothed Dolphin I8I 7. Delphinus rostratus Desmarest, Nouv. Dict. H.N. 9: i6o. Near Paimpol, France. Not of Shaw, i8or.

I828. Delphinus bredanensis Lesson, H.N. Mamm. et Ois. depuis I788, Cétacés, 206. European seas.

1936. Stenopontistes zambezicus Miranda-Ribeiro, Bol. Mus. Nac. Rio de Janeiro, I2: 20. Zambezi River, coast, southern East Africa.

Distribution: France, Portugal, Holland, Japan (Kuroda), Aden district, Bay of Bengal, Java, the Zambezi coast, Florida.

This species is better known under the specific name rostratus, which is preoccupied.

\section{Genus TURSIOPS Gervais, I 855}

I855. Tursiops Gervais, H.N. des Mamm. 2: 323. Delphinus truncatus Montagu, from England.

Tursiops aduncus Ehrenberg, I 833

Red Sea Bottlenosed Dolphin

For synonymy of this species (after F. C. Fraser) see Ellerman \& Morrison-Scott, I95 I, 736 .

1833. Delphinus aduncus Ehrenberg in Hemprich \& Ehrenberg, Symb. Phys. Mamm. 2: sig. k. (footnote). Belhosse Island, Red Sea.

I862. Delphinus catalania Gray, P.Z.S. I43. Northern coast of Australia.

Distribution: Australian and South African seas (recorded from Natal, more recently from Noordhoek, near Cape Town (K. H. Barnard, in litt) ). Sumatra, Java, the Indian Ocean and the Red Sea.

\section{Genus LAGENORHYNGHUS Gray, 1846}

1846. Lagenorhynchus Gray, Ann. Mag. N.H. I7: 84. Lagenorhynchus albirostris Gray, from England. 
Lagenorhynchus obscurus Gray, $1828 .^{1}$

Gray's Dolphin. (Porpoise in South Africa)

I828. Delphinus (Grampus) obscurus Gray, Spic. Zool., 2. Cape of Good Hope.

1829. Phocaena homeii A. Smith, Zool. J. 4: 440. Table Bay, and seas about Cape of Good Hope.

Distribution: Cape seas, where it appears to be one of the commoner species; New Zealand; Falkland Islands. (Blanford recorded a specimen from Ceylon).

\section{Genus GEPHALORHYNGHUS Gray, I 846}

I846. Cephalorhynchus Gray, Zool. Voy. Erebus \& Terror, I, Mamm.: 36. Delphinus heavisidii Gray.

Cephalorhynchus heavisidei Gray, 1828

Tonine

1828. Delphinus (Grampus) heavisidii Gray, Spic. Zool., 2. Cape of Good Hope.

I829. Phocaena capensis F. Cuvier, H.N. Mamm. livraison 58 and pl.

I836. Delphinus cephalorhynchus F. Cuvier, H.N. des Cétacés, I 58. Cape of Good Hope. I 836. Delphinus hastatus F. Cuvier, loc. cit. i6 . . Cape of Good Hope.

I873. Delphinus tridens Van Beneden, ex Sunk MS., Bull. Acad. Roy. Sci. Lettres et Beaux-arts, Belgique, Bruxelles (2) 36: 33. Cape Town.

1873. Orca capensis Van Beneden, loc. cit.: 37. Cape Town. Not of Gray, I846.

Distribution: Cape seas, and according to Roberts, has been recorded from New Zealand.

Genus PSEUDORCA Reinhardt, I 862

1862. Pseudorca Reinhardt, Overs. Danske Vidensk. Selsk. Forh. I5I. Phocaena crassidens Owen.

Pseudorca crassidens Owen, I846

False Killer

I846. Phocaena crassidens Owen, British Fossil Mamm. and Birds, 516. Lincolnshire Fens, near Stamford, England (subfossil).

Distribution: Cosmopolitan. Includes Cape seas where it is periodically stranded in large numbers (as happens in many other parts of the world).

\section{Genus ORGINUS Fitzinger, I 86o}

I 86o. Orcinus Fitzinger, Wiss. Naturg. Säugeth. 6: 204. Delphinus orca Linnaeus.

On nomenclature of this genus see Ellerman \& Morrison-Scott, I95 I, 739.

Orcinus orca Linnaeus, $\mathrm{I} 75^{8}$

Killer Whale

I 758. Delphinus orca Linnaeus, Syst. Nat. Ioth ed. 1 : 77. European seas.

${ }^{1}$ Possible synonym of Lagenorhynchus cruciger; 1824 . Delphinus cruciger Quoy \& Gaimard, Zool. Voy. Uranie: 87, pl. I I, figs. 3-4, between Cape Horn and Australia. See Bierman \& Slijper, I947, Verh. Ned. Akad. Wet. 50, I0: I 353 . 
ORCINUS ORCA [contd.]

I 846. Orca capensis Gray, Zool. Voy. Erebus \& Terror, I: Mamm. 34. Cape of Good Hope.

I86o. Delphinus victorini Grill, K. Svenska Vetensk. Akad. Handl. 2, Io: 21. In $33^{\circ}, 26^{\prime} \mathrm{S} ., 6^{\circ} 33^{\prime} \mathrm{E}$. (which is about 700 miles west of Cape Town).

ı 87 . Orca africana Gray, Cat. Suppl. Seals and Whales, B.M., 9i. Algoa Bay, eastern Cape Province.

I 877. Orca australis Van Beneden \& Gervais, Ostéogr. Cétacés, 540, pl. 47, fig. 2. Algoa Bay, eastern Cape Province.

Distribution: Cosmopolitan. Reported from various places in South African seas.

\section{Genus GRAMPUS Gray, 1828}

I 828. Grampus Gray, Spic. Zool., 2. Delphinus griseus G. Cuvier.

1933. Grampidelphis Iredale \& Troughton, Records Austral. Mus. I9: 31. Grampidelphis exilis Iredale \& Troughton, from Australia.

On nomenclature of this genus see Ellerman \& Morrison-Scott, I95 I, 739.

Grampus griseus G. Cuvier, I81 2

Risso's Dolphin

I 8 1 2. Delphinus griseus G. Cuvier, Ann. Mus. H.N. Paris, I9: i4. Brest, France.

I850. Grampus richardsoni Gray, Cat. Spec. Mamm. B.M. Cetacea, 85. Cape seas.

Distribution: has been recorded from the Cape seas. Europe, northwards about to the British Isles, Atlantic and Pacific United States, Australia, New Zealand, China, Japan, the Red Sea, etc.

\section{Genus GLOBICEPHALA Lesson, 1828}

I828. Globicephala Lesson, H.N. Mamm. et Ois. depuis I 788, Cétacés, 441. Delphinus deductor Scoresby $=$ Delphinus melas Traill, from the Orkney Islands.

Dr. F. C. Fraser writes: "Smith distinguished two kinds of Globicephala at the Cape, the one which he called Phocaena globiceps is certainly $G$. macrorhyncha, the other he called Phocaena edwardii. Phocaena edwardii is described as having a white breast and belly. There is no evidence of the range of distribution of Globicephala melaena extending southwards beyond northern temperate waters. There is a good deal of evidence that it is replaced in warmer waters by G. macrorhyncha. Abundant evidence exists of a Globicephala species in southern colder water which is characterized by having a white breast and belly, a whitish flash on the side of the head and a grey saddle mark near the dorsal fin. Rayner distinguished this southern species as G. leucosagmaphora. His specimen was obtained near the Cape, about 40 miles S.S.W. The rapidity with which details of colour markings are obscured in dead dolphins is well known. The appearance of a dead Delphinus delphis, for instance, is strikingly different from that of the living animal. I suggest that this is sufficient explanation of the absence of mention of the light head flash and saddle-mark in Smith's description of Phocaena edwardii. If my suggestion is accepted then Globicephala edwardii must have priority and G. leucosagmaphora be included in the synonymy." 
Globicephala macrorhyncha Gray, I846 Indian Pilot Whale or Blackfish I846. Globicephalus macrorhynchus Gray, Zool. Erebus \& Terror, I, Mamm.: 33. "South Seas."

Recorded by A. Smith, I834, S. Afr. J. 2: 238 from the seas on the South-East coast of Africa as Phocaena globiceps Cuvier (1812, from France; a synonym of Globicephala melaena Traill, I8og, the Northern Blackfish).

Distribution: India, Cape of Good Hope, West Africa, Straits of Malacca, Sumatra, Java, etc.

Globicephala edwardi A. Smith, I $834 \quad$ Southern Pilot Whale or Blackfish 1834. Phocaena edwardii A. Smith, S. Afr. J. 2: 239. "Cast on the shore near Slangkop" (which is south of Cape Town, western Cape Province).

(1939. Globicephala leucosagmaphora Rayner, Ann. Mag. N.H. 4: 543. 40 miles S.S.W. of the Cape of Good Hope).

Distribution: South African seas.

\section{Genus LISSODELPHIS Gloger, I 84I}

I84I. Lissodelphis Gloger, Gemeinn. Naturgesch. I: I69. Delphinus peronii Lacépède.

Lissodelphis peroni Lacépède, I 804

Southern Right Whale Dolphin I 804. Delphinus peronii Lacépède, H.N. des Cétacés, xliii and 3 I6. Off the southern tip of Tasmania.

Distribution: recorded by Hamilton in the R.R.S. William Scoresby, I 927 (unpublished Discovery report) from $38^{\circ} 34^{\prime}$ S., $8^{\circ}$ o6 $6^{\prime}$ E. Also recorded from Tasmania, New Zealand. 


\section{NEW NAMES PROPOSED IN THIS WORK.}

Felis serval robertsi for Leptailurus (= Felis) capensis limpopoensis Roberts, I926, not of Roberts, I926.

Rattus paedulcus robertsi for Thallomys (= Rattus) leuconoe bradfieldi Roberts, I933, not of Roberts, 1926.

Rattus angolensis legerae for Myomys shortridgei St. Leger, 1933, not of Thomas \& Hinton, I923. 


\section{B I B L I O G R A P H Y}

Allen, G. M. I939. A checklist of African mammals, Bull. Mus. Comp. Zool. Harv. 83. Allen, J. A. I922. The American Museum Congo Expedition collection of Insectivora. Bull. Amer. Mus. Nat. Hist. 47: I.

I922. Sciuridae, Anomaluridae and Idiuridae collected by the American Museum Congo Expedition. Bull. Amer. Mus. Nat. Hist. 47: 39.

1924. Carnivora collected by the American Museum Congo Expedition. Bull. Amer. Mus. Nat. Hist. 47: 73 .

I925. Primates collected by the American Museum Congo Expedition. Bull. Amer. Mus. Nat. Hist. 47: 283

Allen, J. A., Lang, H., \& Chapin, J. P. igi 7. The American Museum Congo Expedition collection of Bats. Bull. Amer. Mus. Nat. Hist. 37: 405.

Andersen, K. I9I 2. Catalogue of the Chiroptera in the collection of the British Museum, I, Megachiroptera (all published). London: British Museum (Natural History).

Bogage, J. V. B. du. i889-189o. Mammifères d'Angola et du Congo. F. Sci. Math. Phys. Nat., Lisboa, I: I-32 and I 74-185 (I889), and 2: I-32 (I89o).

Bohmann, L. I942. Die Gattung Dendromus A. Smith. Zool. Anz. I39: 33.

BRoom, R. I9I6. On the structure of the skull in Chrysochloris. P.Z.S. 449. I 946 . Some new and rare Golden Moles. Ann. Transv. Mus. 20: 329. 1948. Some South African pliocene and pleistocene mammals. Ann. Transv. Mus. 2I: I.

— I950. Some further advances in our knowledge of the Cape Golden Moles. Ann. Transv. Mus. 21: 234.

Bryden, H. A. i 899. Great and small game of Africa. London: Rowland Ward.

Burchell, W. J. I822-3. Travels in the interior of Southern Africa. 2 vols. (vol. I, March I 822; vol. 2, title page has "I 824 " but according to Sherborn the date of publication was November, I823). London: Longman, Hurst \& Co.

Cabrera, A. I936. Subspecific and individual variation in the Burchell zebras. 7. Mammal. I7: 89 .

ConISBEe, L. R. I953. A list of the names proposed for genera and subgenera of recent mammals, from the publication of T.S. Palmer's 'Index generum mammalium', I904 to the end of I95I. London: British Museum (Natural History).

Davis D. H. S. I949. The affinities of the South African gerbils of the genus Tatera. P.Z.S. II 8: 1002.

Dollman, J. G. I9I 5. On the Swamp-rats (Otomys) of East Africa. Ann. Mag. N.H. I5: 149 .

I9I5-I6. On the African shrews belonging to the genus Crocidura. Ann. Mag. N.H. I5: 507, 562; I6: 66, I 24, 357, 506; I 7: 188.

Dollman, J. G., \& Burlace, J. B. i928. Records of big game (9th edition). London: Rowland Ward.

I935. Records of big game ( Ioth edition). London: Rowland Ward.

Duncan, F. Martin. I 937. On the dates of publication of the Society's "Proceedings" ... and of the "Transactions". Proc. Zool. Soc. London, I07, Ser. A: 7 I.

Ellerman, J. R. I940-I, I949. Families and genera of living rodents (3 vols.). London: British Museum (Natural History).

Ellerman, J. R., \& Morrison-Scott, T. G. S. i95 I. Checklist of Palaearctic and Indian Mammals, I 758-1946. London: British Museum (Natural History). 
Elliot, D. G. I9I3. A reviere of the Primates (3 vols.). New York: American Museum of Natural History.

Fitzsimons, F. W. I9I9-20. The natural history of South Africa. Mammals (4 vols.). London: Longmans, Green.

Flower, W. H., \& LydekKer, R. i8gi. An introduction to the study of mammals, living and extinct. London: A. \& C. Black.

Frade, F. ig33a. Éléphants du Mozambique. Bull. Soc. Portug. Sci. Nat. i I: 307.

— I 933 b. Éléphants d'Angola. Bull. Soc. Portug. Sci. Nat. II: 3 I 9.

I936. Distribution géographique des éléphants d'Afrique. C.R. XII Int. Congr. Zool.-Lisbonne, 1935: I I 9 I.

Fraser, F. G. I937. Whales and dolphins in Norman, J. R. and Fraser, F. C., Giant fishes, whales and dolphins. London: Putnam.

Frechkop, S. i93 I. Notes sur les mammifères. VI. Quelques observations sur la classification des Pangolins (Manidae). Bull. Mus. Hist. Nat. Belge, 7, No. 22.

Gordon-Brown, A. I 95I. The year book and guide to Southern Africa. Also The year book and guide to East Africa. (Published annually by the Union-Castle Mail Steamship Company, and containing useful maps and geographical information.) London: Robert Hale.

HaAgner, A. i920. South African mammals. London: Witherby.

Hahn, H. i934. Die Familie der Procaviidae. Z. Säugetierk, 9: 207.

HARPER, F. I940. The nomenclature and type localities of certain Old World mammals. F. Mammal. 21: I9I and 322.

1945. Extinct and vanishing mammals of the Old World. Spec. Publ. Amer. Comm. Int. Wild Life Prot. No. I 2.

HArris, W. C. I840-43. Portraits of the game and wild animals of southern Africa; (issued in 5 parts). London: W. Pickering.

Hatr, R. T. I940. Lagomorpha and Rodentia other than Sciuridae, Anomaluridae and Idiuridae, Collected by the American Museum Congo Expedition. Bull. Amer. Mus. Nat. Hist. 76: 457.

Hayman, R. W. i95i. Notes on some Angolan mammals. Publ. Cult. Compan. Diamantes Angola, Dundo, No. I I : 33 .

Hewitt, J. I931. A guide to the vertebrate fauna of the Eastern Cape Province, Part I, Mammals and Birds. Grahamstown: Trustees of the Albany Museum.

Hill, J. E., \& Garter, T. D. ig4i. The mammals of Angola, Africa. Bull. Amer. Mus. Nat. Hist. 78: I.

Hill, W. C. Osman. I953. Primates: comparative anatomy and taxonomy. I, Strepsirhini. Edinburgh: University Press.

Hollister, N. I 918-ig, I924. East African mammals in the United States National Museum, Bull. U.S. Nat. Mus. No. 99. Part I, Insectivora, Chiroptera and Carnivora (I918). Part II, Rodentia, Lagomorpha and Tubulidentata (I9I9). Part III, Primates, Artiodactyla, Perissodactyla, Proboscidea and Hyracoidea (I924).

Lawrence, B., \& Loveridge, A. I953. Zoological results of a fifth expedition to East Africa. I. Mammals from Nyasaland and Tete. Bull. Mus. Comp. Zool. Harv. I IO: I. (This paper, published in June, I953, was received too late for us to incorporate its findings. The authors record three species from Nyasaland which we did not know occurred in the area we deal with: Crocidura hildegardeae Thomas (probably a race of $C$. somalica Thomas), Hipposideros ruber Noack, and Otomys kempi Dollman). 
Lundholm, B. I95I. A skull of the true Quagga (Equus quagga) in the collection of the Transvaal Museum. S. Afr. F. Sci. 47: 307.

Lydekker, R. igo4. On the subspecies of Giraffa camelopardalis. P.Z.S. I: 202. I9I3-I6. Catalogue of the ungulate mammals in the British Museum (Natural History) (5 vols.). London: British Museum (Natural History). I926. The game animals of Africa. (This is a second edition, revised by J. G. Dollman; the first edition was published in I 908.) London: Rowland Ward.

Miller, G. S. I907. The families and genera of bats. Bull. U.S. Nat. Mus. No. 57.

- I9I2. Catalogue of the mammals of Western Europe. London: British Museum (Natural History).

Monard, A. I935. Contribution à la Mammalogie d'Angola et prodrome d'une faune d'Angola. Arch. Mus. Bocage, No. 6.

Moreau, R. E., Hopkins, G. H. E. and Hayman, R. W. i946. The type-localities of some African mammals. P.Z.S. II5: 387 .

Morrison-Scott, T. C. S. i 947. A revision of our knowledge of African Elephants' teeth, with notes on Forest and "Pygmy" Elephants. P.Z.S. I I 7: 505.

Nigolls, J. A., \& Eglington, W. I892. The sportsman in South Africa. London: British and Colonial Publications.

Palmer, T. S. igo4. Index generum mammalium. $\mathcal{N}$. Amer. Fauna, No. 23.

Pitman, G. R. S. I934. A report on a faunal survey of Northern Rhodesia. (Check lists of the vertebrate fauna-Mammals, p. I 57.) Livingstone: Government Printer.

Poche, F. I9I 2. Ueber den Inhalt und die Erscheinungszeiten der einzelnen Teile, Hefte, etc., und die verschiedenen Ausgaben des Schreber'schen Säugetierwerkes (I774-1855). Arch. Naturgesch. 77, Band I, Supplementheft 4: I 24.

Pocock, R. I. I902. A new arrangement of the existing species of Equidae, with the description of a new subspecies of Zebra. Ann. Mag. Nat. Hist. IO: 304.

I904. The Cape Colony Quaggas. Ann. Mag. Nat. Hist. I4: 3 I 3.

I 907. Notes on the Quagga and Burchell's Zebra in the Paris Museum. Ann. Mag. Nat. Hist. I9: $5 \mathrm{I} 6$.

I907. Notes upon some African species of the genus Felis, based upon specimens recently exhibited in the Society's gardens. P.Z.S. 656 .

1907. A monographic revision of the monkeys of the genus Cercopithecus. P.Z.S. 677 .

I9I5. On the feet and glands and other external characters of the Viverrinae, with the description of a new genus. P.Z.S. I 3 I.

I917. The classification of the existing Felidae. Ann. Mag. Nat. Hist. 20: 329. I9I9. The classification of the mongooses (Mungotidae). Ann. Mag. Nat. Hist. 3: 5 I 5 .

I 92 I. On the external characters of some species of Lutrinae (Otters). P.Z.S. 535 .

I922. On the external characters and classification of the Mustelidae. P.Z.S.

I921: 803 .

1924. The external characters of the pangolins (Manidae). P.Z.S. 707.

I930. The panthers and ounces of Asia. F. Bombay N.H. Soc. 34: 64 and 307.

I932. The leopards of Africa. P.Z.S. 543 .

I939, I94I. The fauna of British India, including Ceylon and Burma. Mammalia ( 2 vols., Primates and Carnivora only published). London: Taylor \& Francis. I945. Some cranial and dental characters of the existing species of Asiatic rhinoceroses. P.Z.S. II 4: 437 .

1951. Catalogue of the genus Felis. London: British Museum (Natural History). 
Raven, H. C., \& Hill, J. E. i942. Notes on Cercopithecus hamlyni Pocock. Amer. Mus. Novit. No. I I 77 .

Roberts, A. I951. The mammals of South Africa. Johannesburg: Trustees of "The Mammals of South Africa" Book Fund.

Roosevelt, T., \& Heller, E. igi5. Life histories of African game animals. (2 vols.). London: John Murray.

Rzasnicki, A. Zebras and quaggas. Ann. Mus. Zool. Polon. I4: 203.

Sanborn, G. G. 1950. Chiroptera from Dundo, Lunda, North-eastern Angola. Pub. Cult. Compan. Diamantes Angola, Dundo, No. Io: $5 \mathrm{I}$.

— 1952. Rodents (Muridae) from Lunda district, North-eastern Angola. Pub. Cult. Compan. Diamantes Angola, Dundo. No. I4: 107.

St. Leger, J. I93 I. A key to the families and genera of African rodents. P.Z.S. 957 . Sahouteden, H. I944-6. De zoogdieren van Belgisch-Congo en van RuandaUrundi. Ann. Mus. Congo Belge, Zoologie, 3: I-576.

Sahwarz, E. I929. On the local races and distribution of the Black and White Colobus Monkeys. P.Z.S. 585 .

— 1930. Die Sammlung afrikanischer Säugetiere im Congo-Museum. Ginsterkatzen (Gattung Genetta Oken). Rev. Zool. Bot. Afr. I9: 275.

— I93 I. On the African long-tailed lemurs or galagos. Ann. Mag. Nat. Hist. 7: 41.

- I928. Notes on the Classification of the African Monkeys in the genus Cercopithecus Erxleben. Ann. Mag. Nat. Hist. I: 649.

Sclater, P. L., \& Thomas, O. I894-1900. The book of antelopes (4 vols.). London: R. H. Porter.

Sclater, W. L. I9oo-I. The mammals of South Africa (2 vols.). London: R. H. Porter. Sherborn, G. D. i892. On the dates of the parts, plates, and text of Schreber's "Säugethiere". Proc. Zool. Soc. London, I89I: 587.

Shortridge, G. G. 1934. The mammals of South-West Africa (2 vols.). London: Heinemann.

1938. A new genus and new species and subspecies of mammals from Little Namaqualand and North-West Cape Province; and a new subspecies of Gerbillus paeba from the Eastern Cape Province. Ann. S. Afr. Mus. 32: 281.

— I942. Field notes on the first and second expeditions of the Cape Museums' Mammal Survey of the Cape Province; and descriptions of some new subgenera and subspecies. Ann. S. Afr. Mus. 36: 27.

Simpson, G. G. I 945 . The principles of classification and a classification of mammals. Bull. Amer. Mus. Nat. Hist. 85.

Sмiтн, A. 1826. A descriptive catalogue of the South African Museum. Pt. i. Mammalia. Cape Town: Bridekirk.

I833-4. African Zoology: Mammalia. S. Afr. (Quart.) 7.22 (in 8 instalments).

I836. Report of the expedition for exploring central Africa, from the Cape of Good Hope $\ldots$ I834, under the superintendence of ....A. Smith. Cape Town: Government Gazette Office.

I837. A catalogue of the South African Museum: now exhibiting in the Egyptian Hall, Piccadilly. London: Smith, Elder.

I849 (1838-48). Illustrations of the zoology of South Africa-Mammalia. London: Smith, Elder.

(For dates of publication see Waterhouse, i88o, P.Z.S. 489.) 
Smuts, J. I 832. Enumerationem mammalium capensium. Leiden: Cyfveer.

Stevenson-Hamilton, J. i 947 . Wild life in South Africa. London: Cassell.

Swynnerton, G. H., \& Hayman, R. W. i95 I. A checklist of the land mammals of the Tanganyika Territory and the Zanzibar Protectorate. F. E. Afr. Nat. Hist. Soc. 20: 274 .

TAte, G. H. H. I94I. A review of the genus Myotis (Chiroptera) of Eurasia, with special reference to species occurring in the East Indies. Bull. Amer. Mus. N.H. 78: 537 .

Tate, G. H. H., I942. Review of the Vespertilionine bats, with special attention to genera and species of the Archbold collections. Bull. Amer. Mus. N.H. 80: 221.

Thomas, O. I893. On mammals from Nyassaland (sic). P.Z.S. I 892: 546.

— I893. On a second collection of mammals sent by Mr. H. H. Johnston, C.B., from Nyasaland. P.Z.S. 500.

I894. On the mammals of Nyasaland: third contribution. P.Z.S. I 36.

I897. On the mammals of Nyasaland: fourth notice. P.Z.S. I 896: 788.

I897. Exhibition of specimens and descriptions of new species of mammals from North Nyasaland, with a note on Petrodromus. P.Z.S. 430.

I 898. On the mammals obtained by Mr. A. Whyte in Nyasaland, and presented to the British Museum by Sir H. H. Johnston, K.G.B.; being a fifth contribution to the mammal-fauna of Nyasaland. P.Z.S. I 897: 925 .

I 898. On a small collection of mammals obtained by Mr. Alfred Sharpe, C.B., in Nyasaland. P.Z.S. 39I.

I9I I. The mammals of the tenth edition of Linnaeus; an attempt to fix the types of the genera and the exact bases and localities of the species. P.Z.S. I 20.

Thomas, O., \& Wroughton, R.C. I 907. The Rudd Exploration of South Africa-VII. List of Mammals obtained by Mr. Grant at Coguno, Inhambane. P.Z.S.: 285 . I907. The Rudd Exploration of South Africa-VIII. List of Mammals obtained by Mr. Grant at Beira. P.Z.S.: 774 .

— I 908. The Rudd Exploration of South Africa-IX. List of Mammals obtained by Mr. Grant on the Gorongoza Mountains, Portuguese S.E. Africa. P.Z.S.: I64. — I 908. The Rudd Exploration of South Africa-X. List of Mammals obtained by Mr. Grant near Tette, Zambesia. P.Z.S.: 535 .

Trouessart, E. L. I897-I905. Catalogus mammalium tam viventium quam fossilium. Berlin: Friedländer. (pp. I-664 (I897), 665-I,264 (I898), I, 265-end (I899);

Supplementum, pp. I-546 (I g04), 547-end (I 905).)

Ward, Rowland. See Dollman, J. G. \& Burlace, J. B.

Weber, M. 1927-8. Die Säugetiere (2 vols.). Jena: G. Fischer.

Winge, H. I923-4. Pattedyr-Slaegter (3 vols.). Copenhagen: H. Hagerup. (English translation by G. M. Allen \& E. Deichmann, I94I-2, Copenhagen: C. A. Reitzel.)

Wroughton, R. G. I9o6. Notes on the genus Otomys. Ann. Mag. N.H. I8: 264 . 



\section{N D E X}

Each name is entered once only - under the genus in which it is recognized in this checklist. Names printed in capitals are those which are given full generic status. Main references are shown in bold face type.

Aalwynvlermuis, 77

Aardvark, I54

Aardwolf, I 40

aberrans, Cryptomys, 234

acaciae, Rattus, 273

acetabulosa, Tadarida, 65, 70

achrotes, Canis, I 09

ACINONYX I 43 , I5I

ACOMYS, 26o, 292

Acronotus, 202

acticola, Rattus, 27 I

acuticornis, Raphicerus, I 84

acutorostrata, Balaenoptera, 325

Adenota, I 76, r92, I 94

aduncus, Tursiops, 330

adustus, Canis, I 08, Io9

adventor, Cricetomys, 296

Aegocera, I 98

Aegocerus, I 98

Aegoryx, I97

aegyptiacus, Rousettus, 45

aegyptiaca, Tadarida, 65, 66

AEPYCEROS, I 74, I 76, I95

aerosa, Kerivoula, 88

aeta, Rattus, 270

Aethechinus, I 7

aethiopicus, Hippotragus, I 99

aethiopica, Nycteris, 52

aethiopicus, Phacochoerus, I 7 I

aethiops, Cercopithecus, 96

aethiops, Rhinolophus, 56, 60

Aethoglis, 253

Aethomys, 264, 265, 270

Aethosciurus, 241, 243

afra, Coleura, 50

afer, Orycteropus, I 54

afra, Tatera, 3 I 8, $3 \mathbf{I 9}$

affinis, Amblysomus, 37

affinis, Nycteris, 53

affinis, Suncus, 24

africaeaustralis, Hystrix, 236

africana, Bathyergus, 228

africanus, Diceros, 163

africana, Ictonyx, I 12

africana, Loxodonta, I 55, $5^{6}$

africana, Orcinus, 332

africana, Poecilogale, I I 4

africanus, Potamochoerus, I 70

africana, Tadarida, 65,66

africanus, Tatera, 320

africanus, Xerus, 250 .

Afrikaanse Tier, I 49

Agriodus, 106

Aigocerus, 198

albaniensis, Lepus, 2 I 8

albaniensis, Otomys, 3 I I

albaniensis, Pedetes, 252

albaniensis, Procavia, I 59

albicauda, Ichneumia, I 34

albicaudus, Orycteropus, I 55

albicaudatus, Mystromys, 3 I 3

albifrons, Amblysomus, 37

albifrons, Damaliscus, 201

albigula, Nycticeius, 85 albigularis, Cercopithecus, 99

albinucha, Poecilogale, I 13

albinuchalis, Potamochoerus, I 70

albinus, Rattus, 275

albipes, Mystromys, 3 I 4

albirostris, Amblysomus, 37

albiventer, Rattus, 268

albiventris, Genetta, I 24

albofuscus, Nycticeius, $83, \mathbf{8}_{4}$

albovittatus, Xerus, 250

albus, Cryptomys, 234

ALCELAPHUS, I 74, I 77, 202

alces, Taurotragus, 2 I 0

alexanderi, Elephantulus, I I

alexandri, Mungos, I 33

algoae, Rhabdomys, 28 I

algoënsis, Redunca, I 92

alleni, Rattus, 270

allmani, Potamogale, 32

Allochrocebus, 96

Allomops, 64

Allosciurus, 248

Alobus, 79

alticola, Graphiurus, 256

alticola, Rattus, 27 I

altifrons, Sylvicapra, 182

amatus, Cryptomys, 232

AMBLYSOMUS, 33, 34

amboellensis, Kobus, I 95

Ammelaphus, 206

amoenus, Cephalophus, I 79

amphibius, Hippopotamus, I 72

Anahyster, I 6

anchietae, Cephalophus, I 80

anchietae, Crocidura, $3 \mathbf{I}$

anchietae, Oenomys, 287

anchietai, Otomys, 307, 308

anchietai, Pipistrellus, 79, 80

anchietai, Plerotes, 46

anchietae, Tadarida, 66

Anchotomys, 306

anderssoni, Saccostomus, 295

angasi, Tragelaphus, 207, 208

angolae, Aonyx, I 17

angolae, Crocidura, 30

angolae, Erinaceus, I 8

angolae, Pedetes, 252

angolae, Rhabdomys, 282

angolae, Saccostomus, 295

angolae, Tatera, 32 I

angolae, Thryonomys, 238

Angolasse Losstertvlermuis, 69

Angolasse Vlerkkliervlermuis, 74

angolensis, Antidorcas, I97

angolensis, Colobus, 94

angolensis, Dendromus, 304

angolensis, Epomophorus, 46, 48, 49

angolensis, Eptesicus, 76

angolensis, Genetta, I 2 I, 123

angolensis, Giraffa, I 74

angolensis, Grammomys, 263

angolensis, Graphiurus, 253, 257

angolensis, Herpestes, I 25

angolensis, Hipposideros, 6 I 
angolensis, Laephotis, 78 angolensis, Lepus, 2 I 6 angolensis, Loxodonta, I 56 angolensis, Nycteris, 53 angolensis, Rattus, 269,276 angolensis, Rhinolophus, 56, 60 angolensis, Rousettus, 45, 46 angolensis, Steatomys, 300 angolensis, Suncus, 24 angolensis, Tadarida, 65,69 angonicus, Heliophobius, 229 angoniensis, Otomys, 309 angusticeps, Eptesicus, 76 annectens, Equus, I 68 annellata, Crocidura, 28 Anomalurella, 250

Anomalurodon, 250

ANOMALURUS, $25^{\circ}$ anomalus, Cryptomys, 235 ansorgei, Cercopithecus, I00 ansorgei, Cricetomys, 296 ansorgei, Crocidura, 30 ansorgei, Cryptomys, 236 ansorgei, Dendromus, 303 ansorgei, Graphiurus, 255 ansorgei, Lepus, 2 I 6 ansorgei, Mungos, I33, 134 ansorgei, Tadarida, 65, 66, 67 antarctica, Arctocephalus, I 53 antarctica, Eubalaena, 326

Antbear, I 54

Anteater, Scaly, I04

ANTIDORCAS, I 74, I 76, 196

antiquorum, Equus, I66, I67

AONYX, i I I, II6

Aper, I 7 I

apiculatıs, Herpestes, 129

Aquias, 55

aquilo, Lepus, 2 I $3,2 \mathbf{2} 4$

aquilus, Lophuromys, 283

arborarius, Rattus, 277

arboreus, Dendrohyrax, I6o, r6r

ARCTOCEPHALUS, I 52

arenarius, Cryptomys, 233

arenarius, Dendromus, 304

arenarius, Ictonyx, I I 3

arenarius, Lepus, 2 I 4

arenarum, Canis, I 09

arge, Nycteris, $5^{\mathrm{I}}, \mathbf{5}^{2}$

argens, Potamogale, 32

argentatus, Crocidura, 27

argentata, Glauconycteris, 82, 83

argentata, Kerivoula, 88

argenteocinereus, Heliophobius, 229

Ariela, I 32

Aroaethrus, 250

arundinacea, Redunca, 192

arundinum, Redunca, I91, 192

ARVICANTHIS, 262, 264

ascanius, Cercopithecus, 99

aschenborni, Oryx, I 98

asiatica, Chrysochloris, 33, 39, 40

Atelerix, I 7, 18

ater, Eptesicus, 77

Athylax, I30

ATILAX, I I 9, 130

atilax, Atilax, I 3 I

attenuata, Stenella, 329

augur, Rhinolophus, 56,5
Aulacodus, 237

aurantii, Lepus, 2 I 7

auratus, Herpestes, 128

auratus, Otomys, 309

aurea, Chrysochloris, 40

auricomus, Rattus, 277

auricularis, Desmodillus, 3 I 4

aurita, Hippotragus, 199

auritus, Otocyon, 107

auritus, Rhinolophus, $5^{8}$

auriventris, Paraxerus, 246

ausensis, Macroscelides, I4

ausensis, Petromus, $24^{\circ}$

australis, Cloeotis, 62

australis, Eubalaena, 326

australis, Galago, 9I

australis, Giraffa, I 74

australis, Graphiurus, 258

australis, Hippopotamus, I 72

australis, Megaptera, 326

australis, Nycticeius, 84

australis, Orcinus, 332

australis, Pelomys, 290

australis, Pipistrellus, 80

australis, Pronolagus, 22 I

avarillus, Rattus, 277

avunculus, Rattus, 278

ayresi, Dendromus, 302

Baboon, Chacma, ro I

Baboon, Yellow, I I I

badius, Herpestes, I 28

Bakoorjakkals, ro6

BALAENOPTERA, 325

baliolus, Grammomys, 263

bangae, Alcelaphus, 204

barbata, Hippotragus, I98

barbatus, Taurotragus, 210

barbertonensis, Rhinolophus, $5^{8}$

barbiensis, Petromus, 240

barbouri, Petromyscus, 298

barlowi, Elephantulus, I I

barretti, Pronolagus, 222

basengae, Alcelaphus, 203

Bastergemsbok, 198

Basterhartbees, 200

Basterwaterbok, I95

basuticus, Dendromus, 303

basuticus, Herpestes, I30

basuticus, Otomys, 3 I I

Bat, African Trident, 62

Bat, Aloe, 77

Bat, Angola Freetailed, 69

Bat, Angola Wing-gland, 74

Bat, Ansorge's Freetailed, 67

Bat, Banana, 80

Bat, Bates' Slit-faced, 52

Bat, Bocage's Freetailed, 67

Bat, Butterfly, 83

Bat, Cape Hairy, 73

Bat, Cape Slit-faced, 53

Bat, Chitau Freetailed, 69

Bat, Damara Woolly, 88

Bat, de Winton's Long-eared, 78

Bat, Egyptian Freetailed, 66

Bat, Egyptian Slit-faced, 53

Bat, Flatheaded Freetailed, 63

Bat, Giant Yellow, 85

Bat, Hairy Slit-faced, 52 


\section{INDEX}

Bat, Horny-skinned, 75

Bat, Large Freetailed, 64

Bat, Large-eared Slit-faced, 54

Bat, Lesser Woolly, 88

Bat, Lesser Yellow, 86

Bat, Lesueur's Wing-gland, 74

Bat, Little Freetailed, 67

Bat, Little Slit-faced, 52

Bat, Long-crested Freetailed, 68

Bat, Masterson's Freetailed, 66

Bat, Moloney's Flatheaded, 82

Bat, Natal Wrinkle-lipped, 70

Bat, Rufous Mouse-eared, 73

Bat, Rüppell's, 8 I

Bat, Rusty, 8o

Bat, Schlieffen's, 84

Bat, Schreiber's, 87

Bat, Seabra's Freetailed, 66

Bat, Silvered, 83

Bat, South African Tomb, 5 I

Bat, Southern Sheath-tailed, 50

Bat, Spillmann's Freetailed, 67

Bat, Sundevall's Freetailed, 70

Bat, Transvaal Freetailed, 66

Bat, Welwitsch's, 73

Bat, Whitebellied Little Freetailed, 68

Bat, Whitebreasted Freetailed, 69

Bat, Wood's Slit-faced, 54

Bat, Yellow-winged, 54

BATHYERGUS, 227, 228

baumi, Tragelaphus, 208

Bayonia, 32

bayoni, Chrysochloris, 4 I

bayoni, Funisciurus, 247, $24^{8}$

BDEOGALE, I 18 , I36

BEAMYS, 26 I, 294

Beatragus, 200

bechuanae, Cynictis, I 38

bechuanae, Lepus, 2 I 8

bechuanae, Paracynictis, I 37

bechuanae, Poecilogale, I I 4

bechuanae, Rhabdomys, 28 I

bechuanae, Tatera, 320

bedfordi, Lepus, 2 I 5

beirae, Crocidura, 25, 28

beirae, Cryptomys, 230, 232

beirae, Felis, I 47

beirae, Heliosciurus, 243

beirae, Petrodromus, I 5

beirae, Tatera, 323

beirensis, Cercopithecus, 99

beirensis, Tatera, 323

Beisa Oryx, I97

bella, Genetta, I 22

Bematiscus, 4I

bembanicus, Rhinolophus, 59

bengalensis, Vulpes, I 07

bensoni, Eptesicus, 76

bentleyae, Dasymys, 288

bergensis, Otomys, 3 I I

Bergkwagga, I 65

Bergvleimuis, 307

berneri, Mimetillus, 82

Bersebase Klipmuis, 298

bethuliensis, Rhabdomys, 282

bezoartica, Oryx, I97

bicolor, Cephalophus, I8o

bicolor, Crocidura 25

bicolor, Eptesicus, 75, 77 bicornis, Diceros, 163

bigalkei, Cryptomys, 233

binotata, Nandinia, 120

bisulcatus, Otomys, 308

Blackfish, 333

blainei, Cryptomys, 236

blainei, Oryx, 198

blasii, Rhinolophus, 56, 59

Blesbok, 200, 20I

Blesmol, 229

bleyenberghi, Panthera, I 5 I

Blouaap, 96

Bloubokkie, I 79

Blouwildebees, 205

bocagei, Cryptomys, 230, 232

bocagei, Dendrohyrax, I6o

bocagei, Herpestes, 127

bocagei, Myotis, 72, 73

bocagei, Rattus, 27 I

bocagei, Steatomys, 298, 301

bocagei, Tadarida, $66, \mathbf{6}_{7}$

Bocagese Losstertvlermuis, 67

Boesmanlandse Karorot, 3 I 3

boehmi, Equus, I66, I67

boehmi, Tatera, 31 7, 3п8

Bontbok, 20 I

Bontebok, 200, 20I

Bontkwagga, I 66

Boocercus, 2 IO

Boocerus, 2 I 0

borbonicus, Scotophilus, 86

borealis, Balaenoptera, 325

borlei, Connochaetes, 205

bororensis, Mungos, I 34

bororensis, Paraxerus, 245

Borselstertnagmuis, 3 I 7

Bosbok, 207

Bosdas, I6 I

Boskaromuis, 3 Io

Boskarorot, 3 I O

Bosklaasneus, I 5

Bosmuis, 263

Bosnagaap, 92

Bosskeerbekmuis, 22

Bosvark, I 70

Bosveldklaasneus, Io

Bosveldvlermuis, 59

Boswaaierstertmuis, 254

bourquii, Raphicerus, I 85

bowkeri, Pronolagus, 2 I 9

brachyptera, Tadarida, 66, 69

brachyrhynchus, Elephantulus, 8, 9

brachyura, Cynictis, I 38

brachyurus, Elephantulus, 9

brachyura, Felis, I 46

bradfieldi, Cynictis, I 38

bradfieldi, Galago, 92

bradfieldi, Helogale, I 32

bradfieldi, Herpestes, I 28

bradfieldi, Rattus, 276

bradfieldi, Sylvicapra, 182

bradleyi, Steatomys, 300

bradshawi, Cephalophus, I 79

brandvleiensis, Macroscelides, I 4

Brantse Karorot, 312

brantsi, Parotomys, 3 I 2

brantsi, Tatera, 3 I 8, 320

brauni, Heliosciurus, 243

bredanensis, Steno, 330 
brevicaudatus, Desmodillus, 3 I 5

breviceps, Kogia, 327

brevirostris, Elephantulus, 9

breyeri, Miniopterus, 87

breyeri, Rattus, 276

breyeri, Tatera, 322

bridgemani, Paraxerus, 246

broomi, Gerbillus 3 I 6

broomi, Otomys, 3 I I

broomi, Pipistrellus, 8I

brucei, Dendrohyrax, 160

bruchus, Petromyscus, 297

brunetta, Helogale, I 32

brunnea, Hyaena, I 42

brunnea, Kerivoula, 88

brunnea, Tadarida, 66

brunnula, Helogale, I 3 I

brydei, Balaenoptera, 325

Bubalis, 202

Bubalus, 202

Buffalo, African, 2 I I

Buffel, 2 I I

buffonii, Georychus, 229

Bunolagus, 2 I 3

burchelli, Diceros, I 64

burchelli, Equus, I64, 166

burchelli, Sylvicapra, I 82

burtoni, Rattus, 279

buselaphus, Alcelaphus, 202

Bushbaby, Senegal, 9I

Bushbaby, Thicktailed, 92

Bushbuck, 207

Bush-pig, I 70

Butragus, 204

byatti, Paraxerus, 244

caama, Alcelaphus, 202, 203

caama, Vulpes, I 08

cacondae, Lycaon, i io

caecutiens, Cryptomys, 23 I

caerula, Cephalophus, 180

caffer, Cephalophus, I80

caffer, Desmodillus, 3 I 5

cafra; Felis, 145

caffra, Herpestes, 129

cafra, Herpestes, 125

caffer, Hipposideros, 6 I

caffer, Otocyon, I07

cafer, Pedetes, 25I, 252

caffer, Rattus, 275

caffra, Redunca, I 92

cafer, Suncus, 20, 23

caffra, Sylvicapra, I 82

caffer, Syncerus, 2 I I

cahirinus, Acomys, 292, 293

calarius, Rattus, 278

Calcochloris, 33, 34

caldatus, Herpestes, 127

calidior, Lemniscomys, 29 I

calidus, Gerbillus, 3 I 6

caligata, Felis, I 45

callewaerti, Mus, 284, 286

Calliope, 206

Callithrix, 95

Callotus, 90

Calogale, I 24

Calotragus, 183

calviniensis, Macroscelides, I4
Camelopardalis, 173

camelopardalis, Giraffa, I 73

campanae, Pelomys, 289, 290

campbelli, Elephantulus, I I

camperi, Diceros, I 63

campestris, Equus, I65, 167

campestris, Raphicerus, I 75, I83, 184

campestris, Saccostomus, 294

camus, Diceros, 164

cana, Eremitalpa, 39

cana, Sylvicapra, I8I

Cane-Rat, Great, 238

Cane-Rat, Lesser, 238

canescens, Crocidura, 28

canescens, Georychus, 230

canescens, Proteles, I4 I

CANIS, r o6, 108

canna, Taurotragus, 2 io

capensis, Aonyx, I 6

capensis, Cephalorhynchus, 331

capensis, Chrysochloris, 40

capensis, Connochaetes, 205

capensis, Crocidura, $3 \mathbf{I}$

capensis, Crocuta, I43

capensis, Dasymys, 289

capensis, Delphinus, 329

capensis, Dendromus, 304

capensis, Diceros, ${ }^{6} 63$

capensis, Elephantulus, I3

capensis, Eptesicus, 75

capensis, Erinaceus, 18

capensis, Felis, 147

capensis, Georychus, 229

capensis, Giraffa, I 73, 174

capensis, Graphiurus, 259

capensis, Hippopotamus, I 72

capensis, Hystrix, 237

capensis, Ictonyx, I 12

capensis, Lepus, 2 I 3

capensis, Loxodonta, ${ }_{5} 6$

capensis, Megaptera, 326

capensis, Mellivora, I 14

capensis, Nycteris, 52, 53

capensis, Orcinus, $33^{2}$

capensis, Orycteropus, I 55

capensis, Oryx, 198

capensis, Otomys, 308

capensis, Panthera, I 5 I

capensis, Papio, 102

capensis, Pedetes, $25^{\mathrm{I}}$

capensis, Petromyscus, 298

capensis, Potamochoerus, I 70

capensis, Procavia, I 57

capensis, Raphicerus, 184

capensis, Rattus, 278

capensis, Rhinolophus, 56, $5^{8}$

capensis, Stenella, 329

capensis, Suncus, 23

capensis, Suricata, I 40

capensis, Tragelaphus, 209

capensis, Xerus, 249

capensis, Ziphius, 328

capensoides, Crocidura, 32

CAPEREA, 326

capreolus, Pelea, I9o

capricornis, Pronolagus, 220

capricornis, Raphicerus, I 85

capricornis, Rattus, 272

Caracal, r44, I 48 
caracal, Felis, I $44, \mathbf{I 4}^{8}$

carillus, Rattus, $270, \mathbf{2 8 0}$

carolinensis, Sciurus, 240

Cat, Blackfooted, I 46

Catablepas, 204

catalania, Tursiops, 330

Catoblepas, 204

catodon, Physeter, 327

caucinus, Pronolagus, 220

cauui, Herpestes, I I 9, I 26

cavirostris, Ziphius, 327

Cemas, 204

centralis, Antidorcas, I 97

centralis, Elephantulus, I 3

centralis, Hipposideros, 6 I

centralis, Lepus, 2 I 4

centralis, Oreotragus, I 89

centralis, Rattus, 278

cepapi, Paraxerus, 244

cepapoides, Paraxerus, 244

cepate, Paraxerus, 244

Cephalolophus, I 77

Cephalophella, i 78

Cephalophia, I 78

Cephalophidium, i 78

Cephalophops, I 78

Cephalophora, I8I

Cephalophorus, I 77

Cephalophula, i 78

CEPHALOPHUS, I 74, I 75, I 77, I 78

CEPHALORHYNCHUS, 33 I

cephalorhynchus, Cephalorhynchus, 33 I

Ceratotherium, I63, 164

Cercocebus, 93

Cercocephalus, 95

Cercoctenus, I 5

\section{CERCOPITHECUS, 93, 95}

Cervicapra, I9I

cervicapra, Damaliscus, 20 I

cervicolor, Mus, 284

Chaerephon, 64, 67

Chaeropithecus, I oo, Ior

chakae, Rhabdomys, 282

Chalinolobus, 82

chama, Vulpes, i o8

chapini, Tadarida, 65,68

chapmanni, Equus, I 67

Cheetah, I 5 I

chimango, Cercopithecus, 98

chirindensis, Heliosciurus, 243

Chirosciurus, 90

chitauensis, Grocidura, 26

chitauensis, Tadarida, 66, 69

chiversi, Dendromus, 304

chiversi, Lepus, 2 I 8

chiversi, Macroscelides, I 4

chiversi, Procavia, I 59

chiversi, Steatomys, 300

Chlorocebus, 95

Chlorotalpa, 33, 34

chobiensis, Lepus, 2 I 8

chobiensis, Lutra, i 16

chobiensis, Papio, I 03

chobiensis, Paraxerus, 245

Choeromys, 237

Choeropithecus, I oo

choeropotamus, Potamochoerus, I 70

Choiropithecus, I oo

Choiropotamus, 169
Chortomys, 30 I

chriseos, Suncus, 2 I

chrvsillus, Amblysomus, 35

CHRYSOCHLORIS, 33, 39

chrysophilus, Rattus, 265, 268, $27 \mathbf{r}$

Chrysopteron, 72, 73

CHRYSOSPALAX, 33, 4I

Chrysotricha, 33, 34

cinderella, Cynictis, I 38

cineraceus, Graphiurus, 254

cinerascens, Graphiurus, 254

cinerascens, Taphozous, 5 I

cinereus, Anomalurus, 25 I

cinerea, Redunca, I 92

cinereus, Rhabdomys, 28 I

cinnamomeus, Crocidura, 3 I

cinnamomeus, Petromus, 240

cirnei, Rhynchocyon, I 7

Cistugo, 70, 72, 74

Civet, African, I 20

civetta, Viverra, I 20

Civettictis, I I 7, 190

Claviglis, 253, 254

Climbing Mouse, Chestnut, 30 I

Climbing Mouse, Lesser, 302

clivosus, Rhinolophus, 56, 57

CLOEOTIS, 55, $6 \mathbf{2}$

cloetei, Cercopithecus, 98

Cobus, I 93

coenosus, Otomys, 309

coerulescens, Redunca, I 92

Coetomys, 230

COLEURA, 50

collaris, Rousettus, 46

collinus, Petromyscus, 297

Colobolus, 94

COLOBUS, 93, 94

Colobus Monkey, Black and White, 94

COLOMYS, 262, 286

coloniae, Felis, I 48

colonicus, Raphicerus, I 86

colonus, Rattus, 265, 268

comatus, Papio, IO2

cometes, Grammomys, 263

commersoni, Hipposideros, 6 I, 62

Commersonse Blaarneusvlermuis, 62

Comopithecus, Ioo

compressa, Arctocephalus, I 53

comptus, Epomops, 47

concinnus, Dendromus, 304

concolor, Chrysochloris, 4I

concolor, Crocidura, 26

condylura, Tadarida, 65, 69

congicus, Funisciurus, 247

congicus, Glauconycteris, 83

CONNOCHAETES, I 74, I 77, 204

connochaetes, Connochaetes, 205

conspicillatus, Galago, 9 I

constrictus, Hippopotamus, I 73

cooksoni, Connochaetes, 206

coombsi, Aonyx, I I 7

coombsi, Cynictis, I 38

coombsi, Gerbillus, 3 I 6

coombsi, Procavia, I 59

corniculatus, Connochaetes, 205

corriae, Amblysomus, 37

cottoni, Hippotragus, I 99

cottoni, Potamochoerus, I 70

coucha, Rattus, 275 
coxi, Cephalophus, I 79

cradockensis, Cryptomys, 23 I

cradockensis, Rhabdomys, 28 I

crassicauda, Bdeogale, 136

crassicaudatus, Galago, 90, 92

crassicaudatus, Pronolagus, 2 I 9

crassidens, Pseudorca, 33 I

crawshayi, Equus, 167

crawshayi, Kobus, I 94

Cremnomys, 265, 269

Cretzschmarse Losstertvlermuis, 67

CRICETOMYS， 225， 260, 295

cristata, Hystrix, 236

cristatus, Proteles, I 40

cristata, Tadarida, 65,68

croacuta, Crocuta, I 43

CROCIDURA, I 8, 20, 24

Crocotta, I 42

CROCUTA, I 4I, 142

crocuta, Crocuta, I 42

Crossarchus, 132, I 33, I 34

cruciger, Lagenorhynchus, 33 I

CRYPTOCHLORIS, 33, 39

GRYPTOMYS, 227,230

crypturus, Epomophorus, 48, 49

cuanzensis, Crocidura, 28

cuanzensis, Graphiurus, 256

cuanzensis, Otomys, 310

cubangensis, Syncerus, 2 I 2

culex, Pipistrellus, 79, 80

cunctator, Cricetomys, 296

cunealis, Petromus, 239

cunenensis, Oreotragus, I 89

cunenensis, Raphicerus, 185

cunenensis, Sylvicapra, I 83

cunenensis, Syncerus, 2 I 2

cupreoides, Otomys, 3 Io

cupreus, Otomys, 309

curryi, Pronolagus, 22 I

cutchicus, Rattus, 269

cuvieri, Crocuta, I43

cyanea, Crocidura, 20, 25, 27

cyclotis, Loxodonta, I 56, 157

Cynailurus, I 5 I

Cynalopex, 107

Cynhyaena, 109

CYNICTIS, I 1 8, 137

Cynocebus, 95

cynocephalus, Papio, roo, ror

Cynogale, 32

Cynonycteris, 45

cynosuros, Cercopithecus, 97

Damalis, 200, 202

DAMALISCUS, I 74, I 77, 200

Damaralandse Hoefystervlermuis, 60

Damaralandse Bloubokkie, I 89

Damaralandse Wolhaarvlermuis, 88

damarensis, Chrysochloris, 40

damarensis, Cryptomys, 230, 232

damarensis, Eptesicus, 75

damarensis, Felis, I 49

damarensis, Funisciurus, 247

damarensis, Lepus, 2 I 7

damarensis, Madoqua, rgo

damarensis, Malacothrix, 305

damarensis, Nycteris, 53

damarensis, Pedetes, 252

damarensis, Rattus, 273 damarensis, Rhinolophus, $5^{8}$

damarensis, Scotophilus, 86

darlingi, Cryptomys, 230, 232

darlingi, Rhinolophus, 56, 57

Darlingse Vlermuis, 57

dasilvai, Graphiurus, 256

dasilvai, Herpestes, 128

Dassie, I 57

Dassie Rat, 239

Dassie, Yellow-spotted, i6o

Dassierot, 239

DASYMYS, 26r , 288

dasythrix, Miniopterus, 87

defassa, Kobus, I93, 194

defriesi, Cephalophus, 180

delalandi, Aonyx, I 17

delalandi, Arctocephalus, I 53

delectorum, Rattus, 270, 279

DELPHINUS 328

delphis, Delphinus, 329

demidoffi, Galago, 9 I

demidovi, Galago, 9o, 9r

DENDROHYRAX, I57, r6o, I6r

DENDROMUS, 297, 3 or

Dendromys, $30 \mathrm{I}$

denniae, Rattus, 270

densirostris, Mesoplodon, 328

denti, Rhinolophus, $56,5^{\mathbf{8}}$

Dentse Vlermuis, 58

Dephomys, 264

derbianus, Anomalurus, 250

deserti, Crocidura, 30

deserti, Mus, 285

deserti, Parotomys, 3 I 2

deserti, Rhabdomys, 28I

DESMODILLUS, 314

Desmomys 289

devilliersi, Amblysomus, 37

De Wintonse Kruipmol, 39

diadematus, Erinaceus, 18

Diademed Monkey, 98

Diademia, 95

Diana, 95

DICEROS, r62, 163

Dikdik, Damara, I 89

Dikstert-muishond, I36

dilectus, Rhabdomys, 28 I

dingani, Scotophilus, 86

Dinochoerus, I 7 I

Dioplodon, 328

Dipodillus, 3 I 5

discolor, Nycteris, 53

dixoni, Chrysochloris, 40

dobsoni, Chrysospalax, 42

dobsoni, Epomops, 46, 47

Dolichohippus, $6_{5}$

dolichurus, Grammomys, 262, 263

dollmani, Rattus, 272

Dolphin, Cape, 329

Dolphin, Common, 329

Dolphin, Euphrosyne, 329

Dolphin, Gray's, 33 I

Dolphin, Longbeaked, 329

Dolphin, Narrow-snouted, 329

Dolphin, Risso's, 332

Dolphin, Red Sea Bottlenosed, 330

Dolphin, Rough-toothed, 330

Dolphin, Southern Right Whale, 333

Dolphin, Speckled, 330 
donavani, Rhabdomys, 28 I

Doratoceros, 2 I 0

dorcas, Alcelaphus, 203

dorcas, Damaliscus, 200, 201

Dormouse, Black and White, 259

Dormouse, Forest, 254

Dormouse, Monard's, $25^{8}$

Dormouse, Rock, 257

dorsalis, Herpestes, I 25

dorsalis, Lemniscomys, 29 I

dorsata, Antidorcas, I97

Doryrhina, 6 I

Draaijakkals, ro6

draco, Tatera, 320

drakensbergensis, Amblysomus, 37

drakensbergi, Rattus, 278

Drietandneusvlermuis, 62

Drill, I 00

dschinschicus, Xerus, 249

dubius, Tadarida, 68, 70

DUGONG, 324

Dugong, 324

dugon, Dugong, 324

Duiker, Blue, I 79

Duiker, Grey, I 8 I

Duiker, Natal, I 78

Duiker, Red, I 78

Duiker, Yellow-backed, I 79

Duikerbok, I 8 I

Duinmol, 228

duthieae, Amblysomus, 35

Dwerg Springhaasmuis, 3 I 5

Dwergmuis, 284

Dwergmuishond, I 3 I

Dwergskeerbekmuis, 25

eastwoodae, Graphiurus, 257

edentatus, Phacochoerus, I 72

edulis, Steatomys, 299

edwardi, Elephantulus, I 2

edwardi, Globicephala, 332, 333

edwardsi, Elephantulus, 12

Eenstreepmuis, 29 I

egeria, Malacothrix, 305

Egiptiese Losstertvlermuis, 66

Egocerus, I 98

EIDOLON, 44

Eland, 2 I 0

electa, Crocidura, 27

elegans, Chrysochloris, 40

elegans, Graphiurus, 259

elegans, Saccostomus, 295

Eleotragus, I9I

eleotragus, Redunca, I91, I 92

Elephant, African, I 56

Elephantomys, 8, ro

Elephant-Shrew, Bushveld, Io

Elephant-Shrew, Checkered, I 7

Elephant-Shrew, Four-toed, I 5

Elephant-Shrew, Knob-bristled Forest, I 6

Elephant-Shrew, Rock, I 2

Elephant-Shrew, Rovuma Four-toed, I 6

Elephant-Shrew, Short-eared, I 3

Elephant-Shrew, Short-snouted, 9

ELEPHANTULUS, 8

Elephas, I 55

Eleutherura, 45

ellipsiprymnus, Kobus, 193

elphicki, Tadarida, 68
Emballonura, 50

empusa, Rhinolophus, 56, 59

encrita, Crocuta, I 43

Eosaccomys, 294

epichrysus, "Vespertilio", 89

Epimys, 264

EPOMOPHORUS, 44, 47

EPOMOPS, 44, $\mathbf{4}^{6}$

Eptesicops, 79

EPTESICUS, 72, 74

equinus, Hippotragus, I 98

EQUUS, I 64

Erdvark, I 54

Erdwolf, I 40

EREMITALPA, 33, 38

erica, Crocidura, 28

ERINACEUS, I 7

ermeloensis, Lepus, 2 I 5

erongensis, Herpestes, I 28

erongensis, Platymops, 64

erythrarchus, Cercopithecus, 98

erythrobronchus, Graphiurus, 254

erythropyga, Cercopithecus, 97

etoschae, Graphiurus, 256

etruscus, Suncus, 20, 2 I

EUBALAENA, 326

euchore, Antidorcas, 197

Euhyrax, I 57

Eulagos, 2 I 3

Eumerus, I 3

euphrosyne, Stenella, 329

Eureodon, I 7 I

europaeus, Erinaceus, I 8

europaeus, Lepus, 2 I 3, 2 I6

Euryalus, 55

Euryceros, 2 I 0

eurycerus, Tragelaphus, 208

Euryotis, 305, 306

Euxerus, 249

evalensis, Alcelaphus, 203

excelsus, Tragelaphus, 209

exenticus, Cryptomys, 23 I

exilis, Gerbillus, 3 I 7

fallax, Pelomys, 289

False Killer, 33 I

fannini, Otomys, 308

fasciatus, Connochaetes, 205

fasciatus, Mungos, I 33

faunus, Cercopithecus, 97

fearoni, Acinonyx, I 5 I

fearonis, Acinonyx, I 5 I

felina, Genetta, I 22

FELIS, I 43, I44

ferrumequinum, Rhinolophus, 55, 56

festivus, Equus, 167

fitzsimonsi, Lemniscomys, 292

fitzsimonsi, Nycticeius, 84

fitzsimonsi, Platymops, 64

fitzsimonsi, Pronolagus, 220

flavescens, Crocidura, I 9, 25, 30

flavescens, Eptesicus, $75, \mathbf{7 6}$

flavescens, Herpestes, I 27

flavescens, Sylvicapra, 182

flavidula, Crocidura, 28

flavidus, Cercopithecus, 97

flavimaculata, Procavia, I 58

flavinus, Funisciurus, 247

flavistriata, Poecilogale, I I4 
flavivittis, Paraxerus, 246

flavopunctatus, Lophuromys, 283

flavovittis, Paraxerus, 243, 246

foai, Equus, r 68

Fossor, 229

fouriei, Pedetes, 252

fouriei, Pipistrellus, 79, 80

fouriei, Rattus, 272

fouriei, Rhabdomys, 282

Fouriese Dwergvlermuis, 8o

Fox, Bat-eared, io6

Fox, Cape, I07

Fox, Delalande's, 106

fractilis, Erinaceus, I 8

francescae, Cercopithecus, 99

franqueti, Epomops, 46, 47

fraseri, Anomalurus, 250

frater, Pelomys, 290

fraterculus, Miniopterus, 87

fraterculus, Tatera, 318, 319

frederici, Equus, 166

frons, Lavia, 54

frontalis, Erinaceus, 18

Fruit-Bat, Anchieta's, 46

Fruit-Bat, Angolan Epauletted, 49

Fruit-Bat, Bocage's, 46

Fruit-Bat, Cape, 45

Fruit-Bat, Dobson's, 47

Fruit-Bat, Dwarf Epauletted, 49

Fruit-Bat, Egyptian, 45

Fruit-Bat, Franquet's, 47

Fruit-Bat, Hammer-headed, 47

Fruit-Bat, Little Collared, 50

Fruit-Bat, Little Epauletted, 48

Fruit-Bat, Peter's Epauletted, 49

Fruit-Bat, Straw-Coloured, 44

Fruit-Bat, Wahlberg's, 48

fryi, Malacothrix, 305

fuchsi, Lycaon, I Io

fuliginosa, Nycteris, 53

fulvorubescens, Raphicerus, I 84

fulvorufula, Redunca, I 75, r9r

fumigatus, Lepus, 2 I 6

fumigatus, Rhinolophus, 56, 6 o

fumosus, Mystromys, 314

FUNISCIURUS, 24I, 243, 247

Fur Seal, Cape, I 53

fuscatus, Pipistrellus, 8I

fuscicolor, Cephalophus, I 8 I

fuscus, Dasymys, 288

fuscus, Elephantulus, 9

fusca, Hyaena, I 42

fuscus, Rattus, 275

fuscus, Saccostomus, 295

GALAGO, 90, 91

Galago, Demidoff's, 9I

Galago, Senegal, 9I

Galago, 'Thicktailed, 92

Galagoides, 90

Galeopardus, I 44

galeopardus, Felis, 147

galera, Atilax, I 30

Galerella, I 19, 124, I26

Galeriscus, I 36

gambianus, Cricetomys, 295

gambianus, Epomophorus, 48

gambianus, Heliosciurus, 242 gariepensis, Crocuta, I43

gariepensis, Syncerus, 2 I I garneri, Amblysomus, 38 garnetti, Galago, 93

gazae, Syncerus, 212

gazella, Oryx, I97

Gebandemuishond, I33

Geelbobbejaan, I I I

Geelbosrot, 3 13

Geeldakvlermuis, 85

Geelkoldas, I6o'

Geelkruipmol, 35

Geelmeerkat, I 37

Geelpooteekhorinkie, 244

Geelvrugtevlermuis, 44

Gemsbok, I 97

Gemsbokmuis, 259

Genet, Large Spotted, 122

Genet, Rusty-spotted, I 23

Genet, Small-spotted, I 2 I

GENETTA, I 18 , r2 1

genetta, Genetta, I 2 I

Gensbok, 197

Geocyon, I40

geoffroyi, Rhinolophus, 56, 57

geoffroyi, Tadarida, 66

Geoffroyse Blaarneusvlermuis, 57

Georhychus, 229

GEORYCHUS, 227, 229

Geosciurus, 240, 249

Gerbil, Bocage's, 31 8

Gerbil, Böhm's, 318

Gerbil, Brushtailed, 3 I 7

Gerbil, Cape Greater, 3 I9

Gerbil, Cape Short-tailed, 3 I 4

Gerbil, Lesser, 31 5

Gerbilliscus, 317, 3 I 8

Gerbillurus, 315, 3I 7

GERBILLUS, 314, 315

gerbillus, Gerbillus, 3 I 5

gerrardi, Nandinia, 120

Gestreepte Eekhorinkie, 247

Gevlektehiëna, I42

ghansiensis, Ictonyx, I I 2

Giant Rat, African, 295

giganteus, Ictonyx, I I 3

gigas, Hipposideros, 62

gigas, Scotophilus, 85

gilli, Tatera, 322

ginginianus, Xerus, 250

Giraf, 173

GIRAFFA, I 73

giraffa, Giraffa, I 74

Giraffe, I 73

glacialis, Eubalaena, 326

GLAUCONYCTERIS, 72, $8 \mathbf{2}$

glaucus, Cercopithecus, 97

gleimi, Genetta, 123

Gliriscus, 253

GLOBICEPHALA, 332

globiceps, Globicephala, 332

gnou, Connochaetes, 204

Gnu, Brindled, 205

gnu, Connochaetes, 205

Gnu, Whitetailed, 204

gobabis, Lycaon, I I

godonga, Alcelaphus, 203

Golden Mole, Cape, 40

Golden Mole, Congo, 35 
Golden Mole, De Winton's, 39

Golden Mole, Giant, 42

Golden Mole, Grant's, 38

Golden Mole, Gunning's, 38

Golden Mole, Hottentot, 36

Golden Mole, Rough-haired, 4 I

Golden Mole, Sclater's, 35

Golden Mole, Yellow, 35

gordoni, Diceros, 163

gordoniensis, Elephantulus, I I

Gorgon, 204, 205

gorgon, Connochaetes, 205

gorongozae, Alcelaphus, 203

goslingi, Colomys, 286

Graatjiemeerkat, I 39

gracilior, Eptesicus, 75

gracilis, Hipposideros, 6 I

gracilis, Suncus, 2 I

grahami, Rattus, 278

GRAMMOMYS, 262

Grampidelphis, 332

GRAMPUS, 332

grandicornis, "Antilope," 199

grandis, Ichneumia, I35

grandis, Micropteropus, 49

granti, Dendrohyrax, I6 1

granti, Eremitalpa, 39

granti, Galago, 92

granti, Lepus, 214

granti, Otomys, 3 I I

granti, Rattus, 266, 268

GRAPHIURUS, 253, 259

gratulus, Suncus, 2 I, 22

grayi, Dendrohyrax, 160

grayi, Lutra, I 16

grayi, Mesoplodon, 328

grayi, Raphicerus, 184

gregorianus, Thryonomys, 237, 238

greyi, Ourebia, 187

Grimmia, I8I

grimmia, Sylvicapra, I8 I

griquae, Procavia, I 59

griquae, Rhabdomys, 28I

griquae, Tatera, 32 I

griquoides, Rhabdomys, 282

griseipes, Papio, I 1 I, 102

griselda, Felis, 145

griselda, Graphiurus, 255

griselda, Lemniscomys, 290, 291

grisea, Damaliscus, 201

griseus, Grampus, 332

griseus, Herpestes, I 25

grisea, Raphicerus, 186

grisonax, Mungos, I 34

Grof haarkruipmol, 4I

Grootgrysmuishond, 125

Grootklaasneus, I 5

Groototter, I 16

Grootkolmuskejaatkat; 122

Grootoormuis, 305

Grootste Losstertvlermuis, 64

Groter Grysdwergskeerbekmuis, 22

Groter Grysmol, 234

Ground Squirrel, Cape Bristly, 249

Ground Squirrel, Kaokoveld Bristly, 250

Growwevelvlermuis, 78

Grysboommuis, 303

Grysbock, 183

Grysbok, 185
Grysbok, Sharpe's, 186

Grysbontvlermuis, 8I

Grysjakkals, 109

gueinzii, Dasymys, 288

Guepar, I5I

Guereza, 94

Guevei, I 78

guillarmodi, Amblysomus, 36

guinasensis, Petromus, 239

gungunyanae, Lepus, 217

gunningi, Amblysomus, 33, 34, 38

Gunningse Kruipmol, 38

haagneri, Cricetomys, 296

haagneri, Ichneumia, I 35

haagneri, Platymops, 63

hahni, Suricata, I40

Halarctus, 152

haldemani, Epomophorus, 48

hamiltoni, Felis, 148

hamiltoni, Suricata, I40

hamiltoni, Tragelaphus, 209

Hare, Bushman, 218

Hare, Cape, 2 I 3

Hare, Natal Red, 219

Hare, Rand Red, 220

Hare, Sala's, 215

Hare, Scrub, 216

Hare, Smith's Red, 22 I

Hare, Southern Bush, 216

Hare, Whyte's, 216

harei, Macroscelides, I4

harei, Rattus, 273

Harige Langoorvlermuis, 52

harrisi, Hippotragus, 200

harrisoni, Proteles, I4I

Hartebeest, 202

Hartebeest, Lichtenstein's, 203

hartmannae, Equus, I65, 166

hartensis, Lepus, 215

harveyi, Cephalophus, I 78

harveyi, Malacothrix, 305

hastatus, Cephalorhynchus, 33 I

hastata, Ourebia, 187

heavisidei, Cephalorhynchus, 33 I

hecki, Cephalophus, 18o

Hedgehog, Cape, I 8

Helamis, 25I

Helamys, 25I

Heleotragus, I9I

HELIOPHOBIUS, 227, 228

HELIOSCIURUS, 24I, 242

Heliosorex 24

HELOGALE, I 8 , 131

helvescens, Cercopithecus, 97

helvum, Eidolon, 44

Hemigalago, 90

hemprichianus, Madoqua, I9o

hendersoni, Crocidura, 26

hendersoni, Rhynchocyon, I 7

hera, Crocidura, 3 I

herero, Crocidura, $3 \mathrm{I}$

herero, Lepus, 213,217

herero, Rattus, 274

herero, Scotophilus, 86

HERPESTES, I I 9, 124, 125

herpestes, Suncus, 23

Heterocephalus, 227 
Heterohyrax, I 58, 16o

heuferi, Alcelaphus, 203

hewitti, Macroscelides, I 4

hildae, Saccostomus, 295

hildebrandti, Rhinolophus, 55, 60

Hildebrantse Vlermuis, 60

hildegardeae, Zelotomys, 287

hindei, Nycticeius, 85

hintoni, Genetta, 122

hintoni, Rattus, 27 I

HIPPOPOTAMUS, I 72

Hippotamus, I 72

HIPPOSIDEROS, 55, 6 o

Hippotigris, $164, \mathbf{r} 65$

HIPPOTRAGUS, I 74, I 77, 198

hirta, Crocidura, 20, 25, 28

hirundo, Nycticeius, $83, \mathbf{8 4}$

hispida, Nycteris, 52

hoamibensis, Raphicerus, I 85

hodsoni, Vulpes, ro8

Hoefystervlermuis, 57

hofmeyri, Antidorcas, 197

holobrunneus, Crocidura, 27

holosericea, Amblysomus, 37

holosericeus, Cryptomys, 230, 231, 234

holubi, Aepyceros, 196

holubi, Canis, rog

homeii, Lagenorhynchus, 33 I

Honey Badger, I I 4

Horseshoe Bat, Angolan, 60

Horseshoe Bat, Bushveld, 59

Horseshoe Bat, Cape, 58

Horseshoe Bat, Damara, 60

Horseshoe Bat, Darling's, 57

Horseshoe Bat, Dent's, 58

Horseshoe Bat, Geoffroy's, 57

Horseshoe Bat, Hildebrandt's, 60

Horseshoe Bat, Lander's, 59

Horseshoe Bat, Peak-saddle, 59

Horseshoe Bat, Swinny's, 58

horstocki, Raphicerus, I 84

Hotnot Kruipmol, 36

Hotnotse Grysmol, 231

hottentotus, Amblysomus, 34, 36

hottentotus, Cryptomys, 230, $23 \mathbf{I}$

hottentotus, Eptesicus, 7 I, 74, 76

hottentottus, Rousettus, 46

House Bat, Dark-winged Lesser, 84

House Bat, Light-winged Lesser, 84

House Bat, Longtailed, 76

House Bat, Melck's, 76

House Bat, Yellow, 85

hueti, Graphiurus, $25^{8}$

Huetia, 34

humpatensis, Tatera, 323

Hunting Dog, I Io

HYAENA, I4I

Hyaena, Brown, I42

hyaena, Hyaena, I 42

Hyaena, Spotted, I 42

Hyaenoides, Io9

Hyenoides, 109

hyenoides, Proteles, I4I

Hydrictis, I I 5

Hydrogale, I I 5

Hydrotragus, I 93, 206

HYDRURGA, I 52, 154

Hylenomys, 284

Hylomyscus, 262, 264, 270, 279 hypoxanthus, Oenomys, 287

HYPSIGNATHUS, 43, 44, 47

Hyrax, I 57

HYSTRIX, 236

ibex, Raphicerus, I 84

icarus, Otomops, 64

ICHNEUMIA, I I 9, 134

Ichneumon, 124, 125

ichneumon, Herpestes, 124, 125

Ictidonyx, I I I

Ictomys, I I I

ICTONYX, i io, $\mathbf{1} \mathbf{x}$

Ietermagog, ro4

ignitoides, Herpestes, 129

ignitus, Herpestes, 129

illovoensis, Rattus, 275

imago, Rattus, 272

Impala, I95

inaurata, Chrysochloris, 40

inauris, Xerus, 24I, 249

inclusa, Tatera, 318, 319

incomtus, Dasymys, 288

indica, Equus, 165

indica, Hystrix, 236

indicus, Ziphius, 328

indutus, Mus, 285

ineptus, Rattus, $27 \mathrm{I}$

infumata, Giraffa, I 74

infumatus, Crocidura, 27

inkulanondo, Alcelaphus, 203

inornatus, Tragelaphus, 208

inselbergensis, Bathyergus, 228

insignatus, Pelomys, 290

Insignicebus, 96

insignis, Dendromus, 304

intensa, Cynictis, 138

intermedius, Bathyergus, 228

intermedius, Rhabdomys, 28 $\mathbf{I}$

intontoi, Galago, 92

intufi, Elephantulus, 8, ro, 12

inunguis, Aonyx, I 16

Inyala, 208

iris, Amblysomus, 37

irroratus, Otomys, 306, 307, 308

irrorata, Sylvicapra, 182

isabellinus, Macroscelides, 14

isabellina, Redunca, 192

ivori, Helogale, ${ }^{32}$

Jackal, Black-backed, ro8 Jackal, Side-striped, ro9 jacksoni, Rattus, 279 jaculus, Macroscelides, I4 Jagluiperd, I 5 I

jamesoni, Cryptomys, 233 jamesoni, Dendromus, 303 jamesoni, Elephantulus, I 2 janetta, Bathyergus, 228 javanica, Nycteris, $5 \mathrm{I}$ jeppei, Otomys, 3 I I joanae, Tatera, 322 Johannesburgse Rooihaas, 220 johnstoni, Aepyceros, 196 johnstoni, Connochaetes, 205

johnstoni, Crocidura, 30

johnstoni, Graphiurus, 255 
johnstoni, Potamochoerus, I 70 johnstoni, Procavia, I 58 jordani, Anomalurus, 25I jordani, Graphiurus, 257 jorisseni, Cryptomys, 233 jubatus, Acinonyx, I 5 I jubata, Hippotragus, I 99 jubilaeus, Papio, I о I junodi, Cryptomys, 235

Kaapse Blaarneusvlermuis, 6 I Kaapse Bobbejaan, I о I

Kaapse Dakvlermuis, 75

Kaapse Hoefystervlermuis, $5^{8}$

Kaapse Kruipmol, 40

Kaapse Langhaarvlermuis, 73

Kaapse Langoorvlermuis, 53

Kaapse Muis, 277

Kaapse Nagmuis, 3 I 9

Kaapse Stekelmuis, 293

Kaapse Vlakhaas, 2 I 3

Kaapse Vrugtevlermuis, 45

kaiseri, Rattus, 265, 268-270

kalaharica, Cynictis, I 39

kalaharicus, Elephantulus, I I

kalaharicus, Gerbillus, 3 I 7

kalaharicus, Herpestes, 127

kalaharicus, Ictonyx, I I 2, I I3

kalaharicus, Lepus, 2 I 5

kalaharicus, Malacothrix, 305

kalaharicus, Paraxerus, 245

kalaharicus, Rattus, 273

kalaharicus, Steatomys, 300

Kalahari-skeerbekmuis, 30

Kameelperd, I 73

kangosa, Alcelaphus, 204

kaokensis, Equus, ${ }^{6} 7$

kaokoensis, Graphiurus, 257

kaokoensis, Herpestes, I 27

kaokoensis, Petromyscus, 298

kaokoensis, Pronolagus, 22 I

Kaokoveld Waaierstertmeerkat, 250

karasensis, Cynictis, I 39

karasensis, Petromus, 240

kariegae, Pronolagus, 2 I 9

karoensis, Elephantulus, 13

karoensis, Otomys, 310

Karroo-Rat, Brants', 312

Karroo-Rat, Bush, 3 I 0

Karroo-Rat, Littledale's, 3 I 3

Karroo-Rat, Sloggett's, 3 I I

kasaicus, Mus, 286

kasaicus, Steatomys, 300

katharina, Crocidura, 30

kaufmanni, Equus, I 67

kaufmanni, Hippotragus, 200

kaufmanni, Taurotragus, 2 I I

Keitloa, I 63

keitloa, Diceros, 163

kelleni, Graphiurus, 255

kelleni, Raphicerus, I 85

KERIVOULA, 7 I, 88

khanensis, Herpestes, I 28

khanensis, Lepus, 2 I 8

kindae, Papio, I $\mathbf{~ I ~}$

kirki, Galago, 92

kirki, Hippotragus, 200

kirki, Madoqua, I 89 klaverensis, Procavia, I6o

klaverensis, Rattus, 278

Kleindakvlermuis, 84

Kleingeelvlermuis, 86

Kleingrysmuishond, 129

Kleinhoringvlermuis, 59

Kleinklimmuis, 302

Kleinklipmuis, 297

Kleinkolmuskejaatkat, I 2 I

Kleinlosstertvlermuis, 68

Kleinnagmuis, 3 I 5

Kleinotter, I I 5

Kleinrietrot, 238

Kleinvleirot, 3 I 0

Kleinvrugtevlermuis, 49

Kleinwitstertmuishond, I 36

Kleiner Wolhaarvlermuis, 88

Kleinste Dwergskeerbekmuis, 2 I

Klimmuis, 30 I

Klimskeerbekmuis, 24

Klipbokkie, I 88

Klipdas, I 57

Klipklaasneus, 12

klippspringer, Oreotragus, I 88

Klipspringer, 188

Klipwaaierstertmuis, 257

Knopharige Bosklaasneus, I 6

knysnae, Crocidura, 32

kob, Kobus, I 93

KOBUS, I 74, I 76, I 92, I 93

kobosensis, Elephantulus, I 2, I3

kobosensis, Petron us, 240

kobosensis, Pronolagus, 220

Koedoe, 209

KOGIA, 327

Koiropotamus, I69

koiropotamus, Potamochoerus, I 70

Kolhaas, 2 I 6

Kolus, I 92

komatiensis, Cryptomys, 233

komatiensis, Rattus, 275

Komemys, 289

Kommetjiegatmuishond, I 30

konzi, Alcelaphus, 204

koodoo, Tragelaphus, 209

Kortneusklaasneus, 9

Kortoorklaasneus, I 3

Kortstertnagmuis, 3 I 4

krebsi, Lycaon, I I o

krebsi, Steatomys, 299

Krimpvarkie, I 8

Kringgat, I93

krugeri, Panthera, I 5 I

kubangensis, Cryptomys, 232

Kudu, 209

kudu, Tragelaphus, 209

kuhli, Pipistrellus, 79, 8r

Kuhlse Vlermuis, 8I

Kusimanse, Angolan, I 34

kuvelaiensis, Zelotomys, 288

labiatus, Cercopithecus, 98 labiatus, Epomophorus, 47, 48 LAEPHOTIS, 7 1,78

LAGENORHYNCHUS, $33^{\circ}$

lalandii, Cercopithecus, 97

lalandianus, Graphiurus, 254

lalandei, Lycaon, I i o 
lalandii, Megaptera, 326

lalandi, Otocyon, 107

lalandi, Proteles, I4I

lalandia, Redunca, I9I

laminatus, Otomys, 306, 307

Lamotomys, 306

lanata, Pelea, I9o

lancasteri, Herpestes, I 28

lancasteri, Ictonyx, I 13

lancasteri, Tadarida, 65, 69

landeri, Rhinolophus, 56, 58, 59

landiana, Redunca, I9I

lanea, Acinonyx, I 5 I

langi, Cryptomys, 235

langi, Elephantulus, 9

langi, Erinaceus, 18

langi, Lepus, 2 I 5

langi, Macroscelides, I4

langi, Rhynchogale, I 35

langi, Tadarida, 68

Langstertdakvlermuis, 76

lanosa, Kerivoula, 88

lanuginosa, Mystromys, 3 I 4

lapidarius, Saccostomus, 295

larseni, Felis, I47

larvatus, Potamochoerus, 170

Lasiomys, 283

Lasiopus, I 34

Lasiopyga, 95

LAVIA, 54

layardi, Mesoplodon, 328

leachi, Rousettus, 45, 46

Leafnosed Bat, Commerson's, 62

Leafnosed Bat, South African Lesser, 6 I

lebombo, Cephalophus, I 79

lebombo, Poecilogale, I I 4

lebombo, Pronolagus, 220

lebomboensis, Rattus, 274

leche, Kobus, I 93, 195

lechwe, Kobus, I 95

leechi, Kobus, 195

Leeu, I 50

legerae, Rattus, 276, 334

Leggada, 284

lehocla, Rattus, 277

lehochloides, Rattus, 279

Leiponyx, 44

lemniscatus, Funisciurus, 247

LEMNISCOMYS, 26r, 290

lentiginosa, Sotalia, 330

Leo, I49, I 50

leo, Panthera, I49, $\mathbf{5} 5^{\circ}$

Leonina, I 49

leonina, Mirounga, I 53

Leopard, 149

leopardus, Panthera. I 50

Leptailurus, r44, I 46

leptonyx, Hydrurga, I 53

lepturus, Cynictis, I 38

LEPUS, 2 1 2, 213

leschae, Chrysospalax, 42

lesueuri, Myotis, 73, 74

Lesueurse Vlerkkliervlermuis, 74

letabae, Genetta, I 24

letabae, Procavia, I 59

leucampyx, Cercopithecus, 98

leucanthus, Gerbillus, 3 I 6

leucogaster, Tatera, 320

leucogenys, Funisciurus, 247 leucomelas, Pipistrellus, 8 I

Leuconoe, 72

leuconoe, Rattus, 274

leucoprosopus, Sylvicapra, I 82

leucops, Georychus, 229

leucopterus, Taphozous, $5^{\mathbf{I}}$

leucopus, Ourebia, 187

leucorhinus, Amblysomus, 34, 35

leucorhynchus, Steatomys, 300

leucosagmaphora, Globicephala, 332, 333

leucostomus, Dendromus, 305

Le Vaillanti, Cynictis, 138

levaillanti, Xerus, 250

libyca, Felis, I44

lichtensteini, Alcelaphus, 202, 203

limbata, Tadarida, 65,68

Limnotragus, 206, 208

limpopoensis, Amblysomus, 35

limpopoensis, Felis, r49, 334

limpopoensis, Ictonyx, I 12

limpopoensis, Rattus, 276

limpopoensis, Saccostomus, 295

limpopoensis, Syncerus, 212

limpopoensis, Tatera, 322

lineatus, Rhabdomys, 28o

liodon, Tatera, 31 7, 318

Lion, 150

Liotomys, 312, 313

Liponycteris, $5 \mathbf{I}$

liposticta, Felis, 147

LISSODELPHIS, 333

Lissonycteris, 45

littledalei, Parotomys, 312, 313

littoralis, Amblysomus, 38

littoralis, Graphiurus, 256

littoralis, Tatera, 323

Livia, 54

livingstonei, Taurotragus, 2 Io

livingstonianus, Nesotragus, 188

lixus, Suncus, 20, 22

loandae, Genetta, 123

loandae, Ichneumia, I 35

loandae, Protoxerus, 248

loandicus, Heliosciurus, 243

lobatus, Rhinolophus, 56, 59

lobengulae, Tatera, 320

longicaudatus, Dendromus, 302

longicaudatus, Lepus, 2 I 6

longiceps, Amblysomus, 37

longipes, Malacomys, 287

longirostris, Stenella, 329

lönnbergi, Felis, 147

lönnbergi, Galago, 93

Lophocolobus, 94

Lophomops, 64

LOPHUROMYS, $262, \mathbf{2 8 3}$

lophurus, Suricata, I40

loveridgei, Steatomys, 299

Loxodon, 156

LOXODONTA, I 55, $\mathbf{5}^{\mathbf{6}}$

lucia, Kerivoula, 88

lucifer, Heliosciurus, 242, 243

ludia, Genetta, 122

ludlami, Cephalophus, I8I

ludwigi, Cryptomys, 23 I

lugardi, Cryptomys, 232

luimbalensis, Crocidura, 32

Luiperd, I 49

luna, Crocidura, 29 


\section{INDEX}

lunatus, Damaliscus, 200

lundensis, Herpestes, 127

Lupulella, 108

luteolus, Parotomys, 312

LUTRA, I I I, II5

lybica, Felis I45

LYGAON, I06, 109

Lynx, 144

Lynx, Caracal, 148

Maanhaarjakkals, I 40

mababiensis, Elephantulus, Io

mababiensis, Felis, I 48

mababiensis, Herpestes, 126

maccalinus, Tatera, 320

macmillani, Platymops, 63

Macrocephalus, I 7 I

Macronycteris, 6 I

Macropus, 90

Macrorhinus, I 53

macrorhynchus, Globicephala, 333

MACROSCELIDES, 8, I3

Macroscelis, I3

macrotis, Nycteris, 52, 54

macrura, Genetta, 122

macrurus, Rhynchocyon, I 7

macuanus, Nyctalus, 78

maculata, Crocuta, I43

maculata, Damaliscus, 20 I

maculicollis, Lutra, I I 5

MADOQUA, I 74, I 75, I89

magalakuini, Rattus, 272

mahali, Cryptomys, 235

major, Beamys, 294

major, Dendromus, 302

major, Lepus, 214

major, Rhabdomys, 28o

makapani, Pronolagus, 220

MALACOMYS, 262, 287

MALACOTHRIX, 226, 296, 305

malayana, Stenella, 329

malosae, Elephantulus, 9

Manatee, African, 324

mandatus, Lepus, 2 I 5

Mandrillus, I 00

Mangusta, 124

MANIS, I03

manningi, Dendrohyrax, I 6 I

mapogonensis, Elephantulus, 12

maputa, Tatera, 323

maquassiensis, Crocidura, 26

marginata, Caperea, 327

marica, Mus, 285

mariepsi, Otomys, 307

Mariko-skeerbekmuis, 26

marikquensis, Rattus, 275

mariquensis, Crocidura, 26

maritimus, Bathyergus, 228

maritimus, Herpestes, 129

marjoriae, Cercopithecus, 98

marjoriae, Petromus, 239

marjoriae, Suricata, 140

markhami, Equus, 167

marleyi, Amblysomus, 34, 36

marlothi, Procavia, I 59

Marshbuck, 208

marsupialis, Antidorcas, 196

martensi, Crocidura, 27

martiensseni, Otomops, 64 marungensis, Hipposideros, 62 maschona, Potamochoerus, I 70 mashona, Otomys, 309

mashonae, Saccostomus, 295

mashonae, Tatera, 32 I

mastersoni, Tadarida, 66

Mastersonse Losstertvlermuis, 66

Mastomys, 264, 266, 275

matschiei, Equus, I 66

matschiei, Viverra, I 2 I

mattosi, Connochaetes, 205

maunensis, Paraxerus, 245

maunensis, Steatomys, 300

maura, Rattus, 279

mauritianus, Taphozous, 5 I

maximus, Ictonyx, I I 2

maximus, Otomys, 309

mayi, Syncerus, 2 I 2

mchughi, Elephantulus, I I

mechowi, Cryptomys, 230, 235

Meerkat, Bushytailed, I 37

Meerkat, Grey, I39

Meerkat, Red, I 37

Meerkat, Selous', I 36

Meerkat, Slendertailed, I 39

Megaderma, 54

megalotis, Lepus, 2 I 7

megalotis, Otocyon, 106

megalurus, Eptesicus, 76

megalura, Suncus, 20, 24

MEGAPTERA, 326

megaspila, Viverra, I I 7

melaena, Globicephala, 332

melampus, Aepyceros, I 95

melampus, Hyaena, 142

Melanocebus, 96

melanochaitus, Panthera, I 5 I

melanogenys, Cercopithecus, 99

melanoticus, Cryptomys, 233

melanotica, Panthera, I 50

melanotis, Dendromus, 30 r, 303

melanotis, Felis, I 48

melanotis, Macroscelides, I 4

melanotis, Raphicerus, I 75, I 83, I85

melanurus, Ourebia, I 87

melanurus, Pronolagus, 22 I

melckorum, Eptesicus, 75, 76

Melckse Dakvlermuis, 76

mellandi, Cryptomys, 236

mellandi, Felis, I 45

melleri, Rhynchogale, I 35

Mellerse Muishond, I 35

MELLIVORA, I I I, II4

mellivorus, Mellivora, i I 5

mergens, Sylvicapra, I 8 I

meridionalis, Lepus, 2 I 7

meridionalis, Rhabdomys 28 I

mertensi, Galago, 92

Mesoctenus, I 5

mesomelas, Canis, I 08

mesomelas, Dendromus, 30 I

MESOPLODON, 328

messorius, Dendromus, 302

methi, Genetta, I 23

Metotomys, 306

Micaëlamys, 264

Michaelomys, 264

micklemi, Gryptomys, 232

micklemi, Lepus, 2 I 7 
Microdillus, 3I 5

microdon, Rattus, 276

Microfelis, I 44

MICROPTEROPUS, 44, 49

microtis, Graphiurus, 255

midas, Tadarida, 65,70

miliaria, Tatera, 321

MIMETILLUS, 72, 82

mimetra, Helogale, 132

mimus, Dendrohyrax, I6 I

minimus, Mus, 285

MINIOPTERUS, 7 ו , 86

minor, Chrysochloris, 40

minor, Epomophorus, 48

minor, Pelomys, 289, 290

minutoides, Mus, 284

minuta, Cephalophus, I8o

minutus, Eptesicus, 76, 77

minutus, Steatomys, 299

Miopithecus, 95

MIROUNGA, I 52 , 153

mitchelli, Tatera, 322

mitis, Cercopithecus, 96, 98

moçambicus, Loxodonta, ${ }_{5} 6$

modestus, Mus, 284

Mofhartbees, 203

moggi, Rattus, 265, 273

moholi, Galago, 9 I

Mole-Rat, Angolan Giant, 235

Mole-Rat, Cape, 228, 229

Mole-Rat, Common, 23 I

Mole-Rat, Greater Grey, 234

Mole-Rat, Hottentot, 231

Mole-Rat, Silvery, 229

moloneyi, Cercopithecus, 99

moloneyi, Mimetillus, 82

molopensis, Malacothrix, 305

molopensis, Parotomys, 3 I 3

molopensis, Rattus, 273

molyneuxi, Cryptomys, 230, 232

Mona, 95

monardi, Graphiurus, 254, $25^{8}$

Mongoose, Banded, I 33

Mongoose, Bushytailed, I 36

Mongoose, Cape Grey, I 29

Mongoose, Dwarf, I 3 I

Mongoose, Egyptian, I 25

Mongoose, Four-toed, I 36

Mongoose, Marsh, I 30

Mongoose, Meller's, I 35

Mongoose, Slender, I 26

Mongoose, Water, I 30

Mongoose, White-tailed, I 34

monstrosus, Hypsignathus, 47

montanus, Amblysomus, 36

montanus, Cryptomys, 233

montanus, Equus, 165

montanus, Tatera, 320

monteiri, Galago, 93

monticola, Cephalophus, I 78, I79

monticularis, Lepus, 2 I 3,218

monticularis, Petromyscus, 297, 298

monticularis, Rattus, 278

montosus, Graphiurus, 257

Mops, 64, 69

mordax, Atilax, I 3 I

morio, Rattus, 269,279

Mormopterus, 64

Morunga, I 53 moschatus, Nesotragus, 187

moshesh, Rhabdomys, 282

mossambicus, Cercopithecus, 99

mossambicus, Dendrohyrax, $\mathbf{I}_{\mathbf{I}}$

mossambicus, Galago, 91

mossambica, Genetta, 123

mossambicus, Herpestes, 129

mossambicus, Paraxerus, 246

mossambicus, Petrodromus, 16

mossamedensis, Elephantulus, I I

Mouse, Bocage's Fat, 30 I

Mouse, Callewaert's, 286

Mouse, Climbing Wood, 280

Mouse, Fat, 298

Mouse, Forest, 263

Mouse Gerbil, 305

Mouse, Larger Pygmy, 286

Mouse, Pygmy, 284

Mouse, Rudd's Forest, 263

mulleri, Gerbillus, 317

mulleri, Pronolagus, 222

multiannulata, Redunca, I 92

multiscutata, Manis, I04

mungo, Mungos, I33

MUNGOS, I I 9, 132, I33

murinus, Graphiurus, 253, 254

MUS, 26r, 284

muscardinus, Rattus, 275

musculus, Balaenoptera, 326

musculus, Mus, 262, 284

Musk-Shrew, Black, 29

Musk-Shrew, Desert, 30

Musk-Shrew, Giant, 30

Musk-Shrew, Reddish Grey, 27

Musk-Shrew, Tiny, 25

Musk-Shrew, Zambesi Lesser, 28

mustelina, Ictonyx, I 12

mutabilis, Heliosciurus, 242

Myomys, 264

Myomyscus, 264

Myonax, I I 9, 124

MYONYCTERIS, 44, 50

Myoscalops, 228

Myosorex, I8, 20, 22

MYOTIS, 7 I, 72

Myotomys, 306

Myrsilus, 248

mystacalis, Dendromus, 301, 302

MYSTROMYS, 226, 313

Mythomys, 32

myurus, Elephantulus, I2

Nagapie, 9I

Nagor, I9I

Namakwalandse Klipmuis, 277

Namakwalandse Nagmuis, 314

namaquana, Felis, I 45

namaquensis, Chrysochloris, 33, 40

namaquensis, Petromus, 240

namaquensis, Rattus, $267,269,277$

namaquensis, Rhabdomys, 282

namaquensis, Suricata, I40

namaquensis, Tatera, 324

namaquensis, Xerus, 250

namibensis, Elephantulus, I I

namibensis, Parotomys, 3 I 3

namibensis, Petromyscus, 298

namibensis, Rattus, 279

namibensis, Rhabdomys, 282 


\section{INDEX}

NANDINIA, I I 7,120

Nannomys, 284

nanus, Graphiurus, 255

nana, Nycteris, 5I, 52

nanus, Pipistrellus, 79, 8o

nanus, Syncerus, 212

narranus, Lepus, 215

Nasilio, 8, 9

natalensis, Amblysomus, 37

natalensis, Cephalophus, I 78

natalensis, Cryptomys, 234

natalensis, Miniopterus, 86, 87

natalensis, Otomys, 309

natalensis, Procavia, I 59

natalensis, Raphicerus, I 85

natalensis, Rattus, 266, 269, 275

natalensis, Steatomys, 300

natalensis, Suncus, 22

natalensis, Tadarida, 70

natalensis, Tatera, 322

Natalse Bosskeerbekmuis, 23

Natalse Losstertvlermuis, 70

Natalse Rooihaas, 2 I 9

ndolae, Tatera, 322

Neamblysomus, 33, 34

neavei, Anomalurus, $25 \mathrm{I}$

neavei, Crocidura, 29

neavei, Mus, 285

neavei, Tatera, 3 I 8

nemo, Cryptomys, 233

nems, Herpestes, I 25

Neobalaena, 326

Neocebus, 96

Neoromicia, 74

nero, Helogale, I 32

NESOTRAGUS, I 74, I 75, 187

ngamiensis, Cercopithecus, 98

ngamiensis, Herpestes, I 28

ngamiensis, Lepus, 218

ngamiensis, Mungos, I 34

ngamiensis, Papio, I03

ngamiensis, Paracynictis, I 37

nictitans, Cercopithecus, 96, 99

nictitans, Sylvicapra, I8 I

nidicola, Kerivoula, 89

niediecki, Alcelaphus, 204

niediecki, Syncerus, 212

niediecki, Taurotragus, 2 I I

niedieckianus, Alcelaphus, 204

niger, Diceros, 163

niger, Felis, 147

niger, Hippotragus, 198, 199

Night-Ape, Senegal, 9 I

Night-Ape, Thicktailed, 92

nigratus, Herpestes, I29, 130

nigrescens, Lepus, 218

nigricans, Crocidura, 29

nigricaudus, Ictonyx, I 12

nigricauda, Rattus, 265, 273

nigrifrons, Dendromus, 304

nigripes, Bdeogale, 136

nigripes, Felis, I44, 146

nigripes, Papio, 102

nigrita, Scotophilus, 85

nigrotibialis, Tatera, 32 I

niloticus, Arvicanthis, 264

nimrodi, Cryptomys, 232

nitela, Rattus, 274

nitidofulvus, Suncus, 2 I niveiventer, Tadarida, 69

nivosus, Arctocephalus, I 53

nkatiensis, Eptesicus, 75

noctula, Nyctalus, 78

Noctule, Common, 78

noomei, Sylvicapra, 182

norvegicus, Rattus, 262

notatus, Kobus, 195

notius, Eptesicus, 75,78

Nototragus, I 75, 183

novaeangliae, Megaptera, 326

nubica, Felis, 148

nudipes, Dasymys, 288

Nyala, 206, 208

Nyalabosbok, 208

nyasae, Cephalophus, 180

nyasae, Cercopithecus, 99

nyasae, Crocuta, I43

nyasae, Dendromus, 303

nyasae, Galago, 92

nyasae, Potamochoerus, I 70

nyasae, Rhabdomys, 282

nyasae, Tatera, $32 \mathrm{I}$

NYGTALUS, $7 \mathrm{I}, 78$

NYCTERIS, $5 \mathrm{I}$

NYCTICEIUS, 7 1,83

Nyctinomus, 64

Nyctiptenus, 74

Nyctochoerus, I69

nyikae, Crocidura, 25, 30

nyikae, Dendromus, 303

nyikae, Otomys, 309

nyikae, Pronolagus, 22 I

nyikae, Rattus, 268, 270

obergi, Acinonyx, I 5 I

obscurus, Alcelaphus, 203

obscura, Felis, I 45

obscurus, Lagenorhynchus, 33 I

obscurus, Mungos, I 33

obscura, Otomys, 308

obtusirostris, Amblysomus, .34, 3.5

occidentalis, Colobus, 95

occidentalis, Crocidura, I9, $3 \mathbf{I}$

occidentalis, Diceros, I63

occidentalis, Papio, 102

occidentalis, Petrodromus, I 5

occidentalis, Redunca, 192

ochraceus, Papio, I I I

Ochromys, 264

ochropoides, Lepus, 2 I 5

ochropus, Lepus, 214

ocularis, Graphiurus, 253, 259

ocularis, Sylvicapra, 182

Oegocerus, 198

OENOMYS, 26r, 287

oenone, Funisciurus, 247

ogilbyi, Cynictis, I 38

Ogmorhinus, I 53

okavangensis, Herpestes, I 28

okombahensis, Elephantulus, I I

oleotragus, Redunca, 192

Olifant, I 56

olivellus, Funisciurus, 247

omurambae, Sylvicapra, 182

Onototragus, 193

Onotragus, I 76, 193

Oorbietjie, 186 
operculatus, Connochaetes, 205 opisthostictus, Cercopithecus, 99 Opsiceros, 162

oralis, Gerbillus, 316 orangensis, Amblysomus, 38

orangensis, Lepus, 218 orangiae, Cryptomys, 235

orangiae, Ictonyx, I 12

orangiae, Mus, 286

orangiae, Pedetes, 252

orangiae, Procavia, I 59

orangiae, Rhabdomys, 282

orangiae, Steatomys, 299

orangiae, Suncus, 2 I

Orasius, I 73

orbicularis, Sylvicapra, 182

orca, Orcinus, 33 I

ORCINUS, 33 I

Oreas, 209

oreas, Taurotragus, 210

Oreinomys, 306

Oreodorcas, I9I

Oreomys, 306

OREOTRAGUS, $174, \mathbf{1} 75, \mathbf{1 8 8}$

oreotragus, Oreotragus, I 88

oriana, Nycteris, 54

Orias, 2 10

Oribi, 186

Oribia, 186

orientalis, Otomys, 310

orientalis, Papio, IO2

orientalis, Viverra, I 2 I

Oritragus, I 88

ornatus, Herpestes, 127

ornatus, Paraxerus, 246

ornatus, Tragelaphus, 208

ORYGTEROPUS, I 54

Orycterus, 228

ORYX, I 74, I 76, 197

oryx, Oryx, 198

oryx, Taurotragus, 210

oswelli, Diceros, 164

otjiwarongensis, Dendrohyrax, I6 I

OTOCYON, I 06

Otogale, 90

Otolemur, 90, 92

Otolicnus, 90

OTOMOPS, $63, \mathbf{6}_{4}$

OTOMYS, 305, 306

Otopithecus, 95

Otter, Cape Clawless, I 6

Otter, Spotted-necked, I I 5

Otter-Shrew, 32

ourebi, Ourebia, I 86

OUREBIA, I 74, I 75, 186

ovamboensis, Cryptomys, 230, 234

ovamboensis, Ictonyx, I I 3

ovamboensis, Rattus, 276

Ozanna, I 98

Pachyotus, 85

Pachyura, 20

Pachyuromys, 314

paeba, Gerbillus, 3 I 5, 316

paedulcus, Rattus, 267, 268, 273

pagei, Saccostomus, 295

palki, Cryptomys, 235

pallasi, Phacochoerus, I 72

palliatus, Colobus, 94 palliatus, Paraxerus, 244, 245

pallidior, Cynictis, 138

pallidior, Eptesicus, 76

pallidipes, Mungos, I 34

pallidus, Cryptomys, 233

pallida, Parotomy`, 312

pallida, Raphicerus, 184

Palm Civet, Two-spotted, 120

Palmsiwet, 120

paludinosus, Atilax, I 30

paludosus, Atilax, I3 I

Pangolin, Cape, I04

Pangolin, Tree, 104

panja, Tatera, 32 I

PANTHERA, I43, 149

papilio, Glauconycteris, 83

PAPIO, 93, 100

PARACYNICTIS, 118,136

Paraonyx, I 6

PARAXERUS, 24I, 243

pardella, Felis, I49

Pardus, 149

pardus, Panthera, I49

PAROTOMYS, 306, 312

parva, Arctocephalus, I 53

parvulus, Graphiurus, 257

parvula, Helogale, I 3 I

pasan, Oryx, 198

pecilei, Dendromus, 304

PEDETES, 25I

Pedestes, 251

Pediotragus, 183

pediotragus, Raphicerus, I 84

pegasus, Syncerus, 212

PELEA, 1 74, 1 76, r9o

PELOMYS, 26r, 289

pembertoni, Funisciurus 248

penicillata, Cynictis, 137

penricei, Equus, 166

penricei, Kobus, I94

penricei, Redunca, 192

pentonyx, Steatomys, 299

percivali, Cloeotis, 62

perforatus, Taphozous, $5^{\mathbf{I}}$

Peroëchinus, 17

peroni, Arctocephalus, 153

peroni, Lissodelphis, 333

perpallida, Tatera, 322

perpusilla, Cephalophus, I 80

personata, Damaliscus, 20 I

pestis, Tatera, 322

Petalia, 5I

Petaurista, 95

petersi, Aepyceros, 196

petersi, Alcelaphus, 204

PETRODROMUS, 8, 15

PETROMUS, 226, 237, 239

Petromys, 239

PETROMYSCUS, 225, 297

petrophilus, Platymops, 63

PHACOCHOERUS, I69, I 7 r

phalaena, Paraxerus, 245

Phascochaeres, I 7 I

Phascochaerus, I 7 I

Phascochoeres, I 7 I

Phascochoerus, I 7 I

phasma, Galago, 91

Phatagin, 103

Phataginus, 103, 104 
Philantomba, 177, I 78, I 79

phillipsi, Damaliscus, 20 I

phippsi, Rattus, 272

Phoniscus, 88

Phygetis, 50

Phyllorhina, 6o, 6I

physalus, Balaenoptera, 325

PHYSETER, 327

picturatus, Cercopithecus, 99

pictus, Lycaon, I I 0

Piesangvlermuis, 80

Piliocolobus, 94

pilosa, Crocidura, 20, 25, 29

Pilot Whale, Indian, 333

Pilot Whale, Southern, 333

Pipistrelle, Anchieta's, 80

Pipistrelle, Kuhl's, 81

Pipistrelle, Minute, 80

PIPISTRELLUS, 7 1, 79, 80

piriensis, Rhinolophus, 58

pitmani, Crocidura, 26

Planiceros, 2 I I

planirostris, Scotophilus, 86

Platkoplosstertvlermuis, 63

platous, Sylvicapra, I 82

platycephalus, "Vespertilio," 89

PLATYMOPS, 63

platyops, Graphiurus, 253, 254, 257

platyotis, Sylvicapra, I 82

PLEROTES, 44, 46

plowesi, Bathyergus, 228

pluto, Cercopithecus, 98

pococki, Equus, I67

POECILOGALE, I I I, II3

Poekoe, 194

Poëlagus, 219

Poemys, 30I

poensis, Glauconycteris, 82

Pogonocebus, 95

polykomos, Colobus, 94

pondoensis, Crocidura, 27

pondoensis, Ictonyx, I 12

pondoensis, Otomys, 307

pondoensis, Scotophilus, 86

pondoensis, Suncus, 23

pondoliae, Amblysomus, 37

pongolensis, Dendromus, 303

porcaria, Papio, I02

Porcupine, Cape, 236

porcus, Potamochoerus, I 70

Porpoise, $33 \mathrm{I}$

POTAMOCHOERUS, 169

POTAMOGALE, 32

Potamotragus, I 78

Pouched Mouse, Cape, 294

Pouched Rat, Larger ' Long-tailed, 294

powelli, Pronolagus, 220

praetextus, Funisciurus, 247

Praomys, 264, 266, 277

pratensis, Chrysospalax, 4I

pratensis, Steatomys, 298

pretoriae, Cryptomys, 235

pretoriae, Dendromus, 304

pretoriae, Graphiurus, 255

pretoriae, Ictonyx, I I 3

pretoriae, Mus, 286

pretoriae, Otomys, 309

pretoriae, Rattus, 272

pretoriae, Tatera, 323 prieskae, Rhabdomys, 282

princeps, Xerus, 249, $25^{\circ}$

proboscideus, Macroscelides, I3

PROCAVIA, I 57

Procolobus, 94

Prodelphinus, 329

PRONOLAGUS, 212 , 219

PROTELES, I05, I40

PROTOXERUS, 241, $24^{8}$

pruinosus, Papio, I I I

Pseudoconomys, 284

Pseudokobus, 193

PSEUDORCA, 33 I

Pterobalaena, 325

Pterocyon, 44

Pterycolobus, 94

ptoox, Sylvicapra, 182

Ptychorhina, 6 I

pudicus, Desmodillus, 3 I 5

puella, Panthera, I 50

puisa, Bdeogale, 136

Puku, 194

pulchella, Lemniscomys, 29 I

pulchra, Genetta, 122

pulverulentus, Herpestes, I 24, I25, 129

pumila, Tadarida, $65, \mathbf{6}_{7}$

pumilio, Dendromus, 301, 302

pumilio, Rhabdomys, 280

punctulatus, Herpestes, 127

pungwensis, Syncerus, 212

punyana, Diceros, $\mathbf{I}_{3}$

pusilla, Arctocephalus, I 53

pusillus, Cercopithecus, 97

pusillus, Eptesicus, 74, 76

pusillus, Micropteropus, 49

pygargus, Antidorcas, 196

pygargus, Damaliscus, 200, 201

pygerithraeus, Cercopithecus, 97

pygerythrus, Cercopithecus, 97

pygmea, Cephalophus, I80

pyrrhopus, Funisciurus, 247, $24^{8}$

pyrrhus, Felis, 146

Quadriscopa, 186

Quagga, I64, I65

quagga, Equus, I64

quotus, Paraxerus, 245

randensis, Otomys, 309

randensis, Pronolagus, 219, 220

Raphiceros, 183

RAPHICERUS, I 74, I 75, 183

Rat, Angola, 276

Rat, Black-tailed Tree, 273

Rat, Broad-headed, 287

Rat, Creek, 289

Rat, Four-striped, 280

Rat, Gosling's Swamp, 286

Rat, Groove-toothed Swamp, 290

Rat, Harsh-furred, 283

Rat, Ice, 3 I I

Rat, The Kaiser's, 270

Rat, Kusu, 264

Rat, Lesser Creek, 290

Rat, Milne-Edwards' Swamp, 287

Rat, Mlanje, 279

Rat, Multimammate, 275

Rat, Namaqua Rock, 277

Rat, Nile, 264 
Rat, Nyika, 270

Rat, Red Veld, 27 I

Rat, Rudd's, 292

Rat, Rufous-nosed, 287

Rat, Single-striped grass, 29 I

Rat, Soft-furred, 279

Rat, Speckled Harsh-furred, 283

Rat, Spotted Grass, 29I

Rat, Verreaux's, 277

Rat, White-tailed, 3 I 3

Rat, Woosnam's Desert, 274

Ratel, I I 4

ratel, Mellivora, I I 5

ratlamuchi, Herpestes, I 19, 128

RATTUS, 262, 264

rattus, Rattus, 262

reclinis, Damaliscus, 20 I

recticornis, Oryx, I97

Red River Hog, 170

REDUNCA, I 74, I 76, I9I

redunca, Redunca, I9I

Reedbuck, 192

Reedbuck, Mountain, I9I

reichardi, Rhynchocyon, I 7

reichei, Connochaetes, 205

rendalli, Alcelaphus, 204

rendalli, Eptesicus, 75, 77

reuningi, Procavia, 158

Reuse Kruipmol, 42

Reuserot, 295

rex, Acinonyx, I5I

Rhabdogale, I I I

RHABDOMYS, 26I, 280

Rhaphiceros, 183

Rhaphicerus, 183

Rhaphocerus, 183

Rhinaster, 162

Rhinoceros, Black, 163

Rhinoceros, White, 164

Rhinogale, I 35

RHINOLOPHUS, 55

Rhinomus, 24

Rhinomys, I3

Rhinonax, 16

Rhinophoca, I 53

Rhinopterus, 70, 74, 78

Rhinostictus, 95

Rhinostigma, 95

rhodesiae, Arvicanthis, 264

rhodesiae, Dendrohyrax, I6 I

rhodesiae, Heliosciurus, 242

rhodesiae, Papio, I02

rhodesiae, Pelomys, 290

rhodesiae, Rattus, 273

rhodesiae, Rhinolophus, 58

rhodesiae, Tadarida, 65,67

RHYNCHOCYON, 8, 16

RHYNCHOGALE, I I 9, I35

Rhynchotragus, I 75, 189

Rhyzaena, I39

Ribbokhaas, 216

richardsoni, Grampus, 332

Rietbok, I92

Rietmuis, 238

Rietrot, 238 .

rita, Lophuromys, 283

Rizaena, I 39

Roan Antelope, 198

Rob, 153 robertsi, Cephalophus, I 79

robertsi, Felis, $\mathbf{1 4} \mathbf{8}, 334$

robertsi, Kobus, 195

robertsi, Otomys, 3 I I

robertsi, Rattus, 274, 334

robustus, Heliophobius, 229

Rock Mouse, Berseba, 298

Rock Mouse, Pygmy, 297

Rock Rat, 239

Roeskleurvlermuis, 80

rogersi, Chalinolobus, 82

Romicia, 79

Rooibok, 195

Rooiboommuis, 301

Rooiduiker, 178

Rooieekhorinkie, 245

Rooigrysskeerbekmuis, 27

Rooihartbees, 202

Rooijakkals, 108

Rooikat, I48

Rooikolmuskejaatkat, I 23

Rooimeerkat, 137

Rooimuishond, 126

Rooipootjie, 213

Rooiribbok, 192

Rooiskeerbekmuis, 30

Rooiveldrot, 271

roothi, Felis, 148

Rorqual, Cape, 325

Rorqual, Common, 325

Rorqual, Lesser, 325

rossi, Mungos, I 34

rostratus, Steno, 330

roualeyni, Tragelaphus, 207

ROUSETTUS, 44, 45

rovumae, Petrodromus, 15 , 16

rowleyi, Otomys, 309

rozeti, Elephantulus, 8

ruacana, Papio, I03

rubellus, Atilax, $\mathbf{I}_{3} \mathbf{I}$

rubiginosa, Genetta, I 2 I, 1 22, 123

rubra, Chrysochloris, 40

rubroalbescens, Raphicerus, 186

ruddi, Cephalophus, 180

ruddi, Dendrohyrax, I6 1

ruddi, Grammomys, 262, 263

ruddi, Herpestes, 129

ruddi, Pronolagus, 2 I 9

ruddi, Tatera, 320

ruddi, Uranomys, 292

Ruddse Bosmuis, 263

Rudolphius, 325

rueppelli, Pippistrellus, 79, 8r

rufa, Crocuta, I 43

rufa, Rattus, 275

rufescens, Elephantulus, 8

rufescens, Raphicerus, 184

ruficeps, Helogale, 132

ruficrista, Cephalophus, 179

rufifrons, Parotomys, 312

rufinucha, Lepus, 216

rufopallidus, Chrysospalax, 42

rufoviridis, Cercopithecus, 97

rufulus, Cryptomys, 233

rupestris, Elephantulus, 8, I0, I I, 12

rupestris, Pronolagus, 219,221

rupestris, Raphicerus, 184

rupicola, Graphiurus, 257

rüppelli, Pipistrellus, 79,81 
russatus, Acomys, 293

russula, Crocidura, I 9, 25, 26

rusticana, Felis, I45

rusticus, Pipistrellus, 79, 80

rutilus, Crocidura, 3 I

rutila, Ourebia, I 87

rutilans, Amblysomus, 37

Rysaena, I39

Ryzaena, I 39

Saalneusvlermuis, 59

sabiensis, Herpestes, I 25

sabiensis, Lemniscomys, 292

sabiensis, Nycteris, 54

sabiensis, Otomys, 3 I 0

Sable Antelope, I99

sabulatus, Lemniscomys, 292

saccata, Antidorcas, I 96

Saccolaimus, 5 I

SACCOSTOMUS, 225, 260, 294

sacralis, Crocidura, 28

salai, Lepus, 2 I 3,2 I 5

saliens, Antidorcas, I97

salinae, Pedetes, 252

salsa, Tatera, 32 I

saltans, Antidorcas, 197

saltatrix, Antidorcas, 197

saltator, Oreotragus, I 89

saltatrix, Oreotragus, I 88

samango, Cercopithecus, 98

Samango Monkey, 98

Samangoaap, 98

Sambesiese Kleinrooiskeerbekmuis, 28

Sand Mole, Cape, 228

sandbergi, Colobus, 94

sanguineus, Herpestes, I I 9, I 24, I 25, 126

Sassaby, 200

saundersiae, Otomys, 307, 310

saundersiae, Pronolagus, 22 I

Sauromys, 63

saxatilis, Lepus, 2 I 6

Scabrifer, 74

Scalytail, Common, $25^{\circ}$

Schaeffia, i 08

schinzi, Elephantulus, 9

schinzi, Tatera, 3 I 8, $\mathbf{3}^{20}$

schisthyperöes, Arctocephalus, I 53

schlegeli, Tatera, 3 I 9

schlieffeni, Nycticeius, $83,8_{4}$

schneideri, Graphiurus, 253, 256

Schreiberse Vlermuis, 86

schreibersi, Miniopterus, 86, 87.

schulzei, Procavia, I 59

schwanni, Petrodromus, 16

schwarzi, Cercopithecus, 99

schwarzi, Viverra, I 2 I

Sciurocheirus, 90

sclateri, Amblysomus, 34, 35

sclateri, Suncus, 23

sclateri, Thryonomys, 238

Sclaterse Kruipmol, 35

scoparia, Ourebia, 187

Scopophorus, I 86

Scoteinus, $\mathbf{8}_{3}, 84$

scotinus, Miniopterus, 87

Scotoecus, 70, 83, 84

SCOTOPHILUS, 7 I , 85

Scotozous, 79, 8I

scripta, Damaliscus, 20 I scriptus, Tragelaphus, 207

seabrai, Myotis, 73, 74

Seal, Elephant, I 53

Seal, Leopard, I 54

Sea-lion, Cape, I 53

Seekoei, I 72

Seeleeu, I 53

selbornei, Alcelaphus, 203

selindensis, Cricetomys, 296

selindensis, Elephantulus, I0

selindensis, Graphiurus, 256

selousi, Acomys, 293

selousi, Equus, I66, I68

selousi, Loxodonta, I 56

selousi, Paracynictis, I 36

selousi, Taurotragus, 2 I I

selousi, Tragelaphus, 208

Selysius, 72, 73

semicircularis, Procavia, I 58

senegalensis, Galago, 90, 9I

senegalensis, Genetta, 122

senegalensis, Trichechus, 324

senescens, Mungos, I 33

sengaani, Paracynictis, 137

senganus, Alcelaphus, 203

senganus, Kobus, I 94

septemvittatus, Rhabdomys, 280

septentrionalis, Amblysomus, 38

Serotine, Bocage's, 77

Serotine, Cape, 75

Serotine, Little, 76

Serotine, Rendall's, 77

Serotine, White-winged, 77

serotinus, Eptesicus, 74

Serval, I 44, I 46

serval, Felis, I44, 146

Servalina, I 44

servalina, Felis, 146

setosus, Xerus, $25^{\circ}$

sharpei, Colobus, 95

sharpei, Raphicerus, I 75, I 83, 186

sheppardi, Suncus, 24

shirensis, Alcelaphus, 203

shirensis, Heliosciurus, 242

shirensis, Sylvicapra, I 82

shirensis, Tatera, 32 I

shortridgei, Amblysomus, 36

shortridgei, Chrysochloris, 40

shortridgei, Crocidura, 25, 30

shortridgei, Dendromus, 304

shortridgei, Elephantulus, Io

shortridgei, Herpestes, I 29, 130

shortridgei, Ictonyx, I I 3

shortridgei, Panthera, I 50

shortridgei, Petromyscus, 297

shortridgei, Phacochoerus, I 72

shortridgei, Rattus, 268, 274, 276

shortridgei, Tadarida, 65,69

shortridgei, Zelotomys, 288

Shrew, Climbing, 24

Shrew, Common EuropeanWhite-toothed, 26

Shrew, Dark-footed Forest, 23

Shrew, Dwarf, 2 I

Shrew, Forest, 22

Shrew, Greater Dwarf, 22

Sibbaldus, 325

siccatus, Rattus, 278

sicialis, Rattus, 276

Sideroderma, 6 I 
Sigmoceros, 202

sikapusi, Lophuromys, 283

silaceus, Cercopithecus, 97

silacea, Crocidura, 26

silaceus, Rattus, 276

silberbaueri, Otomys, 307

silindensis, Grammomys, 263

silindensis, Rattus, 272

silvestris, Felis, I 45

silvicultor, Cephalophus, I 78, 179

silvicultrix, Cephalophus, I 79

Silwerjakkals, 107

Simenia, 108

similis, Stenella, 329

simulator, Rhinolophus, 56, 59

simus, Diceros, I63, r64

sindi, Paraxerus, 244

Sitatunga, 208

Siwetkat, 120

Slangmuishond, I 13

Sloggetse Karorot, 3 I I

sloggetti, Otomys, 307, $3 \mathbf{1}$

smithemani, Kobus 195

smithi, Crocidura, I 9, 25, 30

smithi, Eptesicus, 76

Smithse Rooihaas, 22 I

smitianus, Miniopterus, 87

Smutsia, 103, 104

soccatus, Paraxerus, 244

socialis, Rattus, 275

Soenie, 187

Son-eekhorinkie, 242

sorella, Suncus, 24

SOTALIA, 329

spekei, Tragelaphus, 206, 208

Spermosciurus, 249

sphingiola, Papio, 102

spillmanni, Tadarida, $65,6_{7}$

spinalis, Lemniscomys, 29 I

spinosissimus, Acomys, 293

Spiny Mouse, Cape, 293

Spiny Mouse, Common, 293

splendidula, Sylvicapra, 182

sponsus, Paraxerus, 246

Spring Hare, 25I

Springbok, 196

Springbuck, 196

Springhaas, 251

Squirrel, African Giant, 248

Squirrel, Bayon's, 248

Squirrel, Bush, 244

Squirrel, Eastern Striped, 246

Squirrel, Nyasa Black and Red, 243

Squirrel, Red-footed, 248

Squirrel, South African Red, 245

Squirrel, Sun, 242

Squirrel, Vincent's, 245

Squirrel, Western Striped, 247

Stachycolobus, 94

stairsi, Cercopithecus, 98

stangeri, Protoxerus, 248

STEATOMYS, 260, 297, 298

steedmanni, Cynictis, I 38

Steenbok, 184

Steinbok, I 84

steinhardti, Oreotragus, 189

steinhardti, Otocyon, 107

steinhardti, Raphicerus, 185

steinhardti, Sylvicapra, 182
Stekelmuis, 293

stellae, Tatera, 321

stellatus, Cryptomys, 230, 233

stenbock, Raphicerus, I84

STENELLA, 329

STENO, 330

Stenonycteris, 45

Stenopontistes, 330

Stenorhinchus, I 53

stevensoni, Cercopithecus, 99

stevensoni, Oreotragus, I 89

stevensoni, Rattus, 274

Stinkmuishond, I I I

Stochomys, 264

Stokstertmeerkat, I 39

stoliczkanus, Suncus, 20

stramineus, Eidolon, 45

Strandjut, I 42

Strandwolf, I 42

Streepmuis, 280

Streeprot, 280

streeteri, Cryptomys, 234

streeteri, Graphiurus, 255

streeteri, Saccostomus, 295

strepitus, Papio, I02

Strepsicerastes, 206

Strepsicerella, 206

Strepsiceros, 206, 208

strepsiceros, Tragelaphus, 206, 209

striata, Hyaena, I42

striatus, Ictonyx, 112

striatus, Lemniscomys, 290, 291

Striped Polecat, I I I

stuhlmanni, Chrysochloris, 33, 39

styx, Stenella, 329

suaveolens, Crocidura, 19, 24, 25

subalbina, Redunca, I9 I

subrufus, Lepus, 217

subspinosus, Acomys, 293

subtilis, Dendromus, 303

subtilis, Pipistrellus, 79, $\mathbf{8 r}$

subulata, Raphicerus, 184

suillus, Bathyergus, 228

sultan, Petrodromus, I 5 , 16

sultani, Petrodromus, I 6

SUNCUS, 18, 20

sundevalli, Phacochoerus, 172

Suni, I 87

surakkta, Suricata, 140

surdaster, Grammomys, 263

SURICATA, I 18,139

Suricate, I 39

suricatta, Suricata 139

swakopensis, Gerbillus, 317

swalius, Gerbillus, 316

swalius, Herpestes, 127

swalius, Steatomys, 299

Swamp-Rat, Anchieta's, 308

Swartskeerbekmuis, 29

Swartoorklimmuis, 303

Swartpootwildekat, 146

Swartrenoster, 163

Swartstertrot, 273

Swartwildebees, 204

Swartwitpens, I99

swellendamensis, Amblysomus, 37

swinderianus, Thryonomys, 237, 238

swynnertoni, Paraxerus, 246

swynnertoni, Petrodromus, 16 
swinnyi, Herpestes, 127

swinnyi, Rhinolophus, 56, $5^{8}$

swinnyi, Suncus, 24

Swinnyse Vlermuis, 58

sybilla, Mus, 285

sylvaticus, Tragelaphus, 207

sylvia, Crocidura, 29

SYLVICAPRA, I 74, I 75, I8r

sylvicultrix, Cephalophus, I 79

Sylvisorex, 20

Synceros, 2 I I

SYNCERUS, I 74, I 77, 2 I I

Synodesmotis, 6 I

TADARIDA, $63, \mathbf{6 4}_{\mathbf{4}}, 66$

taenianotus, Mungos, I 33

talapoin, Cercopithecus, 96, 100

Talapoin Monkey, 100

talpinus, Suncus, 23

talpoides, Gryptomys, 23 I

Tamiscus, 243

tangalunga, Viverra, I 17

TAPHOZOUS, 50, 5I

tarri, Elephantulus, I I

tasmani, Graphiurus, 256

TATERA, 3 I 4, 3I7, 3 I 8

Taterona, 3 I 7

taurinus, Connochaetes, I 77, 204, 205

TAUROTRAGUS, I 74, I 77, 209

taylori, Chrysochloris, $4^{I}$

temmincki, Eubalaena, 326

temmincki, Manis, I03, 104

tenebrosus, Uranomys, 292

tenuipinnis, Eptesicus, 75, 77

tenuis, Chrysochloris, 33, 40

tenuis, Gerbillus, 3 I 6

tenuis, Suncus, 23

tenuis, Tatera, 321

Terpone, $\mathbf{I} 78$

tetradactylus, Petrodromus, I 5

tetradactyla, Suricata, I 39

Thallomys, 264

Thamnomys, 262

thebaica, Nycteris, 52, 53

thomasi, Felis, 146

thomasi, Mimetillus, 82

thomasi, Rattus, 270

thomasinae, Redunca, 192

thornicrofti, Giraffa, I 74

thorntoni, Dendromus, 304

Thos, 1 06, 108

THRYONOMYS, 225, 237

Tierboskat, 146

tigrina, Genetta, 12 I, 122

Tigris, I 49

tongensis, Grammomys, 263

tongensis, Paraxerus, 246

tongensis, Rattus, 272

tongensis, Steatomys, 300

tongensis, Tatera, 323

Tonine, 33I

tordayi, Petrodromus, I 5

torquata, Myonycteris, 50

toxotis, Loxodonta, I 56

Trachelotherium, I 73

TRAGELAPHUS, I 74, I 76, 206, 207

tragulus, Raphicerus, 184

transvaalensis, Acomys, 293 transvaalensis, Atilax, I 31

transvaalensis, Chrysospalax, 4 I

transvaalensis, Cryptomys, 233

transvaalensis, Equus, 167

transvaalensis, Oreotragus, 189

transvaalensis, Papio, IO2

transvaalensis, Poecilogale, I I 4

transvaalensis, Proteles, I4I

transvaalensis, Steatomys, 300

transvaalensis, Suncus, 23

transvaalensis, Sylvicapra, 183

Transvaalse Losstertvlermuis, 66

Tree-Dassie, I6 I

Tree-mouse, Chestnut, 30 I

Tree Mouse, Grey Pygmy, 303

trevelyani, Chrysospalax, 42

triangularis, Taurotragus, 210

Triaulacodus, 237

TRICHECHUS, 324

tricolor, Lycaon, I Io

tricolor, Myotis, 72, 73

tricuspis, Manis, I03, I04

tridens, Cephalorhynchus, 33 I

tridentata, Manis, I 04

Triglochinopholis, 103

triton, Mus, 284, 286

tropicalis, Petromus, 239

Tropicolobus, 94

Tropiese Groeftandrot, 289

Tropiese Grysbok, 186

Tropiese Waterbok, 194

truteri, Hippotragus, I 99

Tsesseby, 200

tsumebensis, Dendrohyrax, I6 I

tsumebensis, Paraxerus, 245

tugelensis, Otomys, 3 I 0

tulbaghensis, Suncus, 22

tullbergi, Rattus, 279

tumbolensis, Galago, 92

turba, Crocidura, 29

turneri, Otomys, 3 I I

TURSIOPS, 330

tyleri, Oreotragus, 189

Typhloryctes, 230

typicus, Aepyceros, I 96

typicus, Cynictis, 138

typicus, Dendromus, 302

typicus, Equus, 167

typicus, Graphiurus, 259

typicus, Hippotragus, 199

typicus, Kobus, I94

typicus, Lycaon, I I

typicus, Macroscelides, I4

typica, Malacothrix, 305

typicus, Mellivora, I I 5

typicus, Oreotragus, I 89

typicus, Otomys, 308

typicus, Pedetes, 252

typicus, Petromus, 239

typicus, Phacochoerus, I 72

typicus, Proteles, I 4 I

typicus, Suricata, I40

typicus, Syncerus, 2 I I

typicus, Taurotragus, 2 I 0

typicus, Tragelaphus, 207, 209

typus, Dendromus, 302

typus, Elephantulus, 12

typus, Macroscelides, I3

tzaneenensis, Elephantulus, 9 
tzaneenensis, Graphiurus, 255 tzaneenensis, Rattus, 272 tzaneenensis, Tatera, 323

ugabensis, Raphicerus, I 85 ugabensis, Sylvicapra, I 83 umbrata, Mus, 285 umbratus, Platymops, 63 umbratus, Steatomys, 299 umbrosus, Galago, 93 undulata, Helogale, 132 unicolor, Epomophorus, 48 unisulcatus, Otomys, 307, 310 upingtoni, Herpestes, 129 URANOMYS, 260, 292 urinatrix, Atilax, I 30

Urolynchus, I 44

Uromanis, I 03 ursinus, Papio, ı oo, ror Ursitaxus, I I 4

Vaal Rhebok, I90

Vaalboskat, I 44 vaalensis, Rhabdomys, 282

Vaaljakkals, 109

Vaalribbok, I90

Vaalveldmuis, 275

valida, Tatera, 3 I 7, 318

vallinus, Gerbillus, 3 I 5, 317

valschensis, Cryptomys,235

valschensis, Mus, 286

vandami, Cryptomys, 230, 233

vandami, Elephantulus, Io, $\mathbf{r}$

vandami, Graphiurus, 256

vanderhorsti, Procavia, I 59

vansire, Atilax, I 3 I

vansoni, Eptesicus, 77

Vansonia, 79

vardoni, Kobus, I93, 194

variani, Hippotragus, I 99, 200

variani, Madoqua, I9o

variegatoides, Vulpes, I 08

variegata, Glauconycteris, 82, 83

variegatus, Thryonomys, 238

varilla, Suncus, 2 I

varia, Helogale, I 32

varius, Suncus, 20, 22

vassei, Cephalophus, I 79

vaughanjonesi, Cricetomys, 296

velox, Potamogale, 32

venatica, Herpestes, 126

venatica, Lycaon, I Io

venustus, Petrodromus, I 5

vernayi, Dendromus, 302

vernayi, Felis, I 45

vernayi, Lepus, 2 I 5

vernayi, Mellivora, I I 5

vernayi, Panthera, I5I

vernayi, Pipistrellus, 8I

vernayi, Rattus, 270

vernayi, Sylvicapra, I 82

verreauxi, Rattus, 265, 269, 277

verroxi, Rattus, 277

Vervet Monkey, 96

vetensis, Cryptomys, 235

Vetmuis, 298 vexillarius, “Aethosciurus", 244

viator, Cricetomys, 296

victorini, Orcinus, 332

villosus, Chrysospalax, 4 I

villosa, Hyaena, 142

villosa, Nycteris, 53

villosa, Pelea, 190

vincenti, Paraxerus, 244, 245

viridis, Scotophilus, 85,86

visagiei, Chrysochloris, 4 I

visserae, Chrysochloris, 40

vittata, Hipposideros, 62

vittatus, Rhabdomys, 28 I

VIVERRA, I I 7, 120

viverrina, Suricata, 140

Vlakbokkie, 184

Vlakvark, I 7 I

Vlei Rat, 308

Vlei Rat, Laminate, 307

Vlei Rat, Saunders', 3 Io

Vleihaas, 2 I 8

Vleimuis, 308

Vleirot, 308

Vlindervlermuis, 83

voangshire, Atilax, 130

volkmanni, Procavia, I 59

VULPES, ı 06, 107

Vulpicanis, 108

vulturnus, Dendromus, 304

vumbae, Heliosciurus, 243

vumbae, Pelomys, 290

vumbaensis, Grammomys, 263

vryburgensis, Crocidura, 28

vryburgensis, Cryptomys, 235

Waaierstertmeerkat, 249

wahlbergi, Epomophorus, 47, $4^{8}$

wahlbergi, Equus, 167

Wahlbergse Witkolvrugtevlermuis, 48

walambae, Rattus, 268, $27 \mathbf{r}$

walkeri, Cephalophus, I 79

Wangsakmuis, 294

wardi, Equus, I66

wardi, Giraffa, I 74

wardi, Orycteropus, I 55

warreni, Petrodromus, I6

warreni, Suncus, 21, 22

Wart Hog, I 7 I

Water Rat, African, 288

waterbergensis, Procavia, I 58

waterbergensis, Rattus, 279

waterbergensis, Tatera, 324

Waterbok, I93

Waterbuck, I 93

Waterbuck, Defassa, I94

Waterbuck, Lechwe, I 95

Waterbuck, Sing-sing, I 94

Waterkoedoe, 208

Waterrot, 288

Weasel, White-naped, I I 3

Weerwolf, I42

weissmanni, Crocuta, I 43

welwitschi, Myotis, 72, 73

welwitschi, Procavia, I 58

Welwitschse Langhaarvlermuis, 73

Whale, Blainville's Beaked, 328

Whale, Cuvier's Beaked, 327

Whale, Great Blue, 326 


\section{INDEX}

Whale, Gray's Beaked, 328

Whale, Humpback, 326

Whale, Killer, $33 \mathrm{I}$

Whale, Little Piked, 325

Whale, Pygmy Right, 327

Whale, Pygmy Sperm, 327

Whale, Sei, 325

Whale, Southern Right, 326

Whale, Sperm, 327

Whale, Strap-toothed, 328

White-nosed Monkey, 99

whitei, Pronolagus, 222

whytei, Cercopithecus, 97

whytei, Cryptomys, 232

whytei, Dendromus, 303

whytei, Lepus, 2 I 3,216

wiesei, Alcelaphus, 203

wiesei, Syncerus, 212

Wild Cat, African, I 44

Wildebeest, Black, 204

Wildebeest, Blue, 205

Wildehond, I IO

wilsoni, Acomys, 293

wilsoni, Malacomys, 287

windhoekensis, Petromus, 240

windhorni, Lycaon, I I

windhuki, Procavia, I 58

wintoni, Cryptochloris, 39

wintoni, Laephotis, 78

wissmanni, Crocuta, I 43

Witkwasjakkals, I09

Witlyfvlermuis, 5 I

Witrenoster, I64

Witstertmuishond, I 34

Witstertrot, 313

Woestynkruipmol, 38

woodi, Nycteris, 52,54

woodi, Nycticeius, 84

woodi, Uranomys, 292

Woodse Langoorvlermuis, 54

woosnami, Crocidura, 25

woosnami, Graphiurus, 255

woosnami, Rattus, 268, 274

Woosnamse Bleekrot, 274

wunderlichi, Canis, Iog

Xantharpyia, 45

xanthella, Felis, I 45

XERUS, 240, 249 yatesi, Georychus, 230

Yerbua, 25I

Ysrot, 3 I I

Ystervark, 236

yulei, Paraxerus, 244

zambesiana, Genetta, 123

zambeziensis, Equus, 167

zambesiensis, Rhinolophus, 57

zambesiensis, Tragelaphus, 209

zambezicus, Steno, 330

Zebra, 164

Zebra, Burchell's, 166

Zebra, Chapman's, 167

zebra, Equus, I 65

Zebra, Grant's, 167

Zebra, Mountain, 165

zebroides, Equus, 167

ZELOTOMYS, 26r , 287

zena, Crocidura, 29

zenik, Suricata, I 39

zenkeri, Epomophorus, 48

zibetha, Viverra, I 7

zimbitiensis, Cryptomys, 230, 234

ZIPHIUS, 327

zombae, Herpestes, 127

Zorilla, I I I

zorilla, Ictonyx, I 12

zukowskyi, Loxodonta, I 56

zukowskyi, Raphicerus, 185

zuleika, Crocidura, $3 \mathbf{I}$

zuluensis, Cryptomys, 234

zuluensis, Eptesicus, 74, 77

zuluensis, Galago, 93

zuluensis, Genetta, I 24

zuluensis, Graphiurus, 256

zuluensis, Hystrix, 237

zuluensis, Kerivoula, 89

zuluensis, Lemniscomys, 292

zuluensis, Lepus, 2 I 7

zuluensis, Lycaon, I Io

zuluensis, Nesotragus, 188

zuluensis, Raphicerus, 185

zuluensis, Rattus, 275

zuluensis, Rhinolophus, 57

zuluensis, Tatera, 323

zyli, Cryptochloris, 39 


\section{$2 \mathrm{BHL}$ Biodiversity Heritage Library}

Ellerman, J. R., Morrison-Scott, T. C. S., and Hayman, Robert William. 1953. "Southern African mammals 1758 to 1951: a reclassification." Southern African mammals 1758 to 1951 : a reclassification 1-363.

View This Item Online: https://www.biodiversitylibrary.org/item/197133

Permalink: https://www.biodiversitylibrary.org/partpdf/192628

\section{Holding Institution}

Natural History Museum Library, London

\section{Sponsored by}

Natural History Museum Library, London

\section{Copyright \& Reuse}

Copyright Status: In copyright. Digitized with the permission of the rights holder. License: http://creativecommons.org/licenses/by-nc-sa/4.0/ Rights: https://biodiversitylibrary.org/permissions

This document was created from content at the Biodiversity Heritage Library, the world's largest open access digital library for biodiversity literature and archives. Visit BHL at https://www.biodiversitylibrary.org. 